Rodrigo Elias de Oliveira

\title{
Avaliação da prevalência de patologias bucais nos oásis de San Pedro de Atacama
}

Evaluation of the prevalence of oral pathologies in San Pedro de Atacama oasis 
Rodrigo Elias de Oliveira

(eliaso@usp.br)

\title{
Avaliação da prevalência de patologias bucais nos oásis de San Pedro de Atacama
}

\author{
Evaluation of the prevalence of oral \\ pathologies in San Pedro de Atacama oasis
}

\author{
Versão corrigida da tese apresentada ao \\ Instituto de Biociências da Universidade de \\ São Paulo, para a obtenção de Título de \\ Doutor em Ciências, na Área de Genética \\ e Biologia Evolutiva
}

(a versão original encontra-se disponível na biblioteca do IB-USP)

São Paulo 


Oliveira, Rodrigo Elias
Avaliação da prevalência de patologias bucais nos
oásis de San Pedro de Atacama. 294 páginas.
Tese (Doutorado) - Instituto de Biociências da
Universidade de São Paulo. Departamento de
Genética e Biologia Evolutiva, 2013.
1. Antropologia dental 2. Bioarqueologia 3.
Paleopatologia 4. Deserto de Atacama 5. Tiwanaku
I. Universidade de São Paulo. Instituto de
Biociências. Departamento de Genética e Biologia
Evolutiva.

Comissão Julgadora:

Prof(a). Dr(a).

$\operatorname{Prof}(a) . \operatorname{Dr}(a)$.

Prof(a). Dr(a).

$\operatorname{Prof}(a) . \operatorname{Dr}(a)$.

Prof(a). Dr(a).

Orientador(a) 
A meus pais 


\section{Agradecimentos}

A meu professor e orientador Walter Alves Neves, que me deu a oportunidade de estudar e participar de sua equipe. Tenho muito orgulho em trabalhar no LEEH (Laboratório de Estudos Evolutivos Humanos - USP).

A Mark Hubbe, que desde a decisão do tema (sugestão feita em parceria com Walter A. Neves), me auxiliou na elaboração e na execução deste trabalho, além de facilitar meu acesso ao material do acervo do museu R.P. Gustavo Le Paige e a Cristina Torres-Rouff, que gentilmente disponibilizou seus dados para que eu pudesse me orientar na coleta dos meus.

A Luis Nicanor Pezo Lanfranco, meu colega nas duas profissões que tento praticar, mas acima de tudo, meu amigo. Agradeço sua paciência e generosidade em discutir e fornecer todas as ferramentas que precisei na construção deste trabalho.

A Antonio Carlos Frias, meu professor, amigo e parceiro. Obrigado por colaborar em praticamente todas as etapas desta pesquisa.

Aos professores Rui Sergio Murrieta, Sabine Eggers e Maria Mercedes Okumura, que participaram da minha qualificação e reorientaram esta tese.

A Pedro da Glória, pelas sugestões na escolha dos protocolos que foram utilizados nesta pesquisa e pelo auxílio na interpretação dos resultados obtidos. 
A todos meus colegas do Laboratório de Estudos Evolutivos Humanos, que ao longo dos últimos anos, dividiram comigo seus espaços e experiências.

A Maria Antonieta Costa, Macarena Oviedo e toda a equipe do museu de San Pedro de Atacama que tornaram extremamente agradáveis meus dois verões no deserto.

A minha família, que aturou minha ausência durante este processo e mesmo assim, me incentivou a seguir trabalhando (e em alguns casos até trabalhou comigo).

A Diane, minha paixão e companheira. Obrigado por me incentivar a começar esta jornada, por caminhar sempre ao meu lado e por festejar comigo cada etapa superada.

NÃO HOUVE CAPÍTULO MAIS DIFICIL DE SER ESCRITO NESTA TESE QUE OS AGRADECIMENTOS A PESSOAS TÃO QUERIDAS E TÃO COMPETENTES COMO VOCÊS.

OBRIGADO!

Agradeço a Capes pelo suporte financeiro que custeou minhas viagens a San Pedro de Atacama, Chile. 


\section{Índice}

Resumo

01

Abstract

02

I - Introdução

03

II - Contexto arqueológico

13

III - Materiais e Métodos

Materiais

44

Métodos

56

IV - Resultados

107

V - Discussão

212

VI - Conclusão

259

Referências bibliográficas

266

Anexos

290 


\section{LISTA DE FIGURAS}

Figura 01 - "Quebrada do Rio San Pedro"

página 13

Figura 02 - Árvores e frutos do Algarrobo (Prosopis chilensis) e do Chañar (Geoffroea decorticans)

página 15

Figura 03 - Espigas de milho arqueológicas e tipos de milhos

plantados atualmente na região

página 17

Figura 04 - Petróglifos de camelídeos do sítio arqueológico

Hierbas Buenas, San Pedro de Atacama

página 18

Figura 05 - Detalhes com características antropomórficas

dos gargalos de garrafas atacamenhas

página 19

Figura 06 - Tabletas para inalação de substâncias psicoativas

página 22

Figura 07 - Anadenanthera colubrina, conhecida na cordilheira

dos Andes como "cebil" ou "villca"

página 23

Figura 08 - Cerâmica, metalurgia, escultura e tecelagem tiwanakota

página 25

Figura 09 - Imagem do sacrificador esculpida em tableta

para inalação de A. colubrina

página 27

Figura 10 - Crânio naturalmente mumificado (sepultamento 44)

encontrado em Caspana, em excelente

estado de conservação

página 29

Figura 11 - O Pukara de Quitor em San Pedro de Atacama, Chile

página 34

Figura 12 - Lesão óssea resultante de trauma violento com

instrumento perfuro-cortante (Catarpe 2 \#1849)

página 36

Figura 13 - Geóglifos encontrados nas quebradas do 
deserto de Atacama, criados para orientar os pastores

e os condutores de caravanas de lhamas

página 37

Figura 14 - Semelhança entre as divindades Wari

(dois vasos cerâmicos) à esquerda e divindades Tiwanaku

("Porta do Sol" do templo Tiwanaku) à direita

página 38

Figura 15 - Tambo de Catarpe com detalhe de suas paredes

feitas de pedras do Rio San Pedro aglutinadas com argila

página 41

Figura 16 - Condição de conservação de alguns exemplares da coleção

do Museu R.P. Augusto Le Paige, San Pedro de Atacama, Chile página 45

Figura 17 - Localização dos sítios arqueológicos

de San Pedro de Atacama, adaptado de Costa et al. (2004) página 46

Figura 18. Instrumentais utilizados nesta pesquisa: 1. Lanterna;

2. Pinça clínica; 3. Espelho clínico; 4. Sonda exploradora;

5. Sonda milimetrada; 6. Lupa

página 57

Figura 19 - Desenvolvimento dental e idade adaptados

de Ubelaker (1989)

página 61

Figura 20 - Os pontos identificados com os números de 6 a 10

foram os utilizados para a estimativa de idade de morte, adaptados de Meindl e Lovejoy (1985)

página 62

Figura 21 - Vista superior dos principais tipos de deformações

cranianas intencionais de San Pedro de Atacama

página 63

Figura 22 - Vista lateral dos tipos e angulações de deformações

cranianas intencionais observadas nos crânios exumados em

San Pedro de Atacama

página 64 
Figura 23 - Crânio com maxilas e mandíbula desdentadas

(Coyo Oriental \#4036), apresentando características de perda dentária ante mortem página 67

Figura 24 - Alvéolos dentários vazios devido à perda post mortem indicados pelas setas página 69

Figura 25 - Ausência congênita dos terceiros molares direitos, tanto superior quanto inferior página 70

Figura 26 - Segundo pré-molar superior esquerdo impactado sob o primeiro pré-molar e o primeiro molar superiores esquerdos

Figura 27 - Ausência de alvéolos e dentes correspondentes página 72

Figura 28 - Abcesso dentário localizado no ápice radicular do canino superior direito (Catarpe 1 \#2404) página 73

Figura 29 - Patologias dentais avaliadas neste trabalho:

1. Abcesso periapical; 2. Cárie dentária; 3. Desgaste dentário;

4. Hipoplasia linear do esmalte; 5. Reabsorção periodontal;

6. Cálculo dentário página 74

Figura 30 - Lesões de cárie dentária com localização e intensidade distintas página 77

Figura 31 - Rios que abastecem os sítios arqueológicos analisados neste trabalho página 87

Figura 32 - Parafernália utilizada na prática de mascar folha de coca (Erythroxylum coca) página 88

Figura 33 - Lesões ósseas e dentárias características do 
Figura 34 - Categorização das lesões causadas pelo hábito de mascar folhas de coca. As lesões de cárie são representadas em negro

página 90

Figura 35 - Desgaste dentário página 92

Figura 36 - Estágios de desgaste dentário proposto por Molnar página 94

Figura 37 - Hipoplasias lineares do esmalte dentário página 97

Figura 38 - Hipoplasias puntiformes e amorfas do esmalte dentário página 97

Figura 39 - Reabsorção periodontal vertical na região do primeiro molar superior direito página 100

Figura 40 - Sonda milimetrada utilizada para medição da reabsorção periodontal página 101

Figura 41 - Cálculos salivares supragengivais (Tulan 58 sep. IV) página 103

Figura 42 - Gráfico apresentando a distribuição das deformações cranianas encontradas em San Pedro de Atacama página 110

Figura 43 - Distribuição das deformações cranianas intencionais entre os períodos estudados, acrescida da amostra de Caspana, identificado como Pós Tiwanaku externo página 111

Figura 44 - Distribuição dos 2 tipos principais de deformação craniana encontrados nos indivíduos deformados página 112

Figura 45 - Proporção dos dentes presentes, perdidos em vida e perdidos após a morte dos indivíduos e seus respectivos períodos página 114 
Figura 46 - Gráficos comparativos entre as perdas dentárias

post mortem dos dentes anteriores e posteriores

página 115

Figura 47 - Prevalência dos dentes presentes atualmente na coleção:

dentes presentes / dentes presentes + perdidos post mortem

página 116

Figura 48 - Prevalência de dentes perdidos ante mortem

página 117

Figura 49 - Prevalências de dentes anteriores e posteriores

perdidos ante mortem

página 118

Figura 50 - Prevalência de dentes perdidos ante mortem apenas

com indivíduos com idade superior a 25 anos

página 119

Figura 51 - Prevalências de dentes anteriores e posteriores

perdidos ante mortem nos indivíduos com mais de 25 anos

página 120

Figura 52 - Prevalência de dentes perdidos ante mortem entre os

indivíduos que apresentaram deformação craniana intencional

e os que não apresentaram

página 121

Figura 53 - Distribuição da prevalência de perda dentária em vida

nos indivíduos que apresentaram ou

não deformações cranianas

página 122

Figura 54 - Prevalência das lesões periapicais

página 124

Figura 55 - Abcessos dentários sem a presença de indivíduos

com menos de 25 anos

página 126

Figura 56 - Prevalências de abcessos dentários em dentes anteriores

e posteriores de indivíduos com mais de 25 anos

página 127

Figura 57 - Prevalências dos dentes acometidos por cárie

e o número de lesões por dente

página 128 
Figura 59 - Extensão do comprometimento do dente por

$$
\text { cárie dentária }
$$

Figura 60 - Prevalência de cárie com destruição total da

$$
\text { coroa dentária }
$$

Figura 61 - valores das prevalências de cáries

$$
\text { dentárias superficiais (grau 1) }
$$

Figura 62 - Distribuição da intensidade das lesões de cárie dentária

Figura 63 - Prevalências de dentes cariados nos indivíduos

$$
\text { divididos pelo sexo }
$$

Figura 64 - Prevalências de dentes cariados nos indivíduos

$$
\text { divididos pelo sexo, ao longo dos períodos }
$$

Figura 65 - Prevalências de dentes cariados nos indivíduos com idade

de morte superior a 25 anos e divididos pelo sexo ao

$$
\text { longo dos períodos }
$$

Figura 66 - Prevalência de cárie dentária presente nos

$$
\text { dentes anteriores e posteriores }
$$

página 139

Figura 67 - Prevalência de cárie dentária em indivíduos com mais de 25 anos encontrada nos períodos estudados

Figura 68 - Prevalência de cárie dentária em dentes anteriores e posteriores de indivíduos com mais de 25 anos de idade

Figura 69 - Prevalências de dentes cariados em indivíduos que apresentaram ou não deformações cranianas intencionais 
Figura 71 - Prevalência de dentes cariados entre indivíduos

$$
\begin{aligned}
& \text { sem deformação craniana intencional, com } \\
& \text { deformação craniana circular e com } \\
& \text { deformação craniana tabular }
\end{aligned}
$$

Figura 72 - Médias dos valores do DMI de Saunders para os

$$
\text { períodos estudados }
$$

Figura 73 - Distribuição das medianas dos valores de DMI de Saunders pelos 3 períodos estudados, além do sítio Caspana página 152

Figura 74 - Relação de polpas expostas devido ao processo de

$$
\text { cárie dentária divididas por todos os casos de polpa exposta }
$$

Figura 76 - Medianas encontradas para os índices de Lukacs de cada período página 154

Figura 77 - Médias dos valores do índice de Lukacs dos indivíduos com idade superior a 25 anos página 155

Figura 78 - Médias dos valores do índice de Lukacs dos indivíduos com idade superior a 25 anos divididos em homens e mulheres

Figura 79 - Médias dos valores do índice de Lukacs dos indivíduos com idade superior a 25 anos e divididos em crânios com deformação e sem deformação

Figura 80 - Valores de flúor observados nas águas dos rios da região do deserto de Atacama página 165

Figura 81 - Níveis de desgaste dentário de S. Molnar (1971) 
encontrados durante os períodos analisados

página 167

Figura 82 - Médias dos valores do desgaste dentário

página 168

Figura 83 - Desgaste dentário classificado pela intensidade

página 170

Figura 84 - Médias das intensidades dos desgastes dentários

(desgaste leve $=1 ;$ desgaste médio $=2 ;$ desgaste intenso $=3$ )

página 172

Figura 85 - Prevalência de dentes com polpa exposta resultante de

desgaste dentário intenso

página 174

Figura 86 - Desgastes dentários observados nos dentes anteriores e posteriores e divididos em 3 níveis de intensidade

página 174

Figura 87 - Distribuição dos indivíduos classificados pelo nível de

desgaste dentário apresentado

página 179

Figura 88 - Distribuição dos indivíduos com e sem deformação craniana que apresentavam desgaste dentário de intensidade baixa

Figura 89 - Distribuição dos indivíduos com e sem deformação craniana que apresentavam desgaste dentário de intensidade média página 182

Figura 90 - Distribuição dos indivíduos com e sem deformação craniana que apresentavam desgaste dentário de intensidade alta página 182

Figura 91 - Médias dos valores do desgaste dentário dos indivíduos com idade superior a 25 anos página 184

Figura 92 - Médias dos valores do desgaste dentário dos indivíduos com idade superior a 25 anos divididos em homens e mulheres página 186

Figura 93 - Médias dos valores do desgaste dentário de indivíduos com idade superior a 25 anos e divididos em crânios com deformação e sem deformação página 190 
Figura 94 - Prevalência de indivíduos acometidos pela

hipoplasia linear do esmalte

página 194

Figura 95 - Prevalência dos indivíduos que apresentaram apenas

1 dente acometido por lesão hipoplásica

página 196

Figura 96 - Prevalências dos níveis de reabsorção periodontal nos

indivíduos distribuídos pelos períodos

página 197

Figura 97 - Prevalências de indivíduos com e sem

reabsorção periodontal

página 197

Figura 98 - Prevalências dos indivíduos acometidos ou não pelas

reabsorções periodontais nos dentes anteriores

página 199

Figura 99 - Prevalências de indivíduos que apresentaram ou não

reabsorção alveolar em seus dentes posteriores

página 200

Figura 100 - Prevalências de reabsorção periodontal de

homens e mulheres ao longo do tempo

página 201

Figura 101 - Prevalências da presença, localização e intensidade dos

cálculos salivares nos indivíduos de cada período

página 204

Figura 102 - Prevalências de presença e ausência de cálculos salivares,

além da localização dos cálculos presentes

página 205

Figura 103 - Prevalência de cálculos salivares supragengivais presentes

nos dentes anteriores ao longo dos períodos avaliados

página 206

Figura 104 - Prevalência de cálculos salivares supragengivais presentes nos dentes posteriores ao longo dos períodos avaliados

página 208

Figura 105 - Prevalências de cálculos salivares observados em homens e mulheres ao longo do tempo

página 209 
Figura 106 - Crânio originário do sítio Toconao Oriente com evidência

de utilização dos dentes como ferramentas

página 220

Figura 107 - Distribuição dos desgastes dentários para o

período Pré Tiwanaku considerando o indivíduo como

unidade de análise

página 222

Figura 108 - Distribuição dos desgastes dentários para o

período Tiwanaku considerando o indivíduo como

unidade de análise

página 236

Figura 109 - Distribuição dos desgastes dentários para o período

Pós Tiwanaku considerando o indivíduo como

unidade de análise

página 249 


\section{LISTA DE TABELAS}

Tabela 01 - Nomenclatura dos mesmos períodos históricos

para os Andes Centrais e para São Pedro de Atacama página 49

Tabela 02 - Datas obtidas para os sítios de San Pedro de

Atacama (Hubbe et al., 2011) página 51

Tabela 03 - Datas obtidas para os sítios de San Pedro de

Atacama (Hubbe et al. 2012) página 52

Tabela 04 - Datas obtidas por Llagostera et al., 1988 página 52

Tabela 05 - Datas obtidas por Berenguer et al. (1988) página 53

Tabela 06 - Datas obtidas por Costa (1988) página 54

Tabela 07 - Datas obtidas por Llagostera (2006) página 54

Tabela 08 - Sítios arqueológicos analisados e seus

respectivos períodos página 55

Tabela 09 - Deformações cranianas intencionais analisadas página 65

Tabela 10 - Códigos de identificação da localização e

característica das lesões de cárie página 81

Tabela 11 - Intensidade de comprometimento das lesões de cárie página 82

Tabela 12 - Quantidade de hipoplasias lineares do esmalte dentário página 98

Tabela 13 - Índice de avaliação da reabsorção alveolar página 101

Tabela 14 - Índice utilizado para a avaliação da presença de cálculo salivar página 105

Tabela 15 - Testes estatísticos utilizados neste trabalho_ página 106

Tabela 16 - Frequência dos indivíduos presentes na amostra,

divididos pelo período, idade e sexo $\quad$ página 108 
Tabela 17 - Valores da correlação entre a idade, o sexo e o período ao qual pertencem os indivíduos desta amostra página 109

Tabela 18 - Valor estatístico e valor-p de Chi-Quadrado entre as deformações cranianas observadas página 113

Tabela 19 - Valor estatístico e valor-p (corrigidos) encontrados nos testes Chi Quadrado para as perdas ante mortem página 118

Tabela 20 - Valor estatístico e valor-p (corrigidos) encontrados nos testes Chi Quadrado para as perdas ante mortem nos indivíduos com idade superior a 25 anos página 120

Tabela 21 - Valor estatístico e valor-p encontrados nos testes Chi Quadrado aplicados sobre a diferença das perdas ante mortem dentária apresentadas por indivíduos com ou sem deformação craniana ao longo dos períodos página 122

Tabela 22 - Valor estatístico e valor-p encontrados nos testes Chi Quadrado para as perdas ante mortem nos indivíduos com deformação craniana intencional página 123

Tabela 23 - Valor estatístico e valor-p encontrados nos testes Chi Quadrado para as perdas ante mortem nos indivíduos sem deformação craniana intencional página 123

Tabela 24 - Valor estatístico e valor-p dos testes Chi Quadrado aplicados na análise das prevalências de abcessos dentários página 125

Tabela 25 - Valor estatístico e valor-p encontrados nos testes

Chi Quadrado das lesões periapicais (sem indivíduos jovens) página 126 Tabela 26 - Valor estatístico e valor-p encontrados nos testes 
Tabela 27 - Valor estatístico e valor-p encontrados nos testes

Chi Quadrado das lesões extremas de cárie dentária, onde há destruição total da coroa do dente página 132

Tabela 28 - Valor estatístico e valor-p encontrados nos testes

Chi Quadrado das lesões superficiais de cárie dentária página 133

Tabela 29 - Valor estatístico e valor-p encontrados nos testes

Chi Quadrado das lesões de cárie dentária página 134

Tabela 30 - Valor estatístico e valor-p encontrados nos testes

Chi Quadrado aplicados sobre a diferença das lesões de cárie dentária apresentadas por ambos os sexos ao longo dos períodos página 136

Tabela 31 - Valor estatístico e valor-p encontrados nos testes Chi Quadrado aplicados sobre a diferença das lesões de cárie dentária apresentadas por ambos os sexos ao longo dos períodos em indivíduos com mais de 25 anos de idade página 137

Tabela 32 - Valor estatístico e valor-p encontrados nos testes Chi Quadrado aplicados sobre a diferença das lesões de cárie dentária apresentadas por indivíduos do sexo masculino com mais de 25 anos página 138

Tabela 33 - Valor estatístico e valor-p encontrados nos testes Chi Quadrado aplicados sobre a diferença das lesões de cárie dentária apresentadas por indivíduos do sexo feminino com mais de 25 anos 
Tabela 34 - Valor estatístico e valor-p encontrados nos testes

Chi Quadrado das lesões de cárie dentária em dentes anteriores página 140

Tabela 35 - Valor estatístico e valor-p encontrados nos testes

Chi Quadrado das lesões de cárie dentária em dentes posteriores página 140

Tabela 36 - Valor estatístico e valor-p encontrados nos testes

Chi Quadrado das lesões de cárie dentária em dentes de indivíduos com idade de morte superior a 25 anos página 141

Tabela 37 - Valor estatístico e valor-p encontrados nos testes

Chi Quadrado das lesões de cárie dentária em dentes anteriores de indivíduos com idade de morte superior a 25 anos

Tabela 38 - Valor estatístico e valor-p encontrados nos testes Chi Quadrado das lesões de cárie dentária em dentes posteriores de indivíduos com idade de morte superior a 25 anos página 143

Tabela 39 - Valor estatístico e valor-p encontrados nos testes Chi Quadrado aplicados sobre a diferença das lesões de cárie dentária apresentadas por indivíduos com ou sem deformação craniana ao longo dos períodos página 145

Tabela 40 - Valor estatístico e valor-p encontrados nos testes

Chi Quadrado das lesões de cárie dentária em indivíduos que apresentaram deformação craniana intencional 
Tabela 41 - Valor estatístico e valor-p encontrados nos testes

Chi Quadrado das lesões de cárie dentária em indivíduos sem deformação craniana intencional página 146

Tabela 42 - Valor estatístico e valor-p encontrados nos testes

Chi Quadrado das lesões de cárie dentária em indivíduos com deformação craniana intencional do tipo circular página 147

Tabela 43 - Valor estatístico e valor-p encontrados nos testes

Chi Quadrado das lesões de cárie dentária em indivíduos com deformação craniana intencional do tipo tabular página 148

Tabela 44 - Valor estatístico e valor-p encontrados nos testes

Chi Quadrado das lesões de cárie dentária em indivíduos sem deformação, com deformação circular e com deformação tabular durante o período Pré Tiwanaku página 148

Tabela 45 - Valor estatístico e valor-p encontrados nos testes

Chi Quadrado das lesões de cárie dentária em indivíduos sem deformação, com deformação circular e com deformação tabular durante o período Tiwanaku página 148

Tabela 46 - Valor estatístico e valor-p encontrados nos testes Chi Quadrado das lesões de cárie dentária em indivíduos sem deformação, com deformação circular e com deformação tabular durante o período Pós Tiwanaku

Tabela 47 - Valor estatístico e valor-p encontrados nos testes

Chi Quadrado das lesões de cárie dentária em indivíduos sem deformação, com deformação circular e com 
Tabela 48 - Valor estatístico e valor-p para averiguação das

diferenças dos DMI entre os períodos

página 151

Tabela 49 - Valor estatístico e valor-p para averiguação das

diferenças dos índices de Lukacs entre os períodos

página 156

Tabela 50 - Valor estatístico e valor-p para averiguação das

diferenças dos índices de Lukacs entre homens e mulheres

em cada período

página 158

Tabela 51 - Valor estatístico e valor-p para averiguação das diferenças

dos índices de Lukacs dos homens entre os períodos

página 159

Tabela 52 - Valor estatístico e valor-p para averiguação das diferenças

dos índices de Lukacs das mulheres entre os períodos

página 160

Tabela 53 - Valor estatístico e valor-p para averiguação das diferenças

dos índices de Lukacs entre crânios deformados e

não deformados em cada período

página 162

Tabela 54 - Valor estatístico e valor-p para averiguação das diferenças

dos índices de Lukacs dos crânios deformados

entre os períodos

página 163

Tabela 55 - Valor estatístico e valor-p para averiguação das diferenças

dos índices de Lukacs dos crânios sem deformação

entre os períodos

página 164

Tabela 56 - Valor estatístico e valor-p para averiguação das diferenças das médias dos desgastes dentários entre os períodos

página 169

Tabela 57 - Valor estatístico e valor-p encontrados nos testes 
Tabela 58 - Valor estatístico e valor-p encontrados nos testes

Chi Quadrado para desgaste dentário médio página 171

Tabela 59 - Valor estatístico e valor-p encontrados nos testes

Chi Quadrado para desgaste dentário intenso página 171

Tabela 60 - Valor estatístico e valor-p para averiguação das diferenças

das médias das intensidades dos desgastes dentários entre os períodos página 173

Tabela 61 - Valor estatístico e valor-p encontrados nos testes

Chi Quadrado para desgaste dentário leve dos dentes anteriores página 175

Tabela 62 - Valor estatístico e valor-p encontrados nos testes

Chi Quadrado para desgaste dentário médio dos dentes anteriores página 175

Tabela 63 - Valor estatístico e valor-p encontrados nos testes Chi Quadrado para desgaste dentário intenso dos dentes anteriores página 176

Tabela 64 - Valor estatístico e valor-p encontrados nos testes Chi Quadrado para desgaste dentário leve dos dentes posteriores página 176

Tabela 65 - Valor estatístico e valor-p encontrados nos testes Chi Quadrado para desgaste dentário médio dos dentes posteriores página 176

Tabela 66 - Valor estatístico e valor-p encontrados nos testes 
Chi Quadrado para desgaste dentário intenso dos

dentes posteriores

página 177

Tabela 67 - Valor estatístico e valor-p para averiguação das diferenças

entre os desgastes dentários dos dentes anteriores e

dentes posteriores em cada período

página 178

Tabela 68 - Valor estatístico e valor-p encontrados nos testes

Chi Quadrado aplicados nos desgastes dentários de

intensidade baixa, quando os indivíduos são levados

em consideração

página 180

Tabela 69 - Valor estatístico e valor-p encontrados nos testes

Chi Quadrado aplicados nos desgastes dentários de

intensidade média, quando os indivíduos são levados

em consideração

página 180

Tabela 70 - Valor estatístico e valor-p encontrados nos testes

Chi Quadrado aplicados nos desgastes dentários de

intensidade alta, quando os indivíduos são levados

em consideração

página 180

Tabela 71 - Valor estatístico e valor-p encontrados nos testes

Chi Quadrado aplicados nos indivíduos com

deformação craniana intencional e que apresentavam

desgaste dentário de intensidade baixa

página 183

Tabela 72 - Valor estatístico e valor-p encontrados nos testes

Chi Quadrado aplicados nos indivíduos com

deformação craniana intencional e que apresentavam 
Tabela 73 - Valor estatístico e valor-p encontrados nos testes

Chi Quadrado aplicados nos indivíduos com

deformação craniana intencional e que apresentavam

desgaste dentário de intensidade alta

página 184

Tabela 74 - Valor estatístico e valor-p para averiguação das

diferenças dos desgastes dentários entre os períodos

página 185

Tabela 75 - Valor estatístico e valor-p para averiguação da variação

dos desgastes dentários entre homens e mulheres em

cada período

página 187

Tabela 76 - Valor estatístico e valor-p para averiguação das médias de

desgaste dentário apresentadas pelos homens

entre os períodos

página 188

Tabela 77 - Valor estatístico e valor-p para averiguação das médias de desgaste dentário apresentadas pelas mulheres

entre os períodos

página 189

Tabela 78 - Valor estatístico e valor-p para averiguação das diferenças das médias de desgaste dentário entre crânios deformados e não deformados em cada período

página 191

Tabela 79 - Valor estatístico e valor-p para averiguação das diferenças

das médias de desgaste dentário dos crânios deformados

entre os períodos

página 192

Tabela 80 - Valor estatístico e valor-p para averiguação das diferenças das médias de desgaste dentário dos crânios não deformados 
Tabela 82 - Valor estatístico e valor-p encontrados nos testes

Chi Quadrado aplicados nos indivíduos com 2 ou mais dentes acometidos pela hipoplasia linear do esmalte

Tabela 83 - Valor estatístico e valor-p encontrados nos testes

Chi Quadrado aplicados nos indivíduos com reabsorção periodontal página 198

Tabela 84 - Valor estatístico e valor-p encontrados nos testes

Chi Quadrado aplicados apenas nos dentes anteriores de indivíduos com reabsorção periodontal página 199

Tabela 85 - Valor estatístico e valor-p encontrados nos testes

Chi Quadrado aplicados apenas nos dentes posteriores de indivíduos com reabsorção periodontal página 200

Tabela 86 - Valor estatístico e valor-p encontrados nos testes

Chi Quadrado aplicados sobre a diferença entre as reabsorções periodontais de homens e mulheres apresentadas em cada período página 202

Tabela 87 - Valor estatístico e valor-p encontrados nos testes

Chi Quadrado aplicados sobre as diferenças das reabsorções periodontais em indivíduos do sexo masculino página 202

Tabela 88 - Valor estatístico e valor-p encontrados nos testes

Chi Quadrado aplicados sobre as diferenças das reabsorções periodontais em indivíduos do sexo feminino página 202 
Tabela 89 - Valor estatístico e valor-p encontrados nos testes

Chi Quadrado quando analisados os dentes portadores de cálculos salivares supragengivais

página 205

Tabela 90 - Valor estatístico e valor-p encontrados nos testes

Chi Quadrado quando analisados os dentes anteriores portadores de cálculos salivares supragengivais

página 207

Tabela 91 - Valor estatístico e valor-p encontrados nos testes

Chi Quadrado quando analisados os dentes posteriores portadores de cálculos salivares supragengivais

página 208

Tabela 92 - Valor estatístico e valor-p encontrados nos testes

Chi Quadrado aplicados sobre a diferença entre as

prevalências de cálculo salivar de homens e mulheres

ao longo dos períodos

página 210

Tabela 93 - Valor estatístico e valor-p encontrados nos testes

Chi Quadrado aplicados sobre as diferenças das

prevalências de cálculo salivar em indivíduos do

sexo masculino

página 210

Tabela 94 - Valor estatístico e valor-p encontrados nos testes

Chi Quadrado aplicados sobre as diferenças das

prevalências de cálculo salivar em indivíduos do

sexo feminino

página 210 


\section{RESUMO}

O deserto de Atacama, no norte do Chile, a despeito da altitude e da aridez que o caracterizam, apresenta evidências da presença humana há pelo menos 13000 anos. San Pedro de Atacama é uma região muito importante deste deserto devido ao grande número de esqueletos arqueológicos ali exumados e ao excelente estado de preservação que o material escavado, seja ele mineral ou orgânico, é encontrado. Equipes independentes de pesquisadores têm colaborado, nos últimos 50 anos, para o entendimento da pré-história atacamenha através de análises do acervo arqueológico e bioantropológico que hoje se encontra sob a guarda do museu arqueológico Padre Gustavo Le Paige. O material analisado neste trabalho é parte integrante da coleção de crânios humanos escavados por Le Paige, coleção que se encontra severamente reduzida por deficiências no processo de cura e guarda.

Foram analisadas as patologias bucais de 402 crânios provenientes de 13 sítios arqueológicos de San Pedro de Atacama e Caspana, com o objetivo de inferir a qualidade de vida biológica dessas populações a partir do período Formativo (350 AC) até a chegada Império Inca (1470 AD) nos oásis atacamenhos. Considerando o período de influência do Império Tiwanaku em San Pedro como referência, os períodos Pré Tiwanaku e Pós Tiwanaku foram comparados com o período Tiwanaku (500 a 1000 AD) e também com o sítio Caspana, utilizado como controle externo.

As redes de troca que foram intensificadas durante o período Tiwanaku em todos os Andes Centrais disponibilizaram aos oásis de San Pedro de Atacama uma maior variedade de alimentos, diminuindo assim a dependência do milho desta sociedade. Prova disso é a queda significativa das cáries dentárias observada entre o período Pré Tiwanaku e o período Tiwanaku. No mesmo período, foram observados aumentos dos cálculos salivares e das reabsorções periodontais que, associados à queda das cáries dentárias, sugerem o aumento no consumo de proteína e sais minerais pelos atacamenhos.

O período subsequente, marcado pela alteração climática responsável pelo desmantelamento do Estado Tiwanaku, afetaria a população dos oásis obrigando-a a retornar ao milho como item principal em sua dieta, fato confirmado pelo aumento das cáries dentárias. A seca característica do período Pós Tiwanaku deve ter pressionado a sociedade atacamenha a intensificar suas técnicas de conservação dos alimentos, sendo esta a mais plausível explicação para o também observado aumento significativo dos cálculos salivares.

Os crânios analisados de Caspana apresentaram uma prevalência de cáries dentárias inferior à prevalência observada durante período Pós Tiwanaku em San Pedro de Atacama, sugerindo uma estratégia de subsistência distinta, baseada numa dieta menos cariogênica. $O$ limitado consumo de proteínas e sais minerais como cálcio e potássio também caracterizou a alimentação dos habitantes de Caspana, confirmado pela baixa prevalência de cálculos salivares e reabsorções periodontais.

As mulheres apresentaram prevalências mais altas de cárie dentária, cálculo salivar e reabsorção periodontal, indicando um acesso maior aos alimentos, em quantidade ou em frequência, que os indivíduos do sexo masculino.

Quanto às deformações cranianas intencionais analisadas nos sítios de San Pedro de Atacama, não foram encontrados sinais de privilégios nutricionais por nenhum grupo estudado, sejam eles não deformados ou deformados, independentemente do período avaliado ou do tipo e angulação da deformação apresentada. 


\section{ABSTRACT}

The Atacama Desert in northern Chile, despite the altitude and dryness that characterize it, displays evidence of human presence for at least 13,000 years. San Pedro de Atacama is a very important region of the desert, for the large number of archaeological skeletons that were exhumed and found there and also for the excellent state of preservation in which the excavated material- whether mineral or organic - was found. Independent teams of researchers have collaborated for the past 50 years to the understanding of Atacamenian prehistory, through analysis of the archaeological and the bio anthropological collection, which are now in the custody of the archaeological museum Padre Gustavo Le Paige. The material analyzed in this dissertation is part of the collection of human skulls excavated by Le Paige, a collection now severely reduced due to deficiencies in the process of safekeeping.

The oral pathologies of 402 skulls from 13 different archaeological sites of San Pedro de Atacama and Caspana have been analyzed in order to infer the biological quality of life of these populations from the Formative period $(350 \mathrm{BC})$ up to the arrival of the Inca Empire (1470 $A D$ ) in the oasis Atacamenõs. Considering the period of influence of the Tiwanaku Empire in San Pedro as reference, the periods Pre and Post Tiwanaku Tiwanaku were compared with the Tiwanaku period (500-1000 AD) and also with the Caspana site, which was used as an external control.

The enhanced networks of exchange during the Tiwanaku period around the whole of the Central Andes have provided the oasis of San Pedro de Atacama greater variety of foods, thereby reducing the reliance this society had on corn. The proof of this is the significant decline in dental caries observed between the pre Tiwanaku and the Tiwanaku periods. During this period, the increase in salivary calculi and periodontal resorption associated to the decrease in dental caries suggests the raise in consumption of protein and minerals by the Atacameños.

The subsequent period is marked by a climate change which was responsible for the dismantling of the Tiwanaku state, thus affecting the population of the oasis and forcing it to return to the consumption of corn as the main item in their diet, a fact that is confirmed by the increase in dental caries. The characteristic drought of this period must have driven the Post Tiwanaku Atacamenian society to intensify their food preservation techniques, and that is the most plausible explanation for the also significant raise in salivary calculi.

The skulls analyzed from Caspana showed a lower prevalence of dental caries than the ones observed during the Post Tiwanaku period in San Pedro de Atacama, suggesting a distinct livelihood strategy based on a less cariogenic diet. The limited consumption of protein and minerals like calcium and potassium also characterize the food intake of the inhabitants of Caspana, which is confirmed by the low prevalence of salivary calculi and periodontal resorption.

The female skulls showed a higher incidence of dental caries, salivary calculus and periodontal resorption, indicating that they had broader access to food, both in quantity and frequency than their male counterparts.

Regarding the intentional cranial deformations analyzed here, no signs of nutritional privileges were found on any of the studied groups, whether deformed or not, regardless of the period studied or the type and angle of these deformations. 


\section{INTRODUÇÃO}

A Paleopatologia busca observar nos remanescentes arqueológicos sinais das doenças que acometeram sociedades passadas. Assim, a especialidade se fundamenta nos conhecimentos desenvolvidos pelas áreas médica e/ou veterinária. Caracterizada como uma disciplina essencialmente descritiva nas primeiras décadas do século $X X$, período categorizado por Aufderheide \& Rodriguez-Martín como "Genesis" (ou segunda fase), a Paleopatologia levaria décadas para extrapolar essa característica descritiva (Roberts \& Manchester, 2005 a).

A partir da segunda metade da década de 1960 é que os trabalhos sobre paleopatologia se aproximaram dos estudos de caso clínico e se associaram a conceitos da ecologia e da biologia evolutiva, com o objetivo de inserir o ser humano no meio onde vive, além de buscar nas patologias respostas sobre essa interação.

Após os anos 1970 e 1980, a Paleopatologia se estabeleceu como importante área do conhecimento nos estudos arqueológicos. Isto se deu graças às grandes sínteses nas áreas da epidemiologia e do estilo e qualidade de vida, que buscaram padronizar os futuros estudos na então emergente disciplina (Da-Gloria, 2006).

A Antropologia Dental tem uma história mais antiga que a própria Paleopatologia. Assim como esta, a Antropologia Dental também esteve, durante longos anos após o seu surgimento, vinculada apenas à descrição pura e simples da morfologia dental. Comumente associada à Antropologia Física geral, anos se passaram desde os primeiros trabalhos nos quais os dentes eram apenas mencionados até que se produzissem trabalhos exclusivamente sobre os dentes e suas patologias.

Turner \& Scott (2008) no recente livro "Technique and Application in Dental Anthropology", apresentam uma revisão profunda da história da Antropologia Dental, na qual dividem sua historia em duas partes fundamentais: antes e depois dos anos 1950. Para estes autores, descontando as raras exceções do final do século XIX, os dentes foram deixados no esquecimento até as primeiras décadas do século XX. A partir de então, trabalhos como o feito por Ales Hrdlicka analisando esqueletos de 
nativos americanos ajudariam os pesquisadores a enxergar o potencial que os dentes tinham para o entendimento da variabilidade humana.

Ainda na primeira metade do século XX, além de A. Hrdlicka, autores como T.D. Campbell, M.S. Goldstein, P. Butlerand e A.A.Dahlberg (apenas para citar alguns pesquisadores) são lembrados como importantes referências na área, através de seus trabalhos sobre morfologia, patologia e desgaste dental, assim como os trabalhos de R.W. Leigh de 1925 e o de C.M. Shaw de 1931 (Scott \& Turner, 2008). Para eles, o ponto de virada na Antropologia Dental seria o trabalho desenvolvido por P.O. Pedersen em 1949 com os esquimós da Groenlândia, no qual o autor expõe um extenso banco de dados sobre as características dentárias dos Inuítes. Enquanto isso, uma importante mudança era observada nos antropólogos, que passaram a aprofundar seus estudos nos processos em detrimento de simplesmente tipificar ou descrever os dentes (Scott \& Turner, 2008).

Visto que a análise de um único dente impossibilita a identificação a qual grupo humano seu portador pertencia, iniciou-se uma busca das evidências na anatomia e na morfologia dental dos grupos humanos para explicar a variabilidade das "raças", abrindo uma nova frente de pesquisa. Liderada por nomes como G.W. Lasker, D.R. Brothwell, C.G. Turner e K. Hanihara, esta nova forma de enxergar os dentes se firmaria como um dos ramos mais promissores da Antropologia Dental nos anos que se seguiriam (Scott \& Turner, 2008).

Em 1950, G. W. Lasker em seu trabalho intitulado "Genetic analysis of racial traits of the teeth" deixaria claro as novas possibilidades de análises que a morfologia dentária trazia consigo além de sua simples descrição. As formas de analisar esta morfologia se iniciam com medidas lineares da coroa dentária. Conhecidos como traços métricos dentários, as medidas extraídas dos dentes de diferentes populações dispersas pelo globo evidenciam diferenças entre elas. Atentos aos problemas apontados por D.R. Brothwell (1967), sobretudo a enorme variação das formas e tamanhos dos dentes humanos, pesquisadores como Kazuro Hanihara iniciaram pesquisas aplicando técnicas estatísticas sofisticadas, conhecidas como análises multivariadas, como uma forma de associar distintas medidas e minimizar os 
problemas da enorme variabilidade encontrada nos dentes (Hanihara, 1977). No mesmo trabalho, o próprio autor já apresentava sua percepção quanto à limitação destas análises métricas e anunciava seu trabalho (em andamento na ocasião) com traços dentários não métricos.

A análise dos traços não métricos se projetava como uma promissora fonte de conhecimento genético sem o acesso direto ao DNA, estrutura isolada em 1969, mas de difícil acesso no material arqueológico, até recentemente.

Os traços não métricos dentais eram registrados simplesmente como presentes ou ausentes na amostra observada. Contudo, quando presente, estes traços também apresentavam distintos graus de expressão. Estas diferenças estão relacionadas a um sistema poligênico no qual vários alelos podem estar relacionados com a expressão destes traços, apresentando assim esta variedade de intensidade de expressões (Scott \& Turner, 2008).

Talvez sem saber desta base genética, mas apenas com o conhecimento empírico obtido das diversas observações feitas sobre esses traços, pesquisadores procuraram criar modelos para padronizar as futuras pesquisas na área. Albert $A$. Dahlberg, um dentista que trabalhava com populações de nativos norteamericanos, iniciou após a Segunda Guerra Mundial a confecção de um conjunto de modelos (placas) de referência, apresentando as principais variações de expressão dos traços não métricos encontrados nos dentes por ele estudados. O mesmo foi feito para dentes decíduos, por Kazuro Hanihara. Nesta mesma direção, após ter estudado a população Aleuta (habitantes tradicionais do atual estado norte americano do Alaska), Christy G. Turner II iniciou a confecção de uma coleção de modelos de referência, baseada na mesma produzida por A. Dahlberg, mas ampliando o número de traços analisáveis, apresentados como "Sistema de Antropologia Dental da Universidade do Estado do Arizona" no livro de M. Kelley "Advances In Dental Anthropology" (Kelley, 1991).

A associação dos traços dentários, tanto métricos como não métricos, com a genética de populações humanas foi intensamente explorada por pesquisadores que buscavam explicações sobre a variabilidade humana no planeta, mas principalmente 
buscando respostas para as dúvidas a respeito das migrações e das expansões territoriais das populações pré-históricas. Associando conhecimentos de genética, linguística e traços não métricos dentais, Greenberg et al. (1986) teorizaram uma colonização do continente americano em três levas migratórias distintas. Este trabalho seria contestado por alguns pesquisadores, discordando desde os métodos estatísticos utilizados (Powell \& Steele, 1992; Powell, 1993, 1995) até os próprios resultados obtidos, tanto para análises de dentes como para as técnicas e amostras utilizadas (Neves \& Pucciarelli, 1989, 1990, 1991; Powell, 1995; Powell et al., 1999; GonzálezJosé et al., 2008; Pucciarelli et al., 2008).

Distante da discussão regional sobre o polêmico povoamento da América, Tsunehiko Hanihara seguiria os passos do pai, analisando tanto os traços métricos como os não-métricos em busca de respostas para as variações humanas planetárias intra e inter-regionais, além da origem do homem moderno (Hanihara \& Ishida, 2005; Hanihara, 2008; Betti et al., 2009).

Retornando à Paleopatologia, os estudos sobre as principais patologias que acometem a boca e os dentes, presentes em esqueletos arqueológicos, iniciaram-se nas primeiras décadas do século XX. Assim como as pesquisas em paleopatologias ósseas, os estudos das paleopatologias dentais também são derivados de estudos médicos e, posteriormente, odontológicos. Por se tratarem de áreas da saúde, tanto a medicina como a odontologia (que na ocasião não era uma disciplina autônoma e sim uma especialidade da primeira) buscavam entender os processos de surgimento e de prevenção de doenças como a cárie dental desde o século XIX (Weeks, 1868; Ffennell, 1888).

Estudos realizados nos anos 1920 começaram a aplicar o conhecimento gerado pelas áreas médicas em exemplares arqueológicos. Pesquisadores da área da saúde e da arqueologia começaram a compartilhar o interesse na união dessas duas áreas com o objetivo de extrair a maior quantidade possível de informações dos esqueletos exumados nos sítios arqueológicos (Gillett, 1927).

Dentre os primeiros trabalhos sobre Paleopatologia das populações nativas norte-americanas, R.C. Bentzen (1929) avaliou as condições dentárias de nativos do 
sudoeste norte-americano, analisando 26 maxilas e 29 mandíbulas dos 130 indivíduos exumados em 2 sítios no Mimbres Valley - Novo México.

Também com amostra de nativos norte-americanos, Leigh teve à sua disposição 4 diferentes etnias, avaliando além da morfologia dentária, cárie, desgaste, abcessos e patologias ósseas periodontais (Leigh, 1925).

Já com amostras escavadas em terras meridionais, outros pesquisadores norteamericanos se beneficiaram das coleções de esqueletos peruanos dos museus e das instituições de ensino norteamericanos. Tendo à sua disposição uma importante coleção de esqueletos originários de sítios localizados na bacia do rio Urubamba e escavados pelo professor Hiram Bingham, G. Mac Curdy apresentou um trabalho descritivo, mas muito minucioso, da morfologia e das patologias, tanto gerais como dentais, dos exemplares disponíveis (Mac Curdy, 1923).

T.D. Stewart (1931) utilizou as amostras de nativos peruanos do período précolombiano que estavam sob a guarda do United States National Museum em seu estudo clássico. Ele observou patologias como cárie, abcessos, dentes perdidos em vida e problemas periodontais, buscando entender as diferenças entre os sexos, a idade e principalmente entre as raças. Para responder a esta última pergunta, ele comparou o padrão dentário encontrado nas amostras sulamericanas com amostras de nativos da região do Ártico, onde ele observou um padrão alterado de marcadores dentários, segundo ele, devido à influência do "homem branco" na dieta destes esquimós do estado do Alaska - EUA. Para o autor, diferenças entre raças poderiam existir, mas esta afirmação dependeria da confirmação por um número maior de trabalhos.

P. Schulz inicialmente buscava relacionar a posição dos esqueletos enterrados com a posição do pôr-do-sol nas diferentes épocas do ano, na costa oeste norteamericana (Califórnia-EUA), tentando descobrir uma sazonalidade nas mortes desta comunidade. $\mathrm{O}$ autor encontrou cerca de $80 \%$ destes enterramentos feitos durante 0 inverno. Continuando seu trabalho com a mesma amostra, P. Schulz procurou nas patologias bucais indicação do padrão de subsistência deste mesmo grupo (Schulz, 1970). A presença de um baixo índice de cárie encontrado somado ao alto índice de 
desgaste dentário nos esqueletos sugeriram uma dieta rica em proteína e pobre em carboidrato, seguindo os conhecimentos sobre a relação positiva entre carboidratos e cárie dentária já sedimentados e aplicados em diversos trabalhos nas áreas médica e antropológica (Anonymous, 1949; Kennedy, 1960; Baumhoff, 1963).

A Paleopatologia de um modo geral ainda estava em crescimento, sendo uma disciplina menos popular quando comparada com o estudo da evolução humana ou da variabilidade biológica humana, mas já se mostrava promissora entre os anos 1970 e 1990 (Roberts \& Manchester, 2005 a). Uma peculiaridade encontrada por C. Turner ao fazer um levantamento dos pesquisadores da área é que durante esses anos, a quantidade de mulheres aumentava significativamente entre os pesquisadores e também entre os alunos interessados em paleopatologia (Turner, 2002).

Em 1963, D. R. Brothwell editaria "Dental Anthropology", um livro reunindo trabalhos apresentados no "Symposia of the Society for the Study of Human Biology", marcando o início das publicações específicas em Antropologia Dental e estabelecendo uma nova especialidade dentro da Antropologia Física (Brothwell, 1963).

Nos anos 1980, as publicações sobre paleopatologia geral apresentavam capítulos cada vez mais elaborados e específicos sobre as patologias dentais, como é o caso da primeira edição de "The Archaeology of Disease" de Roberts \& Manchester de 1981. Mas uma vez emancipada, a Antropologia Dental impulsionaria publicações independentes (Roberts \& Manchester, 2005 b).

A criação de uma associação de pesquisadores em Antropologia Dental surgiu como ideia durante o encontro anual da Associação Americana de Antropologia Física - Knoxville-TN, em 1985, para no ano seguinte, contando com 41 assinaturas de antropólogos e dentistas, tivesse sua fundação efetivada. No mesmo ano de sua criação, a Associação de Antropologia Dental iniciou a publicação de um boletim, o "Dental Anthropology Newsletter", totalmente dedicado ao tema (Scott \& Turner, 2008).

Com o objetivo de reafirmar a importância desta nova área e de publicar a história breve mas densa da Antropologia Dental, G.R. Scott publicou no Annual 
Review of Anthropology um artigo também chamado "Dental Anthropology" (Scott \& Turner, 1988).

Já no início da década de 1990, Marc A. Kelley publicou “Advances in Dental Anthropology", no qual evidencia o progresso da Antropologia Dental desde o trabalho de D.R. Brothwell em 1963 e apresentou métodos e pesquisas sobre tópicos como desgaste dentário, estimação de idade através dos dentes, crescimento e desenvolvimento dental além, claro, das patologias acometidas pelos dentes (Kelley, 1991). Foi nesta década que a busca por padronização nas pesquisas das paleopatologias impulsionou a produção científica na área de paleopatologias dentais. Diversos autores se esmeraram em produzir protocolos de conduta na avaliação das condições gerais e das patologias encontradas nos remanescentes esqueletais exumados pelos arqueólogos.

Em 1994, Buikstra \& Ubelaker editaram o "Standards for Data Collection from Human Skeletal Remains" que se tornaria o "guia prático" de análise de material arqueológico esqueletal, inclusive das principais patologias encontradas nos esqueletos (Buikstra \& Ubelaker, 1994).

Exatamente com o mesmo objetivo, 10 anos depois seria publicado o "Guidelines to the Standards for Recording Human Remains", editado por Brickley \& McKinley. No capitulo destinado ao registro dos dentes e de suas patologias, B. Connell sugere um inventário dental contendo além dos tradicionais tópicos codificados como presença e ausência, perda dentária antes e após a morte, abcessos e cáries, também a computação de dentes fraturados, não erupcionados e em erupção (Brickley \& McKinley, 2004).

Em seu livro "Identification of Pathological Conditions in Human Eskeletal Remains" de 1995, D. Ortner, apresentou um capítulo inteiramente destinado às patologias dentais, dando à cárie dental o devido destaque através da relação entre alimentos ricos em carboidratos e esta patologia oral (Ortner, 2003). No mesmo ano, Charlotte Roberts e Keith Manchester publicam "The Archaeology of Disease", reservando o capítulo de número 4 às patologias dentais e também de alterações dentárias culturais, apresentando raros mas importantes trabalhos evidenciando 
"terapias" cirúrgicas como desgastes intencionais com "obturações" metálicas em indivíduos encontrados em Israel há 2200 anos e na Dinamarca entre 5200 e 3800 anos AP (Roberts \& Manchester, 2005 b).

Outro importante livro "Bioarchaeology: Interpreting Behavior from the Human Skeleton" de Clark S. Larsen enfatizaria a importância, como o próprio nome diz, do entendimento do comportamento e da qualidade de vida humana através das análises de seus esqueletos. Além dos ossos, os dentes e suas patologias são discutidos em capítulos que foram organizados levando-se em conta o comportamento humano e as evidências deixadas no esqueleto. Um dos capítulos aborda as pesquisas que utilizam os elementos químicos presentes nos ossos e nos dentes. Entre os elementos químicos analisáveis estão o cobre, o estrôncio, o magnésio, o manganês e o zinco que são encontrados em concentrações bastante distintas entre populações com agricultura insipiente ou intensiva. Outros elementos químicos e seus isótopos, como o carbono, o nitrogênio, o oxigênio e também os isótopos de estrôncio são utilizados para inferir mobilidade grupal ou tipo de alimentação consumida pelo grupo. Como muitos destes elementos são encontrados tanto na parte orgânica (colágeno) como na parte inorgânica (minerais e apatita) dos ossos e dos dentes, estes últimos passaram a ser entendidos como importantes órgãos fornecedores de material para estas análises (Larsen, 1997 a).

A Antropologia Dental, já amadurecida, ganharia seu marco na literatura acadêmica específica com a publicação do homônimo "Dental Anthropology", de Simon Hillson. Esta publicação é fruto de um longo trabalho iniciado ainda na década de 1970 (Hillson, 1979) e parcialmente publicado no livro "Teeth" de 1986, sendo este último uma obra sobre os dentes de 150 gêneros de mamíferos, incluindo os humanos. Em "Dental Anthropology", S. Hillson dedica cerca de $50 \%$ de seu trabalho às matérias básicas como anatomia, histologia e bioquímica dos elementos dentais, fornecendo ao leitor de forma criteriosa e clara, o conhecimento necessário às associações de causa e efeito das patologias dentais (Hillson, 1996 a).

Assim como a Odontologia impulsionou a Medicina Veterinária no que tange o tratamento das patologias dentais que acometem atualmente os animais domésticos, 
a Antropologia Dental também estimulou o aprofundamento nos estudos dos órgãos dentais de outros mamíferos, principalmente dos primatas.

A criação recente do termo "Ecologia Dental" busca levar ao estudo dos primatas não humanos (mas não exclusivamente a eles) as mesmas relações entre comportamento (principalmente dieta) e dentes. Esta "nova" linha de pesquisa não se limita à morfologia dental, analisando também patologias dentárias como a presença de abcessos, de desgastes, de perdas dentais em vida, de fraturas a até mesmo de cáries nestes animais (Cuozzo \& Sauther, 2012; Cuozzo et al., 2012; Klukkert et al., 2012; Scott et al., 2012).

Retornando às publicações científicas na área dento-antropológica, o boletim informativo "Dental Anthropology Newsletter" se transformou, ao longo de duas décadas de existência, no atual "Dental Anthropology Journal", uma revista on-line, que, apesar da ausência de edições impressas, possibilita aos autores a publicação de seus trabalhos em formato PDF com imagens em cores e em alta definição (Scott \& Turner, 2008).

A Antropologia Dental tem hoje seus trabalhos publicados em jornais específicos como o "Dental Anthropology Journal" e o "International Journal of Dental Anthropology", ambos eletrônicos; mas não exclusivamente, pois há também espaço para este tema nas principais revistas de Antropologia Física como o "American Journal of Physical Anthropology" (AJPA), "International Journal of Osteoarchaeology", "Current Anthropology", entre outras. Também são encontrados trabalhos sobre Antropologia Dental em revistas odontológicas como "Journal of Dental Research" ou "Caries Research". Este aumento na oferta de opções para as publicações na área é para Scott \& Turner (2008) a resposta pelo decréscimo do número de publicações em antropologia dental que o American Journal of Physical Anthropology apresentou nos anos 2000, após impressionante ascensão entre os anos 1970 e 1990.

Hoje, os elementos dentais fornecem muito mais informação do que a simples análise de sua morfologia e das patologias neles presentes. O dente e os tecidos que o constituem são uma importante matéria-prima para análises químicas, como datações através do carbono 14; análises de mobilidade e dieta através dos isótopos de 
estrôncio, carbono, oxigênio e nitrogênio; diagnóstico de deficiências alimentares ou toxicidade através de elementos traços como ferro, zinco e cobre ou de metais pesados como arsênico e chumbo (Larsen, 1997 a; Smith \& Tafforeau, 2008). Além das análises químicas, os trabalhos com microscopia ótica, eletrônica e de varredura vêm apresentando avanços importantes na caracterização da taxa de crescimento de $H$. sapiens e H. neanderthalensis (Smith et al., 2007 a; b, 2010; Smith \& Tafforeau, 2008), na inferência da dieta através do micro-desgaste (Schmidt, 2001; Ungar et al., 2008, 2012; Krueger \& Ungar, 2009; Pontzer et al., 2011) ou mesmo na observação das diferenças de microdesgaste entre indivíduos jovens e adultos e até entre as diversas espécies de hominínios fósseis (Pérez et al., 2011).

Apesar de sua história de quase um século e uma enorme quantidade de trabalhos publicados, a Antropologia Dental ainda se apresenta como um campo promissor de pesquisa nas áreas da Arqueologia, Paleontologia e Ecologia.

Neste trabalho buscarei evidências da qualidade de vida biológica da população pré-histórica dos oásis do deserto de Atacama, à luz das análises das patologias dentárias.

O conhecimento acumulado pela Antropologia Dental ao longo dos anos será aplicado em amostras representativas de 3 períodos distintos presentes no registro arqueológico da região. O impacto na qualidade de vida biológica local durante a influência do Império Tiwanaku na região será avaliada em uma amostra ainda não estudada de crânios do Instituto de Investigações Arqueológicas e Museu da Universidade do Norte do Chile, localizado em San Pedro de Atacama, Chile. 


\section{CONTEXTO ARQUEOLÓGICO}

A bacia do Salar de Atacama, localmente chamada de cuenca, é formada por um grande platô a 2500 msnm e com cerca de $3500 \mathrm{Km}^{2}$ de superfície. Esta bacia é margeada pela cordilheira de Domeyko a oeste, pela cordilheira do Sal a norte e pela cordilheira dos Andes desde o nordeste até o sudeste. Esta bacia drena água tanto subterrânea como superficial, sendo grande parte dela proveniente de rios que descem desde a cordilheira dos Andes pelas quebradas, enormes fraturas geológicas de drenagem e que se orientam majoritariamente no sentido leste-noroeste (Pimentel, 1976).

Foram estas quebradas e as bordas do salar, que recebem essas águas e formam os oásis atacamenhos (Figura 01), as responsáveis pela condição básica de formação dos assentamentos humanos nesta região do deserto de Atacama, há pelo menos 13000 anos (Núñez, 1995; Llagostera \& Costa, 1999; Agüero, 2005; Grosjean et al., 2005).

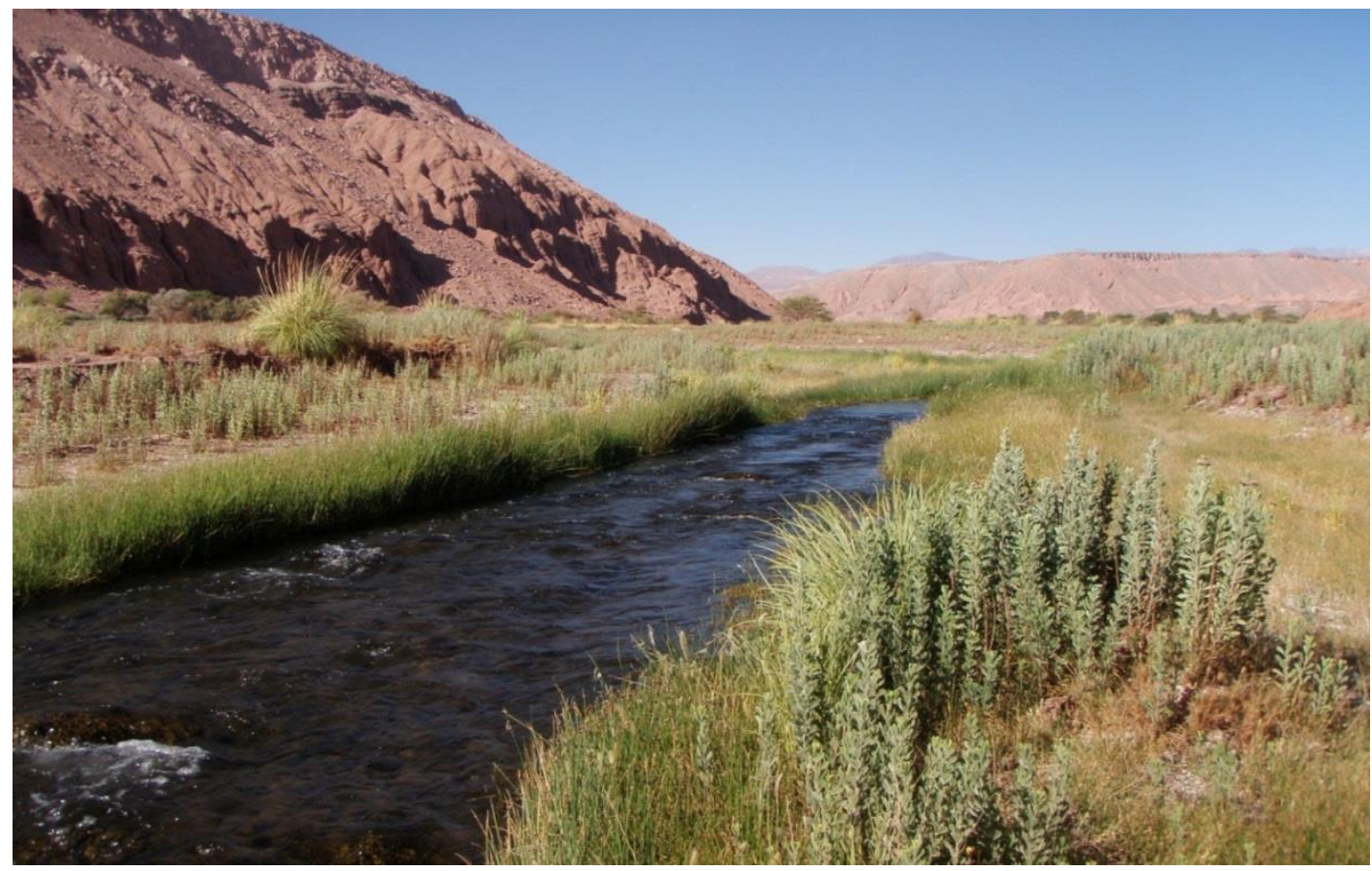

Figura 01 - Quebrada do Rio San Pedro. 
Diferentemente do que propuseram Llagostera \& Costa (1999), que os assentamentos nos oásis das bordas do salar foram estabelecidos apenas a partir do plantio do milho na região, C. Agüero (2005) afirma que estes oásis já estavam ocupados muito tempo antes da domesticação e da utilização deste vegetal na região. Porém, entre 6500 e 3000 anos AC, os ocupantes do deserto buscaram áreas com recursos mais estáveis, abandonando a região próxima ao salar (Núñez \& Grosjean, 1994; Núñez et al., 1997), provavelmente devido a uma enorme seca que aparentemente assolou esta área do deserto (Grosjean et al., 2007).

Apesar dos atacamenhos terem uma história longa de adaptação ao ambiente desértico e também de adequação deste mesmo meio às suas necessidades, foi a partir do período Formativo, após ciclos de presença e ausência na bacia de Atacama (Núñez \& Grosjean, 1994; Núñez et al., 1997), que os oásis do salar ganharam maior relevância arqueológica, devido ao maior número de indivíduos se estabelecendo de forma sedentária na bacia.

J. Rowe (1962) divide o período entre 1500 AC e 500 AD nos Andes Centrais em 3 fases: Período Inicial, Horizonte Temprano e Intermediário Temprano. Este período recebe uma nomenclatura distinta para a região dos oásis do salar, onde o intervalo de 1500 AC a 200 AD é chamado de Período Formativo e entre 200 e 500 AD de Período Agropastoril (Llagostera, 2004). Já para autores como Berenguer et al. (1986) este mesmo período de 1500 AC a 500 AD é denominado simplesmente de período Temprano.

O período Formativo na bacia do salar de Atacama se caracteriza, como o próprio nome sugere, por ser uma etapa na formação das sociedades que viriam a se estabelecer ao redor do salar. Inicialmente considerados como caçadores coletores com alta mobilidade, estas sociedades teriam iniciado sua sedentarização nas próprias quebradas, usadas como se fossem incubadoras do processo por vir. As atividades domesticadoras dos camelídeos andinos se intensificaram nesses sítios devido ao microclima favorável criado dentro dos vales. No entanto, foi mantida a coleta de frutos arbóreos como o algarrobo (algaroba) e o chañar (Figura 02), típicos da região desértica da América do Sul Ocidental (Núñez, 1995). Estes vegetais que são 
fartamente encontrados nos sítios arqueológicos da região, atualmente se encontram em situação de escassez em muitos lugares do deserto devido, principalmente, à utilização de sua madeira como lenha para os centros mineiros da região (Serracino \& Stehberg, 1975).

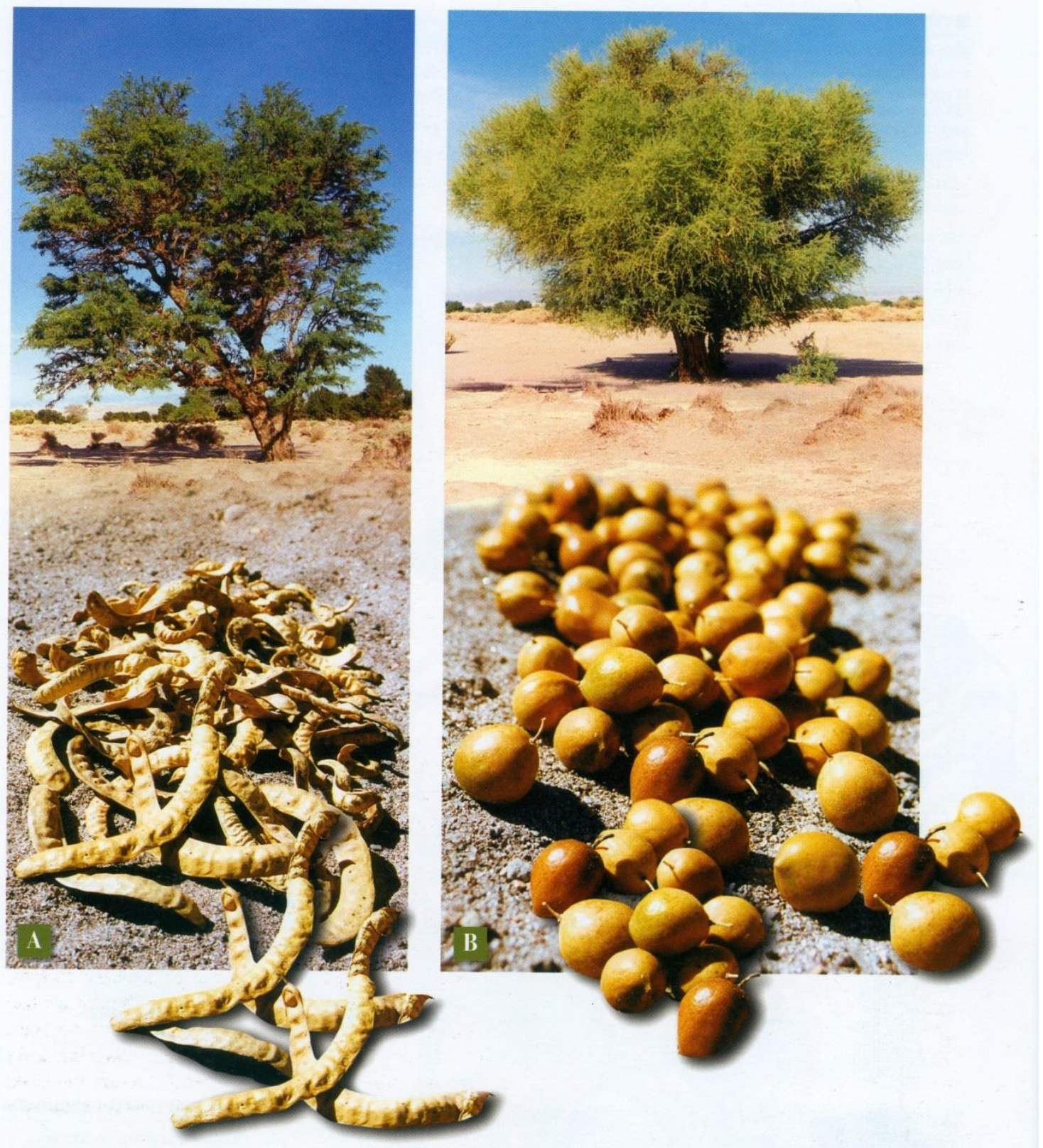

Figura 02 - Árvores e frutos do Algarrobo (Prosopis chilensis) e do Chañar (Geoffroea decorticans) (Llagostera, 2004). 
Por volta de 1800 anos AC, estes assentamentos às bordas do salar iniciaram um caminho sem volta para a sociedade atacamenha, na qual a formação de aldeias estruturadas nos circunscritos mas produtivos oásis do salar debutariam o Período Agropastoril (Llagostera, 2004). Para Llagostera, o Período Agropastoril se estenderia até o fim da presença Incaica nos oásis, no século XVI.

Diferentemente do que propõe Llagostera, outros autores preferem considerar divisões mais detalhadas, subdividindo o Formativo em 3 períodos: Inicial (fase I), Médio (fase II) e Tardio (fase III), sendo que este último se encerra no período conhecido para toda a região Centro-Andina como Horizonte Médio (Agüero, 2005; Adán \& Urbina, 2007; Agüero \& Uribe, 2011).

Independente das diferentes divisões temporais para o período, comum a todos é a mudança evidente do ambiente escolhido para o assentamento. Este período de transição entre a vida preferencialmente dentro das quebradas para o ambiente periférico da puna, muitas vezes às margens do salar, ficou conhecido como Formativo Inicial, compreendido entre 1400 e 400 anos AC (Núñez, 2005). Foi durante o Formativo Inicial que chegou às comunidades atacamenhas o milho, vegetal domesticado na América Central há pelo menos 10000 anos, com alta capacidade produtiva e capaz de propiciar crescimento populacional graças a seu alto potencial calórico (Miranda, 2000). Com o passar dos anos, o milho se estabeleceu como principal produto agrícola e modificou o sistema produtivo horticultor para sistemas agrícolas em maior escala (Figura 03). Assim, observa-se uma expansão das áreas produtivas em direção ao norte do salar, onde se encontravam os demais oásis mantidos pelas águas dos rios San Pedro e Vilama. Esta expansão caracteriza a fase II ou Formativo Médio, tendo os sítios Tulor-1, Toconao Oriente e Coyo como principais zonas de moradia e também como centros políticos (Llagostera \& Costa, 1999). Segundo L. Núñez (2005), até mesmo as aldeias do setor de Tulan, mais ao sul, estariam sob comando destes centros. 


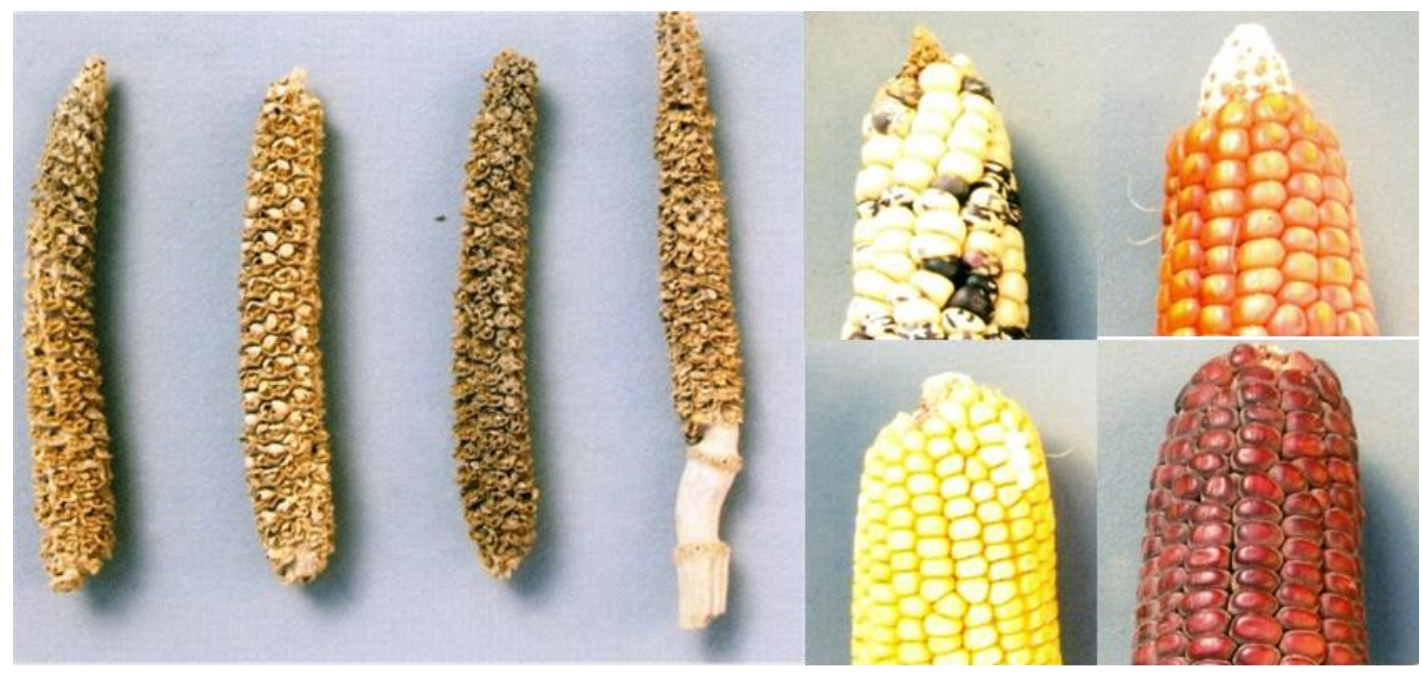

Figura 03 - Espigas de milho arqueológicas e tipos de milhos plantados atualmente na região (Llagostera, 2004).

Apesar das expansões de suas atividades agrícolas para outros oásis, os atacamenhos não abandonaram o costume de utilizar todos os recursos que os diversos ambientes vizinhos ao deserto ofereciam. A alta mobilidade desses grupos, característica do período Arcaico, ficou ainda mais evidente nesta fase de formação da identidade atacamenha. Uma prova disso é a manutenção da criação de camelídeos, principalmente a lhama, nas desembocaduras dos rios, quebradas e nos campos de altitude (Puna), a alguns quilômetros de distância dos oásis. Com essa criação, mantinham a produção de animais utilizados para o transporte de carga e que também forneciam a proteína animal através do leite e da carne necessários para a alimentação da sociedade em expansão (Adán \& Urbina, 2007).

Os camelídeos são, ao longo de toda a pré-história atacamenha, extensivamente representados em inúmeros painéis espalhados por todo o deserto, seja na forma de petróglifos (desenhos esculpidos em pedras) como na forma de geóglifos (desenhos no solo através da disposição de pedras ou de escavações do terreno). A domesticação dos camelídeos andinos data de 5000 anos AC (Janusek, 2008). Porém, as evidências arqueológicas indicam que o fenômeno ocorreu na região do deserto de Atacama apenas por volta de 4500 anos atrás e que os camelídeos passaram a ser organizados em caravanas cerca de 1000 anos mais tarde (1500 anos 
AC). Painéis com imagens destes camelídeos gravados, muitas vezes até pintados em vermelho, são encontrados no vale do rio Loa e também nas quebradas que desaguam no salar de Atacama, mostrando a grande importância que estes animais representavam para que a rede de troca entre as comunidades andinas locais fosse bem sucedida (Gallardo \& Yacobaccio, 2007) (Figura 04).

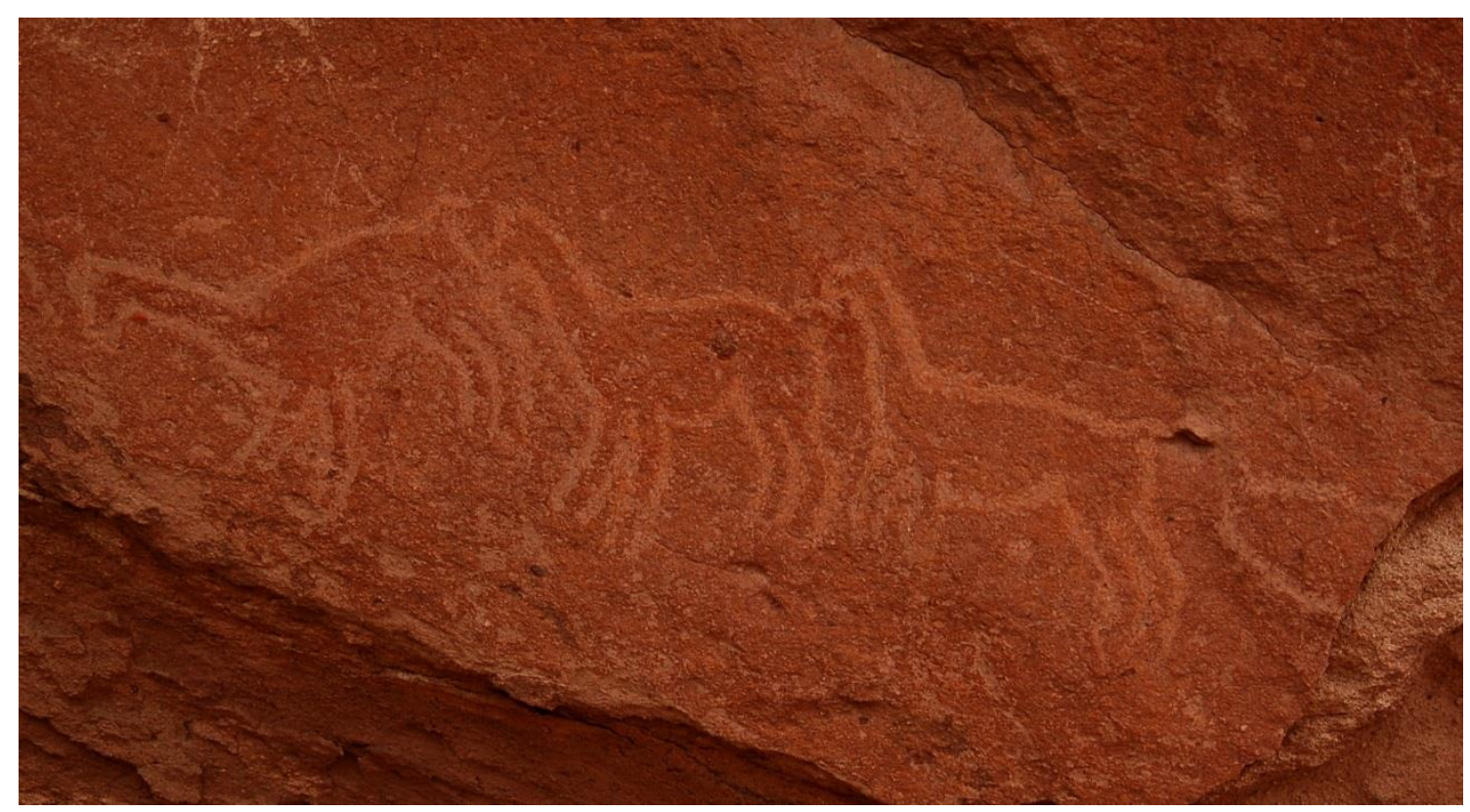

Figura 04 - Petróglifos de camelídeos do sítio arqueológico Hierbas Buenas, San Pedro de Atacama.

Mesmo mantendo o contato necessário com as comunidades vizinhas para suplantar as carências do ambiente desértico e assim criar um padrão de estrutura política e social muito peculiar de integração puneña, a sociedade atacamenha começou a formar neste momento uma identidade própria, claramente evidenciada na cestaria e na cerâmica produzida a partir de então (Llagostera, 2006).

A cerâmica é talvez o maior representante arqueológico de uma comunidade sedentária e agrícola. Utilizadas como recipientes para alimentos, mas sobretudo para transportar água e a bebida fermentada mais comum nos Andes Centrais, a chicha, a cerâmica atacamenha manteve a opção monocromática feita desde o início de sua produção, durante o Formativo Inicial. Sendo Vermelha Polida ou Cinza Polida, as 
características da cerâmica atacamenha do Formativo Médio as diferenciavam da cerâmica do Formativo Inicial, no qual as vasilhas não apresentam pigmentos externos nem mesmo polimento de sua superfície (Tarragó, 1976). Mas foi no período conhecido como Formativo Tardio, que a cerâmica Negra Polida, criada a partir da inclusão de hematita à argila, despontou como uma das mais belas cerâmicas do mundo andino. Mesmo mantendo sua principal característica de ser objeto utilitário e não apenas decorativo, as peças em Negro Polido apresentam, frequentemente, detalhes antropomórficos que também as diferenciam das cerâmicas que as antecederam (Figura 05). Assim, esta assinatura atacamenha "monocromática e polida" encontrada em sua cerâmica destaca-se por primeira vez e em definitivo da cerâmica dos Períodos Formativo Inicial e Médio (Tarragó, 1976; Berenguer et al., 1986).

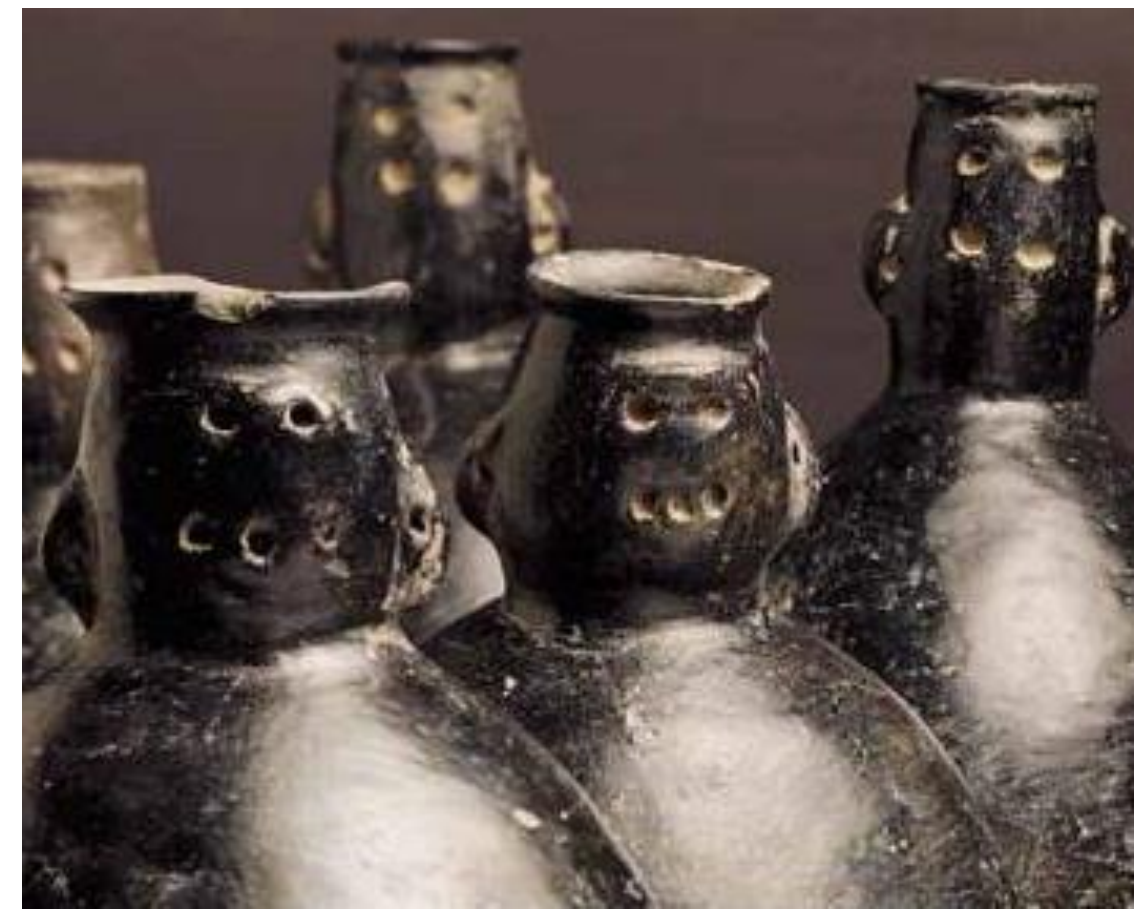

Figura 05 - Detalhes com características antropomórficas dos gargalos de garrafas atacamenhas (Berenguer, 2000).

A cestaria e a produção têxtil atacamenhas trilhariam o mesmo caminho, consolidando suas identidades através de cores, formas e desenhos sofisticados, 
originais e delicados. Estes produtos da cultura atacamenha cuja natureza orgânica prejudicam sua preservação no registro arqueológico, são encontrados na região graças às condições ambientais extremas do deserto.

Os tecidos e cestos apresentam padrões gráficos semelhantes a ícones já anteriormente representados. Um exemplo disso são as lâminas de ouro encontrados no sítio Tulan-54, onde uma delas foi recortada, desenhando assim uma figura antropomórfica que tem, saindo de sua cabeça, raios. Este desenho, além de estar presente em inúmeros geóglifos e petróglifos, se repetiria tanto em tecidos como em outras peças decorativas (Horta, 2004).

Além da produção artística acima descrita, a sedentarização desses grupos também se caracterizou pelo aumento da população. Este adensamento populacional demandou, necessariamente, um aumento na disponibilidade de alimentos seja através de expansão comercial seja através da ampliação da produção agrícola.

A presença da cerâmica Negra Polida típica de San Pedro em lugares tão distantes como a região de Taltal, a mais de $500 \mathrm{Km}$ ao sul, sugere que não apenas a cerâmica mas que toda a sorte de produtos do deserto tenham se difundido, confirmando a necessidade acima descrita de ampliação da rede de troca transandina. Evidentemente, esta não era uma via de mão única. Os oásis de San Pedro apresentam, no seu registro arqueológico, uma grande quantidade de produtos indiscutivelmente estrangeiros. Inúmeras peças cerâmicas com distintas características de forma e cor, produzidas em lugares distantes do salar como as cerâmicas do tipo "Isla" provenientes da quebrada de Humahuaca, localizada na vertente oriental dos Andes, estavam presentes no dia a dia da comunidade atacamenha (Tarragó, 1977).

Alguns metais, principalmente o cobre, foram encontrados e extraídos em abundância do solo norte-chileno nesse período, porém nunca houve extração desses minérios em San Pedro de Atacama propriamente. Assim sendo, a presença de cobre nos oásis confirmaria a atividade das redes de troca. O metal parece trazer consigo um significado importante na substituição de alguns produtos antes produzidos em pedra, conferindo aos poucos indivíduos que os possuíam um status diferenciado na esfera religiosa e política da sociedade atacamenha (Llagostera, 2004). 
Produtos orgânicos com alto valor nutricional ou com valor simbólico também eram trazidos de terras distantes como é o caso da quinoa, cereal andino cultivado no altiplano, ou peixes e conchas de certos moluscos tanto marinhos como de água doce, utilizados como alimento, objetos ornamentais ou mesmo parte do aparato mágicoreligioso (Llagostera et al., 1984). Para transportar estes produtos, as caravanas de Ihamas atravessavam enormes distâncias, ligando o deserto à região costeira do oceano Pacífico, às florestas do noroeste argentino e ao altiplano boliviano, utilizando as inúmeras rotas transdesérticas já estabelecidas desde pelo menos 1300 anos AC por caçadores, coletores e pescadores (Briones et al., 2005).

Talvez o produto estrangeiro mais emblemático, que se tornou parte importante no entendimento da relação entre os atacamenhos e seus deuses, são os artefatos utilizados para o consumo de produtos alucinógenos encontrados em abundância nos sepultamentos. Vindos da Argentina, onde se consumiam produtos alucinógenos desde 2000 AC ou mesmo da costa peruana, também utilizados desde 1200 AC (Torres, 1996), os cachimbos em cerâmica (pipas) de estilos variados já eram encontrados em San Pedro desde o início do Período Formativo. Mas durante o Formativo Médio, estes cachimbos foram substituídos por tabuinhas (tabletas) e tubos para inalar cebil, um produto alucinógeno vindo de regiões mais úmidas da América Andina (Figura 06). Mais de 600 destas tabletas, encontradas apenas em San Pedro de Atacama, são citadas na literatura arqueológica (Torres, 1996). 


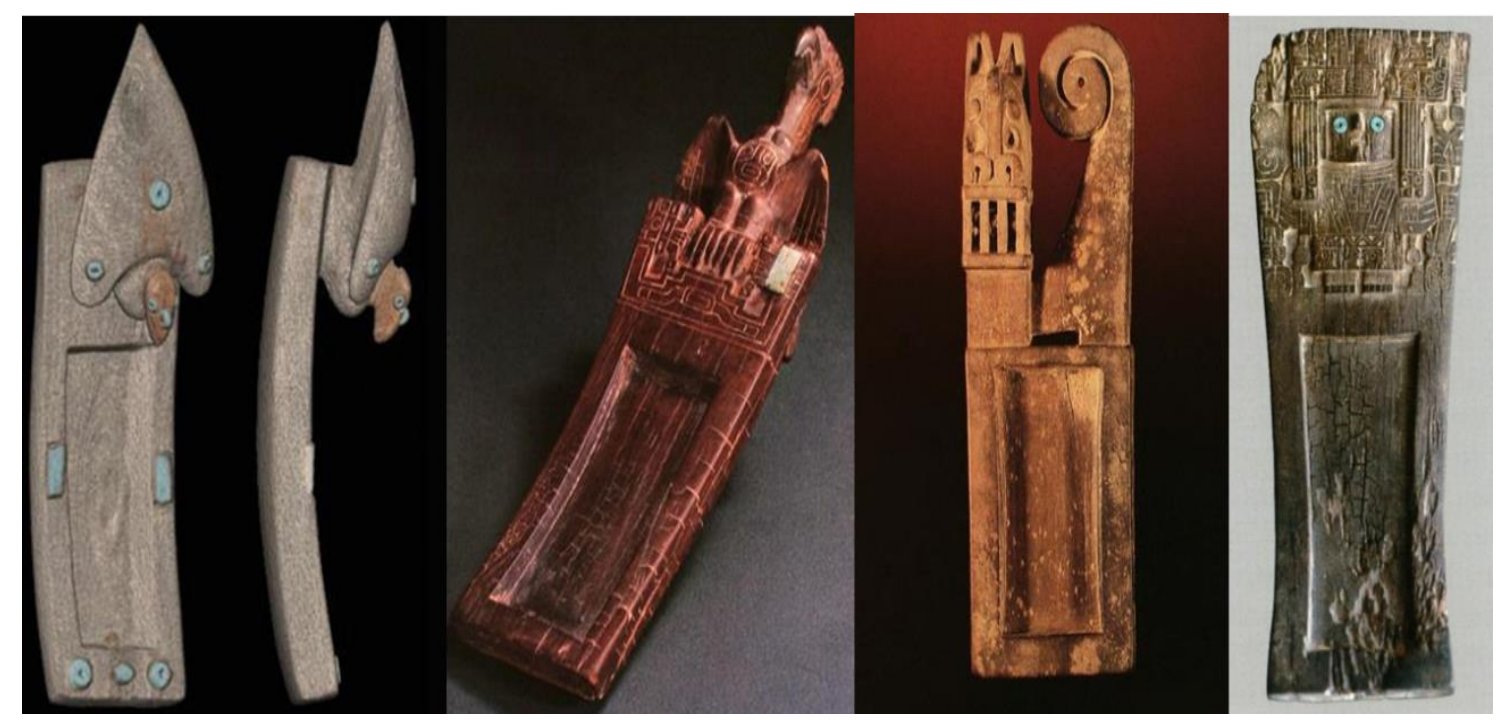

Figura 06 - Tabletas para inalação de substâncias psicoativas (Llagostera \& Torres, 1988; Berenguer, 2000; Cook, 2012; Niemeyer et al., 2013).

Esse alucinógeno, consumido em forma de pó, era extraído das sementes da Anadenanthera colubrina, árvore que cresce desde a face oriental da cordilheira dos Andes até as terras baixas centrais da América do Sul (Figura 07). Para a moagem destas sementes, que podiam ser preparadas após serem torradas ou não, foram utilizados almofarizes e pistilos em pedra ou madeira. Completando a parafernália, espátulas em osso ou madeira para a manipulação do produto além de bolsas em tecido ou couro para armazenagem e carregamento deste kit foram encontrados nos sepultamentos, principalmente do sexo masculino, estando presentes em até $20 \%$ dos enterramentos durante o período 200-900 AD (Torres, 1996). 

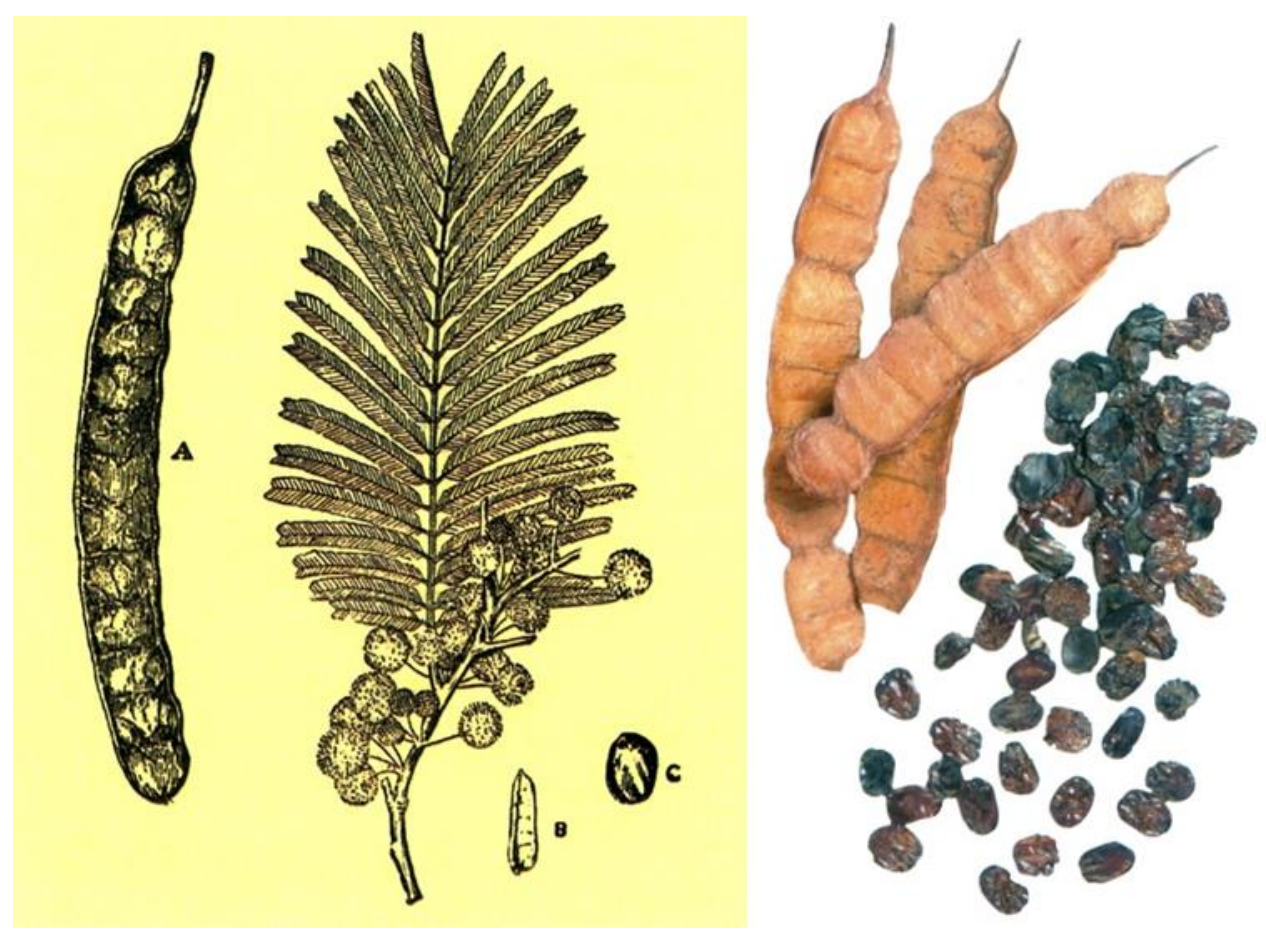

Figura 07 - Anadenanthera colubrina, conhecida na cordilheira dos Andes como "cebil" ou "villca" (Llagostera, 2004; Zuidema, 2009).

Durante o Formativo Inicial, as figuras esculpidas nas tabletas de alucinógenos encontradas em San Pedro não seguiam o estilo atacamenho. Uma destas imagens é a de um personagem com forma humana, dentadura de felino e portando uma cabeça troféu em uma das mãos. Esta figura antropozoomorfa, até então inédita nos oásis atacamenhos, desaparecerá dos oásis atacamenhos durante o período Formativo Médio e retornará séculos mais tarde (Llagostera, 2004).

Numa segunda fase, durante o período Formativo Médio e Tardio, as tabletas começaram a apresentar um estilo próprio regional. Nelas, as figuras humanas (e em alguns casos, felinos) são esculpidas de forma bastante estilizada. Outra característica destas tabletas atacamenhas é a frequente repetição destas imagens humanas, variando de um a até cinco indivíduos na mesma peça, com um grande cuidado em manter a semelhança entre os personagens esculpidos. Nesta fase, as imagens esculpidas nas tabletas nos apresentam informações importantes sobre a estrutura social local e seus símbolos de poder. Os cetros, machados e massas encontrados em diversos sepultamentos da região também eram esculpidos nas mãos das figuras 
humanas presentes nessas tabletas, demonstrando claramente o status social de seus portadores, importantes caciques ou curacas (representantes da nobreza local) (Llagostera, 2006).

Mas enquanto nas terras "pré-punenhas" do norte do Chile a comunidade atacamenha desenvolve sua identidade, buscando independência cultural sem isolarse comercialmente, no altiplano boliviano começava a se desenvolver uma sociedade organizada ao redor de um centro político e de peregrinação religiosa chamado Tiwanaku.

Durante as fases I e II de desenvolvimento deste império, compreendida entre 400 AC a 100 AD, Tiwanaku em nada se destacava das inúmeras aldeias/vilas do altiplano boliviano ao redor do lago Titicaca. Mas foi durante a fase III, entre 100 a 400 $A D$, que essa simples aldeia se transformou, envolvendo então a construção de edificações monumentais jamais vistas na bacia do Titicaca. Coincidindo com a decadência de um importante cacicado desta mesma bacia, chamando Pukara, Tiwanaku se firmou como centro politico e religioso e criou, a seu redor, uma importante cidade utilizando técnicas agrícolas herdadas de outros cacicados da região como Wankarani e Chiripa. Assim, Tiwanaku entrou no seu Período Clássico (400 a 800 AD) ou fase IV, no qual se fortaleceu econômica e politicamente, firmando-se como Estado, expandindo sua presença nos quatro sentidos a partir do Titicaca, alcançando do sul do Peru (que no momento vivia a expansão de outro estado andino, os Wari) ao norte do Chile, da Costa Pacífica ao noroeste da Argentina. Foi durante o período clássico do império Tiwanaku que sua presença se tornou evidente em San Pedro de Atacama (Berenguer, 2000).

O Horizonte Médio, período compreendido nos oásis atacamenhos entre 450 e 1000 AD, apresentou mudanças importantes nas esferas política, econômica e social dessa sociedade local. O aumento das relações comerciais regionais, da densidade populacional e também das oferendas funerárias tanto em qualidade como em quantidade sustenta a ideia de ser este o período de maior desenvolvimento social que as terras habitadas da bacia do Atacama testemunharam até a chegada dos espanhóis no século XVI (Hubbe et al., 2012). 
Quanto ao material associado aos sepultamentos, mais importante que a quantidade destes elementos é a natureza dos produtos que os acompanham. Iniciando em 450 anos AD, a presença Tiwanaku é evidente nos sepultamentos de San Pedro de Atacama, porém, não foram encontrados objetos que sugiram uma miscigenação das características artísticas. Enquanto as cerâmicas tipicamente tiwanakota são encontradas em menor quantidade nos sepultamentos, carregando todas suas cores e enorme diversidade de formas (Figura 08), as cerâmicas atacamenhas se desenvolveram paralelamente, seguindo um curso iniciado na transição do Período Arcaico para o Formativo da região (Llagostera, 2004).

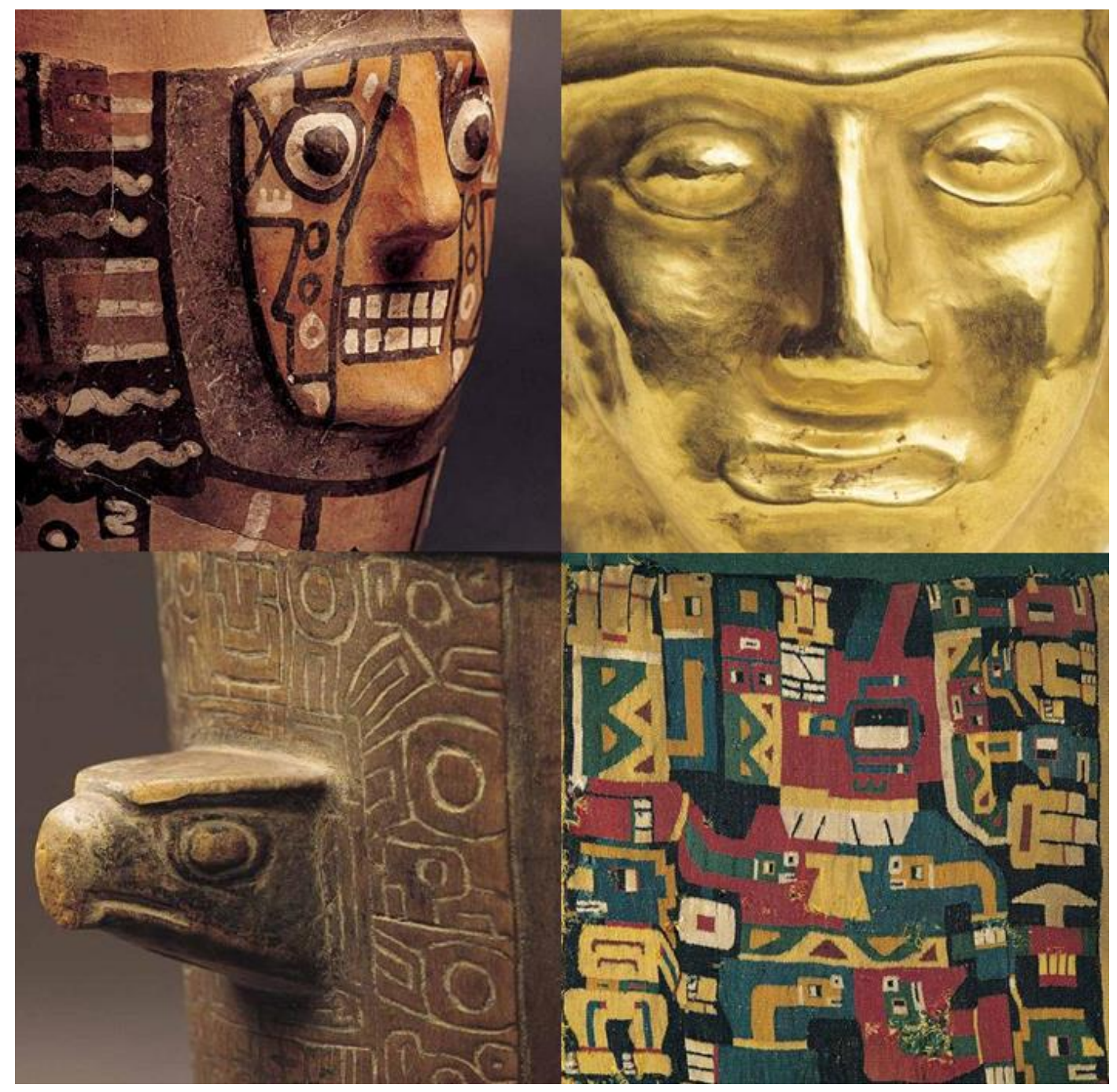

Figura 08 - Cerâmica, metalurgia, escultura e tecelagem tiwanakota (Berenguer, 2000). 
O mais importante trabalho sobre as características da cerâmica atacamenha foi realizado por M. Tarragó (1976) dividindo o período cerâmico em 8 fases distintas, iniciando no período Formativo e terminando no período de colonização espanhola.

Para M. Tarragó, o Horizonte Médio atacamenho foi dividido em 4 fases (fases III, IV, V e VI). Nessas fases, as peças vão "perdendo" a qualidade, aparentando menor cuidado na confecção. Esta mudança é encontrada na cerâmica Vermelha Polida, na Cinza Grossa, mas principalmente na Negra Polida. Esta última, que anteriormente apresentava suas paredes delicadamente acabadas e seus garrafões (botellones) com gargalos esculpidos com representações estilizadas de cabeças humanas, também apresenta esta perda. A cerâmica presente nesse período foi se transformando, gradativamente, em peças mais robustas, aumentando a espessura de suas paredes, diminuindo o nível de polimento e, em relação aos garrafões, perdendo suas características até o completo abandono de sua confecção (Llagostera, 2004).

Berenguer et al. (1986) revisaram as fases propostas por M. Tarragó, somando datas obtidas por termoluminescência às já apresentadas no trabalho dela de 1976. Para eles, as 4 fases que M. Tarragó subdividiu o Horizonte Médio poderiam ser simplificadas em apenas 2 fases distintas, uma vez que a fase III, segundo esses autores, está bem definida quanto às características, porém foi datada entre 100 e 400 $A D$, já a fase VI não se sustentaria como uma fase distinta, devendo ser incorporada às demais. Com isso, a fase IV de M. Tarragó foi renomeada como a fase Quitor (entre 400 e 700 AD) enquanto a fase $V$ passou a ser chamada de fase Coyo (700 a 1000 AD).

As tabletas utilizadas para inalar psicotrópicos, durante o Horizonte Médio, exibem algumas características tipicamente altiplânicas como as imagens de deuses antropomórficos ou antropozoomórficos decapitadores, as imagens de felinos (onças ou jaguares e pumas) e de aves de rapina (falcões) ou necrófagas (condores). Em quantidade menor, foram encontradas tabletas com representações de camelídeos, de répteis e de outros animais. Para A. Llagostera, a quantidade de tabletas com características estritamente tiwanakotas é relativamente pequena frente à quantidade total encontrada em sítios desse período. 0 autor encontrou apenas $17,5 \%$ de tabletas com estas características. Porém, os mais de $80 \%$ restantes encontrados nos sítios 
atacamenhos apresentam o estilo tiwanakota evidentemente miscigenado com o de outras culturas sul-americanas vizinhas. Um ser mítico decapitador ou também chamado de sacrificador (Figura 09), muitas vezes representado por uma figura antropomórfica ou antropozoomórfica, é fartamente encontrada nas tabletas e nos tubos inaladores de origem tiwanakota (Llagostera, 2006).

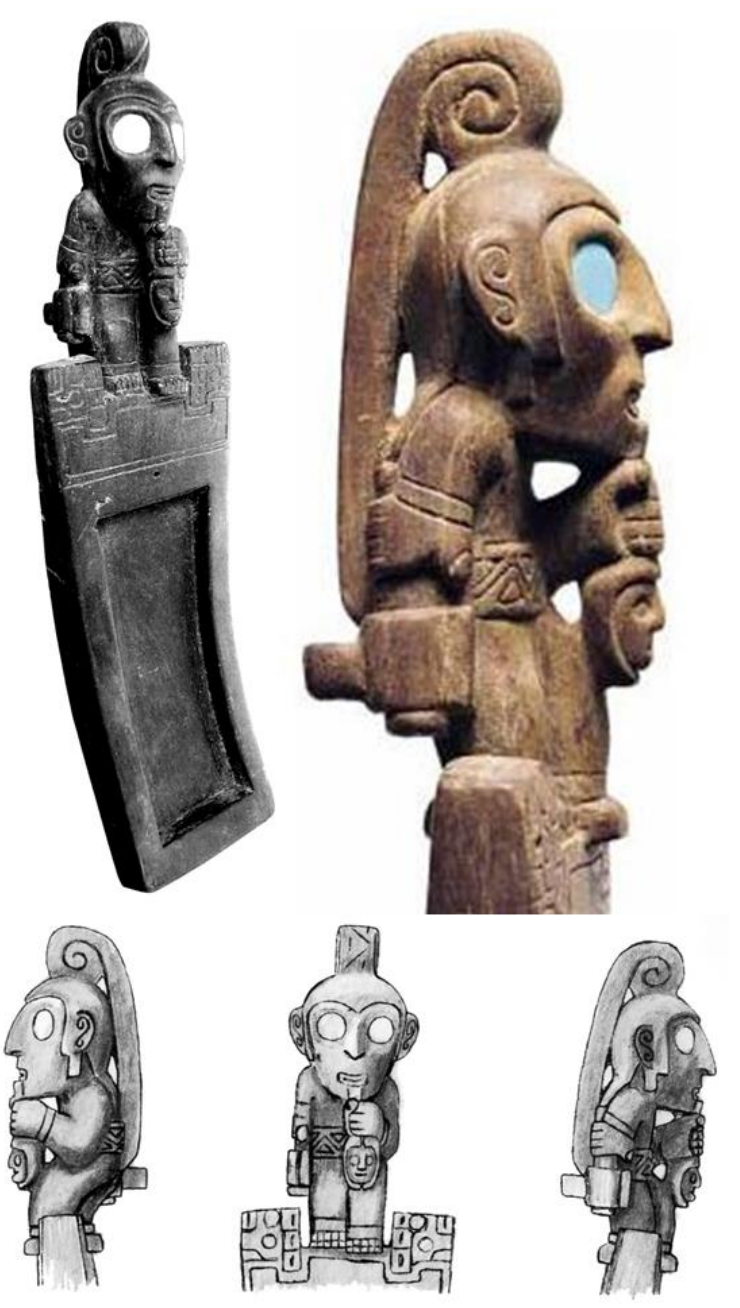

Figura 09 - Imagem do sacrificador esculpida em tableta para inalação de A. colubrina (Berenguer, 2000; Llagostera, 2004).

Esta imagem está diretamente associada ao ritual de sacrifícios realizado pelo Império Tiwanaku, confirmado por achados numa das pirâmides do centro cerimonial de Tiwanaku chamada Akapana. Ali, além dos restos humanos e de camelídeos 
encontrados nitidamente manipulados, diversas peças em cerâmica e em metais preciosos como o ouro foram achados (Manzanilla \& Woodard, 1990).

Considerado o período de maior fartura em toda a história dos oásis, durante o Horizonte Médio não só os acompanhamentos funerários encontrados apresentaram um aumento em quantidade e qualidade. Esta evidente riqueza material encontrada nos sepultamentos também deve ter se estendido aos viventes, indicando que foram direta ou indiretamente beneficiados pelo esplendor altiplânico (Berenguer, 2000).

Em busca desta resposta, pesquisadores dedicaram-se a elucidar, através das análises de estatura de homens e mulheres. Além das patologias encontradas nos sepultamentos, a influência direta ou não do Império Tiwanaku na qualidade de vida da população atacamenha. Para isso, estes pesquisadores contaram com a amostra esqueletal presente no museu de San Pedro. O excelente estado de conservação da maioria do material arqueológico encontrado nos sítios da região se deve, primordialmente, à natureza local conforme já comentado (Figura 10). O solo de desertos como os de Sechura e Ica no Peru e de Atacama no Chile, nos Andes Centrais, apresenta uma condição muito particular para a preservação de restos orgânicos animais e vegetais. Com isso, a quantidade de material arqueológico encontrado nesses setores andinos é abundante e de excelente qualidade para análise. Devido à sua alta salinidade, sua altitude e consequentemente menor pressão de oxigênio e por fim, a baixíssima umidade ali encontrada, o deserto de Atacama apresenta um importante acervo de material esqueletal humano disponível para o estudo da "Qualidade de Vida" dos seus habitantes (Alonso \& Risacher, 1996; Costa et al., 1998). 


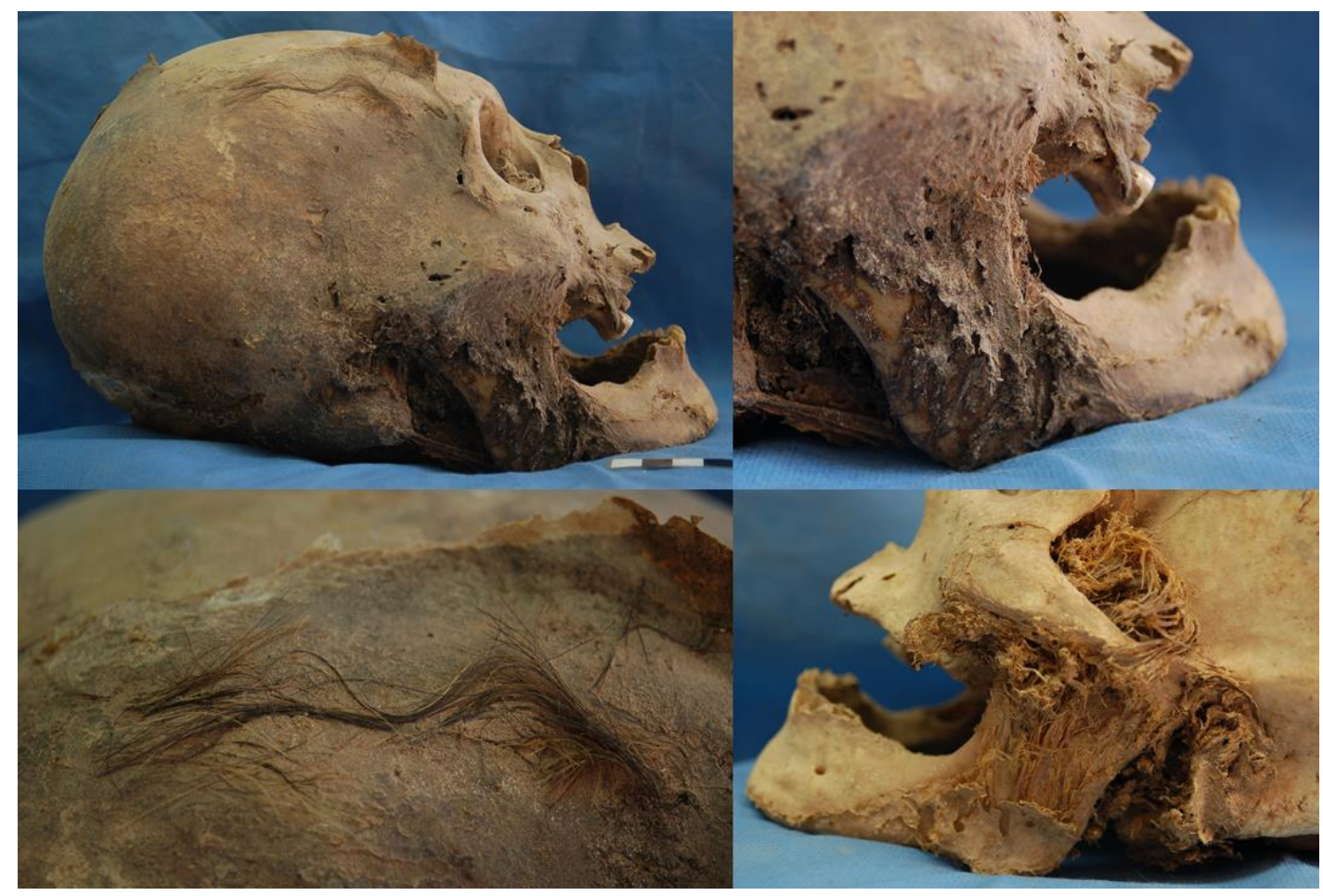

Figura 10 - Crânio naturalmente mumificado (sepultamento 44) encontrado em Caspana, em excelente estado de conservação.

Neves \& Costa (1998), por exemplo, analisaram o comprimento dos fêmures de 117 indivíduos encontrados em 3 diferentes sítios arqueológicos representantes de 4 períodos distintos de ocupação dos oásis atacamenhos. Os autores encontraram variações importantes, principalmente para os indivíduos do sexo masculino durante os 4 períodos. Nesse trabalho os autores encontraram melhoria na alimentação da população masculina durante o período de influência Tiwanaku em San Pedro, representada pela maior estatura desses indivíduos.

Aumentando o número de indivíduos destes 3 sítios para 161 e também analisando as patologias bucais e os traumas encontrados nestes exemplares, Costa et al. (2004) encontraram as mesmas diferenças do trabalho anterior, ou seja, que teria havido uma melhoria na qualidade de vida da população durante o período Tiwanaku em San Pedro de Atacama, regredindo paulatinamente no período após o declínio de influência do estado andino na região. 
Apesar das ideias até então defendidas de uma presença tiwanakota marcada apenas através de ideais religiosos e de uma expansão na rede de troca entre as comunidades andinas (Núñez, 2007), Lessa \& Souza (2006) discordam dessa expansão pacífica proposta pela maioria dos autores. Para ambas, esse período não foi tão tranquilo como apresenta a análise de traumas feita por Costa et al. (1998). Essas pesquisadoras encontraram traumas na face e no neuro-crânio, considerados como resultados de episódios violentos e não como lesões casuais, em maior número na população atacamenha durante o Horizonte Médio, principalmente na população masculina. Para elas, assim como outros autores, tais traumas foram resultados de um antigo ritual andino conhecido como Tinku, até hoje presente em algumas regiões bolivianas, no qual os homens de diferentes famílias ou grupos lutavam com o objetivo de oferecer seu sangue à Pachamama, considerada a deusa da terra e responsável pela fertilidade e pela abundância de alimentos (Celestino, 1997; Lessa, 2007). Mas Lessa \& Souza explicam a violência do período através das lesões resultantes de agressões por armas brancas como flechas, que segundo elas, indicam um aumento de violência entre grupos distantes, num combate diferente do corpo-a-corpo encontrado nos rituais do Tinku (Lessa \& Souza, 2004).

Este mesmo aumento de violência, é creditado por alguns autores à expansão dos ayllus (aldeias) e ao aumento da densidade demográfica observado na região, ao aumento de combates internos e à crescente tensão intra-grupal, descartando a ideia de uma presença militar violenta de Tiwanaku na região de San Pedro de Atacama (Torres-Rouff \& Costa Junqueira, 2006).

Independente desse aumento de violência, o aumento das áreas ocupadas nos oásis, o aumento da densidade populacional e também uma notada abundância na disponibilidade de proteína animal, provavelmente carne de lhama, para alguns atacamenhos (novamente com preferência aos indivíduos do sexo masculino) indicam uma melhor qualidade de vida desta população durante o período em questão (Hubbe et al., 2012).

Contudo, Tiwanaku é considerado um estado que teve sua força expansiva mas também agregadora baseada num mecanismo de reciprocidade e de ideologia comum, 
aliciando as elites locais e procurando manter a estrutura social local inalterada (Albarracin-Jordan, 1996).

Por volta de $1000 \mathrm{AD}$, uma mudança climática de proporções continentais assolou grande parte da América Central e da América do Sul, desestabilizando grandes estados que tinham na sua produção agrícola o alicerce fundamental. Diferentes áreas da América do Sul apresentaram variações extremas de temperatura, afetando o meio ambiente local e forçando, assim, migrações, adaptações e em algumas regiões do continente americano, colapsos de grandes sociedades (Peterson \& Haug, 2005).

Nas terras baixas, enquanto os verões no norte da Patagônia apresentavam-se mais frios entre 900 e 1070 AD (Villalba, 1994), o registro arqueológico mostra interrupções em diversas culturas amazônicas devido a períodos de secas na região (Meggers, 1994). Quando atravessamos os Andes e buscamos evidências desses episódios de variações climáticas extremas do lado oriental da América do Sul, os vales costeiros do Norte do Peru nos mostram um cenário diametralmente oposto: expressivos períodos de chuva intensa, provocando alagamentos e enchentes em diversas regiões, principalmente nos vales de Moche e Jequetepeque como resultado do que se convencionou chamar de mega El Niño (Meggers, 1994).

Estudos com o sedimento encontrado em solo venezuelano da Bahia de Cariaco sugerem um período de importante seca na região, o que para Peterson \& Haug (2005) explica o colapso do grande Império Maya na península de Yucatán, localizada na costa Atlântica do Caribe.

Secas também são encontradas em outros pontos da América do Sul por volta de 1000 AD. Para Mayewski et al. (2004), a face ocidental da cordilheira dos Andes sofreu um longo período de seca nessa época.

Observando os sedimentos do leito e da borda do Lago Titicaca, principal lago do altiplano boliviano e a apenas $30 \mathrm{~km}$ do centro de Tiwanaku, Binford et al. (1997) encontraram uma diminuição considerável no nível do lago por volta do ano 1000 AD, estando cerca de 10 metros abaixo do nível mínimo encontrado atualmente. 
Diretamente relacionado ao índice pluviométrico, a seca encontrada também em outras regiões andinas parece ter sido o principal motivo de uma desestruturação Tiwanaku.

Mayewski et al. (2004) analisaram dados obtidos através de estudos com espeleotemas/estalactites, gelos glaciares, variações de emissão de raios-X, pólen, conchas lacustres entre outros para formularem um mapa global com a distribuição das variações climáticas durante o período compreendido entre 7000 AC e 1400 AD. Nesse trabalho, os autores apresentam dados que corroboram a ideia de que os anos próximos a 1000 AD foram épocas de grandes secas em toda a face ocidental dos Andes.

Quando as variações climáticas são extremas em termos de amplitude e de duração, elas excedem a capacidade humana de adaptação (Binford et al., 1997). Isto explicaria como o Império Tiwanaku, possuidor de uma tecnologia de irrigação e plantio tão sofisticados para a época, sucumbiu após séculos de êxito às margens do lago Titicaca.

Porém, o colapso do império Tiwanaku só ocorreu por esta grave alteração climática incidir sobre um estado já fragmentado política e socialmente (Janusek, 2004).

Conhecido como Período Intermediário Tardio (PIT) para todos os Andes Centrais, a fase que se segue após o colapso do Estado Tiwanaku foi mais impactada pela alteração climática do que pelo desmantelamento da rede de troca comercial e religiosa que se estabeleceu durante o Horizonte Médio. Este período é considerado como o período da segunda diáspora de Tiwanaku, no qual os habitantes das regiões altiplânicas mais afetadas pela seca migraram em busca de áreas mais amenas encontradas em regiões com menor altitude e mais próximas a recursos hídricos permanentes (Owen, 2005).

Se o período de transição entre o Formativo e o Horizonte Médio foi marcado por um empobrecimento na qualidade das peças cerâmicas encontradas nos sepultamentos, a transição deste segundo para o Período Intermediário Tardio 
apresentou uma queda de qualidade ainda maior, além de importante diminuição na quantidade dos acompanhamentos funerários. Aliás, durante os primeiros anos do PIT, é muito comum encontrar sepulturas sem nenhum tipo de acompanhamento funerário (Costa, 1988). As peças cerâmicas encontradas como acompanhamento mortuário são em sua quase totalidade, exclusivamente utilitárias, representadas por pratos simples com pouquíssimo acabamento, pintura e polimento. Por vezes, os recipientes cerâmicos foram substituídos por cabaças demonstrando uma simplificação nunca antes observada na região (Llagostera, 2004).

Porém chama atenção a presença, ainda que em menor frequência, de acompanhamentos funerários contendo materiais metálicos. Diferentemente do acontecido no período anterior, no qual era observada a presença majoritária do cobre e do bronze (liga metálica contendo cobre e estanho) ou da abundância de obras em ouro, como nos sepultamentos encontrados no cemitério de Larache ou "Señorio de Larache", outros metais passaram a ser mais frequentes nas oferendas mortuárias. 0 cobre, extraído de minas do próprio deserto como as de Chuquicamata (maior mina de extração de cobre a céu aberto atualmente no mundo), foi então substituído pela prata, metal obtido de localidades distantes como a região de Lípez, atual Potosí, importante região mineradora desse metal na Bolívia.

Apesar do enfraquecimento das redes de comércio da região, San Pedro continuou conectado com seus vizinhos mais próximos do sul boliviano e também do noroeste da Argentina, comunidades que sempre se fizeram presentes através de diversos produtos utilitários em cerâmica, cestaria e tecido (Costa, 1988; Llagostera, 2004).

Devido à grande seca, a água se tornou o recurso primordial e mais cobiçado pelos atacamenhos. Os ayllus localizados mais ao norte/noroeste de San Pedro tornaram-se zonas preferenciais de concentração da população remanescente no local. A construção de fortificações ao longo das quebradas por onde descem os dois principais rios da região indica uma mudança brusca na relação entre as comunidades do deserto durante este período. 
Conhecidas como Pukaras, estas fortificações são encontradas nas encostas dos vales dos rios San Pedro e Vilama e foram utilizadas não apenas como pontos de vigília ou guarda da população (por estarem localizadas em pontos estrategicamente favoráveis ao monitoramento do espaço) mas também como áreas de moradia do povo atacamenho, aparentemente buscando proteção durante este período no qual o aumento das tensões intra e interpopulacional se fez presente (Costa, 1988; TorresRouff \& Costa Junqueira, 2006; Hubbe et al., 2012) (Figura 11). O já mencionado Señorio é a nova estrutura política e social encontrada na região (Hubbe et al., 2012).

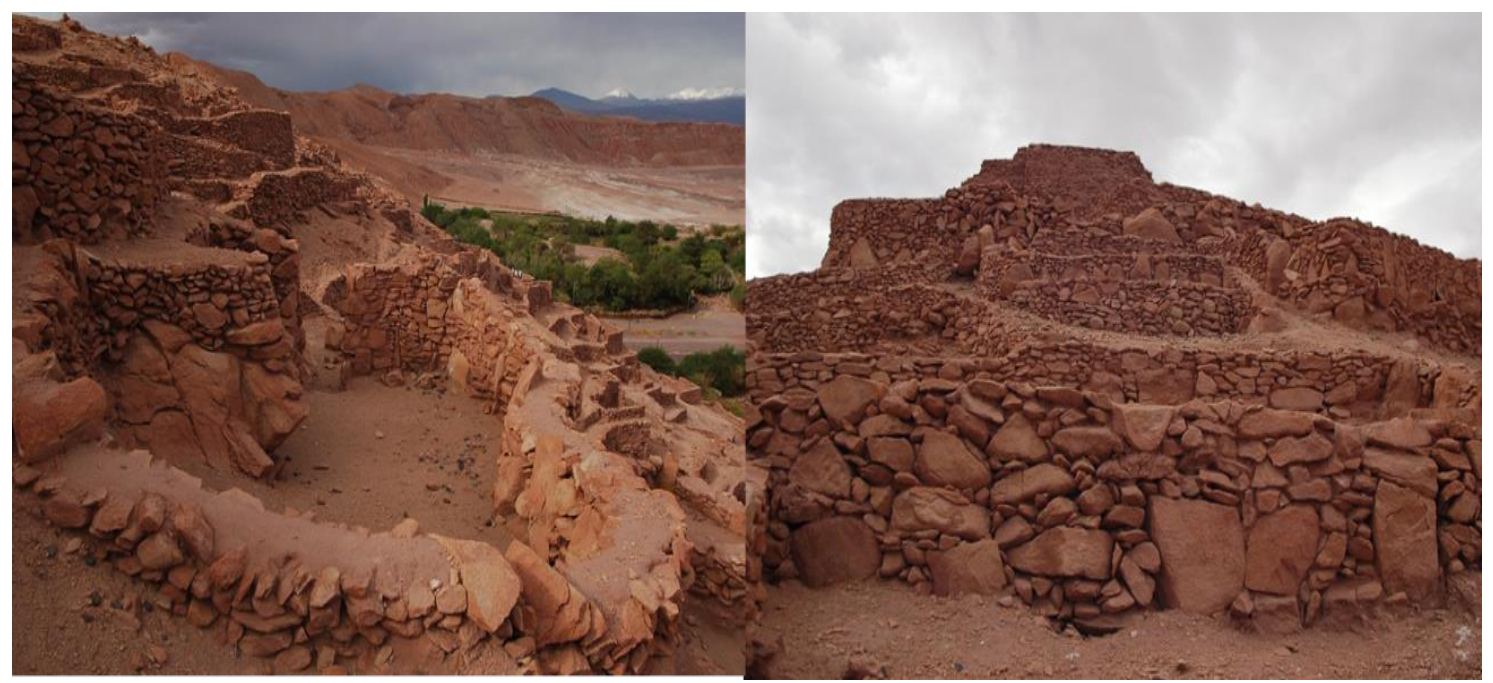

Figura 11 - O Pukara de Quitor em San Pedro de Atacama, Chile.

Obviamente com o fim do Estado forte de Tiwanaku, a cosmovisão por ele difundida durante seu esplendoroso período de influência, também ruiu. Muitos dos ícones tiwanakotas desapareceram do registro arqueológico em San Pedro mas um deles ainda persistiu: o Sacrificador. A imagem do ser decapitador, apesar de presente principalmente em tubos de inalação de alucinógenos, também sofreu com a transformação que toda a comunidade atacamenha testemunhou. A forma antropomórfica deste ser mítico desapareceu, restando um antropozoomórfico diferente dos observados durante o Horizonte Médio. Agora este ser é representado por uma entidade demoníaca, com aparência vampiresca, muito diferente dos 
zoomórficos do período Tiwanaku que se remetiam a animais como o puma ou os camelídeos andinos (Llagostera, 2004).

Discordando da semelhança entre as imagens encontradas e os morcegos durante o Período Intermediário Tardio, C. Torres acredita que esta entidade representada em abundância nos tubos inalatórios são representações de zorros (raposas) que até hoje, segundo o autor, seguem fazendo parte do folclore local (Torres, 1984).

Novos personagens surgiram no "panteão" atacamenho, representados nas tabletas de alucinógeno: o condor e os grandes felinos, porém de forma mais estilizada. O puma e a onça (jaguar) são animais recorrentes nas associações com os psicotrópicos não apenas nos Andes mas por toda a América do Sul, sendo encontradas referências a estes dois grandes felinos em culturas na Colômbia e até mesmo na Amazônia brasileira (Torres, 1984).

Na cerâmica, surgiu um novo estilo, retomando o esmero que qualificava a cerâmica regional durante o período pré-Tiwanaku, com suas cerâmicas negras polidas. Agora, as cerâmicas sanpedrinas voltam a ter seu desenho mais elaborado e a apresentar, como de praxe, uma aparência monocromática. Porém, as panelas e tigelas são acabadas com engobe ou mesmo pinturas na cor vinho ou vermelhovioláceo, inéditas na cerâmica da região (Tarragó, 1976; Berenguer et al., 1988).

Para os oásis de San Pedro, o Período Intermediário Tardio é chamado de Período de Desenvolvimento Regional (Costa, 1988). É neste período que a violência encontrada nos territórios atacamenhos atinge níveis expressivos.

Costa et al. (1998), ao analisarem as lesões traumáticas de origem violenta, não observaram diferenças significativas entre os períodos estudados. Já Lessa \& Mendonça de Souza (2009), ao analisarem apenas indivíduos do sítio Quitor 6, encontraram nesta amostra uma prevalência menor de traumas violentos durante o Período Intermediário Tardio que durante o Horizonte Médio.

Torres-Rouff et al. (2005), contradizendo estes dois trabalhos, encontraram um aumento destas lesões traumáticas. Este aumento está em concordância com o 
aparecimento, durante o Período Intermediário Tardio, das fortificações construídas em San Pedro de Atacama (pukaras). Com frequência superior a 35\%, os indivíduos analisados de Coyo 3, sítio datado do período de transição entre o Horizonte Médio e o Intermediário Tardio, apresentam traumas tanto entre os homens, como nas mulheres (Figura 12). Para os sítios Quitor 6 e Yaye, representantes da fase intermediária do Período de Desenvolvimento Regional, os valores apresentam uma retração, chegando a patamares de $23,8 \%$ e $29,2 \%$ respectivamente, ainda altos em comparação aos períodos anteriores ao Desenvolvimento Regional (Torres-Rouff et al., 2005; Torres-Rouff \& Costa Junqueira, 2006).

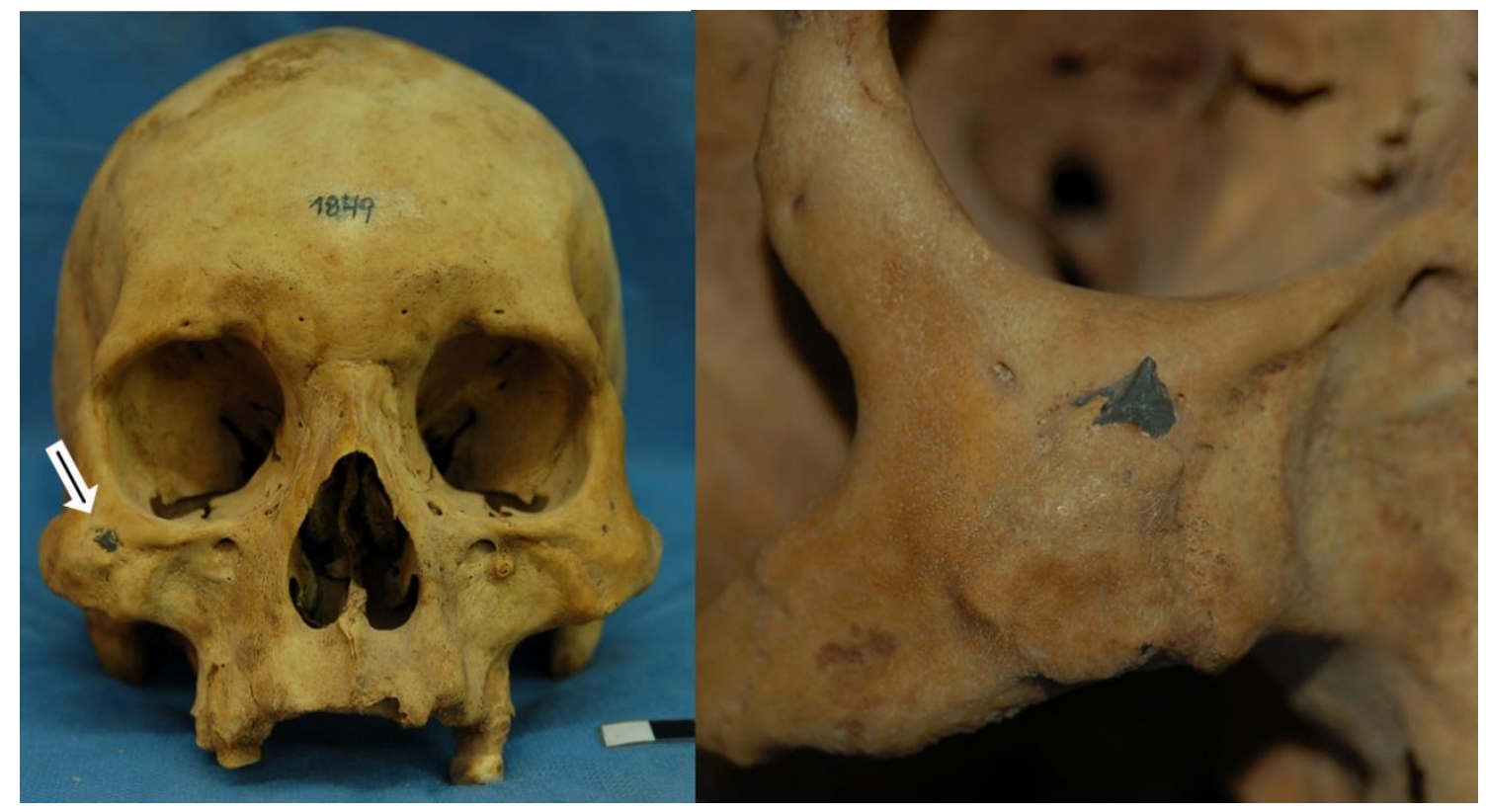

Figura 12 - Lesão óssea resultante de trauma violento com instrumento perfuro-cortante (Catarpe 2 \#1849).

Inversamente proporcional aos traumas e racionalmente esperado, a qualidade de vida biológica nos assentamentos atacamenhos apresentou uma queda. A estatura dos homens que apresentou um aumento significativo durante o período Tiwanaku sofreu uma queda, também significativa, neste período (Neves \& Costa, 1998). A qualidade de vida também se deteriorou quando se analisam as lesões de cárie nos dentes dos atacamenhos, encontrando-se um aumento desta patologia assim como 
um aumento do desgaste dentário durante o período de Desenvolvimento Regional (Costa et al., 2004).

Com as dificuldades em produzir produtos agrícolas em diversas partes do altiplano, do deserto e arredores, as caravanas de lhamas se fizeram essenciais para o fornecimento de produtos a estas regiões.

A comunicação e interligação entre zonas distantes que antes pareciam fazer parte de um programa do Estado Tiwanaku, neste momento passaram a ser "responsabilidade" das caravanas independentes que cruzavam as vastas áreas do deserto, possibilitando a manutenção de fornecimento de produtos como moluscos marinhos do Oceano Pacífico, moluscos lacustres de zonas mais quentes e úmidas, o sempre presente e necessário cebil e toda a sorte de alimentos, entre outros produtos. Ao longo do deserto de Atacama, as áreas usadas como descanso (paskanas) por estas caravanas eram marcadas com petróglifos e geóglifos. Numa rota conhecida como "La Transecta Pica-Pintados-Alto Barranco", rota que ligava os oásis da região de Pica (deserto de Atacama) até o litoral, os caminhos e paskanas, além dos cemitérios e os próprios geóglifos forneceram evidências de um intenso fluxo de caravanas ao longo do Período Intermediário Tardio (Briones et al., 2005) (Figura 13).

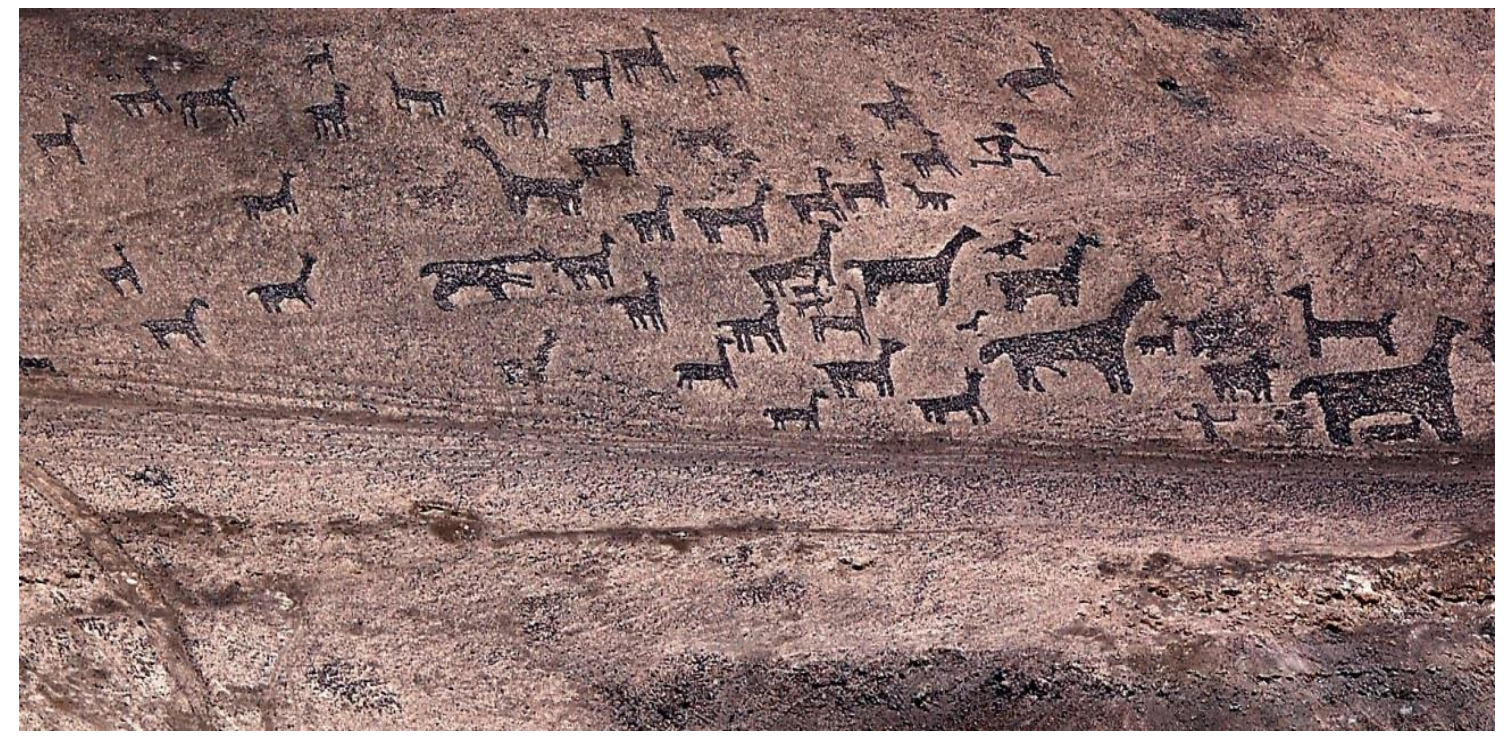

Figura 13 - Geóglifos encontrados nas quebradas do deserto de Atacama, criados para orientar os pastores e os condutores de caravanas de lhamas. 
Enquanto as sociedades atacamenhas, órfãs do Império Tiwanaku, se reestruturaram socialmente e conseguiram, à sua maneira, superar o período de escassez entre os séculos X e XV da era cristã, outra sociedade começava também a se estruturar nos Andes peruanos. Assim como os atacamenhos viram o declínio do Estado Tiwanakota, os peruanos viram o ruir do estado Wari ainda durante o Horizonte Médio (Bergh \& Jennings, 2012).

A cultura Wari é considerada resultado de uma mestiçagem da cultura altiplânica Tiwanaku com a cultura costeira Nazca (Cáceres, 2007) (Figura 14). Seu território ia desde o vale do Moquegua, próximo à fronteira com o Chile, até o vale do rio Moche, no norte peruano. Este Império que floresceu em $600 \mathrm{AD}$, presente em todo o território peruano, tem sua história muito semelhante ao seu vizinho altiplânico boliviano, tendo desaparecido também por volta do ano $1000 \mathrm{AD}$, concomitantemente ao início do declínio Tiwanaku (Bergh \& Jennings, 2012).
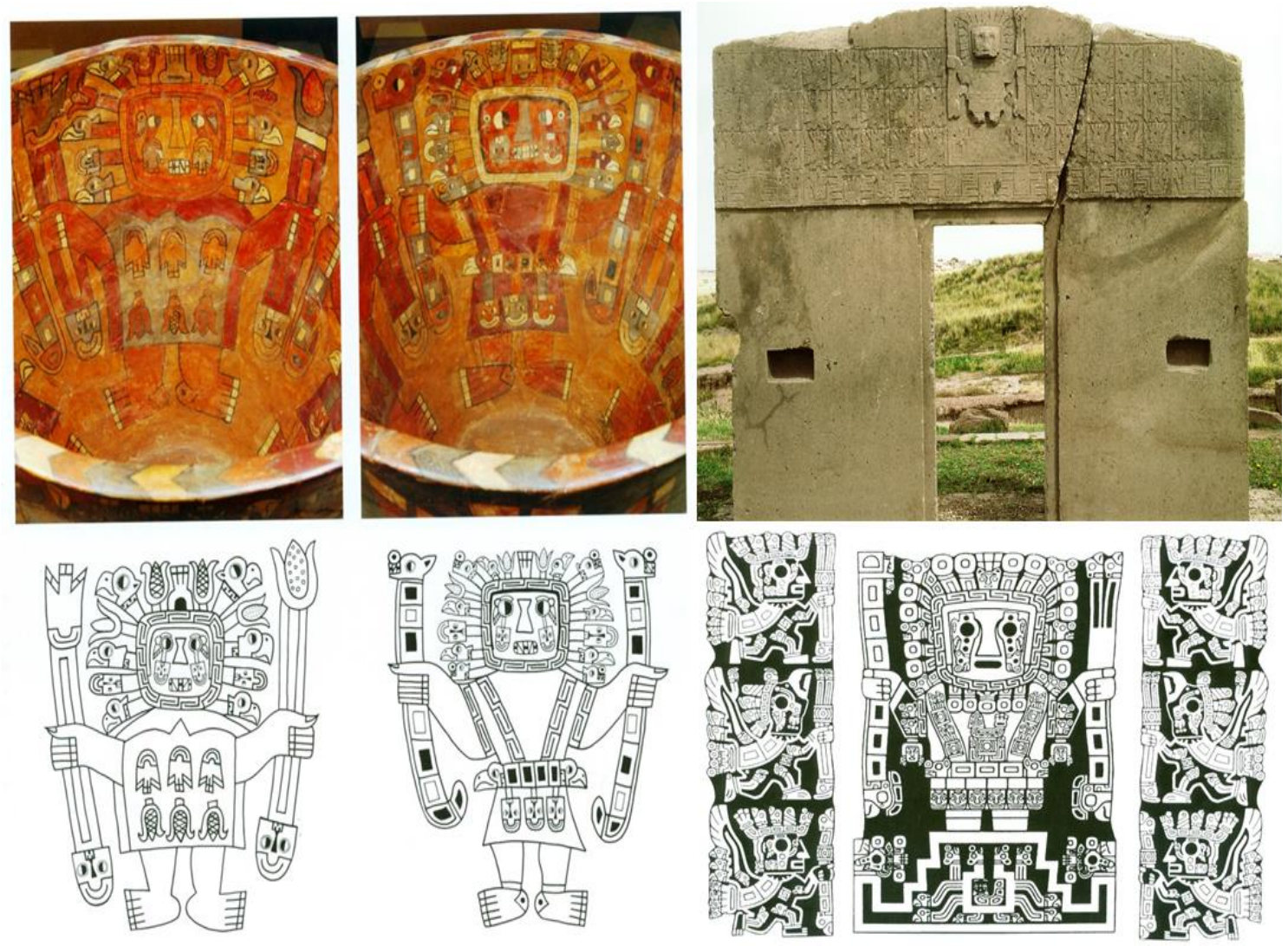

Figura 14 - Semelhança entre as divindades Wari (dois vasos cerâmicos) à esquerda e divindades Tiwanaku ("Porta do Sol" do templo Tiwanaku) à direita. 
Também organizados em senhorios, o período Inca Temprano ou Inca Inicial se inicia justamente no Período Intermediário Tardio (1000 AD a 1430 AD). A cerâmica de estilo Killke, de baixa qualidade artística encontrada nesta zona, está relacionada com os grupos chamados ayarmacas, considerados a origem do senhorio dos Incas. A partir do reinado de Pachacútec o Estado Inca se transformou em grande potência expansionista, sendo considerado este momento o surgimento do verdadeiro Império Inca (Rostworowski, 1999; Cáceres, 2007).

Conhecido como Tahuantinsuyu, o Império dos 4 estados ou Suyus, tinha como capital a cidade de Cuzco, centro administrativo e de residência de toda a realeza, dos sacerdotes e dos militares e curacas mais importantes do reino. Toda a arquitetura encontrada em Cuzco é reproduzida nos centros de controle administrativos (tambos) construídos à medida que o exército avançava e ampliava, assim, as fronteiras do Tahuantinsuyu (Rostworowski, 1999; Cáceres, 2007).

Este enorme território incaico com mais de $5000 \mathrm{~km}$ de extensão, abarcando terras desde o rio Ancasmayo no Sul da Colômbia até o rio Maule nos vales centrais chilenos, criou também uma grande e funcional rede de caminhos.

Novamente, como aconteceu durante o Horizonte Médio, os produtos litorâneos subiram a serra, abastecendo La Sierra e o altiplano com produtos marinhos, enquanto os produtos altiplânicos caminharam em direção oposta. Juntamente com os produtos, também viajaram por estes caminhos e pontes cuidadosamente construídas pelo Tahuantinsuyu, costumes e doenças (Vinton et al., 2009).

Com esta grande rede de comércio transandina novamente reestabelecida e ampliada, quando comparada à rede durante o Horizonte Médio sob influência dos estados Wari e Tiwanaku, as comunidades sob o domínio Inca tiveram à sua disposição produtos de ambientes distantes e distintos, além de redefinirem em alguns casos, o papel e o emprego de objetos e alimentos bastante familiares. Um exemplo a ser citado é a condição do milho, usado tanto como alimento na forma direta de consumo como também sob a forma de bebida (chicha), que variou conforme a localidade e sua produção (Vinton et al., 2009). 
Estes caminhos também testemunharam o trânsito de informação através dos chasquis, corredores profissionais que, em conjunto, cobriam até $270 \mathrm{~km}$ de distância num só dia, mantendo assim o Inca, em Cuzco, atualizado e ciente das notícias de qualquer parte do seu império (Cáceres, 2007).

Sem a pressa dos chasquis, as caravanas de produtos agrícolas, têxteis, minerais ou de diversos produtos demandavam áreas de descanso e de abastecimento ao longo da malha viária. Espalhados na "Quapaq Ñam", como era conhecida a rede viária inca, os tambos eram estes refúgios que albergavam os viajantes. Tão importante quanto levar as notícias à Cuzco, era fornecer ao Inca todos os produtos que os quatro Suyus geravam (Cáceres, 2007).

Já estabelecido como importante ponto de encontro das rotas que interligavam o litoral do Pacífico, as florestas úmidas do noroeste argentino e as terras altas do altiplano boliviano desde o período formativo, San Pedro de Atacama se tornou novamente um ponto estratégico após a expansão do Collasuyu (parte sul do Estado Inca-Tahuantinsuyu). O tambo de San Pedro foi estabelecido em Catarpe, sítio de habitação e cemitério já utilizado desde o Período de Desenvolvimento Regional, localizado no vale do rio San Pedro (Figura 15). Apesar de não ser uma unanimidade (Dillehay \& Netherly, 1998) Catarpe é dividido em duas partes, contando com um "Catarpe Oeste", um sítio habitacional enquanto "Catarpe Leste" era utilizado apenas como tambo (Lynch, 1977; Uribe et al., 2002). 


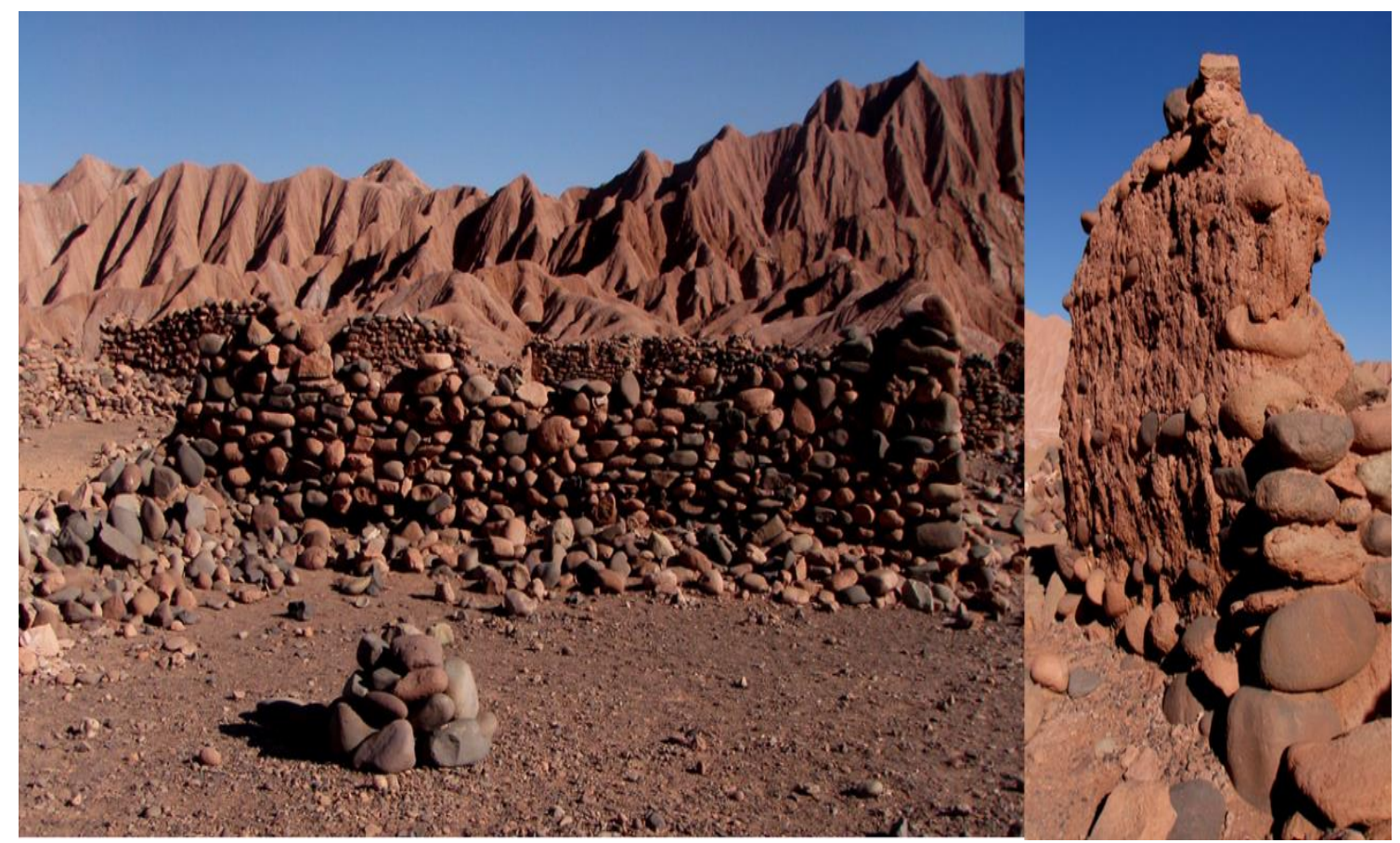

Figura 15 - Tambo de Catarpe com detalhe de suas paredes feitas de pedras do Rio San Pedro aglutinadas com argila (adobe).

Quando os incas chegaram a San Pedro e encontraram uma sociedade organizada e bem estabelecida, após o período de instabilidade durante o Período Intermediário Tardio, a relação criada entre os atacamenhos e o poder central incaico se fez num formato de quase parceria (Llagostera, 2004).

Para isso, o Império Inca se beneficiava da força de trabalho local e delegava poderes administrativos, políticos e até ideológicos a importantes personagens locais. Assim, sem a necessidade do uso da violência, o império Inca avançou sua fronteira, obteve mais recursos com os impostos recolhidos, criou mais entrepostos que complementaram a sua rede viária e aumentou suas fontes de minérios e produtos agrícolas. Por outro lado, os atacamenhos, sem sofrer com uma conquista violenta, inevitável frente a esta grande potência bélica que foi o estado Inca, se beneficiaram das vantagens da enorme rede comercial criada pelos mesmos (Uribe et al., 2002; Bray, 2003; Horta, 2011).

Para A. Llagostera este contato apenas com os líderes locais ou curacas e não com a população em geral é nítido quando se observa a ausência quase total de 
cultura material incaica associada à população atacamenha durante o Horizonte Tardio. Além dos centros administrativos e cerimoniais, Catarpe e Vilama são exceções a esta regra, apresentando, mesmo assim, pequena quantidade de objetos incaicos como os aríbalos ou makas, potes cerâmicos com fundo cônico geralmente utilizado para transporte de líquidos (Uribe et al., 2002). Esses objetos de desenho característico incaico eram produzidos pela população atacamenha nos próprios oásis, sendo decorados muitas vezes com as características da cerâmica atacamenha monocromática e roxo-violácea, encontrada durante o Período Intermediário Tardio (Llagostera, 2004).

Os relatos de Gamán Poma de Ayala, importante cronista peruano, dizem que todos os "falsos feiticeiros" foram condenados à morte pelo estado Inca. Assim sendo, somado à ausência de tabletas para alucinógenos nos sepultamentos, desapareceram também durante este período os xamãs locais e as crenças atacamenhas, provavelmente substituídos por uma "religião" imposta pela nova ordem (Llagostera, 2004). De acordo com esse autor, esta é a principal diferença encontrada no registro arqueológico, em termos da influência dos estados Tiwanaku e Inca, separados por quase 500 anos, em San Pedro de Atacama.

A retomada da atividade mineira também foi uma importante contribuição incaica aos habitantes do deserto, tendo em vista que a geografia local não favorece a produção agrícola extensiva. Às margens do caminho Inca rumo ao sul, minas de exploração de prata, ouro e cobre foram reabertas e a produção controlada pelos centros administrativos criados próximos a elas. Catarpe é considerado um centro administrativo importante da região atacamenha, uma vez que grandes minas de cobre como Cerro Verde, Incahuasi e San Bartolo se encontram, no máximo, a $50 \mathrm{~km}$ dali (Aldunate et al., 2001).

Contudo, a presença do estado Inca nos oásis atacamenhos foi fugaz, perdurando por menos de um século. Sem data precisa para a chegada do Império Inca a San Pedro, sendo apenas estimada durante o período expansionista de Tupac Yupanqui entre 1471 e 1493 AD (Cáceres, 2007) e terminando com a chegada dos espanhóis em 1540 AD com a tomada do Pukara de Quítor por Francisco de Aguirre, a 
influência deste império entre os atacamenhos ainda resistiria à presença hispânica no deserto. A paz efetiva aconteceria apenas no dia 05 de Março de 1557 AD, quando, após anos de batalhas travadas dentro das quebradas e caminhos do deserto, os atacamenhos baixaram a guarda, entregaram suas armas e assinaram por fim um tratado de paz entre eles e as autoridades espanholas, finalizando para os oásis do salar de Atacama o período pré-histórico (Llagostera, 2004).

Concordando com o padre Gustavo Le Paige, Dillehay \& Netherly (1998) acreditam que mesmo que por um período curto de tempo, o Império Inca deixou um importante registro na região norte atacamenha, organizando e ampliando as redes de troca e seus caminhos, construindo o centro administrativo e militar em Catarpe e o centro religioso no sopé do vulcão Licancabur, além de ser o mentor da resistência atacamenha contra os espanhóis por quase 20 anos. 


\section{MATERIAIS E MÉTODOS}

\section{MATERIAIS}

O Instituto de Investigações Arqueológicas e Museu da Universidade Católica do Norte do Chile é depositário de uma das coleções mais expressivas e bem conservadas de crânios humanos pré-históricos das Américas. Apesar de vários pesquisadores terem colaborado para a formação deste acervo, a maior parte dele é formada pelo material escavado por Gustavo Le Paige, padre jesuíta belga fundador do museu em 1957.

Segundo levantamento feito por Hubbe et al. (2011), a coleção do museu apresenta atualmente, dos 5482 crânios e múmias registrados pelo Padre Augusto Le Paige, apenas 2343 em bom estado de conservação e 723 em estado regular. Esta diferença entre os registros e os crânios atualmente disponíveis é considerada pelos autores resultado de anos de conturbados programas de curadoria e musealização ineficientes, incluindo até mesmo doações deste material a instituições estrangeiras (Figura 16). O caso mais emblemático deste problemático processo é o material proveniente do cemitério Toconao Oriente, com 545 registros feitos pelo padre e atualmente apenas 145 destes estão presentes no acervo do museu (Hubbe et al., 2011). 


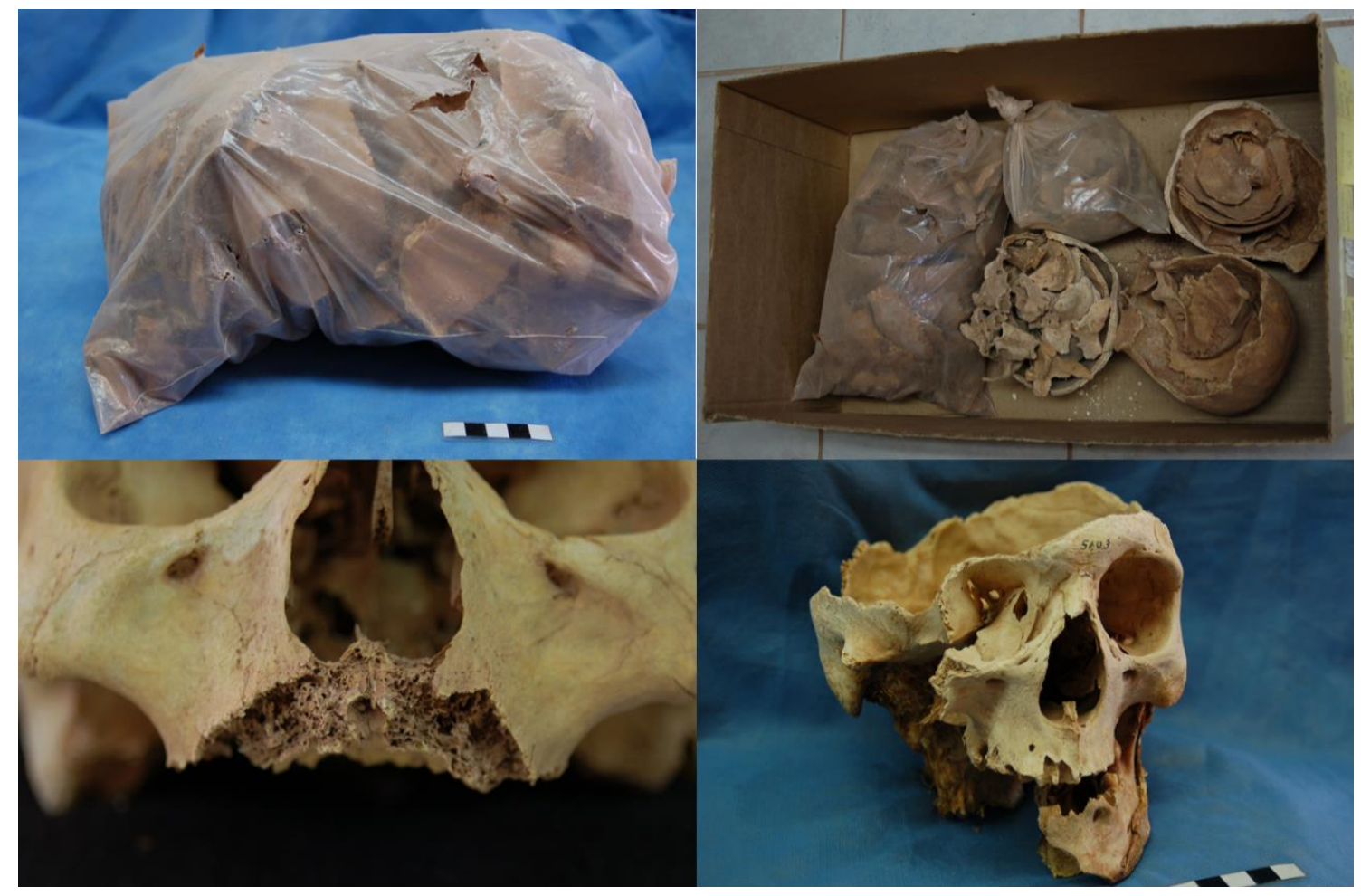

Figura 16 - Condição de conservação de alguns exemplares da coleção do Museu R.P. Augusto Le Paige, San Pedro de Atacama, Chile.

Dentre esta expressiva quantidade de material esqueletal disponível, durante a primeira etapa de coleta de dados em janeiro de 2010 optamos (eu, meu orientador e o então diretor do museu, Dr. Mark Hubbe) por alguns dos sítios presentes na coleção e que seriam representantes de 3 distintos períodos de desenvolvimento social ocorrido em San Pedro de Atacama. Devido a enorme dificuldade em analisar as condições de saúde bucal em múmias, dispensei os 219 corpos mumificados presentes na coleção e me ative apenas aos 3066 crânios em bom ou regular estado de conservação.

Assim, ao final das duas etapas de coleta de dados, a primeira entre janeiro e dezembro de 2010 e a segunda, entre janeiro e fevereiro de 2011, o material analisado totalizou 517 indivíduos provenientes de 16 sítios distintos, todos localizados na bacia do salar do Atacama à exceção de um sítio localizado na bacia do rio Loa, cerca de 100 km ao norte de San Pedro de Atacama, chamado Caspana (Figura 17). 


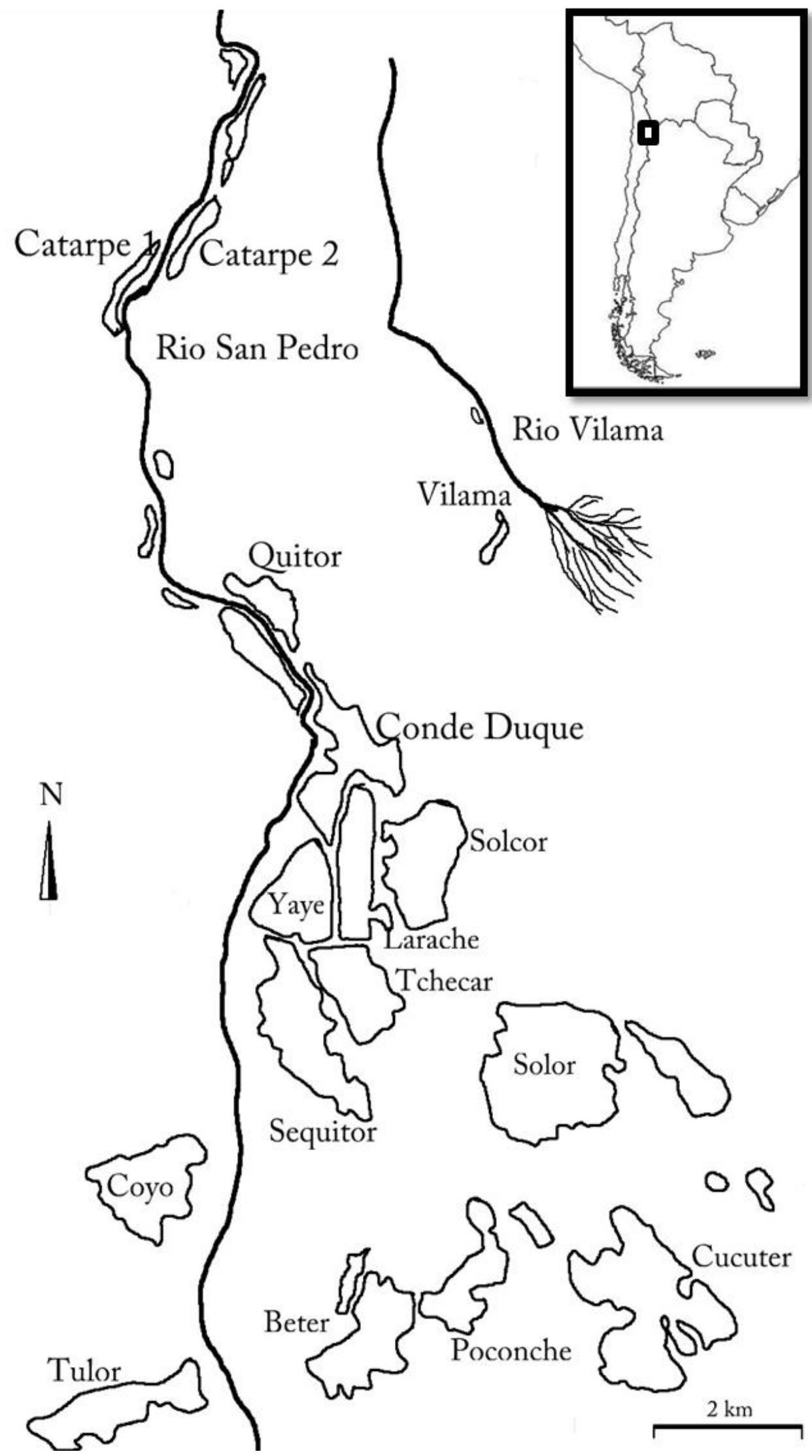

Figura 17 - Localização dos sítios arqueológicos de San Pedro de Atacama, adaptado de Costa et al. (2004) (desenho de Waldiane Cossermelli). 
Levando em consideração que minhas necessidades poderiam ser distintas das que foram consideradas importantes para a classificação no trabalho de Hubbe et al. (2011), uma pré-seleção foi feita apenas com os crânios considerados pelos autores em bom ou regular estado de conservação. O critério de avaliação utilizado pelos autores para definir o estado de conservação dos exemplares em bom, regular e ruim divergiu ligeiramente das minhas necessidades pois, enquanto para meu trabalho os crânios que mantiveram os marcadores de idade e sexo e de pelo menos uma das arcadas (maxilas ou mandíbula) foram considerados em bom ou regular estado, para Hubbe et al. (2011) os critérios utilizados para esta classificação eram mais referentes ao processo de cura do material do que propriamente da presença ou não de partes anatômicas especificas.

Inicialmente determinado a examinar apenas sítios que disponibilizasse mais de 20 indivíduos para a minha análise, precisei reconsiderar esta premissa de meu projeto inicial para que eu conseguisse equilibrar minhas amostras de acordo com a quantidade disponível de crânios para cada período a ser comparado. Uma segunda razão para esta readequação também se apresentou durante a execução deste trabalho quando, entre a primeira e a segunda etapa, novas datações foram realizadas e alteraram as disposições de alguns dos sítios por nós previamente escolhidos.

Destes mais de 500 crânios eleitos para a minha avaliação, um número bastante expressivo, totalizando 191 crânios, não possuíam a mandíbula correspondente. Nos poucos casos onde havia grande discrepância entre a mandíbula e o crânio a este associada, desconsiderei a presença da mandíbula e analisei apenas as maxilas destes crânios. O mesmo aconteceu quando o dente colado ao alvéolo divergia demasiadamente da anatomia esperada do elemento original do alvéolo. Nestes casos, considerei o fato resultante de um equívoco durante a etapa de cura deste material e analisei-o como elemento pertencente ao indivíduo, porém computado como o elemento dental ao qual sua anatomia era condizente.

Ainda dentro desta minha amostra inicial, precisei excluir cerca de $1 / 5$ destes crânios pré-selecionados. Os motivos para estas exclusões foram: 1. ausência de uma ou das duas maxilas; 2 . se tratar de indivíduos jovens ou crianças (menores que 18 
anos); 3. haver dentro da mesma caixa dois crânios num mesmo saco plástico e sem a correta identificação de qual deles se tratava a numeração encontrada na caixa; 4. haver exemplares com numeração duplicada, problema este bem evidenciado e bastante preocupante na visão dos autores do levantamento publicado em 2011, que encontraram até 696 crânios com numeração duplicada na coleção (Hubbe et al., 2011).

Finalmente, após selecionar os crânios entre os considerados bons ou regulares pelos curadores do museu e dentre estes, os que representavam os sítios de meu interesse, minha amostra analisada foi de 402 indivíduos.

Estes crânios apresentavam as condições adequadas para as análises a que me propus neste trabalho:

- Identificar a idade (ou faixas etárias).

- Identificar o sexo (mesmo que, em alguns casos, seja considerado como indefinido).

- Identificar e quantificar as patologias dentais e as alterações de uso dos dentes (desgaste).

- Identificar as deformações cranianas intencionais.

Respeitando as limitações da coleção que estava à disposição para a minha análise, procurei distribuir a quantidade de indivíduos analisados de acordo com os períodos que eles representavam. Porém, ao longo da execução deste trabalho, algumas datações foram obtidas pelo grupo do pesquisador Mark Hubbe, remanejando de forma importante as amostras que eu havia coletado. Assim, com a atual distribuição do material arqueológico presente em minha amostra, foram analisados 371 indivíduos dos oásis de San Pedro de Atacama e 31 indivíduos exumados em Caspana.

Estes 371 indivíduos representantes dos oásis de San Pedro foram divididos em três períodos pré-históricos local, excluindo o período Arcaico, o período Inca e o 
período Pós-Colonização Espanhola, por não possuir exemplares em estado adequado de preservação nem em quantidade.

Neste trabalho, utilizei a presença de um dos dois grandes impérios na região como marco temporal na nomenclatura dos períodos, como apresento na Tabela 01, desconsiderando as fases propostas por M. Tarragó (1976) para a região.

Tabela 01 - Nomenclatura dos mesmos períodos históricos para os Andes Centrais e para São Pedro de Atacama

Nomenclatura utilizada para os

Andes Centrais
Nomenclatura utilizada para

DATAS

San Pedro de Atacama

PRÉ TIWANAKU

TIWANAKU

PÓS TIWANAKU
$1500 \mathrm{AC}-500 \mathrm{AD}$

500 AD - 1000 AD

HORIZONTE MÉDIO

INTERMERDIÁRIO TARDIO

FORMATIVO 
Mark Hubbe e Cristina Torres-Rouff que me disponibilizaram seus dados anteriormente à publicação mencionada, pude selecionar minha amostra.

Devido a algumas divergências encontradas entre as datas obtidas diretamente dos ossos (Hubbe et al., 2011, 2012) e as obtidas por termoluminescência apresentadas pelas cerâmicas de cada sítio arqueológico (Tarragó, 1976; Berenguer et al., 1986, 1988), optei por utilizar as datas provenientes dos esqueletos já que a minha unidade de análise foi formada por crânios. Dentre os sítios que analisei, as exceções são os sítios Toconao Oriente, Coyo Oriental e Quitor 6, que não estão presentes na amostra destes dois trabalhos de Mark Hubbe e colaboradores (Tabela 02; Tabela 03). 
Tabela 02 - Datas obtidas para os sítios de San Pedro de Atacama (Hubbe et al., 2011).

\begin{tabular}{|c|c|c|c|c|}
\hline Cemitério & Sepultura & Laboratório & $\begin{array}{c}\text { Data } \\
\text { Absoluta }\end{array}$ & $\begin{array}{c}\text { Data Calibrada } \\
\text { (Anos }\end{array}$ \\
\hline & & & (Anos AP) & Calendário) \\
\hline CASPANA & 32 & Beta 263464 & $660 \pm 40$ & 1294-1403 AD \\
\hline CASPANA & 43 & Beta 263465 & $610 \pm 40$ & 1304-1435 AD \\
\hline CASPANA & 45 & Beta 263466 & $670 \pm 40$ & $1291-1400$ AD \\
\hline CATARPE 1 & 294 & AA 87009 & $752 \pm 43$ & $1225-1388 A D$ \\
\hline CATARPE 1 & 2397 & AA 87010 & $689 \pm 43$ & $1284-1396$ AD \\
\hline CATARPE 2 & 1753 & Beta 251747 & $1220 \pm 40$ & 734-983 AD \\
\hline CATARPE 2 & 1786 & Beta 251748 & $750 \pm 40$ & $1228-1387$ AD \\
\hline CATARPE 2 & 1801 & Beta 251749 & $1030 \pm 40$ & $992-1151$ AD \\
\hline CATARPE 2 & 1850 & Beta 251750 & $770 \pm 40$ & $1221-1382$ AD \\
\hline QUITOR 5 & 1921 & AA 87017 & $1164 \pm 44$ & 782-1019 AD \\
\hline QUITOR 5 & 2009 & AA 87018 & $1511 \pm 46$ & $443-664$ AD \\
\hline QUITOR 5 & 2179 & AA 87019 & $1338 \pm 45$ & 656-865 AD \\
\hline QUITOR 5 & 3394 & AA 87020 & $1623 \pm 46$ & 401-599 AD \\
\hline SOLOR 3 & 983 & AA 87026 & $1616 \pm 46$ & 406-602 AD \\
\hline SOLOR 3 & 991 & AA 87027 & $1859 \pm 47$ & 83-375 AD \\
\hline YAYE 1 & 5494 & Beta 251755 & $920 \pm 40$ & $1042-1260 A D$ \\
\hline YAYE 1 & 5498 & Beta 251756 & $1100 \pm 40$ & 892-1102 AD \\
\hline YAYE 2 & 3309 & Beta 251757 & $1300 \pm 40$ & 667-881 AD \\
\hline YAYE 2 & 3417 & Beta 251758 & $1040 \pm 40$ & 988-1150 AD \\
\hline
\end{tabular}


Tabela 03 - Datas obtidas para os sítios de San Pedro de Atacama (Hubbe et al., 2012).

\begin{tabular}{ccc}
\hline Cemitério & Laboratório & Data Calibrada \\
\hline SOLCOR 3 & Beta 305869 & $673-867$ AD \\
SOLCOR 3 & Beta 305870 & 781-981 AD \\
\hline
\end{tabular}

Com o objetivo de confirmar a antiguidade do sítio Solcor 3 e reforçar as duas datas obtidas especificamente para este trabalho, Hubbe et al. (2012) apresentam outras 6 datas anteriormente publicadas por Llagostera et al. (1988), também calibradas e representativas do período Tiwanaku (tabela 04).

\begin{tabular}{|c|c|}
\hline Cemitério & Data \\
\hline SOLCOR 3 & $433-774$ AD \\
\hline SOLCOR 3 & $607-865$ AD \\
\hline SOLCOR 3 & 689-986 AD \\
\hline SOLCOR 3 & $775-1024 A D$ \\
\hline SOLCOR 3 & $909-1176 A D$ \\
\hline SOLCOR 3 & 465-769 AD \\
\hline
\end{tabular}

Como eu buscava sítios representativos do período Pré-Tiwanaku e os trabalhos de Hubbe et al. (2012) e Llagostera et al. (1988) não apresentaram, em seu pool de amostras, nenhum dado sobre este período, utilizei as datações presentes em publicações de autores também mencionados ou mesmo coautores dos artigos aqui citados (Berenguer et al., 1988; Costa, 1988; Llagostera, 2006) (Tabela 05, Tabela 06 e Tabela 07). 
Tabela 05 - Datas obtidas por Berenguer et al. (1988).

\begin{tabular}{|c|c|c|c|c|}
\hline Cemitério & Sepultura & Amostra & Idade (ano) & Data \\
\hline TOCONAO ORIENTE & $\mathrm{S} / \mathrm{N}$ & CERÂMICA & $2330 \pm 235$ & $350 \mathrm{AC}$ \\
\hline TOCONAO ORIENTE & $S / N$ & CERÂMICA & $2320 \pm 170$ & $340 \mathrm{AC}$ \\
\hline TOCONAO ORIENTE & 4340 & CERÂMICA & $2150 \pm 180$ & $170 \mathrm{AC}$ \\
\hline TOCONAO ORIENTE & 4331 & CERÂMICA & $1970 \pm 170$ & $10 \mathrm{AD}$ \\
\hline TOCONAO ORIENTE & 4262 & CERÂMICA & $1900 \pm 200$ & $80 \mathrm{AD}$ \\
\hline TOCONAO ORIENTE & 4731 & CERÂMICA & $1890 \pm 200$ & $90 \mathrm{AD}$ \\
\hline TOCONAO ORIENTE & $4646 / 4648$ & CERÂMICA & $1860 \pm 140$ & $120 \mathrm{AD}$ \\
\hline TOCONAO ORIENTE & 4645 & CERÂMICA & $1840 \pm 150$ & $140 \mathrm{AD}$ \\
\hline TOCONAO ORIENTE & 4240 & CERÂMICA & $1830 \pm 115$ & $150 \mathrm{AD}$ \\
\hline TOCONAO ORIENTE & $\mathrm{S} / \mathrm{N}$ & CERÂMICA & $1820 \pm 180$ & $160 \mathrm{AD}$ \\
\hline TOCONAO ORIENTE & $4448 / 4449$ & CERÂMICA & $1760 \pm 130$ & $220 A D$ \\
\hline TOCONAO ORIENTE & 4263 & CERÂMICA & $1750 \pm 160$ & $230 A D$ \\
\hline TOCONAO ORIENTE & 4607 & CERÂMICA & $1740 \pm 140$ & $240 A D$ \\
\hline TOCONAO ORIENTE & 4650 & CERÂMICA & $1725 \pm 120$ & $255 A D$ \\
\hline TOCONAO ORIENTE & 4383 & CERÂMICA & $1670 \pm 160$ & $310 A D$ \\
\hline TOCONAO ORIENTE & 4343 & CERÂMICA & $1655 \pm 190$ & $325 \mathrm{AD}$ \\
\hline TOCONAO ORIENTE & 4274 & CERÂMICA & $1630 \pm 130$ & $350 A D$ \\
\hline COYO ORIENTAL & 4060 & CERÂMICA & $1190 \pm 70$ & $790 A D$ \\
\hline QUITOR 6 & $54 / 688$ & CERÂMICA & $1040 \pm 130$ & $940 A D$ \\
\hline QUITOR 6 & $35 / 409$ & CERÂMICA & $840 \pm 70$ & $1140 \mathrm{AD}$ \\
\hline
\end{tabular}


Tabela 06 - Datas obtidas por Costa (1988).

\begin{tabular}{ccccc}
\hline Cemitério & Sepultura & Laboratório & Amostra & Idade absoluta \\
\hline QUITOR 6 & 35 & Beta 11307 & MADEIRA & $1240 \pm 70$ AD \\
QUITOR 6 & 36 & Beta 11208 & TECIDO & $920 \pm 70$ AD \\
QUITOR 6 & 50 & Beta 9349 & MADEIRA & $1060 \pm 180$ AD \\
\hline
\end{tabular}

Tabela 07 - Datas obtidas por Llagostera (2006).

\begin{tabular}{cccc}
\hline Cemitério & Sepultura & Laboratório & Data (não calibrada) \\
\hline COYO ORIENTE & 9085 & UCTL 1488 & $1085+100$ AD \\
& & & \\
\hline
\end{tabular}

Encontrar sítios representantes do período Inca nos oásis de San Pedro é um grande desafio devido ao curto espaço de tempo no qual este império andino esteve presente naquela região. Por anos os cemitérios de Catarpe como um todo foram considerados "cemitérios incas", mas as novas datações apresentadas pelos trabalhos acima apresentados sugerem que estes cemitérios já eram ocupados pelos atacamenhos até mesmo 500 antes da chegada dos incas no deserto (Hubbe et al., 2011).

Um destes casos é o sítio Catarpe 1. Apesar das amostras enviadas pelo grupo do pesquisador Mark Hubbe para datação deste sítio terem apresentado datas que o colocaria no período anterior à presença Inca na região de San Pedro de Atacama, os dados arqueológicos apontam para uma caracterização Incaica deste sítio. Assim, as evidências como as estruturas arquitetônicas e as disposições residenciais e monumentais encontradas neste sítio, além da presença de objetos como os aríbalos, colheres de madeira e da ausência total de tabletas de alucinógeno (muito comuns durante toda a pré-história atacamenha mas "proibidas" pelo império Inca), favorecem 
a classificação de Catarpe 1 como um sítio incaico ou pelo menos, um sítio do período de transição (Lynch \& Núñez, 1994; Aldunate et al., 2001; Torres-Rouff \& Costa Junqueira, 2006; Núñez, 2007). Apesar das evidências arqueológicas acima dispostas, considerarei as datas publicadas como referência temporal. Com isso, os esqueletos exumados dos sítios Catarpe 1 e 2 serão considerados como representantes do período Pós Tiwanaku.

Assim, a distribuição final das amostras analisadas neste trabalho está apresentada na Tabela 08:

Tabela 08 - Sítios arqueológicos analisados e seus respectivos períodos.

\begin{tabular}{ccc}
\hline SÍTIOS & PERÍODO & INDIV. \\
\hline SOLOR 3 & PRÉ TIWANAKU & \\
TOCONAO & & \\
\hline TCHECAR & & 146 \\
COYO & TIWANAKU & \\
QUITOR 5 & & \\
SOLCOR 3 & & \\
\hline CATARPE 1 & & \\
CATARPE 2 & & \\
YAYE 1 & & \\
YAYE 2 & & \\
YAYE OC & & \\
QUITOR 6 & & \\
\hline CASPANA & & \\
\hline TOTAL & & \\
\hline
\end{tabular}




\section{MÉTODO}

Após a seleção dos sítios a serem incorporados nesta pesquisa, a análise dos crânios foi dividida em duas fases.

A primeira fase foi responsável pela identificação do chamado perfil bioantropológico de cada indivíduo, identificando sexo e idade de cada crânio. Além desta identificação, também foi feita a identificação da presença ou não de deformações cranianas intencionais destes mesmos indivíduos. Somente após serem obtidos estes dados é que parti para a análise das patologias dentais das amostras.

Na segunda fase do processo, as análises dentais foram executadas seguindo os protocolos anteriormente mencionados, mas que em alguns casos foram necessárias adaptações.

Todas as análises foram executadas no do Museu de San Pedro de Atacama. O laboratório apresentava uma boa luminosidade natural, sem a luz direta do sol sobre o material a ser estudado, mas também contava com uma iluminação artificial complementar. Poucas vezes foi necessária a utilização de uma terceira fonte de luz (pequena lanterna de LED - luz branca) para a observação de pontos específicos.

Como instrumento auxiliar também foram utilizadas lentes de aumento para as análises das patologias dentais além de instrumentos de exame clínico odontológicos como pinça clínica, espelho intraoral, explorador ou sonda exploradora de ponta dupla \#5 e sonda periodontal milimetrada (Figura 18). 


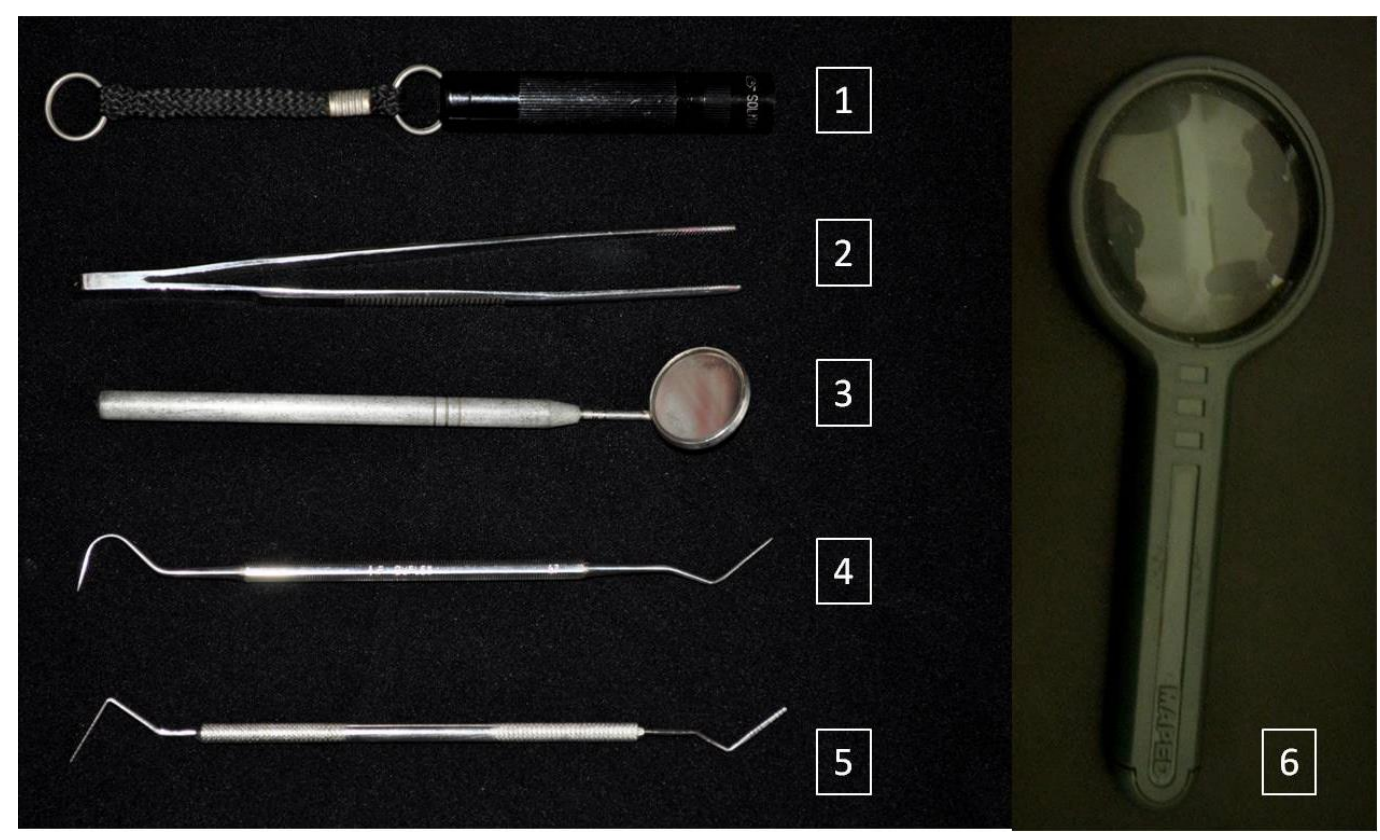

Figura 18. Instrumentais utilizados nesta pesquisa: 1. Lanterna; 2. Pinça clínica; 3. Espelho clínico; 4. Sonda exploradora; 5. Sonda milimetrada; 6. Lupa.

Todos os dados obtidos destes exemplares foram registrados de forma escrita e gráfica para posteriormente serem convertidos ao formato digital. Para este registro, criei uma "Ficha de Inventário das Patologias Dentais" a partir de protocolos utilizados em antropologia física mas também adaptando fichas de avaliação e odontogramas trazidos da clínica odontológica e do material gentilmente cedido pelo pesquisador Luis N.P. Lanfranco (Anexo 01).

Alguns casos específicos também foram fotografados, além do preenchimento da ficha de inventário comum a todos os exemplares, como forma de complementar o registro. Para todas estas fotos, foram utilizados um fundo negro e uma escala em centímetros padronizando-as. 


\section{Registro do perfil bioantropológico}

O entendimento do perfil bioantropológico de uma amostra é de essencial importância para ratificar as conclusões advindas das análises osteológicas executadas sobre o material arqueológico. As diferenças encontradas entre os esqueletos de ambos os sexos são desde o tamanho (estatura) e a robustez dos ossos até o formato de alguns destes ossos. O mesmo acontece quando observamos esqueletos humanos com distintas idades de morte, variando também em forma ou mesmo apresentando desgastes oriundos do uso destes corpos ao longo da vida (Larsen, 1997 b; c; White \& Folkens, 2005 a).

Quando o objetivo das análises do material é compreender as patologias acometidas pelos indivíduos estudados, estas diferenciações são ainda mais importantes pois patologias podem apresentar predileção distinta pelos sexos e nos casos de patologias crônicas, a idade de morte pode justificar o estágio em que se encontra a patologia em questão (White \& Folkens, 2005 b).

Apenas para citar um exemplo bastante emblemático, a cárie dentária é uma patologia crônica e irreversível pois, uma vez iniciado o processo de cavitação, não há regressão do quadro histológico, ou seja, uma vez cariado, o dente nunca se reconstituirá, podendo no máximo estabilizar a progressão da doença. Com isso, é natural que indivíduos mais velhos possuam mais dentes cariados (cavitados) que indivíduos mais novos. Este é o motivo que fundamenta o argumento de alguns autores que para uma análise epidemiológica adequada, deveriam ser utilizadas, principalmente, amostras com indivíduos jovens (Roberts \& Manchester, 2005 b). Outra diferença encontrada quando analisamos cárie dentária é sua prevalência maior em indivíduos do sexo feminino comparados aos do sexo masculino (Hillson, 1996 b; Lukacs, 1996; Larsen, 1997 d).

As deformações cranianas intencionais são encontradas em diversas sociedades pré-históricas nas Américas e no mundo. Ainda com uma grande dificuldade na interpretação deste marcador, cada região do globo parece apresentar sua explicação 
para a prática desta modificação corpórea que, como outras, buscam representar uma identidade do grupo que a pratica. Assim, estas deformações podem indicar uma estratificação social, uma diversidade de origem regional ou familiar dos grupos estudados (Neumann, 1942; Arensburg \& Hershkovitz, 1988; White \& Folkens, 2005 b; Perez, 2007; Durband, 2008; Nelson \& Madimenos, 2010).

\section{Diagnóstico do sexo}

Para a estimativa do sexo existe, disponíveis na literatura, uma grande quantidade de protocolos de análises e que são focados em diferentes áreas do esqueleto humano. Com distintas margens de segurança, cada protocolo busca minimizar as dificuldades encontradas pelos antropólogos devido aos diferentes níveis de expressão dos marcadores osteológicos característicos de cada sexo. Esta expressão pode ser influenciada por modificações corporais de origem cultural presentes em algumas sociedades mas também pela robustez dos indivíduos avaliados, tanto homens como mulheres. Outro fator importante quando optamos por um protocolo para a estimativa do sexo é a região a ser avaliada. Há no esqueleto humano distintas áreas que nos possibilita a identificação do sexo de uma amostra, porém cada uma apresenta também diferentes níveis de acurácia e precisão. Para finalizar, outro fator importante desta análise está na acuidade do observador e sua experiência com a amostra a ser analisada (White \& Folkens, 2005 c).

Neste trabalho, apenas os crânios foram o objeto de estudo e mesmo assim, em muitos dos casos avaliados, a mandíbula correspondente estava ausente. Assim, descontados os marcadores mandibulares e alguns pontos como a inclinação do osso frontal e da protuberância occipital (estes excluídos pela possibilidade de serem alterados nos casos nos quais a deformação craniana estava presente), escolhi 5 pontos de observação (glabela, processo mastoide do osso temporal, arco supraciliar, osso zigomático e formato da órbita) e optei por utilizar um protocolo de identificação 
onde pudesse valorar cada expressão destes traços. Assim, utilizei parte do protocolo proposto por Walrath et al. (2004) para a minha análise.

\section{Diagnóstico da idade de óbito}

Procedimento que apresenta uma acurácia relativamente baixa, o diagnóstico da idade de óbito de cada esqueleto é mais corretamente chamada de estimativa de idade, uma vez que não só a acuidade de seu diagnóstico mas também a precisão deste a coloca longe de um quadro de exatidão (White \& Folkens, 2005 c).

Para estimar a idade dos exemplares, utilizei alguns pontos cranianos. 0 mesmo procedimento aplicado na estimativa do sexo de evitar áreas possivelmente afetadas pelas deformações cranianas intencionais foi adotado para a estimação de idade de óbito.

A erupção dentária foi o primeiro método aplicado para distinguir indivíduos jovens e adultos, sendo consideradas e registradas as dentições em permanente, decídua ou mista (Figura 19). 


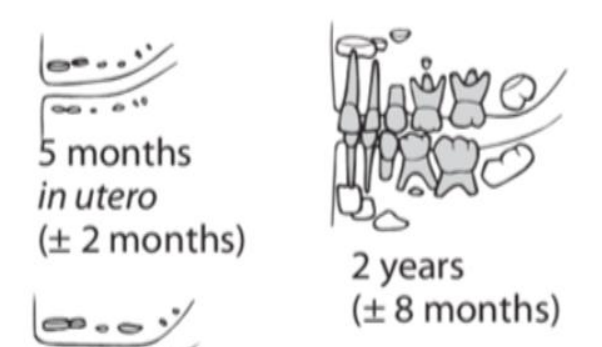

$00^{\circ-0 . .}$

7 months

( \pm 2 months)

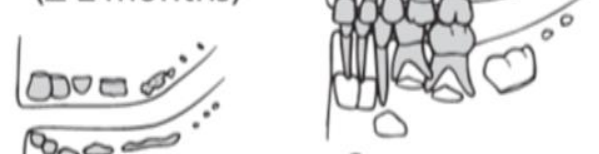

Bon

Birth

( \pm 2 months)
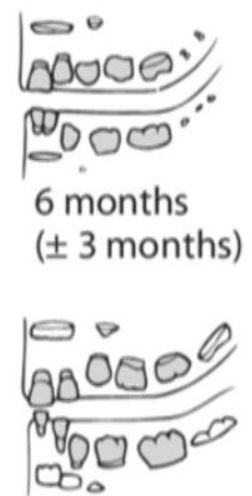

9 months ( \pm 3 months)

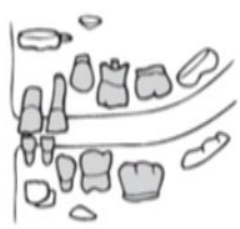

1 year

( \pm 4 months)

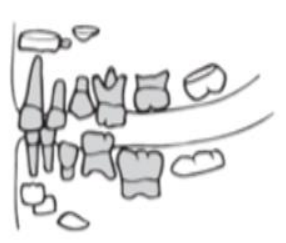

18 months ( \pm 6 months)

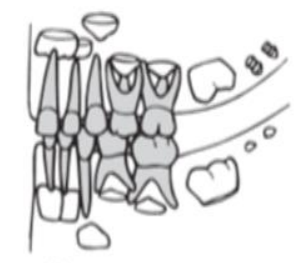

3 years

( \pm 1 year)

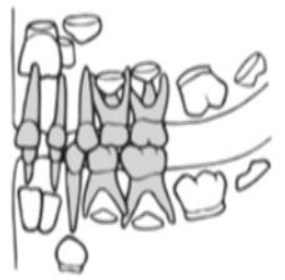

4 years ( \pm 1 year)

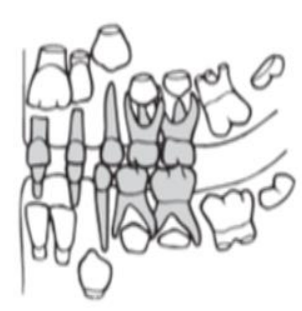

5 years

( \pm 1.5 years)

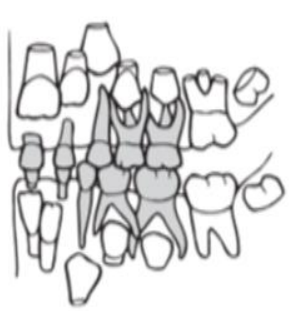

6 years

( \pm 2 years)

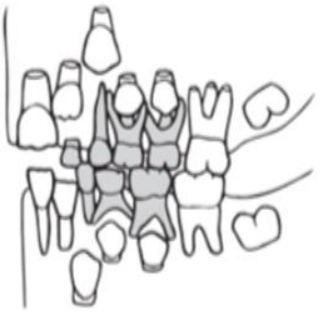

7 years

( \pm 2 years)

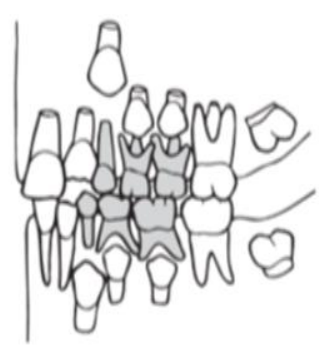

8 years

( \pm 2 years)

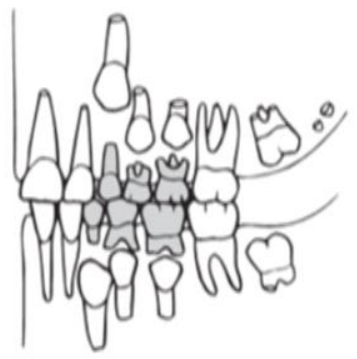

9 years

( \pm 3 years)

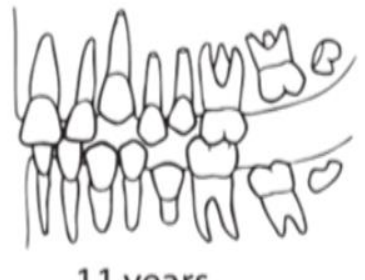

11 years

$( \pm 2.5$ years)

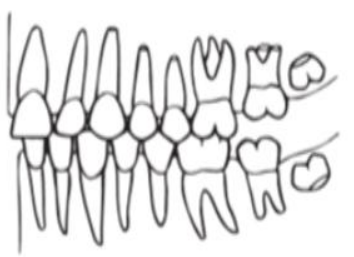

12 years

( \pm 2.5 years)

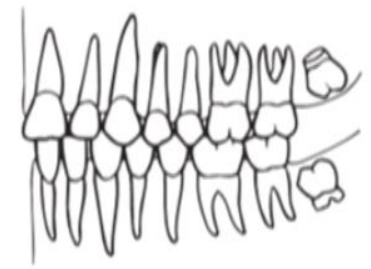

15 years

( \pm 3 years)

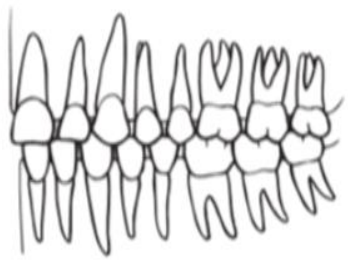

21 years

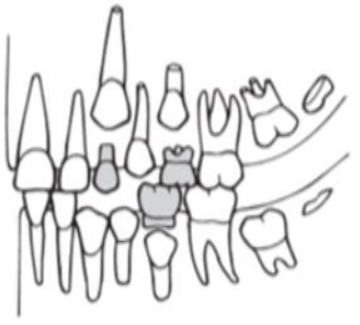

10 years

( \pm 2.5 years)

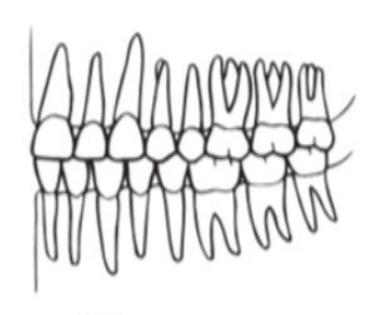

35 years

Figura 19 - Desenvolvimento dental e idade adaptados de Ubelaker (1989) (White \& Folkens, 2005 c). 
Sendo a minha amostra reconhecidamente danificada e apresentando um número consideravelmente alto de perda dentária post mortem, optei por não utilizar a técnica de estimação de idade através do desgaste dentário proposta por C.O. Lovejoy (1985). Evitando também as suturas ósseas do palato e as suturas localizadas na linha média craniana ou também chamadas de suturas da abóbada craniana (Meindl \& Lovejoy, 1985), utilizei para a estimação da idade de óbito as suturas lateroanteriores do crânio, divididos em 5 pontos observáveis de $1 \mathrm{~cm}$ de comprimento cada, localizados nas suturas fronto-parietal, fronto-esfenóide, fronto-esfeno-temporal e dois pontos distintos da sutura esfeno-temporal (White \& Folkens, 2005 c) (Figura 20).

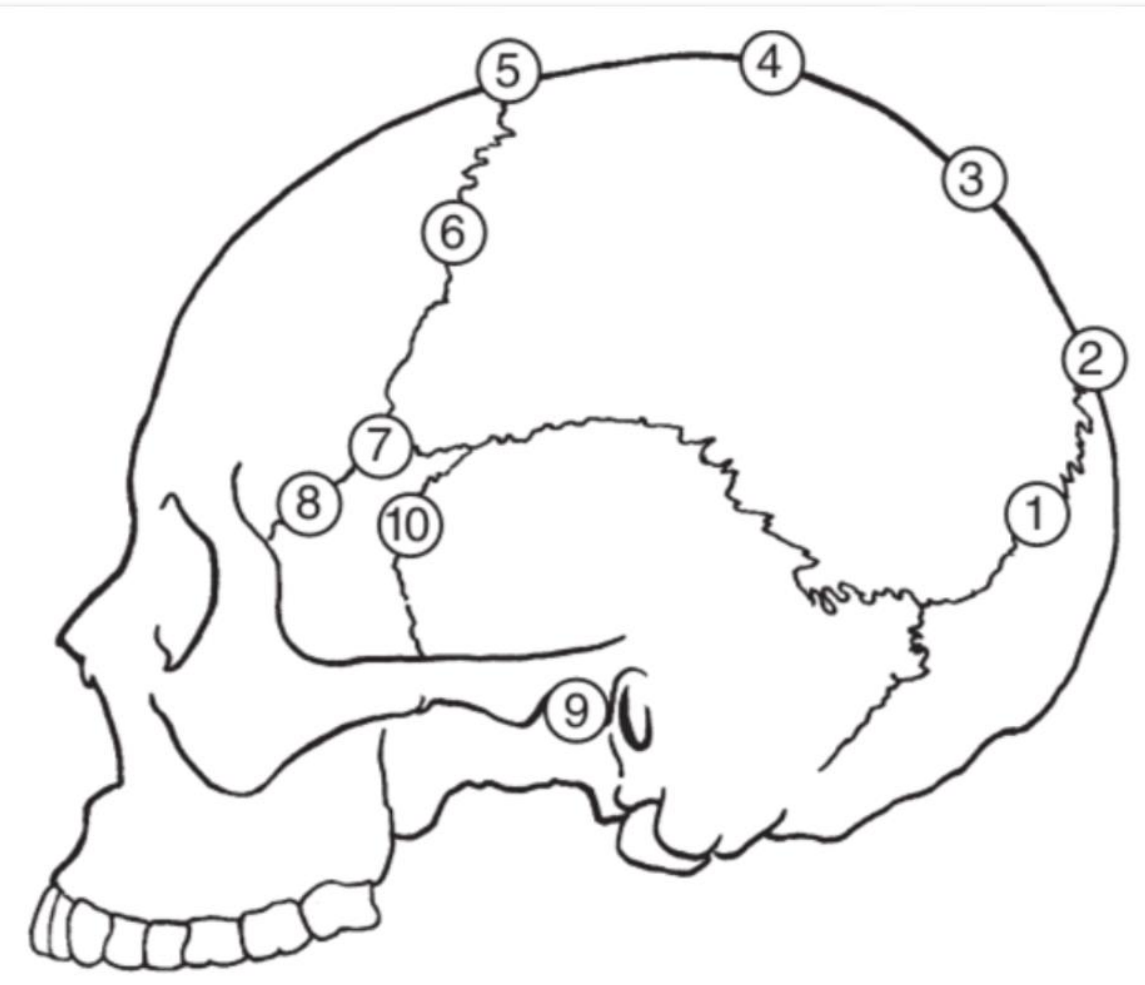

Figura 20 - Os pontos identificados com os números de 6 a 10 foram os utilizados para a estimativa de idade de morte, adaptados de Meindl e Lovejoy (1985) (White \& Folkens, 2005 c). 


\section{Determinação das deformações craniana intencionais}

As deformações cranianas intencionais foram praticadas ao longo de toda a pré-história de San Pedro de Atacama (Torres-Rouff, 2007).

Divididas em duas principais formas propostas por Dembo \& Imbelloni (1938), tabular e anular (Figura 21), as deformações também foram subdivididas em duas variações destas formas principais: ereta e oblíqua. Estes quatro tipos de deformação artificial do crânio foram contrastados com a morfologia craniana natural por meio exclusivamente visual. Em concordância com C. Torres-Rouff (2002), parto da premissa de que se a deformação craniana teve o objetivo de expressar perante a sociedade uma identidade, os crânios que não apresentaram sinais claros de modificação foram considerados como não deformados. As deformações muito sutis foram também desconsideradas pela possibilidade de serem resultados de deformações provocadas apenas pela posição de repouso deste indivíduo no "berço" durante a primeira infância (Torres-Rouff, 2007).

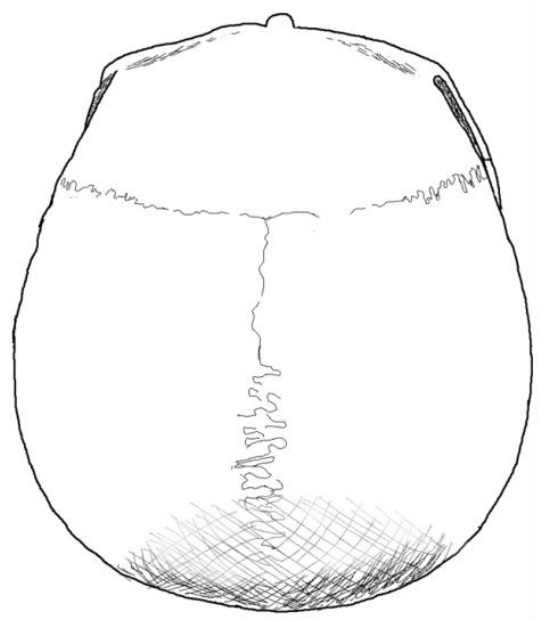

DEFORMAÇÃO CIRCULAR

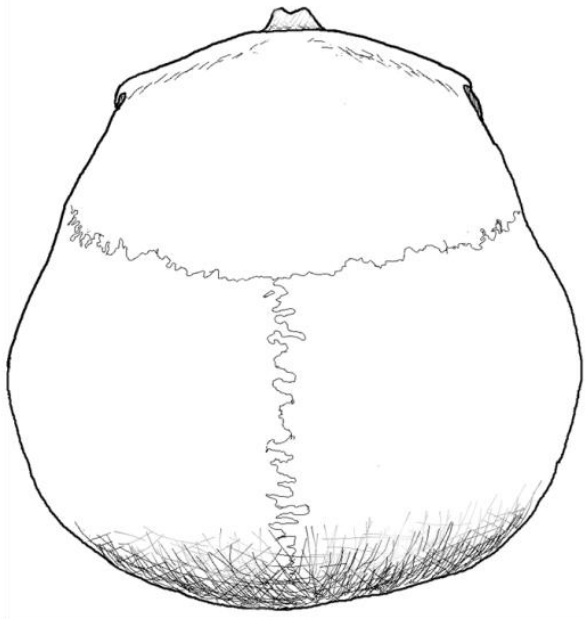

DEFORMAÇÃO TABULAR

Figura 21 - Vista superior dos principais tipos de deformações cranianas intencionais de San Pedro de Atacama (desenho de Waldiane Cossermelli). 
Apesar de haver em toda a América uma grande quantidade de variantes destas deformações cranianas artificiais (Neumann, 1942) (Figura XXXX), para este trabalho computei apenas os quatro principais tipos de deformação craniana intencional encontrados em San Pedro de Atacama: os tabulares ereto e oblíquo e os circulares ereto e oblíquo (Figura 22).

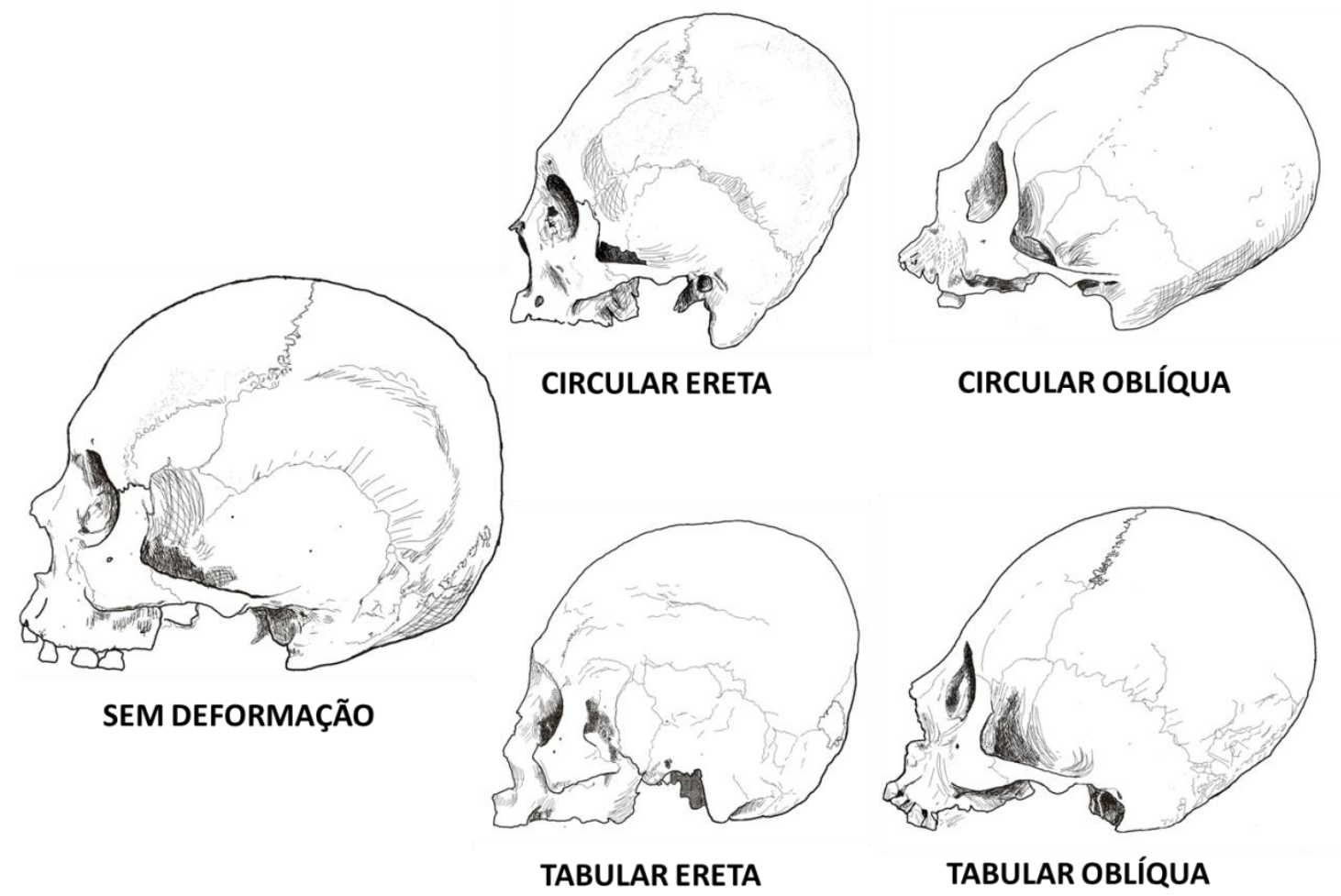

Figura 22 - Vista lateral dos tipos e angulações de deformações cranianas intencionais observadas nos crânios exumados em San Pedro de Atacama (desenho de Waldiane Cossermelli).

Como forma de identificar cada deformação encontrada em minhas amostras, criei um código de forma a simplificar a identificação destas em minhas fichas (Tabela 09): 
Tabela 09 - Deformações cranianas intencionais analisadas.

\section{CATEGORIAS}

\begin{tabular}{cc}
\hline $\mathbf{0}$ & Ausência de deformação \\
TE & Tabular ereta \\
TO & Tabular oblíqua \\
CE & Circular ereta \\
CO & Circular oblíqua \\
\hline
\end{tabular}

\section{Identificação das patologias dentais e desgaste fisiológico do esmalte}

Após a caracterização do perfil bioantropológico de cada crânio observado, o próximo passo foi a identificação da condição "bucal" do indivíduo.

A análise foi iniciada pela identificação da presença e ausência de cada elemento dentário, diferenciando a ausência em perdas antes e após a morte, ausências congênitas ou dentes retidos dentro do osso alveolar. A seguir, a identificação da presença e localização das lesões periapicais, também conhecidas como abcessos dentários. Seguindo a sequência, foram observadas as cáries dentárias, o desgaste fisiológico dentário, a presença de hipoplasia linear do esmalte, as reabsorções ósseas periodontais e por fim, a presença e a intensidade de cálculo salivar (tártaro). 


\section{Presença e ausência dentária}

Este registro é feito com o objetivo de diferenciar as possíveis etiologias responsáveis pela ausência do dente no momento da análise. Após o registro dos dentes presentes nas arcadas dentárias, iniciei a identificação das diferentes origens das ausências dentárias.

Entre as possibilidades registradas neste trabalho, elenquei 4 principais classes para a ausência dentária estudados em antropologia física:

\section{Perda ante mortem}

O osso alveolar é o tecido ósseo que circunda todos os dentes, sendo totalmente dependente da presença do dente para sua existência. Responsável por fixar as fibras periodontais às maxilas e mandíbula, a lâmina dura (como também é chamado) é considerada como um tecido ósseo do tipo imaturo, cuja matriz é pouco estruturada. Este tecido ósseo, na ausência do dente que nele é inserido (perdido por qualquer patologia ou trauma) é reabsorvido e remodelado até seu total desaparecimento, sendo mantido apenas o osso basal tanto da mandíbula como da maxila (Junqueira \& Carneiro, 1990).

Este processo de remodelação inicia-se com um arredondamento das bordas ósseas do alvéolo dentário (cavidade óssea que alberga o dente), seguido por um preenchimento desta cavidade com osso neoformado e se encerra com um aplainamento desse tecido ósseo, deixando a superfície praticamente lisa, como se no local nunca houvera um dente inserido (Marieb \& Hoehn, 2007)(Figura 23). 


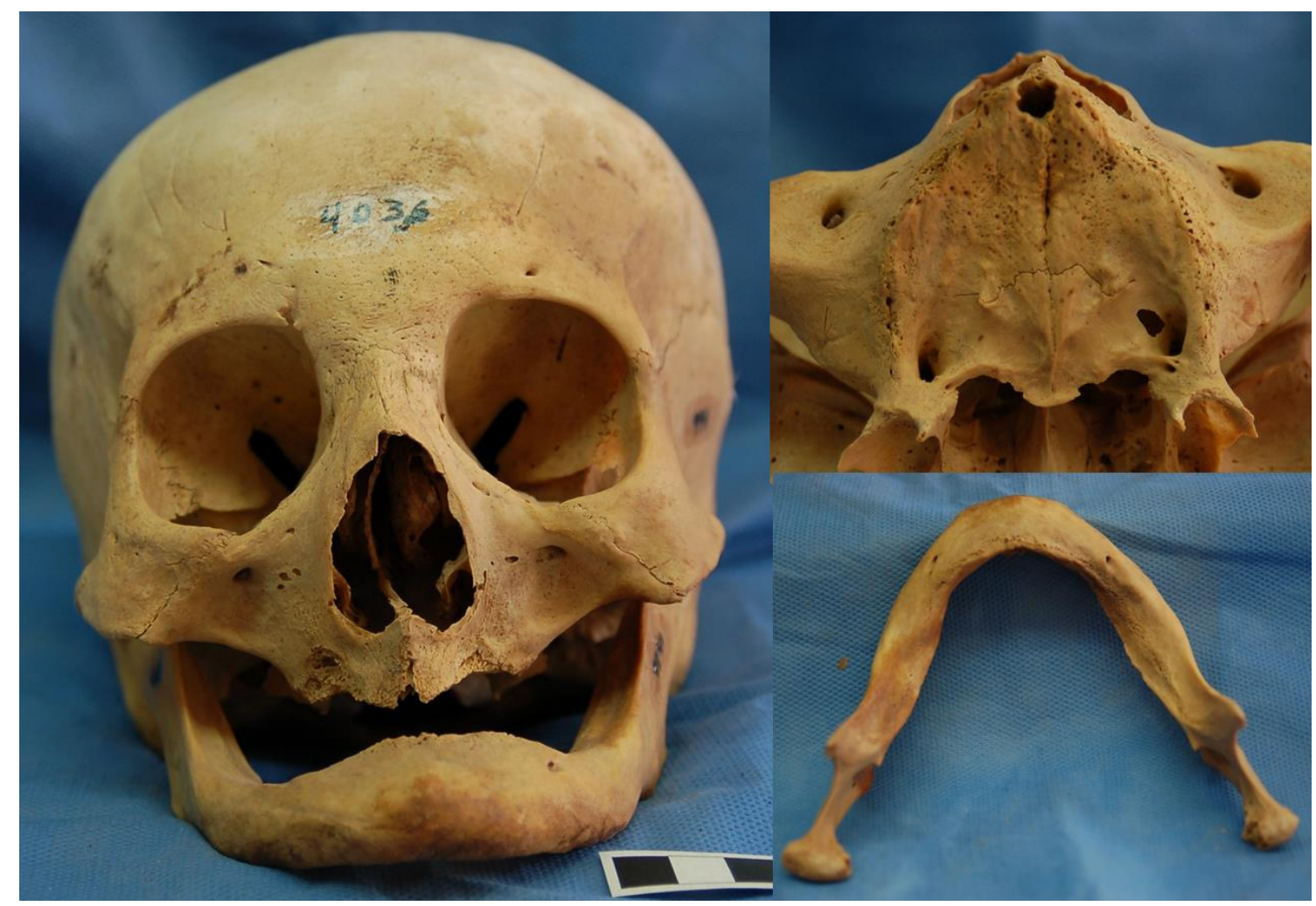

Figura 23 - Crânio com maxilas e mandíbula desdentadas (Coyo Oriental \#4036), apresentando características de perda dentária ante mortem.

As perdas dentárias ante mortem podem ser resultantes de processos traumáticos ou patológicos ocorridos durante a vida do indivíduo. Entre as causas traumáticas, quedas ou choques violentos podem causar a remoção do dente, sendo mais comuns em dentes anteriores superiores e normalmente removendo parte do osso alveolar que o circunda. Já entre as etiologias patológicas, as infecções que acometem os dentes como cáries ou periodontites avançadas são capazes de provocar a reabsorção óssea periodontal e assim, "expulsar" o dente do osso alveolar. Por último, esta perda pode ser resultante de um processo fisiológico, o desgaste dentário que, ao avançar, expõe a polpa dentária à cavidade oral e assim, permite que bactérias infectem o dente, levando ao aparecimento de um abcesso periapical e ao mesmo processo de expulsão dental ocorrido nos processos patológicos anteriormente descritos (Neville et al., 2003 a; b). 
As perdas dentárias ante mortem foram anotadas e posteriormente associadas à presença e intensidade de cáries, assim como às doenças periodontais, como forma de inferir sua origem.

\section{Perda post mortem}

A perda dentária post mortem é resultante de inúmeros processos tafonômicos a que foi submetida a amostra.

Estes processos podem ter ocorrido nos primeiros momentos após a morte do indivíduo (peri mortem); durante o ritual funerário; no período em que o corpo esteve enterrado ou depositado no solo; no processo de exumação do mesmo; no procedimento de cura do material na instituição responsável ou ainda durante o período de guarda deste exemplar.

Assim, para distingui-la da perda ante mortem procurei padronizar a observação da seguinte forma: nos casos em que a diferença era evidente, ou seja, quando na ausência dentária o alvéolo está intacto ou bem preservado, não houve dificuldade na identificação e diferenciação entre ambas. Porém em casos de dúvida, foi considerada perda post mortem quando foi observada qualquer borda óssea afilada ou ainda qualquer remanescente do alvéolo dentário presente (Figura 24). 


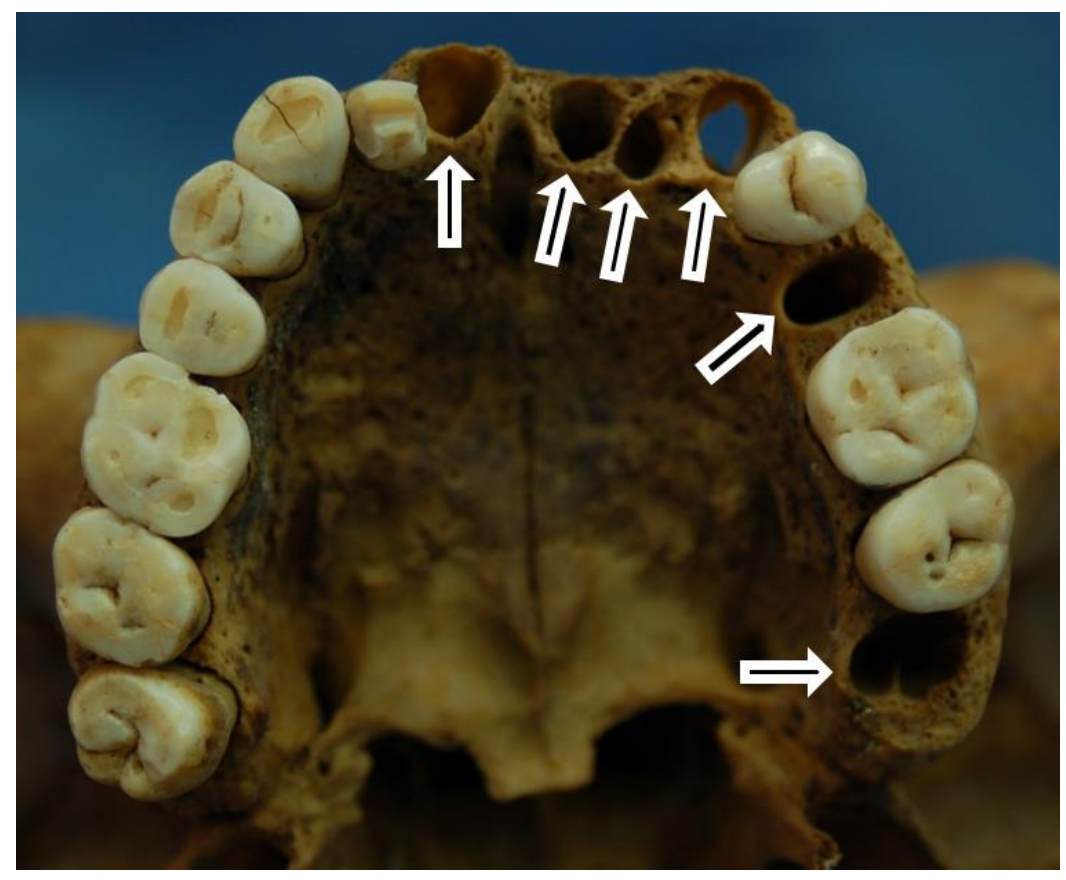

Figura 24 - Alvéolos dentários vazios (Yaye Orilla Occidental \#1432) devido à perda post mortem indicados pelas setas.

\section{Ausência dentária congênita}

A ausência dentária congênita ou hipodontia é resultado da "não formação" do germe dentário de um ou mais dentes. Raramente presente na dentição decídua, a hipodontia acomete principalmente os terceiros molares, incisivos laterais e prémolares permanentes (nesta ordem) e apresenta uma maior prevalência em mulheres (Neville et al., 2003 a) (Figura 25). 


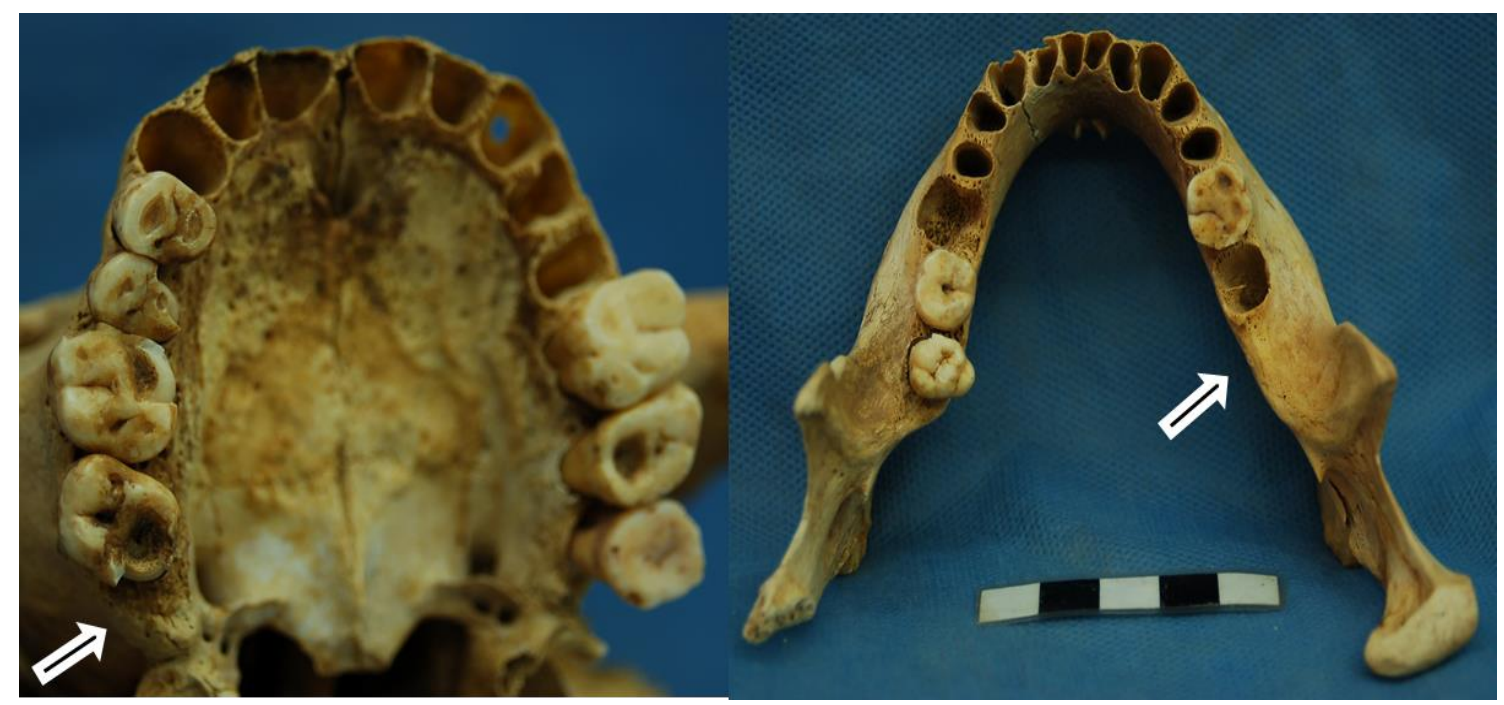

Figura 25 - Ausência congênita dos terceiros molares direitos, tanto superior quanto inferior (Yaye Orilla Occidental \#1435).

Apesar de não ter radiografado os casos suspeitos de ausência dentária congênita, o que confirmaria a ausência do germe dentário, considerei as ausências congênitas os casos nos quais observei a falta do elemento dental em seu alvéolo natural. A correta posição verticalizada dos dentes contíguos ao dente ausente me auxiliou na diferenciação desta ausência dentária com a ausência resultante das perdas ante mortem.

\section{Dentes retidos nos alvéolos ou dentes impactados}

Também representado pela ausência do elemento dental em sua posição adequada de oclusão, os dentes retidos nos alvéolos são resultantes de um mal posicionamento do dente em erupção ou do mal posicionamento dos dentes já erupcionados contíguos a ele. Podendo acometer qualquer dente, esta alteração do processo eruptivo é mais frequente em terceiros molares e nos dentes caninos (Neville et al., 2003 a). 
Como os casos de retenção intraóssea não ser possível distingui-los das ausências dentárias congênitas, considerei neste trabalho apenas os dentes que iniciaram o processo de erupção, rompendo a cortical óssea e sendo visível a olho nu, porém sem conseguir alcançar seu correto posicionamento na boca, ficando em infraoclusão (Figura 26).

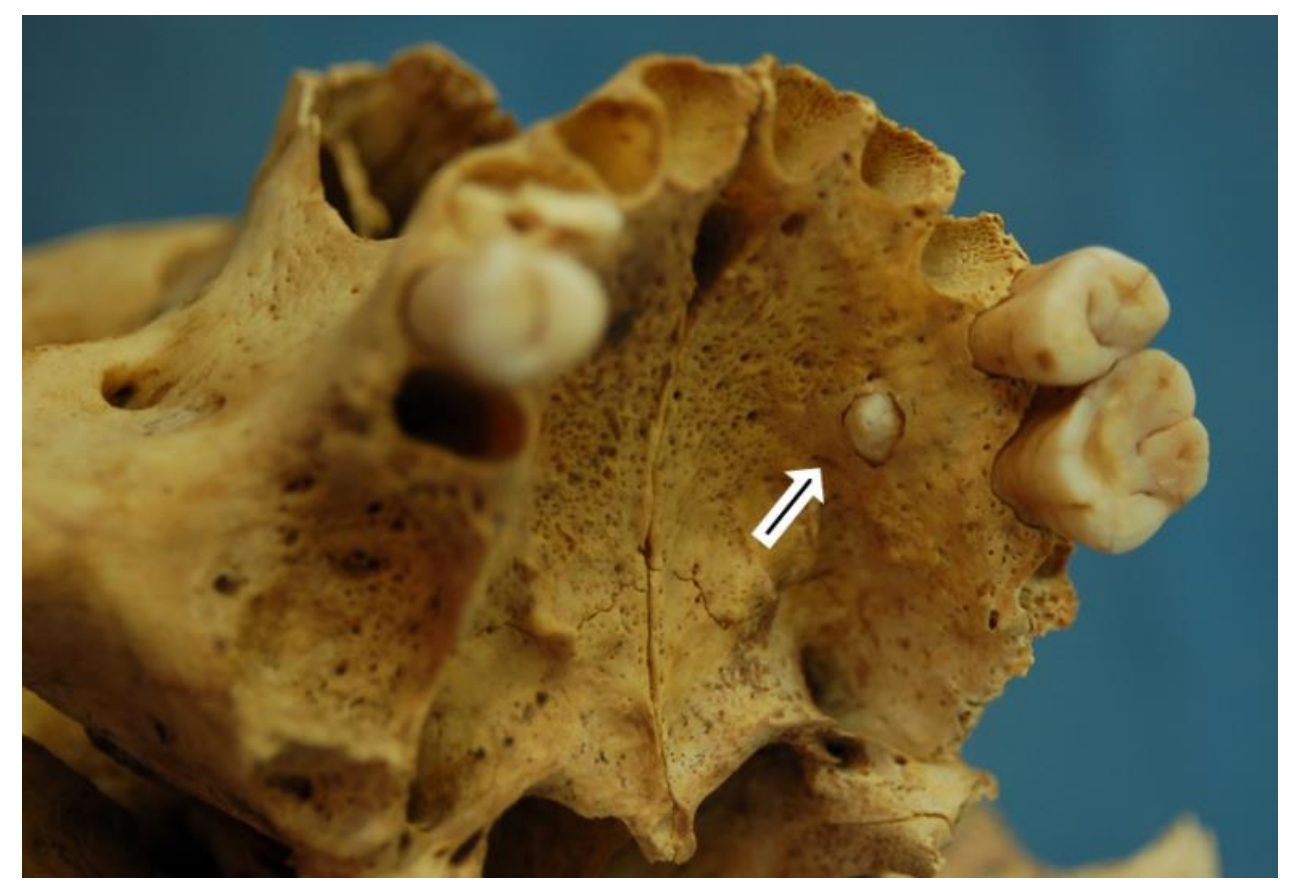

Figura 26 - Segundo pré-molar superior esquerdo impactado sob o primeiro pré-molar e o primeiro molar superiores esquerdos (Yaye Orilla Occidental \#1417).

\section{Ausência do alvéolo e do dente correspondente}

Apenas como forma de registro, a ausência do alvéolo dentário foi assim considerada quando as duas tábuas ósseas do osso alveolar estavam ausentes, ficando impossível avaliar se esta era, mesmo com a ausência dentária, resultante de uma perda ante ou post mortem (Figura 27). 


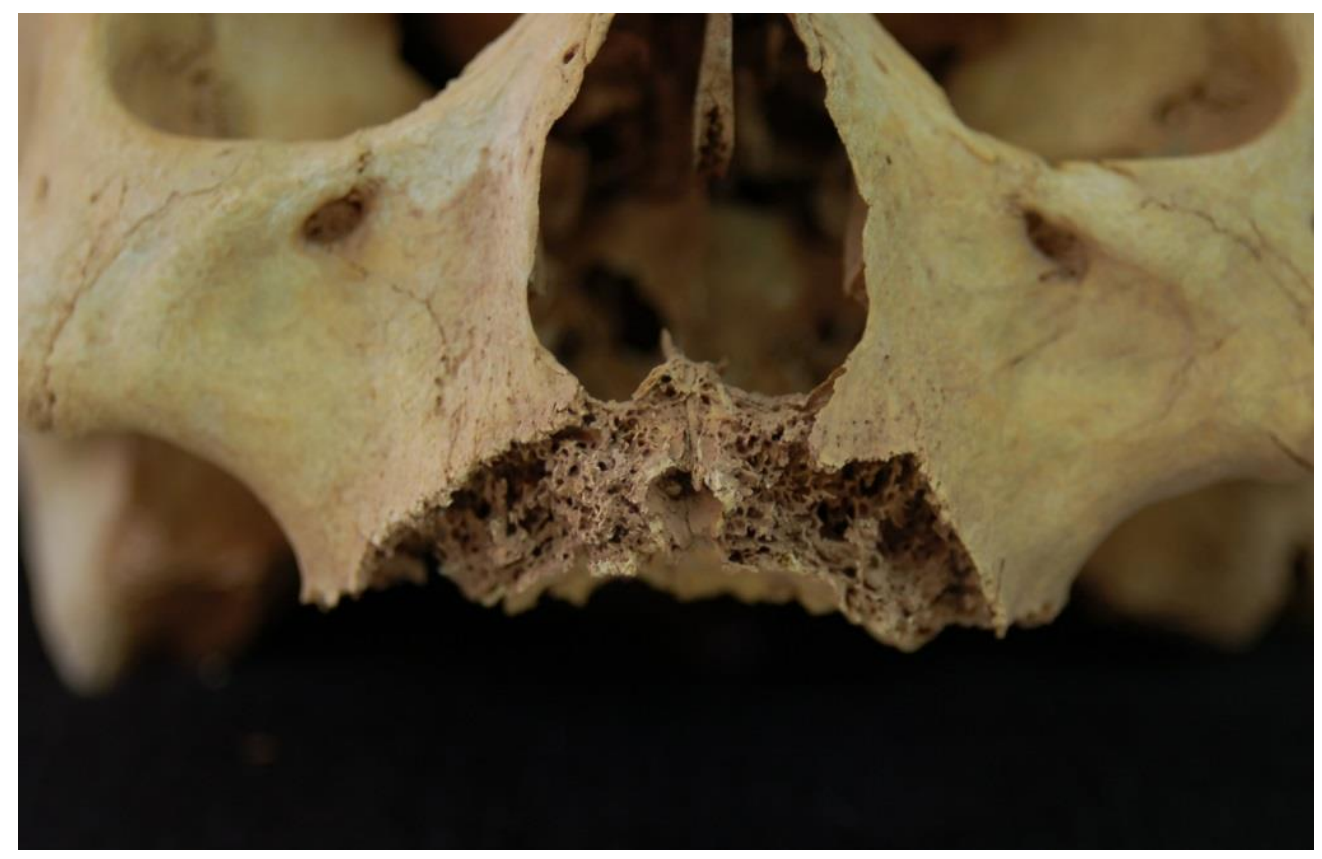

Figura 27 - Ausência de alvéolos e dentes correspondentes (Catarpe 1 \#2397).

\section{Lesão periapical ou abcesso dentário}

Lesão óssea lítica, ou seja, patologia que reabsorve o osso acometido pela mesma, o abcesso é causado pela infecção do osso alveolar por bactérias presentes na cavidade oral. Quando localizado no ápice da raiz dentária, é chamada de lesão periapical e tem com o principal meio de contaminação a exposição da câmara pulpar dentária ao meio bucal, seja pela presença de cárie no referente dente, seja por um grande desgaste que este possa apresentar (Figura 28). Com a presença de bactérias e células de defesa (macrófagos e neutrófilos) formando uma coleção purulenta dentro do osso, este fluído pressiona as paredes ósseas que são reabsorvidas e assim, seja por lingual ou por bucal, a lesão aparece na superfície óssea em forma de cavidade (Neville et al., 2003 b; Roberts \& Manchester, 2005 b). A "predileção" de cada abcesso em exteriorizar-se para o lado lingual ou para o lado bucal é diretamente relacionada à espessura da tabua óssea alveolar e à posição e morfologia da raiz dentária de cada dente. Este é o motivo de observarmos em muito maior frequência estas lesões na 
face bucal do maxilar do que em sua face lingual, com poucas exceções (Scheid \& Weiss, 2012 a).

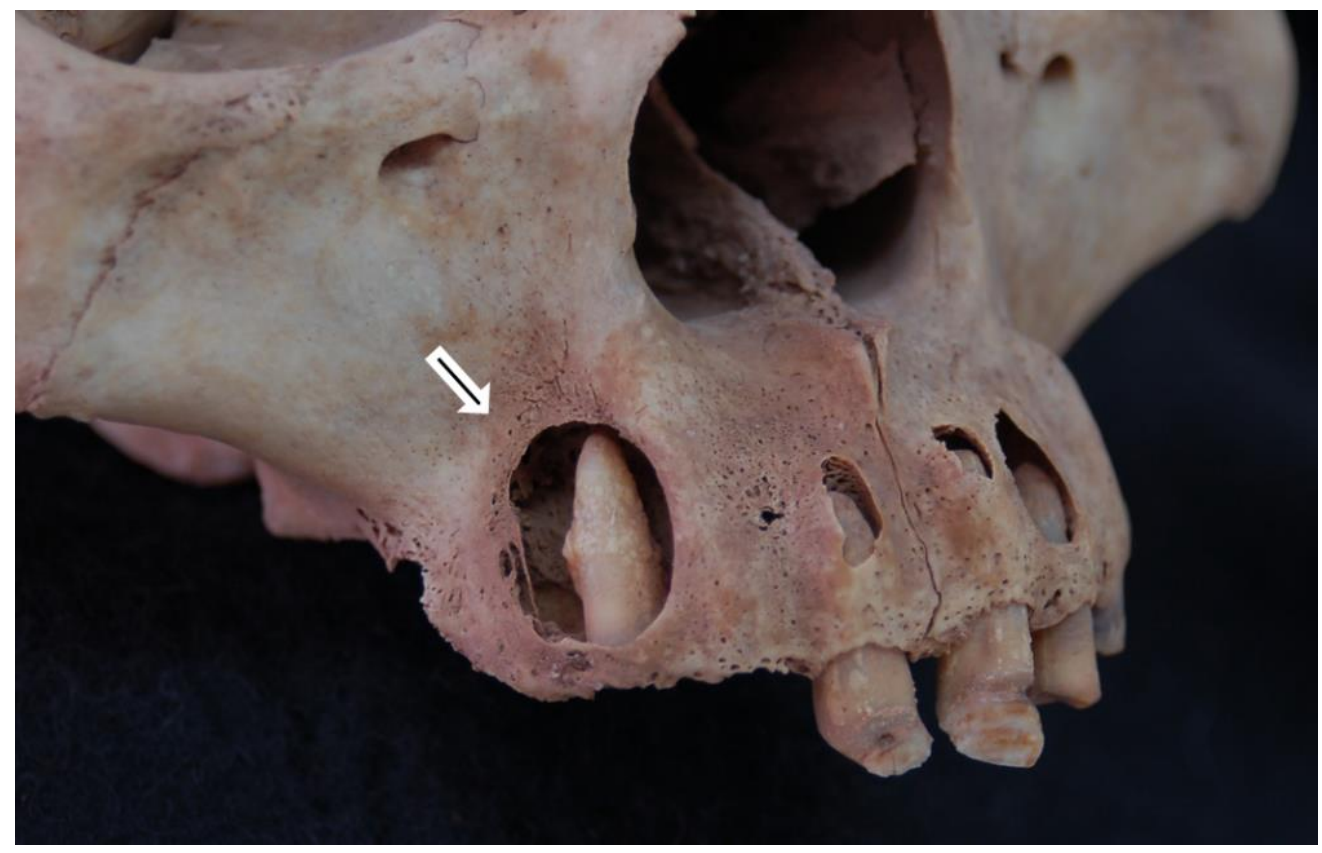

Figura 28 - Abcesso dentário localizado no ápice radicular do canino superior direito (Catarpe 1 \#2404).

Cistos de origem odontogênica (não infecciosas) podem ser confundidos com os abcessos (Neville et al., 2003 c; Roberts \& Manchester, 2005 b), mas por serem casos excepcionais, foram desconsiderados neste trabalho.

Assim, desconsiderando se a cavidade óssea encontrada nos esqueletos avaliados era resultante de um cisto, um granuloma ou de um abcesso propriamente dito, computei neste trabalho as lesões periapicais encontradas nos exemplares de acordo com sua localização, divididas em lesões com fenestração bucal, lingual ou não fenestradas. Estas últimas só foram consideradas quando observadas em alvéolos vazios, provenientes de uma perda post mortem do elemento dentário, pois não utilizei de exames complementares como radiografias ou tomografias para identificar estas patologias. 


\section{Patologias dentais}

As perdas dentárias ante mortem e as lesões periapicais encontradas na coleção esqueletal estudada foram causadas por processos infecciosos de origem bacteriana que acometeram o dente a eles associados. Sendo assim, o entendimento da relação entre o patógeno (agente causador) e o hospedeiro (ser humano) é de fundamental importância, uma vez que se trata de agentes que são dependentes do meio ambiente criado nas superfícies dentais e periodontais. Este ambiente é composto pelas estruturas corpóreas do indivíduo hospedeiro, pelos alimentos que ele ingere e pelas proteínas e enzimas carreadas pela saliva do mesmo (Marsh \& Martin, 2009 a) (Figura 29).

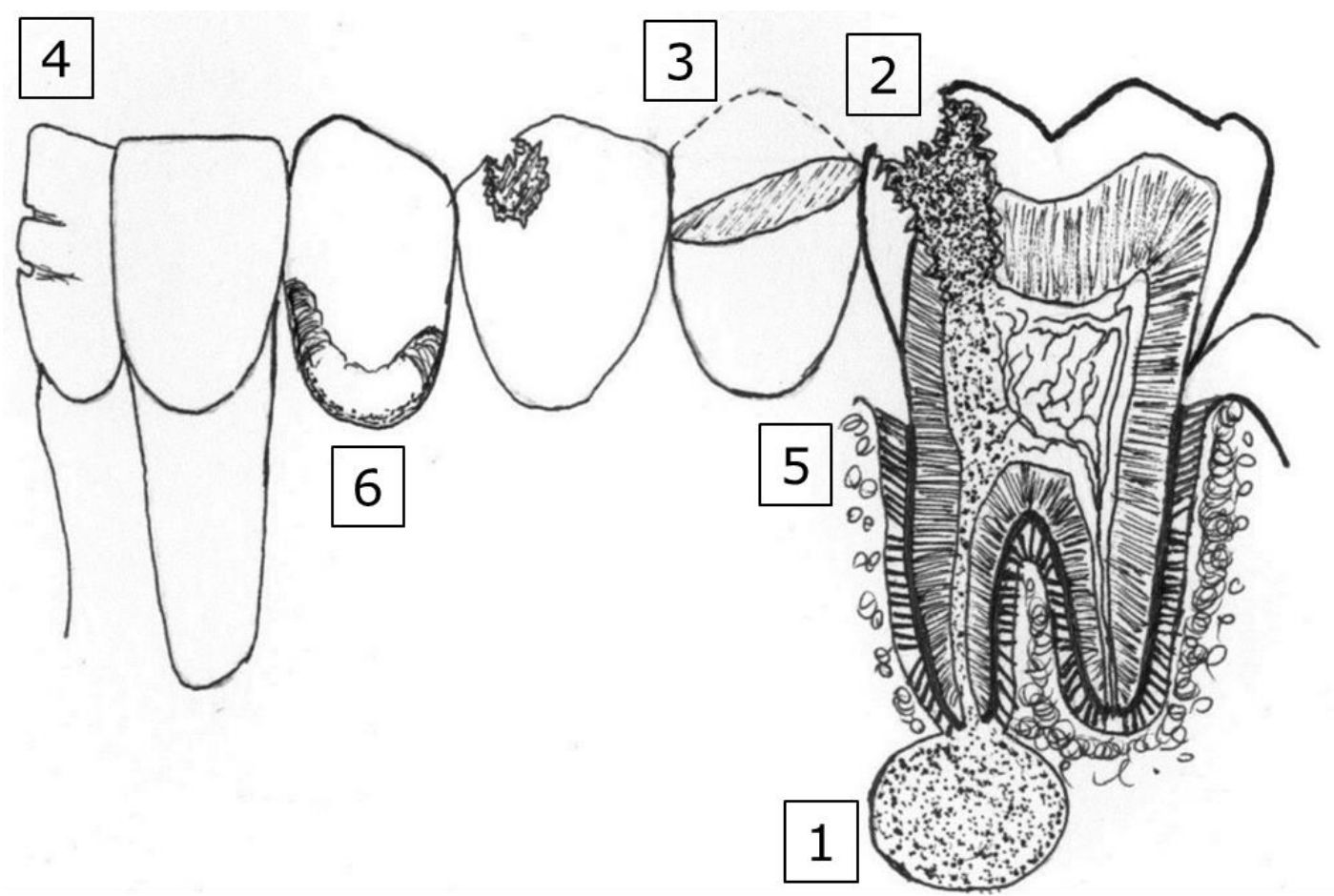

Figura 29 - Patologias dentais avaliadas neste trabalho: 1. Abcesso periapical; 2. Cárie dentária; 3. Desgaste dentário; 4. Hipoplasia linear do esmalte; 5. Reabsorção periodontal; 6. Cálculo dentário. (desenho de Rodrigo Elias de Oliveira) 
O entendimento da tríade PATÓGENO-HOSPEDEIRO-SUBSTRATO explicará as frequências de algumas patologias encontradas nas amostras e também, num sentido oposto, analisando estas frequências, encontraremos informações sobre possíveis variações anatômicas, morfológicas ou funcionais, mas principalmente sobre a dieta dos indivíduos destas amostras.

\section{Cárie dentária}

Indubitavelmente, a cárie dentária é a patologia dental mais estudada entre odontólogos e antropólogos físicos.

Apesar da cárie dentária ser considerada, por alguns, não como uma patologia mas sim como um desequilíbrio de fatores fisiológicos (Lima, 2007), a imensa maioria de pesquisadores da área de Cariologia (nome da disciplina clínica/laboratorial responsável pelos estudos da cárie dentária humana) e de antropólogos dentais consideram-na uma patologia infecciosa e multifatorial (Black, 1914; Keyes, 1960; Newbrun, 1982). Para autores como Ole Fejerskov (2004) não se deve considerar a cárie dentária como uma patologia infecciosa (pelo menos, não uma doença infecciosa convencional) por não se tratar de uma patologia na qual há um patógeno específico e que pode ser identificável e, por consequência, combatido. Também para ele, a possibilidade de haver mais de um agente causador é que faz a cárie dentária extrapolar este conceito.

G.V. Black afirmava, já nos primeiros anos do século XX, que a cárie dentária é resultante da simples dissolução química dos sais de cálcio presentes no esmalte dentário, sendo um processo lento e progressivo e ocorrendo sempre de fora para dentro do dente. Para ele, este processo ocorre nos lugares onde se agregam microrganismos e que, por não serem removidos do local, se acumulam e propiciam o aparecimento da doença cárie (Black, 1914). 
Assim, de forma simplificada, o processo carioso se baseia em dissolver os minerais de hidroxiapatita encontrados no esmalte e na dentina, em maior proporção que o processo inverso, chamado de remineralização, que ocorre após o período de ação do ácido lático produzido pelas bactérias contidas na placa bacteriana (Brown et al., 1977).

A tríade que explica as patologias que foram anteriormente descritas, no caso da cárie dentária, foi proposta por P.H. Keyes e tinha como patógenos, bactérias e como substrato, a dieta (Keyes, 1960; Larson et al., 1962). Anos mais tarde, E. Newbrun acrescentaria a esta equação a variável TEMPO, destacando a necessidade de admitir que, os fatores da tríade precisam de tempo para agir, desequilibrando a equação desmineralização X remineralização (Hillson, 1979; Newbrun, 1982). Mesmo uma cárie em estágio de lesão branca (primeiro estágio da lesão de cárie clinicamente observável) é resultado de inúmeras e recorrentes flutuações de PH sobre a superfície do esmalte atingida (Fejerskov et al., 2005).

Devido à anatomia da coroa dentária, com suas variações morfológicas de origem genética, os dentes apresentam áreas distintas em cada região da coroa, favorecendo o acúmulo de placa bacteriana em lugares específicos. Assim, os sulcos, as fóssulas e as fissuras da coroa são as regiões mais propícias a isto, seguidas da região sob o ponto de contato interdental e finalmente da região do colo, próximo à gengiva (Figura 30). Ainda dentro da variante hospedeiro, também é necessário considerar a saliva do indivíduo. Quanto à saliva, as principais funções deste fluido corpóreo são: iniciar o processo de digestão de alguns alimentos ainda na boca, como por exemplo o amido através da enzima amilase; limpar as superfícies de dentes e mucosas através da ação mecânica do líquido em movimento (fluxo salivar) e sua capacidade de tamponar, ou seja, elevar o PH na superfície dental, sobre e sob a placa bacteriana, quando a superfície é atacada pelo ácido produzido por esta placa (Marsh \& Martin, 2009 b). 


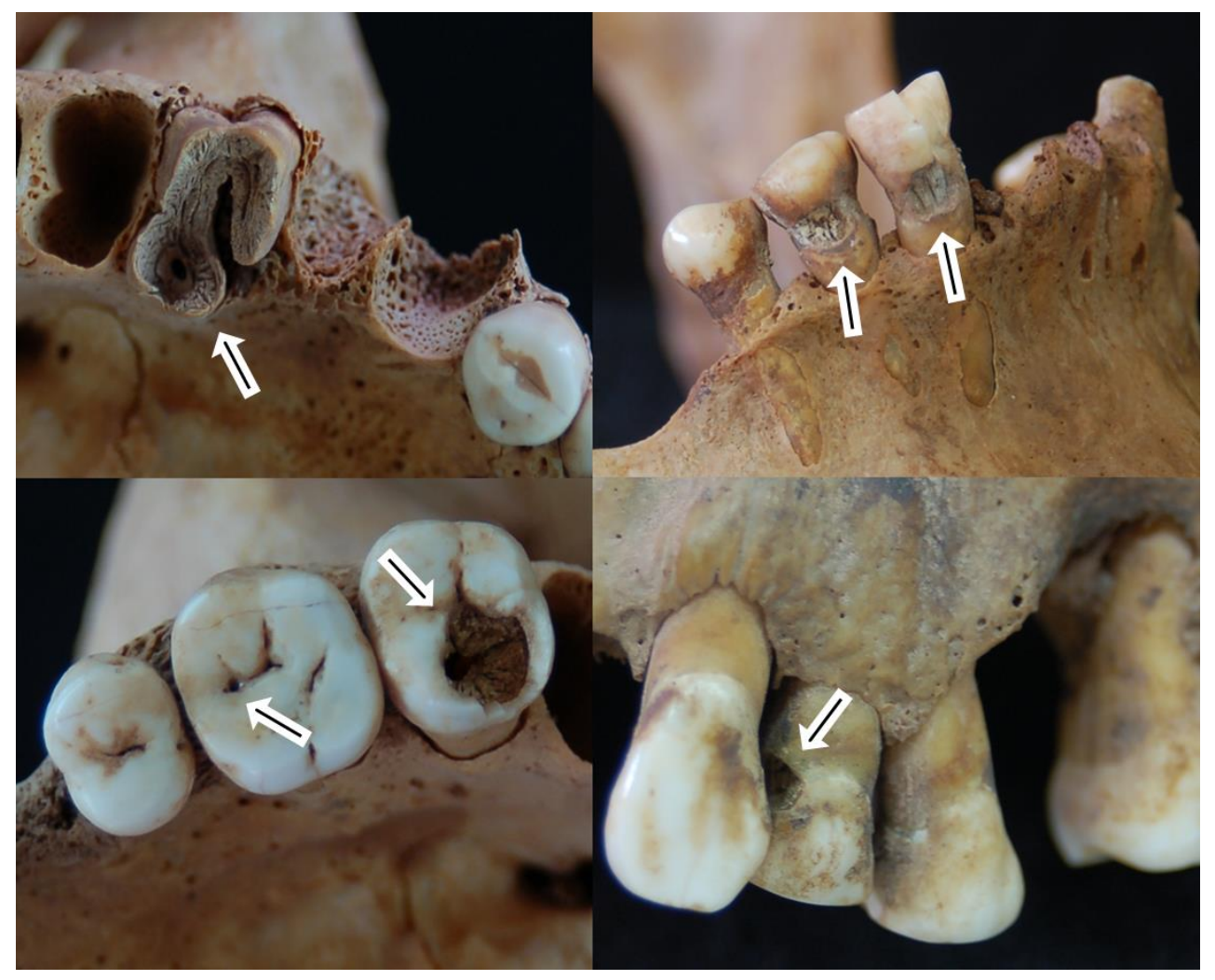

Figura 30 - Lesões de cárie dentária com localização e intensidade distintas.

Apesar da flora bacteriana bucal ser constituída por centenas de bactérias distintas, um pequeno grupo destas estão atualmente associadas às cáries. Após um breve período durante a primeira metade do século $X X$, quando se acreditava ser o Lactobacillus a principal bactéria responsável pelas cáries, o Streptococcus mutans passou a ser a principal bactéria relacionada às cáries dentárias. Anteriormente consideradas como sorotipos de S. mutans, as bactérias como a S. sobrinus (antiga $S$. mutans sorotipo A) atualmente são espécies distintas. Com isso, atualmente se utiliza a denominação "Estreptococos do grupo mutans" para estas bactérias. Este é considerado o principal responsável pela formação das cáries, juntamente com os Lactobacillus, apesar de algumas discordâncias sobre o tema (Fejerskov, 2004; Marsh \& Nyvad, 2005; Marsh \& Martin, 2009 c; Russell, 2009).

Dentre este grupo, outras espécies de streptococos também foram consideradas corresponsáveis pela formação da cárie dentária, entre elas S. sanguinis, S. oralis e S. anginosus. Hoje a cárie é considerada uma doença resultante da 
solubilização do esmalte e da dentina devido à produção de ácido lático pela placa bacteriana (ou biofilme) que são formados por uma sucessão de bactérias produtoras e resistentes a este ácido (Russell et al., 2004; Marsh \& Nyvad, 2005). A condição de atividade ou inatividade da placa bacteriana e, consequentemente, de ambiente cariogênico $(\mathrm{pH}<5,5)$ ou não, favorecerá o aumento de bactérias mais acidófilas ( $S$. mutans e Lactobacillus) ou menos acidófilas (S. sanguinis e S. oralis) respectivamente (Marsh \& Martin, 2009 c).

Tendo em vista que estes dois fatores são imponderáveis nas amostras arqueológicas, todas as pesquisas nas quais o objeto de análise é a cárie dentária objetivam entender a dieta dos indivíduos analisados.

Desde os anos 1930, os estudos focaram no papel da nutrição como um importante fator no entendimento do processo carioso. Tida como principal suspeita, a dieta rica em carboidratos começou a ser estuda ainda na primeira metade do século XX, apresentada em "Dietary Carbohydrate and Dental Cáries" (Anonymous, 1949) como principal responsável pelo processo de fermentação e consequentemente, como principal fator de risco para cárie.

Nos anos seguintes, sendo considerado um marco nas pesquisas experimentais sobre dieta e cariogenicidade dos alimentos, o trabalho de B. Gustafsson (1954) conhecido como "Estudo de Vipeholm" semearia a dúvida que perdura desde então sobre a relação entre quantidade de carboidrato ingerido e frequência de ingestão. Uma vez que, em muitos casos, o aumento da segunda significa em certo modo também o aumento da primeira, mais trabalhos buscam alternativas experimentais para isolá-las e assim, compará-las adequadamente (Moynihan et al., 2005).

Estabelecida a relação entre ingestão de carboidratos e aumento de produção de ácido lático pela placa bacteriana, iniciou-se uma busca para entender as associações e os tipos de carboidratos presentes na dieta que seriam mais cariogênicos. Apesar de ser um polissacarídeo (polímeros contendo 20 ou mais monossacarídeos) e ser mais difícil de ser utilizado pela placa bacteriana em sua cadeia metabólica, o amido possui um poder de adesão à superfície dental maior que a glicose ou a frutose, diminuindo por mais tempo o pH na superfície dental (Lingstrom 
et al., 2000; Moynihan et al., 2005; Nelson \& Cox, 2008). Além disso, quando associado a um destes monossacarídeos (açúcares simples), passam a ser mais cariogênicos que quando isolados. Outra consideração importante a ser feita é sobre o preparo de alguns alimentos. Quando se processam os alimentos em alta temperatura, os amidos contidos neles sofrem um processo conhecido como gelatinização, facilitando a reação de quebra destes polissacarídeos e tornando este alimento ainda mais cariogênico (Grenby, 1997; Lingstrom et al., 2000; Touger-Decker \& van Loveren, 2003; Moynihan et al., 2005).

Nos trabalhos com material arqueológico, desde o início do século $\mathrm{XX}$, a associação direta entre a dieta cariogênica ou seja, rica em carboidratos, e a alta frequência da presença de cárie tem sido usada para inferir padrões alimentares de diversas populações (Hillson, 1979, 1996 b, 2008; Kelley, 1991; Larsen, 1997 d; Cornero et al., 1999; Temple \& Larsen, 2007).

A base para futuras interpretações neste trabalho seguirá a premissa segundo a qual, quanto maior a quantidade de açúcares e amidos (carboidratos) encontrados na dieta de determinada população pretérita analisada, maior será a frequência de lesões de cárie dentária encontradas em seus indivíduos.

Neste trabalho, as análises de cárie dentária foram executadas buscando não apenas a presença e a ausência dessa patologia nos dentes estudados mas também a localização e a intensidade do comprometimento dentário por essas patologias.

Para o registro, foi criada uma ficha específica a partir de um odontograma utilizado na clínica odontológica. Nesta ficha, cada elemento dental foi identificado com seu número segundo o "FDI System" da Fédération Dentaire Internationale (FDI World Dental Federation) (Scheid \& Weiss, 2012 b). Para cada elemento, foi apontada a ausência ou a presença da cárie dentária. Quando presente, o número de lesões em cada dente era evidenciado na primeira coluna. Nas quatro (04) colunas seguintes, as localizações de cada lesão e nas quatro últimas, a intensidade da lesão. As localizações e intensidade das lesões foram computadas seguindo um protocolo criado a partir da dissertação de mestrado de Luis Lanfranco (2010). Os trabalhos de Watt et al. (1997) e 
Silmon Hillson (2001) foram utilizados na avaliação da localização das lesões cariosas e o trabalho de Sakashita et al. (1997) na avaliação da intensidade da cárie observada.

Para a avaliação da localização das cáries, foi utilizado um número referente a localização e característica da cárie observada. Com o valor 0 para a ausência desta patologia, os números de 1 a 9 foram utilizados para identificar cada uma das lesões que os dentes apresentavam, sendo computadas de forma individualizada. Assim, um dente que apresentou 3 lesões distintas de cárie, teve cada uma destas lesões identificadas quanto à sua localização, seguindo a Tabela 10: 
Tabela 10 - Códigos de identificação da localização e característica das lesões de cárie.

CAT. LOCALIZAÇÃO

CARACTERÍSTICAS

0

Sadio

Sem Lesão.

$1 \quad$ Cárie Oclusal

Cárie em sulcos e fóssulas oclusais

(dentes posteriores).

$2 \quad$ Cárie Pontual

Cárie em sulco bucal ou palatino de molares e sulco lingual de incisivos.

3 Cárie Superfície Lisa

Cárie de superfície lisa por bucal e/ou

lingual.

4 Cárie Interdental (Ponto Cárie em área de contato interdental. de Contato)

5 Cárie de superfície lisa Cárie localizada imediatamente abaixo da interdental área de contato interdental. (abaixo de PC)

6 Cárie radicular ou LEC Cárie em superfície radicular ou no colo (limite esmalte-cemento) coronário, no limite esmalte-cemento (LEC).

7 Cárie em dentina exposta Cárie em dentina exposta devido à fratura por fratura da crista do esmalte da crista marginal fragilizada marginal pelo desgaste oclusal.

8 Exposição pulpar devido a Exposição da cavidade pulpar devido ao desgaste oclusal desgaste oclusal intenso.

$9 \quad$ Raiz residual Destruição total da coroa, impossibilitando identificar origem da lesão. 
Para a avaliação da intensidade com que a cárie avançou na superfície dental, uma escala de 0 a 4 foi criada. Nesta escala, o valor 0 significava a ausência da cárie enquanto que, de 1 a 4, o comprometimento da estrutura dental foi computado também de forma crescente, onde 1 correspondia à uma cárie superficial com apenas o esmalte ou o cemento atingidos e 4 onde a coroa dentária se encontrava totalmente destruída pelo avanço da doença (tabela 11). Também individualizei a intensidade de cada lesão de cárie, possibilitando a associação das localizações e intensidade das cáries observadas.

Tabela 11 - Intensidade de comprometimento das lesões de cárie.

Cat. Tecido

Característica

comprometido

0 Nenhum Sem lesão observável.

1 Esmalte ou Cárie que acomete apenas o esmalte ou cemento. Lesões cemento brancas de esmalte não foram consideradas. Apenas cavitações de coloração parda ou negra, com no máximo $2 \mathrm{~mm}$ de profundidade.

2 Dentina Cárie que acomete a dentina, mas não a polpa, com mais de $2 \mathrm{~mm}$ de profundidade.

3 Câmara Pulpar Cárie que atinge a cavidade pulpar.

4 Coroa Total Destruição completa da coroa dentária.

Também como sugestão do pesquisador Luis N. Lanfranco, adicionei a minha ficha de análise algumas lacunas nas quais pudesse anotar um resumo das patologias observadas. Isso me obrigou, ao final de cada avaliação dos dentes presentes, a rever 
todos os dentes avaliados, aumentando a acurácia dos dados computados neste formulário. Assim, foram revisadas as anotações de cáries, abcessos e perdas ante e post mortem de cada dente computados anteriormente.

\section{O Flúor e sua relação com as cáries}

Mundialmente conhecido como substância protetora dos dentes frente às cáries, o flúor começou a ser estudado pela Odontologia no início dos anos 1900, devido a seu potencial toxicológico e não à sua capacidade benéfica.

Conhecido como "Denti di Chiaie", "mancha amarronzada do Colorado" ou simplesmente como fluorose dentária (Pestana, 2012), o excesso de íons de flúor agregados à hidroxiapatita do esmalte dentário é caracterizado pela formação de máculas na superfície dental que varia desde pontos esbranquiçados a grandes manchas amarronzadas, resultantes da má formação deste esmalte (Neville et al., 2003 a). Porém, quando presente em baixa incidência, a fluorose provê ao dente uma resistência maior aos ataques ácidos das placas bacterianas cariogênicas (McKay, 1928).

Ao longo do século passado, inúmeros trabalhos buscaram encontrar as condições ideais para a utilização dos fluoretos como forma de aproveitar apenas os efeitos protetores do flúor. As pesquisas buscaram padronizar a forma de administração e a concentração exatas de flúor para a população.

Considerada uma das dez (10) mais importantes conquistas da saúde pública nos Estados Unidos durante o século XX, a fluoretação da água potável em 1999, após 55 anos de sua implantação, era fornecida a 144 milhões de habitantes dos Estados Unidos, reduzindo a cárie dentária em $70 \%$ nas crianças e diminuindo a perda dentária em adultos em até 60\% (CDC, 1999). No Brasil, a fluoretação da água começou em 
1953 em Baixo Guandu-ES, corrigindo o teor natural de $\mathrm{F}^{-}$da água da região que passou de 0,15 mg/l para 0,8 mg/l (Ramires \& Buzalaf, 2008).

Segundo a portaria número 635/BSB de 26/12/1975 do Ministério da Saúde brasileiro, a concentração ótima de fluoretos na água a ser distribuída à população deve ficar entre 0,7 e 1,2 mg/l de $\mathrm{F}^{-}$, variando conforme a temperatura média local. Isso porque, em regiões onde a temperatura é mais alta, a tendência natural é que a população consuma mais água e por isso a concentração dos fluoretos deve ser compensada, evitando a ocorrência de fluorose (Ramires et al., 2008). Assim, o Ministério da Saúde estipulou na portaria número 518 de 25/03/2004 que o Valor Máximo Permissível (VMP) é de 1,5 mg/l de flúor em todo o território nacional.

Todo esse empenho mundial em prover à população flúor suficiente tem uma razão: sua efetividade em diminuir a incidência de cáries.

O flúor ingerido é rapidamente absorvido pelo estômago, elevando seus níveis séricos no plasma sanguíneo. Transferido em quantidades muito baixas para o leite materno, dificultando assim o provimento via amamentação, estes íons de flúor estão disponíveis para os ossos e dentes via corrente sanguínea. Por esta via, tanto os ossos como a superfície interna da câmara pulpar dos dentes ficam acessíveis à incorporação de flúor nas já existentes hidroxiapatitas formadoras destes tecidos. Porém, para poder acessar a superfície dental, estes íons precisam ser transferidos para a saliva do indivíduo e assim, em contato com a superfície dental e através do mecanismo de desmineralização e remineralização dentária, ser anexada ao esmalte dentário (Ekstrand \& Oliveby, 1999; Olivares \& Uauy, 2004; Ellwood \& Fejerskov, 2005; Fejerskov et al., 2005; ten Cate et al., 2005).

O processo de desmineralização do esmalte dental ocorre quando o $\mathrm{pH}$ sobre a superfície deste desce a valores inferiores a 5,5. Quando isso acontece, a hidroxiapatita encontrada na estrutura do esmalte se solubiliza e é retirada do tecido dentário. Porém, quando esta hidroxiapatita encontra, diluído na saliva, íons $\mathrm{F}^{-}$, ela se junta a este formando a fluorapatita, retornando à estrutura dentária. Quando isso acontece, a fluorapatita faz com que o dente fique mais resistente ao processo de desmineralização, uma vez que, ao contrário da hidroxiapatita que se solubiliza a um 
$\mathrm{pH}$ de 5,5, a fluorapatita só se solubiliza quando o $\mathrm{pH}$ chega a valores inferiores a 4,5 (Ten Cate et al., 2005).

\section{Disponibilidade de flúor no ambiente}

Apesar de serem um elemento-traço, elemento encontrado em pequena quantidade porém necessário à vida de alguns organismos, os íons de flúor são encontrados em associações solúveis em água e estão amplamente distribuídos na atmosfera. Isto se deve a lixiviação dos solos pelas águas subterrâneas e devido também às erupções vulcânicas que disponibilizam-no na superfície terrestre. Estes mecanismos distribuem os fluoretos de formas distintas através do globo, dependendo das estruturas geológicas que formam cada região (Ellwood \& Fejerskov, 2005).

Para o deserto de Atacama, região de intensa atividade vulcânica tanto em sua formação quanto atualmente, diversos trabalhos de levantamento geológico foram executados, porém buscando metais e outros minerais (Pimentel, 1976; Alonso \& Risacher, 1996). Alonso \& Risacher (1996) fizeram um importante levantamento dos sais que são acumulados e assim, formam o salar de Atacama. Com uma velocidade de sedimentação extremamente baixa $(0,1 \mathrm{~mm} / \mathrm{ano})$, os autores sugerem que a principal formação do salar se deu, principalmente, durante o máximo glacial do Pleistoceno, quando os aportes de água na região teriam sido mais intensos. Apesar de um grande detalhamento dos sais presentes no salar e nas fontes de água que nele desaguam, nenhuma informação sobre os íons de flúor ou seus fluoretos foi mencionada nesse trabalho.

Devido à sua importância na prevenção de cáries dentárias e a possibilidade de haver na região uma disponibilidade de flúor na água dos rios locais, este trabalho buscou evidências desta presença, seja nos dentes analisados seja na água dos rios da região. 
Para a análise das águas dos rios, foram efetuadas coletas em todos os principais rios que chegam no salar e que de alguma forma pudessem ter sido utilizados como fonte de água potável nos oásis estudados. Conforme as normas de coleta sugeridas pelo Laboratório de Bioquímica Oral da Universidade Estadual de Campinas (UNICAMP), 11 amostras de pelo menos $50 \mathrm{ml}$ de água corrente foram coletadas, entre os anos 2011 e 2012, dos rios que chegam ao salar de Atacama e dos rios Caspana, Salado e Loa. Estes três últimos são pertencentes à bacia do Rio Loa e que no caso do rio Caspana, abastece a cidade de mesmo nome, de onde também analisei amostras envolvidas neste trabalho.

Os rios analisados neste trabalho foram (Figura 31):

- Socaire (1)

- Toconao (Quebrada de Jerez) (2)

- Vilama (3)

- Guatin (4)

- San Pedro (5)

- Hierbas Buenas (6)

- $\quad$ Rio Grande (7)

- Caspana (8)

- Salado (9)

- Loa (10) 


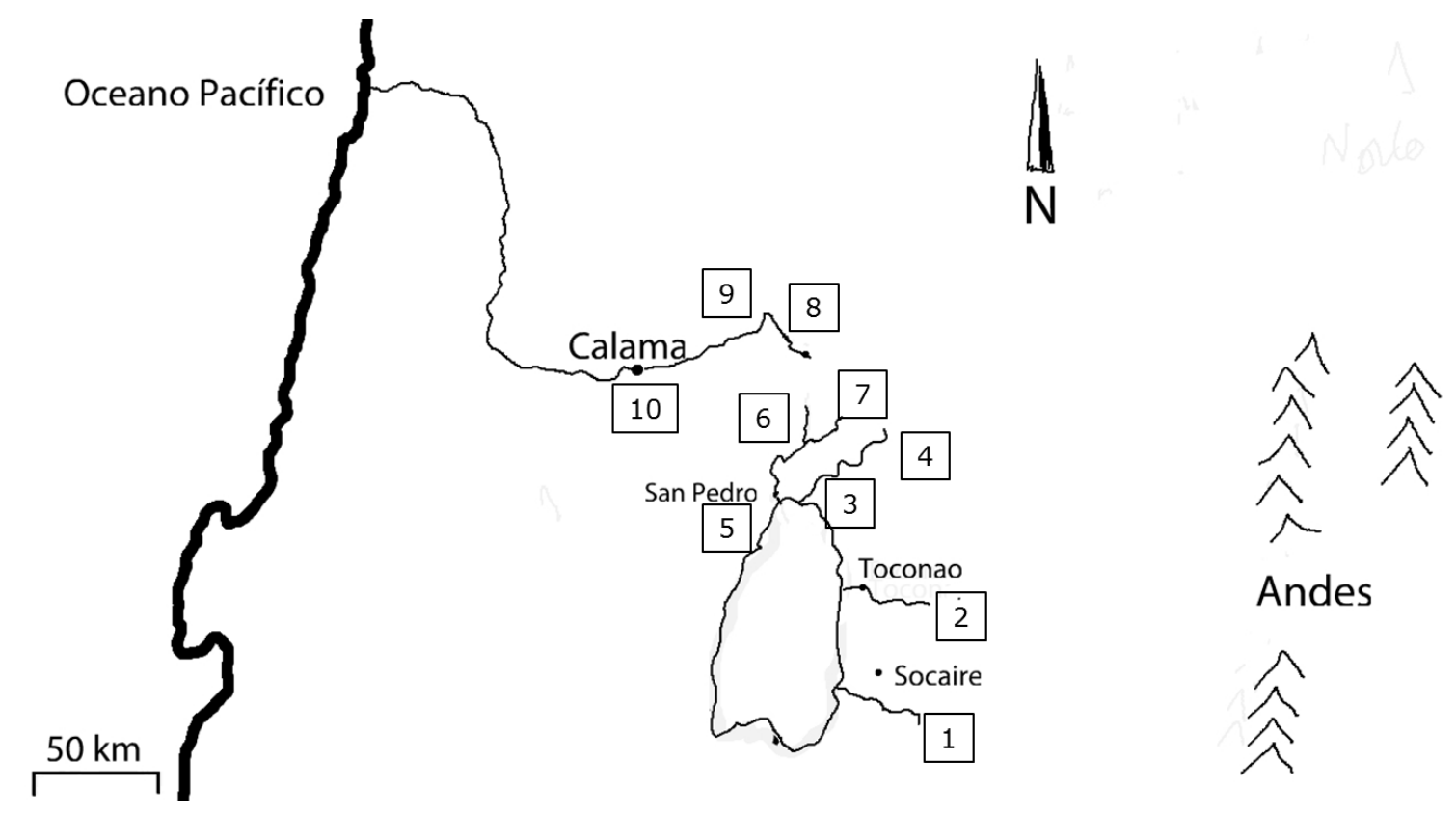

Figura 31 - Rios que abastecem os sítios arqueológicos analisados neste trabalho (desenho de Waldiane Cossermelli).

Evidência dental de consumo de folhas de coca

O hábito de mascar folhas de coca é uma herança que os povos andinos mantêm até os dias atuais. Muito comum nas terras altiplânicas bolivianas e peruanas, as evidências mais antigas do consumo de folhas de coca datam de 8000 AP, no norte do Peru (Dillehay et al., 2010). Este hábito também chegou às terras do norte do Chile, sendo encontrada em culturas como os Maitas Chiribaya (1100 a 1250 AD) com uma frequência de $60 \%$ de usuários entre os indivíduos analisados. Estes usuários apresentavam uma tendência 4 vezes maior de perda de dentes ante mortem do que os que não mascavam as folhas (Langsjoen, 1996).

De acordo com A. Llagostera (2004), a presença de folhas de coca (Erythroxylum coca) no registro arqueológico atacamenho é fruto da relação que esta comunidade mantinha com as sociedades altiplânicas, principalmente as comunidades do atual território boliviano. Apesar de não serem encontradas folhas de coca em alta 
frequência como acompanhamento funerário, o hábito de mascar estas folhas poderia estar também presente na sociedade atacamenha assim como esteve presente no vale de Azapa, região mais ao norte desde pelo menos 1000 AC (Langsjoen, 1996; Rivera et al., 2005) (Figura 32).
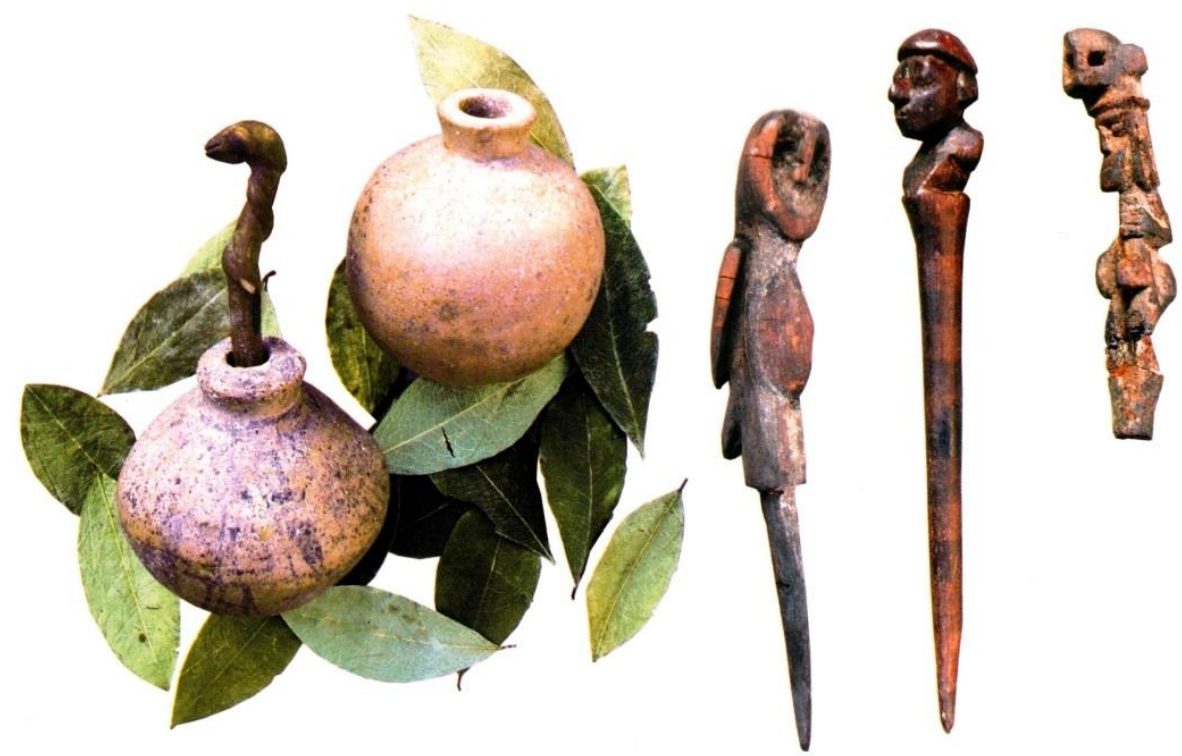

Figura 32 - Parafernália utilizada na prática de mascar folha de coca (Erythroxylum coca) (Llagostera, 2004).

Segundo Indriati \& Buikstra (2001), o hábito de mascar folhas de coca misturadas com substâncias alcalinas, que objetivam a extração dos alcaloides encontrados na coca, provoca lesões bucais características. A destruição do tecido gengival ao redor dos dentes (gengiva inserida) e a exposição das raízes dentárias que normalmente ficam em contato com o bolo de folha e cinzas/cal formado na boca é uma destas características. As raízes exposta são acometidas por cáries e o osso alveolar sob esta gengiva agredida também é atingido, ficando pigmentado com as mesmas manchas marrons esverdeadas encontradas nos dentes adjacentes (Figura 33). 


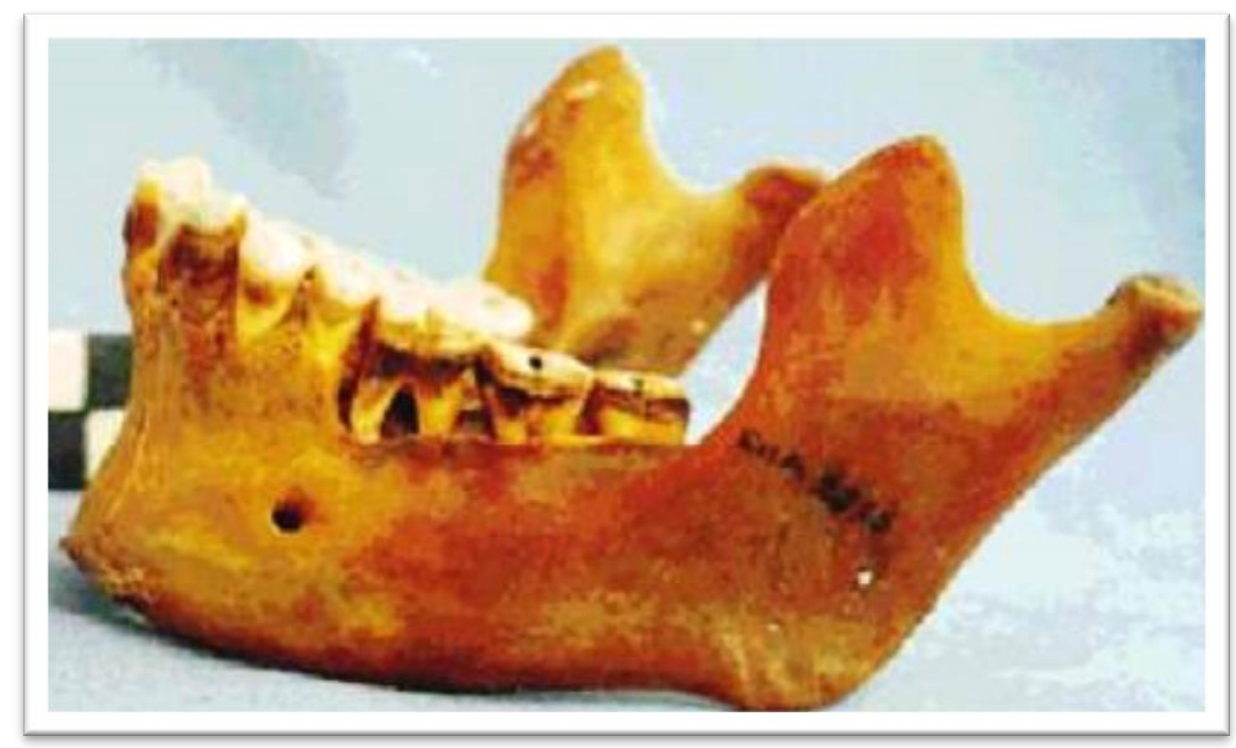

Figura 33 - Lesões ósseas e dentárias características do hábito de mascar folhas de coca (Indriati \& Buikstra, 2001).

Conforme o protocolo de Indriati \& Buikstra (2001), a presença das lesões abaixo elencadas, em diferentes graus de associação, confirma o costume de mascar coca e gradua a frequência ou a intensidade deste hábito. São elas:

- Presença de cárie nas raízes dos pré-molares e molares.

- Perda ante mortem dos pré-molares e molares.

- Cáries interproximais nos pré-molares e molares

- Reabsorção alveolar, de moderada a severa, na face bucal de prémolares e molares.

- Pigmentação do rebordo alveolar ósseo, principalmente na face bucal mandibular, na região de pré-molares e molares.

- Presença de raízes residuais de molares.

A Figura 34 sintetiza e ilustra as características acima citadas. 

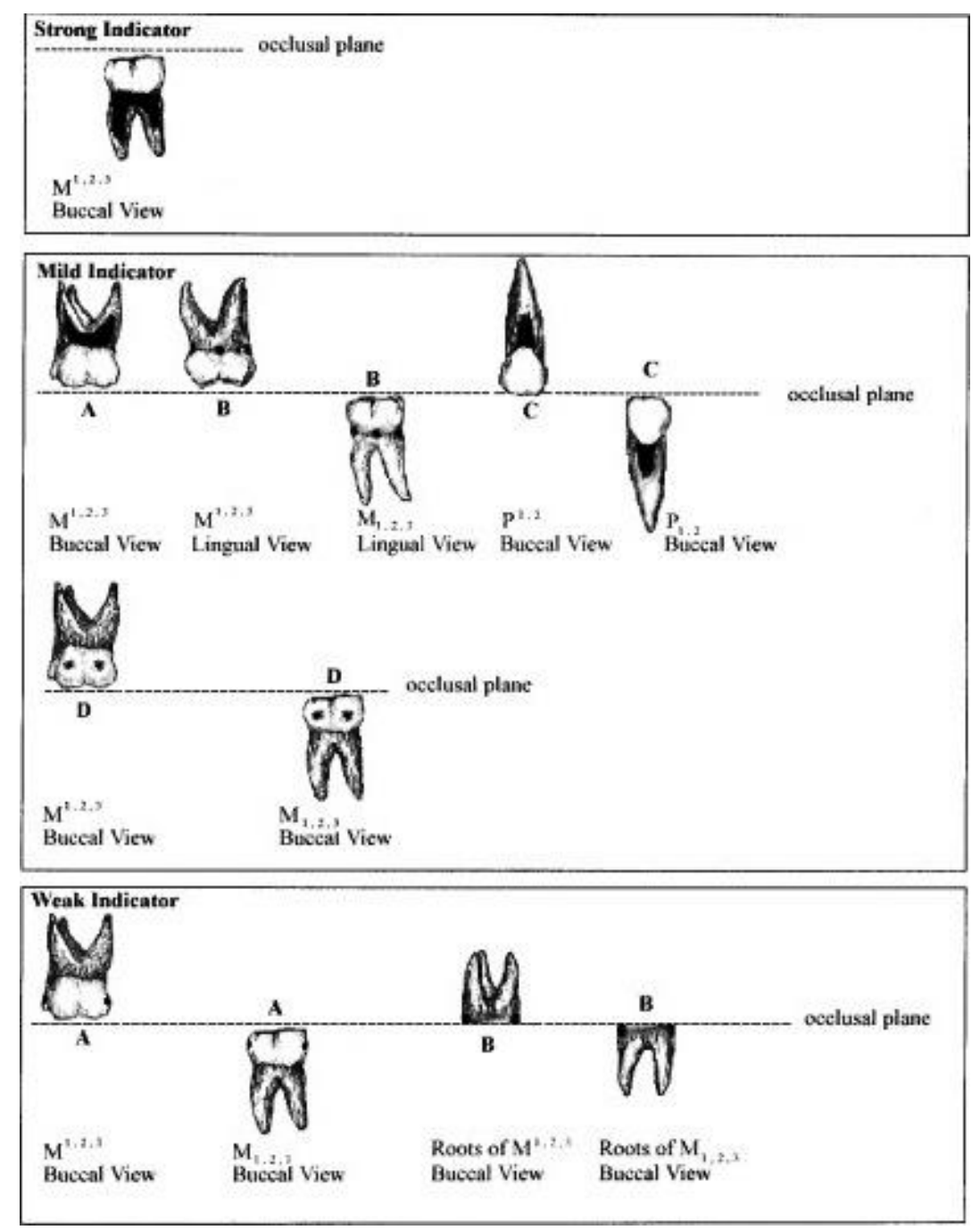

Figura 34 - Categorização das lesões causadas pelo hábito de mascar folhas de coca. As lesões de cárie são representadas em negro (Indriati \& Buikstra, 2001).

\section{Desgaste dentário}

Apesar de ser a única parte do esqueleto exposto ao meio ambiente e também por isso ser constituído pelo tecido mais duro do corpo humano, os dentes sofrem desgastes de diferentes naturezas. O desgaste dentário pode ser definido pela perda do tecido mineralizado, seja ele do esmalte, da dentina ou do cemento. Esta perda pode ter 4 principais etiologias: abfração, erosão, atrição e abrasão. Abfração é a 
perda de tecido radicular devido à pressão oclusal excessiva, provocando trincas e posteriormente lascamento da porção radicular próxima ao limite amelo-dentinário, gerando uma lesão radicular muito similar à cárie de raiz, porém sem que a ação bacteriana esteja envolvida neste processo. Erosão é um processo químico a que o dente é submetido. Alimentos e líquidos ácidos, além de ácidos provenientes do estômago através de refluxos podem, em contato prolongado com a superfície dentária, dissolver o esmalte dentário e assim remover o tecido mineralizado da superfície dental. Atrição é a perda do esmalte e/ou dentina causada pelo contato e atrito entre os dentes antagonistas ou adjacentes. Abrasão é a perda de tecido mineralizado dental devido ao atrito dos alimentos e partículas misturadas a estes durante o processo de mastigação (Grippo et al., 2004; Milosevic, 2004).

Destes quatro processos de perda de tecido dentário, apenas a atrição e a abrasão foram estudadas neste trabalho, visto que a abfração, se presente, seria diferenciada de processos cariosos e a erosão seria apenas anotada dentre as observações gerais. Com a impossibilidade de discernir a atrição da abrasão em uma análise macroscópica, unifiquei-as e considerei-as simplesmente como "desgaste dentário".

O desgaste dentário estudado em material arqueológico é dividido em duas grandes formas de análise: O micro-desgaste e o macro-desgaste.

O micro-desgaste, assim denominado pela dimensão micrométrica das marcas deixadas no esmalte e na dentina, pode ser analisado de duas diferentes formas: a análise direta do dente através de microscopia confocal ou a análise indireta de um modelo, gerado a partir da moldagem com silicone do dente a ser avaliado, em microscópio eletrônico de varredura. Recentemente muito estudado, o micro-desgaste tem buscado através da observação de marcas pontuais ou de "arranhões" no esmalte dentário, identificar o tipo de alimentação consumida (Mahoney, 2006, 2007; Krueger et al., 2008; Ungar et al., 2012). A relação entre a largura destes "arranhões" encontrados na superfície dental e o macro-desgaste é positiva, enquanto a quantidade de arranhões é inversamente proporcional à intensidade do macrodesgaste (Schmidt, 2010). 
O macro-desgaste é amplamente estudado desde a primeira metade do século XX. Sendo necessária apenas a observação a olho nu, o macro-desgaste pode ser utilizado para o diagnóstico da idade de óbito, sendo progressivo conforme o envelhecimento do indivíduo (Lovejoy, 1985), mas principalmente para a determinação ou a inferência do tipo de dieta consumida por uma determinada população (Hillson, 1996 c) (Figura 35).

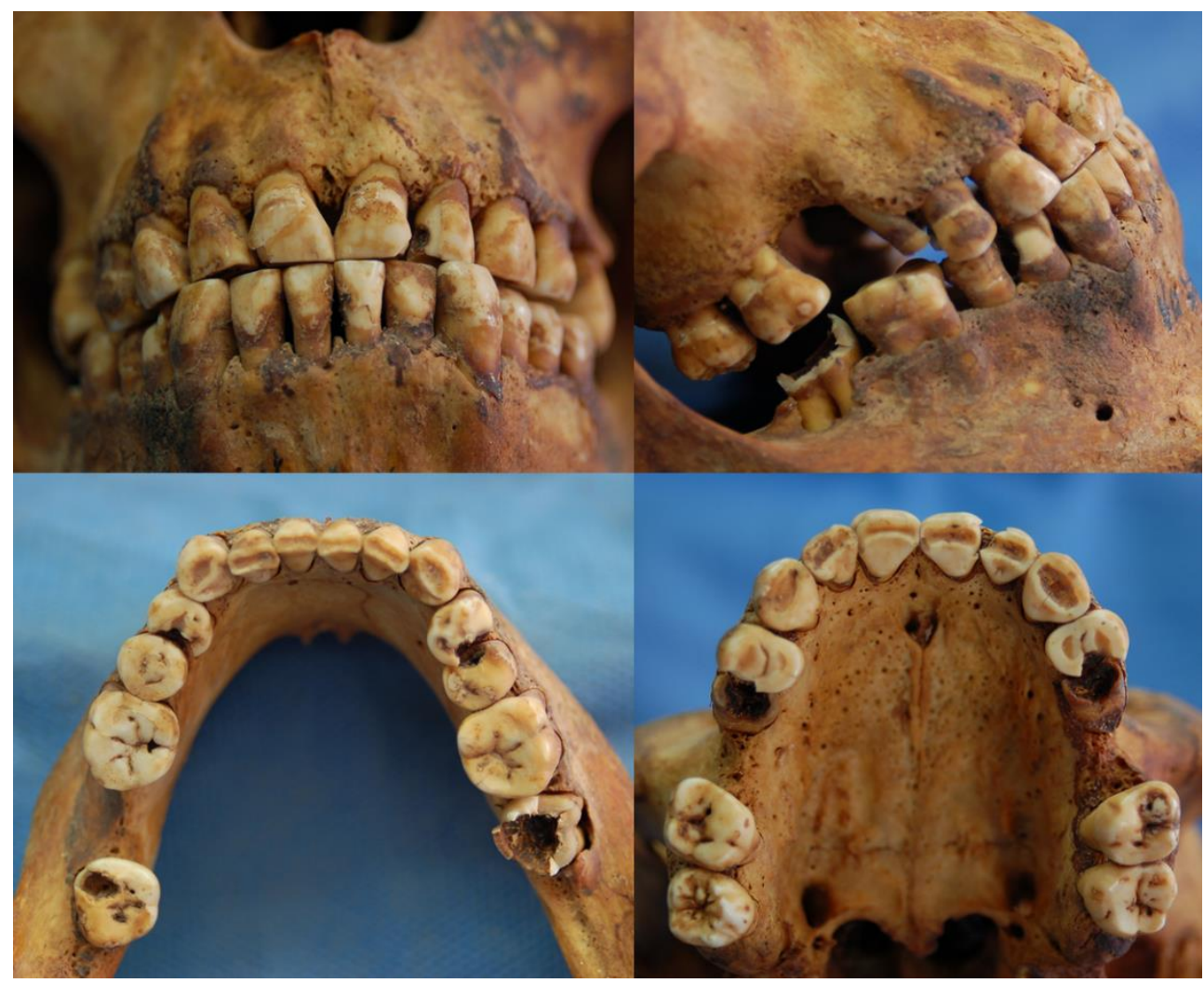

Figura 35 - Desgaste dentário (Coyo Oriental \#4074).

As diferenças entre as dietas de grupos humanos caçadores-coletores e grupos agricultores são responsáveis por expressiva distinção entre os desgastes dentários apresentados por estes grupos (Larsen, 1997 e). O processamento prévio do alimento como o cozimento ou a trituração, muito comum entre os grupos agricultores, diminui consideravelmente o esforço necessário para a deglutição desta dieta, diminuindo assim o atrito entre os dentes pela menor força mastigatória e também diminuindo a 
abrasão dos dentes, já que o alimento já foi processado fora da boca. Com isso, encontramos em grupos humanos de caçadores-coletores um desgaste significativamente mais acentuado do desgaste encontrado em grupos agricultores. Este desgaste é tão maior que, se compararmos indivíduos jovens de caçadorescoletores e indivíduos adultos ou velhos agricultores, ainda assim encontraremos desgastes maiores no grupo caçador-coletor, confirmando a maior importância da dieta no grau de desgaste encontrado nos dentes analisados (Schmidt, 2001, 2010; Deter, 2009; Waters-Rist et al., 2010).

Quanto ao macro-desgaste ou simplesmente "desgaste dentário" (distinto do micro-desgaste dentário), trabalhos da década de 1980 e início dos anos 1990 do século XX foram fundamentais para a padronização dos trabalhos na área.

Brace \& Molnar (1967), interessados em entender a força mastigatória causadora do intenso desgaste dentário que observavam, tanto nas coleções arqueológicas como em populações vivas, construíram uma máquina que simulava os movimentos mandibulares. Anos mais tarde, S. Molnar apresentou um sistema de mensuração do desgaste dentário, dividindo em oito (08) níveis distintos e crescentes onde o nível um (01) significava dente sem desgaste aparente e o nível oito (08) a total destruição da coroa dentária pelo desgaste, expondo totalmente a raiz dentária (Molnar, 1971).

No final da mesma década, E.C. Scott propôs uma nova forma de analisar o desgaste dentário, considerando que a técnica proposta por S. Molnar era fortemente influenciada pela idade do indivíduo avaliado. Assim, criou um novo protocolo observando apenas as facetas de desgaste dos dentes molares, dividindo-os em quadrantes e, segundo ele, aumentando a precisão de sua análise (Scott, 1979 a; b).

B. Smith (1984) aplicou em seu estudo a avaliação dos estágios de desgaste que S. Molnar propôs, porém acresceu o ângulo de desgaste que os dentes apresentavam em relação ao plano oclusal. B. Smith encontrou diferenças significativas do ângulo de desgaste entre grupos agricultores e caçadores-coletores. Os desgastes dos molares no grupo de agricultores chegou a exceder $10^{\circ} \mathrm{em}$ relação ao desgaste apresentado pelo grupo de caçadores-coletores. 
Neste trabalho optei por avaliar a minha amostra seguindo os padrões de macro-desgaste estabelecidos por S. Molnar, uma vez que não pretendia analisar o micro-desgaste desta amostra devido à necessidade de equipamentos sofisticados e caros. A opção por este autor foi feita parte pela desconfiança da eficácia do método apresentado por E.C. Scott (1979), parte pela assumida incapacidade de reprodução do método. Aqui também utilizei o desenho esquemático apresentado por B. Smith (1984) (Figura 36).

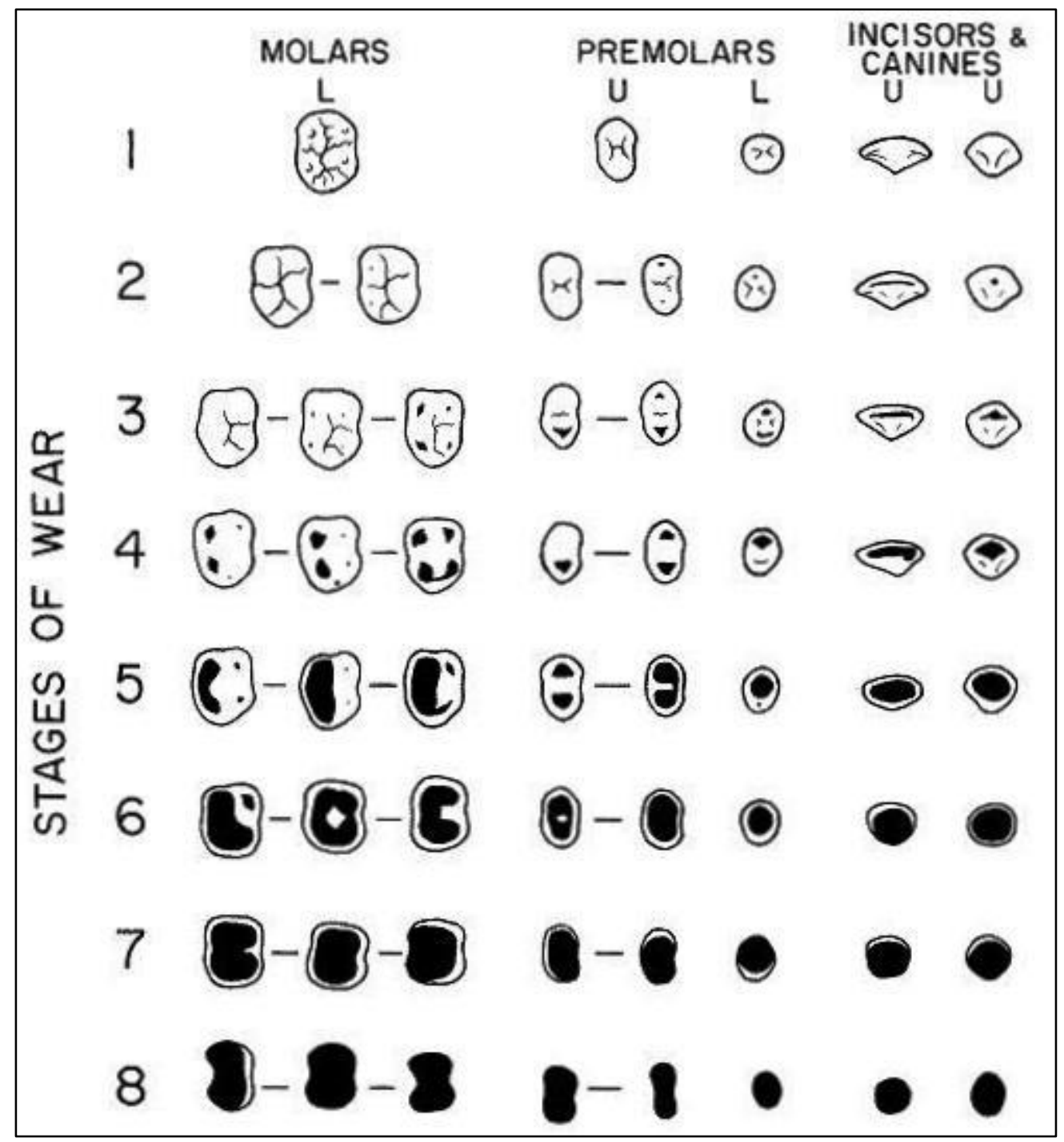

Figura 36 - Estágios de desgaste dentário proposto por Molnar (Smith, 1984). 


\section{Hipoplasia linear do esmalte}

A hipoplasia do esmalte dentário é uma doença resultante da alteração da deposição do esmalte dentário durante o período de formação do dente, quando este ainda se encontra intra-ósseo. Esta doença do desenvolvimento se apresenta na superfície do esmalte dental, após a erupção do dente na cavidade oral, como linhas ou pontos em baixo relevo (Goodman \& Rose, 1990). Podendo variar tanto na quantidade de linhas ou pontos apresentados como também na extensão destes pontos, estas depressões na superfície dentária se apresentam com uma coloração ligeiramente mais escurecida que o esmalte normal. Desconsiderando as grandes hipoplasias de esmalte onde há uma má formação extensa deste tecido mineralizado, as hipoplasias lineares ou puntiformes resultam em áreas onde o esmalte se torna mais delgado, deixando a dentina subjacente transparecer, ocasionando a coloração amarelo-amarronzada destas lesões (Suckling, 1989; Hib, 2001; Hillson, 2005; King et al., 2005; Roberts \& Manchester, 2005 b).

Por ter sua etiologia indeterminada, as lesões hipoplásicas são consideradas indicadores inespecíficos de estresse biológico e estão relacionadas a traumas localizados, anomalias hereditárias, estresses metabólicos como doenças infecciosas sistêmicas ou desnutrição durante a infância (Suckling et al., 1983; Goodman, 1991; Hillson \& Bond, 1997; King et al., 2005; Roberts \& Manchester, 2005 b), porém sem preferência por sexo (Berbesque \& Doran, 2008). Diferentes estudos encontraram em suas amostras uma maior sensibilidade à cárie dentária em indivíduos acometidos por hipoplasias de esmalte e uma menor expectativa de vida dos indivíduos que apresentam muitas lesões hipoplásicas em seus dentes (Palubeckaitė et al., 2002; Armelagos et al., 2009; Costa et al., 2010).

As análises microscópicas das hipoplasias de esmalte buscam relacionar as extensões e as localizações das lesões com o tempo de duração do estresse ao qual a pessoa foi submetida e com a fase de desenvolvimento do dente incidido. Observando os tipos de hipoplasias de esmalte encontradas, a quantidade de perikimatas comprometidas e em qual posição da coroa dentária as lesões se apresentam, as 
análises feitas com microscópios eletrônicos tem buscado inferir a frequência e a intensidade com que estes possíveis fatores etiológicos acometeram o indivíduo (Hillson \& Bond, 1997; Guatelli-Steinberg et al., 2004; Smith et al., 2007 a; b; Armelagos et al., 2009; Bocaege et al., 2010).

Além das análises microscópicas, as hipoplasias do esmalte podem ser observadas diretamente no dente lesionado ou através de fotografias digitais, nas quais o relevo da superfície dentária pode ser evidenciado com jogo de luz e sombra do flash fotográfico (Berbesque \& Doran, 2008). Quanto aos dentes a serem observados, os estudos oscilam, variando entre avaliar apenas os dentes decíduos (Halcrow \& Tayles, 2008), avaliar somente os dentes caninos (Berbesque \& Doran, 2008; Halcrow \& Tayles, 2008), avaliar os dentes anteriores superiores e inferiores (Reid \& Dean, 2000) ou todos os dentes, exceto os pré-molares (Reid \& Dean, 2006).

Optei por analisar neste trabalho somente as lesões macroscópicas. Dentre elas, apenas as hipoplasias lineares encontradas no esmalte dos incisivos centrais e laterais, caninos e também os primeiros molares permanentes (Figura 37). As hipoplasias puntiformes ou em formato irregular foram anotadas nas fichas de análise, porém, não foram computadas (Figura 38). Fiz esta opção de análise para ter, ao final deste trabalho, maior quantidade de estudos na literatura específica à disposição para comparar com meus resultados, uma vez que grande parte dos trabalhos publicados sobre hipoplasia de esmalte, quando observadas apenas as lesões de forma macroscópica, são de hipoplasias lineares (Goodman, 1991; Buikstra \& Ubelaker, 1994; Brickley \& McKinley, 2004; Berbesque \& Doran, 2008; Halcrow \& Tayles, 2008; Armelagos et al., 2009). 


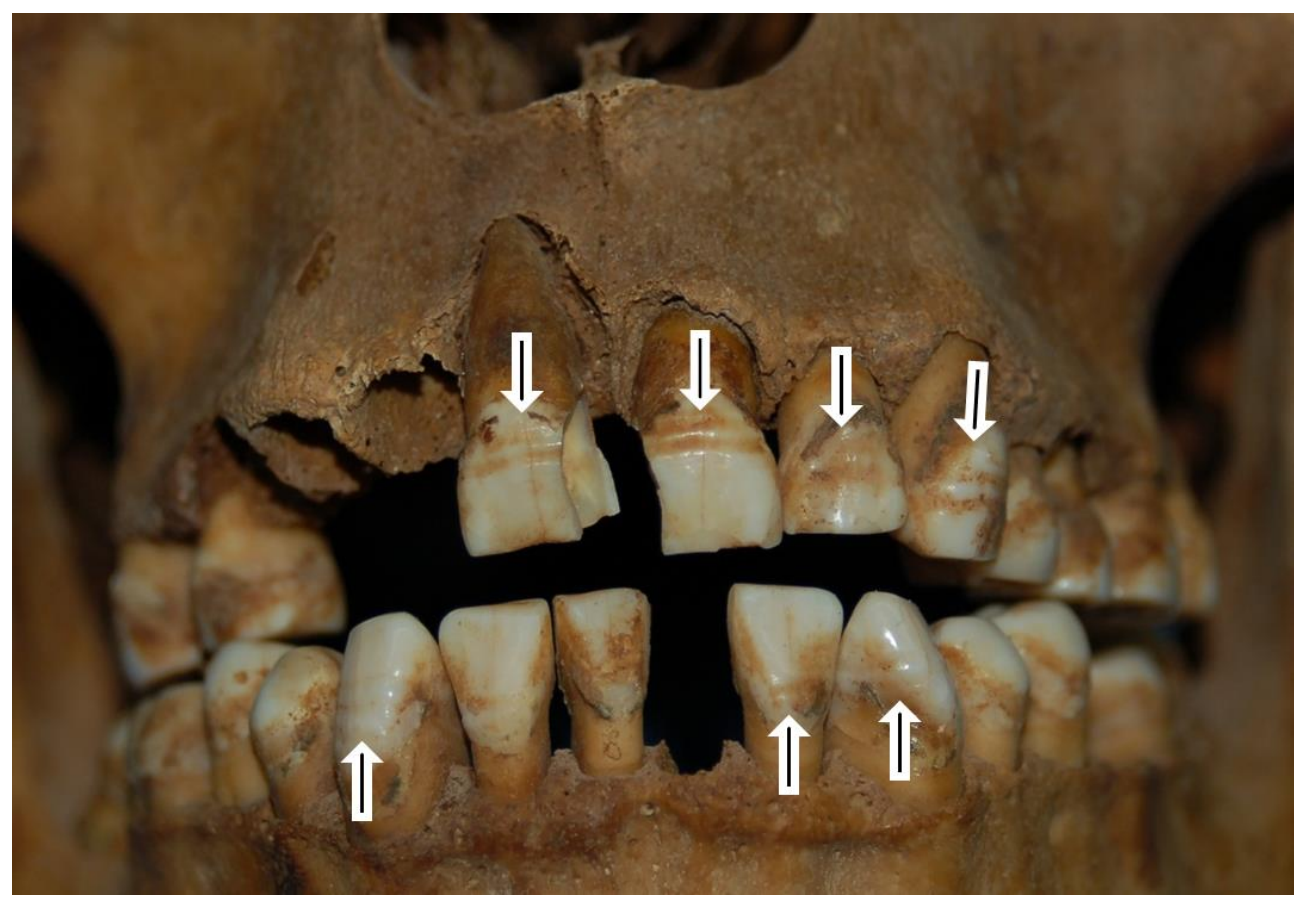

Figura 37 - Hipoplasias lineares do esmalte dentário (Solcor 3 sep.XCVII).

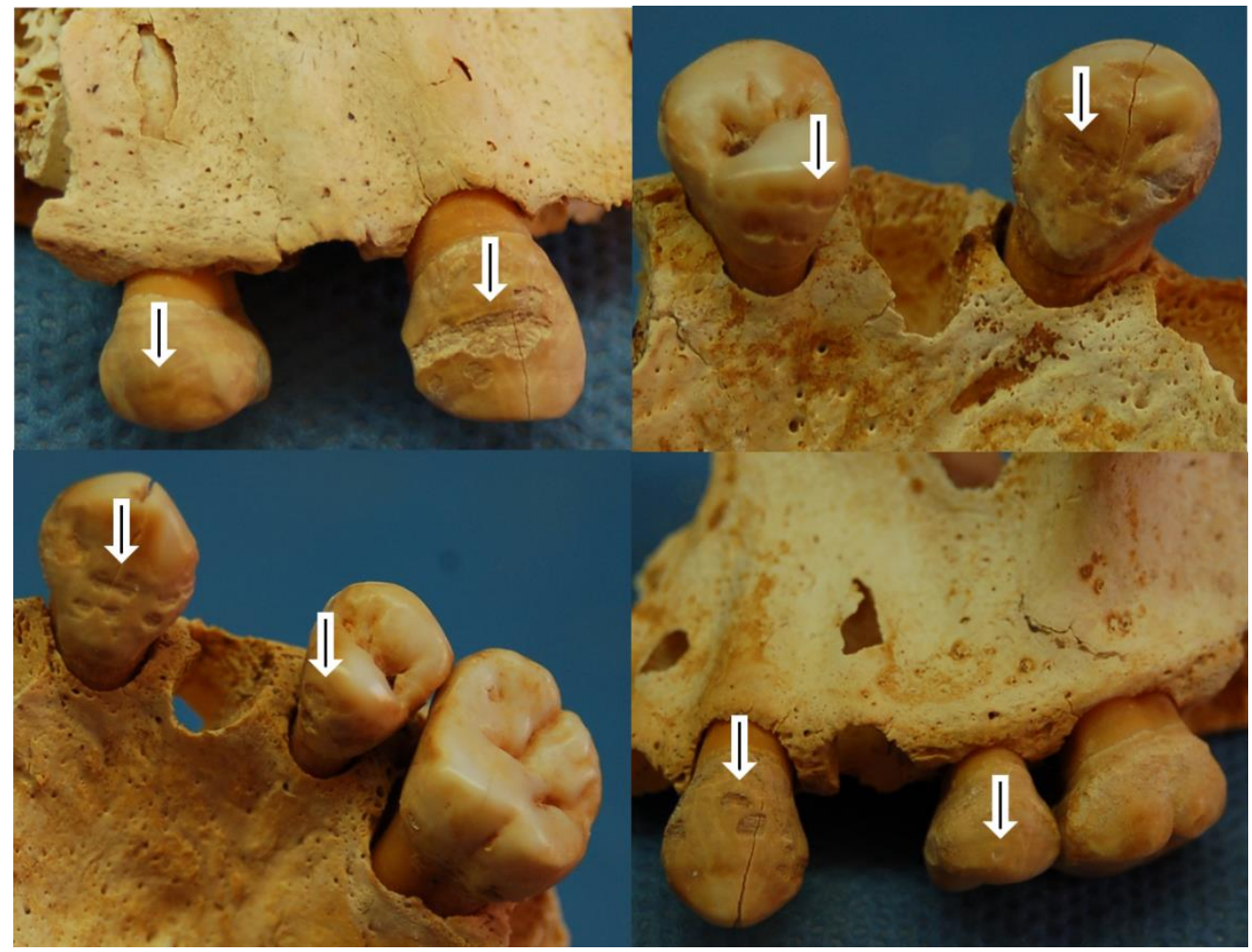

Figura 38 - Hipoplasias puntiformes e amorfas do esmalte dentário (Toconao Oriente \#4700). 
Apesar de Palubeckaite et al. (2002) afirmarem ter encontrado diferenças entre as frequências de hipoplasias de esmalte em mandíbulas e maxilas das amostras por eles estudadas e assim, apenas observarem os crânios que possuíssem as duas arcadas, minha amostra apresentava limitação quanto à sua integridade, me obrigando a analisar os crânios tendo ou não as mandíbulas associadas.

Para o preenchimento de minha ficha de análise, utilizei a seguinte escala de intensidade de comprometimento da coroa dentária pelas lesões hipoplásicas apresentada na Tabela 12.

Tabela 12 - Quantidade de hipoplasias lineares do esmalte dentário.

\begin{tabular}{cc}
\hline $\mathbf{0}$ & Sem hipoplasia \\
$\mathbf{2}$ & $\mathbf{1}$ linha \\
$\mathbf{X}$ & Seu + linhas \\
\end{tabular}

\section{Reabsorção periodontal}

A reabsorção periodontal é um fenômeno resultante da perda do osso ao redor dos dentes e tem como principal etiologia a doença periodontal. Esta perda da crista óssea alveolar acontece após um longo período de infecção gengival, causado pela irritação da gengiva inserida (que se localiza ao redor do dente) graças à presença de bactérias aderidas às superfícies do esmalte ou das raízes do dente atingido. Esta 
infecção superficial que inicialmente contamina somente a gengiva, aos poucos caminha apicalmente pela raiz do dente, criando a chamada bolsa periodontal. Esta bolsa é o aumento do espaço natural que existe entre a superfície dentária e a gengiva inserida. Este aumento de espaço cria um nicho que alberga bactérias anaeróbicas, facultativas ou exclusivas, que após formarem a placa subgengival, se calcificam e formam os cálculos subgengivais (Socransky \& Haffajee, 2003; Marsh \& Martin, 2009 c). Apesar de serem bactérias comensais, quando estas bactérias e suas toxinas estão presentes dentro da bolsa periodontal, causam uma irritação tecidual e a ação de células do sistema imunológico humano provocará a inflamação local e posteriormente a perda do tecido ósseo contíguo (Clarke et al., 1986; Hirsch \& Clarke, 1989).

Apesar de ser a principal causa da perda óssea periodontal, a doença periodontal não é o único processo responsável por estas reabsorções. As perdas periodontais podem ser divididas em perdas verticais e horizontais. As verticais são perdas resultantes do processo acima descrito, no qual uma lesão localizada em cada dente infectado é responsável por uma perda óssea em forma de "V", como se acompanhasse a anatomia radicular do dente a ela associada (Figura 39). As perdas horizontais são perdas mais uniformizadas em toda a arcada ou pelo menos em setores mais amplos que apenas um ou dois dentes. Estas perdas são perdas menos agressivas e normalmente ocorrem devido à remodelação do osso periodontal ligada ao envelhecimento natural ou ao processo de esforço mastigatório intenso que o sobrecarrega (Budtz-Jørgensen, 1980; Becker et al., 1997). 


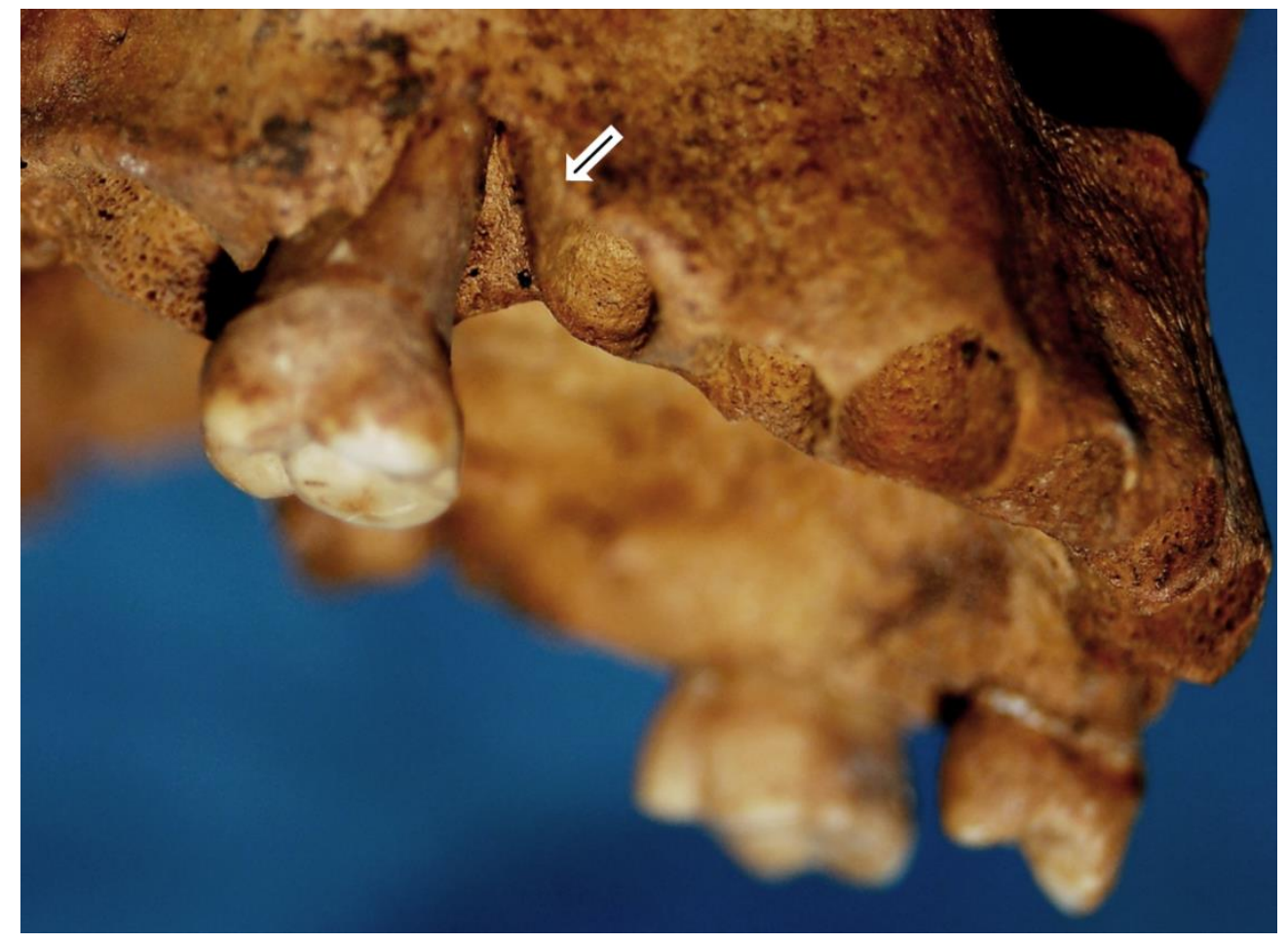

Figura 39 - Reabsorção periodontal vertical na região do primeiro molar superior direito (Yaye Orilla Occidental \#1448).

A reabsorção alveolar foi avaliada apenas nos alvéolos onde o respectivo dente estava presente. Para a aferição das reabsorções, utilizei uma sonda periodontal milimetrada (Figura 40), instrumento utilizado na clínica odontológica exatamente para medir, em vivo, a bolsa periodontal presente nos pacientes (Lindhe \& Papapanou, 2003). Estimada a partir do limite amelo-dentinário de cada dente presente, a reabsorção foi anotada em milímetros na minha ficha de análise mas também foi, em um nicho especifico, registrada em 3 grandes grupos de análise (Brickley \& McKinley, 2004; Arnold et al., 2007) (Tabela 13). 


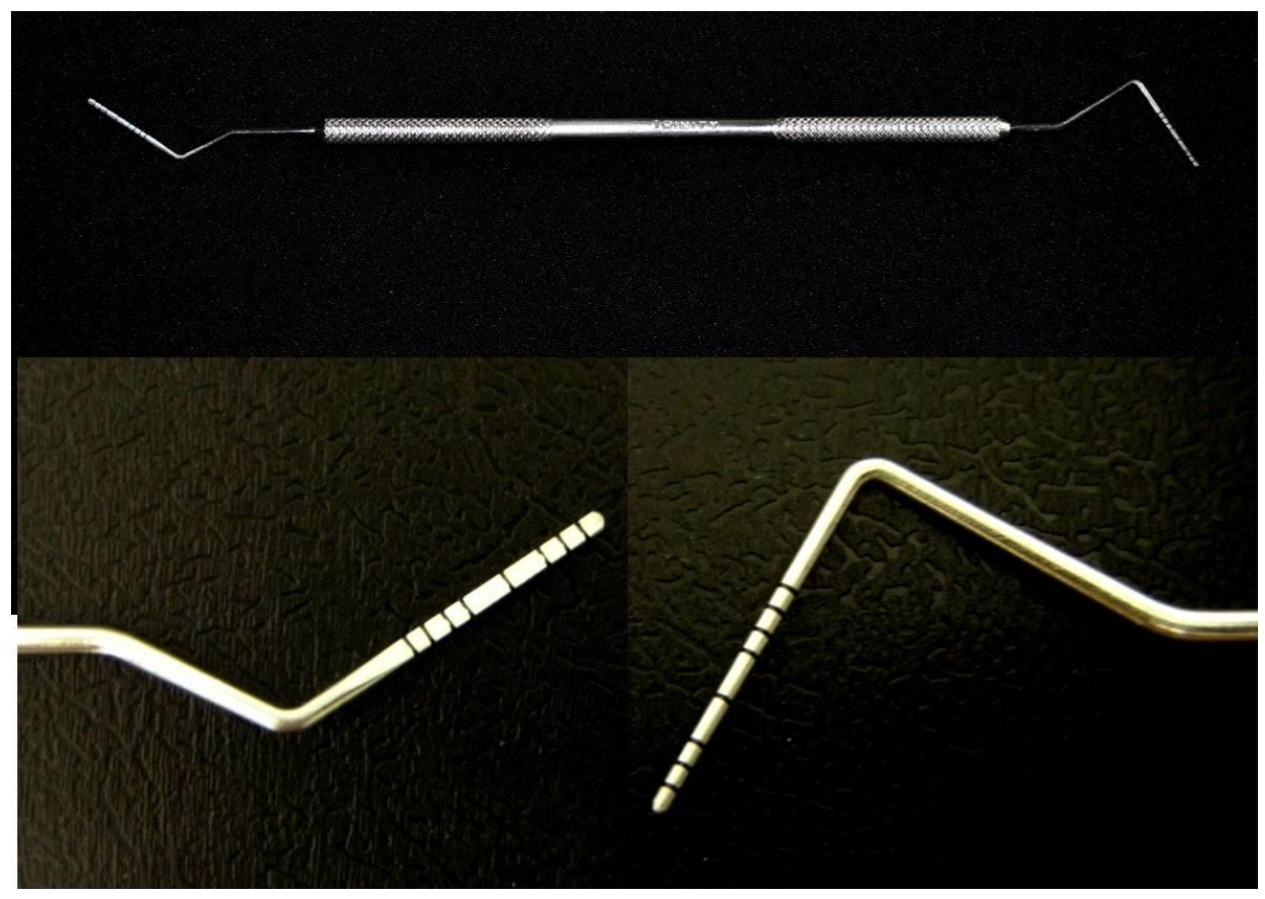

Figura 40 - Sonda milimetrada utilizada para medição da reabsorção periodontal.

Tabela 13 - Índice de avaliação da reabsorção alveolar (modificado - Brickley \& McKinley, 2004).

\begin{tabular}{cc}
\hline Cat. & Medidas das reabsorções \\
\hline $\mathbf{0}$ & Ausente $(<2 \mathrm{~mm})$ \\
$\mathbf{1}$ & $2,1-4 \mathrm{~mm}$ \\
$\mathbf{2}$ & $4,1-6 \mathrm{~mm}$ \\
$\mathbf{3}$ & $>6,1 \mathrm{~mm}$ \\
$\mathbf{x}$ & Sem condição de análise \\
\hline
\end{tabular}




\section{Cálculo salivar}

Os cálculos salivares, cálculos dentários ou simplesmente tártaros dentários são cristalizações do biofilme dental formado nas superfícies dentárias, tanto acima como abaixo do limite gengival de cada dente. Este biofilme que anteriormente era conhecido apenas como placa bacteriana é assim denominado pois, além da presença fundamental das bactérias, há também proteínas e fluídos salivares que são os responsáveis pela adesão desta placa bacteriana ao dente. Assim como a placa bacteriana cariogênica, as placas supra e subgengival demandam tempo para serem formadas e se tornarem virulentas. Apesar de serem formadas por bactérias distintas das placas cariogênicas, o processo de formação do biofilme supragengival ou subgengival é o mesmo: forma-se a película adquirida sobre a superfície dental, permitindo assim a adesão de bactérias colonizadoras primárias; a elas se agregam as colonizadoras secundárias, para daí então, quando já existe uma estabilização desta placa bacteriana, há a possibilidade de colonização de bactérias patogênicas. Este processo pode levar de 10 a 20 dias, independentemente se supra ou subgengival, iniciando um processo inflamatório do tecido gengival chamado gengivite. Assim como no biofilme encontrado nas faces oclusais dos dentes, onde encontramos biofilmes patogênicos (cariogênicos) ou não, os biofilmes supra ou subgengivais também podem ser patogênicos ou não, dependendo diretamente das bactérias que o formam (Hirsch \& Clarke, 1989; Socransky \& Haffajee, 2003; Hillson, 2005; Marsh \& Nyvad, 2005; Marsh \& Martin, 2009 c).

Apesar de serem formados pelo mesmo processo, os cálculos salivares supragengivais são bastante distintos dos cálculos salivares subgengivais. Além da diferença já mencionada de bactérias presentes na placa bacteriana, estes cálculos se formam por agregarem sais de diferentes origens e assim, adquirem forma, textura e cor bastante distintas. Enquanto os cálculos supragengivais são formados pela placa bacteriana calcificada pelos sais provenientes tanto da saliva como da própria alimentação do indivíduo, os cálculos subgengivais sofrem este processo de cristalização utilizando os sais encontrados no fluído gengival e no sangue encontrado 
dentro da bolsa periodontal. Assim, o cálculo salivar supragengival tem como características principais ser geralmente mais volumoso e de coloração que varia entre o amarelo, o cinza e um marrom claro (Figura 41). Já os cálculos subgengivais são mais duros, mais resistentes à remoção da superfície radicular e de cor mais escura, podendo ser marrom escuro, negro ou até mesmo esverdeado (Hillson, 1996 b; Lang et al., 2003; Roberts \& Manchester, 2005 b).

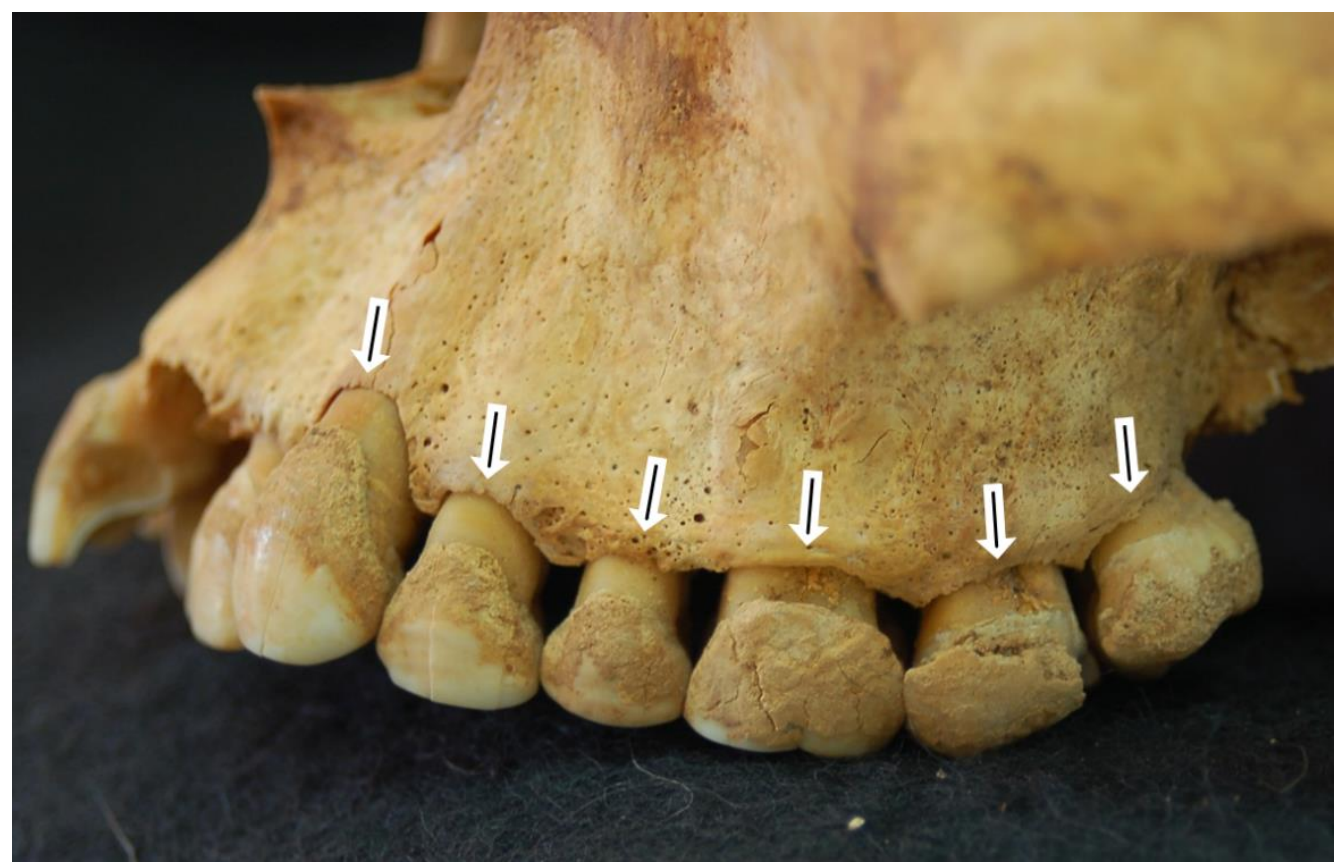

Figura 41 - Cálculos salivares supragengivais (Tulan 58 sep. IV).

A distinção entre estes dois tipos de cálculos se faz necessária devido à diferente "agressividade" patológica a que cada um está associado. 0 simples fato de serem estruturas cristalizadas não faz dos cálculos um elemento patogênico. Estas estruturas servem de abrigo a bactérias que ali se alojam e assim, através de seus produtos metabólicos, agridem o tecido gengival e assim iniciam o processo inflamatório (Neville et al., 2003 b). 
Como forma de facilitar a descrição, os cálculos serão considerados os responsáveis pelas patologias, apesar da explicação acima deixar claro que as reais responsáveis pela doença são as bactérias a eles agregados.

Enquanto os cálculos salivares supragengivais são menos injuriosos ao tecido gengival, os cálculos salivares subgengivais são mais patogênicos, causando uma doença periodontal mais agressiva. Esta diferença entre eles é devida às diferentes bactérias associadas, não em termos de qualidade da placa bacteriana (similar também nas placas saudáveis), mas na quantidade de cada espécie ali encontrada. As bactérias anaeróbicas encontradas nas bolsas periodontais e consequentemente, nos cálculos subgengivais, são patógenos mais virulentos que as bactérias encontradas nas superfícies dos cálculos supragengivais, levando assim a uma reabsorção do osso periodontal mais intensa (Whittaker et al., 1998; Socransky \& Haffajee, 2003; Marsh \& Martin, 2009 c).

Como as reabsorções alveolares são a consequência da doença crônica causada pela presença dos cálculos salivares, principalmente os subgengivais, estes dois marcadores dentais foram avaliados concomitantemente e foram apenas computados neste trabalho os dentes totalmente erupcionados. Para o registro dos cálculos salivares presentes, criei um protocolo de análise a partir dos protocolos de D.R. Brothwell (1981) e Buikstra \& Ubelaker (1994), já consagrados e utilizados por diversos autores (Dobney \& Brothwell, 1987; Hillson, 1996 b; Brickley \& McKinley, 2004; Greene et al., 2005; Roberts \& Manchester, 2005 b).

Em meu protocolo, o 0 corresponde a ausência de cálculos salivares, os números de 1 a 3 referem-se ao cálculos presentes na porção supragengival dos dentes avaliados, de 4 a 6 os cálculos subgengivais e o $\mathrm{X}$ refere-se à ausência de condições de análise (Tabela 14). 
Tabela 14 - Índice utilizado para a avaliação da presença de cálculo salivar (adaptado de D.R. Brothwell, 1981 e Buikstra \& Ubelaker, 1994).

\begin{tabular}{cc}
\hline Cat. & Intensidade de comprometimento \\
\hline $\mathbf{0}$ & Ausente \\
$\mathbf{1}$ & SUPRA LEVE (até $1 / 3$ da coroa) \\
$\mathbf{2}$ & SUPRA MODERADO (até $2 / 3$ da coroa) \\
$\mathbf{3}$ & SUPRA INTENSO (+ de $2 / 3$ da coroa) \\
$\mathbf{4}$ & SUB LEVE (1/3 da raiz) \\
$\mathbf{5}$ & SUB MODERADO (2/3 da raiz) \\
$\mathbf{6}$ & SUB INTENSO (+ de $2 / 3$ da raiz) \\
$\mathbf{X}$ & Sem condição de análise \\
\hline
\end{tabular}

\section{Análise estatística}

Para as análises estatísticas deste trabalho, os dados contidos na ficha de análise das patologias dentais tiveram que ser digitalizados. Como a quantidade de variáveis foi muito grande, excedendo a capacidade de contensão de dados do programa Excel (Microsoft - propriedade particular), foi necessária a criação de uma tabela virtual no programa Epi Info 6 (CDC). Este programa foi criado pelo Centro para Controle e Prevenção de Doenças dos Estados Unidos (Center for Disease Control and Prevention - $C D C$ ) e por ser um programa estatístico direcionado para pesquisadores da área de Epidemiologia, facilitou a conversão dos dados do formato gráfico para o formato digital (programa disponibilizado pelo Depto. de Odontologia Social - USP). A etapa seguinte foi seccionar em tabelas distintas e transportá-las para o programa Excel. Após os ajustes necessários, os dados foram finalmente transferidos para o programa SPSS 17 (disponibilizado a mim pela Universidade de São Paulo). 
Através do programa SPSS os testes estatísticos foram aplicados conforme a natureza dos dados a serem testados e de acordo com a pergunta a ser respondida. De forma resumida e assumindo que minhas amostras não serão amostras normais (paramétricas), como se deve esperar de uma coleção esqueletal, os testes aplicados seguiram as regras da Tabela 15.

Tabela 15 - Testes estatísticos utilizados neste trabalho.

\section{TESTES NÃO PARAMÉTRICOS}

\begin{tabular}{ccc}
\hline OBJETIVOS & MEDIDAS (POPULÇÕES NÃO & BINOMIAL \\
& NORMAIS) & Teste de Fisher / \\
Comparar 2 grupos independentes & Teste de Mann-Whitney U e & Chi-Quadrado \\
Comparar 2 ou + grupos & Teste de Kruskal-Wallis & (X $^{2}$ ) \\
independentes & \\
As análises estatísticas de Correlação (Spearman r) foram usadas em casos específicos.
\end{tabular}




\section{RESULTADOS}

Os resultados obtidos neste trabalho serão expostos de acordo com a ordem estabelecida no capítulo anterior. Portanto, apresentarei inicialmente os resultados advindos das análises para a caracterização do perfil bioantropológico da minha amostra esqueletal e em seguida, os resultados das análises das patologias dentais.

\section{Perfil bioantropológico}

Após as exclusões já mencionadas no capítulo anterior, minha amostra final contou com exatos 402 indivíduos, distribuídos em 13 sítios arqueológicos. Esses sítios são representantes dos 3 períodos temporais definidos para a pré-história atacamenha.

Por se tratar de um estudo exploratório e sujeito às limitações que toda coleção esqueletal apresenta, a distribuição dos indivíduos, mesmo com meu esforço de equilibrar a quantidade destes da melhor forma possível, é apresentada na Tabela 16. 
Tabela 16 - Frequência dos indivíduos presentes na amostra, divididos pelo período, idade e sexo.

\begin{tabular}{|c|c|c|c|c|c|c|}
\hline \multirow{2}{*}{\multicolumn{3}{|c|}{ PERÍODO }} & \multicolumn{3}{|c|}{ SEXO } & \multirow{2}{*}{ Total } \\
\hline & & & FEM & IND & MASC & \\
\hline \multirow{5}{*}{ PRÉ TIWANAKU } & \multirow{4}{*}{ IDADE } & $<25$ & 1 & 0 & 0 & 1 \\
\hline & & $25-40$ & 24 & 2 & 19 & 45 \\
\hline & & $40-55$ & 15 & 4 & 16 & 35 \\
\hline & & $>55$ & 5 & 1 & 7 & 13 \\
\hline & \multicolumn{2}{|c|}{ Total } & 45 & 7 & 42 & 94 \\
\hline \multirow{5}{*}{ TIWANAKU } & \multirow{5}{*}{ IDADE } & $<25$ & 0 & 0 & 0 & 0 \\
\hline & & $25-40$ & 28 & 3 & 14 & 45 \\
\hline & & $40-55$ & 31 & 5 & 24 & 60 \\
\hline & & $>55$ & 18 & 3 & 20 & 41 \\
\hline & & & 77 & 11 & 58 & 146 \\
\hline \multirow{5}{*}{ PÓS TIWANAKU } & \multirow{4}{*}{ IDADE } & $<25$ & 5 & 1 & 1 & 7 \\
\hline & & $25-40$ & 37 & 6 & 25 & 68 \\
\hline & & $40-55$ & 10 & 4 & 22 & 36 \\
\hline & & $>55$ & 6 & 1 & 13 & 20 \\
\hline & \multicolumn{2}{|c|}{ Total } & 58 & 12 & 61 & 131 \\
\hline \multirow{5}{*}{$\begin{array}{c}\text { PÓS TIWANAKU } \\
\text { externo }\end{array}$} & \multirow{4}{*}{ IDADE } & $<25$ & 0 & 2 & 0 & 2 \\
\hline & & $25-40$ & 6 & 1 & 5 & 12 \\
\hline & & $40-55$ & 5 & 0 & 5 & 10 \\
\hline & & $>55$ & 4 & 0 & 3 & 7 \\
\hline & \multicolumn{2}{|c|}{ Total } & 15 & 3 & 13 & 31 \\
\hline
\end{tabular}

As diferenças observadas entre os períodos em relação à idade dos indivíduos, assim como a distribuição dos sexos, foram analisadas através do teste estatístico de Correlação de Spearman. Os resultados, apresentados na tabela 17, não indicam a presença de relação entre as variáveis analisadas. 
Tabela 17 - Valores da correlação entre a idade, o sexo e o período ao qual pertencem os indivíduos desta amostra.

\begin{tabular}{ccc}
\hline & Spearman $\mathbf{r}$ & Sig. \\
\hline IDADE E SEXO & 0,025 & 0,615 \\
PERÍODO E IDADE & $-0,072$ & 0,152 \\
PERÍODO E SEXO & 0,025 & 0,615 \\
\hline
\end{tabular}

sig. $p<0,05$

Finalizando a caracterização do perfil bioantropológico desta amostra, a observação dos crânios presentes objetivou a determinação da presença ou ausência de deformação craniana. Em seguida, na presença, a classificação do tipo de deformação e por fim, a angulação desta.

Apenas 24 indivíduos foram excluídos da amostra por apresentarem alterações ou ausências de partes anatômicas importantes para a análise. Este grupo representa apenas $6 \%$ da amostra total.

A ausência de deformação craniana encontrada foi predominante quando analisamos a amostra como um grupo único, sendo observada em $57 \%$ dos crânios avaliados. Dos deformados intencionalmente, $70,2 \%$ das deformações encontradas eram do tipo Tabular, enquanto $29,8 \%$ do tipo Circular. A distribuição dos tipos de deformação craniana intencional e as angulações apresentadas estão dispostas na Figura 42. 


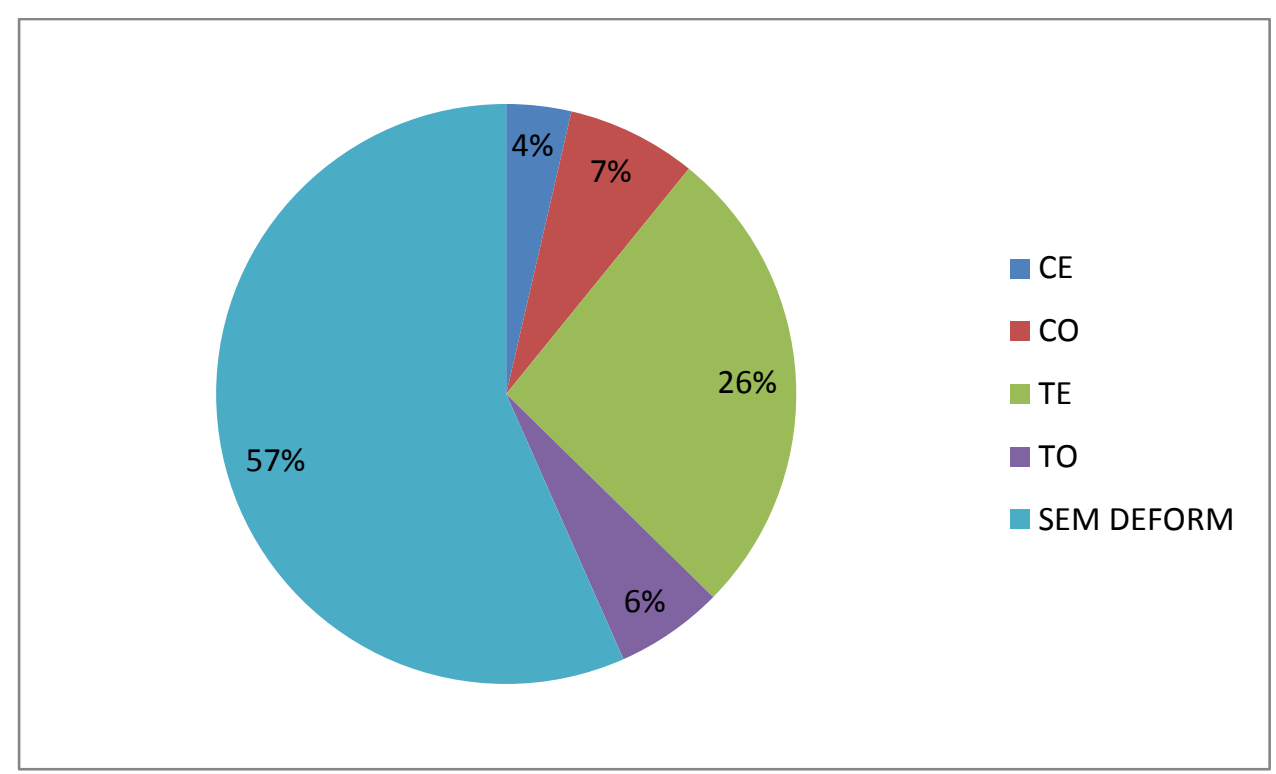

Figura 42 - Gráfico apresentando a distribuição das deformações cranianas encontradas em San Pedro de Atacama de acordo com o tipo e angulação de cada modificação corporal, onde as deformações estão classificadas como $\mathrm{CE}=$ circular ereta; $\mathrm{CO}=$ =ircular oblíqua; $\mathrm{TE}=$ tabular ereta; $\mathrm{TO}=$ tabular oblíqua.

As prevalências variaram bastante, com a deformação Tabular Ereta sendo quase quatro vezes mais presente que a Circular Oblíqua, que é a deformação mais frequente entre as restantes.

Quando os indivíduos são separados de acordo com o período ao qual estão relacionados, a distribuição das deformações cranianas se apresenta conforme é observado na Figura 43. 


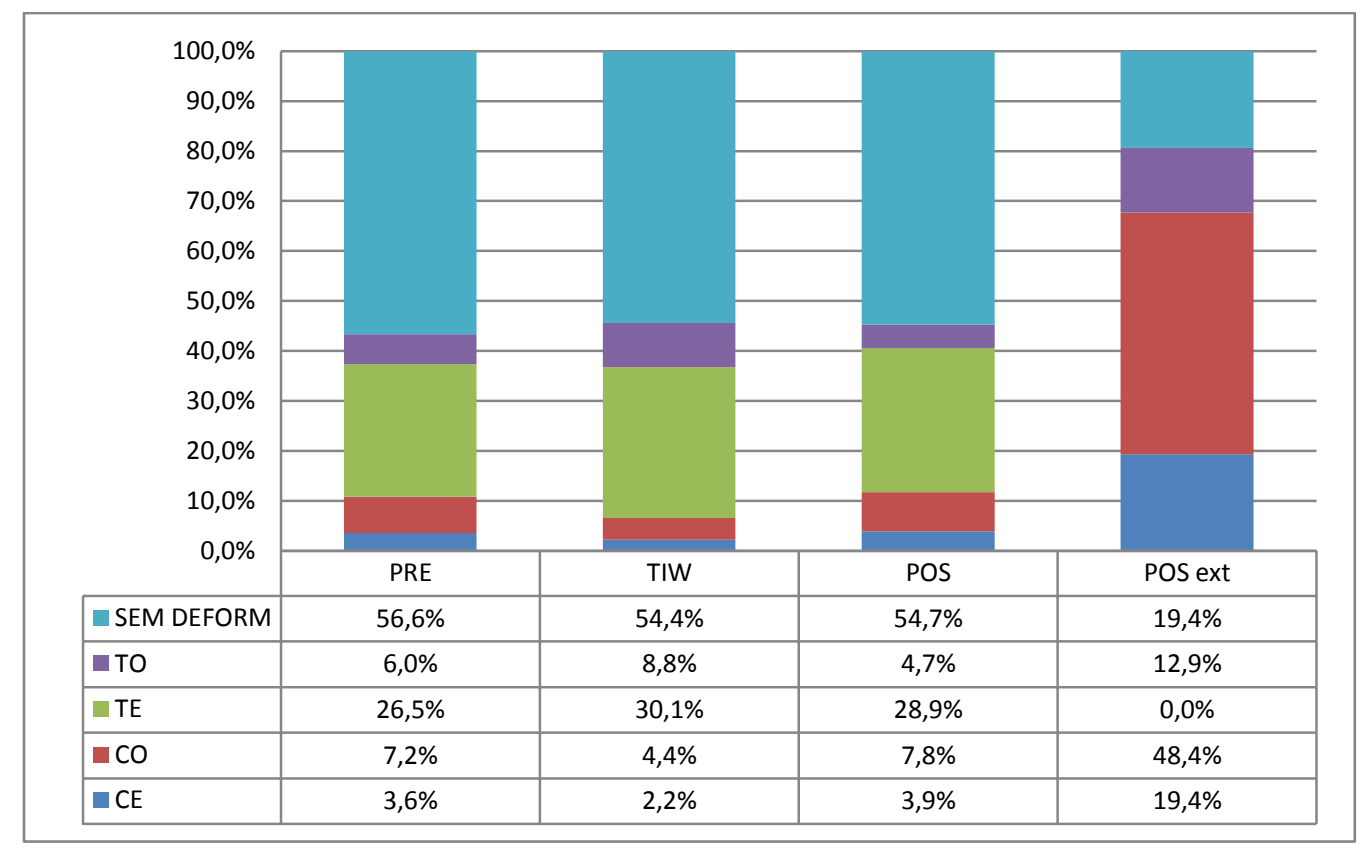

Figura 43 - Distribuição das deformações cranianas intencionais entre os períodos estudados, acrescida da amostra de Caspana, identificado como Pós Tiwanaku externo (POS ext).

A distribuição das deformações cranianas encontradas durante os períodos pré Tiwanaku e pós Tiwanaku segue o padrão encontrado na amostra como um todo, na qual a maioria absoluta de indivíduos não apresenta deformação, seguidos pelos crânios com deformação Tabular Ereta, Circular Oblíqua, Tabular Oblíqua e finalmente Circular Ereta.

A primeira exceção desta distribuição de deformações pelos períodos foi encontrada nos indivíduos dos sítios do período Tiwanaku, no qual as deformações Tabulares Oblíquas são mais frequentes que as Circulares Oblíquas, evidenciando a preferência às deformações cranianas Tabulares em detrimento às Circulares durante o período de influência do Império Tiwanaku no Salar.

Os indivíduos originários do sítio Caspana, aqui considerados como representantes do período pós Tiwanaku, são colocados nesta tabela com o objetivo de servirem como grupo de comparação entre os sítios representantes do salar de Atacama e um sítio arqueológico da bacia do Rio Loa, externo aos oásis de San Pedro. Nesta comparação, é observada uma grande diferença entre as deformações cranianas presentes, apresentando uma evidente predileção pelas deformações cranianas 
Circulares nos crânios de Caspana. Estas diferenças ficam mais evidentes quando observamos apenas os crânios modificados de cada período, como na Figura 44.

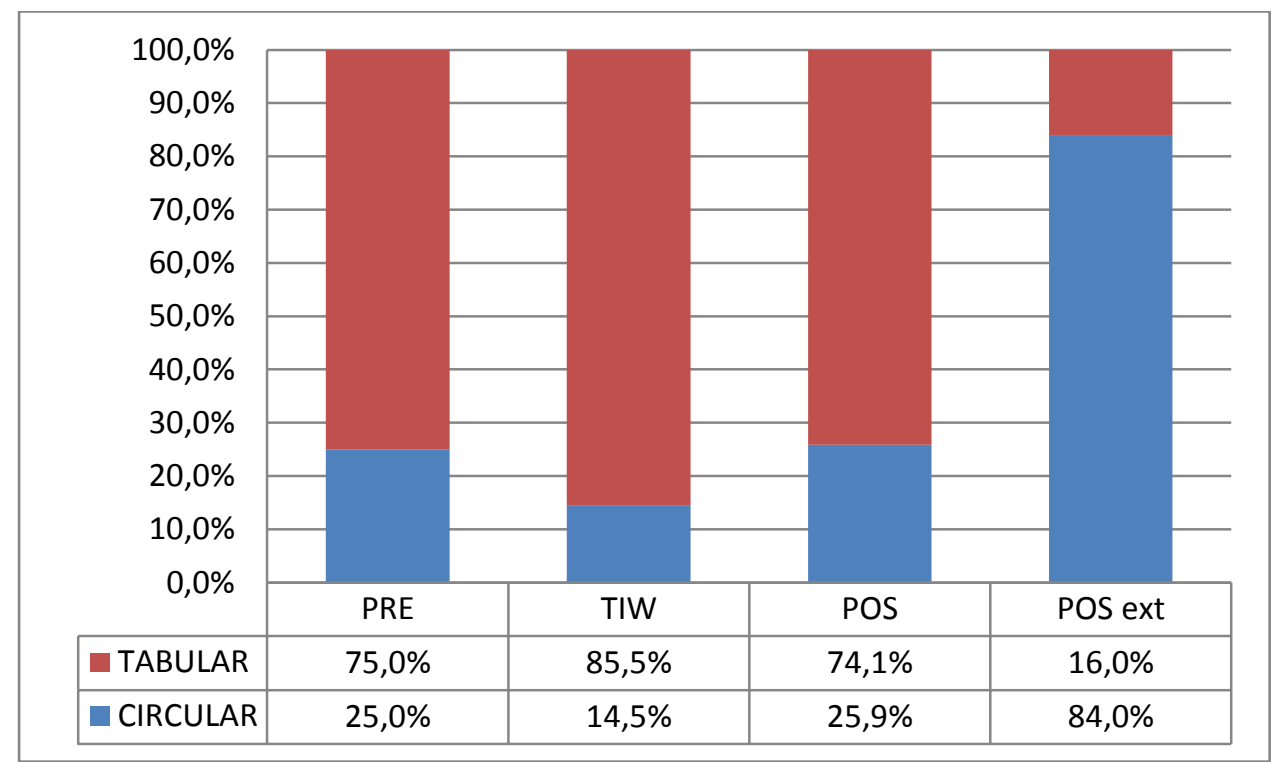

Figura 44 - Distribuição dos 2 tipos principais de deformação craniana encontrados nos indivíduos deformados.

Entre os indivíduos portadores de deformações intencionais, a opção pelas deformações Tabulares é a regra nos oásis de San Pedro de Atacama. Independente do período estudado, as deformações Circulares foram observadas em apenas $1 / 4$ da população dos períodos Pré e Pós Tiwanaku, diminuídas ainda mais, a menos de $15 \%$ durante o período de influência Tiwanaku, porém esta diferença observada não se mostrou estatisticamente significativa (Kurskal-Wallis $-\boldsymbol{X}^{2}=1,170 ; \mathrm{df}=2 ; \mathbf{p}=0,557$ ).

As prevalências destas deformações também foram comparadas entre os períodos, através do teste Chi Quadrado (Tabela 18). 
Tabela 18 - Valor estatístico e valor-p (entre parênteses) de Chi-Quadrado (corrigidos) entre as deformações cranianas observadas. Os valores em destaque representam as diferenças estatisticamente significantes.

\begin{tabular}{cccc}
\hline & PRE & TIW & POS \\
\hline PRE & $\mathrm{X}$ & & \\
TIW & $1,0435(0,3070)$ & $X$ & $X$ \\
POS & $0,0225(0,8807)$ & $1,7540(0,1854)$ & $\mathbf{2 1 , 7 3 2 9 ( 0 , 0 0 0 0 )}$ \\
POS ext & $\mathbf{1 8 , 2 5 6 3 ( 0 , 0 0 0 0 )}$ & $\mathbf{3 5 , 0 6 0 0 ( 0 , 0 0 0 0 )}$ & \\
\hline
\end{tabular}

sig. $p<0,05$

\section{Patologias dentais}

Primeiramente descreverei a condição de preservação do material arqueológico disponível para este trabalho, pois, apesar deste assunto fazer mais sentido no tópico anterior, caracterizando a natureza da minha amostra, o fato de ser o dente o objeto desta avaliação me fez incluí-las neste tópico.

Na realidade, a discussão se iniciará na ausência do elemento dentário destes crânios analisados, mas para isso, apresentarei a distribuição da ausência e presença dos dentes por mim observadas.

O gráfico da Figura 45 ilustra a condição bucal dos crânios presentes em minha amostra, indicando uma expressiva diferença entre os dentes presentes no momento de minha coleta de dados e os dentes que estiveram in situ no momento de sua morte. 


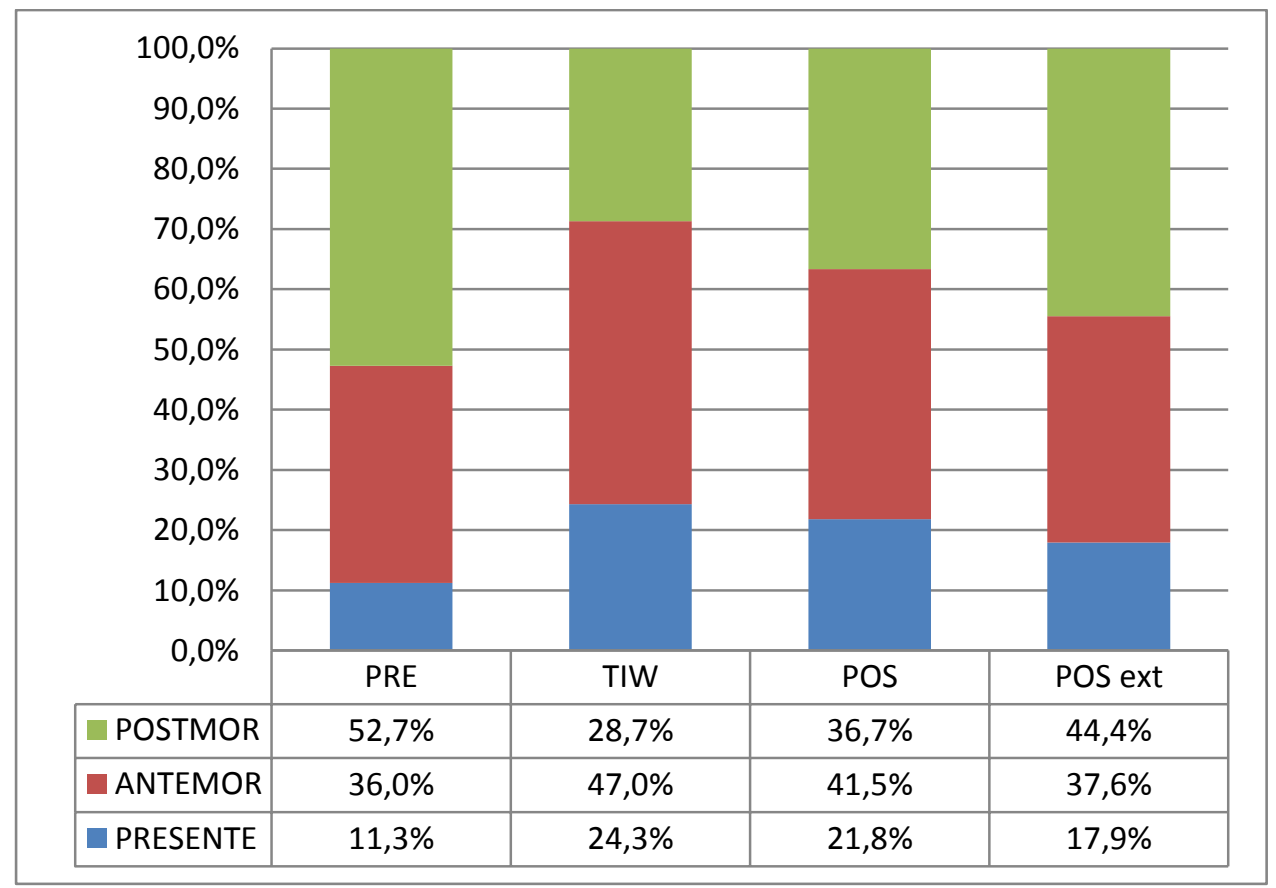

Figura 45 - Proporção dos dentes presentes, perdidos em vida (ANTEMOR) e perdidos após a morte (POSTMOR) dos indivíduos e seus respectivos períodos.

Apesar dos 402 esqueletos analisados representarem menos de $14 \%$ de todos os crânios em bom ou regular estado de conservação da coleção de crânios escavados pelo padre Gustavo Le Paige, esta amostra aclara a crítica situação em que se encontra esta coleção. Com um número muito grande de dentes perdidos após a morte, todos os períodos apresentam um número maior de dentes perdidos desta maneira quando comparados com os dentes ainda presentes nos crânios desta coleção. A situação mais alarmante situa-se na amostra representativa do período Pré Tiwanaku, maciçamente representada pelo sítio Toconao Oriente, sítio intensamente danificado ao longo dos anos (Hubbe et al., 2011). O período Pré Tiwanaku apresenta o maior número de dentes perdidos post mortem, representando mais de $50 \%$ dos alvéolos avaliados. Esta deterioração do material arqueológico reduz a amostra dentária analisável de $64 \%$ no momento da morte do individuo para apenas $11,3 \%$ presentes atualmente.

Menos expressiva mas ainda alta, a prevalência de dentes perdidos post mortem das amostras de Tiwanaku (a menor dos quatro grupos) e Pós Tiwanaku são também menores do que a encontrada para Caspana. 
Dividindo a amostra quanto à localização dos dentes, a diferença entre a perda de dentes anteriores (incisivos e caninos) e posteriores (pré-molares e molares) é demonstrada na Figura 46.

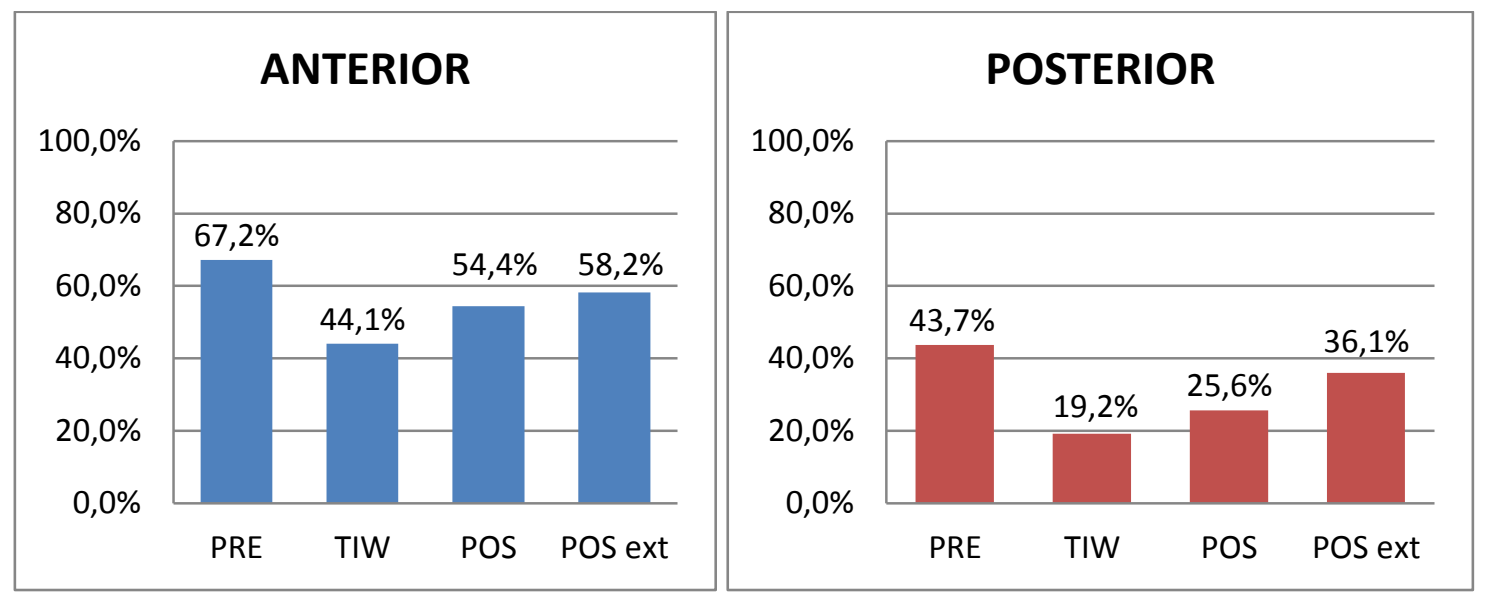

Figura 46 - Gráficos comparativos entre as perdas dentárias post mortem dos dentes anteriores e posteriores.

A diferença encontrada entre as perdas dos dentes anteriores e posteriores, bastante favorável aos anteriores, pode ser explicada pela anatomia destes elementos. Diferentemente dos dentes anteriores que são unirradiculares, os dentes posteriores possuem, em sua maioria, raízes múltiplas (duas, três e até quatro raízes por dente). Esta morfologia dificulta a avulsão destes dentes, minimizando este processo tafonômico degenerativo das maxilas e mandíbulas da coleção.

Representando apenas $33 \%$ dos dentes presentes no momento da morte dos indivíduos, os elementos dentais atualmente presentes na minha amostra somam 1745 dentes em 402 indivíduos, ou seja, uma média de 4,34 por crânio analisado.

O gráfico abaixo mostra a proporção dos dentes atualmente disponíveis para estudo em relação aos dentes presentes originalmente nos crânios observados de minha amostra (Figura 47). 


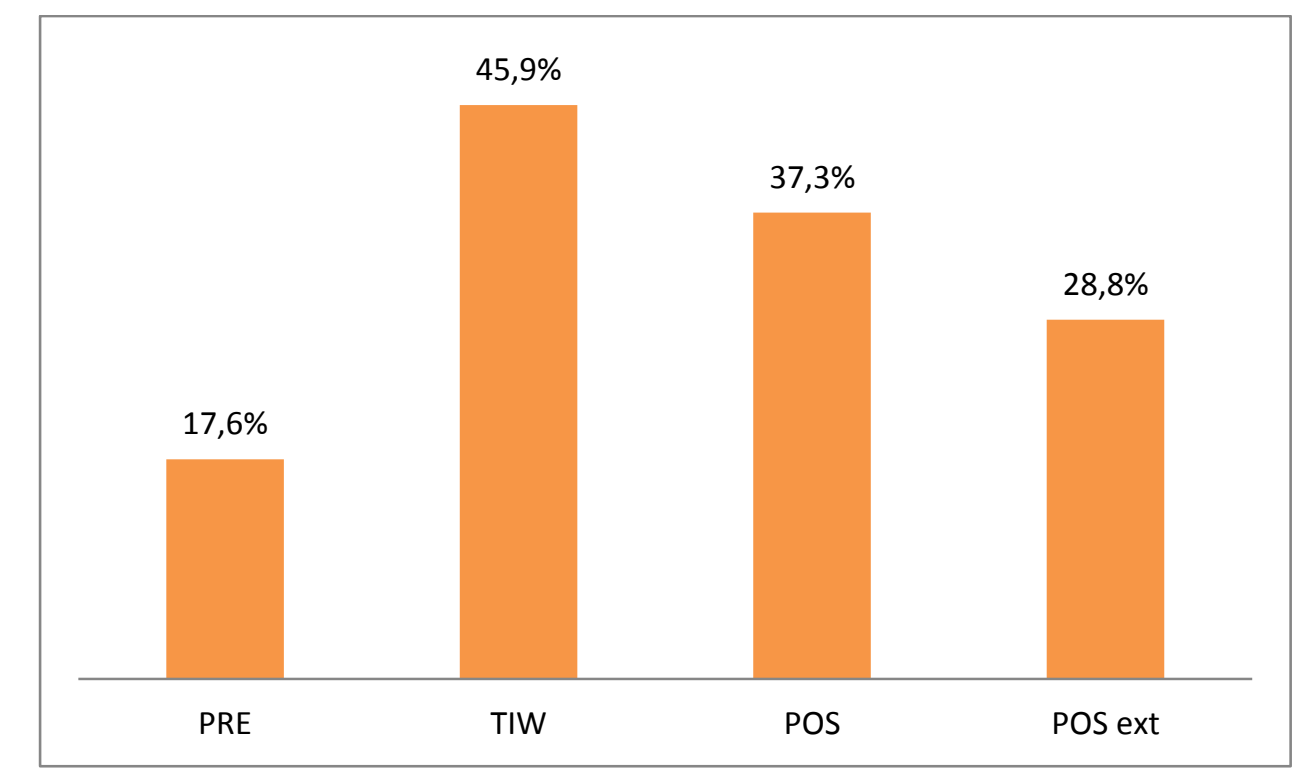

Figura 47 - Prevalência dos dentes presentes atualmente na coleção: dentes presentes / dentes presentes + perdidos post mortem.

Com isso, os resultados que serão apresentados a partir deste momento neste trabalho serão baseados nestes 1745 dentes presentes, além dos alvéolos cicatrizados de 3597 dentes perdidos durante a vida dos atacamenhos por mim estudados.

\section{Perda ante mortem}

Os 3597 dentes perdidos em vida na amostra total, representavam 43\% dos dentes analisáveis no momento da morte dos indivíduos. Todavia, após a ação dos processos tafonômicos sobre esta coleção esqueletal, hoje os dentes perdidos (ante mortem e post mortem) são responsáveis por $67 \%$ dos alvéolos analisáveis para as patologias dentais propostas neste trabalho.

A prevalência de perdas dentárias em vida varia consideravelmente entre os períodos analisados para os oásis de San Pedro. Ao analisarmos cronologicamente esta amostra, o período Pré Tiwanaku apresenta o menor valor de dentes perdidos em 
vida, seguido pelo maior aumento observado neste estudo, quando encontramos no período Tiwanaku um aumento de $11 \%$ de perdas ante mortem. Por último, durante o período Pós Tiwanaku, observamos uma retração no número de dentes perdidos em vida, porém sem atingir o patamar apresentado pelo primeiro período histórico avaliado (Figura 48).

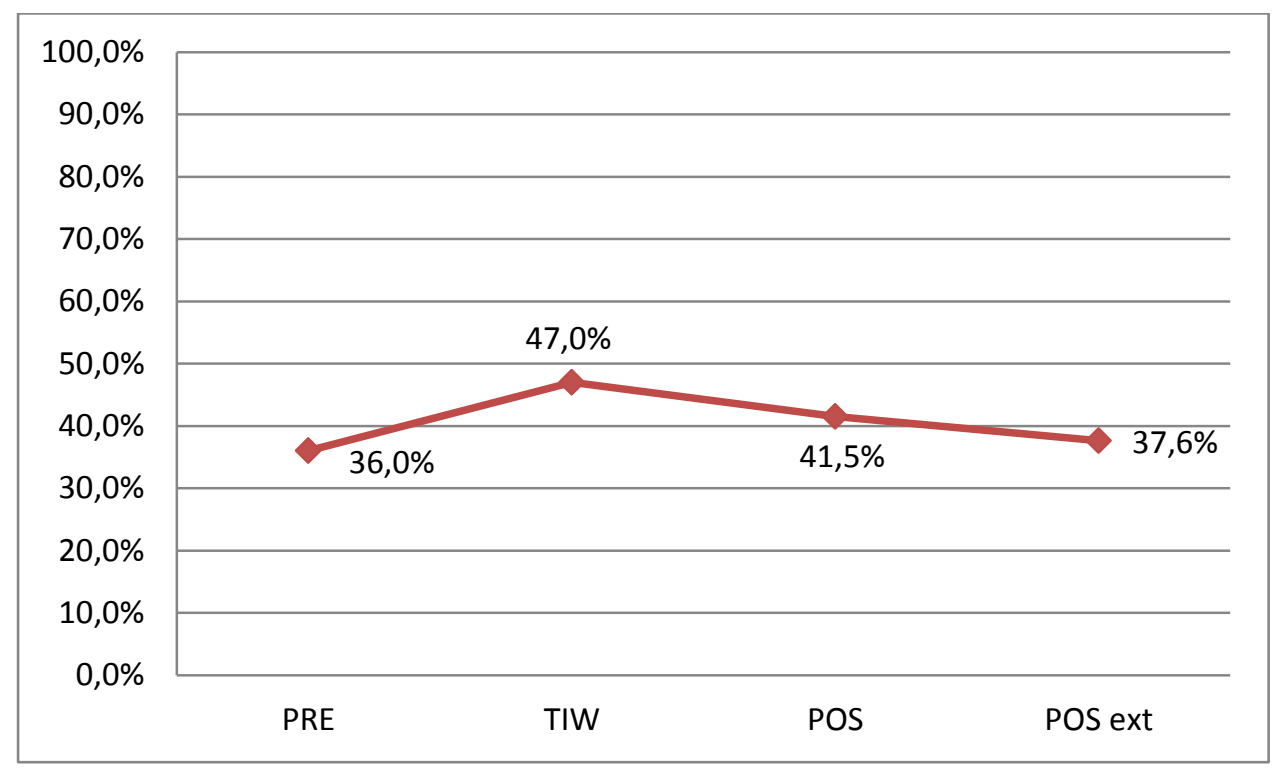

Figura 48 - Prevalência de dentes perdidos ante mortem.

As variações encontradas entre os períodos estudados são estatisticamente significativas, como pode ser observado na Tabela 19. A utilização do sítio Caspana como referência externa aos sítios da bacia do salar de Atacama evidencia o aumento apresentado por Tiwanaku. 
Tabela 19 - Valor estatístico e valor-p (corrigidos) encontrados nos testes Chi Quadrado para as perdas ante mortem.

\begin{tabular}{|c|c|c|c|}
\hline & PRE & TIW & POS \\
\hline PRE & $x$ & & \\
\hline TIW & $54,3007(0,0000)$ & $x$ & \\
\hline POS & $12,5110(0,0004)$ & $18,7561(0,0000)$ & $x$ \\
\hline POS ext & $0,3709(0,5425)$ & $15,5546(0,0001)$ & $2,5261(0,0624)$ \\
\hline
\end{tabular}

sig. $p<0,05$

Quando desmembramos estes dados em dentes anteriores e posteriores, é notória a influência dos dentes posteriores para as diferenças encontradas entre os períodos. Enquanto as prevalências de perdas ante mortem nos dentes anteriores exibem uma variação de magnitude modesta entre os períodos estudados, os posteriores apresentam o mesmo padrão presente na distribuição do gráfico da Figura 47, evidentemente em amplitudes mais intensas que o mesmo (Figura 49).
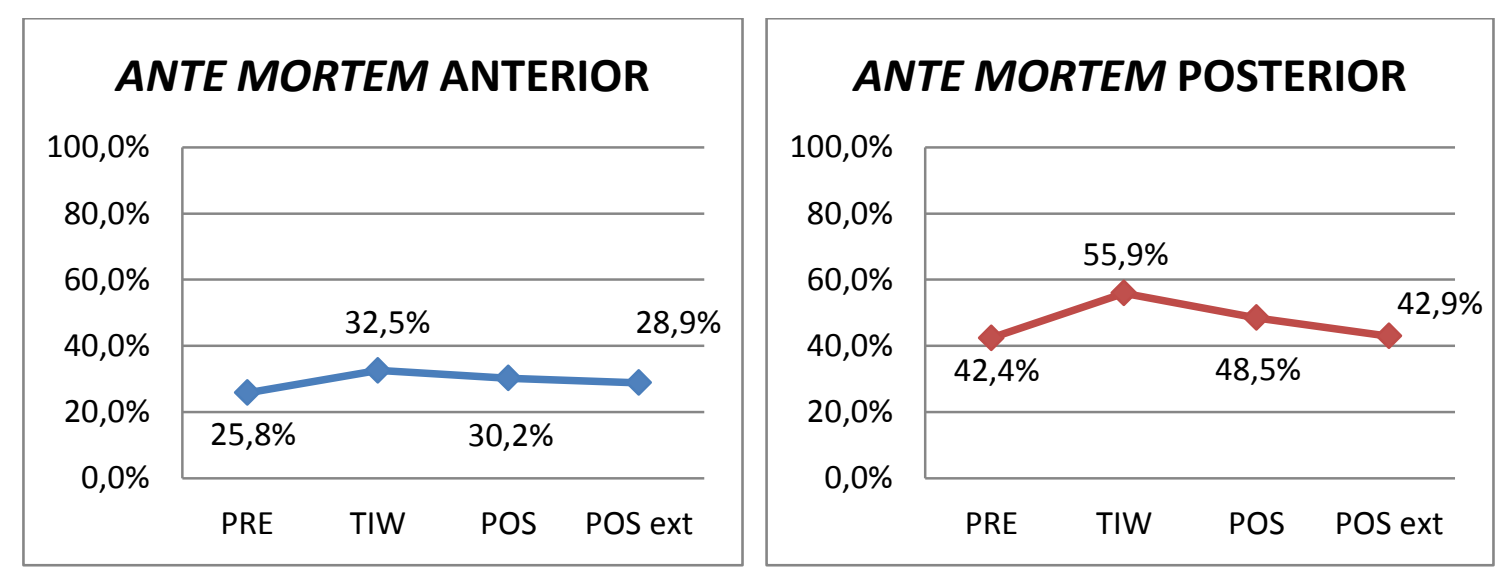

Figura 49 - Prevalências de dentes anteriores e posteriores perdidos ante mortem. 
Uma vez que a perda dentária ante mortem é influenciada pela idade do indivíduo, exclui os indivíduos jovens, com idade de morte inferior a 25 anos, encontrando os seguintes resultados (Figura 50):

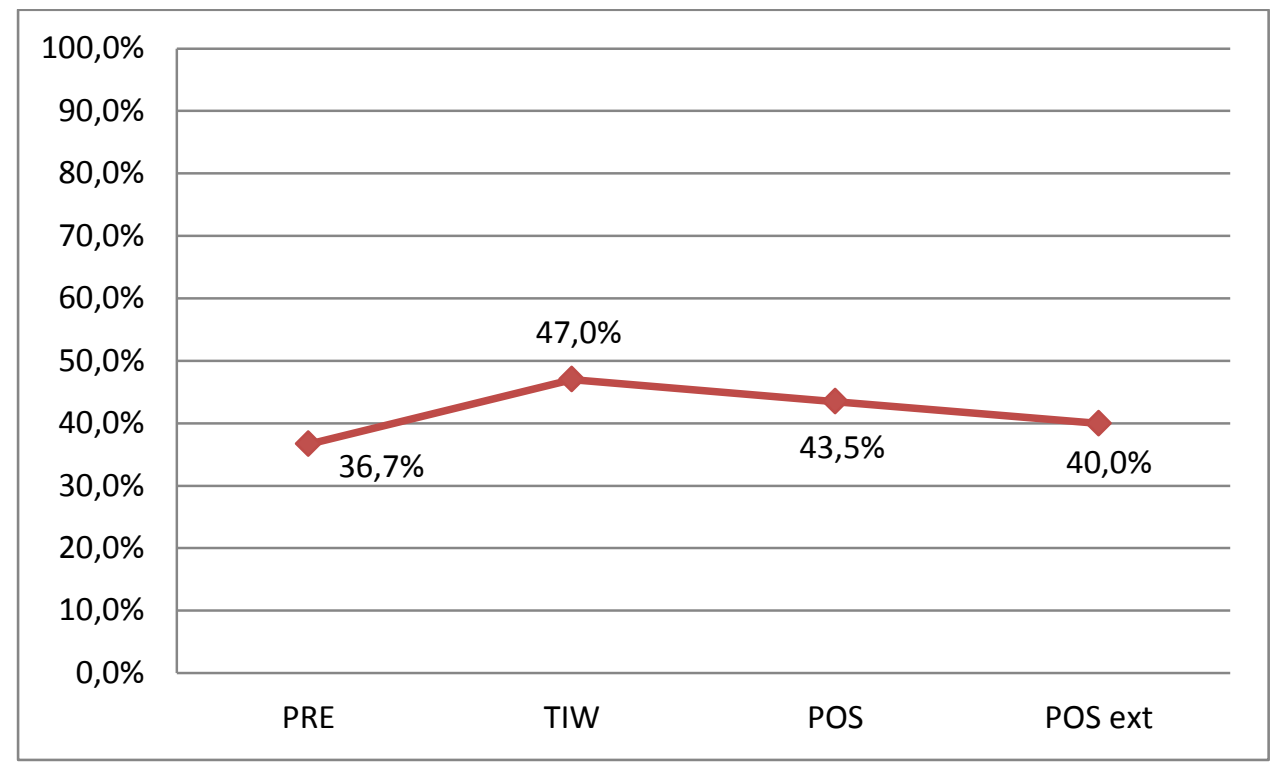

Figura 50 - Prevalência de dentes perdidos ante mortem apenas com indivíduos com idade superior a 25 anos.

Observamos a manutenção do mesmo padrão de evolução deste marcador dental encontrado na amostra geral, onde os indivíduos com idade de morte menor que 25 anos estavam incluídos, com pequena diferença nos valores de todos os períodos, exceto Tiwanaku, por não conter indivíduos com idade inferior a 25 anos em sua amostra. A análise estatística destas prevalências manteve também o mesmo padrão, apresentando diferenças significativas entre os períodos Pré Tiwanaku e Tiwanaku e os períodos Tiwanaku e Pós Tiwanaku (Tabela 20). 
Tabela 20 - Valor estatístico e valor-p (corrigidos) encontrados nos testes Chi Quadrado para as perdas ante mortem nos indivíduos com idade superior a 25 anos.

\begin{tabular}{cccc}
\hline & PRE & TIW & POS \\
\hline PRE & $X$ & & \\
TIW & $\mathbf{4 7 , 2 7 4 8 ( 0 , 0 0 0 0 )}$ & $X$ & $X$ \\
POS & $\mathbf{1 8 , 5 3 2 4 ( 0 , 0 0 0 0 )}$ & $\mathbf{7 , 3 8 3 1 ( 0 , 0 0 6 6 )}$ & $\mathbf{1 , 9 2 1 4 ( 0 , 1 6 5 7 )}$ \\
POS ext & $1,5715(0,2100)$ & $\mathbf{8 , 2 2 9 1 ( \mathbf { 0 , 0 0 4 1 ) }}$ & \\
\hline
\end{tabular}

sig. $p<0,05$

Também foram divididas as prevalências de perdas dentárias ante mortem para os dentes anteriores e posteriores (Figura 51).
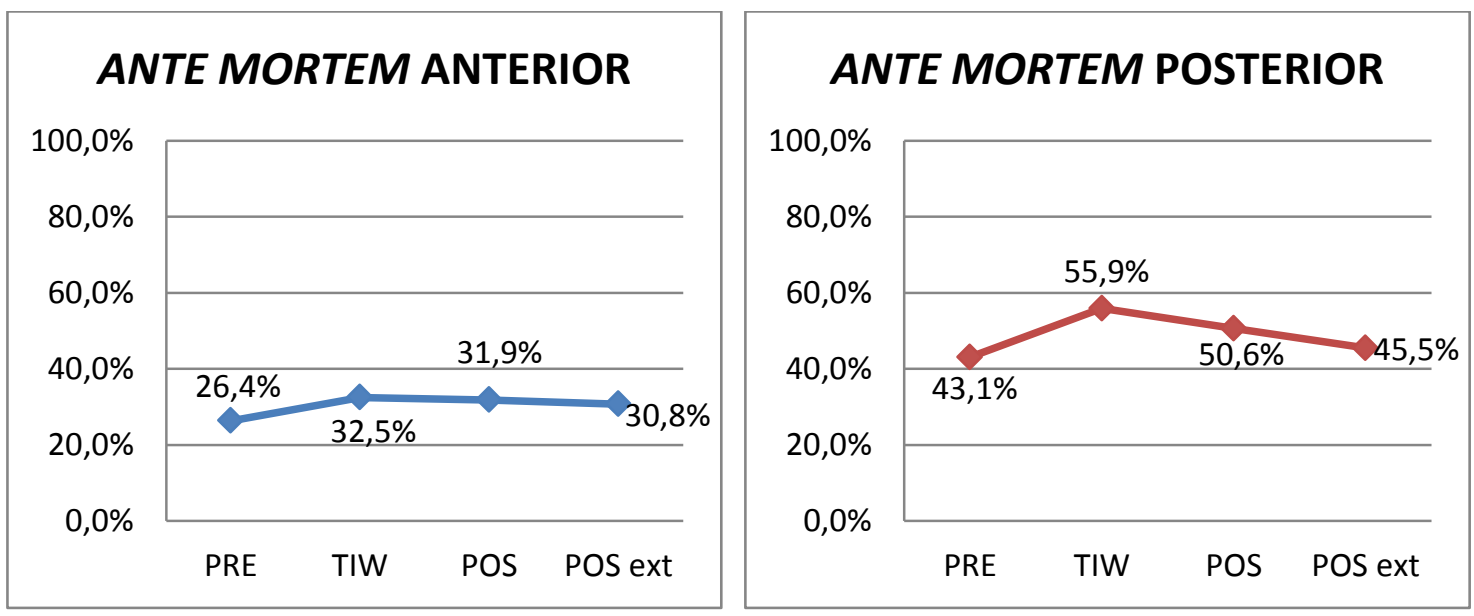

Figura 51 - Prevalências de dentes anteriores e posteriores perdidos ante mortem nos indivíduos com mais de 25 anos.

A distinção entre as possíveis causas destas perdas dentárias será apresentada nos tópicos seguintes.

Outra análise executada com os dados de dentes perdidos em vida foi a relação destas perdas com as deformações cranianas encontradas em seus portadores. A 
distribuição das lesões entre os indivíduos que apresentaram deformação craniana e os indivíduos que não apresentaram está exposta na Figura 52.

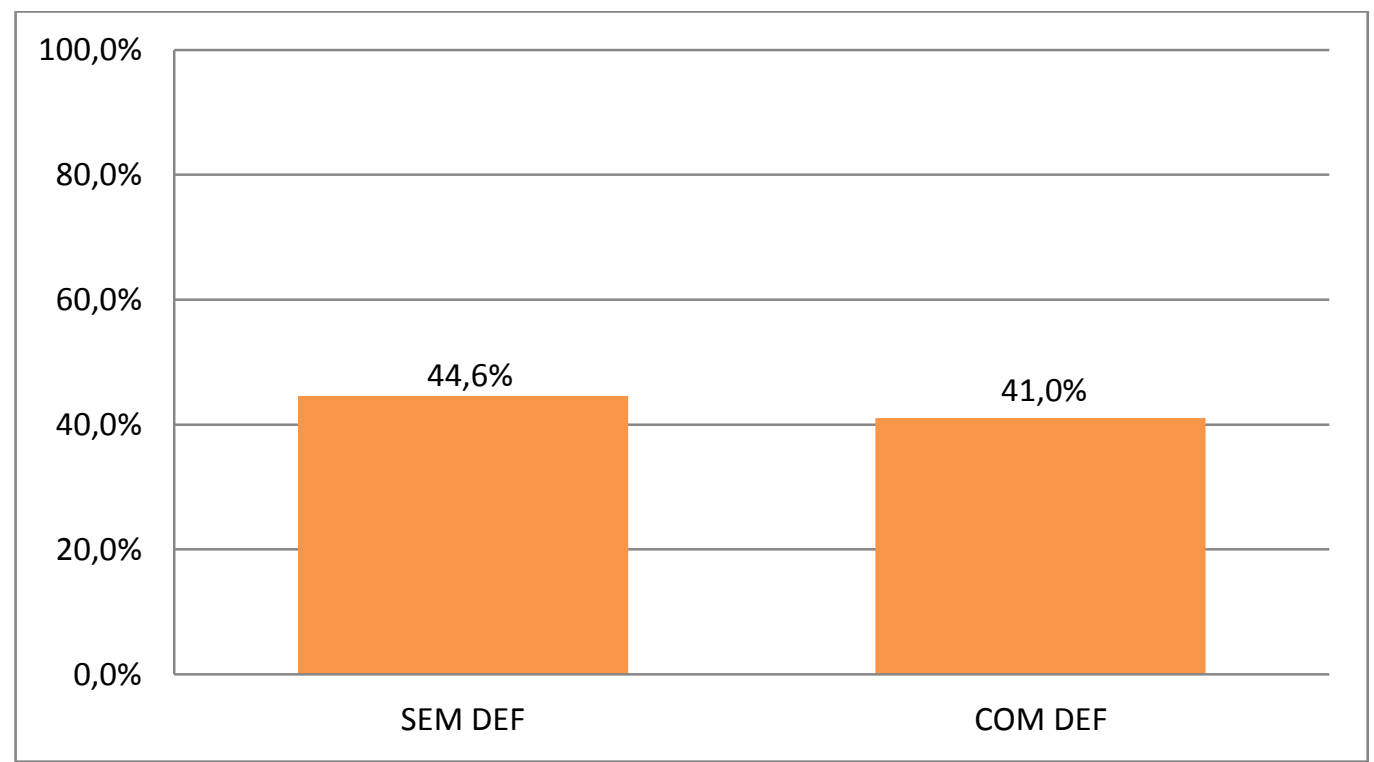

Figura 52 - Prevalência de dentes perdidos ante mortem entre os indivíduos que apresentaram deformação craniana intencional (COM DEF) e os que não apresentaram (SEM DEF).

A diferença encontrada entre os dois grupos, com uma maior prevalência de perdas em vida no grupo dos indivíduos que não apresentaram deformação craniana, se mostrou estatisticamente significativa $\left(X^{2}=9,9550 ; \mathbf{p}=0,0016\right)$.

A distribuição destas perdas também foi avaliada ao longo do tempo, sendo observado, em ambos os casos, um aumento durante o período Tiwanaku para ambos os grupos (Figura 53). 


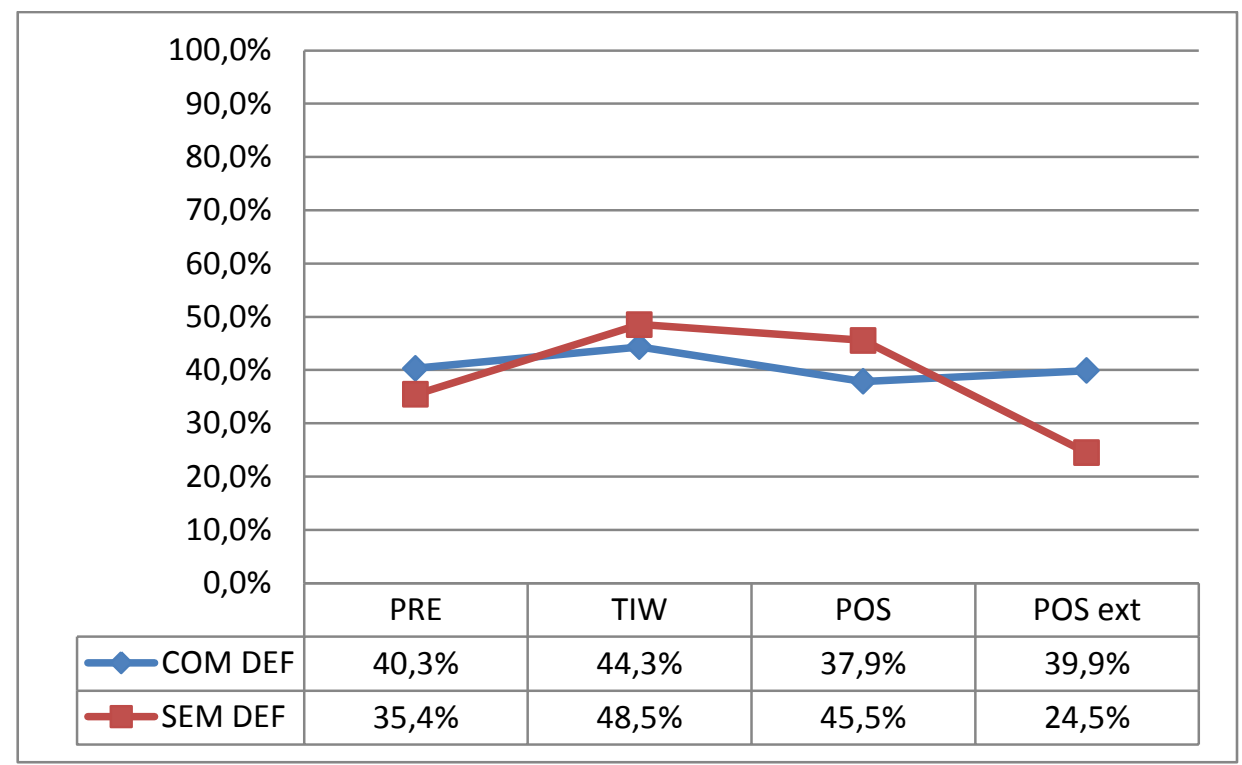

Figura 53 - Distribuição da prevalência de perda dentária em vida nos indivíduos que apresentaram (COM DEF) ou não deformações cranianas (SEM DEF).

As prevalências de perdas ante mortem de indivíduos deformados e não deformados foram comparadas em cada período avaliado (Tabela 21).

Tabela 21 - Valor estatístico e valor-p (corrigidos) encontrados nos testes Chi Quadrado aplicados sobre a diferença das perdas ante mortem dentária apresentadas por indivíduos com ou sem deformação craniana ao longo dos períodos.

\begin{tabular}{ccc}
\hline & $\mathbf{x}^{\mathbf{2}}$ & $\mathbf{p}$ \\
\hline Pré Tiwanaku & 3,4205 & 0,0644 \\
Tiwanaku & $\mathbf{5 , 6 3 9 1}$ & $\mathbf{0 , 0 1 7 6}$ \\
Pós Tiwanaku & $\mathbf{1 5 , 5 8 7 5}$ & $\mathbf{0 , 0 0 0 1}$ \\
Pós Tiwanaku externo & $\mathbf{7 , 2 1 6 0}$ & $\mathbf{0 , 0 0 7 2}$ \\
\hline
\end{tabular}

sig. $p<0,05$

Analisando a evolução da perda dentária ante mortem nos grupos separadamente, temos no grupo de indivíduos que apresentaram deformação 
craniana intencional apenas uma variação significativa entre os períodos Tiwanaku e Pós Tiwanaku (Tabela 22).

Tabela 22 - Valor estatístico e valor-p (corrigidos) encontrados nos testes Chi Quadrado para as perdas ante mortem nos indivíduos com deformação craniana intencional.

\begin{tabular}{cccc}
\hline & PRE & TIW & POS \\
\hline PRE & $X$ & & \\
TIW & $2,8265(0,0927)$ & $X$ & $X$ \\
POS & $0,9536(0,3288)$ & $10,9246(0,0009)$ & \\
POS ext & $0,0045(0,9463)$ & $2,4553(0,1171)$ & $0,4663(0,4917)$
\end{tabular}

sig. $\mathrm{p}<0,05$

Já as variações observadas nas perdas dentárias dos indivíduos sem deformação craniana foram significativas entre o período Pré Tiwanaku e Tiwanaku. Caspana também apresentou prevalência de perdas dentárias em vida diferente estatisticamente de todos os períodos avaliados (Tabela 23).

Tabela 23 - Valor estatístico e valor-p (corrigidos) encontrados nos testes Chi Quadrado para as perdas ante mortem nos indivíduos sem deformação craniana intencional.

\begin{tabular}{cccc}
\hline & PRE & TIW & POS \\
\hline PRE & $X$ & & \\
TIW & $\mathbf{3 8 , 5 3 1 4 ( 0 , 0 0 0 0 )}$ & $X$ & $X$ \\
POS & $\mathbf{2 1 , 2 6 5 6 ( 0 , 0 0 0 0 )}$ & $2,8860(0,0894)$ & $\mathbf{1 5 , 0 7 4 2 ( 0 , 0 0 0 1 )}$ \\
POS ext & $\mathbf{4 , 0 1 3 4 ( 0 , 0 4 5 1 )}$ & $\mathbf{1 9 , 8 6 8 3 ( 0 , 0 0 0 0 )}$ & $\mathbf{1 5}$ \\
\hline
\end{tabular}

sig. $p<0,05$ 


\section{Lesões periapicais ou abcessos}

Os abcessos dentais periapicais estiveram presentes em 17,3\% dos alvéolos e dentes avaliados da amostra total deste trabalho.

Apesar do meu dedicado empenho em diagnosticar a presença destas lesões, mesmo nos casos de alvéolos dentários vazios resultantes de perda post mortem do dente em questão, os casos de dúvida foram considerados cautelosamente como ausentes, tornando o resultado final necessariamente subestimado.

No caso dos abcessos dentários, manteve-se a mesma evolução da lesão ao longo dos períodos históricos que encontramos para os dentes perdidos em vida, iniciando com uma menor prevalência durante o período Pré Tiwanaku, sofrendo um aumento durante a transição deste período com o subsequente (Tiwanaku) e diminuindo levemente durante o último período (Pós Tiwanaku) (Figura 54). Caspana também apresenta o segundo menor valor entre as amostras (32,6\%), sendo maior apenas que o primeiro período histórico estudado neste trabalho.

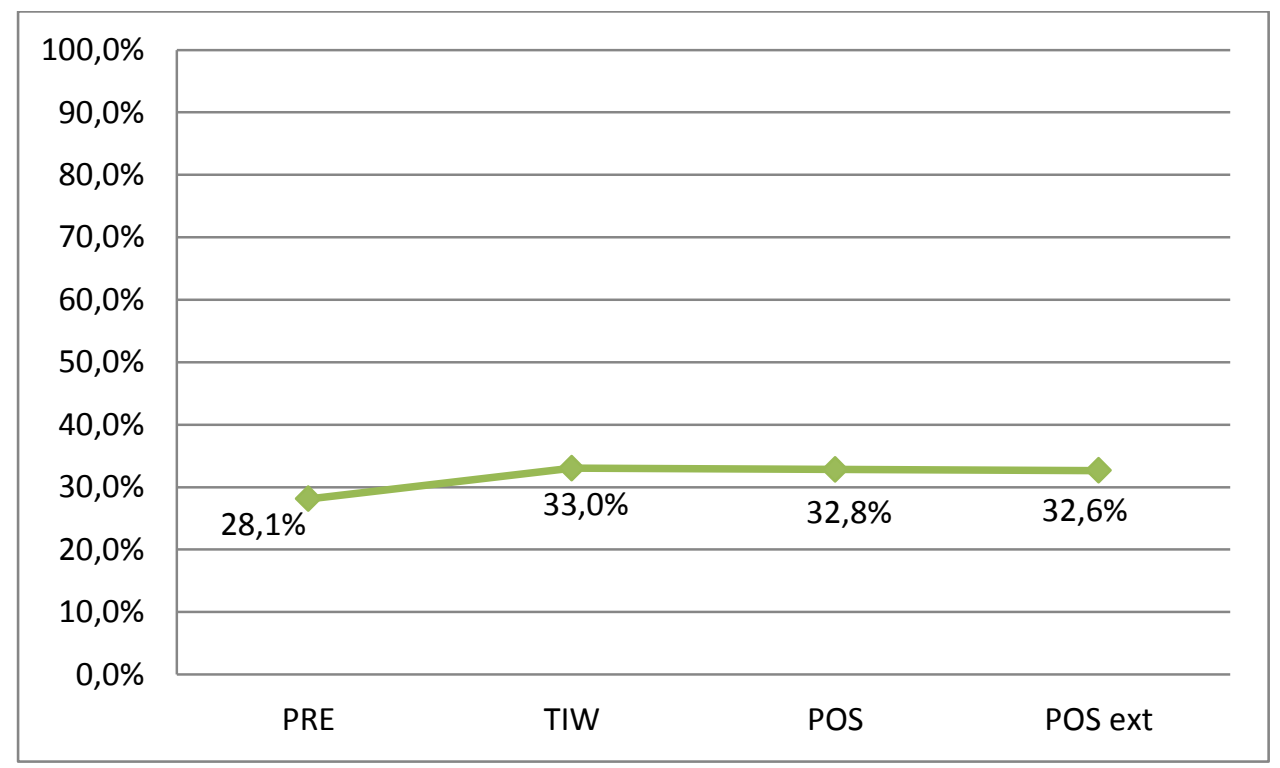

Figura 54 - Prevalência das lesões periapicais. 
O aumento na prevalência de abcessos encontrado entre o período Pré Tiwanaku e Tiwanaku se mostrou estatisticamente significativo (Tabela 24). Quando comparamos os dois últimos períodos entre si ou qualquer dos períodos com o sítio Caspana, não encontramos diferenças significativas.

\begin{tabular}{|c|c|c|c|}
\hline \multicolumn{4}{|c|}{ prevalências de abcessos dentários. } \\
\hline & PRE & TIW & POS \\
\hline PRE & $x$ & & \\
\hline TIW & $7,1163(0,0076)$ & $x$ & \\
\hline POS & $6,0579(0,0138)$ & $0,0096(0,9221)$ & $x$ \\
\hline POS EXT & $2,2897(0,1302)$ & $0,0600(0,9385)$ & $0,0000(0,9978)$ \\
\hline
\end{tabular}

sig. $p<0,05$

O pequeno grupo de apenas 9 indivíduos com idade de morte inferior a 25 anos foi excluído em um segundo momento desta análise. Por estarem mal distribuídos ao longo dos períodos, optei por também analisar as lesões periapicais da minha amostra sem este possível viés.

Os resultados obtidos sem estes indivíduos jovens são apresentados na Figura 55, na qual observamos, diferentemente da análise anterior, um aumento contínuo da prevalência dos abcessos conforme avançamos no tempo. 


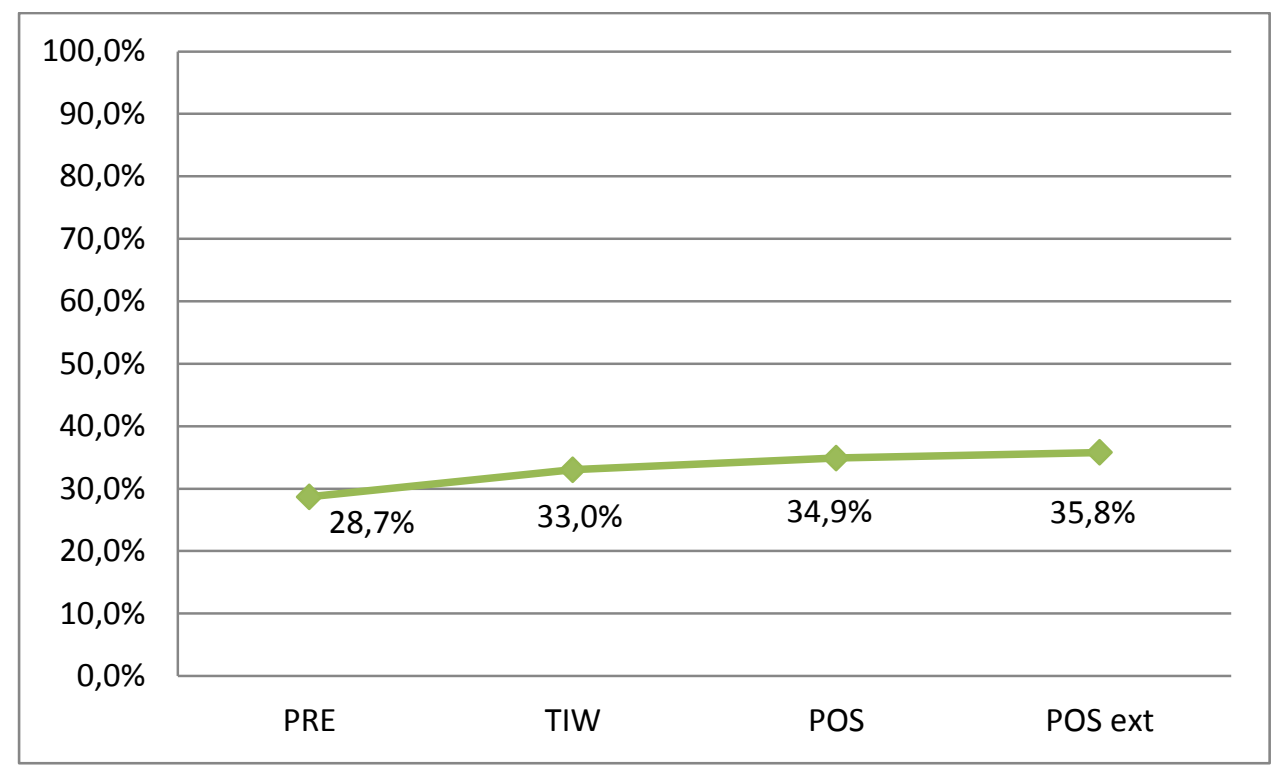

Figura 55 - Abcessos dentários sem a presença de indivíduos com menos de 25 anos.

Apesar de diminuir ligeiramente a diferença entre os períodos Pré Tiwanaku e Tiwanaku, ela continua sendo significativa. Caspana também apresentou uma alteração na prevalência de abcessos quando retiramos os indivíduos jovens, subindo dos 32,6\% já descritos para 35,8\%, ainda sem apresentar significância estatística quando comparada com o período Pós Tiwanaku dos oásis de San Pedro de Atacama (Tabela 25).

Tabela 25 - Valor estatístico e valor-p (corrigidos) encontrados nos testes Chi Quadrado das lesões periapicais (sem indivíduos jovens).

\begin{tabular}{|c|c|c|c|}
\hline & PRE & TIW & POS \\
\hline PRE & $x$ & & \\
\hline TIW & $5,4335(0,0198)$ & $x$ & \\
\hline POS & $9,9311(0,0016)$ & $1,1872(0,2759)$ & $x$ \\
\hline POS EXT & $5,3019(0,0213)$ & $0,7997(0,3712)$ & $0,0555(0,8137)$ \\
\hline
\end{tabular}

sig. $\mathrm{p}<0,05$ 
Uma vez que a cárie dentária é responsável pela maioria dos abcessos dentários desta amostra (vide tópico "cárie dentária") e ser uma patologia que acomete preferencialmente os dentes posteriores, as lesões periapicais também foram divididas entre abcessos em dentes anteriores e posteriores (Figura 56).

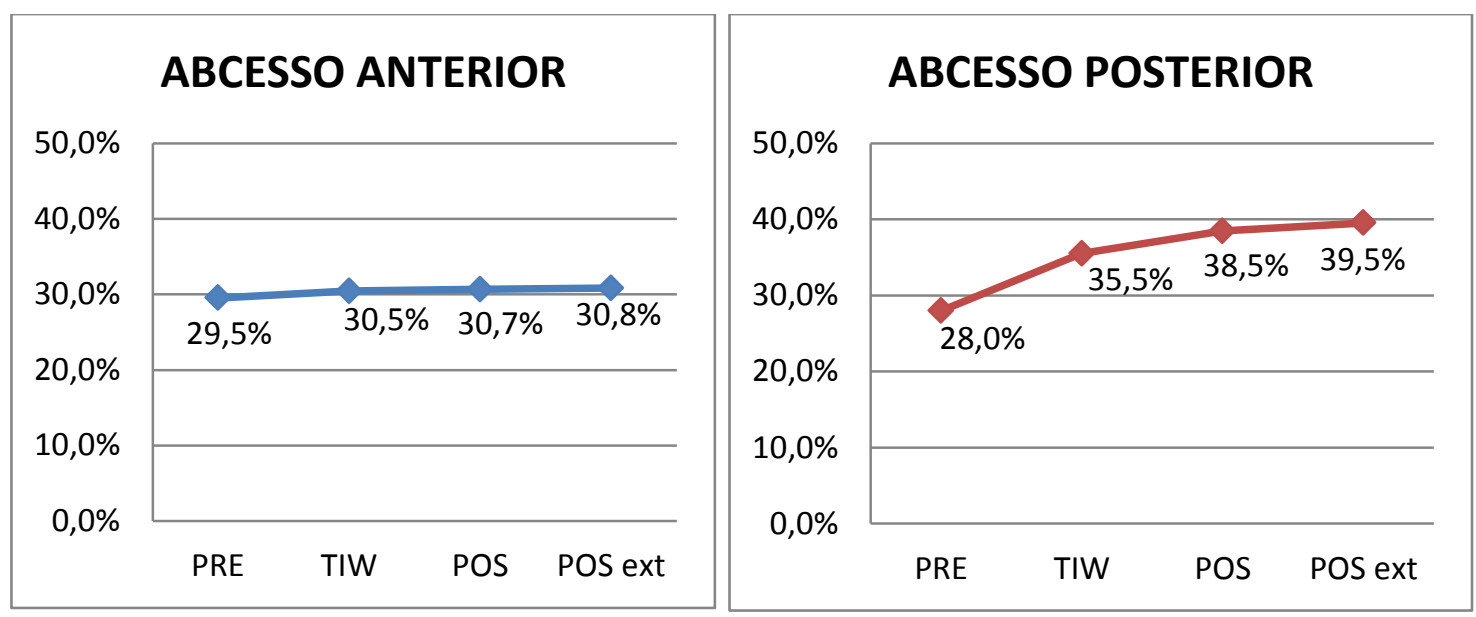

Figura 56 - Prevalências de abcessos dentários em dentes anteriores e posteriores de indivíduos com mais de 25 anos.

As prevalências de abcessos dentários observados, tanto em dentes anteriores como em dentes posteriores, indicam o mesmo aumento crescente observado ao longo do tempo apresentado na Figura 55.

\section{Cárie dentária}

As cáries dentárias são as patologias mais comumente encontradas nas coleções esqueletais arqueológicas e, juntamente com o desgaste dentário, a patologia mais utilizada para inferência de padrões alimentares (Hillson, 1979; Larsen, 1997 d). 
Como as lesões de cárie podem se desenvolver de formas independentes no mesmo dente, provocando distintas lesões, as dentes foram classificados quanto à presença e ausência de lesão cariosa e, na presença destas lesões, a quantidade de lesões apresentadas por cada dente (Figura 57).

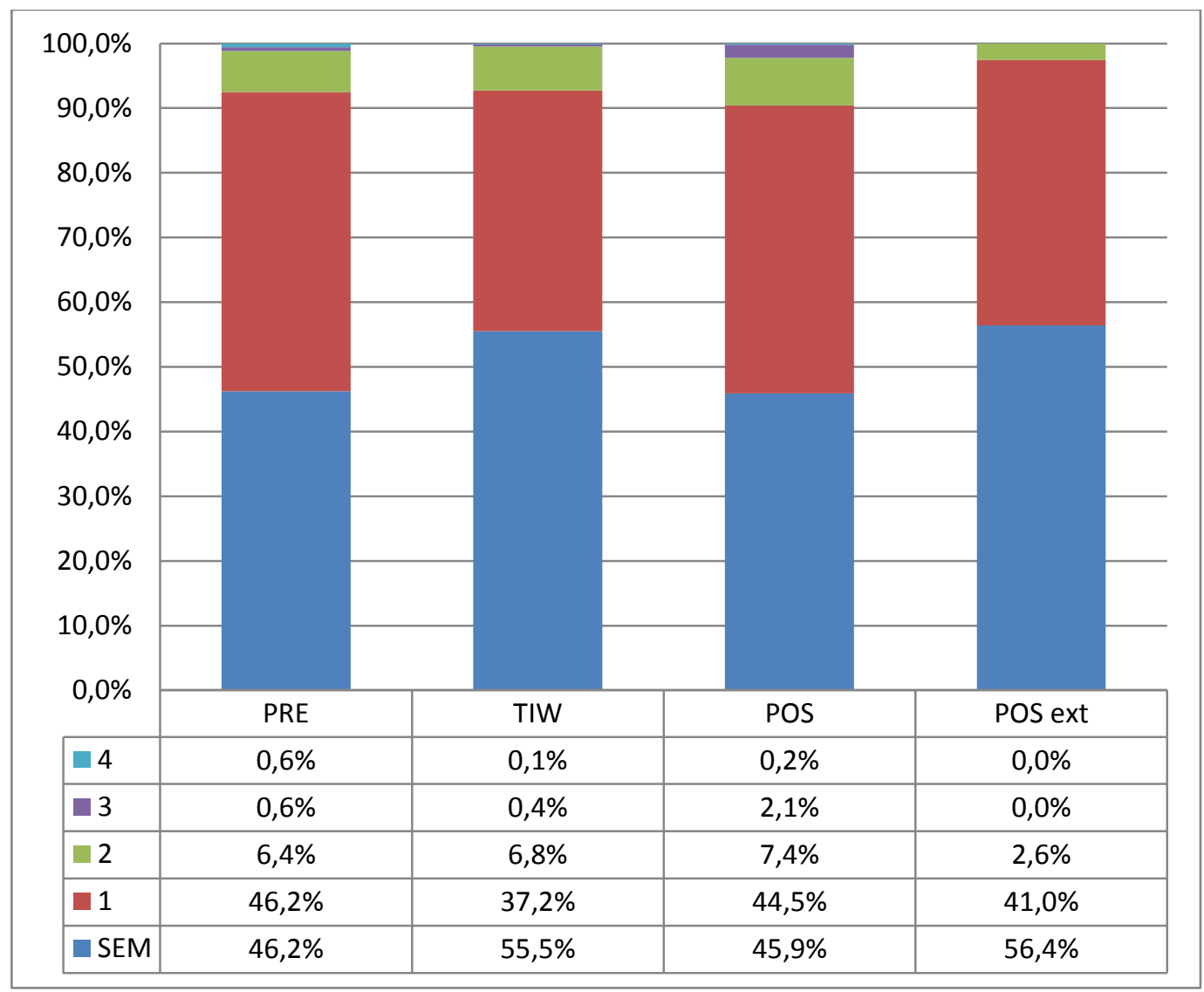

Figura 57 - Prevalências dos dentes acometidos por cárie e o número de lesões por dente.

Os dentes que apresentaram pelo menos 1 lesão de cárie dentária foram a maioria da amostra analisada dos períodos Pré e Pós Tiwanaku, representando 53,8\% e $54,1 \%$ respectivamente. Sendo que $83,8 \%$ de todos os dentes cariados apresentaram apenas uma lesão de cárie dentária, independente da extensão da lesão, optei por analisar dicotomicamente os dados, considerando apenas os dentes como acometidos ou livres de cárie dentária (Figura 58). 


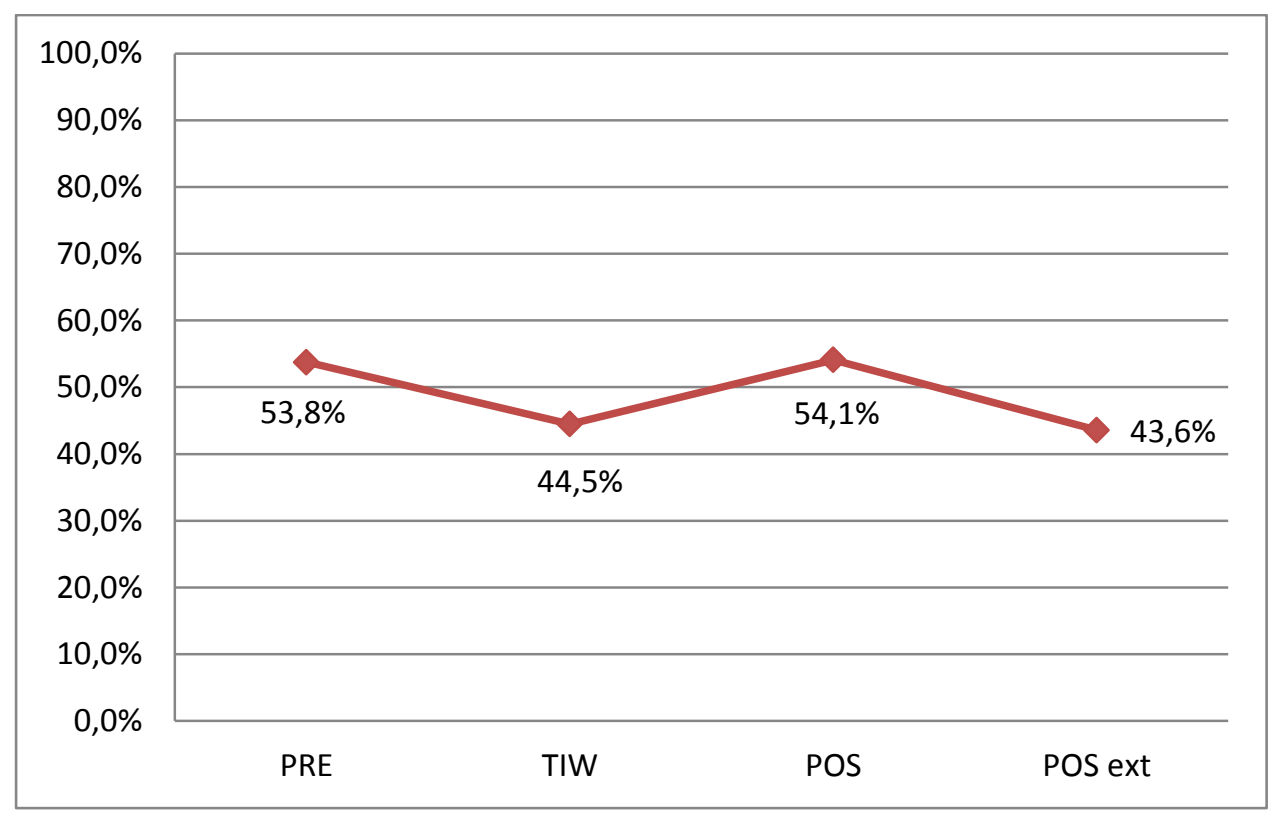

Figura 58 - Prevalência de dentes acometidos por cárie dentária.

Distribuídos desta forma, a prevalência de dentes cariados encontrada nos 146 indivíduos presentes no período Tiwanaku apresenta um valor menor quando comparado aos observados nos 94 indivíduos do período Pré Tiwanaku e também nos 131 indivíduos do período Pós Tiwanaku. Somente Caspana, com seus 43,6\%, apresenta valor menor que o período Tiwanaku.

As diferenças encontradas entre estes períodos, tanto entre Pré Tiwanaku e Tiwanaku como entre Tiwanaku e o período subsequente, são estatisticamente significativas, mostrando uma queda importante na prevalência de cárie dentária na população atacamenha durante o período de influencia Tiwanaku na região (Tabela 26). 
Tabela 26 - Valor estatístico e valor-p (corrigidos) encontrados nos testes Chi Quadrado das lesões de cárie dentária.

\begin{tabular}{cccc}
\hline & PRE & TIW & POS \\
\hline PRE & $\mathrm{X}$ & & \\
TIW & $\mathbf{4 , 6 2 3 2 ( 0 , 0 3 1 5 )}$ & $\mathrm{X}$ & $\mathrm{X}$ \\
POS & $0,0000(0,9959)$ & $\mathbf{1 2 , 4 9 5 1 ( 0 , 0 0 0 4 )}$ & $2,6485(0,1037)$ \\
POS ext & $1,8352(0,1755)$ & $0,0009(0,9754)$ & \\
\hline
\end{tabular}

sig. $\mathrm{p}<0,05$

Quando comparamos os períodos analisados de San Pedro com o sítio Caspana quanto à prevalência de cárie dentária encontrada, não encontramos significância entre qualquer período e aquele sítio. Isto se deve provavelmente ao pequeno número de indivíduos analisados (31 indivíduos) para este sítio externo à bacia do salar, mas, sobre tudo, ao pequeno número de dentes presentes nestes já escassos exemplares (78 dentes presentes no total).

Além da análise da quantidade de cáries encontradas em cada elemento dental, a extensão de comprometimento do dente por lesão cariosa também foi objeto de estudo, como é apresentado no gráfico da Figura 59. 


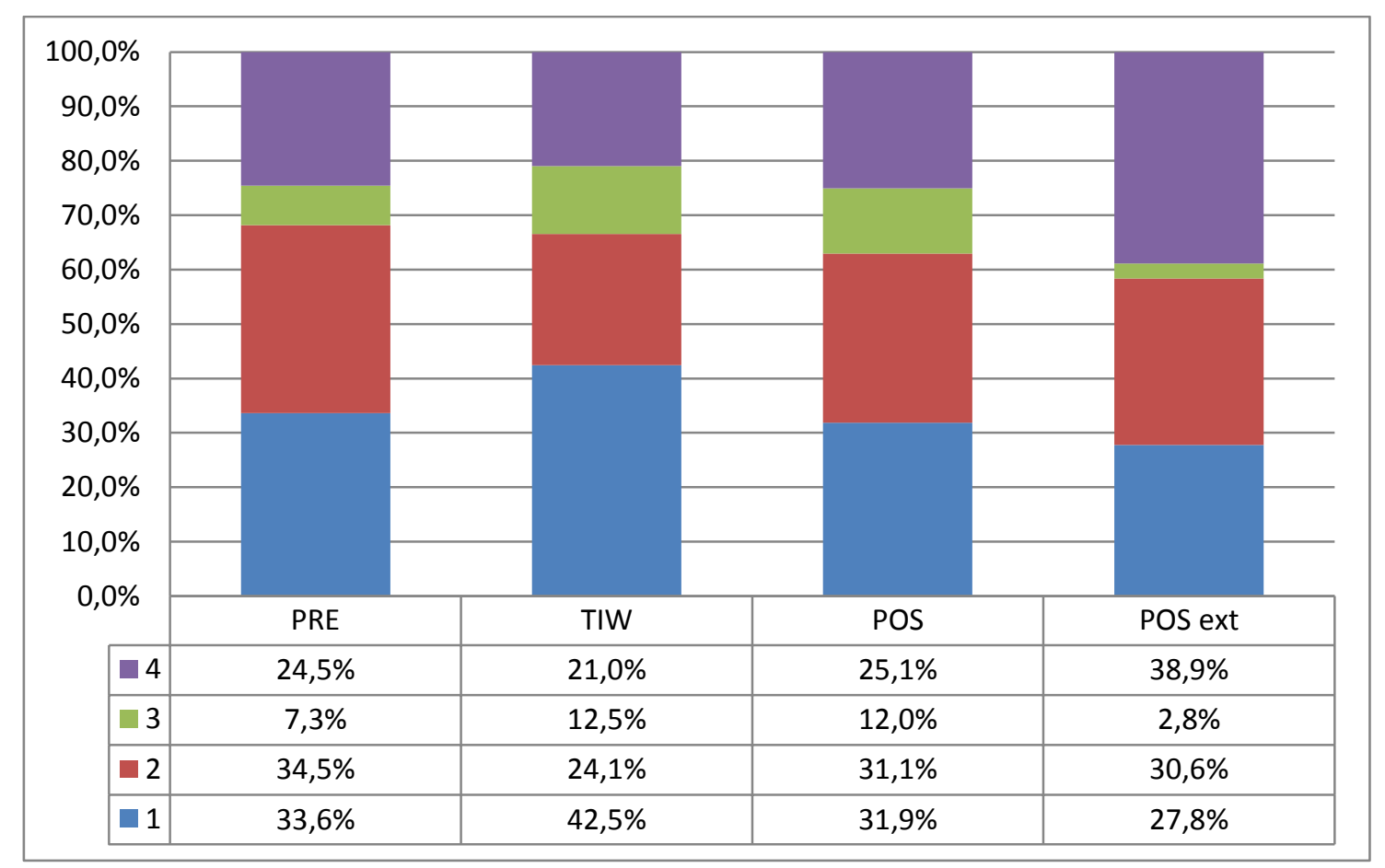

Figura 59 - Extensão do comprometimento do dente por cárie dentária.

As cáries grau 4 do gráfico, representantes das lesões onde há destruição total da coroa dentária, são apresentadas na Figura 60 indicando uma diminuição da frequência destas leões durante o período Tiwanaku.

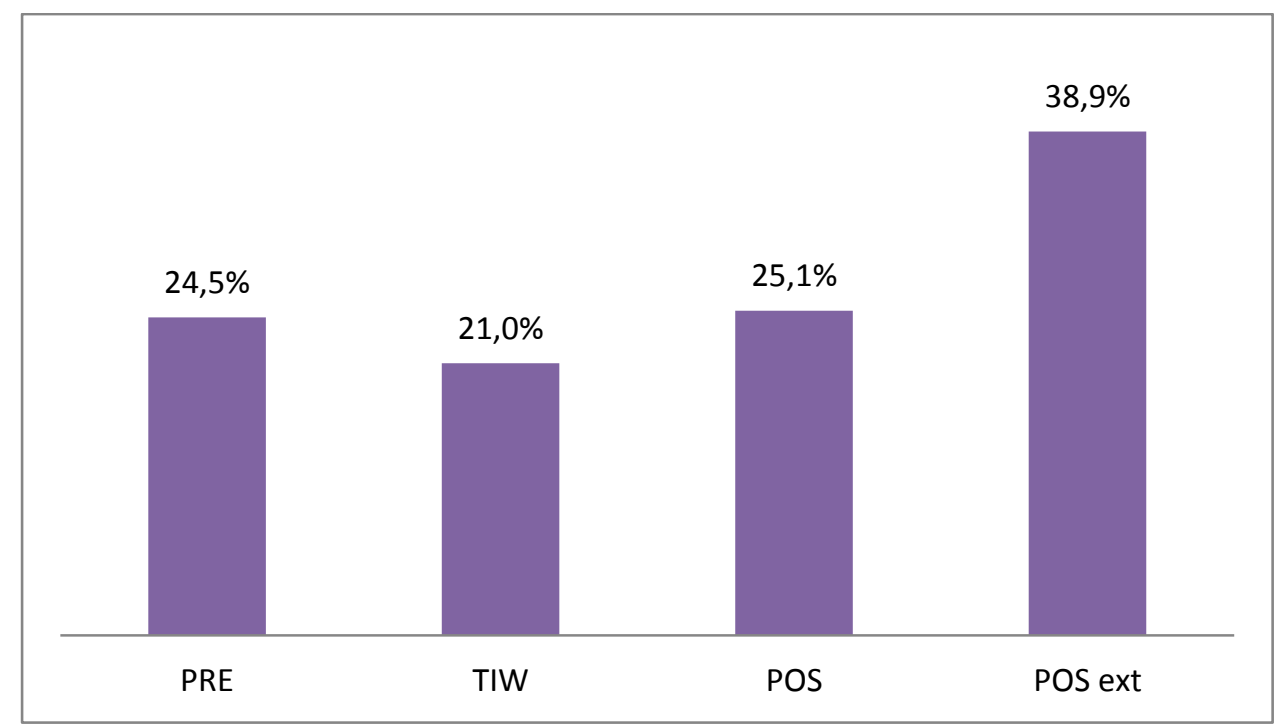

Figura 60 - Prevalência de cárie com destruição total da coroa dentária. 
As diferenças encontradas entre as prevalências de cada período não se mostraram significativas, conforme o teste estatístico aplicado, mesmo quando comparamos os períodos sanpedrinos com o sítio Caspana, com exceção encontrada entre o período Tiwanaku e Caspana (Tabela 27).

Tabela 27 - Valor estatístico e valor-p (corrigidos) encontrados nos testes Chi Quadrado das lesões extremas de cárie dentária, onde há destruição total da coroa do dente.

\begin{tabular}{cccc}
\hline & PRE & TIW & POS \\
\hline PRE & $X$ & & \\
TIW & $0,4619(0,4967)$ & $X$ & $X$ \\
POS & $0,0002(0,9889)$ & $1,7233(0,1893)$ & $X$ \\
POS ext & $2,0984(0,1475)$ & $\mathbf{5 , 1 6 7 9}(\mathbf{0 , 0 2 3 0})$ & $2,5732(0,1087)$ \\
\hline
\end{tabular}

sig. $\mathrm{p}<0,05$

Já as lesões de cárie superficiais, atingindo apenas o esmalte dentário, indicam o oposto do encontrado para as lesões extremas, apresentando um aumento das lesões grau 1 durante o período Tiwanaku (Figura 61).

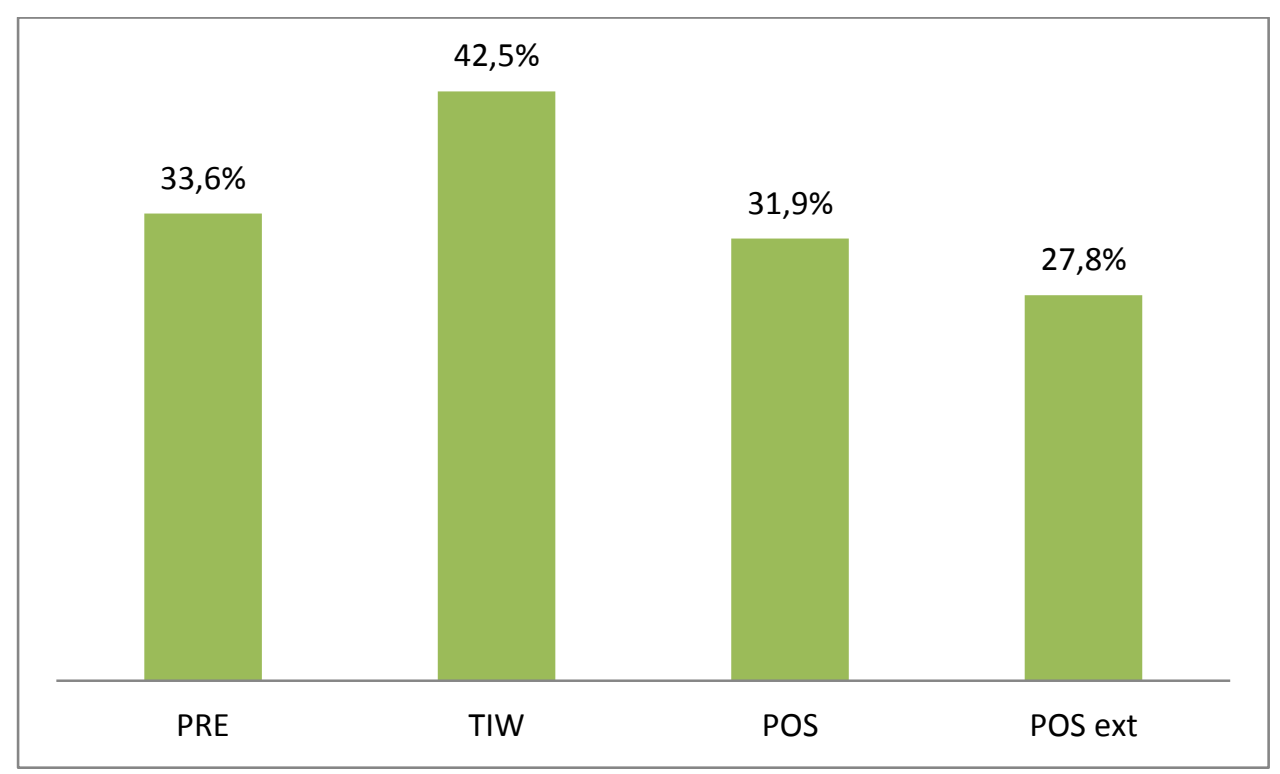

Figura 61 - valores das prevalências de cáries dentárias superficiais (grau 1). 
Apesar do aumento observado entre os períodos Pré Tiwanaku e Tiwanaku não ser considerado significativo, encontramos significância entre o período Tiwanaku e o período seguinte, no qual uma queda na prevalência de cárie superficial (quando há o comprometimento apenas do esmalte dentário) foi observada (Tabela 28).

\begin{tabular}{|c|c|c|c|}
\hline \multicolumn{4}{|c|}{ superficiais de cárie dentária. } \\
\hline & PRE & TIW & POS \\
\hline PRE & $\mathrm{x}$ & & \\
\hline TIW & $2,4997(0,1139)$ & $x$ & \\
\hline POS & $0,0561(0,8128)$ & $9,5246(0,0020)$ & $x$ \\
\hline POS ext & $0,2003(0,6545)$ & $2,3879(0,1223)$ & $0,0997(0,7522)$ \\
\hline
\end{tabular}

sig. $p<0,05$

Também como forma de facilitar a comparação entre os grupos, as 4 categorias de extensão das lesões cariosas foram divididas em dois grupos, classificados como cáries leves e cáries intensas (Figura 62).

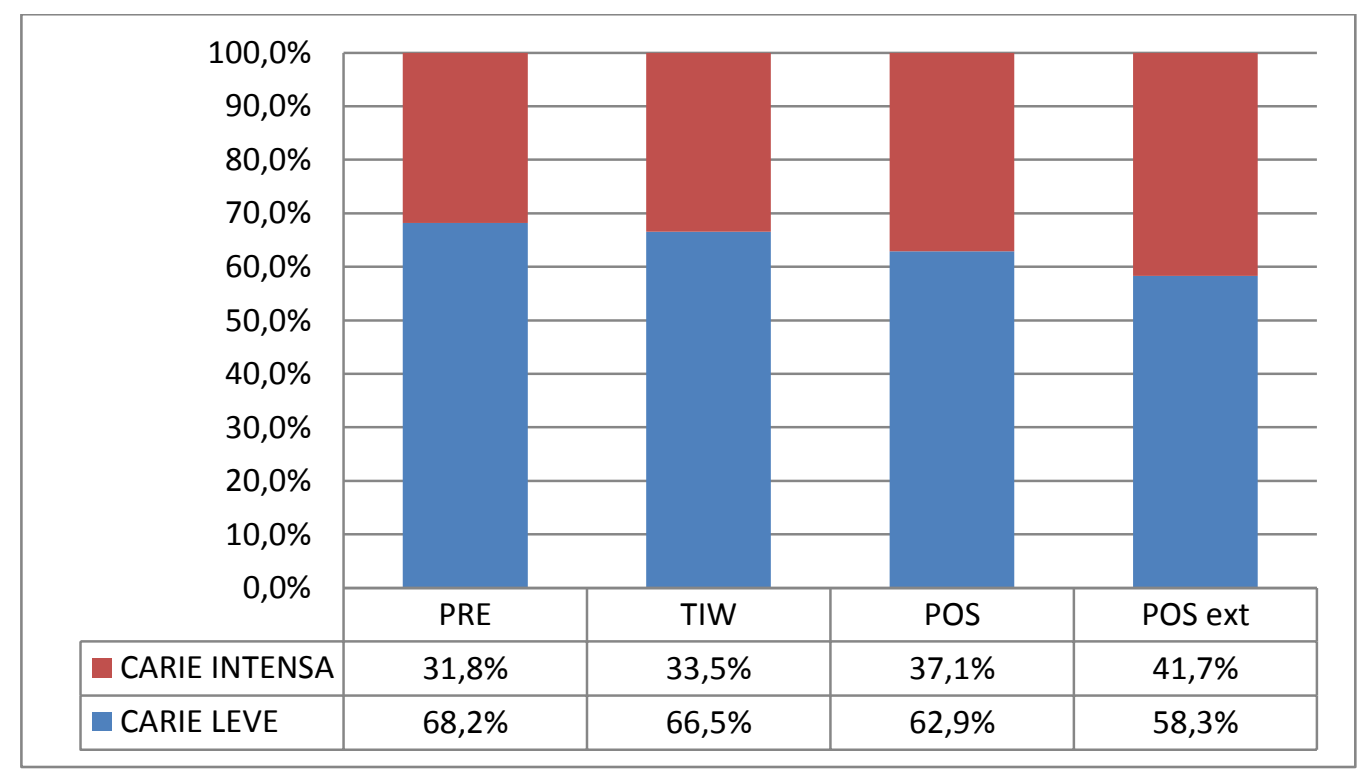

Figura 62 - Distribuição da intensidade das lesões de cárie dentária. 
As diferenças das intensidades de cárie observadas entre os períodos não se mostraram significativas estatisticamente em nenhum caso, como podemos observar na Tabela 29.

Tabela 29 - Valor estatístico e valor-p (corrigidos) encontrados nos testes Chi Quadrado das
cárie dentária.
\begin{tabular}{cccc} 
PRE & TIW & POS \\
\hline PRE & X & & \\
TIW & $0,0481(0,8263)$ & X & X \\
POS & $0,8107(0,3679)$ & $1,0303(0,3101)$ & $0,1325(0,7159)$ \\
POS ext & $0,7719(0,3796)$ & $0,6647(0,4149)$ & 0, \\
\hline
\end{tabular}

sig. $p<0,05$

Uma vez separados em dentes com ou sem a presença de cárie dentária, foi realizada a comparação entre indivíduos do sexo masculino e do sexo feminino, buscando averiguar se minha amostra manteria uma das premissas já descritas neste trabalho de que as mulheres apresentam um número de cárie dentária superior ao dos indivíduos do sexo masculino (Lukacs \& Largaespada, 2006).

Quando se observa as prevalências de cárie dentária encontradas em homens e mulheres desta amostra, a premissa acima é mantida (Figura 63). 


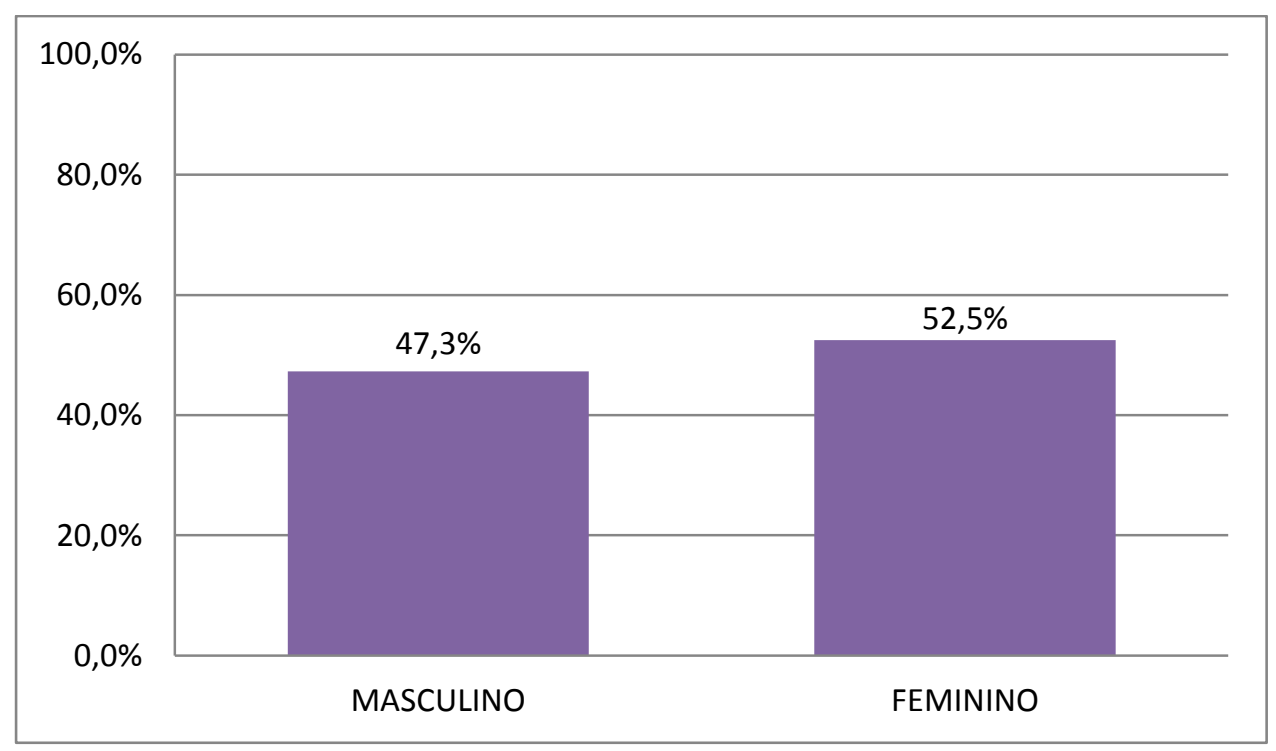

Figura 63 - Prevalências de dentes cariados nos indivíduos divididos pelo sexo.

Também quando analisamos estas prevalências com teste estatístico, a diferença observada no gráfico da Figura 62 se mantem, sendo as prevalências significativamente distintas $\left(X^{2}=3,4905 / p=0,0466\right)$.

As prevalências de cárie dentária apresentadas por cada sexo, ao longo do tempo, também foram analisadas separadamente (Figura 64).

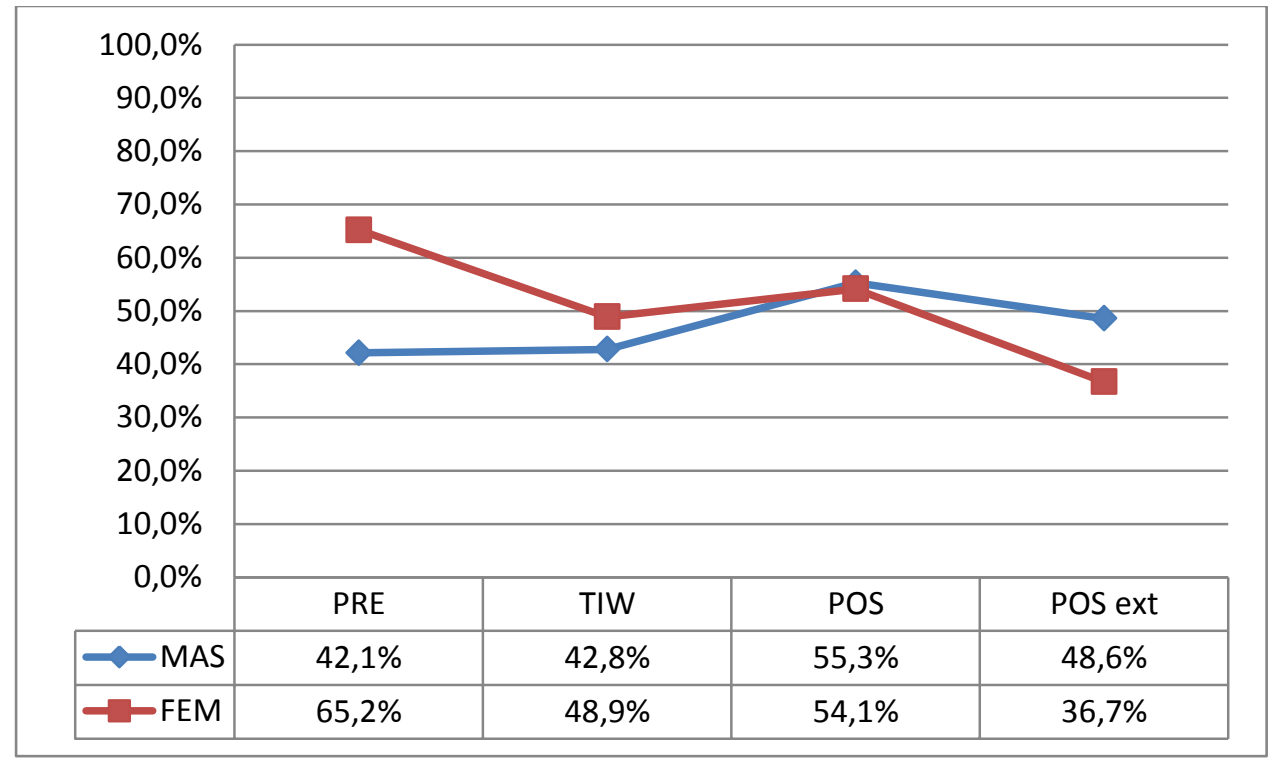

Figura 64 - Prevalências de dentes cariados nos indivíduos divididos pelo sexo, ao longo dos períodos. 
Apesar de haver diferença estatisticamente significativa entre a prevalência de cárie dentária entre homens e mulheres quando comparamos estes dois grupos sem distinção do período, ao observarmos a Figura 63 encontramos períodos onde homens e mulheres apresentam valores muito próximos. Por isso, foram aplicados testes estatísticos em cada período, buscando significância entre os sexos (Tabela 30).

Tabela 30 - Valor estatístico e valor-p (corrigidos) encontrados nos testes Chi Quadrado aplicados sobre a diferença das lesões de cárie dentária apresentadas por ambos os sexos ao longo dos períodos.

$\mathrm{x}^{2} \quad \mathrm{p}$

$\begin{array}{lcc}\text { Pré Tiwanaku } & \mathbf{8 , 0 6 5 4} & \mathbf{0 , 0 0 4 5} \\ \text { Tiwanaku } & 2,5939 & 0,1073 \\ \text { Pós Tiwanaku } & 0,0282 & 0,8665 \\ \text { Tiwanaku externo } & 0,5113 & 0,4546\end{array}$

sig. $p<0,05$

Dentre os períodos, o único que apresenta diferença significativa entre a prevalência de carie dentária em homens e mulheres é o período Pré Tiwanaku. A diferença de $11 \%$ encontrada nas prevalências de cáries dentárias entre homens e mulheres do sítio Caspana não se mostrou significativa provavelmente devido ao pequeno número de indivíduos avaliados.

A exclusão dos esqueletos diagnosticados com idade de morte inferior a 25 anos alterou a distribuição das prevalências de cárie dentária (Figura 65). 


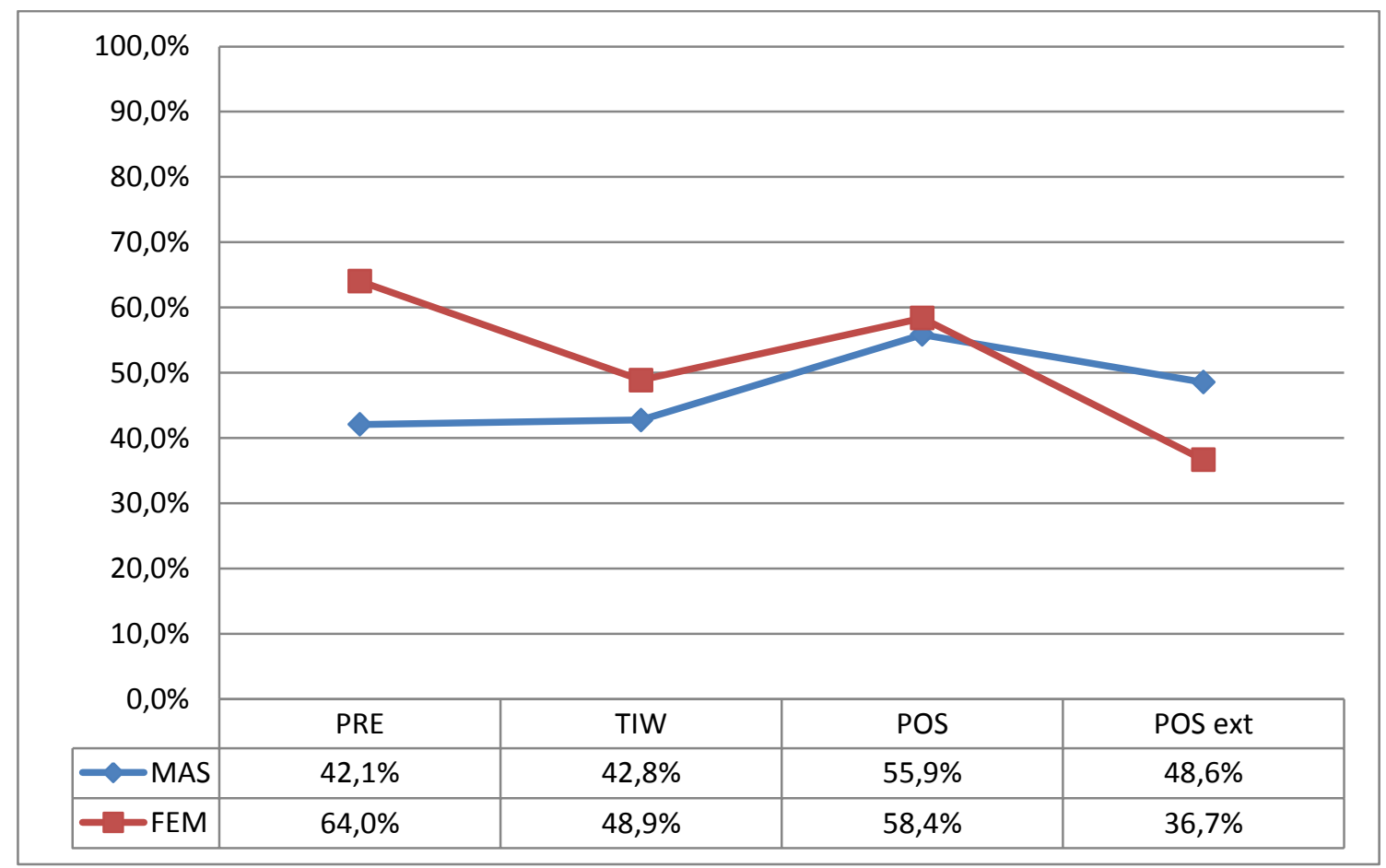

Figura 65 - Prevalências de dentes cariados nos indivíduos com idade de morte superior a 25 anos e divididos pelo sexo ao longo dos períodos.

Apesar da redistribuição dos grupos após excluirmos os indivíduos mais jovens, a diferença entre os sexos ao longo dos períodos se manteve estável, sendo apenas significativa a diferença encontrada entre homens e mulheres durante o período Pré Tiwanaku (Tabela 31).

Tabela 31 - Valor estatístico e valor-p (corrigidos) encontrados nos testes Chi Quadrado aplicados sobre a diferença das lesões de cárie dentária apresentadas por ambos os sexos ao longo dos períodos em indivíduos com mais de 25 anos de idade.

\begin{tabular}{ccc}
\hline & $\mathbf{X}^{\mathbf{2}}$ & $\mathbf{p}$ \\
\hline Pré Tiwanaku & $\mathbf{7 , 0 8 3 7}$ & $\mathbf{0 , 0 0 7 8}$ \\
Tiwanaku & 2,5939 & 0,1073 \\
Pós Tiwanaku & 0,2031 & 0,6522 \\
Pós Tiwanaku externo & 0,5113 & 0,4546
\end{tabular}

sig. $p<0,05$ 
A evolução da cárie dentária observada nos indivíduos do sexo masculino e do sexo feminino foi analisada separadamente, testando a significância de suas variações (Tabela 32; Tabela 33).

Tabela 32 - Valor estatístico e valor-p (corrigidos) encontrados nos testes Chi Quadrado aplicados sobre a diferença das lesões de cárie dentária apresentadas por indivíduos do sexo masculino com mais de 25 anos.

\begin{tabular}{cccc}
\hline & PRE & TIW & POS \\
\hline PRE & $X$ & & \\
TIW & $0,0003(0,9869)$ & $X$ & \\
POS & $\mathbf{4 , 0 6 2 9 ( 0 , 0 4 3 8 )}$ & $\mathbf{1 2 , 0 9 3 7 ( 0 , 0 0 0 5 )}$ & $X$ \\
POS ext & $0,1864(0,6659)$ & $0,2424(0,6225)$ & $0,4094(0,5223)$ \\
\hline
\end{tabular}

sig. $\mathrm{p}<0,05$

Tabela 33 - Valor estatístico e valor-p (corrigidos) encontrados nos testes Chi Quadrado aplicados sobre a diferença das lesões de cárie dentária apresentadas por indivíduos do sexo feminino com mais de 25 anos.

\begin{tabular}{cccc}
\hline & PRE & TIW & POS \\
\hline PRE & $X$ & & \\
TIW & $\mathbf{5 , 7 8 9 4 ( 0 , 0 1 6 1 )}$ & $X$ & $X$ \\
POS & $0,5863(0,4439)$ & $3,8283(0,0504)$ & $X$ \\
POS ext & $\mathbf{5 , 7 9 4 9 ( 0 , 0 1 6 1 )}$ & $1,1816(0,2770)$ & $\mathbf{4 , 0 8 4 5 ( 0 , 0 4 3 3 )}$ \\
\hline
\end{tabular}

sig. $p<0,05$

Enquanto para o sexo masculino o aumento na prevalência observado no período Pós Tiwanaku, em relação ao período anterior, se mostrou significativo, para as mulheres, a queda na prevalência de cárie dentária observada no período Tiwanaku é que foi significativa. Há também uma diferença significativa entre a prevalência de cárie dentária durante o período Pós Tiwanaku, entre as mulheres, quando comparamos os sítios dos oásis com o sítio Caspana. 
A diferença encontrada entre a prevalência de cárie dentária nos dentes anteriores e posteriores foi avaliada. Conforme o esperado, os dentes anteriores apresentaram em todos os períodos avaliados uma prevalência de cárie dentária inferior à encontrada para os dentes posteriores (Figura 66).
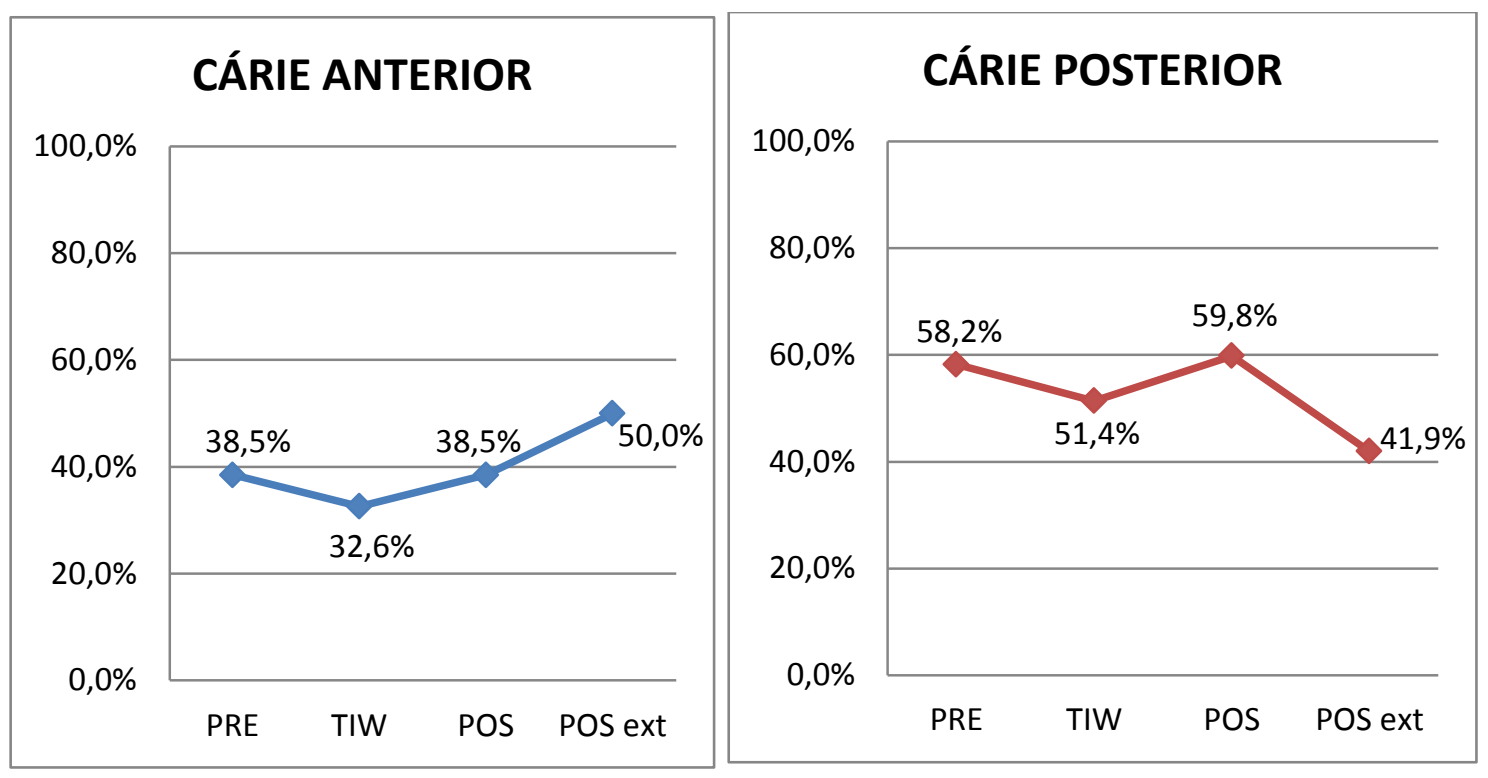

Figura 66 - Prevalência de cárie dentária presente nos dentes anteriores e posteriores.

A análise estatística das prevalências de cárie encontradas nos dentes anteriores dos indivíduos analisados mostrou não haver diferença significativa entre nenhum período estudado (Tabela 34). Quando comparamos os períodos dos oásis do salar com o sítio Caspana, tampouco encontramos significância entre as prevalências observadas nos períodos Pré Tiwanaku, Tiwanaku e Pós Tiwanaku com a apresentada por Caspana (50\%) para os dentes anteriores. 
Tabela 34 - Valor estatístico e valor-p (corrigidos) encontrados nos testes Chi Quadrado das lesões de cárie dentária em dentes anteriores.

\begin{tabular}{cccc}
\hline & PRE & TIW & POS \\
\hline PRE & $X$ & & \\
TIW & $0,3070(0,5796)$ & $X$ & $X$ \\
POS & $0,0000(1,0000)$ & $1,3394(0,2471)$ & X \\
POS ext & $0,2371(0,6263)$ & $1,3650(0,2427)$ & $0,3976(0,5283)$ \\
\hline
\end{tabular}

sig. $p<0,05$

Para os dentes posteriores, quando comparamos os períodos de San Pedro, apenas o aumento observado entre os períodos Tiwanaku e Pós Tiwanaku foi estatisticamente significativo (Tabela 35). Quando comparamos estes períodos com nossa amostra externa, apenas o período Tiwanaku não se distingue significativamente da prevalência observada em Caspana $\left(x^{2}=1,6298 / p=0,2017\right)$.

Tabela 35 - Valor estatístico e valor-p (corrigidos) encontrados nos testes Chi Quadrado das lesões de cárie dentária em dentes posteriores.

\begin{tabular}{cccc}
\hline & PRE & TIW & POS \\
\hline PRE & $\mathrm{X}$ & & \\
TIW & $1,7328(0,1881)$ & $\mathrm{X}$ & \\
POS & $0,0525(0,8187)$ & $\mathbf{6 , 4 8 4 3 ( 0 , 0 1 0 9 )}$ & $\mathrm{X}$ \\
POS ext & $\mathbf{3 , 8 7 7 3 ( 0 , 0 4 8 9 )}$ & $\mathbf{1 , 6 2 9 8 ( 0 , 2 0 1 7 )}$ & $\mathbf{6 , 3 7 2 1 ( 0 , 0 1 1 6 )}$ \\
\hline
\end{tabular}

sig. $p<0,05$

A possibilidade de encontrarmos um viés na amostra devido ao pequeno número de indivíduos jovens (abaixo de 25 anos) sugeriu o estudo das cáries dentárias, patologia fortemente influenciada pela idade do indivíduo acometido, excluindo-os (Figura 67). 


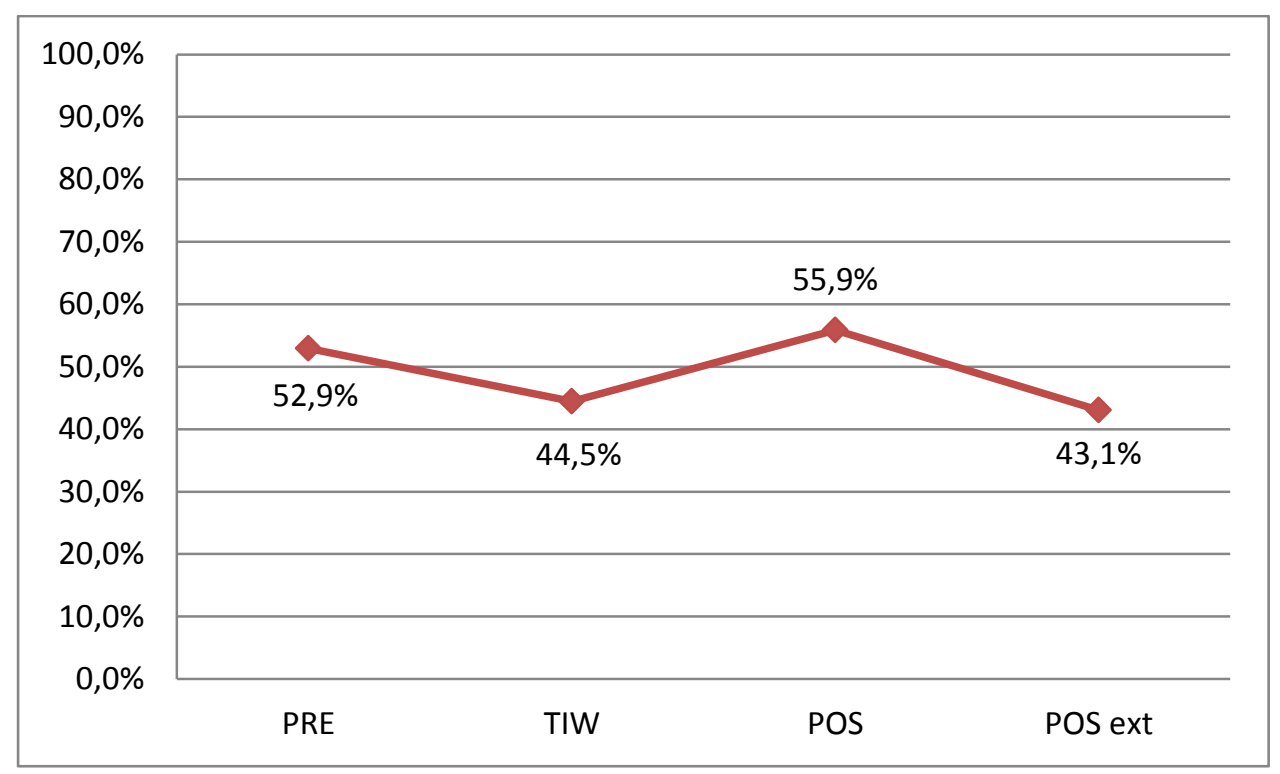

Figura 67 - Prevalência de cárie dentária em indivíduos com mais de 25 anos encontrada nos períodos estudados.

Caspana apresentou, após a exclusão dos indivíduos com idade de morte menor de 25 anos, 43,1\% de cárie dentária. Não influenciado pela presença de jovens na amostra, o período Tiwanaku manteve seus $44,5 \%$ de cárie dentária enquanto no período Pós Tiwanaku observa-se um aumento das prevalências de cárie dentária, como esperado. Apesar das variações mencionadas, a diferença significativa entre os períodos Tiwanaku e Pós Tiwanaku se manteve (Tabela 36).

Tabela 36 - Valor estatístico e valor-p (corrigidos) encontrados nos testes Chi Quadrado das lesões de cárie dentária em dentes de indivíduos com idade de morte superior a 25 anos.

\begin{tabular}{cccc}
\hline & PRE & TIW & POS \\
\hline PRE & $X$ & & \\
TIW & $3,7596(0,0525)$ & $X$ & $X$ \\
POS & $0,3416(0,5589)$ & $\mathbf{1 6 , 6 7 4 8 ( 0 , 0 0 0 0 )}$ & X \\
POS ext & $0,0114(0,9148)$ & $0,0078(0,9295)$ & $3,3367(0,0678)$
\end{tabular}

sig. $p<0,05$ 
A divisão entre anteriores e posteriores também foi aplicada após a exclusão dos indivíduos menores de 25 anos, sendo apresentadas e testadas separadamente.

Os dentes anteriores apresentaram pouca variação entre a amostra com indivíduos mais jovens e sem estes (Figura 68).
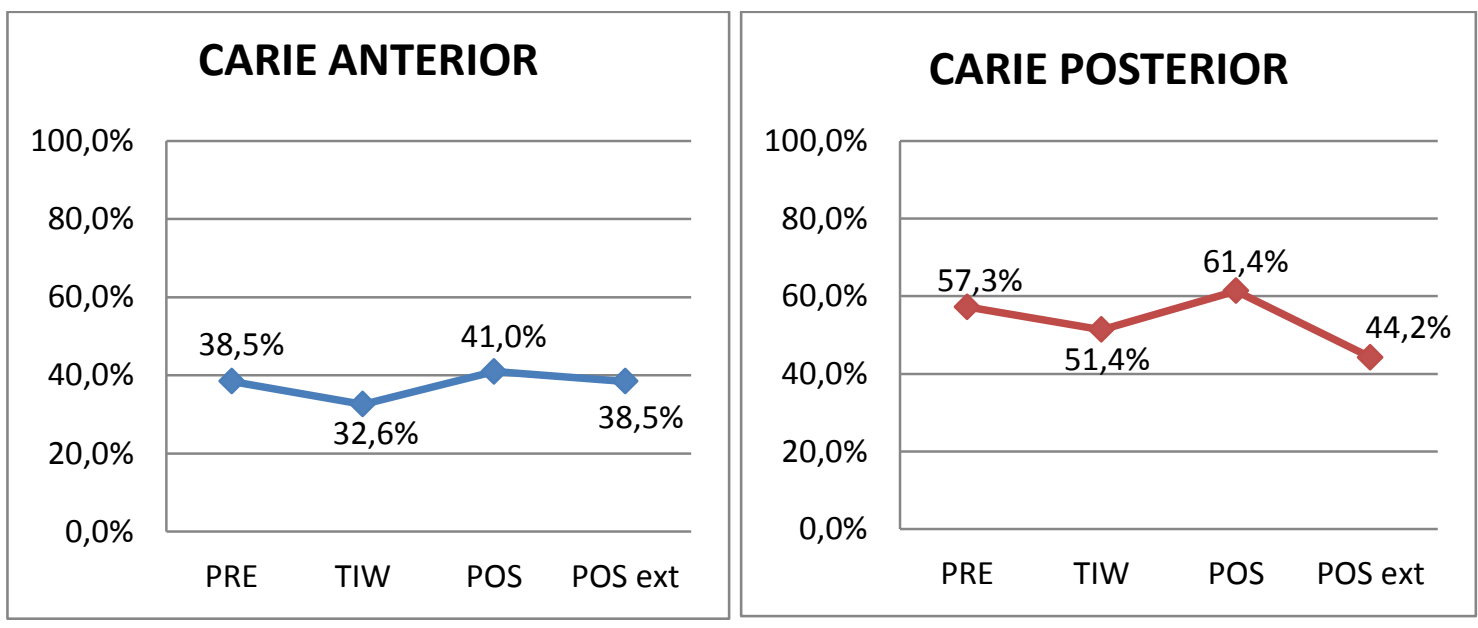

Figura 68 - Prevalência de cárie dentária em dentes anteriores e posteriores de indivíduos com mais de 25 anos de idade.

As diferenças encontradas entre os períodos, assim como na amostra contendo os indivíduos com menos de 25 anos, não apresentou diferenças significativas entre os períodos analisados (Tabela 37).

Tabela 37 - Valor estatístico e valor-p (corrigidos) encontrados nos testes Chi Quadrado das lesões de cárie dentária em dentes anteriores de indivíduos com idade de morte superior a 25 anos.

\begin{tabular}{cccc}
\hline & PRE & TIW & POS \\
\hline PRE & $X$ & & \\
TIW & $0,3070(0,5796)$ & $X$ & $X$ \\
POS & $0,0099(0,9207)$ & $2,6821(0,1015)$ & $X$ \\
POS ext & $0,0000(1,0000)$ & $0,0197(0,8882)$ & $0,0140(0,9059)$ \\
\hline
\end{tabular}

sig. $p<0,05$ 
Também na análise com a amostra na qual os indivíduos com menos de 25 anos foram excluídos, a diferença entre a prevalência de cárie presente nos dentes posteriores durante o período Tiwanaku e o período Pós Tiwanaku é significativa (Tabela 38). O valor de cárie em dentes posteriores encontrado para o sítio Caspana se mostrou diferente apenas do período Pós Tiwanaku.

Tabela 38 - Valor estatístico e valor-p (corrigidos) encontrados nos testes Chi Quadrado das lesões de cárie dentária em dentes posteriores de indivíduos com idade de morte superior a 25 anos.

\begin{tabular}{cccc}
\hline & PRE & TIW & POS \\
\hline PRE & X & & \\
TIW & $1,2226(0,2688)$ & $X$ & $X$ \\
POS & $0,5372(0,4636)$ & $\mathbf{8 , 7 3 6 9 ( 0 , 0 0 3 1 )}$ & $X$ \\
POS ext & $2,0409(0,1531)$ & $0,7084(0,4000)$ & $\mathbf{4 , 9 0 7 9}(\mathbf{0 , 0 2 6 7 )}$ \\
\hline
\end{tabular}

sig. $p<0,05$

As prevalências de cárie dentária também foram avaliadas relacionando-as como a presença ou não de deformações cranianas (Figura 69).

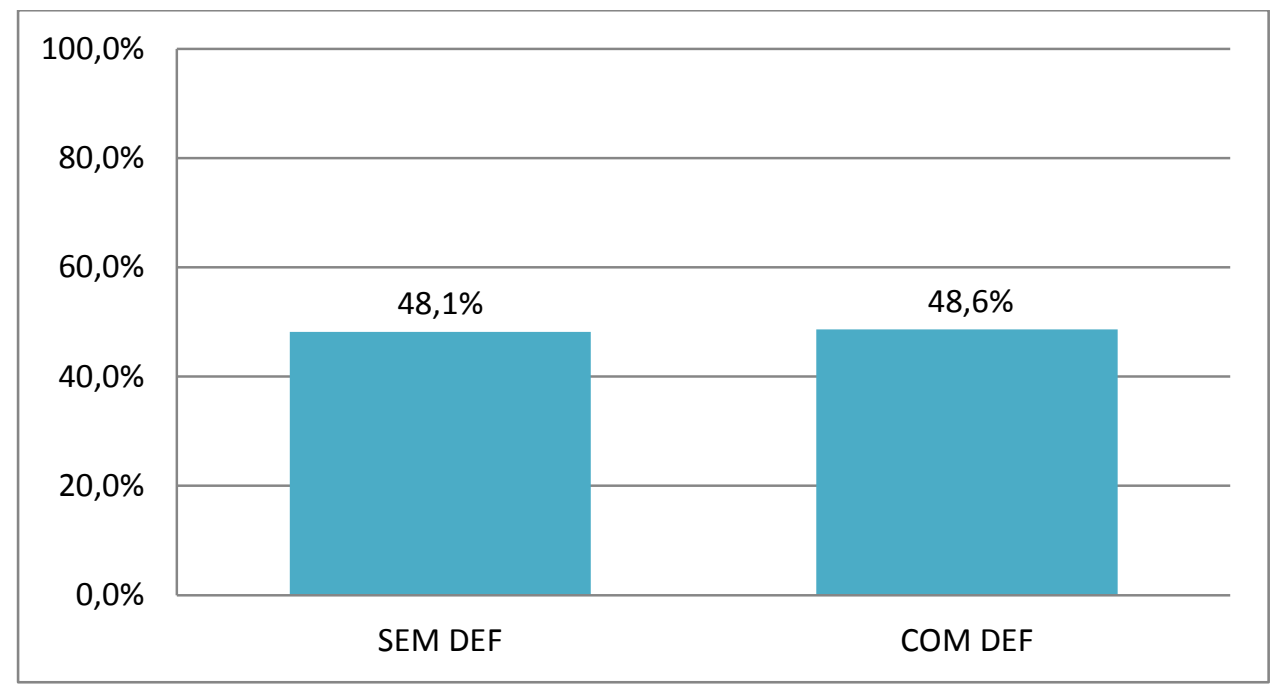

Figura 69 - Prevalências de dentes cariados em indivíduos que apresentaram ou não deformações cranianas intencionais. 
A proximidade observada entre as prevalências também foi confirmada através de teste estatístico, provando não haver diferença significativa entre indivíduos com deformação craniana ou sem deformação, quando analisamos todos os dentes cariados dos indivíduos da amostra $\left(X^{2}=0,0219 / p=0,8825\right)$.

Apesar da não significância encontrada entre os indivíduos que apresentavam deformações cranianas e os que não apresentavam, quando analisamos os dentes cariados da amostra como um todo, foi decidido averiguar se haveria variação entre estes indivíduos ao longo dos períodos (Figura 70).

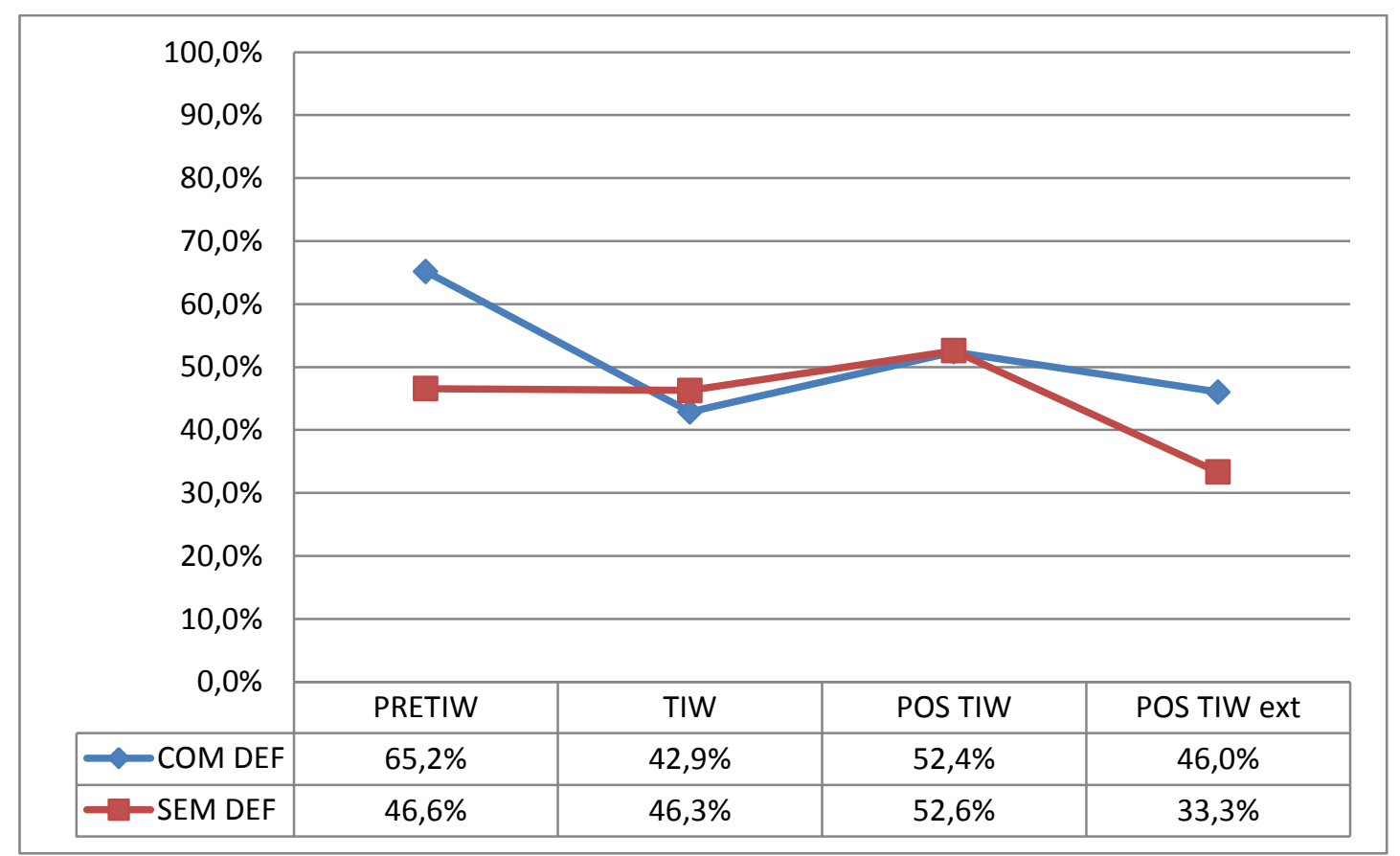

Figura 70 - Prevalência de dentes cariados entre indivíduos com ou sem deformação craniana intencional.

Quando segmentamos o gráfico, analisando as variações encontradas dentro de cada período, apenas o período Pré Tiwanaku apresenta diferença significativa entre as prevalências de dentes cariados nos indivíduos com deformação craniana e nos indivíduos sem deformação craniana (Tabela 39). 
Tabela 39 - Valor estatístico e valor-p (corrigidos) encontrados nos testes Chi Quadrado aplicados sobre a diferença das lesões de cárie dentária apresentadas por indivíduos com ou sem deformação craniana ao longo dos períodos.

\begin{tabular}{ccc}
\hline & $\mathbf{X}^{\mathbf{2}}$ & $\mathbf{p}$ \\
\hline Pré Tiwanaku & $\mathbf{4 , 1 1 8 1}$ & $\mathbf{0 , 0 4 2 4}$ \\
Tiwanaku & 0,8216 & 0,3647 \\
Pós Tiwanaku & 0,0016 & 0,9680 \\
Pós Tiwanaku externo & 0,4753 & 0,4906 \\
\hline
\end{tabular}

sig. $\mathrm{p}<0,05$

Outra forma de segmentar o mesmo gráfico foi separar as duas linhas e analisar a evolução da cárie dentária ao longo do tempo dentro de cada grupo, distinguindo a evolução da cárie nos indivíduos com crânios deformados da evolução da cárie nos indivíduos com crânios sem modificação.

Nos indivíduos com crânios deformados intencionalmente, a grande queda na prevalência de cárie dentária observada entre o período Pré Tiwanaku e o período Tiwanaku se mostrou significativa, assim como a ascensão desta prevalência encontrada entre o período Tiwanaku e Pós Tiwanaku (Tabela 40). Quando comparamos estes períodos com o sítio Caspana, apenas o período Pré Tiwanaku se distingue significativamente $\left(X^{2}=4,0340 / p=0,0446\right)$.

Tabela 40 - Valor estatístico e valor-p (corrigidos) encontrados nos testes Chi Quadrado das lesões de cárie dentária em indivíduos que apresentaram deformação craniana intencional.

\begin{tabular}{cccc}
\hline & PRE & TIW & POS \\
\hline PRE & X & & \\
TIW & $\mathbf{1 0 , 2 9 0 9 ( 0 , 0 0 1 3 )}$ & $X$ & $X$ \\
POS & $3,0817(0,0792)$ & $\mathbf{5 , 7 6 6 9 ( 0 , 0 1 6 3 )}$ & X \\
POS ext & $\mathbf{4 , 0 3 4 0 ( 0 , 0 4 4 6 )}$ & $0,1101(0,7400)$ & $0,6146(0,4330)$ \\
\hline
\end{tabular}

sig. $p<0,05$ 
Nos indivíduos sem crânios deformados, mesmo o aumento da prevalência de cárie encontrada entre o período Tiwanaku e o período Pós Tiwanaku, não apresentou diferença estatisticamente significativa (Tabela 41). O mesmo aconteceu quando foram comparados os três períodos com o sítio Caspana.

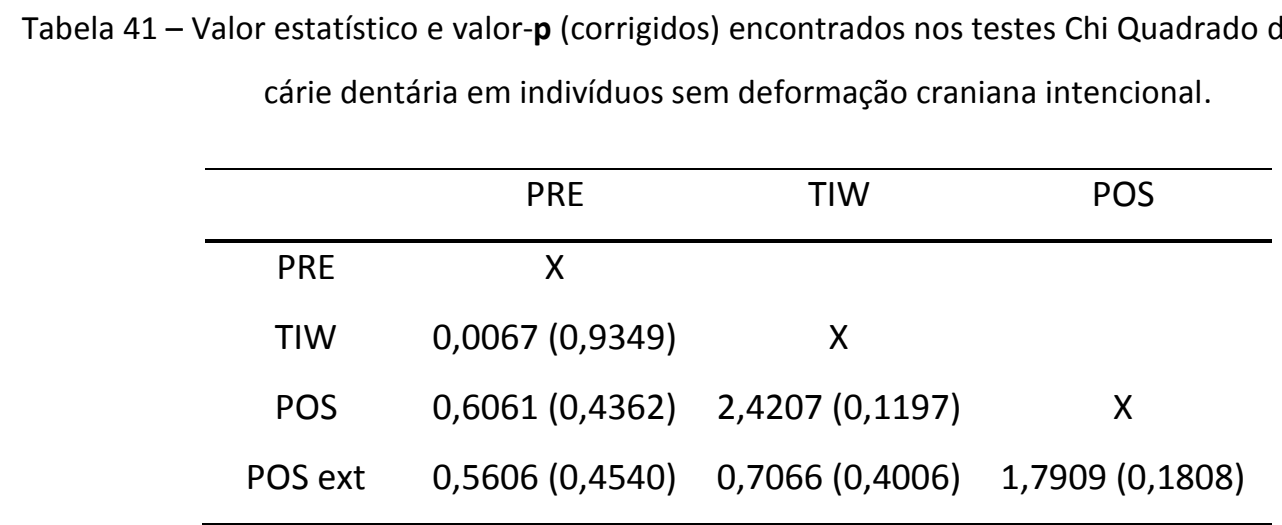

sig. $\mathrm{p}<0,05$

Visto que as prevalências de cárie dentária dos indivíduos com deformações cranianas eram significativamente diferentes entre os períodos estudados, separei os indivíduos deformados em indivíduos com deformações cranianas tabulares e indivíduos com deformações cranianas circulares, e os comparei com os indivíduos sem deformação craniana (Figura 71). 


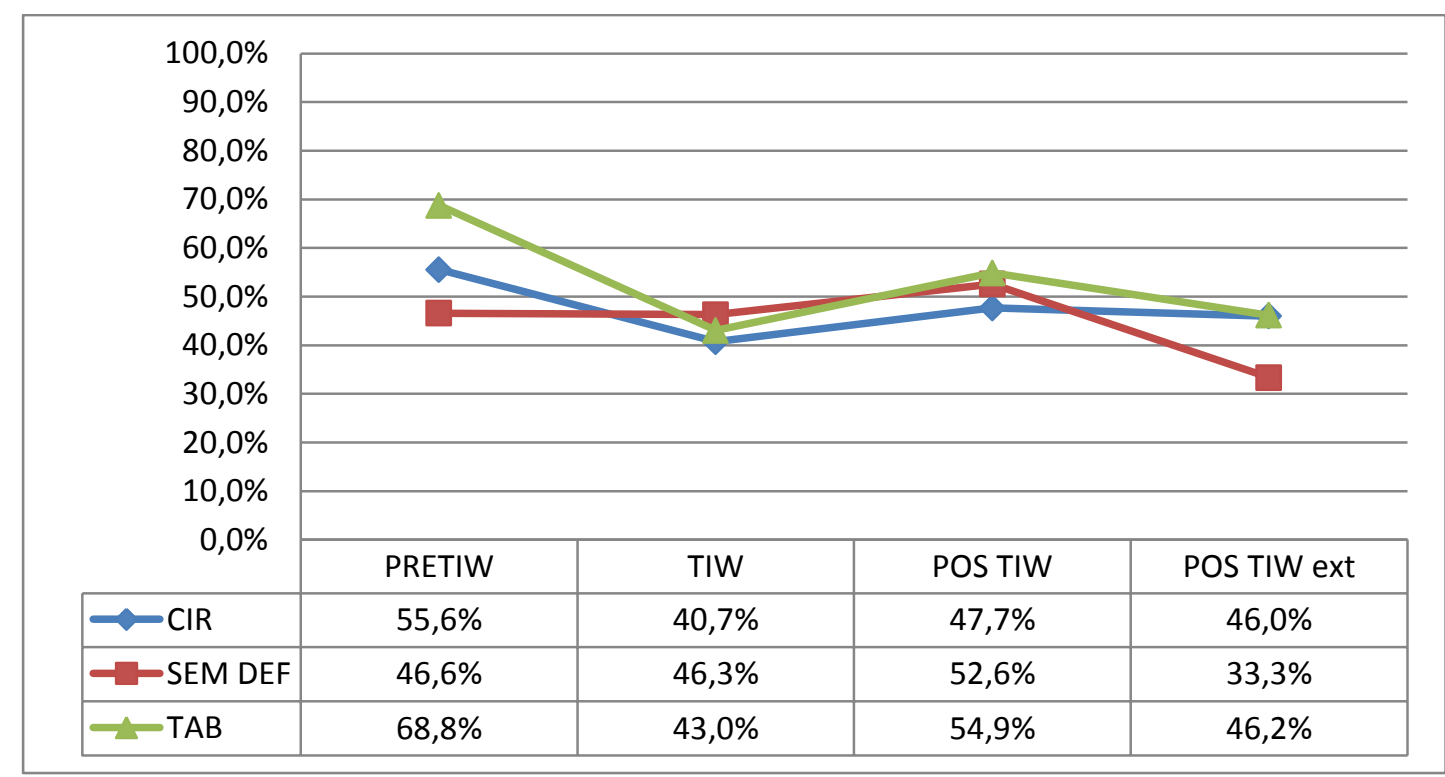

Figura 71 - Prevalência de dentes cariados entre indivíduos sem deformação craniana intencional (SEM DEF), com deformação craniana circular (CIR) e com deformação craniana tabular (TAB).

A prevalência de cárie dentária em cada tipo de deformação foi avaliada ao longo do tempo (Tabela 42; Tabela 43). Também foram comparados, dentro de cada período, os dois tipos de deformação craniana intencional e os indivíduos sem deformação craniana (Tabela 44; Tabela 45; Tabela 46; Tabela 47).

Tabela 42 - Valor estatístico e valor-p (corrigidos) encontrados nos testes Chi Quadrado das lesões de cárie dentária em indivíduos com deformação craniana intencional do tipo circular.

\begin{tabular}{cccc}
\hline & PRE & TIW & POS \\
\hline PRE & $X$ & & \\
TIW & $0,4501(0,5023)$ & $X$ & \\
POS & $0,1332(0,7152)$ & $0,1838(0,6681)$ & $X$ \\
POS EXT & $0,1769(0,6741)$ & $0,0412(0,8391)$ & $0,0005(0,9817)$
\end{tabular}

sig. $\mathrm{p}<0,05$ 
Tabela 43 - Valor estatístico e valor-p (corrigidos) encontrados nos testes Chi Quadrado das lesões de cárie dentária em indivíduos com deformação craniana intencional do tipo tabular.

\begin{tabular}{cccc}
\hline & PRE & TIW & POS \\
\hline PRE & $X$ & & \\
TIW & $\mathbf{1 0 , 1 7 3 1 ( 0 , 0 0 1 4 )}$ & $X$ & \\
POS & $2,5333(0,1115)$ & $\mathbf{6 , 7 0 5 4 ( 0 , 0 0 9 6 )}$ & $X$ \\
POS EXT & $1,3912(0,2382)$ & $0,0038(0,9506)$ & $0,1048(0,7461)$
\end{tabular}

sig. $p<0,05$

Tabela 44 - Valor estatístico e valor-p (corrigidos) encontrados nos testes Chi Quadrado das lesões de cárie dentária em indivíduos sem deformação (SEM), com deformação circular (CIR) e com deformação tabular (TAB) durante o período Pré Tiwanaku.

\begin{tabular}{|c|c|c|}
\hline & SEM & $\mathrm{CIR}$ \\
\hline $\mathrm{CIR}$ & $0,1760(0,6748)$ & $\mathrm{X}$ \\
\hline TAB & $4,8999(0,0296)$ & $0,5068(0,4765)$ \\
\hline
\end{tabular}

sig. $p<0,05$

Tabela 45 - Valor estatístico e valor-p (corrigidos) encontrados nos testes Chi Quadrado das lesões de cárie dentária em indivíduos sem deformação (SEM), com deformação circular (CIR) e com deformação tabular (TAB) durante o período Tiwanaku.

\begin{tabular}{ccc}
\hline & SEM & CIR \\
\hline CIR & $0,1319(0,7165)$ & $\mathrm{X}$ \\
TAB & $0,6999(0,4028)$ & $0,0008(0,9770)$
\end{tabular}

sig. $p<0,05$ 
Tabela 46 - Valor estatístico e valor-p (corrigidos) encontrados nos testes Chi Quadrado das lesões de cárie dentária em indivíduos sem deformação (SEM), com deformação circular (CIR) e com deformação tabular (TAB) durante o período Pós Tiwanaku.

\begin{tabular}{ccc}
\hline & SEM & CIR \\
\hline CIR & $0,5575(0,4553)$ & $X$ \\
TAB & $0,1620(0,6873)$ & $1,1858(0,2762)$
\end{tabular}

sig. $p<0,05$

Tabela 47 - Valor estatístico e valor-p (corrigidos) encontrados nos testes Chi Quadrado das lesões de cárie dentária em indivíduos sem deformação (SEM), com deformação circular (CIR) e com deformação tabular (TAB) durante o período Pós Tiwanaku Externo (Caspana).

\begin{tabular}{ccc}
\hline & SEM & CIR \\
\hline CIR & $0,4275(0,5132)$ & $X$ \\
TAB & $0,1222(0,7267)$ & $0,0914(0,7624)$
\end{tabular}

sig. $\mathrm{p}<0,05$

O índice DMI (Dental Missing Index) e o índice de Lukacs utilizados neste trabalho visam associar as perdas dentárias em vida com os dentes cariados.

O DMI, por não distinguir as perdas dentárias, considera todas as perdas como resultantes do processo infecciosos carioso, necessariamente superestimando os números de cáries que acometeram o indivíduo. Os valores encontrados nesta amostra, divididos pelos períodos estudados, estão dispostos na Figura 72. 


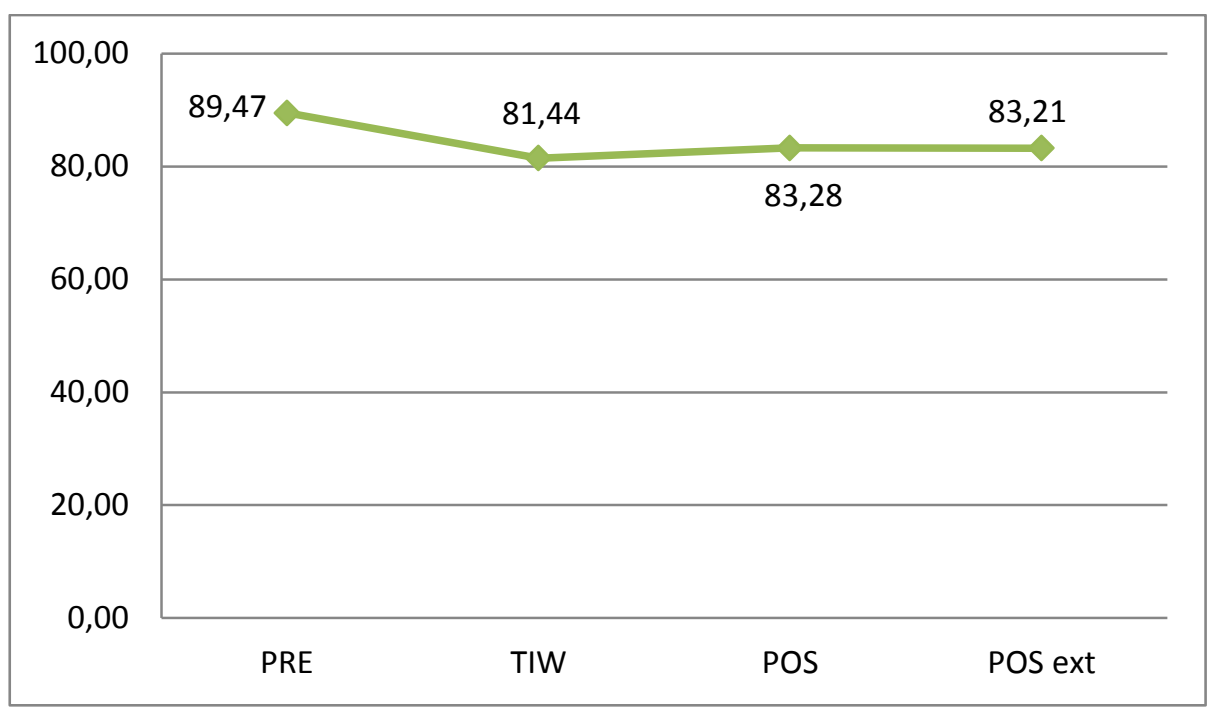

Figura 72 - Médias dos valores do DMI de Saunders para os períodos estudados.

Ao aplicar o teste estatístico Kurskal - Wallis, foi encontrada significância na variação deste índice ao longo dos períodos estudados $\left(X^{2}=14,728 ; d f=3 ; p=0,003\right)$. Com isso, se fez necessária a análise dos períodos pareados (Tabela 48). 
Tabela 48 - Valor estatístico e valor-p para averiguação das diferenças dos DMI entre os períodos.

\begin{tabular}{|c|c|}
\hline \multicolumn{2}{|c|}{ PRÉ TIWANAKU X TIWANAKU } \\
\hline Mann Whitney U & 4888,500 \\
\hline Wilcoxon W & 15473,500 \\
\hline Z & $-3,693$ \\
\hline $\mathbf{p}$ & 0,000 \\
\hline \multicolumn{2}{|c|}{ TIWANAKU X PÓS TIWANAKU } \\
\hline Mann Whitney U & 9288,000 \\
\hline Wilcoxon W & 19873,000 \\
\hline Z & $-0,326$ \\
\hline p & 0,744 \\
\hline \multicolumn{2}{|c|}{ PÓS TIWANAKU X PÓS TIWANAKU ext } \\
\hline Mann Whitney U & 1985,500 \\
\hline Wilcoxon W & 10631,500 \\
\hline Z & $-0,200$ \\
\hline $\mathbf{p}$ & 0,841 \\
\hline
\end{tabular}

sig. $p<0,05$

As medianas dos valores do DMI encontradas para estes períodos também são apresentadas juntamente com alguns indivíduos discrepantes (outlier) (Figura 73). 


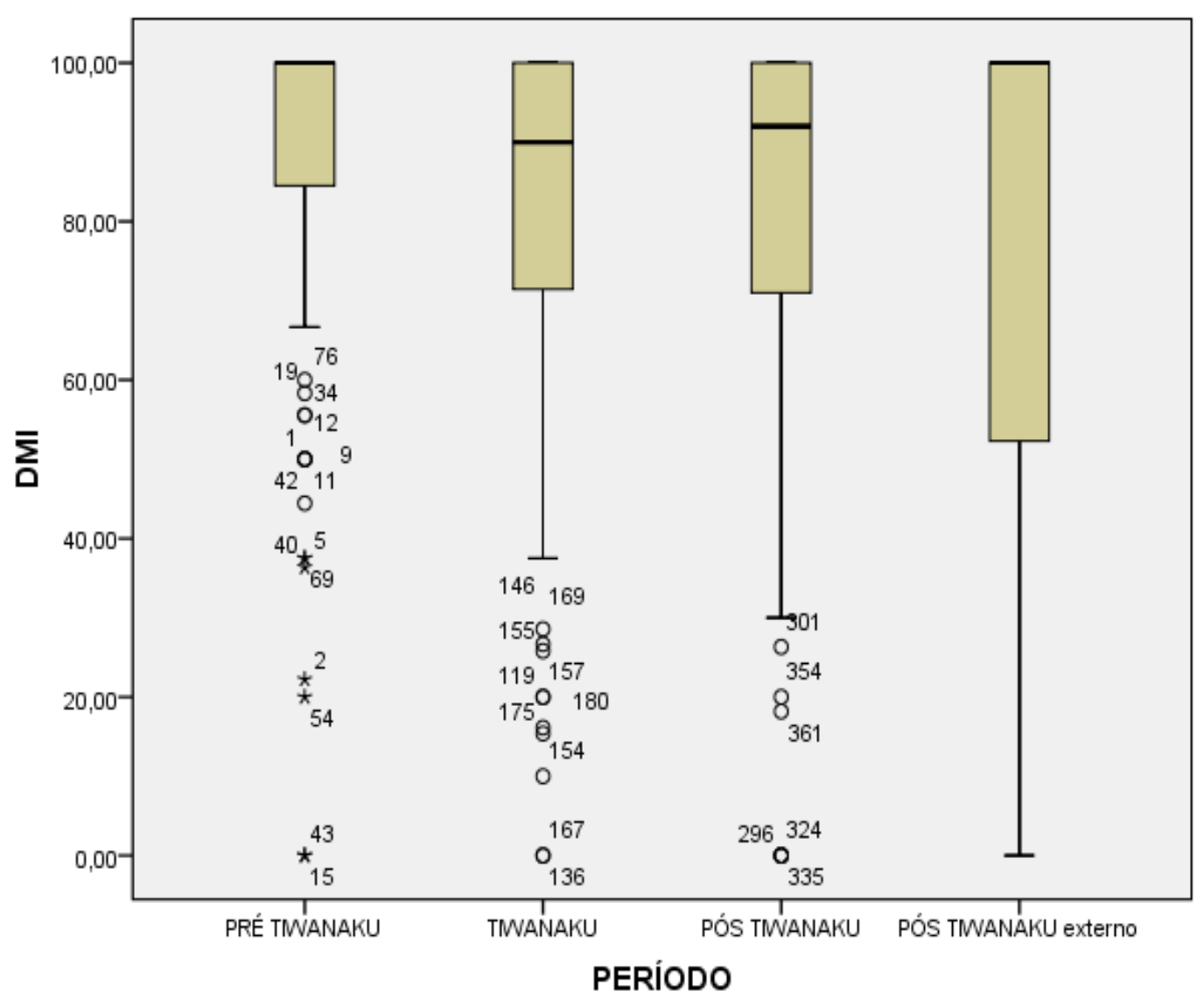

Figura 73 - Distribuição das medianas dos valores de DMI de Saunders pelos 3 períodos estudados, além do sítio Caspana (Pós Tiwanaku externo). Os indivíduos discrepantes de cada período estão representados por pontos ou asteriscos fora da distribuição principal.

Já o índice de Lukacs prevê a distinção entre os dentes perdidos ante mortem por cárie dentária e por desgaste. Para tanto, esta distinção é feita no momento em que se identifica a extensão das cáries encontradas na amostra, identificando as exposições pulpares causadas pelo processo carioso e as exposições pulpares ocorridas pelo processo de desgaste intenso do elemento dental (Figura 74). 


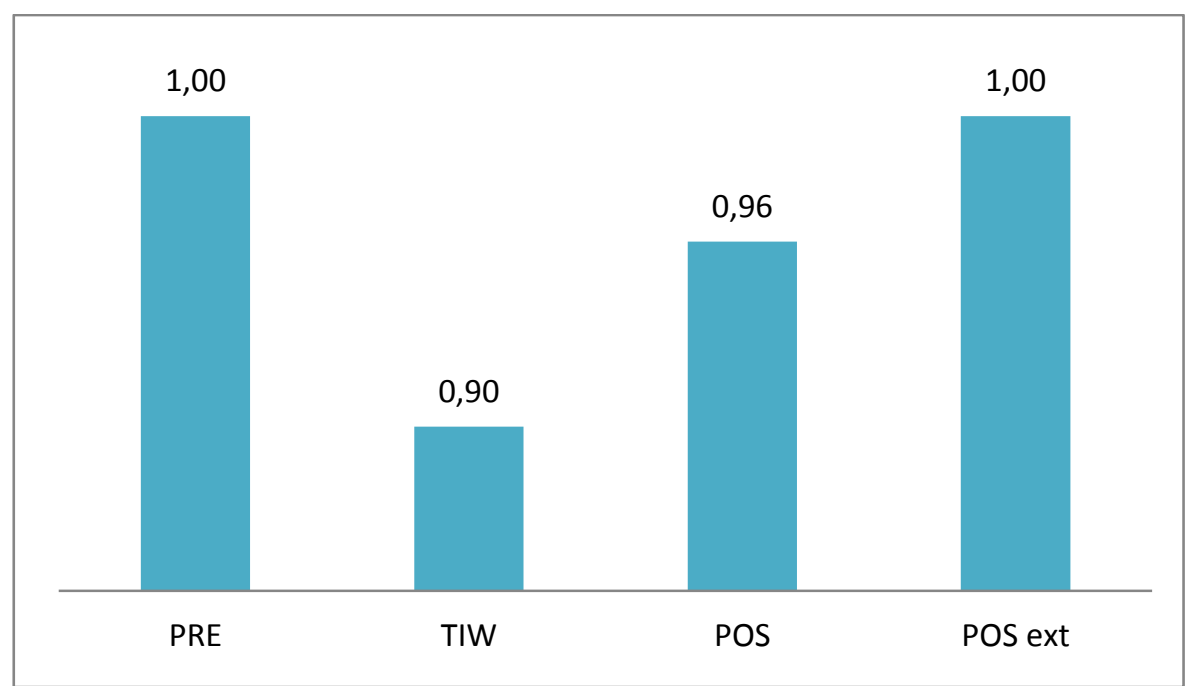

Figura 74 - Relação de polpas expostas devido ao processo de cárie dentária divididas por todos os casos de polpa exposta.

Os valores acima dispostos indicam que os períodos Pré Tiwanaku e Pós Tiwanaku externo apresentarão valores iguais aos encontrados em DMI, uma vez que a relação entre as polpas expostas por cárie e todas as polpas expostas observáveis nos indivíduos destes períodos é 1 , ou seja, $100 \%$ dos dentes perdidos em vida foram considerados, por este método, resultantes de processos cariosos avançados (Figura 75).

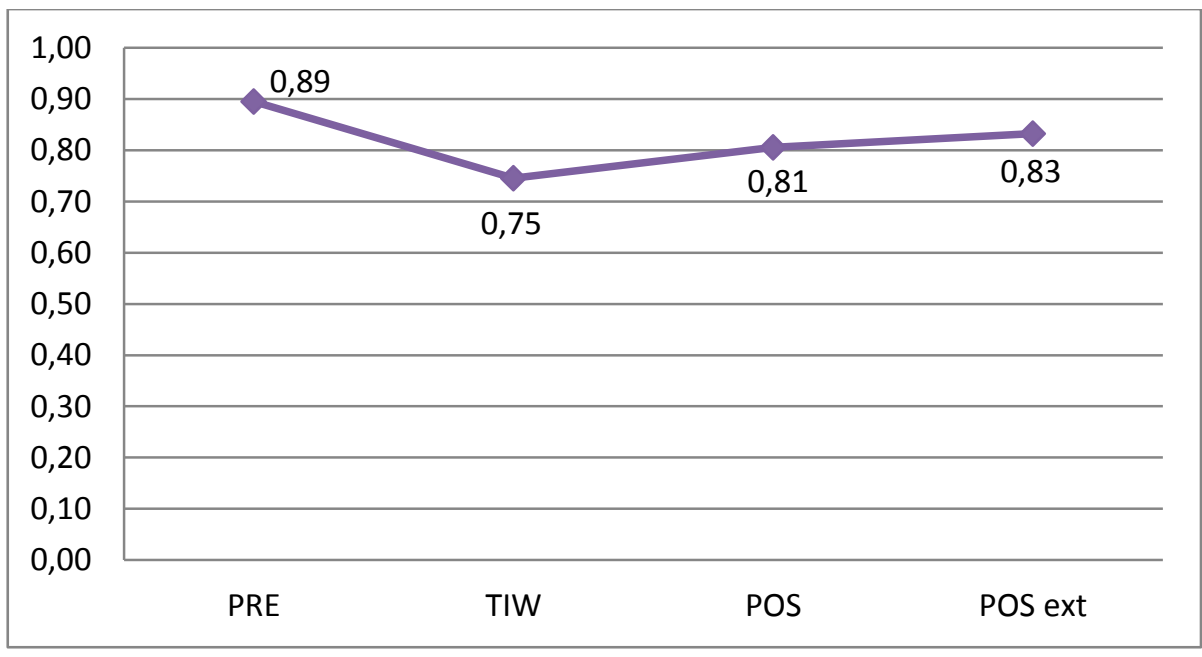

Figura 75 - Médias dos valores do índice de Lukacs. 
As medianas do índice de Lukacs, encontradas para cada período analisado, estão expostas no gráfico abaixo (Figura 76).

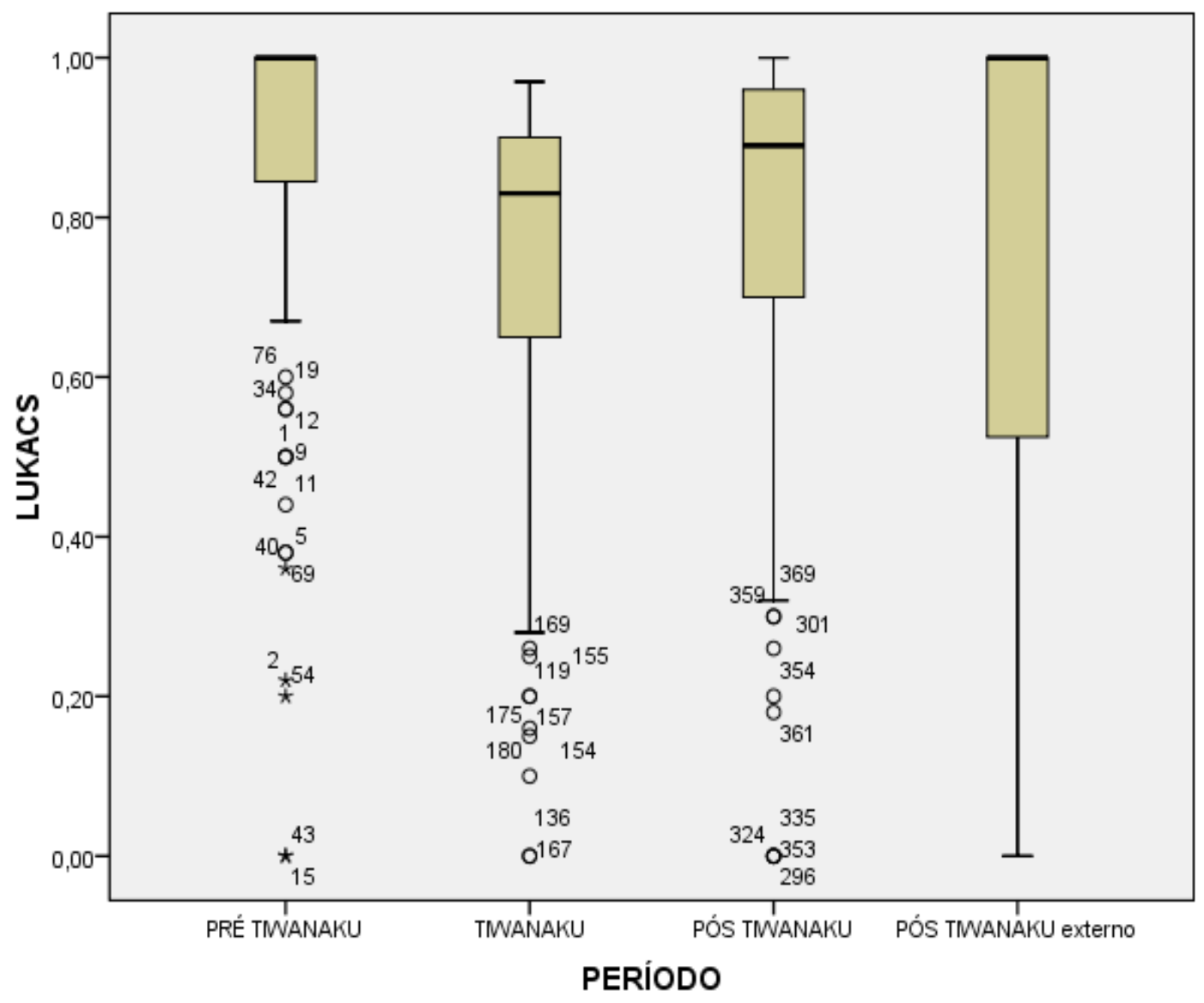

Figura 76 - Medianas encontradas para os índices de Lukacs de cada período. Os indivíduos discrepantes de cada período estão representados por pontos ou asteriscos fora da distribuição principal.

Assim como as outras análises anteriores, a remoção dos indivíduos com idade de morte inferior a 25 anos foi aplicada sobre os dados deste índice, resultando no seguinte cenário (Figura 77). 


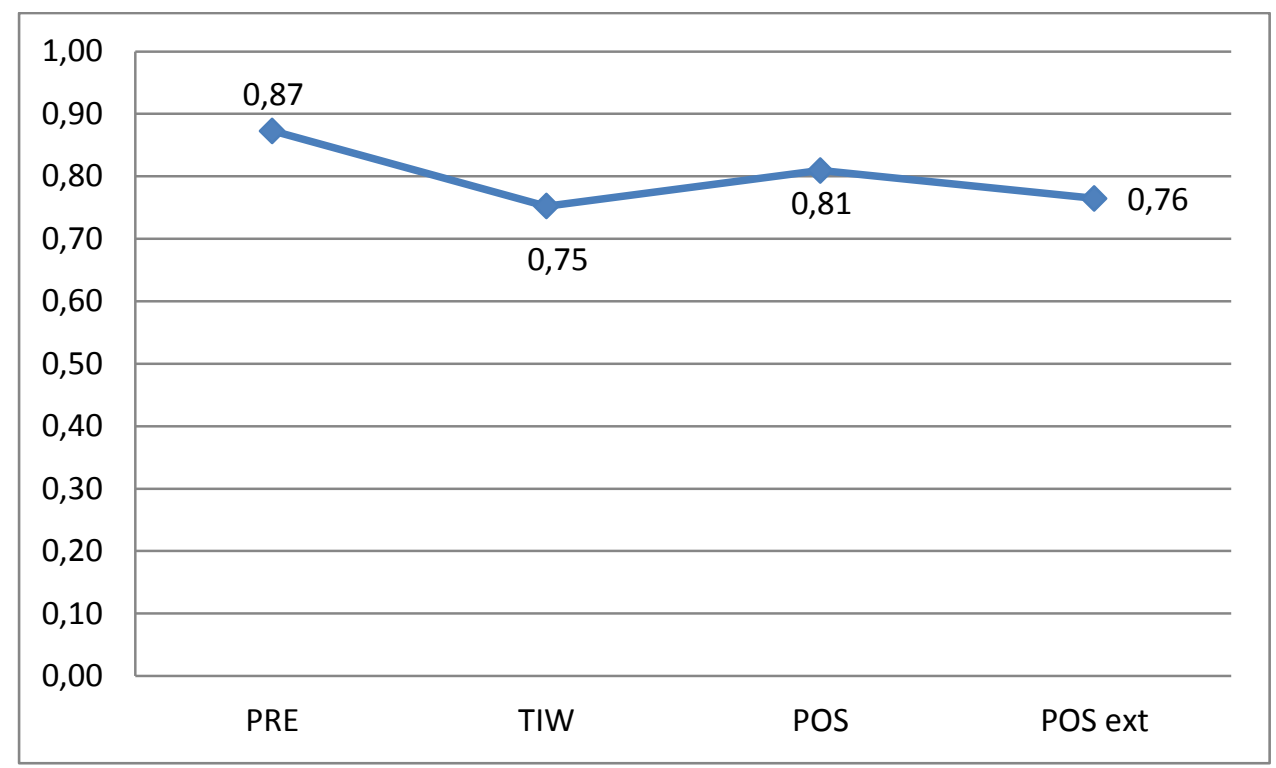

Figura 77 - Médias dos valores do índice de Lukacs dos indivíduos com idade superior a 25 anos.

O Índice de Lukacs do período Tiwanaku não foi afetado após a exclusão dos indivíduos mais jovens da amostra, pois como já fora mencionado, não havia esqueletos nestas condições dentro deste grupo. O período Pós Tiwanaku fora afetado minimamente após tal manobra, praticamente sem alterar o índice deste período (com jovens: 0,8051; sem jovens: 0,8095). Porém, tanto o período Pré Tiwanaku como o período Pós Tiwanaku externo foram impactados com a remoção dos esqueletos com idade de morte inferior a 25 anos, diminuindo o índice em ambos os casos; durante o período Pré Tiwanaku a queda foi de 0,89 para 0,87 e durante o período Pós Tiwanaku externo foi de 0,83 para 0,76 , sendo esta última a mais expressiva das quedas observadas.

Analisando estatisticamente este novo cenário, encontramos uma importante variação do índice ao longo do tempo (Kruskal - Wallis $X^{2}=74,564 ; d f .=3 ; p=0,000$ ) e observamos diferença significativa entre todos os períodos estudados (Tabela 49). 
Tabela 49 - Valor estatístico e valor-p para averiguação das diferenças dos índices de Lukacs entre os períodos.

\begin{tabular}{cc}
\hline \multicolumn{2}{c}{ PRÉ TIWANAKU X TIWANAKU } \\
\hline Mann Whitney U & 2884,500 \\
Wilcoxon W & 13469,500 \\
Z & $-7,369$ \\
p & $\mathbf{0 , 0 0 0}$ \\
\hline
\end{tabular}

TIWANAKU X PÓS TIWANAKU

\begin{tabular}{cc}
\hline Mann Whitney U & 6286,500 \\
Wilcoxon W & 16871,500 \\
Z & $-4,358$ \\
p & $\mathbf{0 , 0 0 0}$ \\
\hline
\end{tabular}

\begin{tabular}{cc}
\hline \multicolumn{2}{c}{ PÓS TIWANAKU X PÓS TIWANAKU ext } \\
\hline Mann Whitney U & 1235,500 \\
Wilcoxon W & 9110,500 \\
Z & $-2,693$ \\
p & $\mathbf{0 , 0 0 7}$ \\
\hline
\end{tabular}

sig. $p<0,05$

Ao separarmos os esqueletos de cada período em indivíduos do sexo masculino e indivíduos do sexo feminino com idade de morte superior a 25 anos, observamos a seguinte distribuição (Figura 78). 


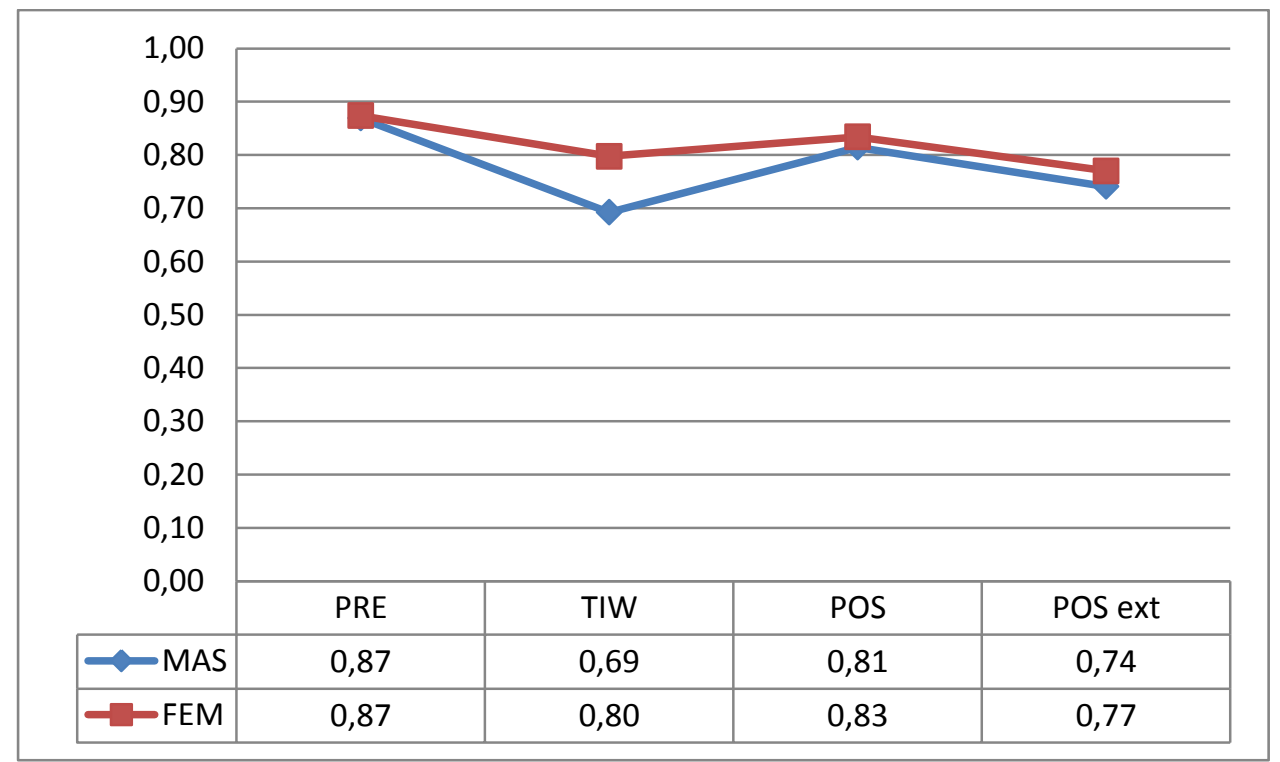

Figura 78 - Médias dos valores do índice de Lukacs dos indivíduos com idade superior a 25 anos divididos em homens (MAS) e mulheres (FEM).

As diferenças dos índices Lukacs entre os dois sexos foram analisadas separadamente em cada período (Tabela 50). 
Tabela 50 - Valor estatístico e valor-p para averiguação das diferenças dos índices de Lukacs entre homens e mulheres em cada período.

\begin{tabular}{cc}
\hline \multicolumn{2}{c}{ PRÉ TIWANAKU } \\
\hline Mann Whitney U & 820,500 \\
Wilcoxon W & 1681,500 \\
Z & $-0,658$ \\
p & 0,510 \\
\hline
\end{tabular}

\begin{tabular}{cc}
\hline \multicolumn{2}{c}{ TIWANAKU } \\
\hline Mann Whitney U & 1414,500 \\
Wilcoxon W & 3125,500 \\
Z & $-3,595$ \\
$\mathbf{p}$ & 0,000 \\
\hline
\end{tabular}

\begin{tabular}{cc}
\hline \multicolumn{2}{c}{ PÓS TIWANAKU } \\
\hline Mann Whitney U & 1396,500 \\
Wilcoxon W & 3226,500 \\
Z & $-1,135$ \\
p & 0,256 \\
\hline
\end{tabular}

\begin{tabular}{cc}
\hline \multicolumn{2}{c}{ PÓS TIWANAKU externo } \\
\hline Mann Whitney U & 83,000 \\
Wilcoxon W & 174,000 \\
Z & $-0,742$ \\
p & 0,525 \\
\hline
\end{tabular}

sig. $\mathrm{p}<0,05$

Ambos os sexos apresentaram variação em seus índices ao longo do tempo, sendo estatisticamente significativas tanto para o sexo masculino (Kruskal - Wallis $\mathrm{X}^{2}=$ 34,$866 ;$ df. $=3 ; \mathbf{p}=0,000$ ) como para o sexo feminino (Kruskal - Wallis $X^{2}=35,849 ; d f$. = 
$3 ; \mathbf{p}=0,000)$. A evolução do índice de Lukacs de cada sexo foi também avaliada separadamente (Tabela 51; Tabela 52), buscando diferenças no índice de cada sexo entre os períodos contíguos.

Tabela 51 - Valor estatístico e valor-p para averiguação das diferenças dos índices de Lukacs dos homens entre os períodos.

\begin{tabular}{cc}
\hline \multicolumn{2}{c}{ PRÉ TIWANAKU X TIWANAKU } \\
\hline Mann Whitney U & 489,000 \\
Wilcoxon W & 2200,000 \\
Z & $-5,021$ \\
p & $\mathbf{0 , 0 0 0}$ \\
\hline
\end{tabular}

\section{TIWANAKU X PÓS TIWANAKU}

\begin{tabular}{cc}
\hline Mann Whitney U & 1051,500 \\
Wilcoxon W & 2762,500 \\
Z & $-3,711$ \\
p & $\mathbf{0 , 0 0 0}$ \\
\hline
\end{tabular}

\begin{tabular}{cc}
\hline PóS TIWANAKU X PÓS TIWANAKU externo \\
\hline Mann Whitney U & 303,500 \\
Wilcoxon W & 2133,500 \\
Z & $-1,252$ \\
p & 0,211 \\
\hline
\end{tabular}

sig. $p<0,05$ 
Tabela 52 - Valor estatístico e valor-p para averiguação das diferenças dos índices de Lukacs das mulheres entre os períodos.

\begin{tabular}{cc}
\hline \multicolumn{2}{c}{ PRÉ TIWANAKU X TIWANAKU } \\
\hline Mann Whitney U & 764,500 \\
Wilcoxon W & 3690,500 \\
Z & $-4,898$ \\
p & $\mathbf{0 , 0 0 0}$ \\
\hline
\end{tabular}

\begin{tabular}{cc}
\hline \multicolumn{2}{c}{ TIWANAKU X PÓS TIWANAKU } \\
\hline Mann Whitney U & 1278,500 \\
Wilcoxon W & 4204,500 \\
Z & $-3,564$ \\
p & $\mathbf{0 , 0 0 0}$ \\
\hline
\end{tabular}

\begin{tabular}{cc}
\hline PÓS TIWANAKU X PÓS TIWANAKU externo \\
\hline Mann Whitney U & 248,500 \\
Wilcoxon W & 1679,500 \\
Z & $-2,265$ \\
p & $\mathbf{0 , 0 2 4}$ \\
\hline
\end{tabular}

sig. $p<0,05$

O índice de Lukacs também foi avaliado nos esqueletos que apresentavam deformações cranianas intencionais e nos que não apresentavam estas deformações (Figura 79). 


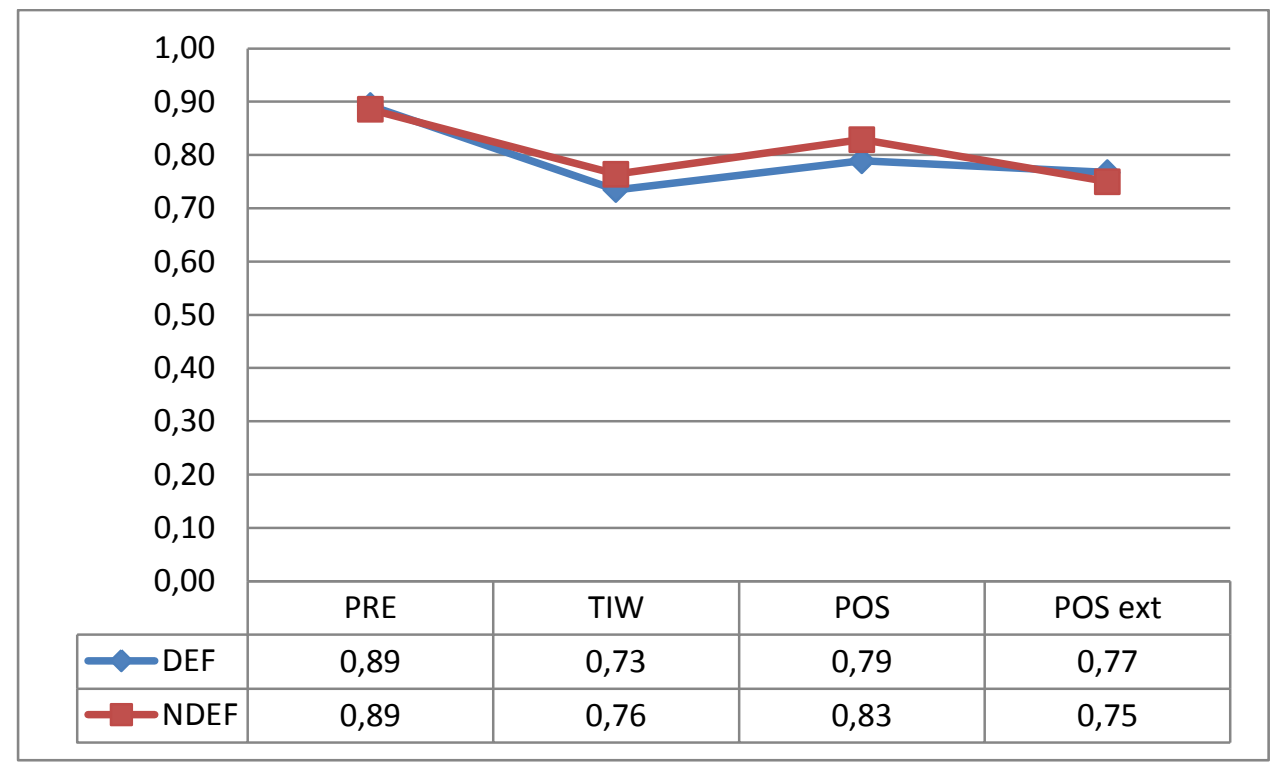

Figura 79 - Médias dos valores do índice de Lukacs dos indivíduos com idade superior a 25 anos e divididos em crânios com deformação (DEF) e sem deformação (NDEF).

As variações dos índices de Lukacs dos indivíduos deformados e não deformados foram analisadas estatisticamente dentro de cada período (Tabela 53). 
Tabela 53 - Valor estatístico e valor-p para averiguação das diferenças dos índices de Lukacs entre crânios deformados e não deformados em cada período.

\begin{tabular}{cc}
\hline \multicolumn{2}{c}{ PRÉ TIWANAKU } \\
\hline Mann Whitney U & 793,500 \\
Wilcoxon W & 1874,500 \\
Z & $-0,138$ \\
p & 0,890 \\
\hline
\end{tabular}

\begin{tabular}{cc}
\hline \multicolumn{2}{c}{ TIWANAKU } \\
\hline Mann Whitney U & 1926,000 \\
Wilcoxon W & 3817,000 \\
Z & $-1,488$ \\
p & 0,137 \\
\hline
\end{tabular}

\begin{tabular}{cc}
\hline \multicolumn{2}{c}{ Pós TIWANAKU } \\
\hline Mann Whitney U & 1637,500 \\
Wilcoxon W & 3068,500 \\
Z & $-1,131$ \\
p & 0,258 \\
\hline
\end{tabular}

\begin{tabular}{cc}
\hline \multicolumn{2}{c}{ PÓS TIWANAKU externo } \\
\hline Mann Whitney U & 44,500 \\
Wilcoxon W & 369,500 \\
Z & $-0,390$ \\
p & 0,737 \\
\hline
\end{tabular}

sig. $p<0,05$

Tanto os crânios deformados como os não deformados apresentaram variações em seus índices ao longo do tempo, sendo estatisticamente significativas para os crânios com deformação craniana intencional (Kruskal - Wallis $X^{2}=38,061$; df. $=3 ; \mathbf{p}=$ 
0,000) e para os crânios que não apresentavam deformação craniana (Kruskal - Wallis $X^{2}=41,979 ;$ df. $\left.=3 ; \mathbf{p}=0,000\right)$. Como isso, as diferenças dos índices Lukacs entre os dois grupos foram analisadas em cada período (Tabela 54; Tabela 55).

Tabela 54 - Valor estatístico e valor-p para averiguação das diferenças dos índices de Lukacs dos crânios deformados entre os períodos.

\begin{tabular}{cc}
\hline \multicolumn{2}{c}{ PRÉ TIWANAKU X TIWANAKU } \\
\hline Mann Whitney U & 344,500 \\
Wilcoxon W & 2235,500 \\
Z & $-5,573$ \\
p & $\mathbf{0 , 0 0 0}$ \\
\hline
\end{tabular}

TIWANAKU X PÓS TIWANAKU

\begin{tabular}{cc}
\hline Mann Whitney U & 1187,000 \\
Wilcoxon W & 3078,000 \\
Z & $-2,451$ \\
$\mathbf{p}$ & $\mathbf{0 , 0 1 4}$ \\
\hline \\
\hline PÓs TIWANAKU X Pós TIWANAKU externo \\
\hline Mann Whitney U & 466,500 \\
Wilcoxon W & 1897,500 \\
$\mathbf{Z}$ & $-2,116$ \\
$\mathbf{p}$ & $\mathbf{0 , 0 3 4}$ \\
\hline
\end{tabular}

sig. $p<0,05$ 
Tabela 55 - Valor estatístico e valor-p para averiguação das diferenças dos índices de Lukacs dos crânios sem deformação entre os períodos.

\begin{tabular}{cc}
\hline \multicolumn{2}{c}{ PRÉ TIWANAKU X TIWANAKU } \\
\hline Mann Whitney U & 724,500 \\
Wilcoxon W & 3499,500 \\
Z & $-5,357$ \\
p & $\mathbf{0 , 0 0 0}$ \\
\hline
\end{tabular}

\begin{tabular}{cc}
\hline \multicolumn{2}{c}{ TIWANAKU X PóS TIWANAKU } \\
\hline Mann Whitney U & 1701,500 \\
Wilcoxon W & 4476,500 \\
Z & $-3,571$ \\
p & $\mathbf{0 , 0 0 0}$ \\
\hline
\end{tabular}

\begin{tabular}{cc}
\hline PóS TIWANAKU X PÓS TIWANAKU externo \\
\hline Mann Whitney U & 69,000 \\
Wilcoxon W & 2554,000 \\
Z & $-1,728$ \\
p & 0,093 \\
\hline
\end{tabular}

sig. $p<0,05$

Flúor

A possibilidade de serem encontradas fontes naturais de fluoretos, potenciais agentes protetores de cáries dentárias, justificou a coleta de água dos rios da região.

As 11 amostras de água dos rios que fazem parte da bacia do salar de Atacama e da bacia do rio Loa foram encaminhadas à Área de Prestação de Serviços de Pequena Monta FOP/Laboratório de Bioquímica Oral da Universidade Estadual de Campinas 
(UNICAMP) em duas datas distintas (15/04/2011 e 23/08/2012). As análises executadas em 15/04/2011 e 03/09/2012 avaliaram a quantidade de íons de flúor em mg F/l de água (ppm) (Figura 80).

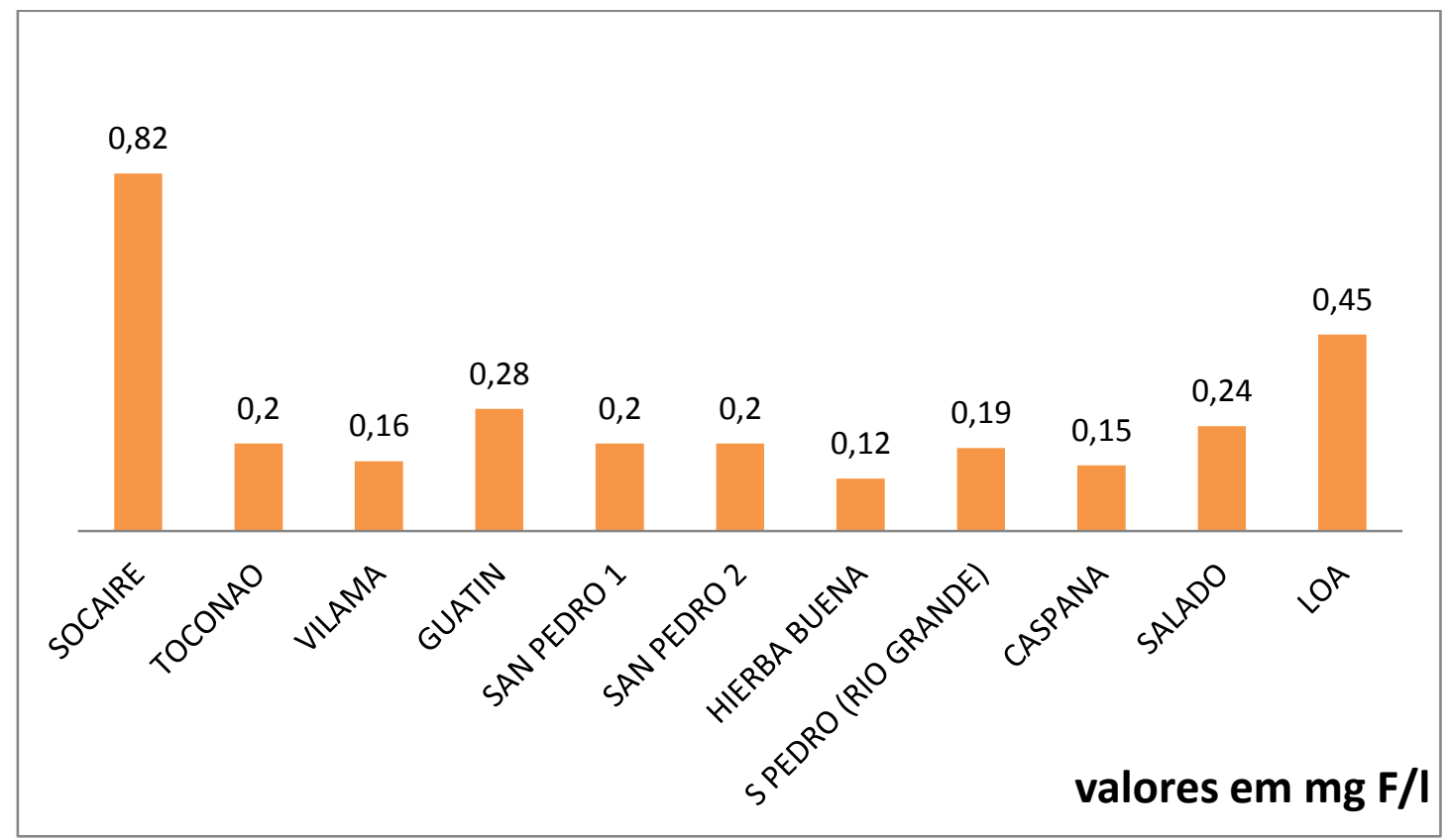

Figura 80 - Valores de flúor observados nas águas dos rios da região do deserto de Atacama. Valores em mg de flúor por litro de água ou partes por milhão (ppm).

As águas do rio Socaire foram as únicas que apresentaram valores acima dos 0,7 ppm de flúor preconizados como concentração necessária para a geração do efeito protetor do flúor contra cáries (Ramires et al., 2008). Todos os outros rios apresentaram concentrações muito abaixo deste valor. 


\section{Evidência dental de consumo de folhas de coca}

Seguindo o protocolo de análise anteriormente descrito (Indriati \& Buikstra, 2001), entre os 402 crânios avaliados neste trabalho, apenas um único indivíduo apresentou indícios, ainda que fracos, de consumo frequente de folhas de coca (Erythroxylum coca). Este indivíduo, registrado no museu sob o número 9672, é um indivíduo masculino, encontrado no sítio Quitor 5, com idade de morte estimada em mais de 55 anos.

\section{Desgaste dentário}

Os desgastes dentários encontrados na amostra, distribuídos entre os 8 níveis preconizados por S. Molnar (1971) estão apresentados, divididos entre os períodos históricos, na Figura 81. 


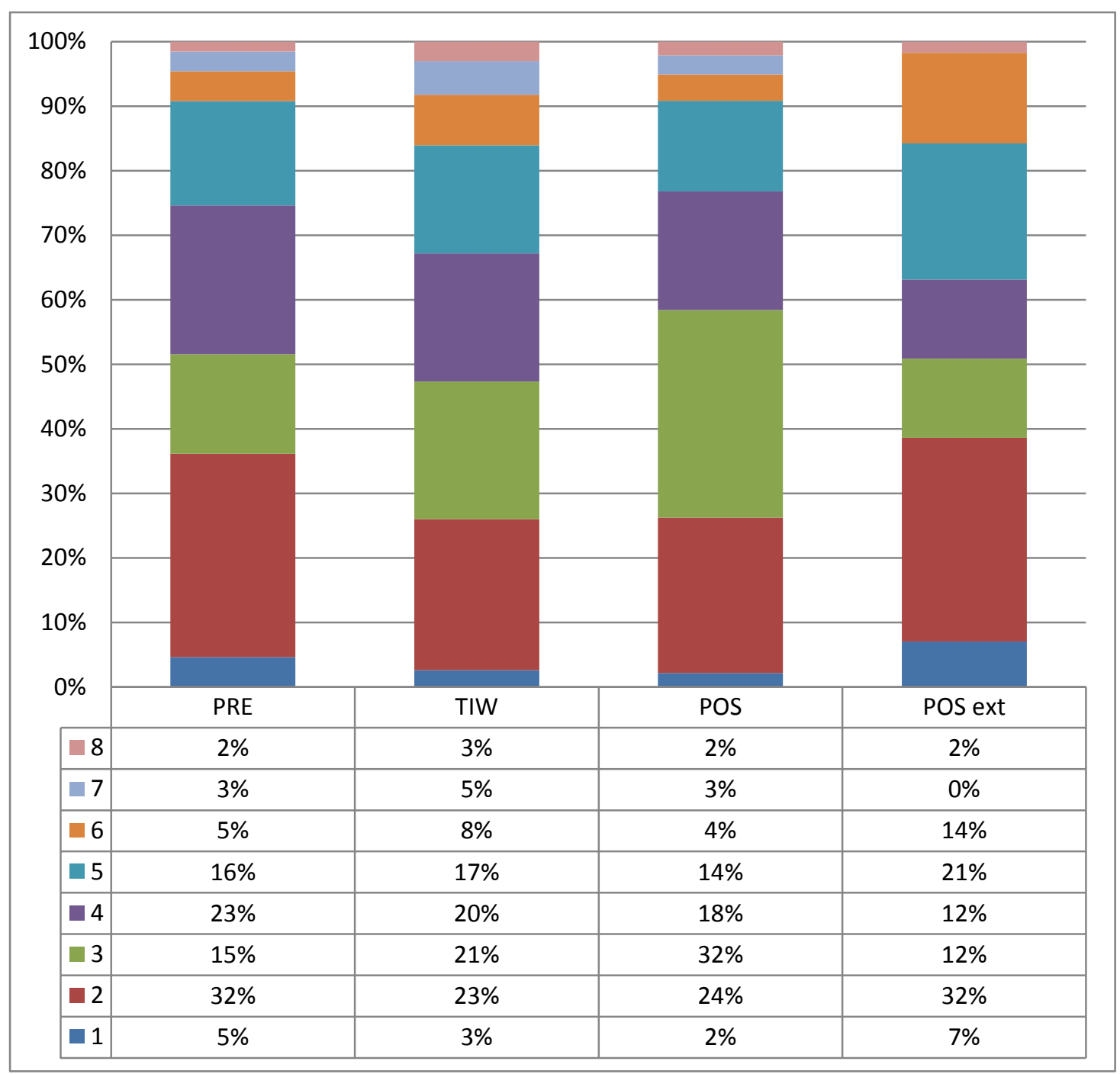

Figura 81 - Níveis de desgaste dentário de S. Molnar (1971) encontrados durante os períodos analisados.

Estes desgastes dentários foram analisados através de suas médias, apresentadas na Figura 82: 


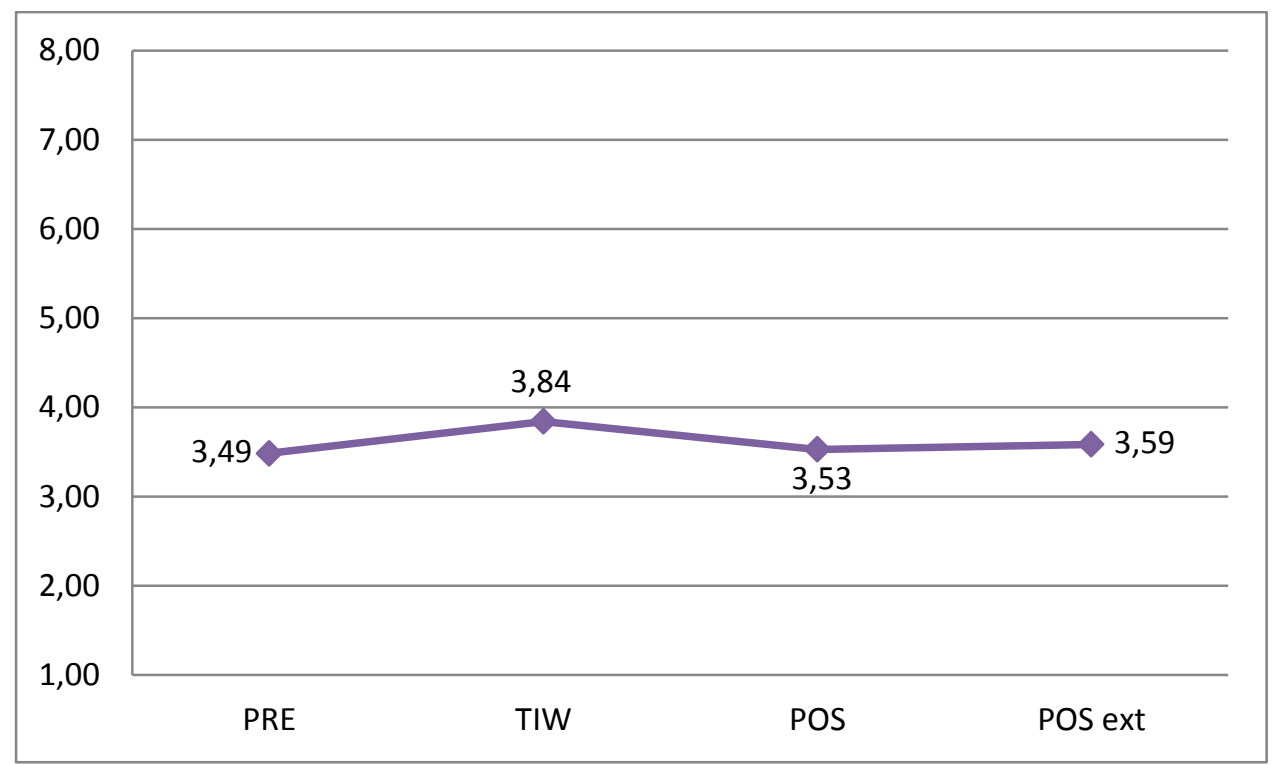

Figura 82 - Médias dos valores do desgaste dentário.

Ao analisarmos estatisticamente as médias dos desgastes dentários durante os três períodos nos oásis de San Pedro de Atacama, encontramos uma variação significativa ao longo do tempo (Kruskal - Wallis $X^{2}=11,989 ; d f .=3 ; \mathbf{p}=0,007$ ). Por isso, foram executados testes avaliando as variações entre cada período (Tabela 56). 
Tabela 56 - Valor estatístico e valor-p para averiguação das diferenças das médias dos desgastes dentários entre os períodos.

\begin{tabular}{cc}
\hline \multicolumn{2}{c}{ PRÉ TIWANAKU X TIWANAKU } \\
\hline Mann Whitney U & 43864,500 \\
Wilcoxon W & 52479,500 \\
Z & $-2,192$ \\
p & $\mathbf{0 , 0 2 8}$ \\
\hline
\end{tabular}

TIWANAKU X PÓS TIWANAKU

\begin{tabular}{cc}
\hline Mann Whitney U & 161056,000 \\
Wilcoxon W & 271271,000 \\
Z & $-3,082$ \\
p & $\mathbf{0 , 0 0 2}$ \\
\hline
\end{tabular}

\begin{tabular}{cc}
\hline \multicolumn{2}{c}{ PóS TIWANAKU X PÓS TIWANAKU ext } \\
\hline Mann Whitney U & 13514,000 \\
Wilcoxon W & 123729,000 \\
Z & $-0,082$ \\
p & 0,935
\end{tabular}

sig. $p<0,05$

Estes desgastes dentários também foram divididos em 3 grupos, levando em conta a intensidade da perda do esmal material orgânico dentário. Classificados com desgaste LEVE, MEDIO E INTENSO, os desgastes foram assim agrupados para facilitar a comparação entre os indivíduos e também, não menos importante, para absorver os possíveis e esperados erros intra-observador no julgamento de pequenas variações entre os 8 níveis de desgaste preconizados pelos autores de referência (Molnar, 1971; Smith, 1984) (Figura 83). 


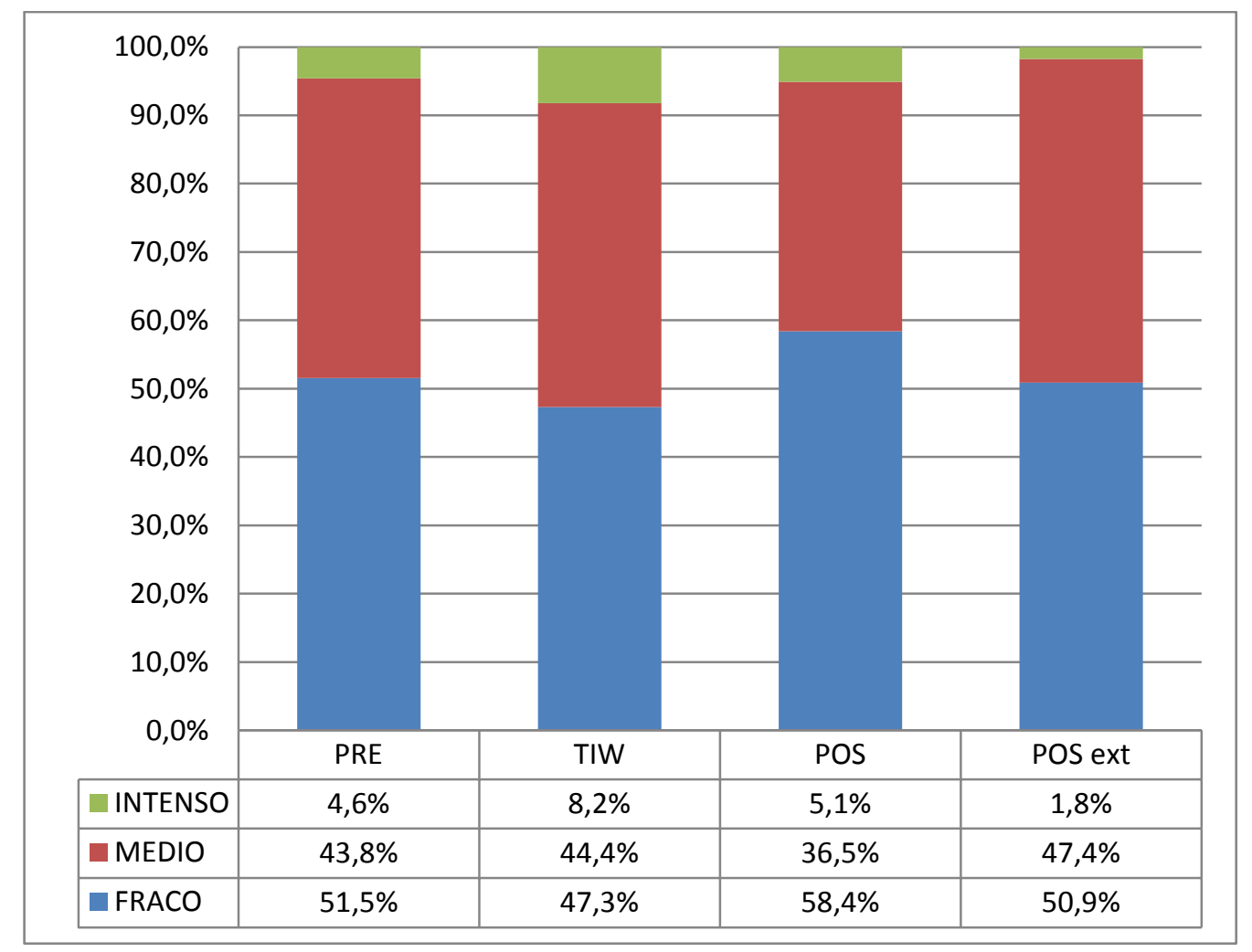

Figura 83 - Desgaste dentário classificado pela intensidade.

As diferenças encontradas entre os períodos para cada nível de desgaste foram testadas estatisticamente buscando encontrar significância entre os valores apresentados (Tabela 57; Tabela 58; Tabela 59).

Tabela 57 - Valor estatístico e valor-p (corrigidos) encontrados nos testes Chi Quadrado para desgaste dentário leve.

\begin{tabular}{cccc}
\hline & PRE & TIW & POS \\
\hline PRE & $X$ & & \\
TIW & $0,6322(0,4265)$ & $X$ & $X$ \\
POS & $1,6963(0,1928)$ & $13,9068(0,0002)$ & \\
POS ext & $0,0014(0,9705)$ & $0,1454(0,7030)$ & $0,8959(0,3439)$ \\
\hline
\end{tabular}

$\operatorname{sig} p<0,05$ 
Tabela 58 - Valor estatístico e valor-p (corrigidos) encontrados nos testes Chi Quadrado para desgaste dentário médio.

\begin{tabular}{cccc}
\hline & PRE & TIW & POS \\
\hline PRE & $\mathrm{X}$ & & \\
TIW & $0,0010(0,9749)$ & $\mathrm{X}$ & \\
POS & $2,0522(0,1520)$ & $7,3132(0,0068)$ & $\mathrm{X}$ \\
POS ext & $0,0818(0,7748)$ & $0,0843(0,7716)$ & $2,1324(0,1442)$ \\
\hline
\end{tabular}

$\operatorname{sig} p<0,05$

Tabela 59 - Valor estatístico e valor-p (corrigidos) encontrados nos testes Chi Quadrado para desgaste dentário intenso.

\begin{tabular}{cccc}
\hline & PRE & TIW & POS \\
\hline PRE & $X$ & & \\
TIW & $1,5693(0,2103)$ & $X$ & $X$ \\
POS & $0,0000(0,9961)$ & $3,8508(0,0497)$ & $X$ \\
POS ext & $0,2812(0,5959)$ & $2,2663(0,1322)$ & $0,6354(0,4254)$ \\
\hline
\end{tabular}

sig $p<0,05$

Independentemente do nível de desgaste dentário apresentado pelos dentes analisados, a única diferença estatisticamente significativa encontrada entre os períodos é a diminuição dos 3 níveis de desgaste dentário entre os períodos Tiwanaku e Pós Tiwanaku.

Como forma de comparar estes níveis de intensidade do desgaste dentário, foi feita uma média dos valores observados durante os períodos, nos quais desgaste leve $=1 ;$ desgaste médio $=2$ e desgaste intenso $=3$ (Figura 84) . 


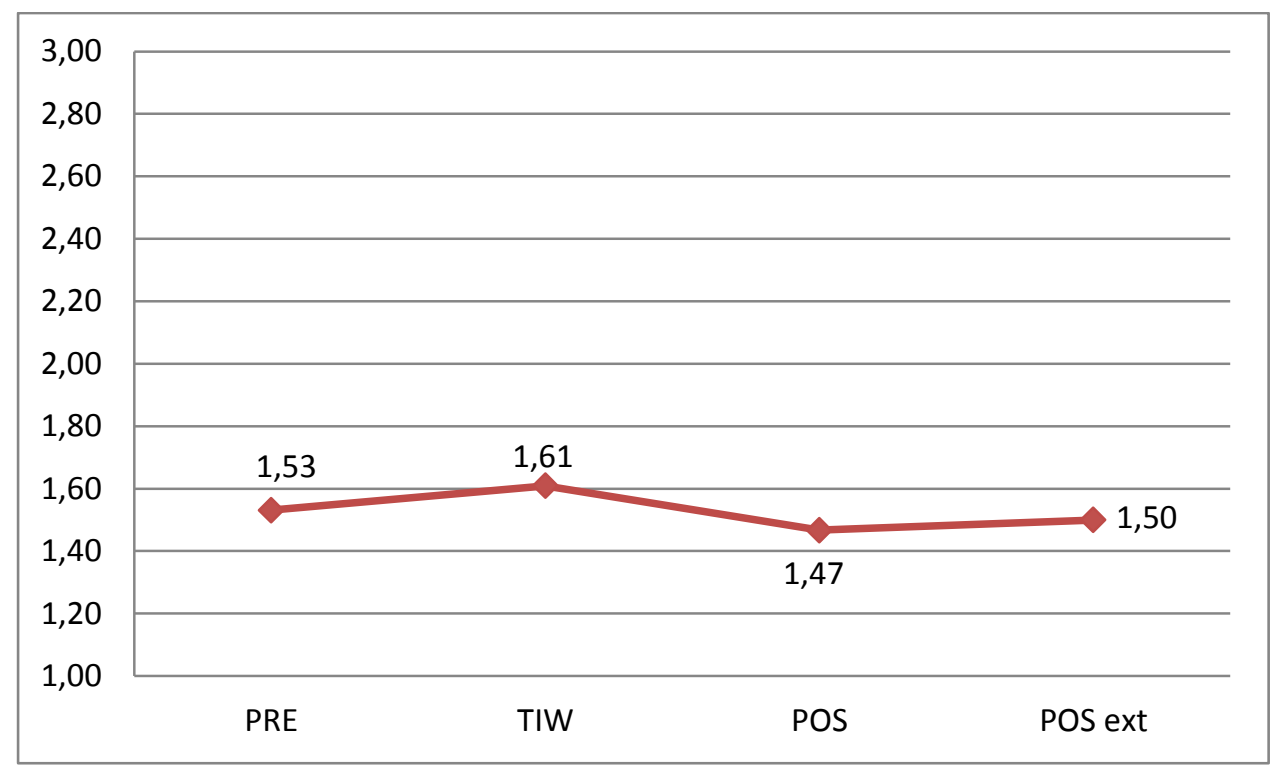

Figura 84 - Médias das intensidades dos desgastes dentários (desgaste leve $=1$; desgaste médio = 2; desgaste intenso $=3$ ).

As médias das intensidades dos desgastes dentários durante os três períodos estudados nos oásis de San Pedro de Atacama apresentaram uma variação significativa ao longo do tempo (Kruskal - Wallis $X^{2}=15,788 ;$ df. = 3; $\mathbf{p}=0,001$ ). Assim, estas médias foram avaliadas período a período (Tabela 60). 
Tabela 60 - Valor estatístico e valor-p para averiguação das diferenças das médias das intensidades dos desgastes dentários entre os períodos.

\begin{tabular}{cc}
\hline \multicolumn{2}{c}{ PRÉ TIWANAKU X TIWANAKU } \\
\hline Mann Whitney U & 46852,000 \\
Wilcoxon W & 35367,000 \\
Z & $-1,177$ \\
p & 0,239 \\
\hline
\end{tabular}

TIWANAKU X PÓS TIWANAKU

\begin{tabular}{cc}
\hline Mann Whitney U & 158170,000 \\
Wilcoxon W & 268385,000 \\
Z & $-3,925$ \\
p & $\mathbf{0 , 0 0 0}$ \\
\hline
\end{tabular}

\begin{tabular}{cc}
\hline PÓS TIWANAKU X PÓS TIWANAKU ext \\
\hline Mann Whitney U & 12928,500 \\
Wilcoxon W & 123143,500 \\
Z & $-0,707$ \\
p & 0,479 \\
\hline
\end{tabular}

sig. $\mathrm{p}<0,05$

Em alguns casos, entre os dentes com desgaste dentário intenso, foram observadas exposições da polpa dentária. As prevalências referentes aos casos de exposição pulpar na amostra estão dispostas no gráfico da Figura 85. 


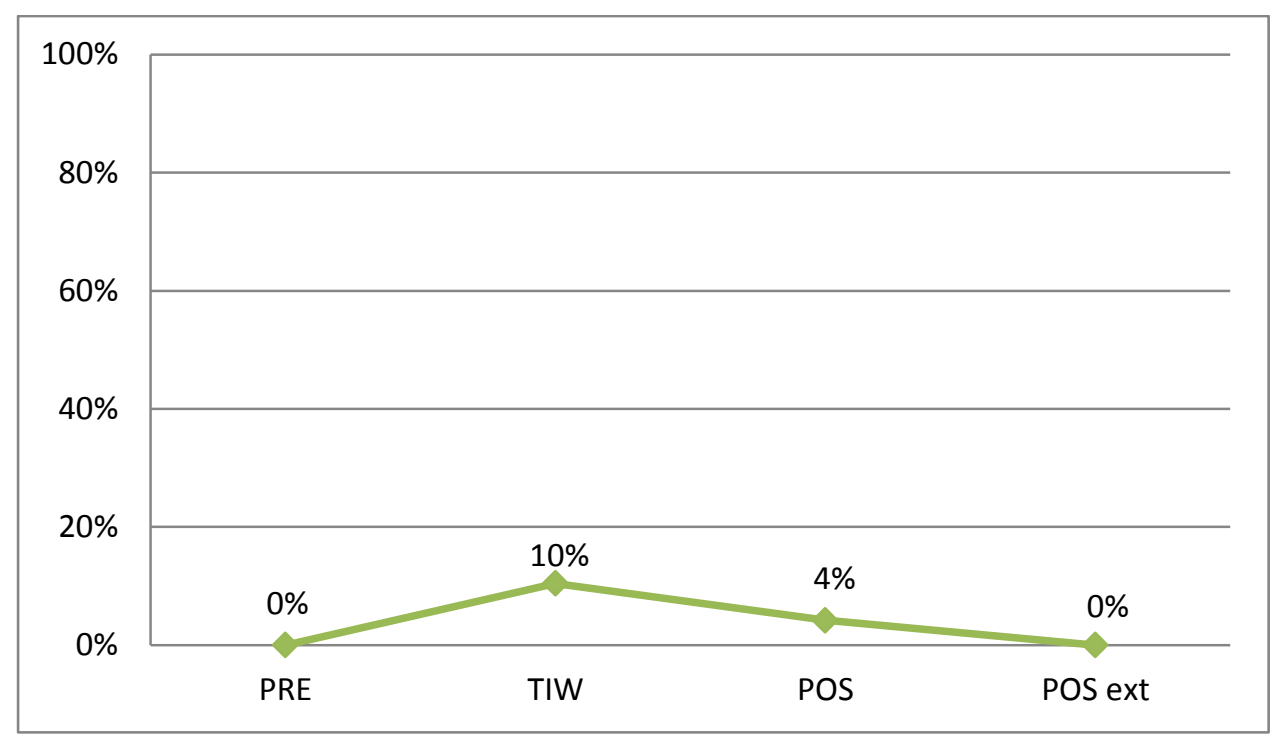

Figura 85 - Prevalência de dentes com polpa exposta resultante de desgaste dentário intenso.

Visto que pode haver uma diferença entre os desgaste dentários encontrados em dentes anteriores e posteriores devido a aspectos culturais mas também alimentares (Larsen et al., 1998; Deter, 2009), a divisão da amostra em dentes anteriores e posteriores também foi executado, gerando os dados observados na Figura 86.
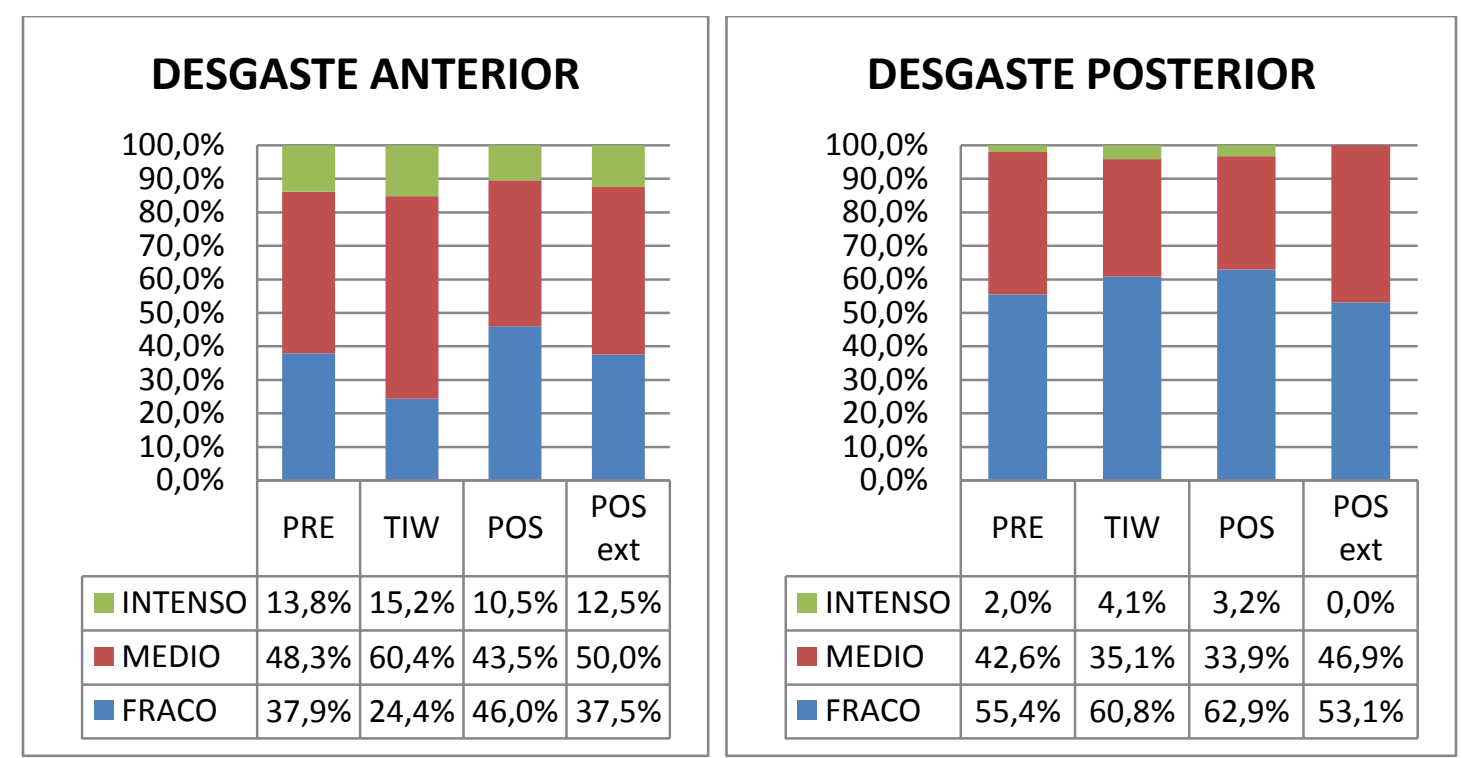

Figura 86 - Desgastes dentários observados nos dentes anteriores e posteriores e divididos em 3 níveis de intensidade. 
Os valores obtidos para os desgastes dentários observados nos dentes anteriores foram submetidos ao teste de Chi Quadrado, comparando a prevalência destes desgastes por períodos. Para estas análises, as intensidades de desgaste dentário foram comparadas separadamente, observando a evolução de cada uma ao longo do tempo (Tabela 61; Tabela 62; Tabela 63)

Tabela 61 - Valor estatístico e valor-p (corrigidos) encontrados nos testes Chi Quadrado para desgaste dentário leve dos dentes anteriores.

\begin{tabular}{cccc}
\hline & PRE & TIW & POS \\
\hline PRE & $X$ & & \\
TIW & $1,8720(0,1712)$ & $X$ & \\
POS & $0,3324(0,5642)$ & $17,8000(0,0000)$ & $X$ \\
POS ext & $0,1517(0,6969) *$ & $0,1871(0,6653)$ & $0,0100(0,9204)$
\end{tabular}

sig. $p<0,05$

* devido ao pequeno número amostral, foi também efetuado o teste exato de Fisher $p=1,0000$.

Tabela 62 - Valor estatístico e valor-p (corrigidos) encontrados nos testes Chi Quadrado para desgaste dentário médio dos dentes anteriores.

\begin{tabular}{cccc}
\hline & PRE & TIW & POS \\
\hline PRE & $X$ & & \\
TIW & $1,1444(0,2847)$ & $X$ & \\
POS & $0,0644(0,7997)$ & $9,2618(0,0023)$ & $X$ \\
POS ext & $0,0980(0,7542) * *$ & $0,0519(0,8199)$ & $0,0001(0,9911)$ \\
\hline
\end{tabular}

sig. $p<0,05$

* devido ao pequeno número amostral, foi também efetuado o teste exato de Fisher $p=1,0000$. 
Tabela 63 - Valor estatístico e valor-p (corrigidos) encontrados nos testes Chi Quadrado para desgaste dentário intenso dos dentes anteriores.

\begin{tabular}{cccc}
\hline & PRE & TIW & POS \\
\hline PRE & $X$ & & \\
TIW & $0,0051(0,9429)$ & $X$ & $X$ \\
POS & $0,0332(0,8553)$ & $1,2397(0,2655)$ & \\
POS ext & $0,2395(0,6246) *$ & $0,0844(0,7714)$ & $0,1704(0,6797)$ \\
\hline
\end{tabular}

sig. $\mathrm{p}<0,05$

* devido ao pequeno número amostral, foi também efetuado o teste exato de Fisher $\mathrm{p}=1,0000$.

As mesmas análises foram executadas para os dentes posteriores, como observado a seguir (Tabela 64; Tabela 65; Tabela 66).

Tabela 64 - Valor estatístico e valor-p (corrigidos) encontrados nos testes Chi Quadrado para desgaste dentário leve dos dentes posteriores.

\begin{tabular}{cccc}
\hline & PRE & TIW & POS \\
\hline PRE & $X$ & & \\
TIW & $0,7822(0,3765)$ & $X$ & \\
POS & $1,5274(0,2165)$ & $0,2948(0,5872)$ & $X$ \\
POS ext & $0,0101(0,9201)$ & $0,8085(0,3686)$ & $1,3651(0,2427)$ \\
\hline
\end{tabular}

sig. $p<0,05$

Tabela 65 - Valor estatístico e valor-p (corrigidos) encontrados nos testes Chi Quadrado para desgaste dentário médio dos dentes posteriores.

\begin{tabular}{cccc}
\hline & PRE & TIW & POS \\
\hline PRE & $\mathrm{X}$ & & \\
TIW & $1,7246(0,1891)$ & $\mathrm{X}$ & \\
POS & $2,1851(0,1394)$ & $0,0721(0,7883)$ & $\mathrm{X}$ \\
POS ext & $0,1087(0,7416)$ & $2,2276(0,1356)$ & $2,6348(0,1045)$ \\
\hline
\end{tabular}

sig. $p<0,05$ 
Tabela 66 - Valor estatístico e valor-p (corrigidos) encontrados nos testes Chi Quadrado para desgaste dentário intenso dos dentes posteriores.

\begin{tabular}{cccc}
\hline & PRE & TIW & POS \\
\hline PRE & $X$ & & \\
TIW & $0,5671(0,4514)$ & $X$ & \\
POS & $0,0891(0,7653)$ & $0,2828(0,5949)$ & $X$ \\
POS ext & $0,0542(0,8160)$ & $1,1231(0,2893)$ & $0,6471(0,4212)$ \\
\hline
\end{tabular}

sig. $p<0,05$

Apenas os desgastes dentários de intensidade leve e média nos dentes anteriores durante os períodos Tiwanaku e Pós Tiwanaku apresentam diferença estatisticamente significativa.

As diferenças no desgaste dentário encontradas entre os dentes anteriores e posteriores, tanto entre os períodos, mas também dentro de um mesmo período, confirmando a premissa de distinção entre desgastes de dentes anteriores e dentes posteriores, demandaram averiguações estatísticas quanto à significância destas variações. Assim, cada período histórico teve seus dentes anteriores e posteriores comparados quanto à intensidade do desgaste dentário (Tabela 67). 
Tabela 67 - Valor estatístico e valor-p (corrigidos) para averiguação das diferenças entre os desgastes dentários dos dentes anteriores e dentes posteriores em cada período.

\begin{tabular}{ccc}
\hline \multicolumn{3}{c}{ PRE TIWANAKU } \\
\hline & X2 & P \\
LEVE & 2,1104 & 0,1463 \\
MEDIO & 0,111 & 0,7390 \\
INTENSO & $\mathbf{4 , 7 1 0 5}$ & $\mathbf{0 , 0 3 0 0}$ \\
\hline
\end{tabular}

\begin{tabular}{ccc}
\hline \multicolumn{3}{c}{ TIWANAKU } \\
\hline & X2 & $\mathrm{P}$ \\
LEVE & $\mathbf{9 3 , 3 5 3 2}$ & $\mathbf{0 , 0 0 0 0}$ \\
MEDIO & $\mathbf{4 5 , 4 2 8 6}$ & $\mathbf{0 , 0 0 0 0}$ \\
INTENSO & $\mathbf{2 7 , 3 4 0 7}$ & $\mathbf{0 , 0 0 0 0}$ \\
\hline
\end{tabular}

\begin{tabular}{ccc}
\hline \multicolumn{3}{c}{ POS TIWANAKU } \\
\hline & X2 & $\mathrm{P}$ \\
LEVE & $\mathbf{1 0 , 0 7 8 5}$ & $\mathbf{0 , 0 0 1 5}$ \\
MEDIO & 3,2513 & $\mathbf{0 , 0 7 1 4}$ \\
INTENSO & $\mathbf{8 , 5 5 2 7}$ & $\mathbf{0 , 0 0 3 5}$ \\
\hline
\end{tabular}

POS TIWANAKU EXTERNO

\begin{tabular}{ccc}
\hline & $X 2$ & $P$ \\
LEVE & 0,1891 & 0,6636 \\
MEDIO & 0,0489 & 0,8250 \\
INTENSO & 1,0912 & 0,2962 \\
\hline
\end{tabular}

sig. $p<0,05$

Outra análise aplicada sobre os dados obtidos neste trabalho foi considerar o indivíduo e não os dentes como minha unidade de análise, tentando assim minimizar um possível viés encontrado na amostra com diferentes taxas de perda dentária post 
mortem. Com este procedimento, encontramos a seguinte condição de distribuição dos desgastes dentários para os períodos estudados (Figura 87).

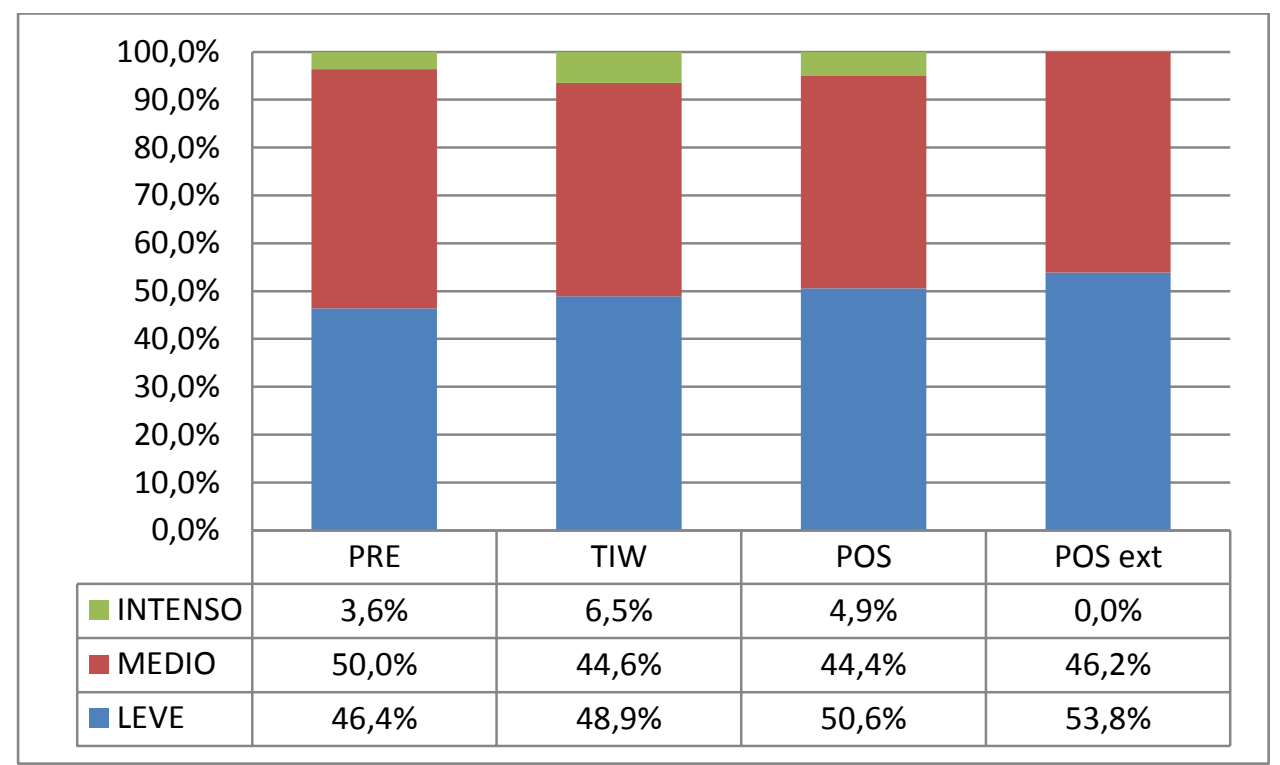

Figura 87 - Distribuição dos indivíduos classificados pelo nível de desgaste dentário apresentado.

Os dados apresentados foram analisados pelos testes estatísticos de Chi Quadrado e pelo teste Exato de Fisher, buscando confirmar a visual semelhança visual entre as distribuições dos níveis de desgaste dentário ao longo dos períodos quando os indivíduos são levados em consideração (Tabela 68; Tabela 69; Tabela 70). 
Tabela 68 - Valor estatístico e valor-p (corrigidos) encontrados nos testes Chi Quadrado aplicados nos desgastes dentários de intensidade baixa, quando os indivíduos são levados em consideração.

\begin{tabular}{cccc}
\hline & PRE & TIW & POS \\
\hline PRE & $X$ & & \\
TIW & $0,0002(0,9885)$ & $X$ & $X$ \\
POS & $0,0265(0,8706)$ & $0,0051(0,9431)$ & \\
POS ext & $0,0113(0,9152)^{*}$ & $0,0013(0,9707)$ & $0,0068(0,9341)$
\end{tabular}

\section{sig. $p<0,05$}

* o valor do teste exato de Fisher aplicado nesta comparação é $p=0,7442$.

Tabela 69 - Valor estatístico e valor-p (corrigidos) encontrados nos testes Chi Quadrado aplicados nos desgastes dentários de intensidade média, quando os indivíduos são levados em consideração.

\begin{tabular}{cccc}
\hline & PRE & TIW & POS \\
\hline PRE & $X$ & & \\
TIW & $0,0834(0,7727)$ & $X$ & $X$ \\
POS & $0,0833(0,7729)$ & $0,0189(0,8908)$ & $X$ \\
POS ext & $0,0113(0,9152)$ & $0,0361(0,8492)$ & $0,0344(0,8529)$ \\
\hline
\end{tabular}

sig. $p<0,05$

Tabela 70 - Valor estatístico e valor-p (corrigidos) encontrados nos testes Chi Quadrado aplicados nos desgastes dentários de intensidade alta, quando os indivíduos são levados em consideração.

\begin{tabular}{cccc}
\hline & PRE & TIW & POS \\
\hline PRE & $X$ & & \\
TIW & $0,0151(0,9023)$ & $X$ & $X$ \\
POS & $0,0510(0,8213)$ & $0,0141(0,9054)$ & X \\
POS ext & $0,1584(0,6906)$ & $0,0961(0,7566)$ & $0,0062(0,9372)$ \\
\hline
\end{tabular}

sig. $p<0,05$ 
Os testes estatísticos aplicados não apresentaram resultados que indicassem diferenças significativas entre os períodos estudados. Os 3 níveis de desgaste dentário observados na amostra também não apresentaram diferenças.

Foi também avaliada a possível relação entre a presença ou não das deformações cranianas intencionais e o nível de desgaste dentário encontrado durante os períodos. Assim, cada nível de desgaste dentário foi avaliado quanto à distribuição de indivíduos que apresentavam ou não deformações cranianas intencionais e comparadas pelos períodos propostos neste trabalho (Figura 88; Figura 89; Figura 90).

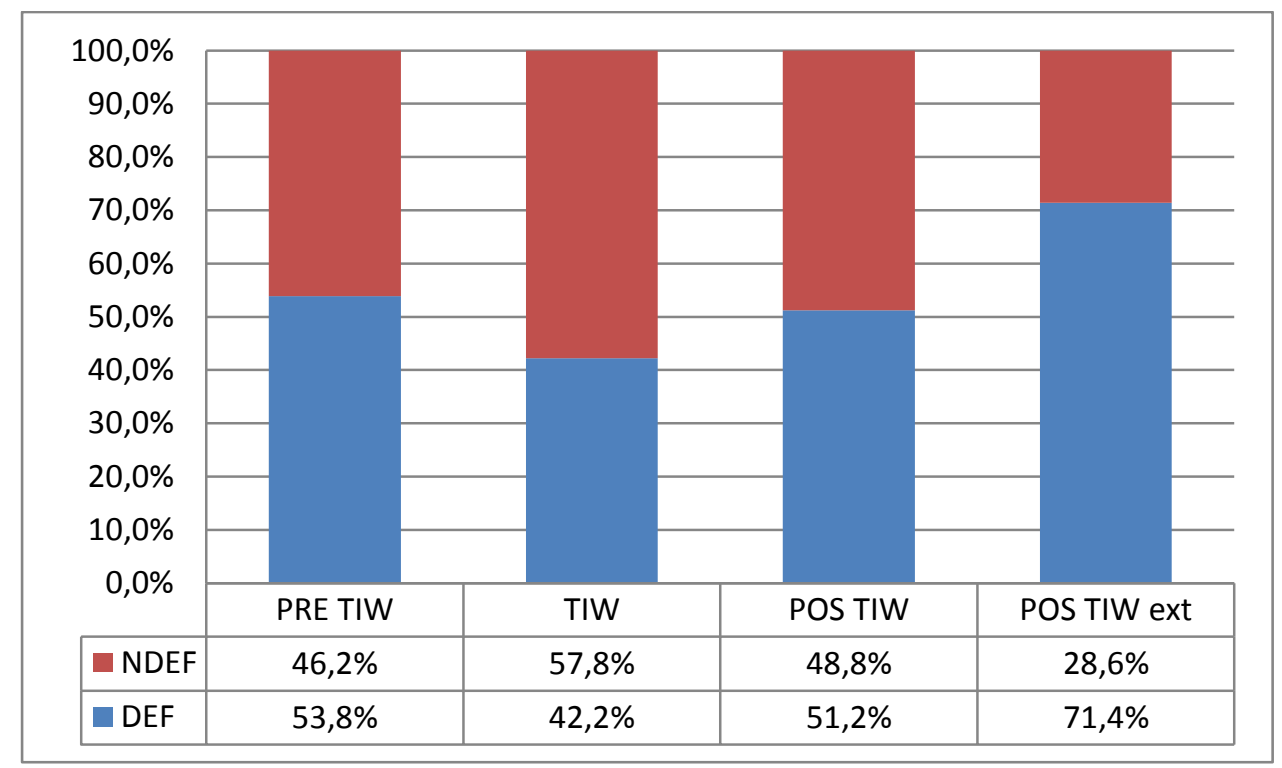

Figura 88 - Distribuição dos indivíduos com (DEF) e sem deformação craniana (SEM DEF) que apresentavam desgaste dentário de intensidade baixa. 


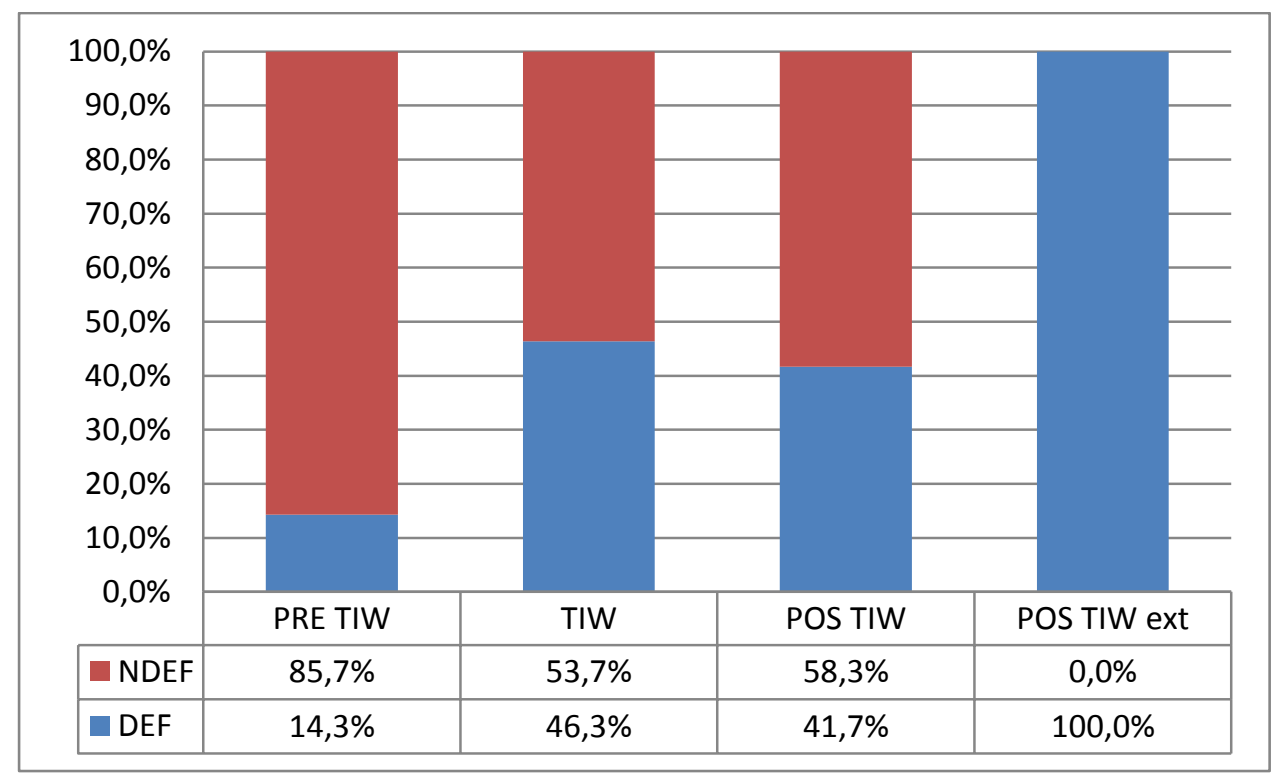

Figura 89 - Distribuição dos indivíduos com (DEF) e sem deformação craniana (NDEF) que apresentavam desgaste dentário de intensidade média.

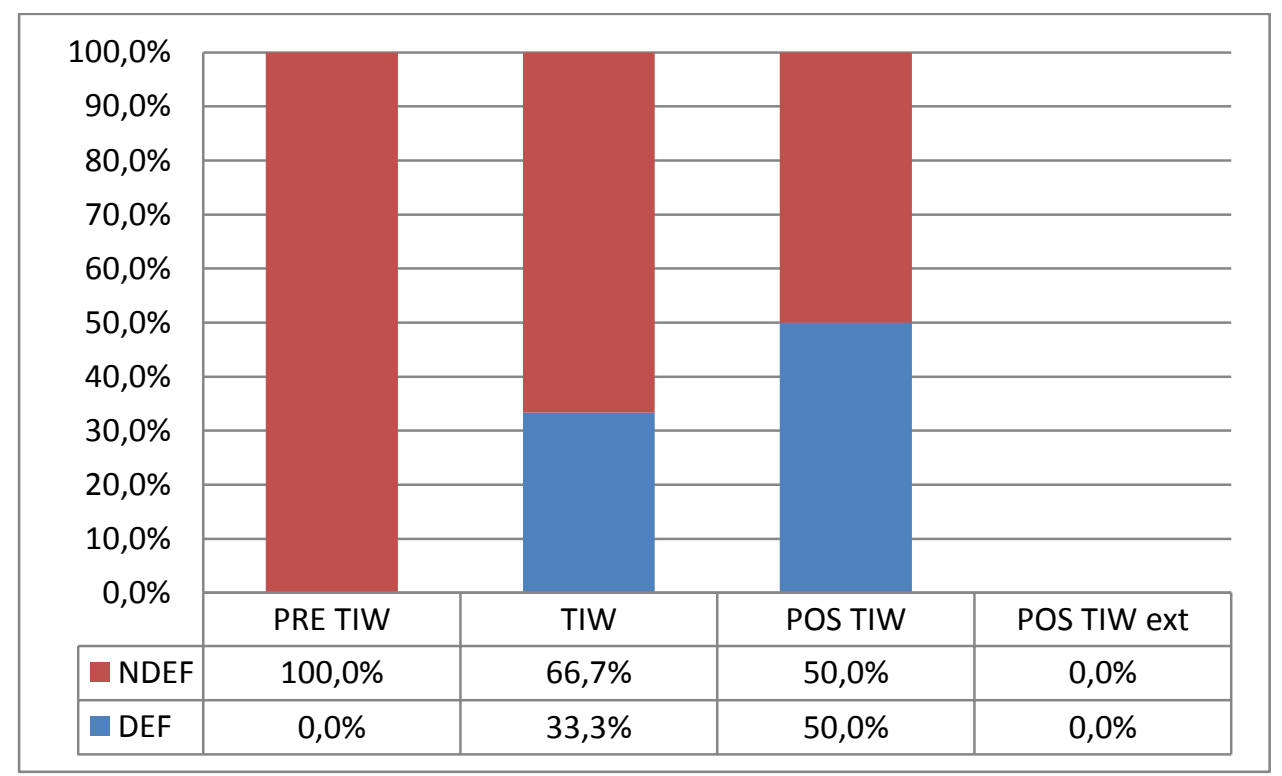

Figura 90 - Distribuição dos indivíduos com (DEF) e sem deformação craniana (NDEF) que apresentavam desgaste dentário de intensidade alta.

Também submetidas aos testes estatísticos de Chi Quadrado, as prevalências de desgaste dentário encontradas nos indivíduos portadores de deformação craniana 
foram comparadas entre os períodos e também entre eles e o sítio Caspana (Tabela 71; Tabela 72: Tabela 73).

Tabela 71 - Valor estatístico e valor-p (corrigidos) encontrados nos testes Chi Quadrado aplicados nos indivíduos com deformação craniana intencional e que apresentavam desgaste dentário de intensidade baixa.

\begin{tabular}{cccc}
\hline & PRE & TIW & POS \\
\hline PRE & $X$ & & \\
TIW & $0,1813(0,6703)$ & $X$ & $X$ \\
POS & $0,0235(0,8781)$ & $0,3833(0,5359)$ & X \\
POS ext & $0,0824(0,7740)$ & $1,0701(0,3009)$ & $0,3380(0,5610)$ \\
\hline
\end{tabular}

sig. $\mathrm{p}<0,05$

Tabela 72 - Valor estatístico e valor-p (corrigidos) encontrados nos testes Chi Quadrado aplicados nos indivíduos com deformação craniana intencional e que apresentavam desgaste dentário de intensidade média.

\begin{tabular}{|c|c|c|c|}
\hline & PRE & TIW & POS \\
\hline PRE & $x$ & & \\
\hline TIW & $3,2869(0,0698)$ & $\mathrm{X}$ & \\
\hline POS & $2,2580(0,1329)$ & $0,0332(0,8554)$ & $\mathrm{X}$ \\
\hline POS ext & $9,5337(0,0020)$ & $4,0894(0,0432)$ & $4,8611(0,0275)$ \\
\hline
\end{tabular}

sig. $\mathrm{p}<0,05$ 
Tabela 73 - Valor estatístico e valor-p (corrigidos) encontrados nos testes Chi Quadrado aplicados nos indivíduos com deformação craniana intencional e que apresentavam desgaste dentário de intensidade alta.

\begin{tabular}{|c|c|c|c|}
\hline & PRE & TIW & POS \\
\hline PRE & $x$ & & \\
\hline TIW & $0,2625(0,6084)$ & $x$ & \\
\hline POS & $0,0521(0,8195)$ & $0,0174(0,8952)$ & $\mathrm{x}$ \\
\hline POS ext & $0,0000(1,0000)$ & $0,0000(1,0000)$ & $0,0000(1,0000)$ \\
\hline
\end{tabular}

sig. $<0,05$

As diferenças observadas na presença ou não das deformações cranianas nos indivíduos portadores de desgastes dentários de qualquer intensidade mostrou-se não serem significativas quando avaliamos os três períodos históricos, mas esta relativa uniformidade das prevalências encontradas para os oásis distingue-se significativamente das prevalências encontradas em Caspana, nosso sítio externo.

Considerando ainda o indivíduo como unidade de análise, os três níveis de desgaste (leve, médio e intenso) foram valorados para comparação entre os períodos, no qual o desgaste leve $=1$; desgaste médio $=2$ e desgaste intenso $=3$. Com isso, as médias destes desgastes dentários foram comparadas entre os períodos (Figura 91).

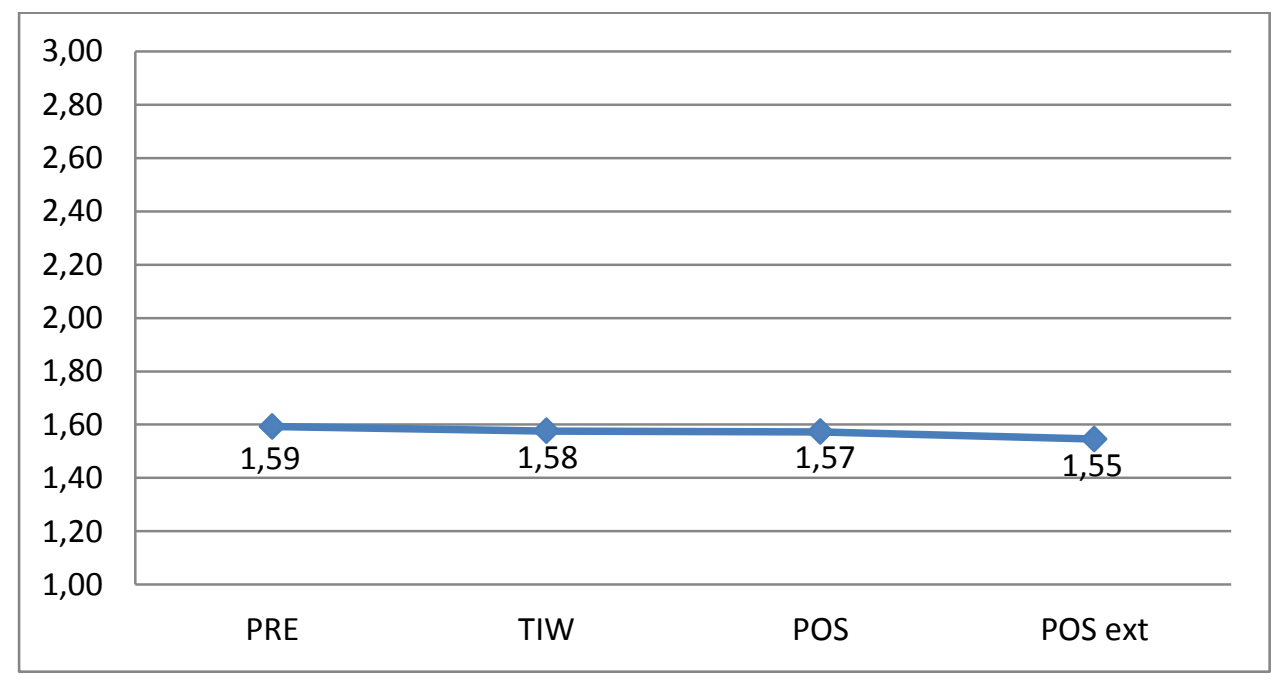

Figura 91 - Médias dos valores do desgaste dentário dos indivíduos com idade superior a 25 anos. 
Ao analisarmos estatisticamente este gráfico que se mantem praticamente estável durante os três períodos nos oásis de San Pedro, não encontramos uma variação significativa do desgaste dentário da população atacamenha ao longo do tempo (Kruskal - Wallis $\left.X^{2}=0,064 ; d f .=3 ; \mathbf{p}=0,996\right)$. Assim mesmo, foram executados testes para avaliação das variações entre cada período, dois a dois (Tabela 74).

Tabela 74 - Valor estatístico e valor-p para averiguação das diferenças dos desgastes dentários entre os períodos.

\begin{tabular}{cc}
\hline \multicolumn{2}{c}{ PRÉ TIWANAKU X TIWANAKU } \\
\hline Mann Whitney U & 1208,000 \\
Wilcoxon W & 5486,000 \\
Z & $-0,243$ \\
p & 0,808 \\
\hline
\end{tabular}

TIWANAKU X PÓS TIWANAKU

\begin{tabular}{cc}
\hline Mann Whitney U & 3441,500 \\
Wilcoxon W & 7719,500 \\
Z & $-0,031$ \\
p & 0,975 \\
\hline
\end{tabular}

\begin{tabular}{cc}
\hline \multicolumn{2}{c}{ PóS TIWANAKU X PÓS TIWANAKU ext } \\
\hline Mann Whitney U & 411,000 \\
Wilcoxon W & 477,000 \\
Z & $-0,022$ \\
p & 0,983 \\
\hline
\end{tabular}

sig. $p<0,05$ 
Com a possibilidade de haver distinção da dieta entre indivíduos do sexo masculino e indivíduos do sexo feminino, a intensidade de desgaste dentário também foi avaliada de forma separada para estes dois grupos (Figura 92).

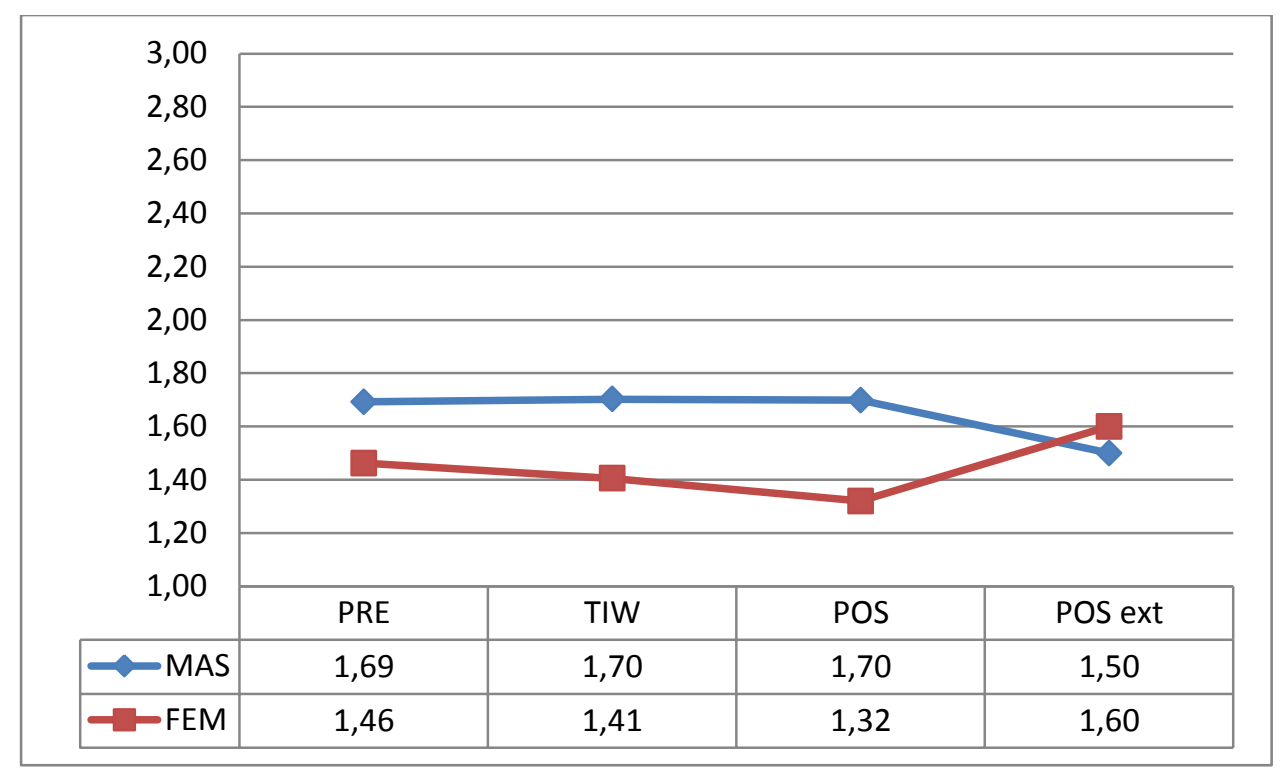

Figura 92 - Médias dos valores do desgaste dentário dos indivíduos com idade superior a 25 anos divididos em homens (MAS) e mulheres (FEM).

As diferenças entre as médias de desgastes dentários apresentadas por homens e mulheres foram analisadas em cada período (Tabela 75). 
Tabela 75 - Valor estatístico e valor-p para averiguação da variação dos desgastes dentários entre homens e mulheres em cada período.

\begin{tabular}{cc}
\hline \multicolumn{2}{c}{ PRÉ TIWANAKU } \\
\hline Mann Whitney U & 68,500 \\
Wilcoxon W & 159,500 \\
Z & $-0,930$ \\
p & 0,418 \\
\hline
\end{tabular}

\begin{tabular}{cc}
\hline \multicolumn{2}{c}{ TIWANAKU } \\
\hline Mann Whitney U & 641,500 \\
Wilcoxon W & 1344,500 \\
Z & $-2,303$ \\
p & $\mathbf{0 , 0 2 1}$ \\
\hline
\end{tabular}

\begin{tabular}{cc}
\hline \multicolumn{2}{c}{ PóS TIWANAKU } \\
\hline Mann Whitney U & 353,500 \\
Wilcoxon W & 678,500 \\
Z & $-2,635$ \\
p & $\mathbf{0 , 0 0 8}$
\end{tabular}

\begin{tabular}{cc}
\hline \multicolumn{2}{c}{ Pós TIWANAKU externo } \\
\hline Mann Whitney U & 13,500 \\
Wilcoxon W & 34,500 \\
Z & $-0,316$ \\
p & 0,792
\end{tabular}

sig. $p<0,05$

Ambos os sexos não apresentaram variações da média de desgaste dentário através do tempo, não sendo estatisticamente significativas nem para o sexo masculino (Kruskal - Wallis $X^{2}=0,554 ; d f .=3 ; p=0,907$ ) nem para o sexo feminino 
(Kruskal - Wallis $X^{2}=1,983 ;$ df. $\left.=3 ; \mathbf{p}=0,576\right)$. A evolução do desgaste dentário de cada sexo foi também avaliada separadamente, comparando os períodos entre si (Tabela 76; Tabela 77).

Tabela 76 - Valor estatístico e valor-p para averiguação das médias de desgaste dentário apresentadas pelos homens entre os períodos.

\begin{tabular}{cc}
\hline \multicolumn{2}{c}{ PRÉ TIWANAKU X TIWANAKU } \\
\hline Mann Whitney U & 303,500 \\
Wilcoxon W & 394,500 \\
Z & $-0,040$ \\
p & 0,968 \\
\hline
\end{tabular}

\section{TIWANAKU X PÓS TIWANAKU}

\begin{tabular}{cc}
\hline Mann Whitney U & 1010,000 \\
Wilcoxon W & 2138,000 \\
Z & $-0,005$ \\
p & 0,996 \\
\hline
\end{tabular}

\begin{tabular}{cc}
\hline PóS TIWANAKU X PÓS TIWANAKU externo \\
\hline Mann Whitney U & 108,000 \\
Wilcoxon W & 129,000 \\
Z & $-0,728$ \\
p & 0,541 \\
\hline
\end{tabular}

sig. $p<0,05$ 
Tabela 77 - Valor estatístico e valor-p para averiguação das médias de desgaste dentário apresentadas pelas mulheres entre os períodos.

\begin{tabular}{cc}
\hline \multicolumn{2}{c}{ PRÉ TIWANAKU X TIWANAKU } \\
\hline Mann Whitney U & 220,000 \\
Wilcoxon W & 923,000 \\
Z & $-0,533$ \\
p & 0,594 \\
\hline
\end{tabular}

\begin{tabular}{cc}
\hline \multicolumn{2}{c}{ TIWANAKU X PóS TIWANAKU } \\
\hline Mann Whitney U & 429,000 \\
Wilcoxon W & 754,000 \\
Z & $-0,588$ \\
p & 0,557 \\
\hline
\end{tabular}

\begin{tabular}{cc}
\hline PÓS TIWANAKU X PÓS TIWANAKU externo \\
\hline Mann Whitney U & 44,000 \\
Wilcoxon W & 369,000 \\
Z & $-1,251$ \\
p & 0,327 \\
\hline
\end{tabular}

sig. $p<0,05$

Mantendo a mesma estratégia de análise dos desgastes dentários, os esqueletos foram separados em indivíduos que apresentavam deformações cranianas intencionais e indivíduos que não apresentavam (Figura 93). 


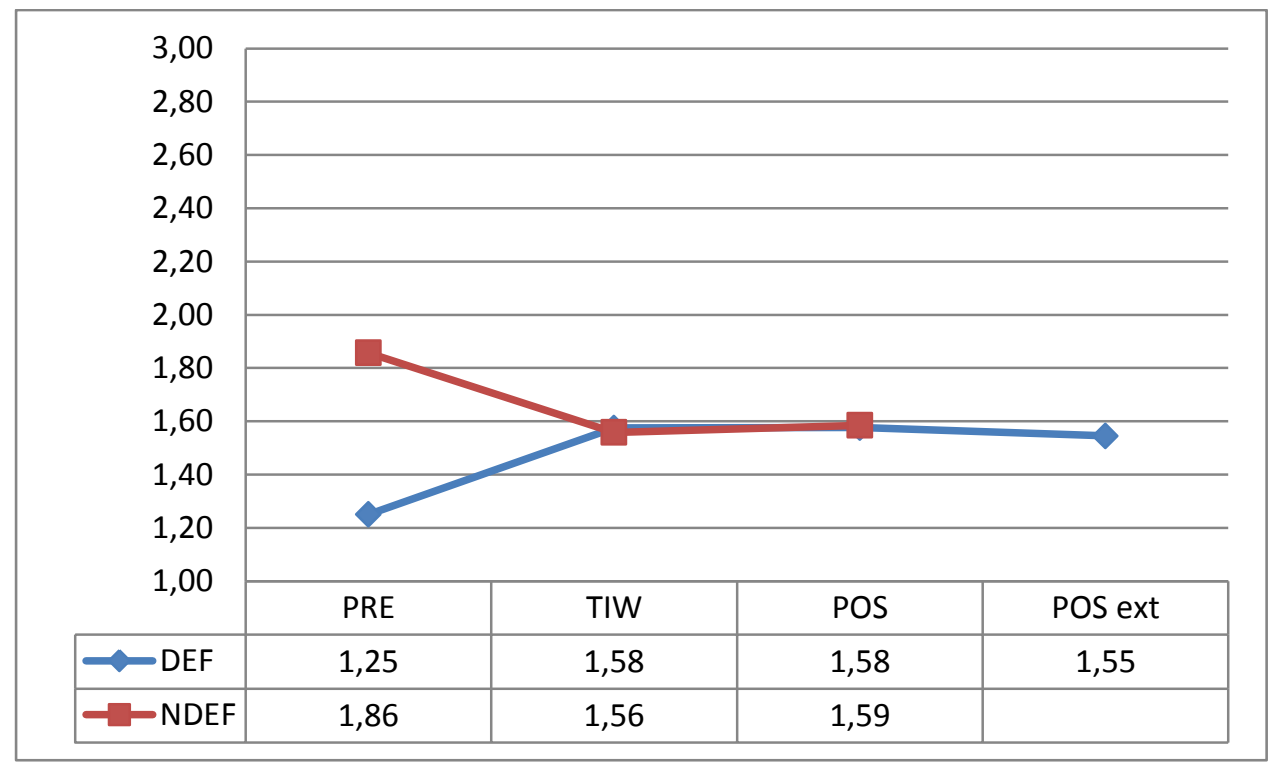

Figura 93 - Médias dos valores do desgaste dentário de indivíduos com idade superior a 25 anos e divididos em crânios com deformação (DEF) e sem deformação (NDEF).

As médias de desgaste dentário foram analisadas comparando indivíduos com e sem deformações cranianas dentro de cada período estudado (Tabela 78). 
Tabela 78 - Valor estatístico e valor-p para averiguação das diferenças das médias de desgaste dentário entre crânios deformados e não deformados em cada período.

\begin{tabular}{cc}
\hline \multicolumn{2}{c}{ PRÉ TIWANAKU } \\
\hline Mann Whitney U & 25,000 \\
Wilcoxon W & 61,000 \\
Z & $-2,410$ \\
p & $\mathbf{0 , 0 3 5}$ \\
\hline
\end{tabular}

\begin{tabular}{cc}
\hline \multicolumn{2}{c}{ TIWANAKU } \\
\hline Mann Whitney U & 847,500 \\
Wilcoxon W & 1793,500 \\
Z & $-0,129$ \\
p & 0,898 \\
\hline
\end{tabular}

\begin{tabular}{cc}
\hline \multicolumn{2}{c}{ PóS TIWANAKU } \\
\hline Mann Whitney U & 667,000 \\
Wilcoxon W & 1228,000 \\
Z & $-0,116$ \\
p & 0,907 \\
\hline
\end{tabular}

sig. $p<0,05$

Os crânios deformados, assim como os não deformados, não apresentaram variações de suas médias de desgaste dentário ao longo do tempo (deformados: Kruskal - Wallis $X^{2}=2,271 ; d f .=3 ; p=0,518$ e não deformados: Kruskal - Wallis $X^{2}=$ 3,173; df. $=2 ; p=0,205)$.

Ainda assim, as diferenças das médias de desgaste dentário entre os dois grupos foram analisadas entre os períodos (Tabela 79 e Tabela 80). 
Tabela 79 - Valor estatístico e valor-p para averiguação das diferenças das médias de desgaste dentário dos crânios deformados entre os períodos.

\begin{tabular}{cc}
\hline \multicolumn{2}{c}{ PRÉ TIWANAKU X TIWANAKU } \\
\hline Mann Whitney U & 114,000 \\
Wilcoxon W & 150,000 \\
Z & $-1,445$ \\
p & 0,213 \\
\hline
\end{tabular}

\begin{tabular}{cc}
\hline \multicolumn{2}{c}{ TIWANAKU X PÓS TIWANAKU } \\
\hline Mann Whitney U & 657,500 \\
Wilcoxon W & 1218,500 \\
Z & $-0,031$ \\
p & 0,975 \\
\hline
\end{tabular}

\begin{tabular}{cc}
\hline PÓS TIWANAKU X PÓS TIWANAKU externo \\
\hline Mann Whitney U & 181,000 \\
Wilcoxon W & 247,000 \\
Z & $-0,015$ \\
$\mathbf{p}$ & 0,988 \\
\hline
\end{tabular}

sig. $p<0,05$ 
Tabela 80 - Valor estatístico e valor-p para averiguação das diferenças das médias de desgaste dentário dos crânios não deformados em cada período.

\begin{tabular}{cc}
\hline \multicolumn{2}{c}{ PRÉ TIWANAKU X TIWANAKU } \\
\hline Mann Whitney U & 218,500 \\
Wilcoxon W & 1164,500 \\
Z & $-1,732$ \\
p & 0,083 \\
\hline
\end{tabular}

\begin{tabular}{cc}
\hline \multicolumn{2}{c}{ TIWANAKU X PÓS TIWANAKU } \\
\hline Mann Whitney U & 859,500 \\
Wilcoxon W & 1805,500 \\
Z & $-0,222$ \\
p & 0,824 \\
\hline
\end{tabular}

sig. $\mathrm{p}<0,05$

\section{Hipoplasia linear do esmalte}

As hipoplasias lineares do esmalte dentário foram avaliadas apenas nos dentes incisivos, caninos e primeiros molares, tanto superiores como inferiores. Apesar da possibilidade hipotética de analisar mais de 6000 dentes numa população de 402 indivíduos, como é o caso da minha amostra, devido às perdas dentárias em vida e principalmente às perdas post mortem, meu universo amostral foi reduzido a exatos 152 dentes, divididos nos 4 períodos avaliados, conforme se observa na Tabela 81. 
Tabela 81 - Quantidade de dentes analisados por período.

\begin{tabular}{cc}
\hline PRE TIWANAKU & 19 \\
TIWANAKU & 71 \\
POS TIWANAKU & 52 \\
POS TIWANAKU externo & 10 \\
\hline
\end{tabular}

Assim, a distribuição das prevalências de hipoplasia linear do esmalte dentário ao longo dos períodos estudados está disposta na Figura 94.

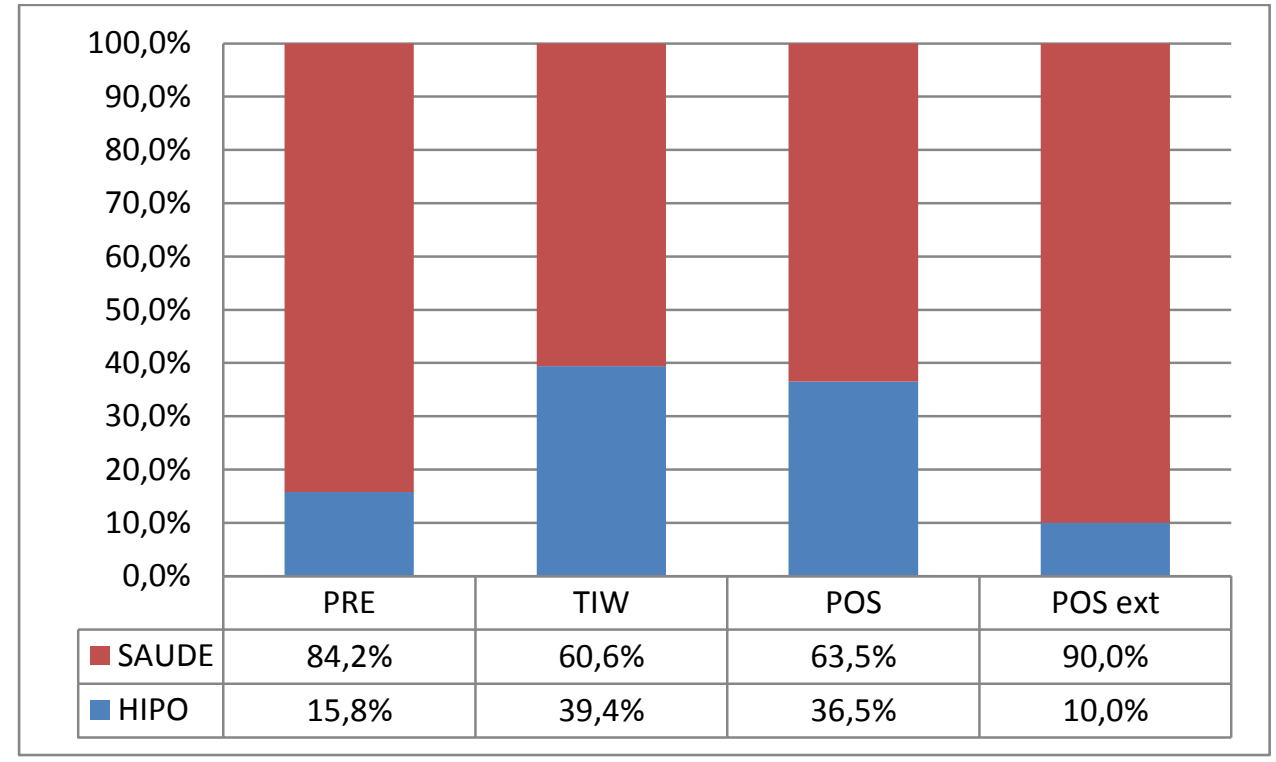

Figura 94 - Prevalência de indivíduos acometidos pela hipoplasia linear do esmalte.

Para a caracterização dos indivíduos acometidos pela hipoplasia linear do esmalte dentário, foram computados apenas os indivíduos que apresentaram no mínimo uma lesão linear em mais de um dente presente. Indivíduos que apresentaram dentes com hipoplasias pontuais ou amorfas, mesmo que em mais de um dente, não foram considerados nesta análise. 
As prevalências dos indivíduos acometidos pela hipoplasia linear do esmalte dentário ( 2 ou mais dentes acometidos) foram analisadas estatisticamente e os resultados estão presentes na Tabela 82.

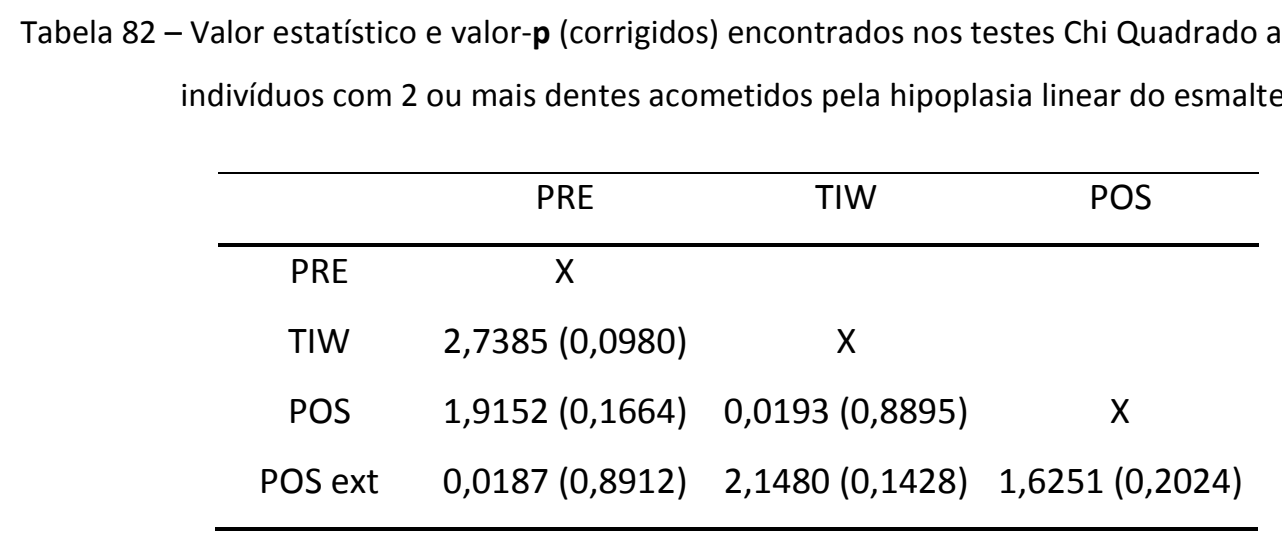

sig. $p<0,05$

Os indivíduos que possuíam apenas um dente com lesão hipoplásica, mesmo que linear, e não apresentavam os outros dentes analisáveis (incisivos, caninos e primeiros molares) por perda ante ou post mortem, também não foram considerados portadores da patologia. Apesar disso, os indivíduos que possuíam apenas um dente acometido por lesão hipoplásica estão apresentados na Figura 95, mostrando que a prevalência de indivíduos acometidos por hipoplasias lineares pode ter sido subestimada. 


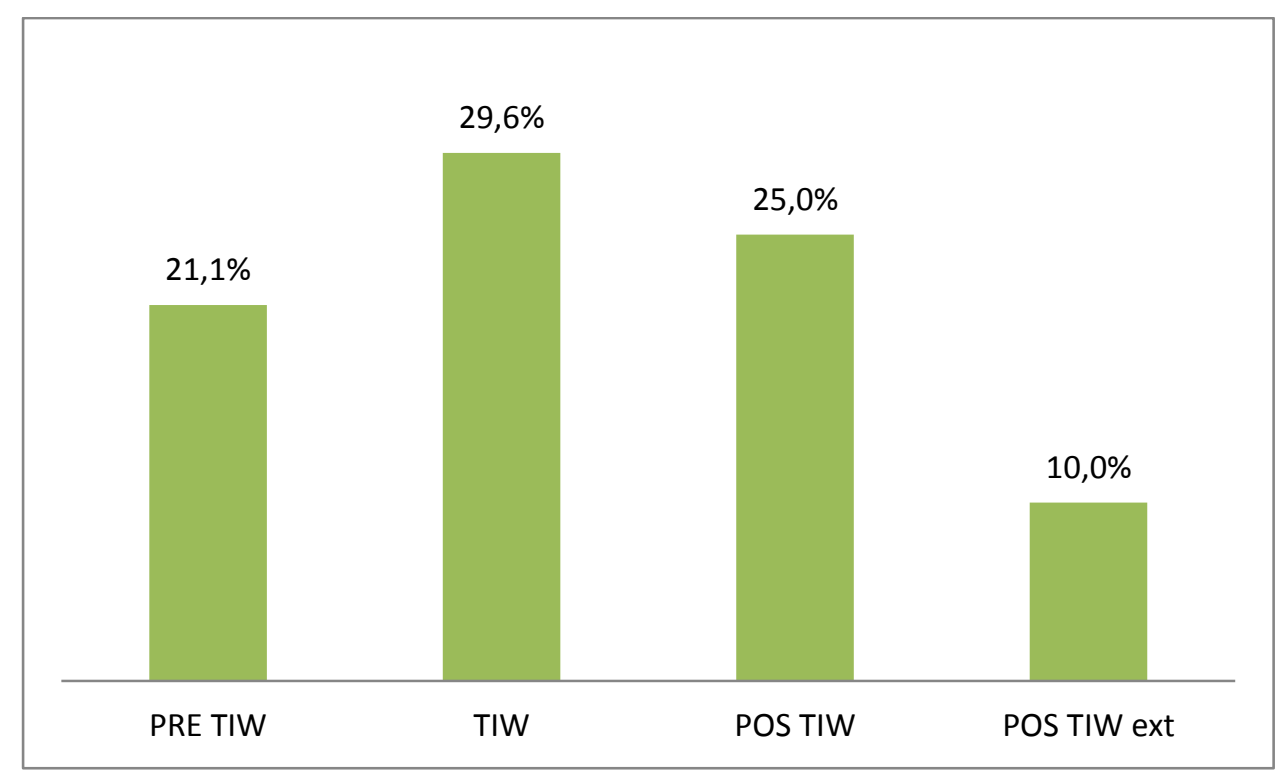

Figura 95 - Prevalência dos indivíduos que apresentaram apenas 1 dente acometido por lesão hipoplásica.

\section{Reabsorção periodontal}

As reabsorções periodontais foram analisadas buscando, independentemente da presença de cálculos salivares, evidências de patologias periodontais causadas por acúmulo de cálculos salivares nos dentes observados. As medidas obtidas com a sonda milimetrada a partir do limite amelo-dentinário foram computadas e agrupadas em 3 grupos de acordo com sua intensidade de reabsorção. Assim como as outras patologias descritas, os três períodos foram comparados entre si e também foram comparados com o sítio Caspana (Figura 96). 


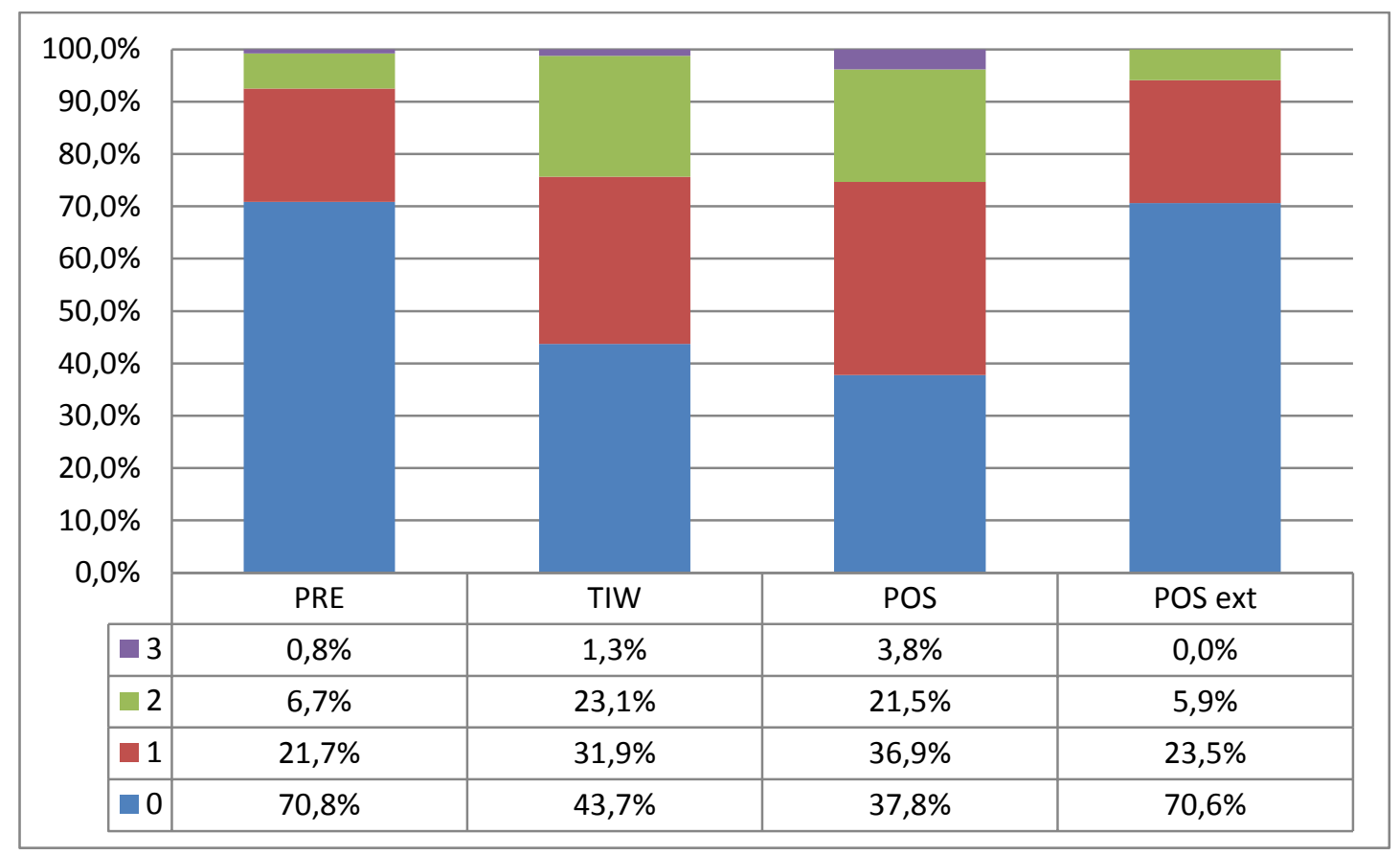

Figura 96 - Prevalências dos níveis de reabsorção periodontal nos indivíduos distribuídos pelos períodos.

Quando avaliamos os indivíduos desta amostra em apenas dois grandes grupos, sendo um grupo de indivíduos com ausência de reabsorção (ou reabsorção dentro dos $2 \mathrm{~mm}$ considerados como indivíduo saudável) e indivíduos que apresentam algum nível de reabsorção, a distribuição encontrada é apresentada na Figura 97.

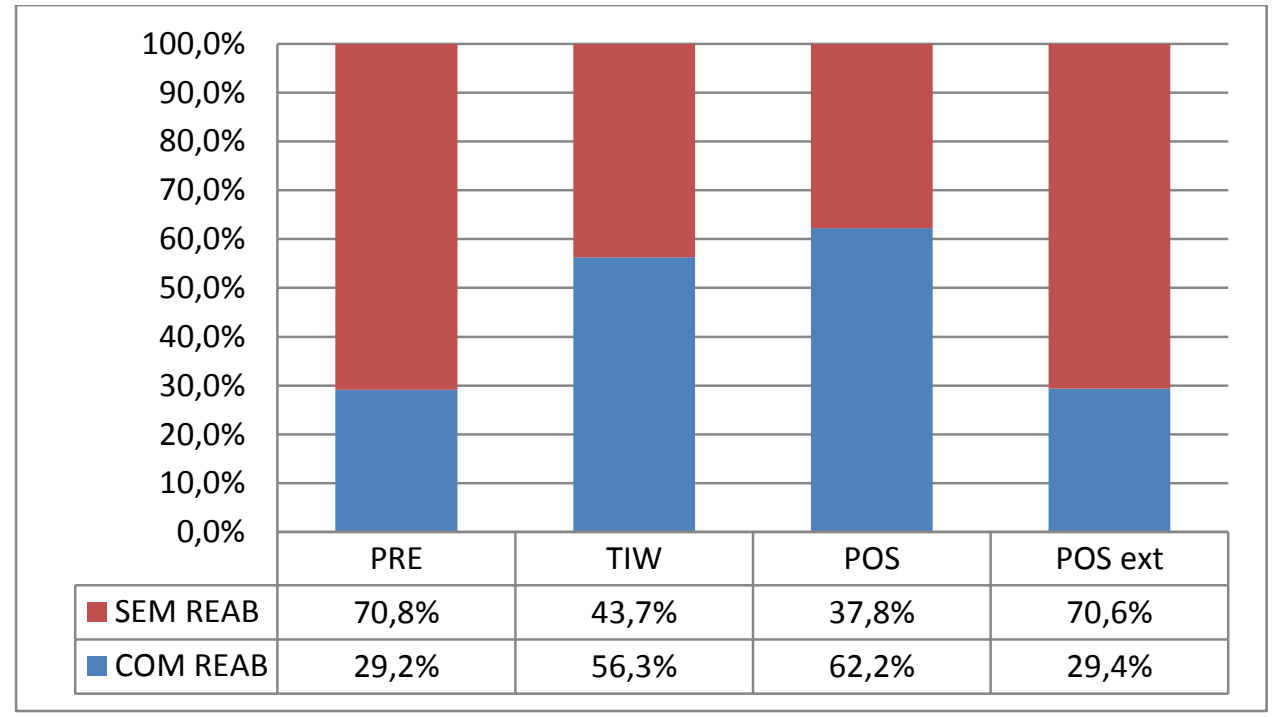

Figura 97 - Prevalências de indivíduos com e sem reabsorção periodontal. 
As prevalências dos indivíduos que apresentaram rebordos alveolares reabsorvidos ou não foram analisadas estatisticamente através de teste Chi Quadrado (Tabela 83).

Tabela 83 - Valor estatístico e valor-p (corrigidos) encontrados nos testes Chi Quadrado aplica
indivíduos com reabsorção periodontal.
\begin{tabular}{cccc} 
PRE & TIW & POS \\
\hline PRE & X & X \\
TIW & $\mathbf{2 9 , 0 9 5 9 ( 0 , 0 0 0 0 )}$ & X \\
POS & $\mathbf{4 0 , 3 5 5 1 ( 0 , 0 0 0 0 )}$ & $3,7148(0,0539)$ & $\mathbf{2 4 , 6 8 1 6 ( 0 , 0 0 0 0 )}$ \\
POS ext & $0,0172(0,8955)$ & $\mathbf{1 6 , 9 3 0 1 ( 0 , 0 0 0 0 )}$ & $\mathbf{2 4}(0,0)$
\end{tabular}

sig. $p<0,05$

O importante aumento na prevalência de reabsorções periodontais observado entre o período Pré Tiwanaku e o período Tiwanaku mostrou ser estatisticamente significativo, assim como a diferença encontrada entre o período Pós Tiwanaku e o sítio Caspana. Se considerarmos significativos valores abaixo ou igual a 0,05 , encontraremos significância também entre os períodos Tiwanaku e Pós Tiwanaku.

A separação entre os dentes anteriores e posteriores já executada para outros marcadores dentários também foi empregada para a avaliação das reabsorções periodontais, pois as formações de cálculos salivares e consequentemente, a presença de reabsorções periodontais, são distintas de acordo com a anatomia dentária e sua localização na arcada dentária.

Assim, as prevalências de indivíduos apresentando reabsorções alveolares encontradas apenas nos dentes anteriores estão dispostas no gráfico a seguir (Figura 98). 


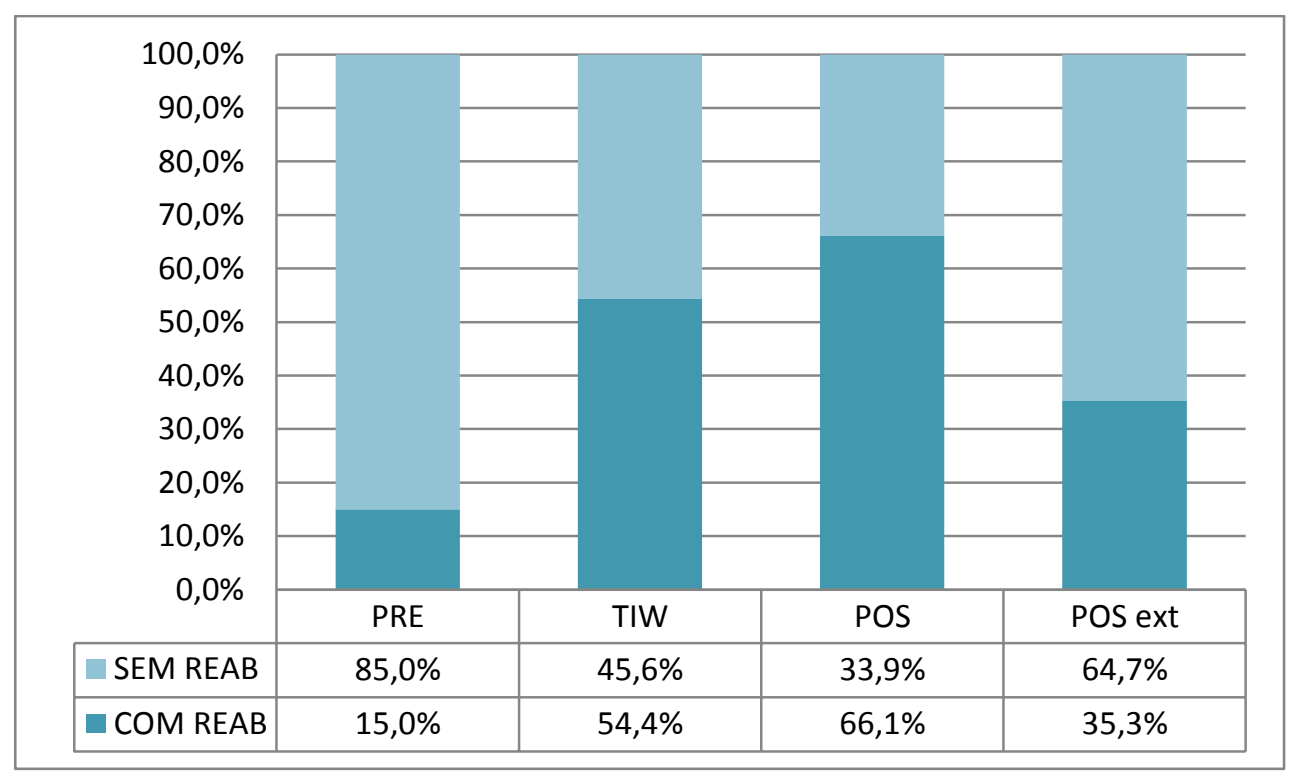

Figura 98 - Prevalências dos indivíduos acometidos ou não pelas reabsorções periodontais nos dentes anteriores.

As variações encontradas entre todas as prevalências dos distintos períodos foram analisadas através do teste de Chi Quadrado. O resultado apresentado comprova uma diferença estatisticamente significativa entre todos os períodos estudados (Tabela 84).

Tabela 84 - Valor estatístico e valor-p (corrigidos) encontrados nos testes Chi Quadrado aplicados apenas nos dentes anteriores de indivíduos com reabsorção periodontal.

\begin{tabular}{cccc}
\hline & PRE & TIW & POS \\
\hline PRE & X & & \\
TIW & $9,9857(0,0016)$ & $X$ & $X$ \\
POS & $16,2734(0,0001)$ & $3,9518(0,0468)$ & $X$ \\
POS ext & $1,1013(0,2940)$ & $1,6294(0,2018)$ & $4,7312(0,0296)$ \\
\hline
\end{tabular}

sig. $p<0,05$ 
Os dentes posteriores também foram igualmente estudados separadamente. As prevalências de indivíduos com e sem reabsorção alveolar ao longo do tempo estão dispostas abaixo (Figura 99).

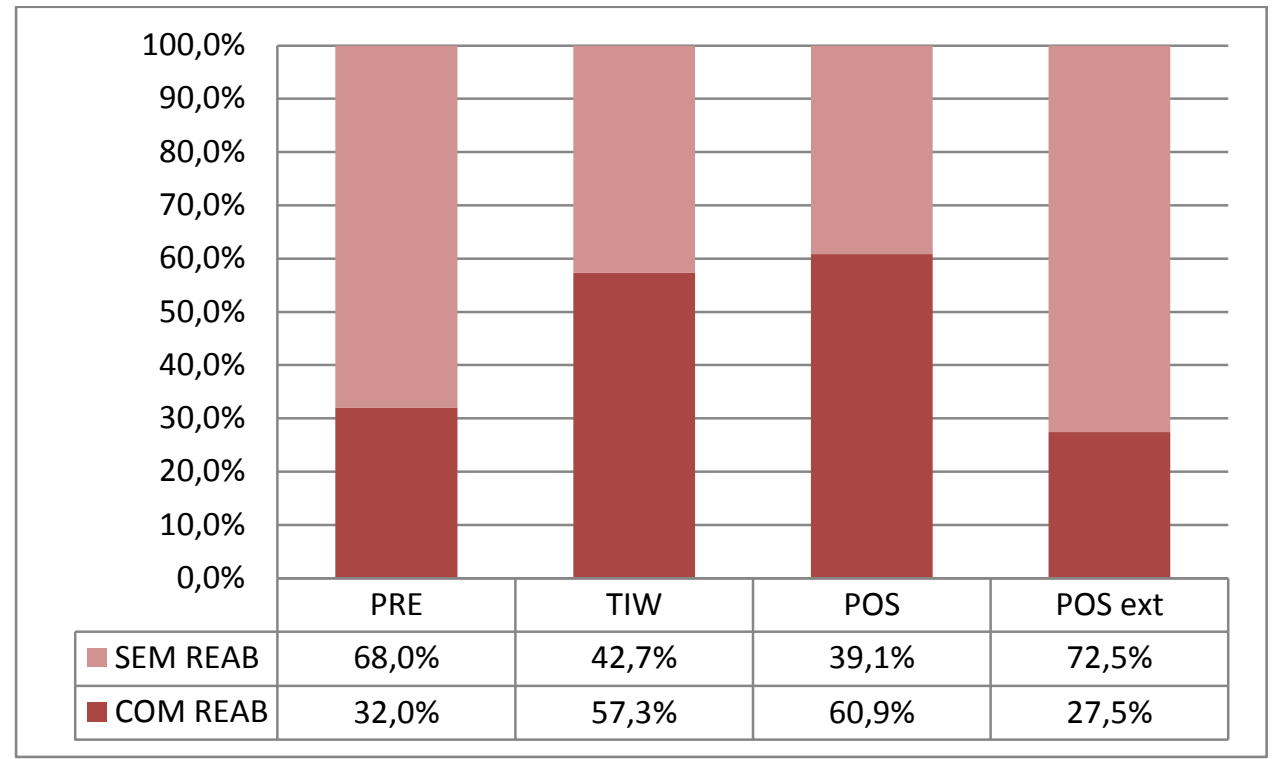

Figura 99 - Prevalências de indivíduos que apresentaram ou não reabsorção alveolar em seus dentes posteriores.

Apesar de apresentar um aumento proporcional menor de indivíduos com reabsorção alveolar ao longo do tempo, as prevalências foram analisadas estatisticamente (Tabela 85).

Tabela 85 - Valor estatístico e valor-p (corrigidos) encontrados nos testes Chi Quadrado aplicados apenas nos dentes posteriores de indivíduos com reabsorção periodontal.

\begin{tabular}{cccc}
\hline & PRE & TIW & POS \\
\hline PRE & $X$ & & \\
TIW & $20,0261(0,0000)$ & $X$ & $X$ \\
POS & $24,5307(0,0000)$ & $0,8487(0,3569)$ & X \\
POS ext & $0,1501(0,6984)$ & $15,2732(0,0001)$ & $18,6809(0,0000)$ \\
\hline
\end{tabular}

sig. $p<0,05$ 
A prevalência de indivíduos portadores de dentes posteriores com reabsorção periodontal encontrada durante o período Tiwanaku é estatisticamente maior que a encontrada no período anterior, porém, para os dentes posteriores, o mesmo não acontece quando comparamos o período Tiwanaku com o período subsequente. Para os dentes posteriores, o sítio Caspana distingue-se significativamente dos períodos Tiwanaku e Pós Tiwanaku.

Homens e mulheres foram analisados individualmente quanto à reabsorção periodontal que seus maxilares apresentaram (Figura 100).

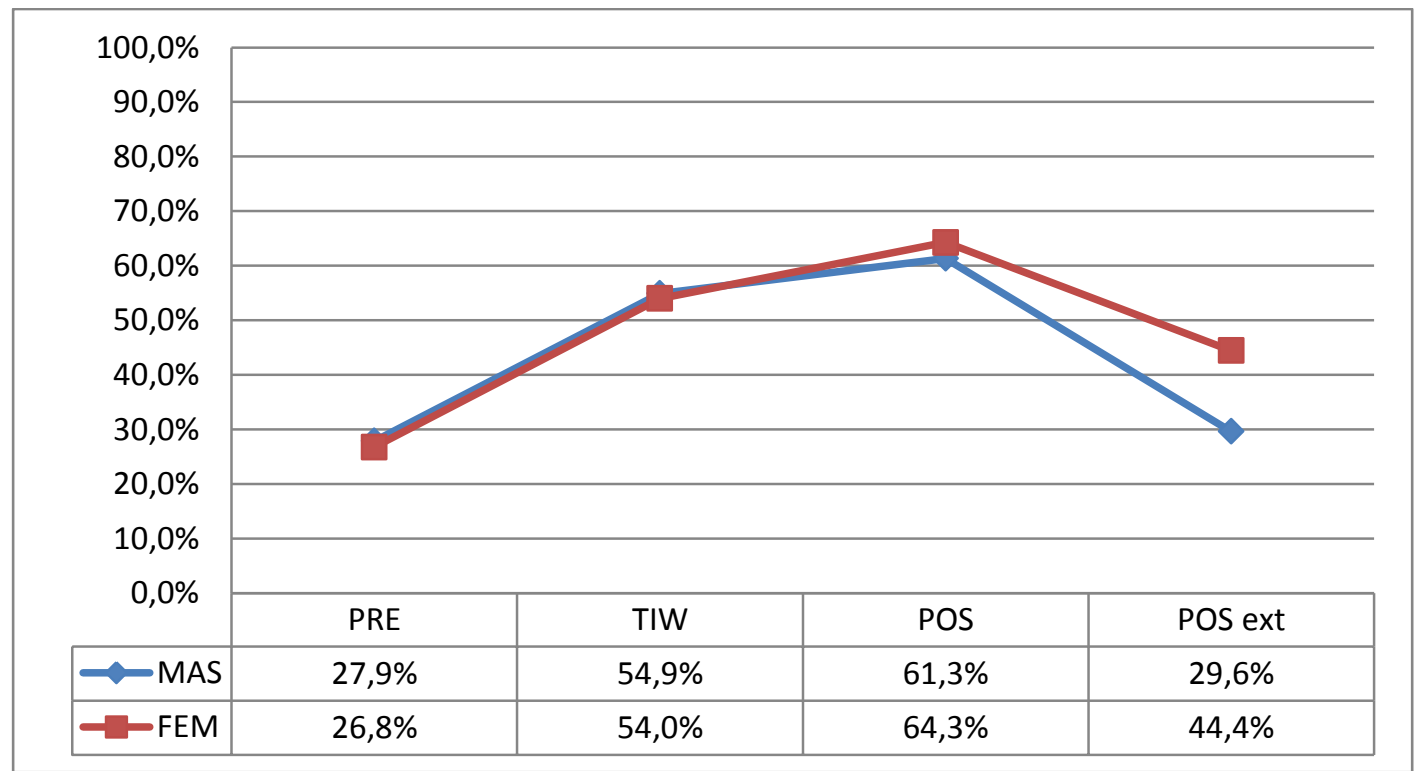

Figura 100 - Prevalências de reabsorção periodontal de homens (MAS) e mulheres (FEM) ao longo do tempo.

As prevalências das reabsorções periodontais de homens e mulheres foram comparadas dentro de cada período (Tabela 86), e posteriormente, estudadas ao longo do tempo (Tabela 87; Tabela 88). 
Tabela 86 - Valor estatístico e valor-p (corrigidos) encontrados nos testes Chi Quadrado aplicados sobre a diferença entre as reabsorções periodontais de homens e mulheres apresentadas em cada período.

\begin{tabular}{ccc}
\hline & $\mathbf{X}^{2}$ & $\mathbf{p}$ \\
\hline Pré Tiwanaku & 0,0058 & 0,9392 \\
Tiwanaku & 0,0181 & 0,8929 \\
Pós Tiwanaku & 0,2490 & 0,6178 \\
Pós Tiwanaku externo & 0,7147 & 03979 \\
\hline
\end{tabular}

sig. $\mathrm{p}<0,05$

Tabela 87 - Valor estatístico e valor-p (corrigidos) encontrados nos testes Chi Quadrado aplicados sobre as diferenças das reabsorções periodontais em indivíduos do sexo masculino.

\begin{tabular}{cccc}
\hline & PRE & TIW & POS \\
\hline PRE & X & & \\
TIW & $\mathbf{1 4 , 5 2 1 3 ( 0 , 0 0 0 1 )}$ & $X$ & $X$ \\
POS & $\mathbf{2 0 , 6 1 4 5 ( 0 , 0 0 0 0 )}$ & $2,3025(0,1292)$ & X \\
POS ext & $0,0076(0,9304)$ & $\mathbf{5 , 5 3 8 9 ( 0 , 0 1 8 6 )}$ & $\mathbf{8 , 7 5 9 5 ( 0 , 0 0 3 1 )}$ \\
\hline
\end{tabular}

sig. $p<0,05$

Tabela 88 - Valor estatístico e valor-p (corrigidos) encontrados nos testes Chi Quadrado aplicados sobre as diferenças das reabsorções periodontais em indivíduos do sexo feminino.

\begin{tabular}{|c|c|c|c|}
\hline & PRE & TIW & POS \\
\hline PRE & $x$ & & \\
\hline TIW & $12,2323(0,0005)$ & $x$ & \\
\hline POS & $22,3645(0,0000)$ & $3,7546(0,0527)$ & $x$ \\
\hline POS ext & $1,8462(0,1742)$ & $0,5439(0,4608)$ & $3,0762(0,0794)$ \\
\hline
\end{tabular}

sig. $p<0,05$ 
As prevalências de reabsorções periodontais de homens e mulheres, quando comparadas entre si, não apresentaram diferenças significativas durante nenhum período analisado; nem mesmo em Caspana, onde os valores apresentados são mais divergentes.

\section{Cálculo salivar}

A presença dos cálculos salivares, ainda que evidentemente subestimada pelo mal estado de conservação da coleção já mencionado, foi primeiramente avaliada quanto à sua localização e também quanto à sua magnitude. As prevalências apresentadas no gráfico abaixo representam os dentes portadores ou não de cálculos salivares. Quando presentes, os cálculos estão divididos em supragengivais (1, 2 e 3 ) e subgengivais (4, 5 e 6), sendo que esta numeração é relativa à intensidade de acometimento, de forma crescente (Figura 101). 


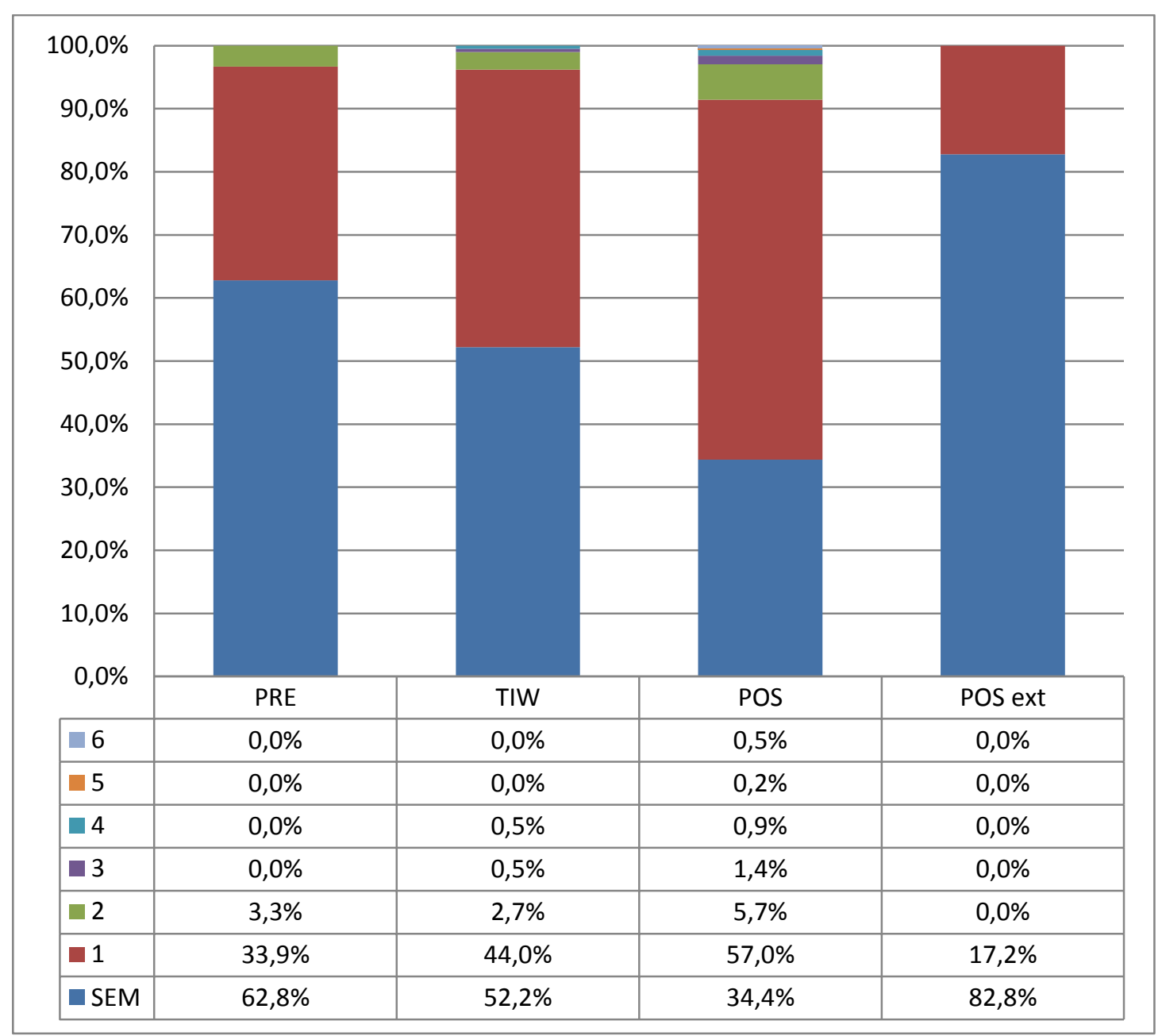

Figura 101 - Prevalências da presença, localização e intensidade dos cálculos salivares nos indivíduos de cada período.

Os cálculos salivares observados foram agrupados em macro-grupos, os supragengivais e os subgengivais. Esta manobra se deve ao fato de que, tanto nos cálculos salivares supragengivais como nos subgengivais, os cálculos salivares de menor intensidade são a maioria dos casos observados. Se analisarmos a amostra como um todo, $91 \%$ dos casos de cálculos salivar supragengival são de intensidade 1 (Figura 102). 


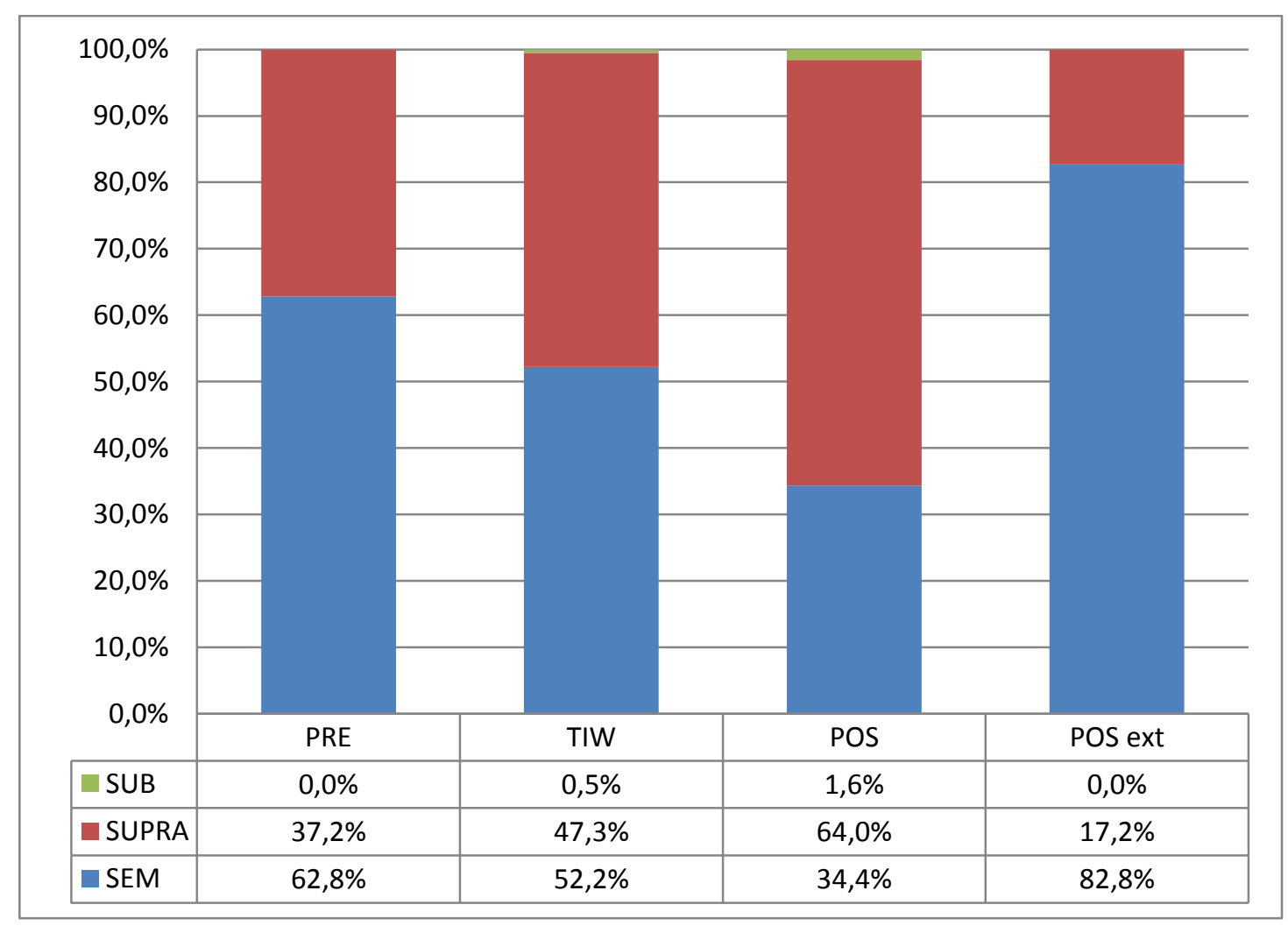

Figura 102 - Prevalências de presença e ausência de cálculos salivares, além da localização dos cálculos presentes.

Por serem os cálculos mais presentes em toda a amostra, as prevalências dos cálculos salivares supragengivais foram analisadas estatisticamente (Tabela 89).

Tabela 89 - Valor estatístico e valor-p (corrigidos) encontrados nos testes Chi Quadrado quando analisados os dentes portadores de cálculos salivares supragengivais.

\begin{tabular}{cccc}
\hline & PRE & TIW & POS \\
\hline PRE & $X$ & & \\
TIW & $4,8671(0,0437)$ & $X$ & $X$ \\
POS & $29,2491(0,0000)$ & $33,6246(0,0000)$ & \\
POS EXT & $6,4229(0,0113)$ & $18,7164(0,0000)$ & $46,5675(0,0000)$ \\
\hline
\end{tabular}

sig. $p<0,05$ 
Os testes estatísticos indicaram diferença significativa entre todos os períodos analisados quanto à presença dos cálculos salivares, demonstrando uma tendência crescente de acúmulo destes cálculos ao longo do tempo nos indivíduos avaliados. Quando incluímos Caspana nesta análise, a quantidade média de dentes contendo cálculos salivares encontrados neste sítio se mostra também diferente estatisticamente, mas neste caso, Caspana apresenta uma quantidade muito inferior de cálculos salivares do que qualquer dos períodos avaliados nos oásis de San Pedro de Atacama.

Novamente, a divisão entre os dentes anteriores e posteriores foi aplicada, sob a justificativa já apresentada nas análises das reabsorções periodontais.

Os dentes anteriores apresentaram a mesma tendência encontrada na análise anterior, na qual não houve separação em anteriores e posteriores (Figura 103).

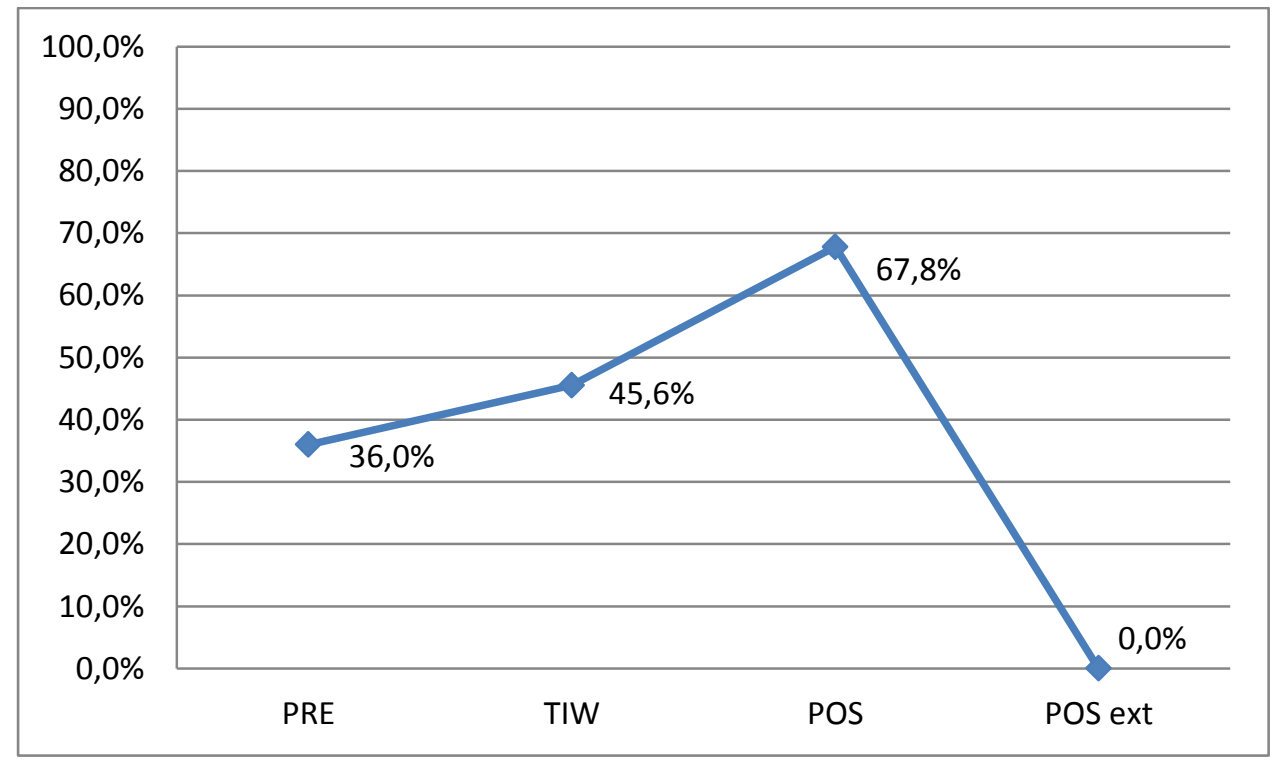

Figura 103 - Prevalência de cálculos salivares supragengivais presentes nos dentes anteriores ao longo dos períodos avaliados.

Os períodos Pré Tiwanaku e o período Tiwanaku apresentaram, nos dentes anteriores, uma prevalência ligeiramente inferior à apresentada na amostra como um 
todo. Quanto ao período Pós Tiwanaku, este apresentou para os anteriores uma prevalência maior.

Apesar de encontrarmos um aumento na prevalência dos cálculos salivares supragengivais presentes nos dentes anteriores entre os períodos Pré Tiwanaku e Tiwanaku, esta diferença não se mostrou estatisticamente significativa. Todas as outras comparações executadas entre as prevalências observadas se mantiveram significativas, assim como na análise anterior (Tabela 90).

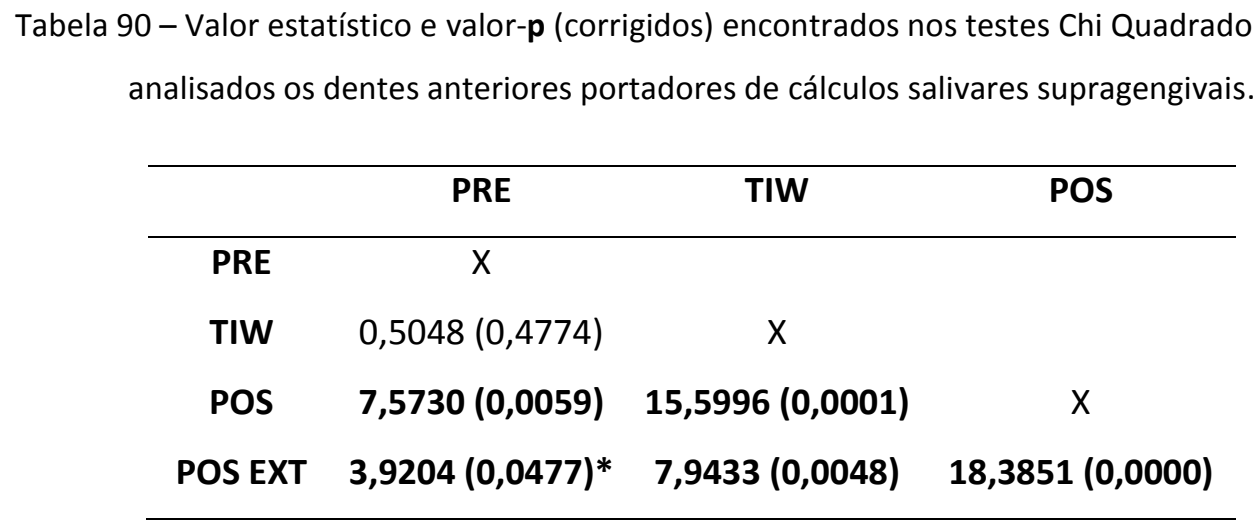

sig. $\mathrm{p}<0,05$

Para a comparação entre os períodos Pré Tiwanaku e o sítio Caspana, devido ao pequeno número de indivíduos com dentes analisáveis, foi também executado o teste exato de Fisher, apresentando valor de $\mathbf{p}$ igualmente significativo $(\mathbf{p}=0,0184)$.

Quanto aos dentes posteriores, a tendência de aumento dos cálculos salivares ao longo do tempo se mantem, assim como na análise dos dentes anteriores. Os períodos Pré Tiwanaku e Tiwanaku apresentam prevalências superiores às encontradas na análise da amostra total e o período Pós Tiwanaku apresenta valores inferiores na mesma comparação (Figura 104). 


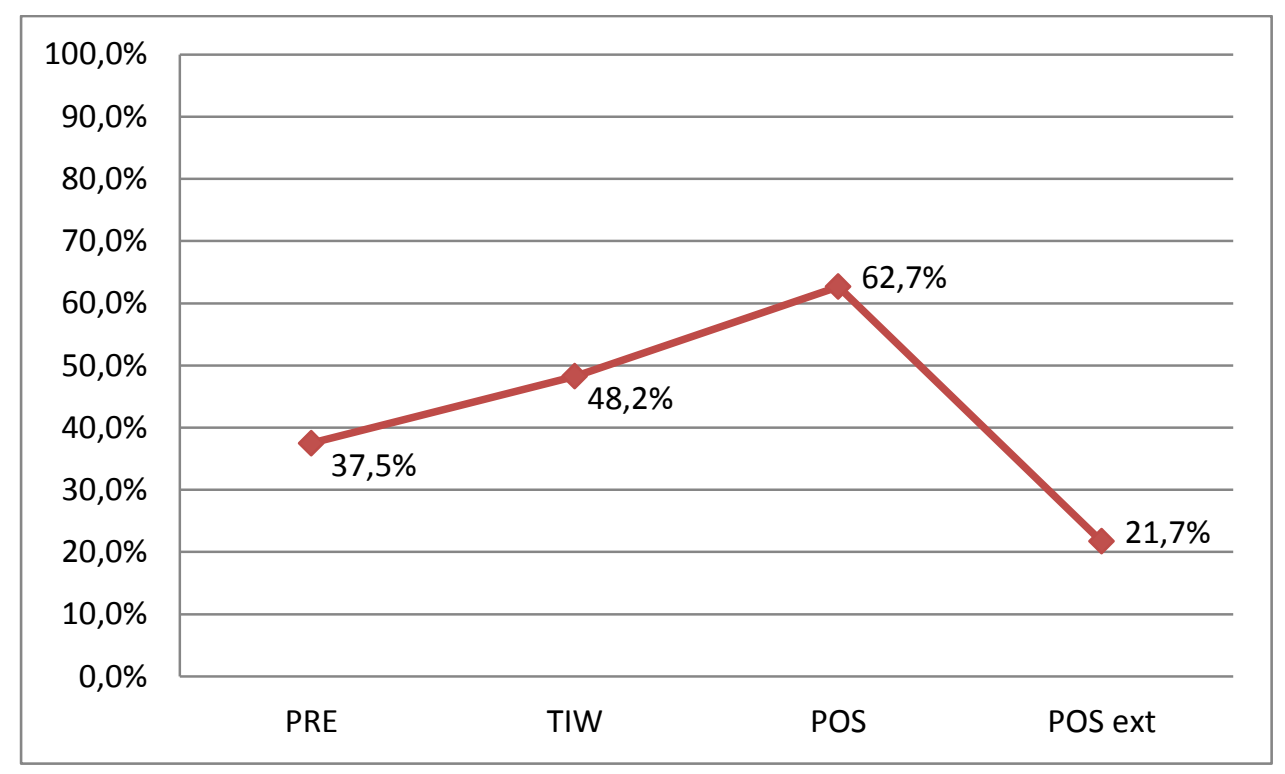

Figura 104 - Prevalência de cálculos salivares supragengivais presentes nos dentes posteriores ao longo dos períodos avaliados.

Para os dentes posteriores, assim como foi encontrado para os dentes anteriores, o aumento entre os períodos Pré Tiwanaku e Tiwanaku não se mostrou significativo e, diferentemente do que foi encontrado quando analisamos os dentes anteriores, a diferença entre o período Pré Tiwanaku e o sítio Caspana, no caso dos dentes posteriores, também não se mostrou estatisticamente significativo (Tabela 91).

Tabela 91 - Valor estatístico e valor-p (corrigidos) encontrados nos testes Chi Quadrado quando analisados os dentes posteriores portadores de cálculos salivares supragengivais.

\begin{tabular}{cccc}
\hline & PRE & TIW & POS \\
\hline PRE & $X$ & & \\
TIW & $3,5599(0,0592)$ & $X$ & $X$ \\
POS & $20,2100(0,0000)$ & $17,6504(0,0000)$ & \\
POS EXT & $2,8444(0,0917)$ & $11,1695(0,0008)$ & $27,9232(0,0000)$
\end{tabular}

sig. $\mathrm{p}<0,05$ 
Também foram analisadas as prevalências de cálculos salivares nos indivíduos do sexo masculino e feminino separadamente, utilizando apenas os cálculos salivares supragengivais nesta comparação, uma vez que foi o tipo de cálculo salivar mais comumente encontrado nos esqueletos estudados (Figura 105).

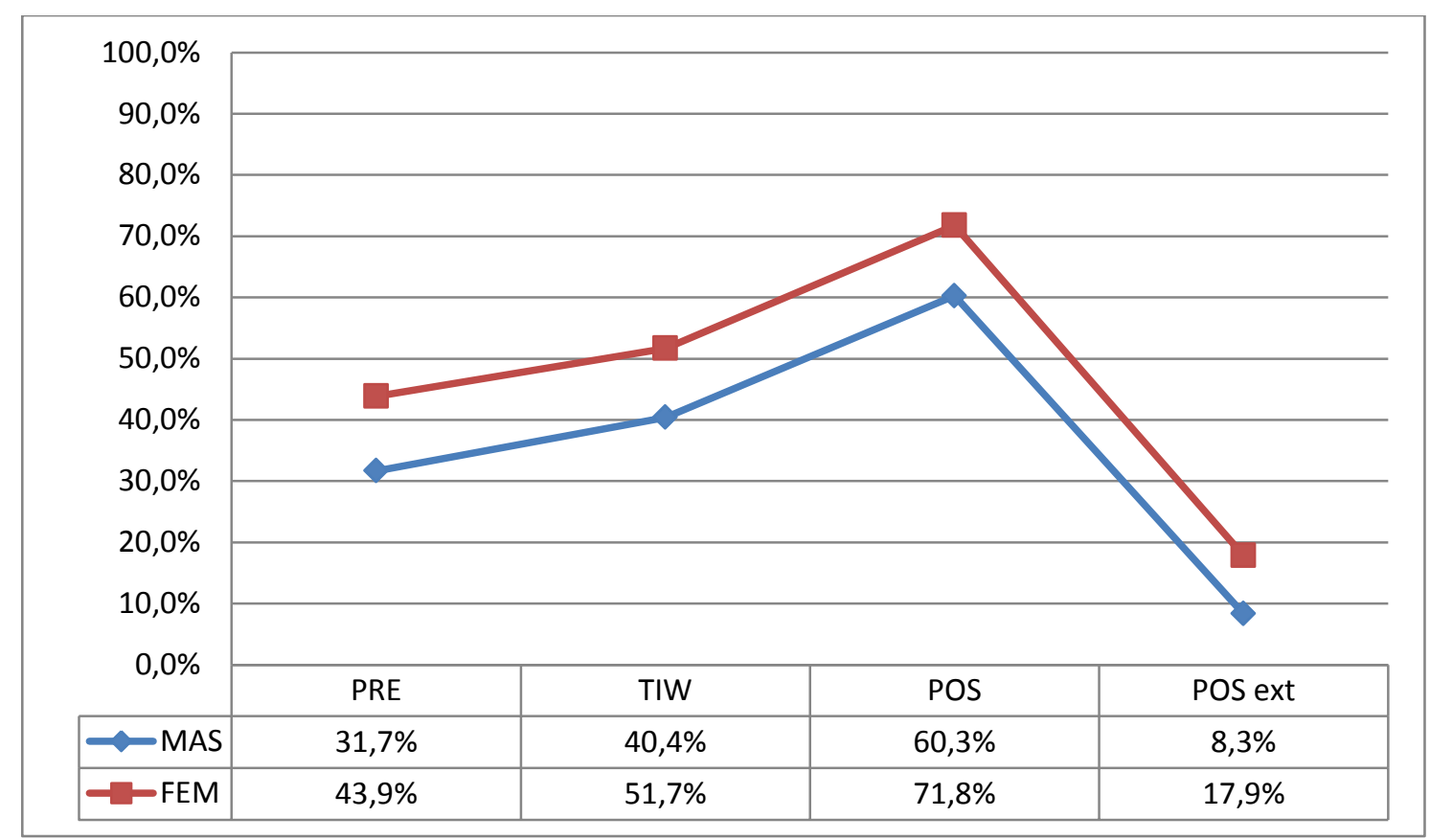

Figura 105 - Prevalências de cálculos salivares observados em homens e mulheres ao longo do tempo.

As comparações estatísticas foram feitas primeiramente entre homens e mulheres dentro de cada período avaliado (Tabela 92), para em seguida, analisar a evolução destes marcadores ao longo do tempo para homens (Tabela 93) e mulheres (Tabela 94). 
Tabela 92 - Valor estatístico e valor-p (corrigidos) encontrados nos testes Chi Quadrado aplicados sobre a diferença entre as prevalências de cálculo salivar de homens e mulheres ao longo dos períodos.

\begin{tabular}{ccc}
\hline & $\mathbf{X}^{\mathbf{2}}$ & $\mathbf{p}$ \\
\hline Pré Tiwanaku & 1,2689 & 0,2420 \\
Tiwanaku & $\mathbf{8 , 0 5 5 7}$ & $\mathbf{0 , 0 0 4 5}$ \\
Pós Tiwanaku & $\mathbf{5 , 2 6 1 2}$ & $\mathbf{0 , 0 2 1 8}$ \\
Pós Tiwanaku externo & 0,3547 & 0,5515 \\
\hline
\end{tabular}

sig. $p<0,05$

Tabela 93 - Valor estatístico e valor-p (corrigidos) encontrados nos testes Chi Quadrado aplicados sobre as diferenças das prevalências de cálculo salivar em indivíduos do sexo masculino.

\begin{tabular}{cccc}
\hline & PRE & TIW & POS \\
\hline PRE & $X$ & & \\
TIW & $1,3435(0,2464)$ & $X$ & $X$ \\
POS & $\mathbf{1 4 , 4 6 5 3 ( 0 , 0 0 0 1 )}$ & $\mathbf{2 2 , 5 5 6 9 ( 0 , 0 0 0 0 )}$ & $X$ \\
POS ext & $3,8111(0,0509)$ & $\mathbf{8 , 5 5 7 5 ( 0 , 0 0 3 4 )}$ & $\mathbf{2 1 , 5 9 3 4 ( 0 , 0 0 0 0 )}$
\end{tabular}

sig. $p<0,05$

Tabela 94 - Valor estatístico e valor-p (corrigidos) encontrados nos testes Chi Quadrado aplicados sobre as diferenças das prevalências de cálculo salivar em indivíduos do sexo feminino.

\begin{tabular}{cccc}
\hline & PRE & TIW & POS \\
\hline PRE & $X$ & & \\
TIW & $0,8573(0,3545)$ & $X$ & $X$ \\
POS & $13,5354(0,0002)$ & $17,0557(0,0000)$ & X \\
POS ext & $4,4787(0,0343)$ & $\mathbf{1 0 , 2 9 6 1 ( 0 , 0 0 1 3 )}$ & $\mathbf{2 8 , 3 1 9 5 ( 0 , 0 0 0 0 )}$ \\
\hline
\end{tabular}

sig. $p<0,05$ 
Os períodos Tiwanaku e Pós Tiwanaku apresentaram diferenças estatisticamente significativas quando comparamos a presença de cálculo salivar entre homens e mulheres, o que não se repetiu nos períodos Pré Tiwanaku e em Caspana provavelmente pelo pequeno número de dentes disponíveis para esta análise.

Encerro aqui a descrição dos dados obtidos neste trabalho, apresentando no próximo capítulo as discussões resultantes destas análises. 


\section{DISCUSSÃO}

Nos capítulos anteriores de "Materiais e Métodos" e "Resultados", busquei manter uma sequência que facilitasse a descrição, a compreensão e até mesmo a checagem dos resultados apresentados.

No presente capítulo, abandonei a rigidez deste formato apresentado anteriormente e discuti os resultados encontrados de forma cronológica. Com isso, os tópicos principais deste capítulo são os momentos temporais observados na préhistória atacamenha que, por convenção, denominei neste trabalho de "períodos".

Os períodos foram caracterizados conforme o perfil bioantropológico e as patologias dentais presentes em seus indivíduos, sendo comparados com o período anterior aos mesmos para criar uma ideia de continuidade que acreditamos existir nos oásis de San Pedro de Atacama. Dentro de cada período busquei manter, quando possível, a sequência dos resultados apresentados no capítulo III.

Assim, este capítulo inicia a discussão pelos resultados obtidos dos sítios representantes do Período Pré Tiwanaku e finaliza com os dados obtidos dos indivíduos exumados em Caspana, sítio representativo do período Pós Tiwanaku, porém, externo aos oásis de San Pedro de Atacama.

\section{Período Pré Tiwanaku}

A amostra que representa o período Pré Tiwanaku neste trabalho é constituída pelos sítios Solor 3 e Toconao Oriente. Apesar do período Pré Tiwanaku ser considerado o intervalo de tempo entre 1500 AC e 500 AD, a datação mais antiga 
obtida através da análise de um fragmento cerâmico, foi encontrada em Toconao Oriente e tem idade estimada em 350 AC (Berenguer et al., 1988).

Os 94 indivíduos estudados deste sítio, divididos quase que de forma equânime (45 mulheres e 42 homens) estão majoritariamente situados na faixa etária entre 25 e 55 anos (45 indivíduos entre 25 e 40 anos e 35 indivíduos entre 40 e 55 anos). Além destes, 13 indivíduos tiveram sua idade de morte determinada acima dos 55 anos e apenas 1 indivíduo com idade inferior a 25 anos. Esta divisão apresentará impacto nas patologias dentais analisadas e será abordada quando cada patologia for descrita, uma vez que algumas delas são fortemente influenciadas pelo tempo de exposição do dente às doenças, ou seja, pela idade do indivíduo analisado.

As deformações cranianas intencionais durante o período Pré Tiwanaku foram encontradas em $43,4 \%$ dos crânios analisados. Destas, $75 \%$ eram do tipo tabular. 0 tipo tabular foi o tipo de deformação mais frequente na amostra dos oásis de San Pedro, independentemente do período observado. A preferência pela deformação craniana do tipo tabular durante o período Pré Tiwanaku nos oásis atacamenhos também foi observada por C. Torres-Rouff (2007), que encontrou a deformação tabular ereta em $79,5 \%$ de todos os indivíduos portadores de deformação craniana de sua amostra para o mesmo período. A baixa frequência de crânios com deformação circular que a autora encontrou nos sítios por ela estudados coincide com os $10,8 \%$ de crânios com deformação circular da minha amostra.

Os 94 indivíduos apresentam, em média, apenas 2 dentes por boca. Os 188 dentes disponíveis para análise dificultam as interpretações de algumas patologias dentais aqui estudadas como a cárie dentária, o desgaste dentário, as hipoplasias lineares do esmalte, a reabsorção periodontal e a presença de cálculo salivar. As únicas patologias que não são fortemente impactadas pelas más condições de preservação do acervo esqueletal são as perdas ante mortem e as lesões periapicais ou abcessos.

A origem da baixa frequência de dentes presentes nos crânios da coleção está nos processos tafonômicos, de coleta, cura e guarda do material esqueletal que agiram nesta coleção, já discutidos neste trabalho. A perda post mortem observada em $52,7 \%$ dos alvéolos dentários nos crânios do período Pré Tiwanaku é a maior entre os três 
períodos, sendo que $67,2 \%$ dos dentes anteriores e $43,7 \%$ dos dentes posteriores foram perdidos desta forma. Dos crânios Pré Tiwanaku analisados, apenas 12 eram originários do sítio Solor 3; e Toconao Oriente, o sítio mais impactado pela má conservação da coleção (Hubbe et al., 2011), é responsável por 82 dos crânios deste período.

A perda de dentes ante mortem durante o período Pré Tiwanaku, apesar de estar presente em mais de um terço dos alvéolos analisados $(36,7 \%)$ de indivíduos com mais de 25 anos, se mostrou a mais baixa entre os períodos estudados. A definição da origem destas perdas dentárias em vida, entre perdas resultantes de processo carioso avançado e de desgaste intenso da coroa dentária, será aclarado mais adiante quando discutirei os tipos de cárie e as possíveis origens das exposições da câmara pulpar encontradas nos crânios deste período.

Outra forma de abordagem sobre o tema das perdas dentárias ante mortem foi avaliá-las separadamente em indivíduos com ou sem deformação craniana intencional. Enquanto os indivíduos sem deformação craniana apresentaram 35,4\% de seus dentes perdidos em vida, os indivíduos que apresentavam algum tipo de deformação craniana, independente do tipo ou angulação desta, apresentaram 40,3\% de perda ante mortem. Apesar desta diferença encontrada entre os dois grupos, ela não se mostrou significativa quando avaliada através do teste estatístico de Chi Quadrado ( $\mathrm{X}^{2}$ $=3,4205 ; \mathbf{p}=0,0644)$, mostrando um equilíbrio entre deformados e não deformados quanto às perdas dentárias durante o período Pré Tiwanaku.

A quantidade de lesões periapicais observadas neste período foi a menor entre os três períodos para os oásis de San Pedro, e até mesmo quando comparamos com Caspana. Esta baixa prevalência (em relação aos demais períodos) está em concordância com a também baixa prevalência de perdas ante mortem encontradas no período.

Um pequeno aumento na prevalência dos abcessos foi identificado quando excluímos o único indivíduo com idade de morte inferior a 25 anos, subindo de $28,1 \%$ da amostra total para $28,7 \%$ de lesões periapicais em todos os alvéolos analisados. Este aumento era esperado, uma vez que indivíduos mais velhos tiveram mais tempo 
para a evolução das cáries dentárias ou do desgaste dentário intenso, as duas principais causas das lesões periapicais.

A cárie dentária, patologia mais frequente dos dentes humanos (Hillson, 2005) e a principal responsável pelas lesões periapicais e perdas dentárias ante mortem nos dentes atacamenhos, esteve presente em 53,8\% dos dentes remanescentes nos crânios Pré Tiwanaku. Destes dentes, 85,9\% possuem apenas uma lesão de cárie dentária. Quando analisamos a presença da cárie de forma setorizada, o segmento anterior apresentou $38,5 \%$ de dentes cariados enquanto o segmento posterior tinha $58,2 \%$ de seus dentes acometidos por esta patologia. Um inesperado resultado foi encontrado quando extraí da análise o indivíduo mais jovem $(<25$ anos) pois a prevalência de cárie dentária caiu, partindo de 53,8\% da amostra geral para 52,9\% entre os indivíduos adultos com mais de 25 anos. Este resultado, apesar de surpreendente, tem sua explicação no indivíduo em questão, originário de Toconao Oriente ( $n$ - 11586) e que possuía apenas 3 dentes no momento de minha análise devido às inúmeras perdas post mortem já descritas para os crânios provenientes deste sítio.

Estes três dentes, coincidentemente, estavam cariados e proporcionaram a este indivíduo uma prevalência de $100 \%$ de dentes com cárie dentária. Assim, quando retiramos este indivíduo da amostra por considerarmos sua idade de morte um fator de "minimização" das lesões cariosas, tivemos o resultado oposto, pois este exemplar atípico elevava e não minimizava a prevalência total da amostra.

Sem este indivíduo jovem sendo computado na amostra, foram notados $38,5 \%$ dos dentes anteriores cariados e 57,3\% dos dentes posteriores. Como o indivíduo no 11586 apresentava apenas 3 dentes posteriores, ao removê-lo da amostra, não se alterou a prevalência de cárie dentária dos anteriores.

A extensão das cáries dentárias encontradas nos dentes também foi estudada, pois, se avaliássemos apenas o número de lesões por dentes não quantificaria o comprometimento destes dentes avaliados. 
Os crânios estudados do período Pré Tiwanaku apresentaram 68,2\% das cáries presentes de intensidade leve ou moderada, ou seja, lesões cariosas que não chegaram a expor a câmara pulpar, sendo quase a metade destas lesões (49,3\%) apenas cárie superficial, com no máximo $2 \mathrm{~mm}$ de profundidade. Os 24,5\% de cárie dentária com destruição total da coroa dentária (cárie extrema), juntamente com os 7,3\% de cáries de intensidade grave (cat. 3), foram utilizados na definição do índice de dentes perdidos em vida, que explicarei mais adiante.

A presença de cárie dentária nos dentes dos indivíduos do sexo feminino durante o período Pré Tiwanaku foi bastante expressiva. Tendo 65,2\% de seus dentes acometidos por cárie, as mulheres deste período apresentaram uma prevalência de cárie dentária $55 \%$ maior que os homens do mesmo período, que tiveram $42,1 \%$ de seus dentes lesionados por cárie. Esta diferença estatisticamente significativa $\left(X^{2}=\right.$ 8,0654; $p=0,0045)$, apresentada no período Pré Tiwanaku, foi a única diferença significativa observada entre os sexos nos períodos avaliados neste trabalho. Apesar de existirem explicações distintas para o recorrente fato de mulheres apresentarem mais lesões de cáries que os homens, como as gestações ou simplesmente as variações hormonais ocorridas ao longo de suas vidas (Lukacs, 1996; Lukacs \& Largaespada, 2006), vou considerar neste trabalho que esta diferença entre homens e mulheres é fruto de uma maior disponibilidade de alimentos ricos em carboidratos em favor das mulheres. Também não pretendo discutir a razão desta disponibilidade díspar dos alimentos cariogênicos entre os dois sexos.

Outra forma de abordar a prevalência de cárie dentária durante o período foi a separação da população em indivíduos com ou sem deformação craniana intencional. Com esta divisão, a cárie dentária foi encontrada em $46,6 \%$ dos dentes de indivíduos que não apresentavam deformações cranianas, enquanto o grupo de indivíduos com algum tipo de deformação intencional, fosse a deformação tabular ou circular, apresentou 65,2\% de seus dentes acometidos por esta patologia dental. Esta diferença de prevalência de cárie dentária entre indivíduos com e sem deformação craniana se mostrou significativa frente aos testes estatísticos aplicados $\left(X^{2}=4,1181 ; p=0,0424\right)$, sendo o único período estudado a apresentar tal resultado, sugerindo que, durante este período, os dois grupos de indivíduos tiveram dietas relativamente distintas a 
ponto de propiciar aos indivíduos portadores de deformações cranianas intencionais um maior aporte de carboidratos cariogênicos.

Esta diferença significativa entre não deformados e deformados foi analisada mais profundamente, buscando identificar se a diferença era entre indivíduos não deformados e indivíduos deformados de forma tabular, circular ou ambas. Enquanto os indivíduos sem deformação craniana intencional apresentaram $46,6 \%$ de seus dentes cariados, os indivíduos com deformação craniana circular apresentaram 55,6\% de seus dentes acometidos por cárie e os indivíduos com crânios deformados em forma tabular tinham $68,8 \%$ dos dentes com cárie, sendo significativa a diferença encontrada entre os indivíduos sem deformação e os indivíduos portadores de deformação do tipo tabular $\left(X^{2}=4,8999 ; p=0,0296\right)$. Assim, os crânios com deformação do tipo tabular, representantes de $75 \%$ de todas as deformações encontradas durante o período Pré Tiwanaku, também eram os que apresentavam a maior prevalência de cárie observada neste período. Esta maior prevalência indica um acesso a recursos distintos entre os três grupos (sem deformação, deformados tabulares e deformados circulares).

As prevalências de cáries dentárias foram "corrigidas" através de dois índices aplicados nos indivíduos do período Pré Tiwanaku: O índice DMI (Saunders et al., 1997) e o índice de Lukacs (Lukacs, 1995).

O DMI encontrado para os indivíduos do período foi de 89,47 . Se considerarmos que um DMI de valor 100 representa uma amostra onde todos os dentes dos crânios avaliados foram acometidos por cárie dentária, o valor observado para o período Pré Tiwanaku é muito elevado, significando que quase $90 \%$ dos dentes e alvéolos observados nos crânios estão cariados ou são remanescentes de dentes que foram perdidos devido a um processo de cárie avançado. Este é o maior valor encontrado entre todos os períodos estudados, tanto para os sítios de San Pedro de Atacama como para o sítio externo à bacia do salar. Obviamente este índice, assim como a prevalência de cárie e também o índice de Lukacs, serão superestimados devido à alta prevalência de perdas post mortem, principalmente nos dentes 
anteriores (que apresentam, normalmente, índices de cárie dentária inferior ao encontrado nos dentes posteriores).

Para o cálculo do índice proposto por Lukacs, diferentemente do DMI acima apresentado, busca-se uma distinção entre as perdas dentárias ante mortem, tentando separar os dentes perdidos em vida resultantes de processos avançados de cárie dentária dos dentes perdidos em vida por uma exposição pulpar causada por desgaste dentário intenso. Apesar disso, a relação "dente perdido por cárie/dente perdido" encontrada para o período Pré Tiwanaku foi igual a um (01), ou seja, para este período, todos os dentes perdidos em vida foram considerados como resultantes de um processo carioso intenso. Com isso, o valor encontrado para o índice de Lukacs $(0,89)$, cuja escala é de 0 a 1, é de mesma magnitude do encontrado para o DMI $(89,47)$. A diferença entre os índices de Lukacs apresentados por homens e mulheres durante o período Pré Tiwanaku (0,869 em homens e 0,974 em mulheres) não se mostrou significativo estatisticamente $(U=820,500 ; W=1681,500 ; \mathbf{p}=0,510)$. Quando comparamos os índices de Lukacs, durante o período Pré Tiwanaku, dos indivíduos com ou sem deformação craniana intencional (0,893 e 0,886 respectivamente), a mesma falta de significância foi observada $(U=793,500 ; W=1874,500 ; p=0,890)$.

A alta prevalência de cárie dentária e por consequência os índices de Lukacs e DMI observados durante o período Pré Tiwanaku, se alterará ao longo dos períodos avaliados. Porém, mesmo nos momentos nos quais serão encontrados os mais baixos valores destes marcadores dentários para os 3 períodos, eles ainda serão muito altos se comparados até mesmo com outras sociedades nas quais o milho era a base da alimentação (Da-Gloria, 2006). A grande variedade de alimentos ricos em carboidratos encontrados no deserto e arredores tem sido, por muitos pesquisadores, responsabilizados pelos altos níveis de cárie dentária observados na região (Cárdenas, 1998; Villagrán et al., 1998; Oshodi et al., 1999; Maestri, 2001; Pardo \& Pizarro, 2008).

O desgaste encontrado nos dentes da população atacamenha durante o período Pré Tiwanaku é majoritariamente de pequena intensidade, classificado entre os graus 1 a 3 da escala de B. Smith (1984). Dos 51,5\% dos dentes que apresentaram desgaste leve, $71 \%$ eram desgastes apenas em esmalte dentário, tanto em dentes 
anteriores como posteriores. O desgaste dentário de intensidade média foi encontrado em $43,8 \%$ dos dentes, enquanto o desgaste intenso foi observado em apenas $4,6 \%$ desta amostra. Destes dentes que apresentaram desgaste intenso, nenhum apresentou desgaste dentário suficiente para expor a câmara pulpar.

Esta distribuição dos desgastes dentários foi observada em 130 dentes disponíveis para a avaliação do desgaste dentário durante o período Pré Tiwanaku. Como estes dentes estão distribuídos de forma desigual, sendo 101 dentes posteriores e apenas 29 dentes anteriores, foram separados os dentes anteriores e posteriores para serem analisados individualmente.

Apesar do pequeno número de dentes anteriores disponíveis para a análise neste trabalho, o padrão observado por Da-Gloria et al. (2010) e Hubbe et al. (2012) onde os dentes anteriores apresentam, em média, um nível de desgaste superior ao encontrado nos dentes posteriores, também foi encontrado neste trabalho. Este padrão foi encontrado em todos os períodos estudados, como veremos adiante. Com a baixa probabilidade deste desgaste acentuado em dentes anteriores ser resultante de uma utilização dos dentes como ferramentas, exceto em casos muito específicos (ex. Alto de Laura - Toconao Oriente - no 11753/237 - Figura 106), a explicação mais plausível para tal padrão é a perda dentária ante mortem intensa encontrada nos dentes dos indivíduos analisados, provavelmente por processo carioso avançado. 


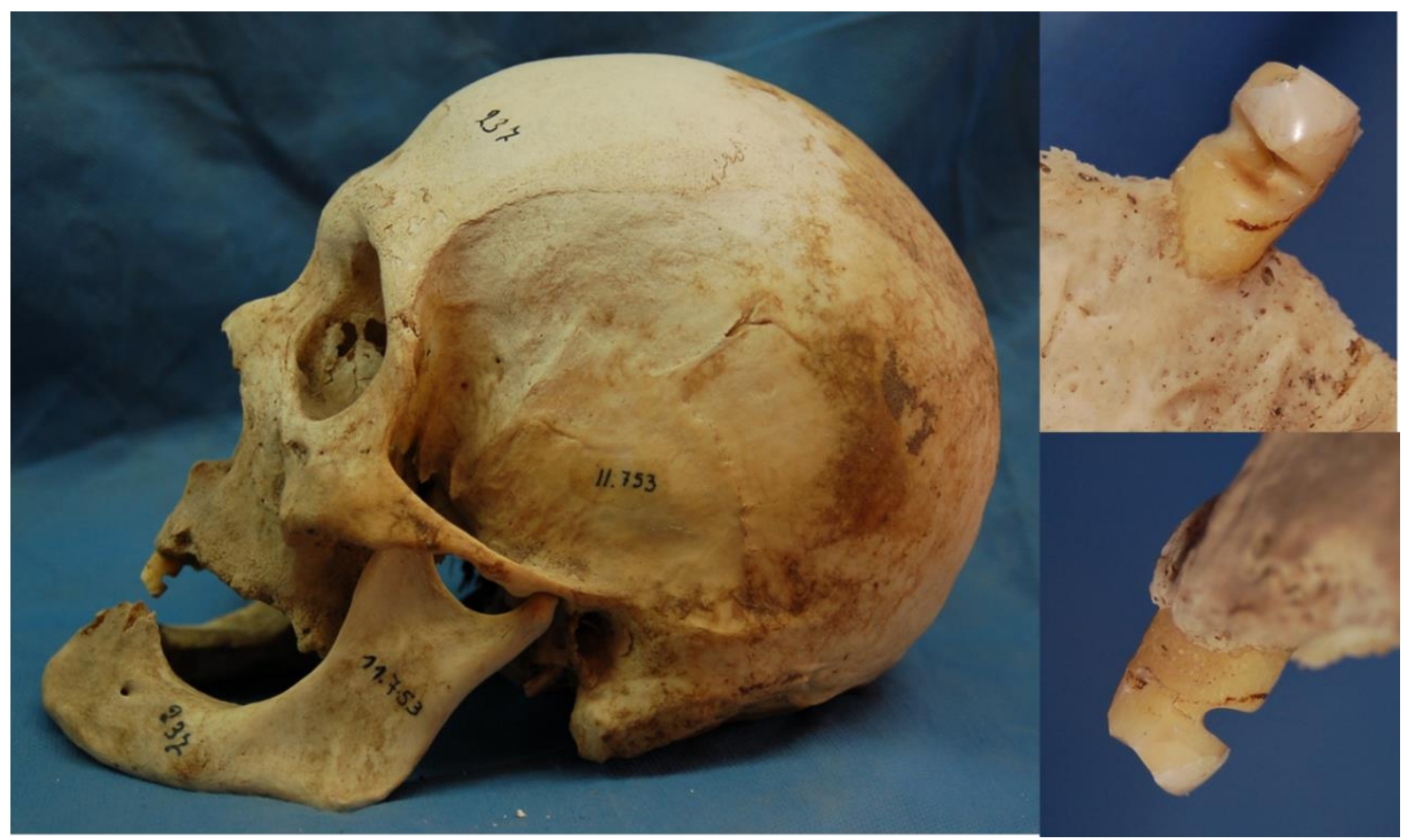

Figura 106 - Crânio originário do sítio Toconao Oriente (Alto de Laura \#11753) com evidência de utilização dos dentes como ferramentas.

Como os dentes posteriores apresentaram uma perda dentária ante mortem 64\% maior que a perda presente nos dentes anteriores, a falta de apoio dos dentes posteriores faz com que, para que a mastigação seja minimamente efetiva, os dentes anteriores sejam sobrecarregados e forçados a fazer parte da mastigação e trituração do alimento, movimento originalmente destinado a pré-molares e molares (Picosse, 1979 a). Apesar de existir uma diferença observável do desgaste dentário entre os dentes anteriores e posteriores, ela não se mostrou estatisticamente significativa quando se avalia os desgastes de intensidade leve e moderada. Contudo, quando se avalia a diferença entre dentes anteriores e posteriores para o desgaste intenso, foi encontrada uma diferença significativa $\left(X^{2}=4,7105 ; p=0,0300\right)$, sendo que os dentes anteriores apresentam desgaste intenso em maior frequência que os posteriores.

Outra estratégia utilizada para analisar o desgaste dentário presente nesta amostra foi considerar o indivíduo como unidade de análise. Esta manobra teve o objetivo de minimizar a supervalorização dos dentes presentes, uma vez que minha amostra encontrava-se bastante deteriorada. Com isso, se o indivíduo possui 2 dentes 
ou 15 dentes, serão comparados com pesos estatísticos iguais, sendo computados como uma unidade de análise cada um. Desta forma, os únicos indivíduos a serem excluídos desta análise, obviamente, foram os indivíduos que não apresentavam nenhum dente, sejam eles perdidos em vida ou após a morte.

Considerei como valor de desgaste dentário de cada esqueleto os dois dentes que apresentaram o menor nível de desgaste dentário de cada boca, diminuindo desta forma uma superestimação do desgaste dentário nos casos onde fora encontrados dentes sem antagonistas, perdidos por cárie ou trauma precocemente.

Quando observamos a distribuição do desgaste dentário destes indivíduos, encontramos $46,4 \%$ dos indivíduos com desgaste dentário de intensidade leve. A diferença encontrada entre as análises sobre dentes e sobre indivíduos, na qual encontramos uma prevalência de desgaste dentário de média e alta intensidade maior quando avaliamos indivíduos e não dentes (53,6\% e 48,5\% respectivamente), sugere que os dentes posteriores, por serem representados por dentes acometidos tanto por cárie como pelo desgaste, indicariam a condição de desgaste desta população mais adequadamente caso o número de perdas post mortem não fosse tão alto.

Também foi avaliado o desgaste dentário encontrado nos crânios do período Pré Tiwanaku conforme a presença ou não de deformações intencionais. Ainda considerando os indivíduos e não dentes, os crânios em condição de análise somavam apenas 28 indivíduos para este período, o que justifica as diferenças encontradas na intensidade de desgaste dentário dos indivíduos com e sem deformação craniana, conforme observamos na Figura 107. Estas diferenças, entretanto, não apresentaram diferenças estatisticamente significativas. 


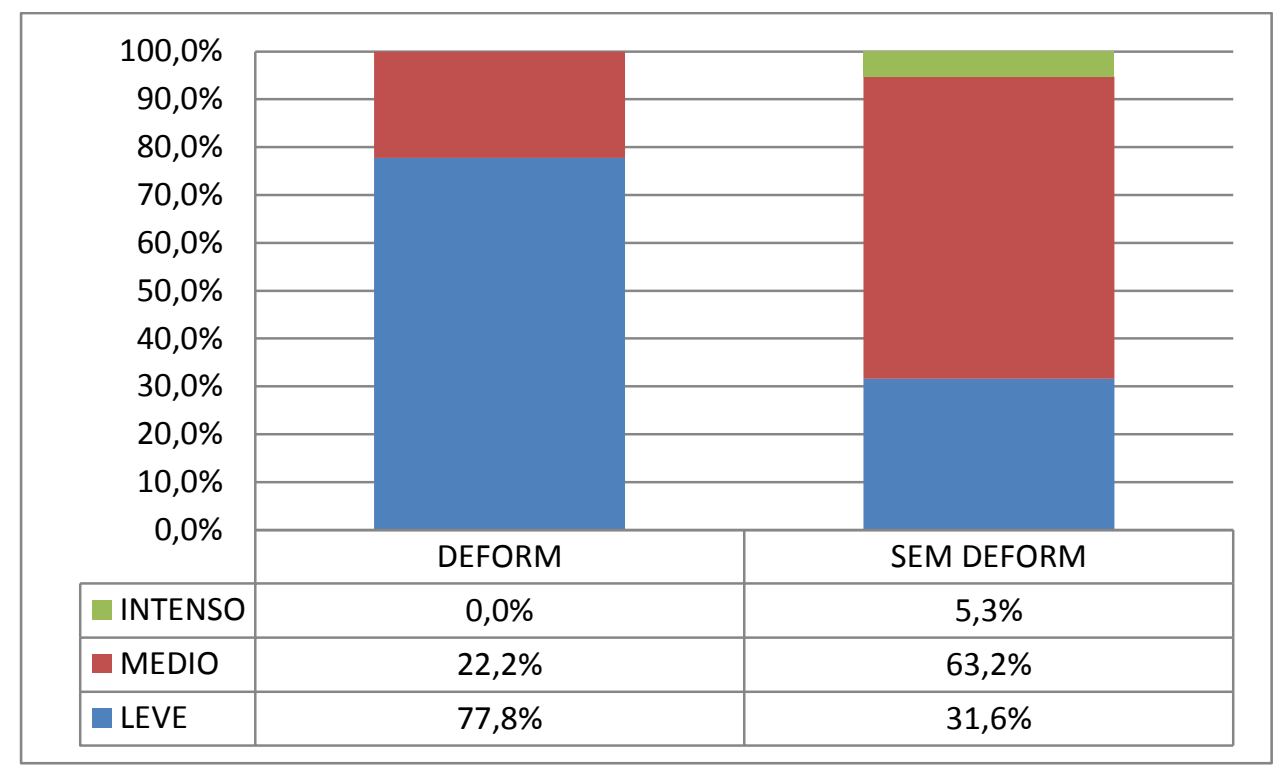

Figura 107 - Distribuição dos desgastes dentários para o período Pré Tiwanaku considerando o indivíduo como unidade de análise.

Ainda considerando o desgaste dentário por indivíduo, a média de desgaste obtida durante o período Pré Tiwanaku foi de 1,59 numa escala de 1 a 3. A média de desgaste dentário obtida para os indivíduos do sexo masculino $(1,69)$ foi superior à encontrada nos indivíduos do sexo feminino $(1,46)$, apesar desta diferença não apresentar significância estatística $(U=68,500 ; W=159,500 ; p=0,418)$, indicando uma semelhança entre a abrasividade das dietas de homens e mulheres durante 0 período Pré Tiwanaku.

As deformações cranianas também foram relacionadas com as médias de desgaste dentário encontradas nesta amostra, na qual os indivíduos portadores de deformação craniana intencional apresentaram uma média de desgaste de 1,25 enquanto os crânios que não estavam deformados exibiram uma média de 1,86. Esta diferença, após análise estatística, se mostrou significativa $(U=25,000 ; W=61,000 ; \mathbf{p}$ $=0,035)$. Esta diferença sugere que os indivíduos com deformação craniana intencional tiveram, durante o período Pré Tiwanaku, uma dieta mais cariogênica porém com menor abrasividade, resultando num desgaste dentário menor que o observado nos indivíduos sem deformação craniana. 
Outra patologia observada foi a presença de hipoplasias lineares em 15,8\% dos 19 dentes disponíveis para este período.

Como considerei portadores de hipoplasia linear apenas os indivíduos que possuíam pelo menos dois dentes acometidos por esta alteração, o número de indivíduos portadores de hipoplasia pode ter sido subestimado pelo pequeno número de dentes disponíveis para análise devido ao grande número de dentes anteriores perdidos post mortem e aos casos de primeiros molares cariados intensamente, com destruição total da coroa dentária, o que impossibilitou a avaliação das hipoplasias nestes dentes. Esta condição fica clara quando analisamos os indivíduos que apresentavam apenas 1 dente acometido pela hipoplasia linear, que para o período Pré Tiwanaku tem prevalência de $21,1 \%$ do total de indivíduos. Assim, temos uma prevalência possível de indivíduos que foram acometidos por esta patologia de 15,8\% (indivíduos identificados com mais de 1 dente portador de linhas hipoplásicas) até $36,9 \%$ (somatória deste indivíduos com os $21,1 \%$ dos que potencialmente tinham mais de 1 dente patologicamente modificado).

Neste trabalho encontrei as mesmas limitações citadas por Costa et al. (2004) devido à pequena quantidade de dentes disponível para avaliação das hipoplasias lineares do esmalte dentário, dificultando a análise estatística, que mesmo com variações consideráveis se mostraram não significativas e assim, limitaram a interpretação dos resultados obtidos.

As reabsorções periodontais encontradas nos crânios estudados estavam presentes em 29,2\% dos alvéolos avaliados durante o período Pré Tiwanaku. Estes 29,2\% são constituídos por $21,7 \%$ de reabsorções leves, $6,7 \%$ de reabsorções médias e apenas $0,8 \%$ de reabsorções intensas. Isto significa que o período Pré Tiwanaku apresentou uma prevalência de apenas 7,5\% de alvéolos dentais com reabsorção periodontal superior a $4 \mathrm{~mm}$, considerado como resultante de uma periodontite de média ou grave intensidade.

Como a presença de cálculo salivar tem distribuição seletiva na cavidade bucal, com predileção a áreas definidas, fez-se necessária a divisão dos alvéolos analisados em dentes anteriores e dentes posteriores. Com esta divisão, foi observado nos 
crânios do período Pré Tiwanaku uma prevalência de reabsorções periodontais em apenas $15,0 \%$ dos dentes anteriores, enquanto os posteriores apresentaram $32,0 \%$ dos alvéolos avaliados acometidos por reabsorção periodontal de algum nível (acima dos 2 $\mathrm{mm}$ considerados saudável). Esta diferença, porém, não se mostrou estatisticamente significativa, provavelmente, devido ao pequeno número da amostra testada $\left(X^{2}=\right.$ $1,5812 ; \mathbf{p}=0,2086)$.

A última das patologias analisadas foi a presença e a localização dos cálculos salivares nos dentes presentes. Devido à ausência de cálculos salivares subgengivais na amostra do período Pré Tiwanaku, os $37,2 \%$ de prevalência de cálculo salivar observados durante este período eram cálculos supragengivais. Destes cálculos, 91,9\% eram cálculos considerados brandos, cobrindo até $1 / 3$ da coroa dentária, enquanto 0 restante cobria apenas $2 / 3$ das coroas avaliadas.

Sendo as faces linguais os dentes anteriores inferiores e as faces bucais dos dentes posteriores superiores as áreas de maior acúmulo dos cálculos salivares devido às saídas de glândulas salivares maiores (Lang et al., 2003), as análises separadas dos dentes anteriores e posteriores, assim como para as reabsorções periodontais, se justifica, pois o acúmulo natural de cálculos salivares não se distribui de forma equilibrada entre as áreas mencionadas.

Enquanto os dentes anteriores apresentaram uma prevalência de cálculos salivares de $36,0 \%$, os dentes posteriores apresentaram $37,5 \%$ dos dentes avaliados contendo cálculos dentários.

A relação positiva encontrada entre a presença de cálculo dentário e reabsorção periodontal é facilmente encontrada nos dentes desta amostra, onde observamos 37,2\% de dentes contendo cálculos salivares e 29,2\% dos alvéolos acometidos pela reabsorção periodontal. O mesmo é observado nos dentes posteriores, sendo portadores de $37,5 \%$ de cálculo salivar e 32,0\% de reabsorção periodontal. A diferença encontrada nas prevalências de cálculo salivar e de reabsorção periodontal pode ser explicada pela relação positiva, porém não necessariamente direta entre a reabsorção periodontal e o cálculo salivar, haja vista que a formação de cálculo salivar supragengival pode não alterar a microbiota 
subgengival, mantendo o periodonto estável (Socransky \& Haffajee, 2003) ou, no sentido oposto, a perda periodontal pode ter outra etiologia que não a presença do cálculo salivar, tanto supra como subgengival (Lindhe et al., 2003).

Porém, a grande diferença observada entre as prevalências de reabsorção periodontal $(15,0 \%)$ e cálculo salivar $(36,0 \%)$ pode ter como explicação a dificuldade em manter o rebordo alveolar intacto, principalmente na face bucal de ambas as arcadas, devido à espessura delgada encontrada na tábua óssea alveolar mandibular e maxilar (Picosse, 1979 b; Scheid \& Weiss, 2012 c; d). Esta pouca espessura óssea possibilita fraturas deste alvéolo, inviabilizando o alvéolo, ainda que o dente esteja presente (e possivelmente com cálculos) para a avaliação das reabsorções alveolares.

\section{Período Tiwanaku}

O período Tiwanaku, compreendido entre os anos de 500 e $1000 \mathrm{AD}$, foi caracterizado pelos pesquisadores como um período no qual foi observada uma importante melhora na qualidade de vida biológica da população atacamenha, representada por uma dieta proteica mais abundante e por consequência, um aumento na estatura media da população, principalmente entre os indivíduos do sexo masculino; uma diminuição na quantidade média de cáries dentárias, desgaste e perda dentária ante mortem, demonstrando uma condição de saúde bucal melhor quando comparamos com o período anterior; uma diminuição na quantidade de patologias infecciosas não específicas também foi observada na fase final da influência deste império altiplânico na região dos oásis (Costa \& Llagostera, 1994; Neves \& Costa, 1998; Costa et al., 2004; Da-Gloria et al., 2010, 2011; Hubbe et al., 2012), enquanto a quantidade de traumas oriundos das atividades corriqueiras diárias e as lesões resultantes de violência interpessoal não foram afetadas pela presença Tiwanaku na região (Costa et al., 1998). 
Apesar de se tratar de um trabalho exploratório, utilizarei esta premissa como linha mestra das discussões neste trabalho, com a qual inevitavelmente compararei os resultados obtidos.

A amostra de crânios do período Tiwanaku é constituída por 146 indivíduos, distribuídos em 58 indivíduos identificados como do sexo masculino, 77 do sexo feminino e 11 indivíduos cujo sexo foi considerado indeterminado. Quanto à distribuição etária desta amostra, nenhum indivíduo com menos de 25 anos de idade no momento de sua morte foi identificado neste grupo, 45 indivíduos com idade entre 25 e 40 anos, 60 indivíduos entre 40 e 55 anos e 41 indivíduos com idade de morte superior a 55 anos.

Assim como o período anterior, as deformações cranianas estavam presentes na minoria da população desta amostra, na qual 54,4\% dos indivíduos observados não apresentaram deformações cranianas indubitavelmente diagnosticadas. Das deformações presentes, $85,5 \%$ eram do tipo tabular e apenas $14,5 \%$ do tipo circular. Esta distribuição dos tipos de deformação craniana se aproxima ainda mais, quando comparamos com o período Pré Tiwanaku, do padrão encontrado por C. Torres-Rouff (2007) para os oásis de San Pedro de Atacama. Apesar de encontrarmos um aumento da prevalência de crânios deformados com o tipo tabular entre os dois períodos mencionados, este aumento não se mostrou significativo estatisticamente $\left(X^{2}=\right.$ $1,0435 ; \mathbf{p}=0,3070)$.

Quanto ao número de dentes disponível para análise, esses 146 crânios continham 856 dentes ainda em seus alvéolos. Estes 856 dentes são apenas 45,9\% dos dentes presentes na boca destes indivíduos no momento de suas mortes, e ainda assim, os esqueletos estudados do período Tiwanaku foram os que apresentaram a menor taxa de perdas dentárias post mortem dentre todos os grupos analisados, acometendo $28,7 \%$ dos alvéolos dentais disponíveis à avaliação. Quando avaliamos os dentes anteriores e posteriores separadamente, os dentes anteriores apresentam $44,1 \%$ e os posteriores $19,2 \%$, mantendo a frequência de perdas post mortem mais alta nos dentes anteriores pelos mesmos motivos expostos para as perdas dentárias durante o período Pré Tiwanaku. 
O impacto das perdas post mortem na coleção do museu é tão grande, e fica bastante evidente nesta amostra do período Tiwanaku, que mesmo sendo o grupo com a maior prevalência de perdas dentárias ante mortem $(47,0 \%)$, ainda assim, Tiwanaku é o período com a maior relação de dentes por indivíduo de todo este trabalho (5,86 dentes por crânio).

Os $47 \%$ de perdas dentárias ante mortem encontrados nos crânios do período Tiwanaku é significativamente superior aos $36 \%$ de dentes perdidos em vida do período anterior $\left(X^{2}=54,3007 ; \mathbf{p}=0,0000\right)$. Mesmo quando comparamos a prevalência de perdas dentárias em vida dos indivíduos com idade superior a 25 anos, o que faz com que a prevalência do período Pré Tiwanaku suba para $36,7 \%$, ainda assim se mantem a significância estatística anteriormente encontrada $\left(X^{2}=47,2748 ; p=\right.$ 0,0000). As perdas dentárias por mim observadas são bastante distintas das que Costa et al. (2004) encontraram, sendo que meu trabalho apresenta um aumento e não uma queda das perdas ante mortem entre os períodos Pré Tiwanaku e Tiwanaku. A distinção entre perdas originadas por dentes cariados ou dentes desgastados, distinção não apresentada pelos autores citados, será apresentada neste trabalho quando discutirmos cárie e desgaste dentário.

As perdas dentárias ante mortem também fora dividas entre as perdas dos dentes anteriores e dos dentes posteriores. Enquanto na região anterior, 32,5\% dos dentes foram perdidos durante a vida, na região posterior da boca, 55,9\% dos dentes foram perdidos em vida.

O mesmo aumento encontrado no número de dentes perdidos ante mortem quando comparamos todos os crânios dos períodos Pré Tiwanaku e Tiwanaku foi observado nos indivíduos com e sem deformação craniana intencional, entre os mesmo períodos. Porém, enquanto o aumento de 40,3\% para 44,3\% de dentes perdidos em vida nos esqueletos com deformação não foi estatisticamente significativo $\left(X^{2}=2,8265 ; \mathbf{p}=0,0927\right)$ entre os períodos Pré Tiwanaku e Tiwanaku, o aumento de $35,4 \%$ para $48,5 \%$ de dentes perdidos ante mortem nos indivíduos sem deformação craniana foi significativo $\left(X^{2}=38,5314 ; \mathbf{p}=0,0000\right)$ para o mesmo período. Foi também observada, durante o período Tiwanaku, uma diferença das perdas 
dentárias ante mortem entre os crânios não deformados (48,5\%) e os deformados $(44,3 \%)$ estatísticamente significativa $\left(X^{2}=5,6391 ; \mathbf{p}=0,0176\right)$. A inversão na prevalência de perdas dentárias em vida entre os crânios com e sem deformação craniana apontam para uma modificação significativa na dieta dos indivíduos sem deformação craniana intencional, o que verificaremos quando discutirmos as cáries e desgastes destes grupos.

Os abcessos, que durante o período anterior estavam presentes em $28,1 \%$ dos alvéolos analisados, durante o período Tiwanaku foram encontrados em $33 \%$ dos alvéolos remanescentes. Este aumento observado entre estes dois períodos, quando analisado por ferramentas estatísticas, se mostrou significativo $\left(X^{2}=7,1163 ; \mathbf{p}=\right.$ 0,0076). Mesmo quando retiramos os indivíduos com idade de morte menor que 25 anos (manobra que impacta apenas a prevalência de abcessos do período Pré Tiwanaku), a diferença ainda se mostra significativa $\left(X^{2}=5,4335 ; \mathbf{p}=0,0198\right)$ entre os $28,7 \%$ de lesões periapicais nas bocas dos indivíduos do período Pré Tiwanaku e os $33 \%$ de abcessos durante o período Tiwanaku. Ambas as regiões, anterior e posterior, também apresentaram aumento do número de lesões periapicais durante os períodos mencionados.

Uma maior prevalência das lesões periapicais nos crânios do período Tiwanaku mantem uma coerência com aumento encontrado nas perdas dentárias ante mortem, afinal, se excluirmos (exatamente como fizemos) o trauma dental como fator responsável pela perda dentária em vida, tanto a cárie como o desgaste dentário poderiam ter exposto a polpa dentária, levado inicialmente a uma infecção do canal dentário; consequentemente contaminado e infeccionado o osso alveolar periapical; só após este processo teria se tornado crônico (abcesso) e acarretado a perda deste elemento dental.

A prevalência de cárie dentária encontrada nos esqueletos de San Pedro de Atacama durante o período Tiwanaku foi a menor dentre todos os períodos estudados, sendo apenas maior que a prevalência encontrada nos crânios de Caspana. Quando comparamos Tiwanaku com o período anterior, a queda na prevalência de cáries dentárias observada entre eles foi testada e se mostrou estatisticamente significativa 
$\left(X^{2}=4,6232 ; \boldsymbol{p}=0,0315\right)$. A queda desta prevalência esta em concordância com os resultados dos pesquisadores já apresentados, indicando uma queda na ingestão dos alimentos cariogênicos ou um aumento nos alimentos protetores ou simplesmente não cariogênicos como a proteína animal advinda do consumo de carne, ovos, leite ou derivados.

Ao compararmos as prevalências de dentes com destruição total da coroa dentária por cárie, entre os dois períodos, encontramos uma queda de 24,5\% durante o período Pré Tiwanaku para $21 \%$ durante o período Tiwanaku, enquanto a prevalência de cárie superficial, sobe de $33,6 \%$ nos esqueletos do Pré Tiwanaku para $42,5 \%$ nos esqueletos de Tiwanaku. Entretanto, nem as cáries intensas $\left(X^{2}=0,4619 ; \mathbf{p}=\right.$ $0,4967)$ nem as cáries superficiais $\left(X^{2}=2,4997 ; \mathbf{p}=0,1139\right)$ apresentaram diferenças estatisticamente significativas entre os dois períodos mencionados.

As mulheres também apresentaram uma maior prevalência de cáries dentárias que os homens durante o período Tiwanaku, como era esperado. Porém, diferentemente do período anterior, as prevalências de cárie dentária para mulheres e homens não se mostraram significativamente distintas $\left(X^{2}=2,5939 ; \mathbf{p}=0,1073\right)$. Esta diferença não significativa entre as cáries de homens e mulheres durante o período Tiwanaku contradiz os resultados de Neves \& Costa (1998), Costa et al. (2004) e Hubbe et al. (2012) que observaram diferença na presença de cáries entre homens e mulheres, sugerindo uma alimentação rica em proteína na dieta masculina durante este período.

O leve aumento na prevalência de cárie dentária entre os homens do período Pré Tiwanaku para o período Tiwanaku, de $42,1 \%$ para $42,8 \%$, não foi significativo $\left(X^{2}=\right.$ $0,0003 ; \mathbf{p}=0,9869)$, enquanto a queda observada entre as mulheres do período Pré Tiwanaku em relação ao período subsequente, de $64,0 \%$ para $48,9 \%$, sim $\left(X^{2}=5,7894\right.$; $\mathbf{p}=0,0161)$. Podemos assumir que há uma alteração na dieta da população atacamenha durante o período Tiwanaku, porém, se levarmos em consideração apenas a prevalência de cárie dentária, meus resultados apontam exatamente no sentido oposto, sugerindo uma dieta menos cariogênica para as mulheres. Mesmo 
assim, ainda observamos durante o período Tiwanaku uma prevalência, ainda que não significativamente distinta, de cárie dentária superior nos esqueletos femininos.

A prevalência de cárie dentária nos dentes anteriores apresentada durante o período Tiwanaku é inferior à prevalência presente no período Pré Tiwanaku (32,6\% e $38,5 \%$ respectivamente), assim como a prevalência nos dentes posteriores $(51,4 \%$ e $58,2 \%)$, mas estas diferenças não se mostraram significativas após teste estatístico (anteriores $-X^{2}=0,3070 ; p=0,5796$ e posteriores $-X^{2}=1,7328 ; \mathbf{p}=0,1881$ ). Mesmo quando retiramos os indivíduos com idade inferior a 25 anos, as prevalências de cárie dentária ainda são menores durante Tiwanaku que durante Pré Tiwanaku, tanto para dentes anteriores (32,6\% e $38,5 \%)$ como para os dentes posteriores $(51,4 \%$ e $57,3 \%)$, mas sem significância estatística (anteriores $-X^{2}=0,3070 ; \mathbf{p}=0,5796$ e posteriores $-X^{2}$ $=1,2226 ; p=0,2688)$.

A remoção dos indivíduos mais jovens fez com que a prevalência de cárie dentária durante o período Pré Tiwanaku, inesperadamente, caísse (fato já explicado anteriormente). Com esta queda, a diferença entre as prevalências de cárie geral deste período e do subsequente, sem distinção entre dentes anteriores e posteriores, também diminuiu e se tornou significativa apenas se considerarmos significante 0 valor de $\mathbf{p} \leq 0,05\left(X^{2}=3,7596 ; \mathbf{p}=0,0525\right)$.

Além da análise de cárie dentária de acordo com o sexo dos indivíduos, as deformações cranianas foram também relacionadas com esta patologia e comparadas ao longo do tempo. Diferentemente do resultado encontrado entre indivíduos portadores ou não de deformação craniana durante o período Pré Tiwanaku, quando os crânios deformados apresentaram uma prevalência de cárie maior que os crânios sem deformação $\left(X^{2}=4,1181 ; p=0,0424\right)$, observamos durante o período Tiwanaku que os crânios sem deformação exibiram uma prevalência de cárie dentária maior que os crânios com deformação craniana (46,3\% e 42,9\% respectivamente), porém, sem ser estatisticamente significativa $\left(X^{2}=0,82165 ; \mathbf{p}=0,3647\right)$. Ao separarmos estes indivíduos, os crânios sem deformação craniana apresentaram uma leve queda na prevalência de cárie dentária entre os períodos Pré Tiwanaku e Tiwanaku (46,6\% para $46,3 \%)$ sem mostrar significância estatística $\left(X^{2}=0,0067 ; \mathbf{p}=0,9349\right)$. Já os crânios com 
algum tipo de deformação craniana apresentaram, durante o mesmo período, uma importante queda nesta prevalência $(65,2 \%$ para $42,9 \%)$, sendo esta diferença significativa $\left(X^{2}=10,2909 ; \mathbf{p}=0,0013\right)$.

Como as deformações cranianas se distribuíram de forma desequilibrada durante os dois primeiros períodos históricos de San Pedro de Atacama, sendo a deformação do tipo tabular a mais presente em ambos os períodos (Pré Tiwanaku: 75\%; Tiwanaku: 85,5\%), a prevalência de cárie também foi avaliada separadamente. Enquanto os crânios com deformação craniana tabular apresentaram uma queda desta prevalência, de $68,8 \%$ durante o período Pré Tiwanaku para 43,0\% durante o período Tiwanaku, sendo esta diferença estatisticamente significativa $\left(X^{2}=10,1731 ; \mathbf{p}=\right.$ 0,0014), a queda observada para os indivíduos com crânios deformados de forma circular, de 55,6\% para 40,7\%, não se mostrou significativa $\left(X^{2}=0,4501 ; \mathbf{p}=0,5023\right)$, o que, apesar de ser uma diferença de quase $15 \%$ entre as duas prevalências, o pequeno número de indivíduos com deformação craniana circular (Pré Tiwanaku: 9 crânios; Tiwanaku: 15 crânios) pode justificar a falta de significância entre os períodos.

Os dois índices utilizados neste trabalho como forma de corrigir as subestimações das cáries dentárias se mostraram coerentes entre si, porém, não idênticos.

O DMI, assim como a prevalência de cárie dentária, também sofreu uma queda entre os períodos Pré Tiwanaku e Tiwanaku (89,47 e 81,44 respectivamente), sendo estatisticamente significativa $(U=4888,50 ; W=15473,50 ; p=0,000)$.

Quanto ao índice de Lukacs, a comparação entre os períodos Pré Tiwanaku e Tiwanaku também apresentou queda, de 0,89 durante o primeiro período para 0,75 no segundo. A exclusão dos indivíduos mais jovens das amostras pouco impactou no resultado final, pois ainda observamos uma queda entre os dois períodos mencionados, dos 0,87 encontrados durante o período Pré Tiwanaku para os mesmos 0,75 do período Tiwanaku. Esta queda, mesmo que de menor amplitude, ainda se mostrou estatisticamente significativa $(U=2884,500 ; W=13469,500 ; \mathbf{p}=0,000)$. 
A possível influência da presença ou não de deformação craniana no índice de Lukacs foi testada, comparando-as entre si dentro do período Pré Tiwanaku $(U=$ 793,500; $W=1874,500 ; p=0,890)$, e do período Tiwanaku $(U=1926,000 ; W=$ 3817,000; $\mathbf{p}=0,137)$, não apresentando diferenças. Ao separarmos os indivíduos portadores de deformações cranianas e os indivíduos não portadores, observamos em ambos os grupos uma diminuição do índice entre os dois primeiros períodos estudados para os oásis atacamenhos. Embora a diminuição do índice de Lukacs apresentada pelos crânios deformados (de 0,89 para 0,73) fosse maior que a apresentada pelos crânios não deformados (de 0,89 para 0,76), tanto os deformados $(U=344,500$; $W=$ $2235,500 ; \mathbf{p}=0,000)$ como os não deformados $(U=724,500 ; W=3499,500 ; \mathbf{p}=0,000)$ apresentaram uma queda estatisticamente significativa entre Pré Tiwanaku e Tiwanaku. Se considerarmos que o índice de Lukacs apresentaria uma prevalência de cárie mais confiável, desconsideraríamos as diferenças observadas anteriormente e assumiríamos que não há distinção na dieta entre deformados e não deformados mas que há, para ambos, uma diminuição na cariogenicidade de suas dietas durante o período Tiwanaku.

As simulações feitas com estes dois grupos dividindo-os em indivíduos do sexo masculino e feminino também indicaram quedas nos dois casos, porém, em intensidades distintas. Enquanto o índice de Lukacs apresentado pelo sexo feminino cai de 0,87 no período Pré Tiwanaku para 0,80 no período Tiwanaku $(U=764,500 ; W=$ $3690,500 ; \mathbf{p}=0,000)$, o sexo masculino apresenta uma queda de 0,87 durante o período Pré Tiwanaku para 0,69 no período Tiwanaku $(U=489,000 ; \mathrm{W}=2200,000 ; \mathbf{p}=$ 0,000), apesar desta diferença de amplitude nas quedas do índice de homens e mulheres, em ambos os grupos as quedas apresentaram significância estatística, indicando uma diminuição nas cáries dentárias em todos os indivíduos do período Tiwanaku, independente do sexo. Ao corrigirmos as prevalências de cárie dentária através destes índices, encontramos quedas tanto para homens (o que não observamos quando apenas analisamos cárie dentária isoladamente) como para mulheres, indicando que a mudança na dieta consumida pelos atacamenhos beneficiou homens e mulheres indistintamente. 
O aumento na rede de trocas durante o período Tiwanaku teria disponibilizado à população atacamenha uma grande variedade de produtos originárias dos distintos ecossistemas circundantes ao deserto, como carne, algas e diversos vegetais que seriam produzidos em regiões vizinhas. Estes produtos proporcionariam à dieta dos habitantes de San Pedro uma quantidade de proteínas de origem animal (Ihama, peixes, etc...), vegetal (quinoa, cañiwa) ou de algas marinhas e lacustres (Berenguer, 2000; Pardo \& Pizarro, 2005) que ajudariam a explicar a diminuição das cáries e o aumento da estatura dos indivíduos masculinos (Neves \& Costa, 1998; Costa et al., 2004). Os tubérculos (batatas, chuño, olluco) e raízes comestíveis, trazidos do altiplano, também poderiam fornecer uma quantidade de amido menos cariogênico que os carboidratos encontrados no milho, também possibilitando a queda na cárie sem o comprometimento da quantidade calórica consumida pelos atacamenhos (Berenguer, 2000). A diferença na prevalência das cáries dentárias e perdas ante mortem observadas entre homens e mulheres dentro do mesmo período poderiam ser explicadas pela diferença natural encontrada entre os sexos na maioria das sociedades pré-históricas (Larson et al., 1962; Lukacs, 1996).

Os crânios do período Tiwanaku também apresentaram um desgaste dentário de fraca a média intensidade, sendo que $47,3 \%$ dos dentes analisados portavam desgaste entre os níveis 1 e 3, e 44,4\% entre os níveis 4 e 6 da escala de B. Smith (1984). Quando comparamos os três grupos de desgaste dentário entre os dois primeiros períodos históricos em San Pedro de Atacama, a queda do desgaste dentário de intensidade leve observada entre Pré Tiwanaku (51,5\%) e Tiwanaku $(47,3 \%)$ não se mostrou estatisticamente significativa $\left(X^{2}=0,6322 ; p=0,4265\right)$. O mesmo aconteceu com os aumentos do desgaste médio encontrados entre Pré Tiwanaku $(43,8 \%)$ e Tiwanaku $(44,4 \%)$ e com o desgaste intenso, entre Pré Tiwanaku (4,6\%) e Tiwanaku $(8,2 \%)$, não sendo significativos $\left(X^{2}=0,0010 ; \mathbf{p}=0,9749\right.$ e $X^{2}=1,5693 ; \mathbf{p}=0,2103$ respectivamente). Apesar da não significância estatística destas diferenças observadas, a queda de desgaste leve e o aumento dos desgastes de média a alta intensidade indicam uma tendência de aumento no consumo de alimentos mais abrasivos, como alguns vegetais fibrosos, durante o período Tiwanaku. Em concordância com esta mudança na dieta está o fato de que dentre todos os dentes que tiveram suas câmaras 
pulpares expostas, $10 \%$ foi devido a um desgaste intenso da coroa dentária. Se compararmos com o período anterior, onde nenhum dente apresentou desgaste intenso a ponto de expor a polpa dentária, podemos assumir este aumento na abrasividade da alimentação durante o período Tiwanaku.

Suportando este argumento, também foi observada uma variação nas médias dos desgastes dentários entre Pré Tiwanaku $(3,485)$ e Tiwanaku $(3,842)$, sendo este aumento estatisticamente significativo $(U=43864,500 ; W=52379,500 ; p=0,028)$.

Os 146 crânios do período Tiwanaku continham 765 dentes em condição adequada de análise do desgaste dentário, sendo 283 dentes anteriores e 482 dentes posteriores. Apesar de haver cerca de $70 \%$ mais dentes posteriores do que anteriores nesta amostra, a diferença entre os dentes anteriores e posteriores é muito menor do que a encontrada no período Pré Tiwanaku onde a diferença entre dentes anteriores e posteriores superava os $300 \%$.

A diferença dos desgastes encontrada nos dentes anteriores entre o período Pré Tiwanaku e Tiwanaku seguiu o padrão encontrado quando analisamos todos os dentes juntos, ou seja, enquanto se observa uma queda na prevalência de desgastes de intensidade leve (37,9\% para $24,4 \%$ ), os desgastes de média e alta intensidade apresentam uma alta entre estes dois períodos. Estas variações não se mostraram significativas para os desgastes leves $\left(X^{2}=1,8720 \mathbf{p}=0,1712\right)$, para os desgastes médios $\left(X^{2}=1,1444 ; \mathbf{p}=0,2847\right)$ ou mesmo para os desgastes intensos $\left(X^{2}=0,0051 ; \mathbf{p}\right.$ $=0,9429)$. Os dentes posteriores apresentaram um ligeiro aumento nos desgastes de leve intensidade entre os períodos mencionados (55,4\% para 60,8\%), porém, sem significância estatística $\left(X^{2}=0,7822 ; \mathbf{p}=0,3765\right)$. A prevalência dos desgastes de média intensidade cai de $42,6 \%$ para $35,1 \%$ enquanto os desgastes intensos sobem de $2,0 \%$ para $4,1 \%$, mas tanto a queda dos desgastes médios como a ascensão dos desgastes intensos não se mostraram significativas estatisticamente $\left(X^{2}=1,7246 ; \mathbf{p}=0,1891\right.$ e $X^{2}$ $=0,5671 ; \mathbf{p}=0,4514$ respectivamente) .

Enquanto durante o período anterior (Pré Tiwanaku) as diferenças encontradas entre os desgastes de dentes anteriores e posteriores foram significativos apenas entre os desgastes de alta intensidade, durante o período Tiwanaku, todos os níveis de 
desgaste dentário apresentaram diferenças significativas entre os apresentados pelos dentes anteriores e os posteriores (leve: $X^{2}=93,3532 ; \boldsymbol{p}=0,0000$ - médio: $X^{2}=$ 45,4286; $\mathbf{p}=0,0000$ - intenso: $X^{2}=27,3407 ; \mathbf{p}=0,0000$ ). Estas diferenças observadas entre os dentes anteriores e posteriores aqui apresentados, resultando em um desgaste maior nos dentes anteriores do que em dentes posteriores, coincidem com as diferenças observadas por Da-Gloria et al. (2010) em crânios oriundos do mesmo período Tiwanaku mas de sítios arqueológicos distintos de San Pedro de Atacama. A explicação mais plausível para esta diferença se baseia na grande perda dentária ante mortem dos dentes posteriores observada durante o período Tiwanaku (55,9\%), sobrecarregando os dentes anteriores com toda a carga mastigatória.

Quando alteramos a unidade de análise dos desgastes dentários, assumindo o indivíduo como unidade e não mais os dentes, os desgastes leves sobem dos $46,4 \%$ observados no período Pré Tiwanaku para 48,9\% durante o período Tiwanaku, mas sem significância estatística $\left(X^{2}=0,0002 ; \mathbf{p}=0,9885\right)$. Os desgastes de média intensidade caem de $50,0 \%$ para $44,6 \%$ nos mesmos períodos $\left(X^{2}=0,0834 ; \mathbf{p}=0,7727\right)$ enquanto os desgastes de intensidade alta sobem de $3,6 \%$ para $6,5 \%\left(X^{2}=0,0151 ; \mathbf{p}=\right.$ 0,9023), ambos igualmente sem significância.

A prevalência de desgaste dentário em esqueletos com presença ou ausência de deformações cranianas intencionais não mostraram diferenças significativas entre os períodos Pré Tiwanaku e Tiwanaku, independente do nível de desgaste apresentado (Figura 108). 


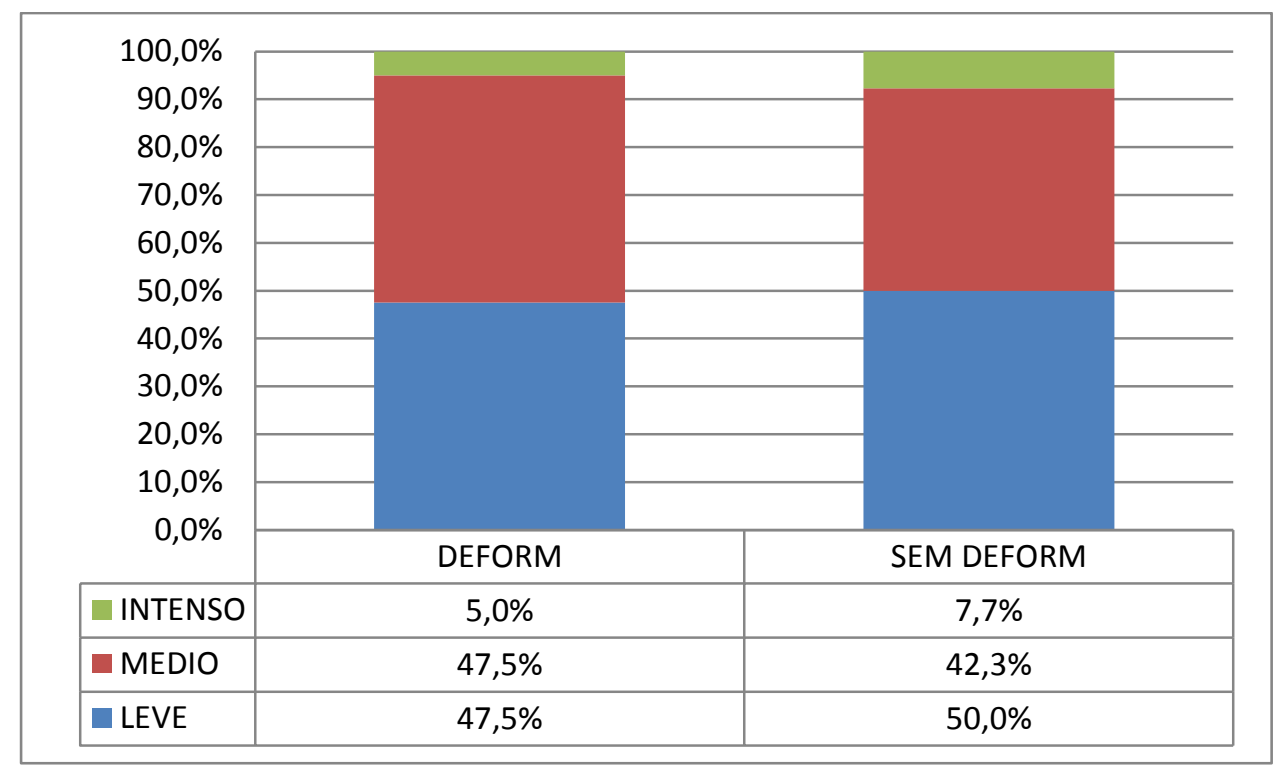

Figura 108 - Distribuição dos desgastes dentários para o período Tiwanaku considerando o indivíduo como unidade de análise.

Ao compararmos as médias do desgaste dentário do período Tiwanaku com o período anterior, constatamos que a mínima variação de 1,59 para 1,58 não foi estatisticamente significante $(U=1208,000 ; W=5486,000 ; p=0,808)$. Assim como no período Pré Tiwanaku, os homens apresentaram um desgaste médio maior do que as mulheres durante o período Tiwanaku (1,70 e 1,41 respectivamente). Mas diferentemente do período Pré Tiwanaku, a diferença do desgaste dentário entre homens e mulheres durante o período Tiwanaku foi estatisticamente significativa $(U=$ 641,500; $W=1344,500 ; \mathbf{p}=0,021)$. Apesar desta diferença observada entre homens e mulheres durante Tiwanaku, quando observamos a evolução do desgaste dentário de cada um destes grupos, comprando os períodos Pré Tiwanaku e Tiwanaku, nem o aumento observado no grupo dos homens (1,69 para 1,70 $-U=303,500 ; W=394,500$; $\mathbf{p}=0,968)$ nem a queda observada no grupo das mulheres $(1,46$ para $1,41-U=$ 220,000; $W=923,000 ; \mathbf{p}=0,594$ ) apresentaram uma variação significativa entre estes dois períodos.

Esta diferença entre homens e mulheres quanto ao desgaste dentário sugere, juntamente com a diferença encontrada para as cáries, que os homens poderiam ter uma dieta diferente das mulheres, porém, esta dieta teria que conter alimentos mais 
abrasivos que simplesmente o aporte de carne de lhama sugerida por outros trabalhos, novamente sustentando a ideia de uma dieta diversificada. Mas devemos lembrar que esta diferença entre a dieta mais ou menos abrasiva entre homens e mulheres não se restringe ao período Tiwanaku, pois já era observada (ainda que sem significância estatística) durante o período Pré Tiwanaku.

Retomando a análise de desgaste dentário entre os crânios deformados e não deformados, apesar de sabermos da ausência de variação significativa entre os períodos quando analisamos cada grau de intensidade do desgaste dentário separadamente, foi decidido analisar a média de desgaste encontrada em cada período. Durante o período Tiwanaku, observamos uma inversão da média de desgaste encontrada durante o período Pré Tiwanaku. Enquanto durante o primeiro período os indivíduos sem deformação craniana apresentaram uma média superior à encontrada nos indivíduos deformados (1,86 e 1,25 respectivamente), durante Tiwanaku observamos uma queda na média dos indivíduos sem deformação e um aumento nos crânios deformados intencionalmente. Apesar disso, a queda da média de desgaste dentário dos crânios sem deformação (de 1,86 para 1,56) não se mostrou significativa $(U=218,500 ; W=1164,500 ; p=0,083)$ assim como o aumento nos indivíduos deformados também não se mostrou significativo $(U=114,000 ; W=$ $150,000 ; \mathbf{p}=0,213)$. Este movimento de aproximação das médias ocorrido durante o período Tiwanaku fez com que a diferença de desgaste dentário entre os indivíduos portadores de deformação craniana intencional e os que não portavam tal modificação corporal não apresentasse significância estatística $(U=847,500 ; W=1793,500 ; \mathbf{p}=$ 0,898), reforçando a ideia na qual indivíduos com ou sem deformação craniana não tiveram uma dieta consideravelmente distinta.

As hipoplasias lineares do esmalte dentário foram avaliadas sobre 71 dentes permanentes dos crânios do período Tiwanaku. Apesar de ser a maior amostra entre os períodos estudados, estes dentes representam apenas $3 \%$ dos possíveis dentes a serem analisados para esta patologia nos 146 indivíduos deste período. Com esta amostra, a prevalência de indivíduos portadores de hipoplasia linear sobe consideravelmente entre os períodos Pré Tiwanaku e Tiwanaku, passando dos 15,8\% observados no primeiro período para $39,4 \%$ no segundo. Esta alta prevalência 
observada durante o período de influência do Império Tiwanaku na região foi também observada no trabalho de Costa et al. (2004) no qual, somando os dois "sub-períodos": "Pico Tiwanaku" e "Tiwanaku Final”, encontraram 43,2\% de prevalência de hipoplasia linear do esmalte durante o período Tiwanaku. Apesar desta expressiva alta na prevalência de hipoplasia entre os dois períodos, a não significância estatística desta diferença $\left(X^{2}=2,7385 ; \mathbf{p}=0,0980\right)$ possivelmente se deve ao pequeno número amostral desta análise. Os indivíduos que apresentaram apenas um dente acometido por hipoplasia linear também foram computados e encontrado um aumento neste número em comparação ao período anterior, subindo de 21,1\% para 29,6\% durante o período Tiwanaku. O aumento da prevalência de hipoplasia linear do esmalte dentário, ainda que não estatisticamente significativo, pode ser compatível ao cenário de aumento populacional observado durante o período Tiwanaku (Llagostera, 2004), no qual a aglomeração de pessoas e a dificuldade na manutenção da higiene poderiam ter aproximado hospedeiros e patógenos (Larsen, 1997 d). Outro fator importante que pode ter contribuído para o aumento das infecções nos oásis atacamenhos foi o intenso transito de caravanas que carregavam, juntamente com os produtos trazidos dos ecossistemas vizinhos, patologias que a população de San Pedro de Atacama desconhecia (Costa et al., 2009).

As reabsorções periodontais também apresentaram um aumento durante o período Tiwanaku. O número de alvéolos dentários que apresentaram algum nível de reabsorção durante este período foi quase o dobro do encontrado durante o período anterior. Enquanto Pré Tiwanaku apresentou 29,2\% dos alvéolos avaliados reabsorvidos, 56,3\% dos alvéolos estudados do período Tiwanaku estavam com algum grau de reabsorção. Este aumento significativo $\left(X^{2}=29,0959 ; \mathbf{p}=0,0000\right)$ das reabsorções periodontais em geral também foi observado tanto nos dentes anteriores como nos dentes posteriores.

Nos dentes anteriores, as reabsorções sobem de $15,0 \%$ para $54,4 \%$ entre os períodos Pré Tiwanaku e Tiwanaku de forma significativa $\left(X^{2}=9,9857 ; \mathbf{p}=0,0016\right)$, enquanto nos dentes posteriores o aumento na prevalência das reabsorções, de 32,0\% para $57,3 \%$, também se mostrou significante estatisticamente $\left(X^{2}=20,0261 ; \mathbf{p}=\right.$ $0,0000)$. 
Diretamente relacionados à reabsorção, os cálculos salivares também apresentaram um aumento durante o período Tiwanaku em comparação ao período anterior. Ausente no período Pré Tiwanaku, os cálculos subgengivais aparecem com prevalência bastante baixa $(0,5 \%)$ durante o período Tiwanaku. Já os cálculos supragengivais, que estavam presentes em $37,2 \%$ dos dentes avaliados no período anterior, foram observados em $47,3 \%$ dos dentes pertencentes a indivíduos do período Tiwanaku, aumento que se mostrou significativo $\left(X^{2}=4,8671 ; p=0,0437\right)$. Apesar disto, quando separamos os dentes em dentes anteriores e posteriores, o aumento dos cálculos supragengivais observado durante os mesmos períodos nos dentes anteriores (de $36,0 \%$ para $46,0 \%$ ) e o aumento observado nos dentes posteriores (de $38,0 \%$ para $48,0 \%)$ não se mostraram estatisticamente significativos $\left(X^{2}=0,5048 ; \mathbf{p}=\right.$ 0,4774 e $X^{2}=3,5599 ; p=0,0592$ respectivamente).

O aumento das reabsorções e da presença de cálculos salivares que foi observado entre os períodos Pré Tiwanaku e Tiwanaku poderia ser explicado pela mesma mudança na alimentação por mim proposta. Esta dieta menos cariogênica e provavelmente mais enriquecida com proteínas proporcionaria, nos indivíduos de San Pedro de Atacama, um ambiente bucal propício a bactérias não cariogênicas devido a menor competitividade destas bactérias com $S$. mutans e outras bactérias cariogênicas. Com isso, seriam formadas placas bacterianas danosas ao periodonto, favorecendo assim, o aumento da formação de cálculos salivares e a um aumento da reabsorção periodontal por consequência (Lang et al., 2003; Socransky \& Haffajee, 2003).

\section{Pós Tiwanaku}

O período Pós Tiwanaku, considerado nos oásis de San Pedro de Atacama entre 1000 AD e 1470 AD, é caracterizado pelo declínio do Império Tiwanaku. As causas e as 
consequências do desmantelamento deste Estado altiplânico impactaram de forma importante os oásis atacamenhos, tanto na estrutura social como na qualidade de vida dos habitantes locais (Janusek, 2002, 2004, 2008). O intenso e prolongado período de seca que assolou os Andes Centrais (Binford et al., 1997) pressionou a população atacamenha em busca dos escassos recursos hídricos do deserto de Atacama, causando um movimento migratório dos assentamentos nas bordas do salar em direção às fozes dos rios San Pedro e Vilama. Este deslocamento também foi associado a um aumento da violência interpessoal na região além da construção de fortificações conhecidas como Pukaras (Llagostera, 2004; Torres-Rouff et al., 2005). Esta tensão social associada à variação climática anteriormente mencionada foram os fatores responsáveis por um aparente declínio na qualidade de vida biológica da população sanpedrina (Neves \& Costa, 1998; Da-Gloria et al., 2011).

Estas condições climáticas durante o início do período Pós Tiwanaku que diminuíram a disponibilidade de água e forçaram a população atamenha a se concentrar nas áreas próximas aos rios, consequentemente teriam restringido as áreas de plantio, forçando esta sociedade a dedicar-se a produção de poucos produtos agrícolas que pudessem suprir adequadamente a demanda energética de seus cidadãos. O milho provavelmente foi o principal produto nos oásis atacamenhos (Llagostera, 2004; Núñez, 2007), devido a sua alta produtividade e ao alto teor calórico de seu fruto (FCF/USP, 2008; USDA, 2012).

Vestígios arqueológicos reforçam esta hipótese, como as palhas e as espigas de milho que foram encontradas em abundância nos sítios arqueológicos de San Pedro durante o período Pós Tiwanaku (Lynch, 1977). Apesar de ser relativamente sensível a períodos de escassez de água (Ferreira \& Magalhães, 1997; Magalhães \& Souza, 2011), as plantações de milho teriam contado com os sistemas de irrigação que já eram utilizados em diversas partes do deserto de Atacama (Santoro et al., 1998; Gómez \& Siarez, 2004).

Evidentemente a dieta dos atacamenhos não se restringia a apenas este vegetal, mesmo com a desestruturação das grandes redes de troca observada neste período, as trocas entre regiões vizinhas ainda se mantiveram (Tarragó, 1977). 
Certamente outros frutos e tubérculos devem ter feito parte da alimentação durante este período, mas com a diminuição dos intercâmbios e as condições ambientais adversas resultantes de um longo período de seca, não seria irresponsável de minha parte assumir que a população teria sido pressionada a desenvolver e a intensificar suas técnicas de conservação e armazenamento de alimentos.

O período Pós Tiwanaku é representado por 131 indivíduos, sendo 61 indivíduos identificados como do sexo masculino, 58 do sexo feminino e 12 indivíduos cujo sexo não foi possível ser determinado pelo protocolo utilizado. Esta amostra tem $57 \%$ de seus indivíduos com idade de morte abaixo dos 40 anos, sendo que 6 destes indivíduos tinham menos que 25 anos e os outros 68 entre 25 e 40 anos de idade. 0 restante da amostra se dividiu em 36 indivíduos com 40 a 55 anos e os 20 restantes, acima de 55 anos.

O que chama a atenção é a diferença entre a distribuição das idades dos indivíduos destes grupos quando os comparamos com o período histórico anterior (Tiwanaku). Enquanto a amostra de crânios de Tiwanaku apresenta apenas 31\% de seus indivíduos com idade inferior a 40 anos, o período Pós Tiwanaku teve quase o dobro deste percentual em sua amostra de indivíduos com a mesma idade. Apesar dos testes estatísticos não apresentarem diferença significativa quanto ao sexo, idade e períodos analisados, evidentemente as patologias dentais cuja idade seja importante por se tratarem de doenças cumulativas, serão avaliadas com ressalvas e pontuadas caso a caso.

A presença das deformações cranianas durante o período Pós Tiwanaku se manteve dentro da distribuição esperada para os oásis atacamenhos, com $54,7 \%$ dos crânios sem apresentarem deformação craniana, enquanto os deformados estão distribuídos em $74,1 \%$ do tipo Tabular e $25,9 \%$ do tipo Circular. A queda na frequência dos indivíduos com deformação craniana tabular de 85,5\% encontrados em Tiwanaku para $74,1 \%$ durante o período Pós Tiwanaku não apresentou significância $\left(X^{2}=1,7540\right.$; $\mathbf{p}=0,1854)$. 
Os 131 crânios analisados do período Pós Tiwanaku apresentavam 591 dentes ainda inseridos em seus alvéolos, representando $21,8 \%$ dos alvéolos disponíveis para análise.

A perda dentária post mortem foi maior nos crânios do período Pós Tiwanaku quando comparadas às do período anterior, com uma prevalência de $36,7 \%$. Estes alvéolos vazios, assim como os períodos Pré Tiwanaku e Tiwanaku, estiveram mais presentes nos dentes anteriores, com $54,4 \%$ dos dentes perdidos durante a vida, do que nos dentes posteriores, com $25,6 \%$ de perdas post mortem.

As perdas dentárias ante mortem sofrem uma queda dos $47,0 \%$ encontrados durante o período Tiwanaku para 41,5\% durante o período Pós Tiwanaku. Esta queda se mostrou significativa $\left(X^{2}=18,7561 ; p=0,0000\right)$. Este quadro deve ser analisado com cautela, devido à faixa etária majoritária entre os indivíduos do período Pós Tiwanaku. Com uma amostra "mais jovem", seria esperado que este período apresentasse marcadores dentais como as perdas ante mortem menos frequentes que o período anterior, pois as duas principais patologias dentárias que levam às perdas dos dentes em vida são patologias cumulativas e diretamente relacionadas com o tempo.

As perdas dentárias ante mortem, independentemente se de dentes anteriores ou posteriores, apresentam quedas em suas prevalências quando comparamos o período Tiwanaku com os sítios representantes do período Pós Tiwanaku, sejam eles na bacia do salar do Atacama ou fora dela. A mesma queda da prevalência e sua significância são observadas quando extraímos das amostras os indivíduos com menos de 25 anos de idade, tanto nas análises dos dentes em geral como divididos em anteriores e posteriores.

Durante o período Pós Tiwanaku, a diferença na prevalência das perdas dentárias em vida entre indivíduos com crânios deformados (37,9\%) e indivíduos sem deformação $(45,5 \%)$ se manteve significativa como durante o período anterior $\left(X^{2}=\right.$ $15,5875 ; \mathbf{p}=0,0001)$. Ao separarmos estes dois grupos e os compararmos com o período anterior, os crânios deformados apresentaram uma queda significativa dos 44,3\% para 37,9\% durante o período Pós Tiwanaku $\left(X^{2}=10,9246 ; p=0,0009\right)$, 
enquanto a queda também observada das perdas ante mortem dos indivíduos não deformados (de 48,5\% para 45,5\%) não foi significativa $\left(X^{2}=2,8860 ; \mathbf{p}=0,0894\right.$ ).

As prevalências dos abcessos dentais presentes nos esqueletos durante 0 período Pós Tiwanaku $(32,8 \%)$ se mostrou muito próxima à prevalência encontrada durante o período Tiwanaku (33,0\%), sendo que não foi observada diferença estatística entre elas $\left(X^{2}=0,0096 ; \mathbf{p}=0,9221\right)$. Quando foram excluídos os indivíduos com menos de 25 anos de idade, a prevalência de abcessos periapicais durante o período Pós Tiwanaku aumenta de $32,8 \%$ para $34,9 \%$. Ainda assim, não foi observada diferença significativa entre este período e Tiwanaku $\left(X^{2}=1,1872 ; \mathbf{p}=0,2759\right)$.

A diferença não significante na prevalência de abcessos encontrada entre 0 período Tiwanaku e o período Pós Tiwanaku não acompanhou o movimento de queda significativa observado nas perdas dentárias ante mortem do mesmo período, porém, não se mostrou contraditória ao mesmo.

O período Pós Tiwanaku apresenta uma prevalência de dentes acometidos pela cárie dentária superior ao período anterior. 0 aumento de $44,5 \%$ de dentes cariados para $54,1 \%$ durante o período Pós Tiwanaku se mostrou estatisticamente significativo $\left(X^{2}=12,4951 ; \mathbf{p}=0,0004\right)$. Aparentemente, a ausência da influencia Tiwanaku na região teria alterado a dieta atacamenha, aumentando a cariogenicidade desta.

Quando analisamos a intensidade das lesões de cárie durante o período Pós Tiwanaku, encontramos um aumento nas cáries extremas, onde há destruição total da coroa dentária (de 21,0\% para 25,1\%) e uma queda nas cáries superficiais (de $42,5 \%$ para 31,9\%) em relação ao período Tiwanaku. Enquanto o aumento das cáries extremas não se mostrou significativo $\left(X^{2}=1,7233 ; \mathbf{p}=0,1893\right)$, a queda das cáries dentárias superficiais se mostrou estatisticamente significativa $\left(X^{2}=9,5246 ; \mathbf{p}=\right.$ 0,0020), aumentando as cáries de média intensidade e reforçando a afirmação anterior a respeito de um aumento na cariogenicidade da dieta Pós Tiwanaku.

Ao dividirmos as cáries dentárias presentes em apenas dois grandes grupos, cáries leves e cáries profundas, não observamos diferenças significativas nem entre 
Tiwanaku e os dois grupos Pós Tiwanaku, nem mesmo entre os dois períodos Pós Tiwanaku entre si.

A diferença da prevalência de cáries entre homens e mulheres que, durante o período Tiwanaku, não era significativa $\left(42,8 \%\right.$ em homens e $48,9 \%$ em mulheres $-X^{2}=$ 2,5939; $\mathbf{p}=0,1073)$, durante o período Pós Tiwanaku diminuiu e se inverteu, sendo $55,3 \%$ em homens e 54,1\% em mulheres. Esta diferença tampouco se mostrou significativa $\left(X^{2}=0,0282 ; \mathbf{p}=0,8665\right)$. Quando avaliamos a mesma patologia, mas não considerando os indivíduos com idade de morte inferior a 25 anos, a prevalência de cárie dentária em mulheres volta a ser superior que nos homens (58,4\% e 55,9\% respectivamente), mas ainda sem ser significativa $\left(X^{2}=0,2031 ; p=0,6522\right)$.

A prevalência de cárie dentária dos homens sofreu um aumento entre o período Tiwanaku e o período Pós Tiwanaku, subindo de 42,8\% para 55,9\%, sendo esta alta significativa $\left(X^{2}=12,0937 ; \mathbf{p}=0,0005\right)$. Nas mulheres também se observou um aumento na prevalência de cárie entre Tiwanaku e Pós Tiwanaku $\left(X^{2}=3,8283 ; \mathbf{p}=\right.$ 0,0504). Este aumento na prevalência de cárie dentária observado principalmente nos homens entre os períodos Tiwanaku e Pós Tiwanaku são similares aos observados por Costa et al. (2004) e Hubbe et al. (2012), justificado por ambos como sendo resultantes de uma maior disponibilidade de proteína de origem animal (carne de camelídeos) para os homens em detrimento das mulheres durante o período Tiwanaku e não durante o período seguinte.

Como esperado, os dentes anteriores apresentaram um número inferior de cáries dentárias quando comparados ao apresentado pelos dentes posteriores, tanto na amostra do período Pós Tiwanaku total como na amostra sem os indivíduos menores que 25 anos. Apesar deste fato, ambas as regiões apresentaram um aumento na prevalência de cárie dentária em comparação ao período Tiwanaku, sendo que nos dentes anteriores com ou sem indivíduos jovens ( $<25$ anos), as prevalências não apresentaram diferença estatisticamente significativa $\left(X^{2}=1,3394 ; \mathbf{p}=0,2471\right.$ e $X^{2}=$ 2,$6821 ; \mathbf{p}=0,1015$ respectivamente) enquanto que nos dentes posteriores, a diferença na prevalência das lesões cariosas se mostrou significativa tanto com o total de 
indivíduos como apenas com indivíduos maiores que 25 anos $\left(X^{2}=6,4843 ; p=0,0109\right.$ e $X^{2}=8,7369 ; \mathbf{p}=0,0031$ respectivamente).

Os crânios deformados e não deformados do período Pós Tiwanaku também foram avaliados separadamente quanto à prevalência de cárie dentária, assim como nos períodos anteriormente discutidos. Apesar de não ter sido encontrada diferença significativa entre os dois grupos durante o período Tiwanaku $\left(X^{2}=0,8216 ; \mathbf{p}=0,3647\right)$ ou mesmo durante o período Pós Tiwanaku $\left(X^{2}=0,0016 ; p=0,9680\right)$, os indivíduos mostrando deformação craniana intencional apresentaram um aumento significativo na prevalência de cárie dentária entre o período Tiwanaku e Pós Tiwanaku $\left(X^{2}=\right.$ 5,7669; $\mathbf{p}=0,0163)$, o que não foi observado para os indivíduos sem deformação. As deformações tabulares, que foram as mais frequentes nos oásis atacamenhos, é a responsável por este aumento observado nos indivíduos deformados $\left(X^{2}=6,7054 ; \mathbf{p}=\right.$ 0,0096). Com este quadro, fica difícil explicar a condição dos indivíduos que apresentaram deformação craniana intencional pois, enquanto observamos uma queda significativa das perdas dentárias ante mortem entre estes esqueletos, um aumento também significativo foi observado na prevalência de cárie dentária, caminhando, aparentemente no sentido oposto. A análise dos índices de correção de cáries foi responsável pela averiguação desta aparente divergência e são apresentados adiante neste trabalho.

O índice de Saunders (DMI) apresentou um pequeno aumento entre o período Tiwanaku $(81,44)$ e o período Pós Tiwanaku $(83,28)$, sem demonstrar significância estatística. Apesar de não ser significante $(U=9288,000 ; W=19873,000 ; \mathbf{p}=0,744)$, quando somadas às prevalências de cárie dentária e as perdas em vida, o resultado sugere um aumento de cárie dentária após o período Tiwanaku, mantendo a premissa que Tiwanaku foi um período representado pela queda nas cáries dentárias e assim, uma melhora na qualidade de vida da população atacamenha.

A tendência observada no DMI entre os períodos Tiwanaku e Pós Tiwanaku foi novamente encontrada na análise do índice de Lukacs. Após identificação de todos os casos de exposição pulpar ocorridos durante o período Pós Tiwanaku, 96\% destes dentes tiveram suas polpas expostas por processos cariosos. Assim, $96 \%$ de todas as 
perdas dentárias ante mortem foram somadas à prevalência de cárie dentária para a criação do índice de Lukacs.

Quando comparamos o índice de Lukacs apresentado pelos esqueletos do período Tiwanaku $(0,75)$ com os apresentados pelos esqueletos do período Pós Tiwanaku $(0,81)$, o aumento encontrado na prevalência de cárie dentária e no DMI é repetido, mesmo quando não consideramos os indivíduos com idade inferior a 25 anos $(0,81)$. Este aumento, assim como o aumento na prevalência de cárie dentária e diferentemente do aumento do $\mathrm{DMI}$, se mostrou estatisticamente significativo $(\mathrm{U}=$ 6286,$500 ; W=16871,500 ; p=0,000$ ).

Durante o período Pós Tiwanaku, assim como no período anterior, as mulheres apresentaram um índice maior que os homens $(0,83$ e 0,81 respectivamente) mas esta diferença não foi estatisticamente significativa $(U=1396,500 ; W=3226,500 ; \mathbf{p}=$ $0,256)$ como a encontrada durante o período Tiwanaku. Porém, o aumento observado entre os homens do período Tiwanaku e os homens do período Pós Tiwanaku $(0,69$ para 0,81$)$ foi estatisticamente significativo $(U=1051,500 ; W=2762,500 ; p=0,000)$. 0 mesmo acontece quando comparamos as mulheres do período Tiwanaku com as mulheres do período Pós Tiwanaku $(0,80$ para 0,83$)(U=1278,500 ; W=4204,500 ; \mathbf{p}=$ 0,000). Este aumento significativo em ambos os sexos, quando foram comparados entre si ao longo do tempo, é condizente com os resultados obtidos por Costa et al. (2004) que também encontraram o mesmo aumento das prevalências de cáries dentárias em homens e mulheres. Os resultados apresentados por Hubbe et al. (2012) diferem dos resultados de Costa et al. (2004) e dos meus, pois neles apenas os homens apresentaram aumento estatisticamente significativo de cárie e também do índice de Lukacs entre o período Tiwanaku e Pós Tiwanaku. Contudo, os três resultados apontam para dois possíveis cenários:

O primeiro seria uma diminuição nos fatores de proteção à cárie, que poderiam ser desde mudança de fontes de água com níveis de flúor menores (o que não foi o caso, visto que todas as fontes de água correntes disponíveis na região possuem níveis de flúor muito próximos) ou uma diminuição na ingestão de alimentos protetores, como leites e derivados (Moynihan, 2005), sendo esta segunda hipótese difícil de ser 
verificada mas condizente com a dificuldade de criação de animais devido às mudanças climáticas e à retração das áreas cultiváveis.

O segundo e mais provável cenário sugere um aumento no consumo de alimentos com carboidratos cariogênicos no período que se segue ao declínio da presença Tiwanaku nos oásis de San Pedro de Atacama. Hubbe et al. (2012) ainda acrescentam a este quadro um declínio na ingestão de carne, também considerada um fator de proteção a cáries (Mays, 2010), pelos indivíduos masculinos após o período Tiwanaku. Visto que o aumento das cáries observado em meus resultados não discrimina o sexo dos indivíduos, a origem deste aumento poderia ser o retorno à predominância do milho na dieta atacamenha devido às dificuldades climáticas e sociais resultantes do desmantelamento do Império Tiwanaku e de suas redes de comércio transandino. Predominante mas não exclusivo, o milho estaria associado a outros produtos agrícolas também cariogênicos como alguns tubérculos ricos em amido e que, ao serem preparados para sua conservação, teriam seu potencial cariogênico aumentado por este processo (Pardo \& Pizarro, 2008).

Os indivíduos que apresentaram crânios deformados foram comparados aos crânios sem deformação quanto ao índice de Lukacs, como foi feito para os dois períodos históricos anteriores.

Durante o período Pós Tiwanaku, assim como durante o período Tiwanaku, os crânios com deformação intencional apresentaram um índice inferior aos crânios sem deformação $(0,79$ e 0,83 respectivamente), porém sem mostrar significância estatística $(U=1637,500 ; W=3068,500 ; \mathbf{p}=0,258)$. Mas o aumento observado entre os dois períodos no índice dos crânios deformados $(0,73$ para 0,79$)$ e o aumento do índice dos crânios não deformados $(0,76$ para 0,83$)$ foram, ambos, significativos $(U=1187,000 ; W$ $=3078,000 ; \mathbf{p}=0,014$ e $U=1701,500 ; \mathrm{W}=4476,500 ; \mathbf{p}=0,000$ respectivamente).

Indivíduos deformados e não deformados, quando comparados entre si dentro de cada período, não apresentaram diferenças significativas em seus índices de Lukacs durante toda a pré-história atacamenha. Apesar disso, a queda entre os períodos Pré Tiwanaku e Tiwanaku e o de aumento entre os períodos Tiwanaku e Pós Tiwanaku no índice de Lukacs apresentaram significância estatística para ambos os grupos, 
sugerindo não haver distinção na dieta (quando se avalia cáries dentárias e perdas dentárias ante mortem juntos) entre estes dois grupos culturalmente ou apenas esteticamente distintos.

Os dentes dos crânios do período Pós Tiwanaku apresentaram um desgaste dentário menor que os indivíduos do período Tiwanaku. A média do desgaste dentário observada durante o período Pós Tiwanaku $(3,529)$ é menor que a do período Tiwanaku $(3,842)$ e estatisticamente significante $(U=161056,000 ; W=271271,000 ; \mathbf{p}=$ $0,002)$.

Ao compararmos os 3 níveis de intensidade, encontramos um aumento dos desgastes de intensidade leve $(47,3 \%$ para $58,4 \%)$ enquanto os desgastes médios e intensos diminuem (44,4\% para $36,5 \%$ e $8,2 \%$ para $5,1 \%$ respectivamente), sendo todos significativos estatisticamente (leve: $X^{2}=13,9068 ; p=0,0002 /$ médio: $X^{2}=$ 7,3132; $\mathbf{p}=0,0068 /$ intenso: $\left.X^{2}=3,8508 ; \mathbf{p}=0,0497\right)$. A média destas intensidades de desgaste dentário também apresenta uma queda entre o período Tiwanaku $(1,609)$ e o período Pós Tiwanaku (1,467), também com significância estatística ( $U$ = 158170,000; $W=268385,000 ; \mathbf{p}=0,000)$. Assim, se utilizarmos os dentes como unidade de análise, as médias dos desgastes dentários e as médias das intensidades de desgaste dentário são significativas entre o período Tiwanaku e Pós Tiwanaku, indicando uma menor abrasividade na dieta consumida pela população atacamenha durante o último período.

Tantos os dentes anteriores como os posteriores apresentaram um aumento dos desgastes leves e uma diminuição dos desgastes de intensidade média ou alta, mas apenas as diferenças dos desgastes de leve e média intensidade observadas nos dentes anteriores foram estatisticamente significativas (leve: $X^{2}=17,8000 ; \mathbf{p}=0,0000$ / médio: $\left.X^{2}=9,2618 ; \mathbf{p}=0,0023\right)$ quando comparados os períodos Tiwanaku e Pós Tiwanaku. Assim como durante o período Tiwanaku, os dentes posteriores são precocemente perdidos por lesões de cárie dentária, deixando a carga mastigatória sobre os dentes anteriores, que por apresentarem menor prevalência de cárie, têm uma sobrevida maior e assim, mais tempo para que as forças oclusais e a abrasividade dos alimentos ingeridos causem o desgaste apresentado. 
Estas diferenças de desgaste dentário entre os dentes anteriores e posteriores também foram comparadas, durante o período Pós Tiwanaku, apresentando significância estatística entre eles nos desgastes de leve e alta intensidade (leve: $X^{2}=$ 10,0785; $\mathbf{p}=0,0015$ / alta: $\left.X^{2}=8,5527 ; \mathbf{p}=0,0035\right)$.

Ao avaliarmos os desgastes dentários, considerando o indivíduo como unidade de análise, os três níveis de desgaste dentário não apresentaram diferença estatística entre Tiwanaku e Pós Tiwanaku (leve: $X^{2}=0,0051 ; \mathbf{p}=0,9431 /$ médio: $X^{2}=0,0189 ; \mathbf{p}=$ 0,8908 / intenso: $\left.X^{2}=0,0141 ; p=0,9054\right)$.

Os desgastes dentários foram avaliados entre os indivíduos que apresentaram ou não deformações cranianas intencionais (Figura 109).

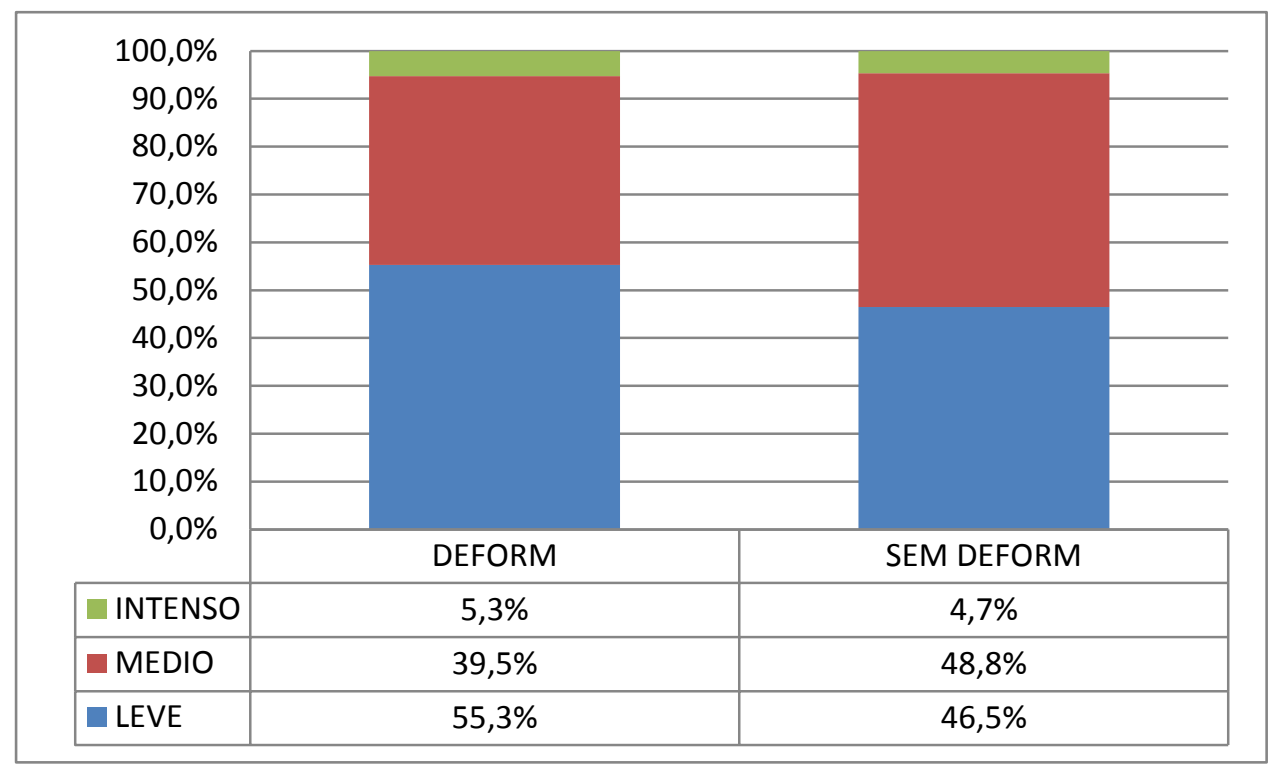

Figura 109 - Distribuição dos desgastes dentários para o período Pós Tiwanaku considerando o indivíduo como unidade de análise.

Durante o período Pós Tiwanaku, os níveis de desgaste dentário foram comparados com os mesmos níveis apresentados durante o período Tiwanaku, não apresentando diferença estatística significativa em nenhum dos três níveis avaliados 
(leve: $X^{2}=0,3833 ; \boldsymbol{p}=0,5359 /$ médio: $X^{2}=0,0332 ; \boldsymbol{p}=0,8554$ / intenso: $X^{2}=0,0174 ; \mathbf{p}$ $=0,8952$ ).

As médias dos níveis de desgaste dentário, ainda considerando os indivíduos como unidade de análise, foram comparadas entre os períodos Tiwanaku e Pós Tiwanaku. A queda observada ao longo do tempo entre os períodos Tiwanaku e Pós Tiwanaku $(1,58$ para 1,57$)$ não se mostrou estatisticamente significativa $(U=3441,500$; $W=7719,500 ; \mathbf{p}=0,975)$, apesar de manter a tendência de queda observada entre os períodos Pré Tiwanaku e Tiwanaku (também não significativa). Se considerarmos apenas os indivíduos como unidade de análise, as diferenças observadas entre os 3 períodos históricos não são significativas, sugerindo a pouca variação de abrasividade da dieta consumida nos oásis atacamenhos. Um fato importante a ser mencionado é a observação de um nível de desgaste leve a moderado para os dentes, independentemente do período analisado, para os oásis de San Pedro. Para ambientes "arenosos" como do deserto de Atacama, era esperado um nível maior de desgaste dentário devido à incorporação não proposital de areia aos alimentos (Meller et al., 2009), como o que é observado para os sambaquis do litoral brasileiro (Okumura \& Eggers, 2005; Eggers et al., 2011), mas esta condição de desgaste esperada não foi confirmada nos dentes dos habitantes dos sítios sanpedrinos.

A diferença entre a média dos desgastes dentários apresentados pelos indivíduos do sexo masculino e feminino durante o período Pós Tiwanaku é o mais expressivo entre todos os períodos avaliados ( $\operatorname{masc}=1,70 ;$ fem $=1,32$ ), sendo estatisticamente significativa $(U=353,500 ; W=678,500 ; p=2,635)$, reforçando a ideia de uma dieta distinta entre homens e mulheres quanto à abrasividade do alimento ingerido. Apesar disto, nem homens nem mulheres apresentaram diferença significativa quando foram comparados a seus iguais do período histórico anterior (mas: $U=1010,000 ; W=2138,000 ; p=0,996-$ fem: $U=429,000 ; W=754,000 ; p=$ $0,557)$.

As médias dos desgastes dentários apresentadas pelos esqueletos com ou sem deformação craniana intencional não apresentaram diferença significativa, nem entre os dois grupos $(U=667,000 ; W=1228,000 ; p=0,907)$ nem entre os períodos 
Tiwanaku e Pós Tiwanaku (deformados: $U=657,500 ; \mathrm{W}=1218,500 ; \mathbf{p}=0,975$ - não deformados: $U=859,500 ; W=1805,500 ; \mathbf{p}=0,824)$.

As quedas na intensidade do desgaste dentário observado durante o período Pós Tiwanaku, independentemente do método de análise utilizado, coincidem com os resultados apresentados por outros autores (Costa et al., 2004; Da-Gloria et al., 2010; Hubbe et al., 2012).

Vale salientar que dois destes trabalhos (Costa et al., 2004; Da-Gloria et al., 2010) apresentaram uma queda importante durante o que eles chamaram de pico de presença Tiwanaku em San Pedro de Atacama, sendo este o menor grau de desgaste observado ao longo do tempo estudado pelos dois grupos. Apesar disso, ambos observaram um aumento deste desgaste dentário ainda durante o período Tiwanaku, mas já no final do período. No período subsequente, estes pesquisadores voltaram a observar uma queda do grau médio de desgaste dentário durante o período Pós Tiwanaku.

A dificuldade de explicar tal diminuição no grau médio de desgaste dentário é apontada tanto no trabalho de Costa et al. (2004) como em Hubbe et al. (2012), sendo que os primeiros autores mencionam a falta de dados que expliquem tal queda enquanto os autores do segundo trabalho tampouco explicam, mas sugerem uma mudança na forma de preparação dos alimentos como possível razão para tais resultados.

Meus resultados apresentam uma queda no desgaste dentário, porém, não significativa entre os períodos. Este quadro de invariabilidade do desgaste ao longo do tempo nos oásis atacamenhos é explicado pela possível variedade de dieta por mim sugerida, na qual a mudança de alimentos possa ter ocorrido apenas em seu teor de cariogenicidade e não em sua consistência ou forma de preparo e mantendo, grosso modo, o mesmo padrão ou intensidade de desgaste entre os períodos estudados.

A pequena variação do desgaste dentário observada em meu trabalho pode sim, ser resultante da composição e consistência destes alimentos, que possivelmente eram trocados com os ecossistemas vizinhos ao deserto, como o litoral, a selva 
argentina e principalmente, o altiplano boliviano. Como já mencionados anteriormente, uma grande quantidade de bulbos, raízes e tubérculos comestíveis encontrados no altiplano poderiam estar disponíveis à população de San Pedro, trazidos pelas redes de troca, e que apresentam grande quantidade de amido e fibra vegetal em sua composição (Pardo \& Pizarro, 2005), proporcionando distintos desgastes principalmente durante o período Tiwanaku, no qual provavelmente estiveram mais presentes. Ao serem interrompidas as redes de troca, estes produtos seriam retirados de circulação e assim, teriam influenciado minimamente o desgaste dentário dos indivíduos viventes durante o período Pós Tiwanaku.

As hipoplasias lineares do esmalte dentário presentes nos crânios do período Pós Tiwanaku foram menos frequentes que as hipoplasias presentes durante o período anterior. Se considerarmos afetados os indivíduos com pelo menos 2 dentes acometidos, a prevalência durante o período Pós Tiwanaku cai de 39,4\% do período Tiwanaku para $36,5 \%$, mas não sendo estatisticamente significativas $\left(X^{2}=0,0193 ; \mathbf{p}=\right.$ $0,8895)$.

Se considerarmos crânios que apresentavam, no momento de minhas análises, apenas um dente acometido pela lesão hipoplásica, a queda é de $29,6 \%$ para $25,0 \%$ entre Tiwanaku e Pós Tiwanaku.

Tenho a mesma dificuldade de interpretação das hipoplasias lineares que a apresentada por Costa et al. (2004). Mesmo minha amostra sendo $87 \%$ maior que a daquele trabalho, ainda assim possuo uma amostra insuficiente para adequada comparação e confiabilidade em meus resultados e para inferir mudanças nos níveis de estresse biológico da população atacamenha.

Mas, se a limitação do número amostral deste trabalho for relevada, a natureza não específica das hipoplasias lineares do esmalte possibilita a suposição de uma origem infecciosa para esta anomalia do desenvolvimento dentário (Goodman \& Rose, 1990; Armelagos et al., 2009), favorecida pelo aumento da população atacamenha durante o período Tiwanaku (Horizonte Médio) que, com o declínio das populações andinas devido às grandes transformações climáticas ocorridas durante os séculos $\mathrm{X}$ e XI da era cristã, também diminuem a frequência desta patologia dentária durante o 
período Pós Tiwanaku, retirando da dieta a responsabilidade da variação das prevalências das hipoplasias do esmalte observadas ao longo da pré-história atacamenha.

As reabsorções encontradas nas arcadas dos crânios do período Pós Tiwanaku foram comparadas às reabsorções periodontais dos crânios do período anterior que, quando simplesmente divididos em alvéolos com ou sem algum grau de reabsorção, não apresentaram diferenças estatisticamente significativas entre estes dois períodos consecutivos $\left(X^{2}=3,7148 ; \mathbf{p}=0,0539\right)$, apesar do aumento observado dos alvéolos acometidos por reabsorção durante o período Pós Tiwanaku. O aumento da reabsorção periodontal acima descrito se repete quando separamos os alvéolos de acordo com a localização na arcada dentária. Tanto os dentes anteriores (54,4\% para $66,1 \%)$ como os dentes posteriores (57,3\% para $60,9 \%)$ apresentaram aumento na prevalência de reabsorções de seus alvéolos, sendo este aumento apenas significativo estatisticamente nos dentes anteriores $\left(X^{2}=3,9518 ; p=0,0468\right)$.

Estas reabsorções podem estar ligadas à presença de cálculos salivares nos dentes acometidos por elas. A dificuldade de observação destes cálculos salivares em material arqueológico limita a interpretação desta associação, principalmente quando a amostra avaliada foi submetida a diversos processos tafonômicos deletérios "in situ" mas também de armazenamento nas instituições responsáveis, como é o caso desta coleção. Apesar desta premissa, os crânios por mim analisados originários do período Pós Tiwanaku apresentaram um aumento da prevalência de cálculos dentários condizente com o aumento das reabsorções periodontais encontrado no mesmo período. Os cálculos salivares subgengivais, ainda que raros de serem encontrados em material arqueológico, estavam presentes em 1,6\% dos dentes analisados, valor 3 vezes superior ao encontrado para o período Tiwanaku $(0,5 \%)$. Os cálculos salivares supragengivais também apresentaram um aumento quando comparamos a prevalência presente no período Tiwanaku $(47,3 \%)$ e a prevalência observada no período Pós Tiwanaku (64\%), sendo este aumento estatisticamente significativo $\left(X^{2}=\right.$ 33,6246; $\mathbf{p}=0,0000)$. Os dentes anteriores e posteriores, quando avaliados separadamente, apresentaram aumentos igualmente significativos $\left(X^{2}=15,5996 ; \mathbf{p}=\right.$ 0,0001 e $X^{2}=17,6504 ; \mathbf{p}=0,0000$, respectivamente). 
Uma explicação para o aumento da prevalência dos cálculos salivares seria o aumento da ingestão de carne e gordura animal por parte da população estudada (Pedersen, 1947). Porém, a amostra do estudo daquele autor se tratava de uma sociedade onde a proteína animal era a base da alimentação (Ford, 2009), significando um consumo em grande quantidade deste recurso. Em San Pedro de Atacama encontramos um cenário bastante distinto, no qual a sociedade atacamenha teve o milho como base alimentar durante a sua pré-história (Llagostera, 2004; Núñez, 2007), obviamente, utilizando a carne animal como complemento nutricional.

Contradizendo a premissa na qual a carne teria sido o fator principal (para não dizer único) na variação das cáries dentárias observadas durante o período Tiwanaku, os valores encontrados nas prevalências de cálculo salivar e da reabsorção periodontal são menores durante Tiwanaku dos encontrados no período subsequente. Apesar da carne de lhama ser uma fonte de proteína com menor teor de gordura que a maioria das outras carnes consumidas por nós (Pérez et al., 2000; Saadoun \& Cabrera, 2008), ela ainda assim fornece ao organismo humano a quantidade de nitrogênio suficiente para a produção e excreção da uréia responsável pela formação e crescimento dos cálculos salivares (White, 1997; Jin \& Yip, 2002).

O aumento das prevalências de cálculo salivar e de reabsorção periodontal observado no período Pós Tiwanaku podem ter sido fruto das mesmas técnicas de armazenamento dos alimentos anteriormente mencionadas.

A utilização de sal ou de fumaça e cinzas (fumagem) nos processos de conservação dos alimentos largamente utilizado nos Andes (Pardo \& Pizarro, 2005, 2008) proporcionaria uma fonte extra de cálcio e potássio ao habitante dos oásis atacamenhos, diminuindo o $\mathrm{pH}$ de seu sangue e consequentemente de sua saliva, aumentando a deposição destes minerais nas placas bacterianas aderidas às superfícies dentárias, aumentando a prevalência de cálculos salivares durante este período e consequentemente, aumentando a reabsorção periodontal de seus dentes. 


\section{Pós Tiwanaku externo}

O sítio Caspana (Pós Tiwanaku externo) será utilizado na discussão como uma referência externa aos oásis e relacionado diretamente com o período Pós Tiwanaku, sendo limitadas as interpretações resultantes destas comparações devido ao pequeno número de indivíduos na amostra de Caspana.

Os 31 indivíduos provenientes do sítio Caspana, 13 homens, 15 mulheres e 3 indivíduos cujo sexo não foi determinado, foram identificados com idade de morte mais avançada, quando o comparamos com o período Pré Tiwanaku. Com $45 \%$ dos crânios estudados tendo idade considerada abaixo dos 40 anos ( 2 esqueletos com menos de 25 anos e 12 com idade entre 25 e 40 anos), o restante (17 esqueletos) está dividido em 10 indivíduos com idade entre 40 e 55 anos e 7 indivíduos com idade de morte superior aos 55 anos.

A prevalência das deformações cranianas intencionais encontradas em Caspana é totalmente distinta da prevalência encontrada para os sítios estudados de San Pedro de Atacama. Com a maior parte dos indivíduos sendo portadores de deformações do tipo Circular, os indivíduos sem deformação craniana somam apenas 19,4\%. Dos indivíduos deformados intencionalmente, $84 \%$ apresentam deformações do tipo Circular e apenas $16 \%$ do tipo Tabular, cenário diametralmente oposto ao encontrado nos oásis atacamenhos, mas coerente com os dados apresentados por Knudson \& Torres-Rouff (2009).

Nos esqueletos originários de Caspana, apenas 92 dentes estavam presentes, correspondendo a 17,9\% dos alvéolos disponíveis para análise. Este número é também resultante da alta prevalência de perdas post mortem $(44,4 \%)$ encontrada neste sítio.

A prevalência de dentes perdidos em vida no sítio Caspana também se mostra significativamente distinta do período Tiwanaku $\left(X^{2}=15,5546 ; \mathbf{p}=0,0001\right)$, mas os $37,6 \%$ de perdas ante mortem presentes em sua amostra não são diferentes 
estatisticamente dos $41,5 \%$ apresentados pelo período Pós Tiwanaku $\left(X^{2}=2,5261 ; \mathbf{p}=\right.$ $0,0624)$.

A prevalência de cárie dentária no sítio Caspana $(43,6 \%)$, a menor entre as amostras analisadas neste estudo, não apresentou diferença significativa em relação a nenhum outro grupo, confirmando a fragilidade destes dados devido ao pequeno número de dentes disponíveis para a avaliação da prevalência de cárie, totalizados em 92 elementos dentais.

As prevalências de cáries superficiais e também de cáries severas observadas em Caspana, se comparadas com o período Pós Tiwanaku, não apresentaram diferenças estatisticamente significativas $\left(X^{2}=0,0997 ; \mathbf{p}=0,1087\right.$ e $X^{2}=2,5732 ; \mathbf{p}=$ 0,1087 respectivamente).

Como único grupo analisado no qual indivíduos com deformação craniana intencional apresentaram perda dentária ante mortem superior estatisticamente significativa que os indivíduos sem deformação $\left(X^{2}=7,2160 ; \mathbf{p}=0,0072\right)$, Caspana se destacou nesta amostra. Apesar disto, apenas os indivíduos sem deformação craniana presentes neste sítio se diferenciaram estatisticamente dos outros grupos, por apresentarem uma prevalência de perdas em vida muito inferior aos demais (24,5\%).

Não foi encontrada diferença estatisticamente significativa entre os abcessos periapicais observados nos períodos Pós Tiwanaku e Caspana $\left(X^{2}=0,0000 ; \mathbf{p}=0,9978\right)$. Ao extrairmos desta amostra os indivíduos com menos de 25 anos, manobra que impactou tanto o período Pós Tiwanaku como Caspana, foi encontrado um aumento na prevalência de abcessos dentais em Caspana (35,8\%). Apesar disso, não foi observada diferença significativa entre Caspana e Pós Tiwanaku $\left(X^{2}=0,0555 ; \mathbf{p}=\right.$ $0,8137)$.

Caspana apresentou uma diferença na prevalência das cáries dentárias entre homens e mulheres de $11,9 \%$, sendo os homens mais atingidos por esta patologia (48,6\% e 36,7\% respectivamente). Apesar de encontrarmos esta condição atípica de distribuição de cárie dentária, novamente a não significância desta diferença se justifica pelo pequeno número de dentes disponíveis. 
Caspana apresentou prevalências menores de cárie dentária que o período Pós Tiwanaku, tanto para crânios com deformação como para os crânios sem deformação intencional. A diferença da prevalência de cárie dentária entre os indivíduos deformados e os indivíduos não deformados não foi estatisticamente significativa dentro deste sítio $\left(X^{2}=0,4753 ; \mathbf{p}=0,4906\right)$ e tampouco foram diferentes quando comparados com os deformados e não deformados do período Pós Tiwanaku $\left(X^{2}=\right.$ 0,$6146 ; \mathbf{p}=0,4330$ e $X^{2}=1,7909 ; \mathbf{p}=0,1808$, respectivamente).

O valor de DMI encontrado nos exemplares de Caspana é muito próximo ao DMI encontrado nos crânios do mesmo período Pós Tiwanaku nas margens do salar de Atacama $(83,21)$, não sendo significativa a diferença entre eles $(U=1985,500 ; W=$ 10631,500; $\mathbf{p}=0,841)$.

Caspana apresenta um quadro peculiar quando analisamos seu índice de Lukacs. Ao computarmos todos os 31 crânios disponíveis desta amostra, este índice se apresentou superior quando foi comparado com o período Pós Tiwanaku. Porém, quando retiramos os dois (02) indivíduos mais jovens desta amostra ( $<25$ anos), observamos um aumento na prevalência de perdas dentárias em vida mas também observamos uma queda na prevalência de cárie dentária e, a reboque, um índice de Lukacs também em queda. Este quadro se explica pela característica atípica dos dois indivíduos mais jovens encontrados neste sítio. Juntos, estes dois crânios contêm 7 dentes sadios e 6 dentes cariados, ou seja, 46,2\% de prevalência de cárie dentária. Como esta prevalência é maior que a média do grupo Caspana, ao serem removidos da amostra, impulsionaram uma queda na prevalência de cáries dentária e também do índice de Lukacs deste grupo. Esta importante alteração do índice causada por apenas dois indivíduos reforça a necessidade de aumentar a amostra deste grupo para maior confiabilidade nas respostas encontradas, mesmo quando observamos significância estatística, como foi neste caso.

Por não haver dentes suficientes nos indivíduos sem deformação craniana intencional em Caspana, foram comparados apenas os indivíduos deformados do período Pós Tiwanaku e Caspana. Quanto ao desgaste dentário, apenas a diferença 
entre os desgastes de baixa intensidade não se mostrou significativa $\left(X^{2}=0,3380 ; \mathbf{p}=\right.$ $0,5610)$.

Caspana é o único grupo entre os 4 estudados onde as mulheres apresentaram a média do desgaste dentário maior que os homens (1,60 e 1,50 respectivamente), mas esta diferença tampouco é significativa estatisticamente $(U=13,500 ; W=34,500$; $\mathbf{p}=0,792)$.

Caspana, com apenas 10 dentes disponíveis para avaliação das hipoplasias lineares do esmalte dentário, apresentou apenas 1 dente acometido, sendo claramente uma amostra limitada para a análise deste marcador dental.

Os crânios de Caspana apresentaram uma prevalência de alvéolos reabsorvidos muito próxima à apresentada pelos esqueletos do período Pré Tiwanaku $(29,4 \%$ e $29,2 \%$ respectivamente), porém muito distinta dos outros dois períodos avaliados neste estudo (Caspana e Tiwanaku: $X^{2}=16,9301 ; \mathbf{p}=0,0000$ - Caspana e Pós Tiwanaku: $X^{2}=24,6816 ; \mathbf{p}=0,0000$ ). A presença de cálculos salivares em apenas $17,2 \%$ dos 78 dentes analisados distingue Caspana dos sítios de San Pedro de Atacama, independentemente do período analisado. Porém, estas diferenças observadas entre Caspana e os sítios sanpedrinos, tanto da prevalência das reabsorções alveolares como das prevalências de cálculos dentários, parecem mais uma vez serem fruto de uma amostragem deficitária para a comparação, sendo a diferença entre as reabsorções alveolares e os cálculos dentários observados dentro do próprio sítio Caspana difíceis de serem explicadas. 


\section{VI - CONCLUSÕES}

Este estudo teve como objetivo principal avaliar a condição de saúde bucal dos esqueletos exumados em San Pedro de Atacama e, através dos resultados obtidos, inferir a qualidade de vida biológica dessa população. Indiretamente, a saúde bucal pode indicar sistemas de subsistência das sociedades através da interpretação das classes de alimentos ingeridos pelos indivíduos analisados.

Estudos sobre a qualidade de vida biológica da população atacamenha são feitos desde a década de 1990, abordando diversos marcadores ósseos e dentários. Mesmo assim, devido ao enorme acervo esqueletal sob a guarda do Instituto de Investigaciones Arqueológicas y Museo, ainda há muito material por ser analisado, mesmo após o trabalho aqui apresentado.

Este estudo utilizou apenas os esqueletos escavados pelo padre Gustavo Le Paige. Essa coleção, apesar de estar bastante danificada, é constituída por um número bastante grande de exemplares, o que compensa o estado crítico da coleção. Mesmo assim, para alguns marcadores dentais ou ósseos, ela tenha sido insuficiente.

Apesar deste estudo se tratar de uma pesquisa exploratória, a vasta quantidade de informação obtida pelos trabalhos anteriormente publicados foi fundamental para a orientação e discussão dos dados aqui apresentados.

A pré-história atacamenha iniciou-se há 13000 anos com os primeiros assentamentos humanos nas bordas do salar de Atacama se estendeu até a chegada dos espanhóis na região e a dominação da população nativa em 1540 AD com a tomada do Pukara de Quitor.

Neste trabalho estudei apenas os últimos 2000 anos desta pré-história, analisando esqueletos humanos originários de sítios datados desde a metade do período Formativo (1300 AC a 500 AD) até a chegada dos Incas em terras sanpedrinas, por volta de $1470 \mathrm{AD}$. 
Apesar dos sepultamentos exumados em Catarpe 1 e 2 apresentarem evidências arqueológicas da presença incaica nestes sítios, as datações recentemente obtidas e publicadas os situam num período anterior ao surgimento do Estado Inca. Por este trabalho se tratar de um estudo bioantropológico e não arqueológico, optei por utilizar apenas as datas publicadas como parâmetro temporal para classificar meu material, mesmo estando ciente da controvérsia existente entre estas datações e as evidências arqueológicas presentes nestes sítios.

O espaço de tempo por mim estudado foi dividido em 3 períodos, classificados como Pré Tiwanaku, Tiwanaku e Pós Tiwanaku. Esta classificação utiliza a presença ou a influência do Império Tiwanaku em San Pedro de Atacama.

O período Pré Tiwanaku é caracterizado por assentamentos permanentes dentro dos vales (quebradas) mais úmidos e seguidos pela expansão a regiões mais abertas, ampliando as terras de plantio e as áreas de pastoreio de camelídeos, animais utilizados para o transporte de carga e principal fonte de proteína. Uma alimentação baseada no milho foi provavelmente a responsável pelos $52,9 \%$ de cáries dentárias observadas nos crânios analisados deste período e pelos maiores índices de cáries dentárias corrigidas entre todos os períodos ( $\mathrm{DMI}=89,47$ e Lukacs $=0,87$ ). Em uma amostra que apresenta um mal estado de preservação como no caso do sítio Toconao Oriente, responsável por $87,2 \%$ da amostra do período Pré Tiwanaku por mim estudada, era esperado encontrar uma baixa prevalência de cálculo salivar pela facilidade com que estes cálculos podem se desprender da superfície dental. Apesar disto, a prevalência de $37,2 \%$ de cálculos salivares encontrada durante o período Pré Tiwanaku é condizente com a prevalência de $29,2 \%$ de reabsorção alveolar observada nos crânios do mesmo período e ambas as prevalências foram as menores entre os 3 períodos estudados. Estes resultados, associados à prevalência de cárie e do índice de Lukacs sugerem que o consumo de proteína animal existia, mas seria complementar ao consumo principal de alimentos altamente cariogênicos como o milho citado. Quanto ao desgaste dentário observado nos dentes dos crânios do período Pré Tiwanaku, apesar de apresentar intensidade próxima aos outros períodos estudados em San Pedro, nenhum dente analisado apresentou exposição pulpar por desgaste dentário severo. Com isso, os dentes perdidos ante mortem e os abcessos periapicais podem, 
com certa segurança, serem associados apenas ao processo de cárie avançada que acometeu estes elementos dentais.

O período Tiwanaku teve como característica principal a expansão da população atacamenha rumo ao norte, utilizando todo o terreno disponível dos oásis de San Pedro de Atacama. Esta expansão foi reflexo do aumento populacional e consequentemente, das áreas produtoras de alimentos necessários para o sustento desta comunidade. Com a intensificação do tráfego de caravanas cruzando o deserto seja em direção ao mar, ao altiplano ou às Yungas argentinas, San Pedro foi evidentemente beneficiada por estas redes de troca que o Estado Tiwanaku incentivou. Os benefícios vieram em diferentes formas, desde uma integração com o Império Altiplânico nas questões religiosas e possivelmente politicas, mas principalmente na oferta de produtos alimentícios diversos, vindos dos diferentes ecossistemas vizinhos ao deserto. A evidência da variação na dieta da população atacamenha é a queda significativa das lesões de cárie dentária encontradas nos indivíduos analisados desse período (44,5\%), queda que também se repete quando analisamos os dois índices de correção das cáries ( $\mathrm{DMI}=81,44$ e Lukacs $=0,75)$, indicando uma alimentação menos cariogênica como a encontrada no período anterior, no qual o milho era o principal alimento consumido pelos sanpedrinos. 0 desgaste dentário observado durante o período Tiwanaku apresenta um aumento significativo quando comparamos as médias entre o período Pré Tiwanaku $(3,485)$ e Tiwanaku $(3,842)$. Mesmo se considerarmos a ausência da variação do desgaste dentário observada quando utilizamos o indivíduo como unidade de análise, Tiwanaku é o período que apresenta a maior prevalência de dentes com desgaste severo. 0 aumento dos desgastes dentários causado pela ingestão de vegetais mais abrasivos, como são os diversos tubérculos consumidos no altiplano sulamericano, explica o aumento da prevalência de abcessos periapicais e de perdas ante mortem também observados durante o período Tiwanaku, a despeito da diminuição incontestável de cárie dentária. Por fim, o aumento das reabsorções periodontais e dos cálculos salivares durante o período Tiwanaku sustentaria a hipótese de um maior aporte de proteína de origem animal, vegetal ou até mesmo de algas marinhas ou lacustres na dieta atacamenha, resultantes do intenso fluxo de mercadorias que transitaram pelas 
rotas de troca que cruzaram o deserto de Atacama durante o período de esplendor do Estado Tiwanaku.

A seca que assolou os Andes Centrais por volta do ano 1000 AD foi um dos fatores principais para o declínio do Império Tiwanaku. Em San Pedro de Atacama, os recursos hídricos naturalmente limitados se tornaram ainda mais escassos, fazendo com que a população atacamenha se concentrasse nas regiões próximas às fozes do rio San Pedro e do rio Vilama. Com o Estado Tiwanaku em ruínas, as redes de troca que floresceram durante o período anterior também minguaram, possivelmente pela dificuldade encontrada por todos em produzir produtos e alimentos em excesso necessários ao comércio ou escambo. Neste cenário, a necessidade da produção de alimentos altamente calóricos e de alta produtividade possivelmente recolocou o milho no centro da dieta sanpedrina. Além da grande quantidade de remanescentes arqueológicos deste vegetal encontrados nos sítios, outro indicador desta adequação alimentar é a maior prevalência de cárie dentária que foi observada exatamente no período Pós Tiwanaku (55,9\%), indicando o aumento da cariogenicidade da dieta consumida nesta época. $O$ índice de Lukacs $(0,81)$ só não é o mais alto entre os três períodos devido à característica dos desgastes dentários encontrados neste período. Se analisarmos a média do desgaste dentário durante o período Pós Tiwanaku $(3,529)$, encontraremos na população atacamenha uma dieta menos abrasiva que o período anterior (Tiwanaku $=3,842$ ), sugerindo uma diminuição considerável na grande variedade de alimentos que estiveram disponíveis aos atacamenhos durante o período de influência do Estado Tiwanaku nos oásis de San Pedro. Outro marcador importante que aponta para a diminuição da abrasividade da dieta atacamenha é a queda observada na prevalência de dentes perdidos por desgaste dentário severo, caindo dos $10 \%$ de dentes com exposição pulpar resultantes deste desgaste durante o período anterior para $4 \%$ durante o período Pós Tiwanaku. Ao analisarmos a presença de cálculo salivar e a presença de reabsorções periodontais nos crânios provenientes de sítios do período Pós Tiwanaku, encontramos um aumento significativo na prevalência de cálculo salivar e um aumento, porém não significativo, das reabsorções periodontais. Poderíamos supor que estes valores indicam um aumento do consumo de proteína, assim como observamos durante o período Tiwanaku, contudo, o 
aumento também significativo da prevalência de cárie dentária apontaria no sentido diametralmente oposto. Considerando as condições sócio-ambientais nas quais os atacamenhos sobreviveram durante o período Pós Tiwanaku, a provável origem deste aumento de cálculo salivar, e que levou ao aumento das reabsorções periodontais, seria principalmente o processamento dos alimentos, visando a conservação e a armazenagem dos produtos agrícolas produzidos durante este período de alteração climática e tensão social.

Caspana, o sítio arqueológico localizado cerca de $100 \mathrm{~km}$ ao norte de San Pedro de Atacama, forneceu 31 esqueletos para este trabalho, tendo um papel apenas de controle externo aos sítios de San Pedro. Os crânios de Caspana presentes na coleção do museu Padre Le Paige estão datados do período Pós Tiwanaku e justamente por este motivo as comparações, salvo exceções, foram feitas entre Caspana e os sítios Pós Tiwanaku dos oásis do salar. Com diferenças culturais importantes, San Pedro e Caspana apresentavam deformações cranianas intencionais com características distintas quanto à presença e ausência destas modificações e, quando presentes, diferentes prevalências destas deformações. Enquanto em San Pedro a maior parte da população não apresentava deformação craniana intencional, em Caspana mais de $80 \%$ da população por mim analisada era deformada. Destes deformados em Caspana, 84\% eram deformações circulares, tipo de deformação que, em nenhum período, ultrapassou $26 \%$ nos oásis atacamenhos. Ao analisarmos a condição de saúde bucal desta população, as patologias dentais encontradas legitimam a variação encontrada nas deformações cranianas, confirmando que a diferença cultural se estendeu até a alimentação deste grupo. A prevalência de cárie dentária observada em Caspana apresenta um valor muito inferior ao apresentado pelos sítios dos oásis de San Pedro durante o mesmo período, não sendo significativo provavelmente pelo pequeno número de dentes analisados mas que, ao "corrigirmos" este dado pelo índice de Lukacs, encontramos uma queda significativa entre San Pedro e Caspana. Com isso, concluímos que os crânios analisados de Caspana tiveram uma dieta menos cariogênica que seus contemporâneos de San Pedro de Atacama. Os resultados das prevalências de cálculos salivares e de reabsorções periodontais, ambos menores significativamente que os sítios sanpedrinos, sugerem uma alimentação pouco 
fornecedora de íons alcalinos, possivelmente sendo uma dieta pobre em proteína, cálcio, sódio ou potássio. Quando nos atentamos ao desgaste dentário dos indivíduos de Caspana, não encontramos uma variação importante em comparação aos crânios de San Pedro, indicando uma similaridade na dieta de ambos quanto à abrasividade dos alimentos ingeridos. Exaustivamente citada ao longo deste trabalho, a insuficiente amostra de dentes e indivíduos originários de Caspana deve servir de ressalva para as comparações que, mesmo apresentando diferenças evidentes entre Caspana e os sítios Pós Tiwanaku de San Pedro, não se mostraram estatisticamente significativas.

A coleta de água dos rios que abastecem os oásis de San Pedro de Atacama e também Caspana visou averiguar um possível fator de proteção que alguns grupos, estabelecidos em áreas abastecidas por fontes distintas, pudessem ter através da disponibilidade natural de íons fluoreto na água consumida. Esta possibilidade foi descartada tendo em vista a baixa concentração de flúor encontrada nas águas que chegam aos oásis estudados.

Evidentemente, por se tratar de um estudo exploratório, certas patologias avaliadas e algumas divisões da minha amostra não apresentaram resultados conclusivos. O primeiro destes casos é a prevalência das hipoplasias lineares do esmalte dentário, que apesar de uma notada variação entre alguns períodos, a não significância estatística limitou minhas discussões, transferindo às evidências arqueológicas, à paleodemografia e à paleopatologia geral a responsabilidade da interpretação destes achados.

Além da condição precária de preservação da coleção esqueletal ser limitante por si só, a intensidade com que algumas patologias dentais acometeram os indivíduos atacamenhos também impactou a observação de outros marcadores dentais. A alta prevalência de cárie dentária e a intensidade severa destas lesões são exemplos deste fato. Esta característica da saúde bucal sanpedrina inviabilizou a observação de cálculo salivar, reabsorção periodontal, desgaste dentário e hipoplasia linear do esmalte nos dentes totalmente destruídos pelas cáries dentárias.

A diferença na dieta entre homens e mulheres que foi observada por outros pesquisadores e que favorecia os homens na ingestão de uma alimentação rica em 
proteína, principalmente durante o período Tiwanaku, não foi encontrada em meus resultados. Neste trabalho, as mulheres apresentaram prevalências superiores em quase todas as patologias dentais avaliadas, sugerindo que, independentemente do produto consumido, as mulheres sempre tiveram maior acesso a alimentos, sejam eles ricos em carboidratos ou proteínas. A exceção é o desgaste dentário, que foi observado em maior intensidade nos indivíduos masculinos. Visto que os homens apresentaram menor prevalência de cárie e de cálculo salivar, o desgaste dentário mais intenso pode ter sido resultante do ato mastigatório mais vigoroso devido à musculatura mais robusta presente no sexo masculino.

Por fim, este trabalho não encontrou diferenças significativas das patologias dentais analisadas entre indivíduos portadores e não portadores de deformações cranianas intencionais. Apesar da presença de indivíduos portadores dos 4 tipos de deformação craniana durante todos os períodos históricos estudados em San Pedro de Atacama, os resultados aqui apresentados sugerem não ter havido distinção quanto à alimentação destes diferentes grupos. 


\section{Referências bibliográficas}

Adán LA, Urbina SA. 2007. Arquitectura formativa en San Pedro de Atacama. Estudios Atacameños: Arqueologia y Antropologia Surandinas 34:7-30.

Agüero C, Uribe M. 2011. Las sociedades Formativas de San Pedro de Atacama: Asentamiento, cronología y proceso. Estudios Atacameños: Arqueologia y Antropologia Surandinastacameños [Internet]:53-78. Available from: http://www.scielo.cl/scielo.php?script=sci_arttext\&pid=S0718$10432011000200004 \& \operatorname{lng}=e n \& n r m=i s o \& t \operatorname{lng}=e n$

Agüero CP. 2005. Aproximación al asentamiento humano temprano en los oasis de San Pedro de Atacama. Estudios Atacameños 60:29-60.

Albarracin-Jordan J. 1996. The Integration of nested hierarchies in the lower Tiwanaku valley. Latin American Antiquity 7:183-210.

Aldunate CS, Sinclaire CA, Jiménez CC, Salazar DS, Vilches F, Gallardo F, Hidalgo JL, Cornejo LEB, Corrales PE, et al. 2001. Tras la Huella del Inca en Chile. primera ed. (Aldunate C del S, Cornejo LEB, editors.). Santiago - Chile: Morgan Impresores.

Alonso H, Risacher F. 1996. Geoquimica del Salar de Atacama: Origen de los componentes y balance salino. Revista Geológica de Chile 23:113-22.

Anonymous. 1949. Dietary carbohydrate and dental caries. JAMA-Journal of the American Medical Association 141:995.

Arensburg B, Hershkovitz I. 1988. Cranial deformation and trephination in the Middle East. Bulletins et Mémoires de la Societé dánthropologie de Paris 5:139-150.

Armelagos GJ, Goodman AH, Harper KN, Blakey ML. 2009. Enamel hypoplasia and early mortality: Bioarcheological support for the Barker hypothesis. Evolutionary Anthropology: Issues, News, and Reviews [Internet] 18:261-271. Available from: http://doi.wiley.com/10.1002/evan.20239

Arnold WH, Naumova EA, Koloda V, Gaengler P. 2007. Tooth wear in two ancient populations of the Khazar Kaganat region in the Ukraine. International Journal of Osteoarchaeology [Internet] 17:52-62. Available from: http://doi.wiley.com/10.1002/oa.859

Baumhoff MA. 1963. Ecological Determinants of Aboriginal California Populations. American Archaeology and Ethnology 49:155-236. 
Becker W, Ochsenbein C, Tibbetts L, Becker BE. 1997. Alveolar bone anatomic profiles as measured from dry skulls - clinical ramifications. Journal of Clinical Periodontology 24:727-731.

Bentzen RC. 1929. Dental Conditions Among the Mimbres People of Southwestern United States Previous to the Years 600 A.D. Dental Cosmos 71:1068-1073.

Berbesque JC, Doran GH. 2008. Brief communication: physiological stress in the Florida Archaic-enamel hypoplasia and patterns of developmental insult in early North American hunter-gatherers. American Journal of Physical Anthropology [Internet] 136:351-6. Available from: http://www.ncbi.nlm.nih.gov/pubmed/18324644

Berenguer J, Deza A, Román A. 1986. La secuencia de Myriam Tarragó para San Pedro de Atacama : Un test por termoluminiscencia. Revista Chilena de Antropologia: 17-54.

Berenguer J, Roman A, Deza A, Llagostera A. 1988. Testing a Cultural Sequence for the Atacama Desert. Current Anthropology 29:341-346.

Berenguer JR. 2000. Tiwanaku: Señores del Lago Sagrado. primera ed. Santiago - Chile: Museo de Arte Precolombino - Santiago - Chile.

Bergh SE, Jennings J. 2012. The History of Inquiry into the Wari and Their Arts. In: Bradley BJ, Mills K, editors. Wari: Lords of the Ancient Andes. first edit. New York USA: Cleveland Museum of Art. p. 296.

Betti L, Balloux F, Amos W, Hanihara T, Manica A. 2009. Distance from Africa, not climate, explains within-population phenotypic diversity in humans. Proceedings. Biological sciences / The Royal Society [Internet] 276:809-14. Available from: http://www.pubmedcentral.nih.gov/articlerender.fcgi?artid=2664379\&tool=pmcentre $z \&$ rendertype $=$ abstract

Binford MW, Kolata AL, Brenner M, Janusek JW, Seddon MT, Abbott M, Curtis JH. 1997. Climate Variation and the Rise and Fall of an Andean Civilization. Quaternary Research [Internet] 47:235-248. Available from: http://linkinghub.elsevier.com/retrieve/pii/S0033589497918822

Black GV. 1914. Operative Dentistry, Vol. I - Pathology of the Hard Tissues of the Teeth. first edit. London: Claudius Ash, Sons \& CO.

Bocaege E, Humphrey LT, Hillson S. 2010. Technical note: a new three-dimensional technique for high resolution quantitative recording of perikymata. American Journal of Physical Anthropology [Internet] 141:498-503. Available from: http://www.ncbi.nlm.nih.gov/pubmed/19953528 
Brace CL, Molnar S. 1967. Experimental studies in human tooth wear: I. American Journal of Physical Anthropology [Internet] 27:361-8. Available from: http://www.ncbi.nlm.nih.gov/pubmed/5675900

Bray TL. 2003. Inka Pottery as Culinary Equipment: Food, Feasting, and Gender in Imperial State Design. Latin American Antiquity 14:3-28.

Brickley M, McKinley Jl. 2004. Guidelines to the Standards for Recording Human Remains. : 1-62.

Briones L, Núñez L, Standen VG. 2005. Geoglifos y tráfico prehispánico de caravanas de Ilamas en el desierto de Atacama (Norte de Chile). Chungará, Revista de Antropologia Chilena 37:195-223.

Brothwell DR. 1963. Dental Anthropology. In: Brothwell DR, editor. Symposia of the Society for the Study of Human Biology. Michigan: Pergamon Press - Universidade de Michigan. p. 288.

Brothwell DR. 1967. Some Problems and Objectives Related to the Study of Dental Variation in Human Populations. Journal of Dental Research [Internet] 46:938-941. Available from: http://jdr.sagepub.com/cgi/doi/10.1177/00220345670460055401

Brothwell DR. 1981. Digging up Bones. third edit. London \& Oxford - UK: British Museum \& Oxford University Press.

Brown WE, Gregory TM, Chow LC. 1977. Effects of fluoride on enamel solubility and cariostasis. Caries Research 11:118-141.

Budtz-Jørgensen E. 1980. Bruxism and trauma from occlusion. An experimental model in Macaca monkeys. Journal of Clinical Periodontology 7:149-162.

Buikstra JE, Ubelaker DH. 1994. Standards for Data Collection from Human Skeletal Remains: Proceedings of a Seminar at the Field Museum of Natural History (Arkansas Archeological Report Research Series). Standards. (Buikstra JE, Ubelaker DH, editors.). Arkansas Archeological Survey.

Cáceres JM. 2007. Culturas Prehispánicas del Perú. primera ed. (Enriquez GL, editor.). Lima - Peru.

Cárdenas UH. 1998. Entre el tolar y el pajonal : Percepción ambiental y uso de plantas en la comunidad atacameña de Talabre, II Región, Chile. Estudio Atacameños 16:251282.

Ten Cate JM, Larsen MJ, Pearce EIF, Fejerskov O. 2005. Interações Químicas entre o Dente e os Fluidos Orais. In: Fejerskov O, Kidd EAM, editors. Cárie Dentária - A Doença e seu Tratamento Clínico. primeira e. São Paulo: Editora Santos. p 49-69. 
CDC. 1999. Ten Great Public Health Achievements - United States, 1900-1999. MMDR 48:241-243.

Celestino O. 1997. Religious transformations in the Peruvian Andes. I: Mythic and ritual cycles. Gazeta de Antropología 13:1-19.

Clarke NG, Carey SE, Srikandi W, Hirsch RS, Leppard PI. 1986. Periodontal disease in ancient populations. American Journal of Physical Anthropology [Internet] 71:173-83. Available from: http://www.ncbi.nlm.nih.gov/pubmed/3541645

Cook AG. 2012. The Coming of the Staff Deity. In: Bradley BJ, Mills K, editors. Wari: Lords of the Ancient Andes. first edit. New York - USA: The Cleveland Museum of Art. $p$ 103-121.

Cornero S, Neves WA, Prous A. 1999. Prevalencia de caries en una muestra de la poblacion de Santana do Riacho I, o El Mito del Paleoindio Cazador. Revista Argentina de Antropología Biológica 2:301-306.

Costa DP, Mota ACM, Bruno GB, Almeida MEL, Fonteles CSR. 2010. Desnutrição energético-protéica e cárie dentária na primeira infância (Protein-energy malnutrition and early childhood caries). Revista de Nutrição 23:119-126.

Costa MA, Llagostera AM. 1994. Coyo 3 : Momentos finales del Período Medio en San Pedro de Atacama. Estudios Atacameños 11:73-107.

Costa MA, Matheson C, lachetta L, Llagostera A, Appenzeller O. 2009. Ancient Leishmaniasis in a highland desert of Northern Chile. PloS One [Internet] 4:e6983. Available

from: http://www.pubmedcentral.nih.gov/articlerender.fcgi?artid=2735183\&tool=pmcentre $z \&$ rendertype $=$ abstract

Costa MA, Neves WA, Barros AM, Bartolomucci R. 1998. Trauma y Estrés en Poblaciones Prejistóricas de San Pedro de Atacama, Norte de Chile. Chungará 30:6574.

Costa MA, Neves WA, Hubbe M. 2004. Influencia de Tiwanaku en la calidad de vida biológica de la población prehistórica de San Pedro de Atacama. Estudios Atacameños 27:103-116.

Costa MA. 1988. Reconstitución física y cultural de la población tardía del cementerio Quitor 6 ( San Pedro de Atacama ). Estudios Atacameños: Arqueologia y Antropologia Surandinas 9:107-135.

Cuozzo FP, Sauther ML. 2012. What is dental ecology? American Journal of Physical Anthropology [Internet] 148:163-70. Available from: http://www.ncbi.nlm.nih.gov/pubmed/22610892 
Cuozzo FP, Ungar PS, Sauther ML. 2012. Primate dental ecology: How teeth respond to the environment. American Journal of Physical Anthropology [Internet] 148:159-62. Available from: http://www.ncbi.nlm.nih.gov/pubmed/22610891

Mac Curdy GG. 1923. Human Skeletal Remains from the Highlands of Peru. American Journal Physical Anthropology VI:218-329.

Da-Gloria P, Hubbe M, Neves WA, Costa MA. 2010. Tooth use and loss at San Pedro de Atacama: The impact of Tiwanaku influence in northern Chile, AD 400-900. In: meeting of American Association of Physical Anthropology. Albuquerque, USA.

Da-Gloria P, Neves WA, Costa MA, Bartolomucci R. 2011. NoNspecific iNfectious diseases iN prehistoric saN pedro de atacama, NortherN chile. Chungará, Revista de Antropologia Chilena 43:135-146.

Da-Gloria P. 2006. Estilo e qualidade de vida biológica em San Pedro de Atacama: o que dizem os esqueletos subadultos. Dissertação de mestrado. Instituto de Biociências - Universidade de São Paulo, São Paulo, Brasil p.217.

Dembo A, Imbelloni J. 1938. Deformaciones Intencionales del Cuerpo Humano de Carácter Étnico. Buenos Aires - Argentina.

Deter C a. 2009. Gradients of occlusal wear in hunter-gatherers and agriculturalists. American Journal of Physical Anthropology [Internet] 138:247-54. Available from: http://www.ncbi.nlm.nih.gov/pubmed/18773466

Dillehay TD, Netherly P. 1998. La frontera del Estado Inca. segunda ed. (Dillehay TD, Netherly P, editors.). Quito - Ecuador: Fundación Alexander von Humboldt y Editorial Abya-Yala.

Dillehay TD, Rossen J, Ugent D, Karathanasis A, Vásquez V, Netherly PJ. 2010. Early Holocene coca chewing in northern Peru. Antiquity 84:939-953.

Dobney K, Brothwell D. 1987. A method for evaluating the amount of dental calculus on teeth from archaeological sites. Journal of Archaeological Science [Internet] 14:343-351. Available from: http://linkinghub.elsevier.com/retrieve/pii/0305440387900240

Durband AC. 2008. Artificial cranial deformation in Pleistocene Australians: the Coobool Creek sample. Journal of Human Evoltuion [Internet] 54:795-813. Available from: http://www.ncbi.nlm.nih.gov/pubmed/18243276

Eggers S, Parks M, Grupe G, Reinhard KJ. 2011. Paleoamerican diet, migration and morphology in Brazil: archaeological complexity of the earliest Americans. PloS One [Internet]

6:e23962.

Available

from: 
http://www.pubmedcentral.nih.gov/articlerender.fcgi?artid=3173364\&tool=pmcentre $z \&$ rendertype $=$ abstract

Ekstrand J, Oliveby a. 1999. Fluoride in the oral environment. Acta Odontologica Scandinavica [Internet] 57:330-3. Available from: http://www.ncbi.nlm.nih.gov/pubmed/10777136

Ellwood RP, Fejerskov O. 2005. Uso Clínico de Flúor. In: Fejerskov O, Kidd EAM, editors. Cárie Dentária - A Doença e seu Tratamento Clínico. primeira e. São Paulo: Editora Santos. p 189-222.

FCF/USP. 2008. Tabela Brasileira de Composição de Alimentos. TBCAUSP Departamento de Alimentos e Nutrição Experimental FCF/USP [Internet]. Available from: http://www.fcf.usp.br/tabela/

Fejerskov O, Nyvad B, Kidd EAM. 2005. Características Clínicas e Hostológicas da Cárie Dentária. In: Fejerskov O, Kidd EAM, editors. Cárie Dentária - A Doença e seu Tratamento Clínico. primeira e. São Paulo: Editora Santos. p 71-97.

Fejerskov O. 2004. Changing paradigms in concepts on dental caries: consequences for oral health care. Caries Research [Internet] 38:182-91. Available from: http://www.ncbi.nlm.nih.gov/pubmed/15153687

Ferreira VM, Magalhães PC. 1997. Aspects of growth, nutrition and water relations in two maize (Zea mays L.) genotypes in function of soils water availability. Ciência e Agrotecnologia 21:93-94.

Ffennell EB. 1888. Tea and Teeth. The British Medical Journal:1833.

Ford JD. 2009. Vulnerability of Inuit food systems to food insecurity as a consequence of climate change: a case study from Igloolik, Nunavut. Regional Environmental Change [Internet] 9:83-100. Available from: http://www.springerlink.com/index/10.1007/s10113-008-0060-x

Gallardo F, Yacobaccio H. 2007. Silvestre o domesticados? Camélidos en el arte rupestre del formativo temprano en el desierto de Atacama (Norte de Chile). Boletín del Museo de Arte Precolombino 12:9-31.

Gillett HW. 1927. Contacts Between Archaeological and Dental Research. American Anthropologist 29:291-295.

Gómez DP, Siarez EF. 2004. Cultura. In: Gómez DP, Siarez EF, editors. Alimentacion tradicional atacameña. segunda ed. Santiago - Chile: Lom Ediciones Ltda. p 20-44.

González-José R, Escapa I, Neves WA, Cúneo R, Pucciarelli HM. 2008. Cladistic analysis of continuous modularized traits provides phylogenetic signals in Homo evolution. 
Nature

[Internet]

453:775-8.

Available

from:

http://www.ncbi.nlm.nih.gov/pubmed/18454137

Goodman AH, Rose JC. 1990. Assessment of systemic physiological perturbations from dental enamel hypoplasias and associated histological structures. American Journal of Physical Anthropology [Internet] 33:59-110. Available from: http://doi.wiley.com/10.1002/ajpa.1330330506

Goodman AH, Martinez, C, Chavez, A. 1991. Nutritional supplementation and the development enamel hypoplasias in children from Tezonteopan, Mexico. The American Journal of Clinical Nutrition 53:773-781.

Greenberg JH, Turner CG, Zegura SL, Campbell L, Fox JA, Laughlin WS, Szathmary EJE, Weiss KM, Woolford E, et al. 1986. The Settlement of the Americas : A Comparison of the Linguistic, Dental, and Genetic Evidence. Current Anthropology 27:477-497.

Greene TR, Kuba CL, Irish JD. 2005. Quantifying calculus: A suggested new approach for recording an important indicator of diet and dental health. HOMO - Journal of Comparative Human Biology [Internet] 56:119-132. Available from: http://linkinghub.elsevier.com/retrieve/pii/S0018442X05000235

Grenby TH. 1997. Summary of the Dental Effects of Starch. International Journal of Food Sciences and Nutrition 48:411-416.

Grippo JO, Simring M, Schreiner S. 2004. Attrition, abrasion, corrosion and abfraction revisited: A new perspective on tooth surface lesions. Journal of American Dental Association 135:1109-1118.

Grosjean M, Nuñez LA, Cartajena I. 2005. Palaeoindian occupation of the Atacama Desert , northern Chile. Journal of Quaternary Science 20 (7-8): 643-653.

Grosjean M, Santoro CM, Thompson LG. 2007. Mid-Holocene climate and culture change in the South Central Andes ' n. In: Climate Change and Cultural Dynamics: A Global Perspective on Mid-Holocene Transitions. p 51-115.

Guatelli-Steinberg D, Larsen CS, Hutchinson DL. 2004. Prevalence and the duration of linear enamel hypoplasia: a comparative study of Neandertals and Inuit foragers. Journal of Human Evolution [Internet] 47:65-84. Available from: http://www.ncbi.nlm.nih.gov/pubmed/15288524

Gustafsson BE. 1954. The Vipeholm Dental Caries Study: Survey of the Literature on Carbohydrates and Dental Caries. Acta Odontologica Scandinavica 11:207-231.

Halcrow SE, Tayles N. 2008. Stress near the start of life? Localised enamel hypoplasia of the primary canine in late prehistoric mainland Southeast Asia. Journal of 
Archaeological Science [Internet] 35:2215-2222. Available from: http://linkinghub.elsevier.com/retrieve/pii/S0305440308000344

Hanihara K. 1977. Distances Between Australian Aborigines and Certain Other Population Based on Dental Measurements. Journal of Human Evolution 6:403-418.

Hanihara T, Ishida H. 2005. Metric dental variation of major human populations. American Journal of Physical Anthropology [Internet] 128:287-98. Available from: http://www.ncbi.nlm.nih.gov/pubmed/15838862

Hanihara T. 2008. Morphological variation of major human populations based on nonmetric dental traits. American Journal of Physical Anthropology [Internet] 136:16982. Available from: http://www.ncbi.nlm.nih.gov/pubmed/18257017

Hib J. 2001. Sistema Digestivo. In: Hib J, editor. Histología de Di Fiore. primera ed. Buenos Aires - Argentina: Editorial El Ateneo. p 185-249.

Hillson S, Bond S. 1997. Relationship of enamel hypoplasia to the pattern of tooth crown growth: a discussion. American Journal of Physical Anthropology [Internet] 104:89-103. Available from: http://www.ncbi.nlm.nih.gov/pubmed/9331455

Hillson S. 1979. Diet and Dental Disease. World Archaeology 11:147-162.

Hillson S. 1996a. Dental Anthropology. first edit. (Hillson S, editor.). Cambridge- United Kingdom: Cambridge University Press.

Hillson S. 1996b. Dental Disease. In: Hillson S, editor. Dental Anthropology. first edit. Cambridge- United Kingdom: Cambridge University Press. p 154-287.

Hillson S. 1996c. Tooth Wear and Modification. In: Hillson S, editor. Dental Anthropology. first edit. Cambridge- United Kingdom: Cambridge University Press. $p$ 231-250.

Hillson S. 2001. Recording dental caries in archaeological human remains. International Journal of Osteoarchaeology [Internet] 11:249-289. Available from: http://doi.wiley.com/10.1002/oa.538

Hillson S. 2005. Teeth. second edi. (Barker G, editor.). Cambridge- United Kingdom: Cambridge University Press.

Hillson S. 2008. The Current State of Dental Decay. In: Irish JD, Nelson GC, editors. Technique and Application in Dental Anthropolgy. first edit. Cambridge- United Kingdom: Cambridge University Press. p 111-135.

Hirsch RS, and Clarke NG. 1989. Infection and Periodontal Diseases. Clinical infectious Disease 11:707-715. 
Horta HT. 2004. Iconografía del Formativo Tardío del norte de Chile. Propuesta de definición e interpretación basada en imágenes textiles y otros medios. Estudios Atacameños 27:45-76.

Horta HT. 2011. El gorro troncocónico o chucu y la presencia de población altiplánica en el Norte de Chile durante el Periodo Tardío (CA. 1470-1536 D.C.). Chungará, Revista de Antropologia Chilena 43:551-580.

Hubbe M, Oviedo M, Torres-Rouff C. 2011. Estado de Conservación y Contextualización Cronológica de la Colección Osteológica "Gustavo Le Paige". Estudios Atacameños 41:29-44.

Hubbe M, Torres-Rouff C, Neves WA, King LM, Da-Gloria P, Costa MA. 2012. Dental health in Northern Chile's Atacama oases: evaluating the Middle Horizon (AD 5001000) impact on local diet. American Journal of Physical Anthropology [Internet] 148:62-72. Available from: http://www.ncbi.nlm.nih.gov/pubmed/22411074

Indriati E, Buikstra JE. 2001. Coca chewing in prehistoric coastal Peru: dental evidence. American Journal of Physical Anthropology [Internet] 114:242-57. Available from: http://www.ncbi.nlm.nih.gov/pubmed/11241189

Janusek JW. 2002. Out of Many, One : Style and Social Boundaries in Tiwanaku. Latin American Antiquity 13:35-61.

Janusek JW. 2004. State Collapse and Cultural Revolution. In: Janusek JW, editor. Identity and Power in the Ancient Andes: Tiwanaku cities through time. first edit. New York: Routledge - Taylor \& Francis Group. p 319.

Janusek JW. 2008. Land and People. In: Janusek JW, editor. Ancient Tiwanaku: case studies in Early Societies. first edit. Cambridge- United Kingdom: Cambridge University Press. p 368.

Jin Y, Yip H-K. 2002. Supragingival Calculus: Formation and Control. Critical Reviews in Oral Biology \& Medicine [Internet] 13:426-441. Available from: http://cro.sagepub.com/cgi/doi/10.1177/154411130201300506

Junqueira LC, Carneiro J. 1990. O Tubo Digestivo. In: Junqueira LC, Carneiro J, editors. Histologia Básica. sétima edi. Rio de Janeiro - Brasil: Guanabara Koogan S.A. p 215239.

Kelley MA. 1991. Advances in Dental Anthropology. (Kelley MA, Larsen CS, editors.). Wiley-Liss - Universidade de Michigan.

Kennedy KAK. 1960. The Dentition of Indian Crania of the Early and Late Archaeological Horizons in Central California. University of California Archaeological Survey Reports 50:41-50. 
Keyes PH. 1960. The infectious and transmissible nature of experimental dental caries. Archives of Oral Biology [Internet] 1:304-IN4. Available from: http://linkinghub.elsevier.com/retrieve/pii/0003996960900911

King T, Humphrey LT, Hillson S. 2005. Linear enamel hypoplasias as indicators of systemic physiological stress: evidence from two known age-at-death and sex populations from postmedieval London. American Journal of Physical Anthropology [Internet] 128:547-59. Available from: http://www.ncbi.nlm.nih.gov/pubmed/15861429

Klukkert ZS, Teaford MF, Ungar PS. 2012. A dental topographic analysis of chimpanzees. American Journal of Physical Anthropology [Internet] 148:276-84. Available from: http://www.ncbi.nlm.nih.gov/pubmed/22610902

Knudson KJ, Torres-Rouff C. 2009. Investigating cultural heterogeneity in San Pedro de Atacama, northern Chile, through biogeochemistry and bioarchaeology. American Journal of Physical Anthropology [Internet] 138:473-85. Available from: http://www.ncbi.nlm.nih.gov/pubmed/19051258

Krueger KL, Scott JR, Kay RF, Ungar PS. 2008. Technical note: Dental microwear textures of "Phase I" and "Phase II" facets. American Journal of Physical Anthropology [Internet] 137:485-90. Available from: http://www.ncbi.nlm.nih.gov/pubmed/18785631

Krueger KL, Ungar PS. 2009. Incisor microwear textures of five bioarcheological groups. International Journal of Osteoarchaeology [Internet] 560:n/a-n/a. Available from: http://doi.wiley.com/10.1002/oa.1093

Lanfranco LNP. 2010. Reconstrução de Padrões Paleopatológicos Dentais em Agricultores Incipientes e Desenvolvidos do Litoral dos Andes Centrais. Dissertação de mestrado. Instituto de Biociências - Universidade de São Paulo, São Paulo, Brasil p.290.

Lang NP, Mombelli A, Attstrom R. 2003. Dental Plaque and Calculus. In: Lindhe J, Karring T, Lang NP, editors. Clinical Periodontology and Implant Dentistry. fourth edi. Oxford - UK: Blackwell Munksgaard Publishing Ltda. p 81-105.

Langsjoen OM. 1996. Dental effects of diet and coca-leaf chewing on two prehistoric cultures of northern Chile. American Journal of Physical Anthropology [Internet] 101:475-89. Available from: http://www.ncbi.nlm.nih.gov/pubmed/9016362

Larsen CS, Teaford MF, Sandford MK. 1998. Teeth as Tools at Tutu: Extramasticatory Behavior in Prehistoric St. Thomas, U.S. Virgin Islands. In: Lukacs JR, editor. Human Dental Development, Morphology, and Pathology: A Tribute to Albert A. Dahlberg. first edit. Oregon - USA: University of Oregon Anthropological Papers. p 401-420. 
Larsen CS. 1997a. Isotopic and Elemental Signatures of Diet and Nutrition. In: Lasker GW, Roberts DF, Mascie-Taylor CGN, Foley RA, editors. Bioarchaeology : Interpreting behavior from the human skeleton. first edit. Cambridge- United Kingdom: Cambridge University Press. p 270-301.

Larsen CS. 1997b. Activity Patterns: 1. Articular and Muscular Modifications. In: Larsen CS, editor. Bioarchaeology : Interpreting behavior from the human skeleton. first edit. Cambridge- United Kingdom: Cambridge University Press. p 161-194.

Larsen CS. 1997c. Activity Patterns: 2. Structural Adaptation. In: Larsen CS, editor. Bioarchaeology : Interpreting behavior from the human skeleton. first edit. CambridgeUnited Kingdom: Cambridge University Press. p 195-225.

Larsen CS. 1997d. Exposure to Infectious Pathogens. In: Larsen CS, editor. Bioarchaeology : Interpreting behavior from the human skeleton. first edit. CambridgeUnited Kingdom: Cambridge University Press. p 64-108.

Larsen CS. 1997e. Mastigatory and Nonmastigatory functions:craniofacial adaptation. In: Larsen CS, editor. Bioarchaeology : Interpreting behavior from the human skeleton. first edit. Cambridge- United Kingdom: Cambridge University Press. p 226-269.

Larson RH, Rubin M, Zipkin I. 1962. Frequency of eating as a factor in experimental dental caries. Archives of Oral Biology [Internet] 7:463-8. Available from: http://www.ncbi.nlm.nih.gov/pubmed/14462539

Leigh RW. 1925. Dental Pathology of Indian Tribes of Varied Environmental and Food Conditions. American Journal Physical Anthropology VIII:179-199.

Lessa A, Mendonça de Souza S. 2004. Violence in the Atacama Desert during the Tiwanaku period: social tension? International Journal of Osteoarchaeology [Internet] 14:374-388. Available from: http://doi.wiley.com/10.1002/oa.722

Lessa A, Mendonça de Souza S. 2006. Broken noses for the gods: ritual battles in the Atacama Desert during the Tiwanaku period. Memórias do Instituto Oswaldo Cruz [Internet] $101 \quad$ Suppl $133-8 . \quad$ Available from: http://www.ncbi.nlm.nih.gov/pubmed/17308820

Lessa A, Mendonça de Souza S. 2009. Invasores à vista: Uma abordagem biocultural sobre a violência durante a era dos pukaras. Revista de Arqueologia 22:105-119.

Lessa A. 2007. Rites of sacrifice: the survival of an ancient dimension of the human body. História, Ciências, Saúde - Manguinhos 14:907-919.

Lima JEDO. 2007. Cárie dentária: um novo conceito. Revista Dental Press de Ortodontia e Ortopedia Facial [Internet] 12:119-130. Available from: 
http://www.scielo.br/scielo.php?script=sci_arttext\&pid=S1415-

$54192007000600012 \& \operatorname{lng}=p t \& n r m=i s o \& \operatorname{lng}=p t$

Lindhe J, Nyman S, Ericsson I. 2003. Trauma from Occlusion. In: Lindhe J, Karring T, Lang $\mathrm{N}$, editors. Clinical Periodontology and Implant Dentistry. fourth edi. Oxford - UK: Blackwell Munksgaard Publishing Ltda. p 352-365.

Lindhe J, Papapanou PN. 2003. Epidemiology of Periodontal Diseases. In: Lindhe J, Karring T, Lang NP, editors. Clinical Periodontology and Implant Dentistry. fourth edi. Oxford - UK: Blackwell Munksgaard Publishing Ltda. p 50-80.

Lingstrom P, Van Houte J, Kashket S. 2000. Food Starches and Dental Caries. Critical Reviews in Oral Biology \& Medicine [Internet] 11:366-380. Available from: http://cro.sagepub.com/cgi/doi/10.1177/10454411000110030601

Llagostera A, Costa MA. 1999. Patrones de asentamiento de San Pedro de Atacama (norte de Chile). Estudios Atacameños: Arqueologia y Antropologia Surandinas 17:175206.

Llagostera A, Baron AM, Bravo L. 1984. Investigaciones arqueológicas en Tulor 1. Estudios Atacameños: Arqueologia y Antropologia Surandinas 7:105-115.

Llagostera A, Torres MC, Costa MA. 1988. El complejo psicotrópico en Solcor 3 (San Pedro de Atacama). Estudios Atacameños: Arqueologia y Antropologia Surandinas 9:67-106.

Llagostera A. 2006. Contextualización e icnografía de las tabletas psicotrópicas Tiwanaku de San Pedro de Atacama. Chungará, Revista de Antropologia Chilena 38:83111.

Llagostera AM, Torres CM. 1988. Tesoros de San Pedro de Atacama. segunda ed. Santiago - Chile: Museo de Arte Precolombino - Santiago - Chile.

Llagostera AM. 2004. Los Antiguos Habitantes del Salar de Atacama. primera ed. (Pehuén Editores, editor.). Santiago: Biblioteca del Bicentenario.

Lovejoy CO. 1985. Dental wear in the Libben population: its functional pattern and role in the determination of adult skeletal age at death. American Journal of Physical Anthropology [Internet] 68:47-56. Available from: http://www.ncbi.nlm.nih.gov/pubmed/4061601

Lukacs JR, Largaespada LL. 2006. Explaining Sex Differences in Dental Caries Prevalence : Saliva , Hormones, and "'Life-History '” Etiologies. American Journal of Human Biology 18:540-555. 
Lukacs JR. 1995. The "Caries Correction Factor": a New Method of Calibrating Dental Caries Rates to Compensate for Antemortern Loss of Teeth. International Journal of Osteoarchaeology 5:151-156.

Lukacs JR. 1996. Sex Differences in Dental Caries Rates with the Origin of Agriculture in South Asia. Current Anthropology 37:147-153.

Lynch T. 1977. Tambo incaico Catarpe Este ( informe de avance ). Estudios Atacameños 5:145-150.

Lynch TF, Núñez LA. 1994. Nuevas evidencias incas entre Collahuasi y Río Frío ( I y II Regiones del norte de Chile ). Estudios Atacameños 11:145-164.

Maestri D. 2001. Compositional Studies of Seeds and Fruits from Two Varieties of Geoffroea decorticans. Journal of Food Composition and Analysis [Internet] 14:585590. Available from: http://linkinghub.elsevier.com/retrieve/pii/S0889157501910208

Magalhães PC, Souza TC. 2011. Cultivo do Milho. Embrapa - Milho e Sorgo [Internet]:ISSN 1679-012X. Available from: http://www.cnpms.embrapa.br/publicacoes/milho_8_ed/index.htm

Mahoney P. 2006. Dental microwear from Natufian hunter-gatherers and early Neolithic farmers: comparisons within and between samples. American Journal of Physical Anthropology [Internet] 130:308-19. Available from: http://www.ncbi.nlm.nih.gov/pubmed/16395722

Mahoney P. 2007. Human Dental Microwear From Ohalo II (22, $500-23,500$ cal BP), Southern Levant. American Journal Physical Anthropology 132:489-500.

Manzanilla L, Woodard E. 1990. Restos Humanos Asociados a la Pirámide de Akapana ( Tiwanaku , Bolivia ). Latin American Antiquity 1:133-149.

Marieb EN, Hoehn K. 2007. Bones and Skeletal Tissues. In: Human Anatomy \& Physiology. seventh ed. San Francisco - USA: Pearson Benjamin Cummings. p 175-201.

Marsh PD, Martin MV. 2009a. Acquisition, Adherence, Distribution and Metabolism of the Oral Microflora. In: Marsh, Philip D \& Martin M V, editor. Oral Microbiology. fiftht edi. london - UK: Churchill Livingstone Elsevier. p 45-73.

Marsh PD, Martin MV. 2009b. Dental Plaque. In: Marsh, Philip D \& Martin M V, editor. Oral Microbiology. fifth edit. London: Churchill Livingstone Elsevier. p 74-102.

Marsh PD, Martin MV. 2009c. Plaque-mediated diseases - dental caries and periodontal diseases. In: Marsh, Philip D \& Martin M V, editor. Oral Microbiology. Fifth Edit. London: churchill Livingstone Elsevier. p 104-144. 
Marsh PD, Nyvad B. 2005. A Microbiota Oral e Biofilmes Formados sobre os Dentes. In: Fejerskov O, Kidd EAM, editors. Cárie Dentária - A Doença e seu Tratamento Clínico. primeira e. São Paulo: Editora Santos. p 29-48.

Mayewski PA, Rohling EE, Curt Stager J, Karlén W, Maasch KA, David Meeker L, Meyerson EA, Gasse F, Van Kreveld S, et al. 2004. Holocene climate variability. Quaternary Research [Internet] 62:243-255. Available from: http://linkinghub.elsevier.com/retrieve/pii/S0033589404000870

Mays S. 2010. Dental Disease. In: Mays S, editor. The Archaeology of Human Bones. Second Edi. New York - USA. p 217-236.

McKay FS. 1928. Mottled Enamel. Journal of Dental Research 8:353-365.

Meggers BJ. 1994. Archeological Evidence for the Impact of Mega-Niño on Amazonia During the Past Two Millennia. Climate Change 28:321-338.

Meindl RS, Lovejoy CO. 1985. Ectocranial suture closure: a revised method for the determination of skeletal age at death based on the lateral-anterior sutures. American Journal of Physical Anthropology [Internet] 68:57-66. Available from: http://www.ncbi.nlm.nih.gov/pubmed/4061602

Meller C, Urzua I, Moncada G, Von Ohle C. 2009. Prevalence of oral pathologic findings in an ancient pre-Columbian archeologic site in the Atacama Desert. Oral Diseases [Internet] 15:287-294. Available from: http://doi.wiley.com/10.1111/j.16010825.2009.01524.x

Milosevic A. 2004. Dietary acids - a risk to dental health? British Food Journal [Internet] 106:457-464. Available from: http://www.emeraldinsight.com/10.1108/00070700410539761

Miranda SC. 2000. Mejoramiento Genético del Maíz en la Época Prehispánica. Agricultura Tecnica en México 26:3-15.

Molnar S. 1971. Human Tooth Function and Cultural Variability. American Journal Physical Anthropology 34:175-190.

Moynihan PJ, Lingström P, Rugg-Gunn AJ, Birkhed D. 2005. O Papel do Controle da Dieta. In: Fejerskov O, Kidd EAM, editors. Cárie Dentária - A Doença e seu Tratamento Clínico. primeira e. São Paulo: Editora Santos. p 223-244.

Moynihan PJ. 2005. The role of diet and nutrition in the etiology and prevention of oral diseases. Bulletin of the World Health Organization [Internet] 83:694-9. Available from:

http://www.pubmedcentral.nih.gov/articlerender.fcgi?artid=2626331\&tool=pmcentre $z \&$ rendertype $=$ abstract 
Nelson DL, Cox MM. 2008. Carbohydrates and Glycobiology. In: Lehninger Principles of Biochemistry. fifth edit. New York - USA: W.H. Freeman Company. p 235-270.

Nelson GC, Madimenos FC. 2010. Obelionic cranial deformation in the Puebloan Southwest. American Journal of Physical Anthropology [Internet] 143:465-72. Available from: http://www.ncbi.nlm.nih.gov/pubmed/20623677

Neumann GK. 1942. Types of Artificial Cranial Deformation in the Eastern United States. American Antiquity 7:306-310.

Neves WA, Costa MA. 1998. Adult Stature and Standard of Living the Prehistoric Atacama Desert. Current Anthropology 39:278-281.

Neves WA, Pucciarelli HM. 1989. Extra-continental biological relationships of early South American human remains: a multivariate analysis. Ciência e Cultura 41:566-575.

Neves WA, Pucciarelli HM. 1990. The origin of the first Americans: an analysis based on the cranial morphology of early South American human remains. American Journal Physical Anthropology 81:274.

Neves WA, Pucciarelli HM. 1991. Morphological affinities of the first Americans : an exploratory analysis based on early South American human remains generated. Journal of Human Evoltuion 21:261-273.

Neville BW, Damm DD, White DH. 2003a. Pathology of the Teeth. In: Neville BW, Damm DD, White DH, editors. Color Atlas of Clinical Oral Pathology. second edi. Hamilton / London: BC Decker Inc. p 41-88.

Neville BW, Damm DD, White DH. 2003b. Pulp, Periapical, and Periodontal Pathology. In: Neville BW, Damm DD, White DH, editors. Color Atlas of Clinical Oral Pathology. second edi. Hamilton / London: BC Decker Inc. p 89-114.

Neville BW, Damm DD, White DH. 2003c. Odontogenic Cysts and Tumors. In: Neville BW, Damm DD, White DH, editors. Color Atlas of Clinical Oral Pathology. second edi. Hamilton / London: BC Decker Inc. p 381-425.

Newbrun E. 1982. Sugar and dental caries: a review of human studies. Science (New York, N.Y.) [Internet] 217:418-23. Available from: http://www.ncbi.nlm.nih.gov/pubmed/7046052

Niemeyer HM, Zapata V, Cantillana P, Missene A, Aguilera J, Torres A. 2013. Computed tomography study of snuff trays from San Pedro de Atacama (Northern Chile). Journal of Archaeological Science [Internet] 40:2036-2044. Available from: http://linkinghub.elsevier.com/retrieve/pii/S0305440312005353 
Núñez L, Grosjean M, Messerli B, Schrelier H. 1997. Cambios ambientales holocénicos en la Puna de Atacama y sus implicancias paleoclimáticas. Estudios Atacameños 12:2533.

Núñez L, Grosjean M. 1994. Cambios ambientales pleistoceno-holocénicos : Ocupación humana y uso de recursos en la Puna de Atacama (norte de Chile). Estudios Atacameños 11:7-20.

Núñez L. 1995. Evolución de la Ocupación y Organización del Espacio Atacameño. In: Pourrut $P$, Núñez L, editors. Agua, ocupación del Espacio y Economía Campesina en la Región Atacameña. primera ed. Antofagasta - Chile: NORprint - U.C.del Norte. p 18-60.

Núñez L. 2005. The nature og village expansion during the Late Formative Period in the Atacama basin. Chungará, Revista de Antropologia Chilena 37:165-194.

Núñez LA. 2007. Vida y Cultura en los Oasis de San Pedro de Atacama. primera ed. (Núñez LA, editor.). Santiago - Chile: Editorial Universitaria S.A.

Okumura MMM, Eggers S. 2005. The people of Jabuticabeira II: reconstruction of the way of life in a Brazilian shellmound. HOMO - Journal of Comparative Human Biology [Internet] 55:263-281. Available from: http://linkinghub.elsevier.com/retrieve/pii/S0018442X04000484

Olivares BM, Uauy R. 2004. Essential Nutrients in Drinking-Water. World Health Organization.

Ortner DJ. 2003. Dental Disease and Miscellaneous Pathological Conditions of Jaws. In: Ortner DJ, editor. Identification of Pathological Conditions in Human Skeletal Remains. second edi. San Diego - CA - EUA: Academic Press - Elsevier. p 589-608.

Oshodi A, Ogungbenle HN, Oladimeji MO. 1999. Chemical composition, nutritionally valuable minerals and functional properties of benniseed (Sesamum radiatum), pearl millet (Pennisetum typhoides) and quinoa (Chenopodium quinoa) flours. International Journal of Food Sciences and Nutrition [Internet] 50:325-31. Available from: http://www.ncbi.nlm.nih.gov/pubmed/10719563

Owen BD. 2005. Distant Colonies and Explosive Collapse: The Two Stages of the Tiwanaku Diaspora in the Osmore Drainage. Latin American Antiquity 16:45-80.

Palubeckaitè Ž, Jankauskas R, Boldsen J. 2002. Enamel hypoplasia in Danish and Lithuanian Late Medieval/Early Modern samples: a possible reflection of child morbidity and mortality patterns. International Journal of Osteoarchaeology [Internet] 12:189-201. Available from: http://doi.wiley.com/10.1002/oa.607 
Pardo OB, Pizarro JLT. 2005. Presentacón de las Especies. In: Pardo OB, Pizarro JLT, editors. Especies Botánicas consumidas por los Chilenos Prehispánicos. Primera Ed. Santiago - Chile: Editorial Mare Nostrum. p 39-193.

Pardo OB, Pizarro JLT. 2008. Las Técnicas de Conservación. In: Pardo OB, Pizarro JLT, editors. Alimentos: Conservación y Almacenamiento en el Chile Precolombino. Primera ed. Arica - Chile: Ediciones Parina. p 75-142.

Pedersen P. 1947. Dental Investigations of Greenland Eskimos. Proceedings of the Royal Society of Medicine - London 40:726-732.

Pérez BP, Romero A, Pérez-Pérez A. 2011. Age-related variability in buccal dentalmicrowear in Middle and Upper Pleistocene human populations. Anthropological Review [Internet] 74:25-37. Available from: http://versita.metapress.com/openurl.asp?genre=article\&id=doi:10.2478/v10044-0100005-0

Pérez P, Maino M, Guzmán R, Vaquero A, Köbrich C, Pokniak J. 2000. Carcass characteristics of llamas (Lama glama) reared in Central Chile. Small ruminant research: The Journal of the International Goat Association [Internet] 37:93-97. Available from: http://www.ncbi.nlm.nih.gov/pubmed/10818308

Perez SI. 2007. Artificial cranial deformation in South America: a geometric morphometrics approximation. Journal of Archaeological Science [Internet] 34:16491658. Available from: http://linkinghub.elsevier.com/retrieve/pii/S0305440306002688

Pestana SRCC. 2012. Análise dos Teores de Flúor da Água de Abastecimento Público do município de Cananéia - São Paulo, Brasil. Dissertação de mestrado. Faculdade de Odontologia - Universidade de São Paulo, São Paulo, Brasil p.130.

Peterson L, Haug G. 2005. Climate and the collapse of Maya civilization. American Scientist [Internet] 93:322. Available from: http://www.ncbi.nlm.nih.gov/pubmed/12637744

Picosse M. 1979a. Parte Geral. In: Picosse M, editor. Anatomia Dentária. terceira e. São Paulo - BR: Sarvier S/A Editora de Livros Médicos. p 1-10.

Picosse M. 1979b. Relação dos Dentes com os Ossos Alveolares e com as Regiões Ósseas Vizinhas. In: Picosse M, editor. Anatomia Dentária. terceira e. São Paulo - BR: Sarvier S/A Editora de Livros Médicos. p 123-130.

Pimentel FB. 1976. Informe geológico resumido : Area San Pedro de Atacama. Estudios Atacameños 4:13-17. 
Pontzer H, Scott JR, Lordkipanidze D, Ungar PS. 2011. Dental microwear texture analysis and diet in the Dmanisi hominins. Journal of Human Evolution [Internet] 61:683-7. Available from: http://www.ncbi.nlm.nih.gov/pubmed/22030152

Powell JF, Neves WA, Ozolins E, Pucciarelli HM. 1999. Afinidades biológicas extracontinentales de los dos esqueletos más antiguos de América: implicaciones para el poblamiento del Nuevo Mundo. Antropologia Fisica Latinoamericana 2:7-22.

Powell JF, Steele DG. 1992. A multivariate craniometric analysis of North American paleo-indian remains. Current Research in the Pleistocene 9:59-62.

Powell JF. 1993. Dental evidence for the peopling of the New-World - Some methodological considerations. Human Biology 65:799-819.

Powell JF. 1995. Dental variation and biological affinity among middle Holocene humans populations in North America (Ph. D). 1995.

Pucciarelli HM, González-José R, Neves WA, Sardi ML, Rozzi FR. 2008. East-West cranial differentiation in pre-Columbian populations from Central and North America. Journal of Human Evolution [Internet] 54:296-308. Available from: http://www.ncbi.nlm.nih.gov/pubmed/18022673

Ramires I, Buzalaf MAR. 2008. Histórico do Uso de Fluoretos em Saúde Bucal. In: Fluoretos e Saúde Bucal. São Paulo: Editora Santos. p 1-10.

Ramires I, Pessan JP, Buzalaf MAR. 2008. Métodos de Uso Sistêmicos dos Fluoretos no Controle da Cárie Dentária. In: Fluoretos e Saúde Bucal. São Paulo: Editora Santos. p 163-194.

Reid DJ, Dean MC. 2000. Brief communication: the timing of linear hypoplasias on human anterior teeth. American Journal of Physical Anthropology [Internet] 113:1359. Available from: http://www.ncbi.nlm.nih.gov/pubmed/10954627

Reid DJ, Dean MC. 2006. Variation in modern human enamel formation times. Journal of Human Evolution [Internet] 50:329-46. Available from: http://www.ncbi.nlm.nih.gov/pubmed/16300817

Rivera MA, Aufderheide AC, Cartmell LW, Torres CM, Langsjoen O. 2005. Antiquity of coca-leaf chewing in the south central Andes: a 3,000 year archaeological record of coca-leaf chewing from northern Chile. Journal of Psychoactive Drugs [Internet] 37:455-8. Available from: http://www.ncbi.nlm.nih.gov/pubmed/16480174

Roberts C, Manchester K. 2005a. The Study of Paleopathology. In: Roberts C, Manchester K, editors. The Archaeology of Disease. third edit. New York: Cornell University Press. p 1-21. 
Roberts C, Manchester K. 2005b. Dental Disease. In: Robets C, Manchester K, editors. The Archaeology of Disease. third edit. New York: Cornell University Press. p 63-84.

Rostworowski MDC. 1999. Historia del Tihuantinsuyu. segunda ed. Lima - Peru: Instituto de Estudios Peruanos.

Rowe JH. 1962. Stages and Periods in Archaeological Interpretation. Southwestern Journal of Anthropology 18:40-54.

Russell MW, Childers NK, Michalek SM, Smith DJ, Taubman MA. 2004. A Caries Vaccine? The state of the science of immunization against dental caries. Caries Research [Internet] 38:230-5. Available from: http://www.ncbi.nlm.nih.gov/pubmed/15153693

Russell RR. 2009. Changing concepts in caries microbiology. American Journal of Dentistry [Internet] 22:304-10. Available from: http://www.ncbi.nlm.nih.gov/pubmed/20225475

Saadoun A, Cabrera MC. 2008. A review of the nutritional content and technological parameters of indigenous sources of meat in South America. Meat Science [Internet] 80:570-81. Available from: http://www.ncbi.nlm.nih.gov/pubmed/22063568

Sakashita R, Inoue M, Inoue N, Pan Q, Zhu H. 1997. Dental disease in the Chinese YinShang period with respect to relationships between citizens and slaves. American Journal of Physical Anthropology [Internet] 103:401-8. Available from: http://www.ncbi.nlm.nih.gov/pubmed/9261502

Santoro CM, Nuñez LA, Standen VG, González H, Marquet PA, Torres AH. 1998. Proyectos de irrigación y la fertilización del desierto. Estudio Atacameños 16:321-336.

Saunders SR, De Vito C, Katzenberg MA. 1997. Dental caries in nineteenth century upper Canada. American Journal of Physical Anthropology [Internet] 104:71-87. Available from: http://www.ncbi.nlm.nih.gov/pubmed/9331454

Scheid RC, Weiss G. 2012a. Application of Root and Pulp Morphology Related to Endodontic Therapy. In: Scheid RC, Weiss G, editors. Woelfel's Dental Anatomy. eighth edi. Philadelphia - USA: Lippincott Williams \& Wilkins. p 231-249.

Scheid RC, Weiss G. 2012b. Basic Terminology for Understanding Tooth Morphology. In: Scheid RC, Weiss G, editors. Woelfel's Dental Anatomy. eighth edi. Philadelphia USA: Lippincott Williams \& Wilkins. p 3-41.

Scheid RC, Weiss G. 2012c. Periodontal Anatomy. In: Scheid RC, Weiss G, editors. Woelfel's Dental Anatomy. eighth edi. Philadelphia - USA: Lippincott Williams \& Wilkins. p 197-230. 
Scheid RC, Weiss G. 2012d. Structures That Form the Foundation for Tooth Function. In: Scheid RC, Weiss G, editors. Woelfel's Dental Anatomy. eighth edi. Philadelphia USA: Lippincott Williams \& Wilkins. p 377-438.

Schmidt C. 2001. Dental microwear evidence for a dietary shift between two nonmaize-reliant prehistoric human populations from Indiana. American Journal of Physical Anthropology [Internet] 114:139-45. Available from: http://www.ncbi.nlm.nih.gov/pubmed/11169903

Schmidt CW. 2010. On the relationship of dental microwear to dental macrowear. American Journal of Physical Anthropology [Internet] 142:67-73. Available from: http://www.ncbi.nlm.nih.gov/pubmed/19902458

Schulz PD. 1970. Solar Burial Orientation and Paleodemography in the Central California Windmiller Tradition. University of California Center for Archeological Research Publication 2:185-198.

Scott EC. 1979a. Dental Wear Scoring Technique. American Journal Physical Anthropology 51:213-218.

Scott EC. 1979b. Principal axis analysis of dental attrition data. American Journal of Physical Anthropology [Internet] 51:203-211. Available from: http://doi.wiley.com/10.1002/ajpa.1330510207

Scott GR, Turner CG. 1988. Dental Anthropology. Annual Review of Anthropology 17:99-126.

Scott GR, Turner CG. 2008. History of Dental Anthropology. In: Irish JD, Nelson GC, editors. Technique and Application in Dental Anthropolgy. first edit. Cambridge- United Kingdom: Cambridge University Press. p 10-34.

Scott RS, Teaford MF, Ungar PS. 2012. Dental microwear texture and anthropoid diets. American Journal of Physical Anthropology [Internet] 147:551-79. Available from: http://www.ncbi.nlm.nih.gov/pubmed/22331579

Serracino G, Stehberg RL. 1975. Vida pastoril en la precordillera andina. Estudios Atacameños 3:73-88.

Smith BH. 1984. Patterns of molar wear in hunger-gatherers and agriculturalists. American Journal of Physical Anthropology [Internet] 63:39-56. Available from: http://www.ncbi.nlm.nih.gov/pubmed/6422767

Smith TM, Tafforeau P, Reid DJ, Grün R, Eggins S, Boutakiout M, Hublin J-J. 2007a. Earliest evidence of modern human life history in North African early Homo sapiens. Proceedings of the National Academy of Sciences of the United States of America [Internet] 104:6128-33. Available from: 
http://www.pubmedcentral.nih.gov/articlerender.fcgi?artid=1828706\&tool=pmcentre $z \&$ rendertype $=$ abstract

Smith TM, Tafforeau P, Reid DJ, Pouech J, Lazzari V, Zermeno JP, Guatelli-Steinberg D, Olejniczak AJ, Hoffman A, et al. 2010. Dental evidence for ontogenetic differences between modern humans and Neanderthals. Proceedings of the National Academy of Sciences of the United States of America [Internet] 107:20923-8. Available from: http://www.pubmedcentral.nih.gov/articlerender.fcgi?artid=3000267\&tool=pmcentre z\&rendertype=abstract

Smith TM, Tafforeau P. 2008. New visions of dental tissue research: Tooth development, chemistry, and structure. Evolutionary Anthropology: Issues, News, and Reviews [Internet] 17:213-226. Available from: http://doi.wiley.com/10.1002/evan.20176

Smith TM, Toussaint M, Reid DJ, Olejniczak AJ, Hublin J-J. 2007b. Rapid dental development in a Middle Paleolithic Belgian Neanderthal. Proceedings of the National Academy of Sciences of the United States of America [Internet] 104:20220-5. Available from:

http://www.pubmedcentral.nih.gov/articlerender.fcgi?artid=2154412\&tool=pmcentre z\&rendertype=abstract

Socransky SS, Haffajee AD. 2003. Microbiology of Periodontal Disease. In: Lindhe J, Karring T, Lang NP, editors. Clinical Periodontology and Implant Dentistry. fourth edi. Oxford - UK: Blackwell Munksgaard Publishing Ltda. p 106-149.

Stewart TD. 1931. Dental caries in Peruvian Skulls. American Journal Physical Anthropology 15:315-326.

Suckling G, Elliott DC, Thurley DC. 1983. The production of developmental defects of enamel in the incisor teeth of penned sheep resulting from induced parasitism. Archives of Oral Biology [Internet] 28:393-9. Available from: http://www.ncbi.nlm.nih.gov/pubmed/6578757

Suckling GW. 1989. Developmental Defects of Enamel - Historical and Present-Day Perspectives of Their Pathogenesis. Advances in Dental Research 3:87-94.

Tarragó M. 1976. Alfarería típica de San Pedro de Atacama (norte de Chile). Estudios Atacameños 4:37-67.

Tarragó M. 1977. Relaciones prehispánicas entre San Pedro de Atacama ( norte de Chile ) y regiones aledañas: La Quebrada de Humahuaca. Estudio Atacameños 5:5164. 
Temple DH, Larsen CS. 2007. Dental Caries Prevalence as Evidence for Agriculture and Subsistence Variation During the Yayoi Period in Prehistoric Japan: Biocultural Interpretations of an Economy in Transition. American Journal of Physical Anthropology 134:501-512.

Torres CM. 1984. Iconografía de las tabletas para inhalar sustancias psicoactivas de la zona de San Pedro de Atacama , norte de Chile. Estudios Atacameños 7:135-147.

Torres CM. 1996. Archaeological evidence for the antiquity of psychoactive plant use in the Central Andes. Annual Museum Civic Rovereto 11:291-326.

Torres-Rouff C, Costa Junqueira MA. 2006. Interpersonal violence in prehistoric San Pedro de Atacama, Chile: behavioral implications of environmental stress. American Journal of Physical Anthropology [Internet] 130:60-70. Available from: http://www.ncbi.nlm.nih.gov/pubmed/16353221

Torres-Rouff C, Costa MA, Llagostera A. 2005. Violence in times of change: the Late Intermediate Period in San Pedro de Atacama. Chungará, Revista de Antropologia Chilena 37:75-83.

Torres-Rouff C. 2002. Cranial Vault Modification and Ethnicity in Middle Horizon San Pedro de Atacama, Chile. Current Anthropology 43:163-171.

Torres-Rouff C. 2007. La deformación craneana en san pedro de atacama. Estudios Atacameños 33:25-38.

Touger-Decker R, Van Loveren C. 2003. Sugars and dental caries. The American Journal of Clinical Nutrition [Internet] 78:881S-892S. Available from: http://www.ncbi.nlm.nih.gov/pubmed/22685053

Turner TR. 2002. Changes in biological anthropology: results of the 1998 American Association of Physical Anthropology Membership Survey. American Journal of Physical Anthropology [Internet] 118:111-6. Available from: http://www.ncbi.nlm.nih.gov/pubmed/12012363

Ungar PS, Grine FE, Teaford MF. 2008. Dental microwear and diet of the PlioPleistocene hominin Paranthropus boisei. PloS One [Internet] 3:e2044. Available from: http://www.pubmedcentral.nih.gov/articlerender.fcgi?artid=2315797\&tool=pmcentre z\&rendertype=abstract

Ungar PS, Krueger KL, Blumenschine RJ, Njau J, Scott RS. 2012. Dental microwear texture analysis of hominins recovered by the Olduvai Landscape Paleoanthropology Project, 1995-2007. Journal of Human Evolution [Internet] 63:429-37. Available from: http://www.ncbi.nlm.nih.gov/pubmed/21784504 
Uribe M, Adán LA, Aguero CP. 2002. El dominio del Inka, identidad local y complejidad social en las tierras altas del desierto de Atacama, Norte Grande de Chile (1450-1541 D.C.). Boletín de Arqueología PUCP 6:301-336.

USDA. 2012. USDA National Nutrient Database for Standard Reference, Release 18. Nutrient Data Laboratory [Internet]. Available from: http://www.nal.usda.gov/fnic/foodcomp/Data/SR18/reports/sr18page.htm

Villagrán C, Castro V, Sanchez G. 1998. Etnobotánica y Percepción del Paisaje en Caspana (Provincia de El Loa, Región de Antofagasta, Chile ): ¿ Una cuña atacameña en el Loa Superior? Estudios Atacameños 16:107-170.

Villalba R. 1994. Tree-Ring and Glacial Evidence for the Medieval Warm Epoch and the Little Ice Age in Southern South America. Climate Change 26:183-197.

Vinton SD, Perry L, Reinhard KJ, Santoro CM, Teixeira-Santos I. 2009. Impact of empire expansion on household diet: the Inka in Northern Chile's Atacama Desert. PloS One [Internet] 4:e8069. Available from: http://www.pubmedcentral.nih.gov/articlerender.fcgi?artid=2777378\&tool=pmcentre $z \&$ rendertype $=$ abstract

Walrath DE, Turner P, Bruzek J. 2004. Reliability test of the visual assessment of cranial traits for sex determination. American Journal of Physical Anthropology [Internet] 125:132-7. Available from: http://www.ncbi.nlm.nih.gov/pubmed/15365979

Waters-Rist A, Bazaliiskii VI, Weber A, Goriunova OI, Katzenberg MA. 2010. Activityinduced dental modification in holocene siberian hunter-fisher-gatherers. American Journal of Physical Anthropology [Internet] 143:266-78. Available from: http://www.ncbi.nlm.nih.gov/pubmed/20853480

Watt ME, Lunt DA, Gilmour WH. 1997. Caries Prevalence in the Permanent Dentition of a Mediaeval Population from the South-West of Scotland. Archives of Oral Biology 42:601-620.

Weeks CS. 1868. Causes of the Decay of Teeth. Philadelphia: Philadelphia: S.S>White Dental Manufacturion CO.

White DJ. 1997. Dental calculus: recent insights into occurrence, formation, prevention, removal and oral health effects of supragingival and subgingival deposits. European Journal of Oral Sciences [Internet] 105:508-22. Available from: http://www.ncbi.nlm.nih.gov/pubmed/9395117

White TD, Folkens PA. 2005a. Bone Biology \& Variation. In: White TA, Folkens PA, editors. The Human Bone Manual. first edit. Iondon - UK: Elsevier Academic Press. $p$ 31-38. 
White TD, Folkens PA. 2005b. Osteological \& Dental Pathology. In: White TD, Folkens PA, editors. The Human Bone Manual. first edit. London - UK: Elsevier Academic Press. p 309-332.

White TD, Folkens PA. 2005c. The Skeletal Biology of Individuals \& Populations. In: White TD, Folkens PA, editors. The Human Bone Manual. first edit. London - UK: Elsevier Academic Press. p 360-418.

Whittaker DK, Molleson T, Nuttall T. 1998. Calculus deposits and bone loss on the teeth of Romano-British and eighteenth-century Londoners. Archives of Oral Biology [Internet] 43:941-8. Available from: http://www.ncbi.nlm.nih.gov/pubmed/9877325

Zuidema RT. 2009. Tiwanaku Iconography and the Calendar. In: Yuong-Sánchez M, editor. Tiwanaku - 2005 Mayer Center Symposium at the Denver Art Museum. Denver, CO - USA: Denver Art Museum. p 83-100. 
Ficha de Inventário das Patologias Dentais

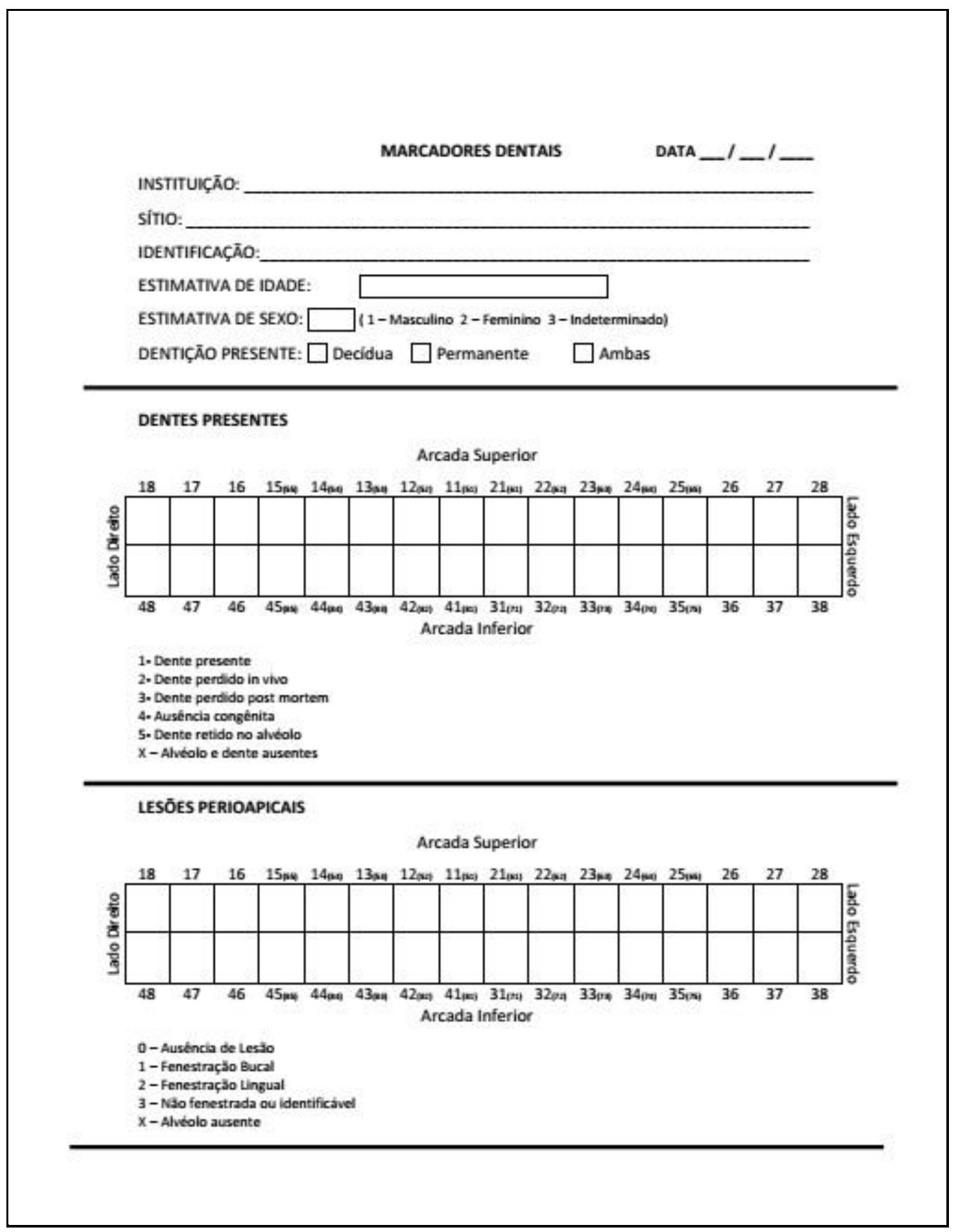




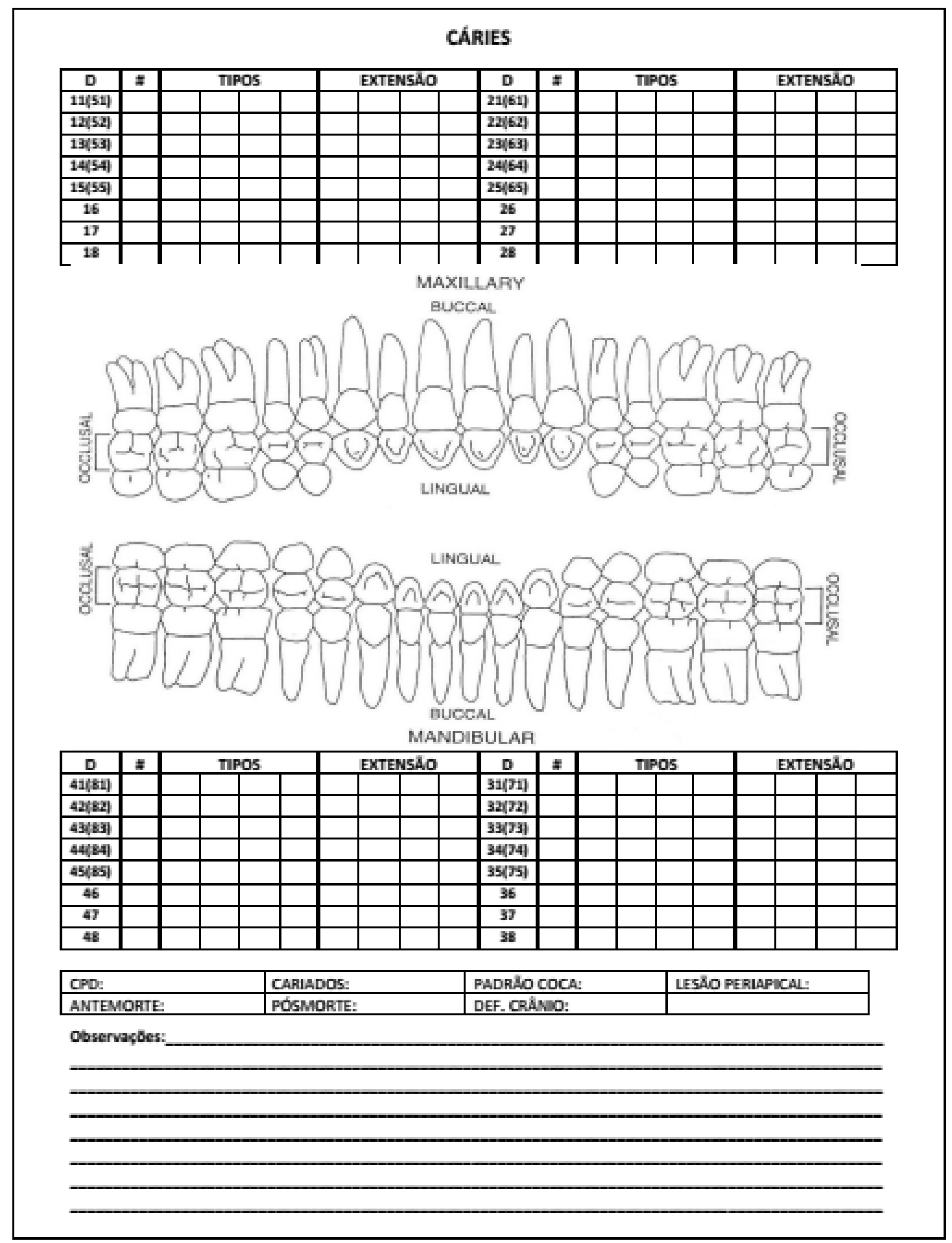




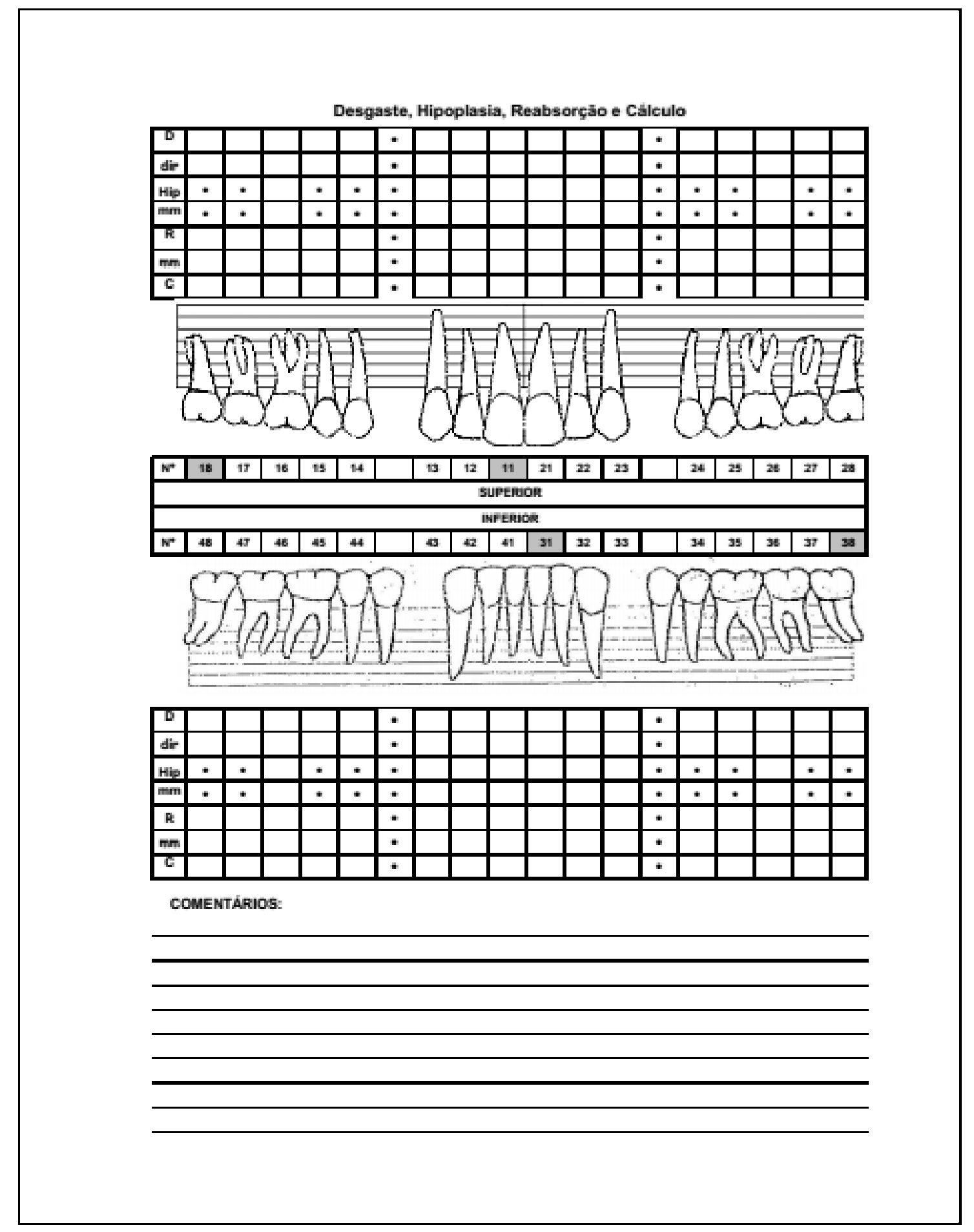


TABELA PARA DETERMINAÇÃO DE SEXO

(D.E. WALRATH ET AL. 2004)

\begin{tabular}{|c|c|c|c|}
\hline PONTOS & PESO & VALOR (-2/-1/0/1/2) & SOMA \\
\hline GLABELA & & & \\
\hline PROCESSO MASTÓIDE & $\mathbf{3}$ & & \\
\hline ARCO SUPRACILIAR & $\mathbf{2}$ & & \\
\hline ZIGOMÁTICO & $\mathbf{2}$ & & \\
\hline FORMA DA ÓRBITA & $\mathbf{1}$ & & \\
\hline & & & \\
\hline PARCIAL & & & \\
\hline TOTAL & 11 & & \\
\hline & & & \\
\hline
\end{tabular}

TABELA PARA DETERMINAÇÃO DE IDADE

(MEINDL \& LOVEJOY, 1985 - pontos 6 ao 10)

\begin{tabular}{|c|c|}
\hline 6 & \\
\hline 7 & \\
\hline 8 & \\
\hline 9 & \\
\hline 10 & \\
\hline TOTAL & \\
\hline
\end{tabular}

PARÂMETROS

\begin{tabular}{|c|c|c|}
\hline VALORES & IDADE & DESVIO \\
\hline 0 & - & - \\
\hline 1 & 32.0 & 8.3 \\
\hline 2 & 36.2 & 6.2 \\
\hline $3-5$ & 41.1 & 10.0 \\
\hline 6 & 43.4 & 10.7 \\
\hline $7-8$ & 45.5 & 8.9 \\
\hline $9-10$ & 51.9 & 12.5 \\
\hline $11-14$ & 56.2 & 8.5 \\
\hline 15 & - & - \\
\hline
\end{tabular}


(Walrath et al. 2004)

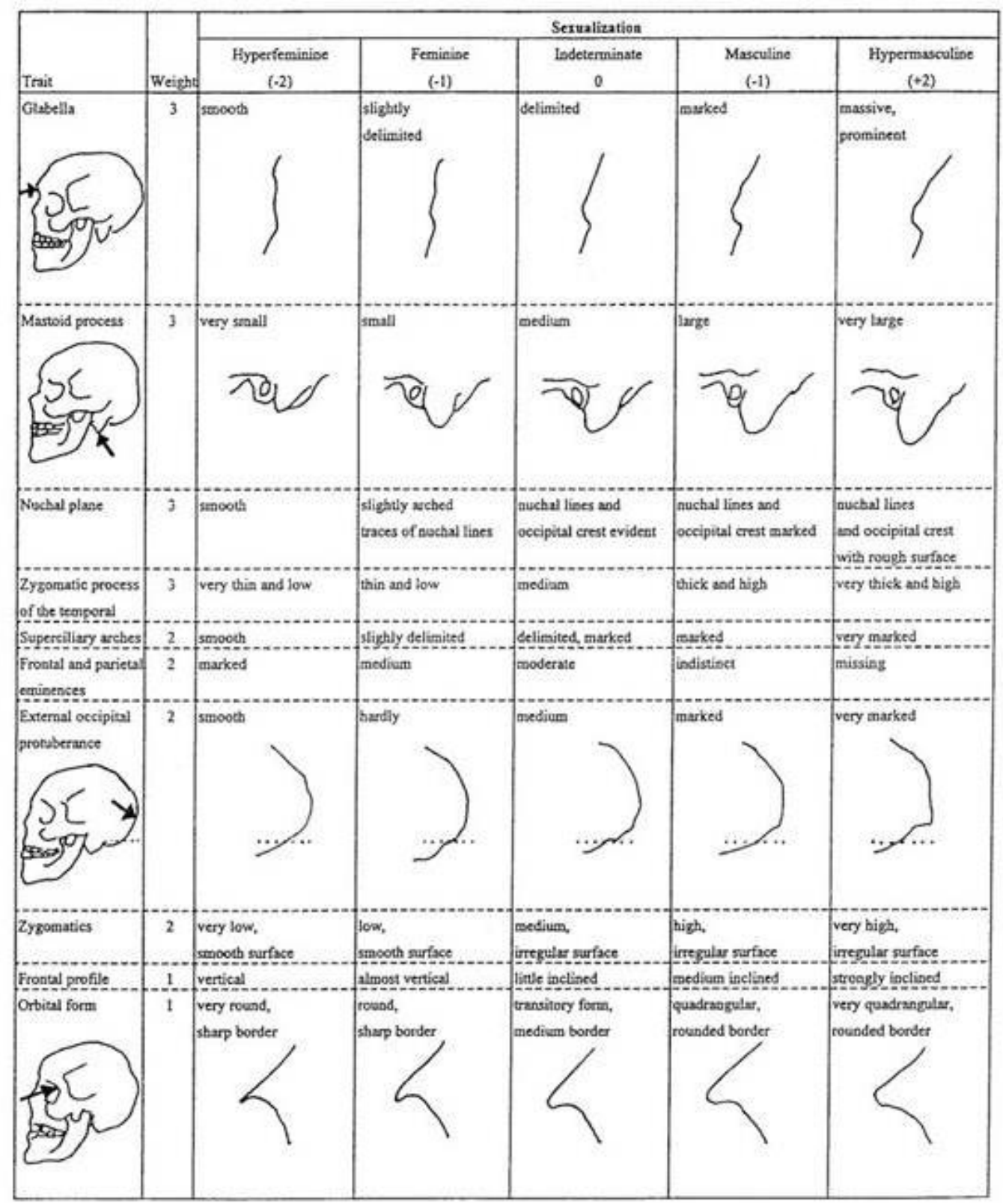




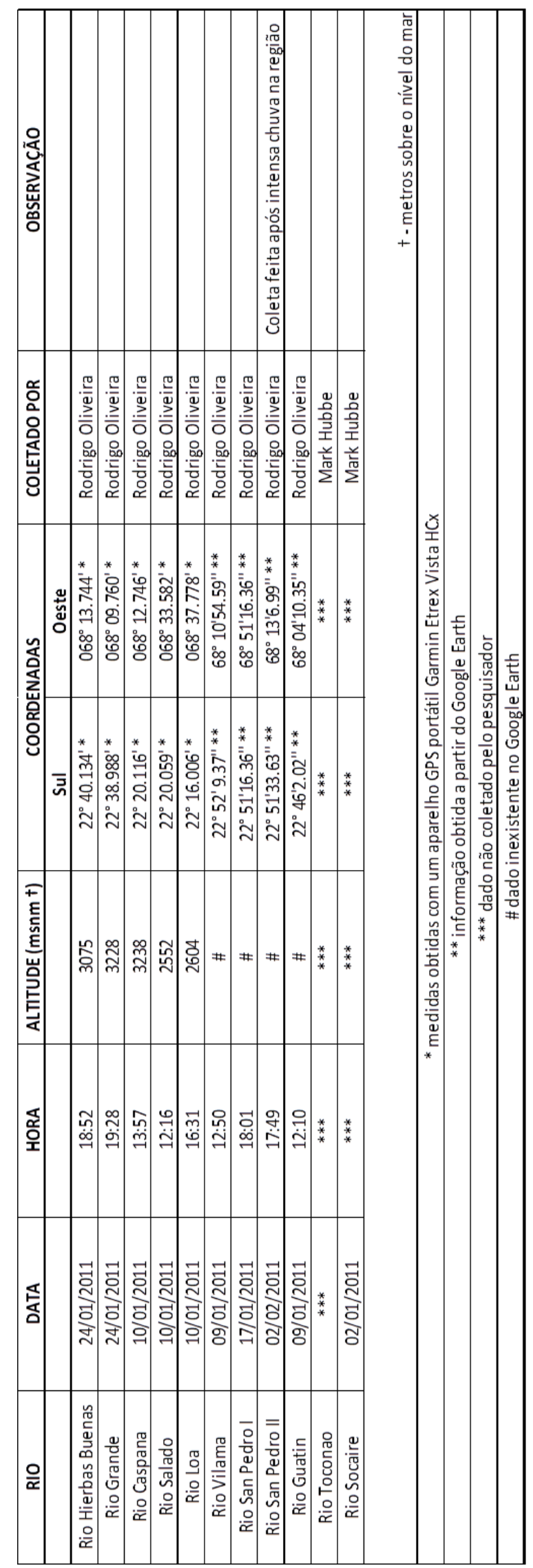

